DOE/WIPP 03-2225

Rev. 1

\title{
Waste Isolation Pilot Plant Site Environmental Report Calendar Year 2002
}

\section{U.S. Department of Energy Carlsbad Field Office} September 2003

This report was prepared for the U.S. Department of Energy, Carlsbad Field Office by Washington Regulatory and Environmental Services

P.O. Box 2078

Carlsbad, NM 88221 
This document has been reproduced directly from the best possible copy. It is available to DOE and DOE contractors from the following address:

Office of Scientific and Technical Information

P.O. Box 62

Oak Ridge, TN 37831

Prices available from (615) 576-8401

Available to the public from the National Technical Information Services

United States Department of Commerce 5285 Port Royal Road Springfield, Virginia 22161

Processing and final preparation of this report was performed by the Waste Isolation Pilot Plant Management and Operating Contractor for the U.S. Department of Energy under Contract No. DE-AC04-01AL66444. 


\section{ACKNOWLEDGMENTS}

We appreciate the reviews by Harold Johnson and Dr. E. B. Nuckols of the United States Department of Energy Carlsbad Field Office, and the Carlsbad Field Office Technical Assistance Contractor.

Don Gray of the Environmental Evaluation Group provided radiological data for scientific comparisons in advance of releasing the data in their own report.

Many Washington TRU Solutions LLC groups contributed to this report, which would not have been complete and accurate without their assistance. Dirk Roberson provided advice and assistance with the color figures and designed the cover. Wesley Nance compiled the meteorological data, and Steve Offner produced the meteorological graphs and supporting information.

The WTS WIPP Laboratories Group: Mansour Akbarzadeh, Okka Maung, Raymond Neuman, Joseph Ortiz, Randy Randolph, Margie Kidwell, Ginny Whiteford, and Ying-Hua Xue provided all radionuclide analyses of environmental samples.

The Washington Regulatory and Environmental Services (WRES) Site Environmental Compliance Authorization Basis Group: Ron Reeves, Koreen Guillermo, Kathi Dunbar, Kathy Zbryk, Parrish Roush, and Steve Travis, were very helpful throughout the writing of this report.

The WTS Radiation Safety and Emergency Management Group: Dave Kump, Marsha Beekman, and Linda Frank-Supka, provided radiological and dosimetry data.

Significant acknowledgment should be made of Dr. Hung Cheng Chiou, who coordinated and wrote the environmental radiological sections of this report. In addition to Dr. Chiou's work, Irene Quintana initiated the data validation for 2002.

WRES and WTS personnel were instrumental in collecting the data and assembling this report. They are Joel Siegel, Stewart Jones, Mel Balderrama, Wes Boatwright, Mark Crawley, Bill Foster, Oscar Garcia, Don Gilbert, Doug Lynn, Ron Richardson, Aurelio Rivas, Rick Salness, and Roger Simmons.

Mak Walker, WTS, provided administrative support; and Beth Aldrich, L\&M Technologies, provided editorial support.

Special thanks to Vivian Allen, L\&M Technologies, Document Services group, for her extensive and thorough document editing and formatting services. 
This page intentionally left blank 


\section{EXECUTIVE SUMMARY}

The United States (U.S.) Department of Energy (DOE) Carlsbad Field Office (CBFO) and Washington TRU Solutions LLC (WTS) are dedicated to maintaining high quality management of Waste Isolation Pilot Plant (WIPP) environmental resources. DOE Order 5400.1, General Environmental Protection Program, and DOE Order 231.1, Environment, Safety, and Health Reporting, require that the environment at and near DOE facilities be monitored to ensure the safety and health of the public and the environment. This Waste Isolation Pilot Plant 2002 Site Environmental Report summarizes environmental data from calendar year 2002 that characterize environmental management performance and demonstrate compliance with federal and state regulations.

This report was prepared in accordance with DOE Order 5400.1, DOE Order 231.1, and Guidance for the Preparation of DOE Annual Site Environmental Reports (ASERs) for Calendar Year 2002 (DOE Memorandum EH-41: Natoli:6-1336, April 4, 2003). These Orders and the guidance document require that DOE facilities submit an annual site environmental report to DOE Headquarters, Office of the Assistant Secretary for Environment, Safety, and Health; and the New Mexico Environment Department (NMED).

The purpose of this report is to provide important information needed by DOE Headquarters to assess field environmental program performance and confirm compliance with environmental standards and requirements. It is also the means by which the WIPP site demonstrates compliance with the radiation protection requirements of DOE Order 5400.5, Release Criteria, and DOE Order 231.1. This report conveys the DOE's environmental performance to members of the public living near DOE sites and to other stakeholders. The 2002 Site Environmental Report outlines significant programs and efforts of environmental merit at WIPP for 2002.

The following highlights are discussed in the 2002 ASER:

- $\quad$ Discussion of WIPP's Environmental Management System (EMS) and its implementation status within the framework of the Integrated Safety Management System (ISMS).

- $\quad$ Activities pursuant to Executive Order (E.O.) 13148, Greening the Government Through Leadership in Environmental Management; and E.O. 13101, Greening the Government Through Waste Prevention, Recycling, and Federal Acquisition.

- $\quad$ Discussion of accomplishments of site pollution prevention activities as applicable to WIPP.

- $\quad$ Report on the radiation protection, radiological doses and releases, if any, at WIPP including authorized limits used for the control or release of real or personal property potentially containing residual radioactive material, and protection of biota. 
- Discussion of WIPP's environmental performance measures program, including specific environmental performance measures applicable to operations conducted at WIPP.

- $\quad$ Reporting of WIPP's Groundwater Monitoring Program results.

\section{Environmental Program Information}

It is the DOE's policy to conduct its operations at WIPP in compliance with all applicable environmental laws and regulations, and to safeguard the integrity of the southeastern New Mexico environment. This is accomplished through a comprehensive management system consisting of radiological and nonradiological environmental monitoring and surveillance, environmental compliance, wildlife monitoring, and the WIPP Raptor Research Program (WRRP). As part of these programs, the DOE collects data needed to detect and quantify potential impacts WIPP may have on the surrounding environment.

Environmental activities at WIPP generally fall into four categories: collecting environmental samples and analyzing them for a variety of contaminants, preparing and publishing documents demonstrating compliance with federal and state regulations, evaluating whether WIPP activities cause any environmental impacts, and taking corrective action when an adverse effect on the environment is identified.

The Waste Isolation Pilot Plant Environmental Monitoring Plan (EMP) (DOE/WIPP 99-2194) outlines the programs that monitor the environment on, and immediately surrounding, the WIPP site. It describes major environmental monitoring and surveillance activities at WIPP and WIPP's quality assurance/quality control (QA/QC) program as it relates to environmental monitoring.

WIPP's effluent monitoring and environmental surveillance programs are designed to ensure adequate protection of the public and the environment during DOE operations and that operations comply with the DOE and other applicable federal and state radiation standards and requirements. The Environmental Monitoring Program monitors the pathways that radionuclides and other contaminants could take to reach the environment surrounding WIPP. Pathways monitored include air, groundwater, surface water, soils, sediments, vegetation, and game animals. Groundwater quality and wildlife populations (raptors) are also monitored. The goal of the program is to determine if the local ecosystem has been impacted during the predisposal and disposal phases of WIPP, and, if so, to evaluate the severity, geographic extent, and environmental significance of those impacts. The Environmental Monitoring Program is conducted in compliance with DOE Orders 5400.1 and 5400.5.

Southeastern New Mexico is home to an abundant array of wildlife. Wildlife species are monitored on the WIPP site to document population changes that may occur as a result of WIPP activities. Species of special concern, including federally listed threatened and endangered species, receive special consideration when planning WIPP activities that may impact wildlife habitat. 
The Waste Isolation Pilot Plant Land Management Plan (LMP) (DOE/WIPP 93-004) was created in accordance with the WIPP Land Withdrawal Act of 1992 (LWA) (Public Law [Pub. L.] 102-579). This plan identifies resource values, promotes multiple-use management, and identifies long-term goals for the management of WIPP lands. In accordance with the LMP, WIPP follows a land reclamation program and a long-range reclamation plan. WIPP also conducts oil and gas surveillance in the region surrounding the site to identify new activities associated with oil and gas exploration and production.

\section{Environmental Compliance}

WIPP is required to comply with applicable federal and state laws and DOE Orders. In order to demonstrate compliance, the following deliverables are submitted to the NMED and the U.S. Environmental Protection Agency (EPA):

\section{$\underline{\text { NMED Deliverables }}$}

A. Hazardous Waste Facility Permit (HWFP)

Annual Volatile Organic Compounds (VOCs) Monitoring and Ventilation Report Quarterly Solid Waste Management Unit (SWMU) Activities Progress Report Biennial Treatment, Storage, and Disposal (TSDF) Report Waste Minimization Report Detection Monitoring Program Statistical Comparison Report Round 14 Water Quality Sampling Program (WQSP) Groundwater Report Round 15 WQSP Groundwater Report Geotechnical Analysis Report Monthly Water Level Results Report

B. New Mexico Water Quality Act

Quarterly Discharge Monitoring Reports

EPA

2002 Annual Change Report

Federal Acquisition, Recycling, and Pollution Prevention

In 1995, WIPP adopted a systematic and cost-effective affirmative procurement plan for the promotion and procurement of products containing recovered materials. Affirmative procurement is designed to "close the loop" in the waste minimization recycling process by supporting the market for materials collected through recycling and salvage operations.

WIPP continued its recycling program in 2002. Noteworthy pollution prevention (P2) activities completed: 
- $\quad$ Chemical use reduction

- Electronic material data safety sheet (MSDS) system implementation

- Recycled metal bin inspection

\section{Resource Conservation and Recovery Act}

The Resource Conservation and Recovery Act of 1976 (RCRA) (42 U.S.C. $§ 6901$ et seq.) requires that hazardous waste be managed from the point of generation through ultimate disposal in a manner that is protective of human health and the environment. The state of New Mexico is authorized by the EPA to implement the provisions of the RCRA in accordance with the New Mexico Hazardous Waste Act (New Mexico Statutes Annotated [NMSA] 1978, §74-4-1 et seq.). WIPP operates in accordance with an HWFP issued by the NMED in accordance with 20.4.1.500 NMAC [New Mexico Administrative Code] and 20.4.1.900 NMAC. The HWFP authorizes the storage of contact-handled $(\mathrm{CH})$ transuranic (TRU) waste in two locations (the Parking Area Unit and Waste Handling Building) and the disposal of $\mathrm{CH}$ TRU waste in the three underground Hazardous Waste Disposal Units.

\section{National Environmental Policy Act}

The National Environmental Policy Act (NEPA) requires the federal government to use all practicable means to consider potential environmental impacts of proposed federal projects as part of the decision-making process. The NEPA dictates the public shall be allowed to review and comment on proposed projects that have the potential to significantly affect the environment. The NEPA also directs the federal government to use all practicable means to improve and coordinate federal plans, functions, programs, and resources relating to human health and the environment.

Title 10 Code of Federal Regulations (CFR) §1021.331, "National Environmental Policy Act Implementing Procedures, Mitigation Action Plans," requires, following completion of each Environmental Impact Statement (EIS) and its associated Record of Decision (ROD), that the DOE prepare a mitigation action plan addressing mitigation commitments expressed in the ROD. DOE Order 451.1B, National Environmental Policy Act Compliance Program, requires DOE facilities to track and report annual progress in implementing a commitment for environmental impact mitigation. To fulfill this DOE Order requirement, the CBFO issued the 2002 Annual Mitigation Report for the Waste Isolation Pilot Plant in July 2002.

\section{National Historic Preservation Act}

The National Historic Preservation Act (NHPA) (16 U.S.C. $\$ 470$ et seq.) was enacted to protect the nation's cultural resources and establish the National Register of Historic Places. Federal agencies are required to ensure that historic and cultural properties are given proper protection and consideration during land use deliberations and in the 
preparation of NEPA-related documents. No new archeological sites were discovered in 2002.

\section{Hazardous Materials Transportation Act}

The Hazardous Materials Transportation Act (HMTA) (49 U.S.C. §5101 et seq.; 49 CFR Parts 105 through 178) is one of the major transportation-related statutes that affects WIPP operations. It provides the requirements for the safe transportation of hazardous materials, including radioactive materials. DOE Orders establish packaging and transportation criteria and require DOE field offices to conduct operations in accordance with all applicable international, federal, state, local, and tribal laws, rules, and regulations governing materials transportation. These DOE Orders also require the development of a transportation plan and use of the DOE TRANSCOM (transportation and tracking communications) system to monitor shipments.

\section{Packaging and Transporting Radioactive Materials}

The WIPP LWA requires TRU waste containers destined for WIPP to be shipped using specification packagings certified by the Nuclear Regulatory Commission (NRC). Certified shipping containers tor TRU waste satisfy NRC QA requirements. CH TRU waste is shipped in TRUPACT-II (Transuranic Package Transporter Model II) and HalfPACT (short Transuranic Package Transporter) containers. Containers for remotehandled $(\mathrm{RH})$ waste were certified in 2001.

\section{Environmental Compliance Assessment Program}

The Environmental Compliance Assessment Program plays a major role in the overall program for environmental protection activities at WIPP. The program was developed to determine if facility activities protect human health and the environment and if these activities are in compliance with applicable federal, state, and local requirements; with permit conditions and requirements; and with best management practices. During 2002, WTS performed environmental assessments (EAs) of the following general areas:

- $\quad$ Construction and demolition debris landfill requirements

- $\quad$ WIPP Hazardous waste management and land disposal restrictions

- $\quad$ WIPP low-volume air sampling program

- $\quad$ Surface water and sediment sampling program

\section{Environmental Management System}

WTS has implemented at the WIPP an EMS that conforms to the criteria of the International Organization for Standardization (ISO) 14001, Environmental Management Systems. The WTS EMS received a third party ISO 14001 registration on August 5, 1997. An annual review of the EMS, which was completed in December 2002, identified no nonconformance or findings. The EMS registrar recommended continuous registration of the WTS EMS. 


\section{Waste Isolation Pilot Plant 2002 Site Environmental Report DOE/WIPP 03-2225}

All environmental safety performance measures and commitments established for WIPP for FY 2002 have been met and new performance goals are established for FY2003. The annual establishment, implementation, tracking, trending, analysis, and reporting of environmental performance measures is consistent with the ISMS 5th core function, Feedback and Continuous Improvement.

Volatile Organic Compound Monitoring

In 2002 bi-weekly VOC samples were collected during the reporting period. The measured VOC concentrations at each station and the differences between the sampling station upstream and downstream of the active waste panel were very small relative to the concentrations of concern. The VOC measurements indicate that the panel contributed little or no VOCs to the mine air downwind of the active panel. Therefore, there were no significant releases of VOCs from the waste in Panel 1 and the measured VOC concentrations downstream of the panel were comparable to the upstream values. There were no Tentatively Identified Compounds that exceeded concentrations that would warrant further investigation. All HWFP requirements were met and no exceedance notifications to the NMED were required in 2002.

\section{Groundwater Monitoring}

In 2002 each of the seven Water Quality Sampling Wells were sampled twice. There were no detections above regulatory thresholds. The analytical data set from each well was compared to the groundwater baseline that was established prior to WIPP being operational. Through this review it was determined that all analytical values for the groundwater samples were within the statistical range established in the baseline. Therefore, all HWFP requirements were met and no exceedance notifications to the NMED or the EPA were required in 2002.

\section{Environmental Radiological Program Information}

Radionuclides present in the environment, whether naturally occurring or from human-made sources, contribute to radiation doses to humans. Therefore, environmental monitoring at nuclear facilities is imperative for characterizing radiological conditions, and for detecting releases and determining their effects, should they occur. The WIPP Environmental Monitoring Program monitors air, surface and groundwater, soils, and biota to characterize the radiation environment and to detect potential releases from WIPP activities. Plutonium-238, ${ }^{239+240} \mathrm{Pu},{ }^{241} \mathrm{Am},{ }^{60} \mathrm{Co},{ }^{90} \mathrm{Sr},{ }^{137} \mathrm{Cs},{ }^{234} \mathrm{U}$, ${ }^{235} \mathrm{U}$, and ${ }^{238} \mathrm{U}$ are monitored because they are components of TRU waste. Potassium-40 is monitored because of possible enhancement in southeastern New Mexico due to potash mining. There were no statistically significant differences between sampling years 2001 and 2002 for the concentration of any radionuclide. 


\section{Radiological Dose Assessment}

The potential radiation dose to members of the public from WIPP operations has been calculated and demonstrates compliance with federal regulations and the DOE's policies and objectives of keeping this dose as low as possible.

\section{Dose Limits}

For more than 50 years, extensive research has been conducted on the effects of radiation on humans and the environment. Much of this research used standard epidemiological and toxicological approaches to characterize the response of populations and individuals to high radiation doses. From these data, a good understanding of the risks associated with high radiation doses was achieved. However, there is still uncertainty as to what risks are incurred from low radiation dose and dose rates, so models are used to predict these risks. Title 40 CFR $\S 61.92$ established that the emissions of radionuclides to the ambient air from DOE facilities shall not exceed an effective dose equivalent of $10 \mathrm{mrem}$ (millirem) per year to a member of the public.

\section{Background Radiation}

Radiation is a naturally occurring phenomenon that has been in the environment since the beginning of time. There are several sources of natural radiation: cosmic and cosmogenic radiation (from outer space and the earth's atmosphere), terrestrial radiation (from the earth's crust), and internal radiation (naturally occurring radiation in our bodies). In addition to natural radioactivity, small amounts of radioactivity from the 1986 Chernobyl nuclear accident and above-ground nuclear weapons tests that occurred from 1945 to 1980 are also present in the environment. Together, these sources of radiation are called "background" radiation. Every human is constantly exposed to background radiation. Exposure to radioactivity from weapons testing fallout is quite small compared to natural radioactivity and continually gets smaller as radionuclides decay. The average annual dose received by a member of the public from naturally occurring radionuclides is about $3 \mathrm{mSv}$ (millisievert) (300 mrem) (NCRP [National Council on Radiation Protection and Measurements], 1987b).

\section{Dose from Air Emissions}

The National Emission Standards for Hazardous Air Pollutants (NESHAP) issued by the EPA set limits for doses due to radionuclide emissions to air. To determine the potential radiation dose received by members of the public from WIPP, WTS used the EPA-approved computer model CAP88-PC, version 2.0. CAP88-PC dose calculations are based on the assumption that exposed people remain at home during the entire year and all vegetables, milk, and meat consumed are home produced. Thus, this dose calculation is a maximum potential dose which encompasses dose from inhalation, plume submersion, deposition, and ingestion of air-emitted radionuclides. 


\section{Waste Isolation Pilot Plant 2002 Site Environmental Report DOE/WIPP 03-2225}

\section{$\underline{\text { Total Potential Dose from WIPP Operations }}$}

The potential dose to an individual from the ingestion of WIPP-related radionuclides transported in water is estimated to be nonexistent. Drinking water for communities near WIPP comes from groundwater sources that are too far away to be affected by potential WIPP contaminants. Groundwater and surface water samples collected around WIPP during 2002 did not contain radionuclide concentrations different from those in samples collected prior to WIPP receiving waste.

Game animals sampled during 2002 were mule deer, quail, and fish. The only radionuclides detected were not different from background levels measured prior to commencement of waste shipments to WIPP. Therefore, no dose from WIPP-related radionuclides is estimated to have been received by any individual from this pathway during 2002.

The only pathway for which a dose could be estimated was that of air emissions. Air emissions from WIPP were not considered above background ambient air levels. Estimated concentrations of radionuclides in air emissions accounted for the calculable dose from WIPP operations during 2002. The radioactivity of environmental samples collected in 2002 is comparable to the preoperational levels (DOE/WIPP 92-037, Statistical Summary of the Radiological Baseline for the Waste Isolation Pilot Plant). The effective dose equivalent to the maximally exposed individual near WIPP is very small $\left(7.61 \times 10^{-6} \mathrm{mrem} / \mathrm{year}\right)$. This dose is insignificant as compared to the EPA limit of $10 \mathrm{mrem} /$ year to a member of the public.

\section{Dose to Nonhuman Biota}

DOE Order 5400.5 lists the environmental radiation protection requirements that WIPP must meet to protect aquatic animals. In addition, dose limits below which no deleterious effects on populations of aquatic and terrestrial organisms have been observed, have been discussed by the NCRP and the International Atomic Energy Agency. Those absorbed dose limits are:

$\begin{array}{ll}\text { - } & \text { Aquatic Animals } 10 \mathrm{mGy} / \mathrm{d}(\mathrm{milli} \text { Gray/day), }(1 \mathrm{rad} / \mathrm{d}) \\ \text { - } & \text { Terrestrial Plants } 10 \mathrm{mGy} / \mathrm{d}(1 \mathrm{rad} / \mathrm{d}) \\ \text { - Terrestrial Animals } 1 \mathrm{mGy} / \mathrm{d}(0.1 \mathrm{rad} / \mathrm{d})\end{array}$

The DOE requires discussion of radiation doses to nonhuman biota in the annual site environmental report using the DOE Technical Standard, DOE-STD-1153-2002, A Graded Approach for Evaluating Radiation Doses to Aquatic and Terrestrial Biota. The Standard uses a multiphase approach, including an initial screening phase with conservative assumptions.

This guidance was used to screen radionuclide concentrations observed around WIPP during 2002. The sum of fractions was less than one for all media. Radiation in the environment surrounding WIPP does not have a deleterious effect on populations of plants and animals. 


\section{$\underline{\text { Release of Property Containing Residual Radioactive Material }}$}

There was no release of radiologically contaminated materials or property in 2002 . The potential for release of contaminated materials or property at WIPP is based on DOE Order 5400.5, and contractor institutional controls.

\section{Quality Assurance}

The fundamental objective of a QA program is to ensure high-quality measurements are produced and reported from the analytical laboratory. The defensibility of data generated by laboratories must be based on sound scientific principles, method evaluations, and data verification and validation. Wastren, of Grand Junction, Colorado; Air Toxics, Ltd. of Folsom, California; and Trace Analysis, of Lubbock, Texas, were the contract laboratories that performed the radiological and nonradiological analyses for WIPP environmental samples. WIPP Laboratories performed the radiological analyses on the environmental monitoring samples. 
This page intentionally left blank 


\section{TABLE OF CONTENTS}

ACKNOWLEDGMENTS $\ldots \ldots \ldots \ldots \ldots \ldots \ldots \ldots \ldots \ldots \ldots \ldots \ldots \ldots \ldots \ldots$ iii

EXECUTIVE SUMMARY $\ldots \ldots \ldots \ldots \ldots \ldots \ldots \ldots \ldots \ldots \ldots$

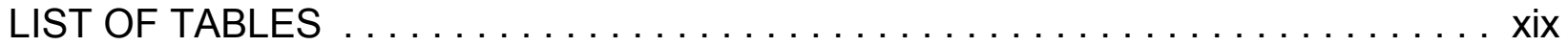

LIST OF FIGURES $\ldots \ldots \ldots \ldots \ldots \ldots \ldots \ldots \ldots \ldots \ldots \ldots \ldots \ldots \ldots \ldots$

CHAPTER 1 - INTRODUCTION $\ldots \ldots \ldots \ldots \ldots \ldots \ldots \ldots \ldots \ldots \ldots \ldots \ldots \ldots$

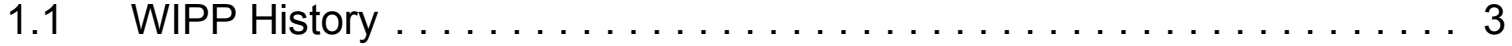

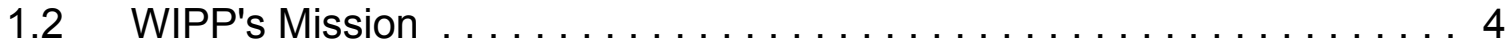

$1.3 \quad$ WIPP Location $\ldots \ldots \ldots \ldots \ldots \ldots \ldots \ldots \ldots \ldots \ldots \ldots$

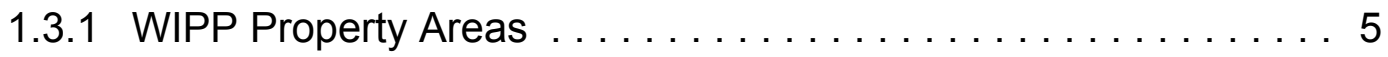

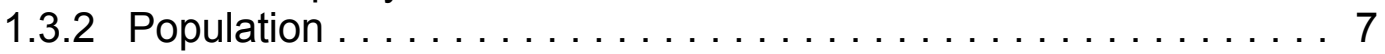

1.4 Environmental Performance $\ldots \ldots \ldots \ldots \ldots \ldots \ldots \ldots \ldots \ldots$

CHAPTER 2 - ENVIRONMENTAL PROGRAM INFORMATION ........... 9

$2.1 \quad$ Environmental Monitoring Plan $\ldots \ldots \ldots \ldots \ldots \ldots \ldots \ldots$

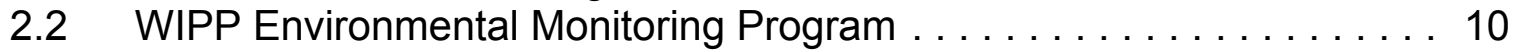

2.3 Land Management Programs $\ldots \ldots \ldots \ldots \ldots \ldots \ldots \ldots \ldots \ldots \ldots$

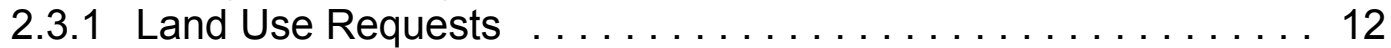

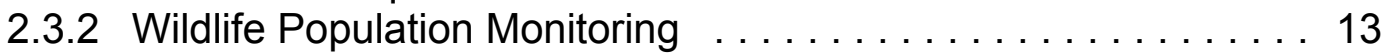

2.3.3 Reclamation of Disturbed Lands . . . . . . . . . . . . 14

2.3.4 Oil and Gas Surveillance $\ldots \ldots \ldots \ldots \ldots \ldots \ldots \ldots \ldots$

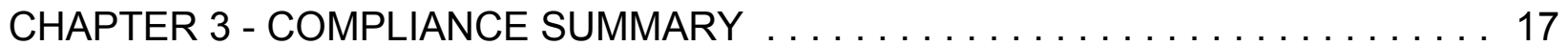

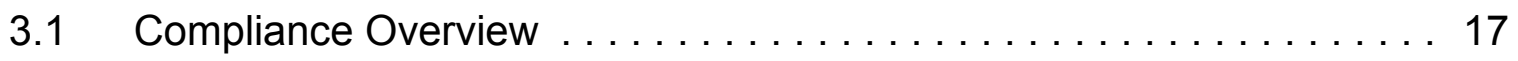

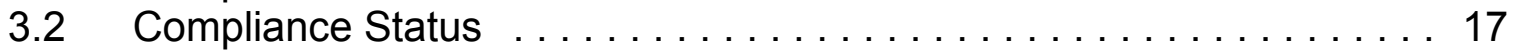

3.2.1 Comprehensive Environmental Response, Compensation, and Liability Act . ................... 17

3.2.2 Federal Acquisition, Recycling, and Pollution Prevention ..... 18

3.2.3 Resource Conservation and Recovery Act . . . . . . . . . . 19

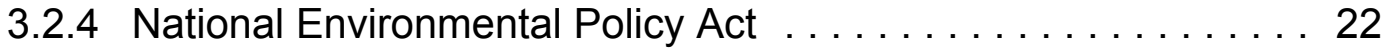

3.2 .5 Clean Air Act . . . . . . . . . . . . . . . . . . . . . . . 23

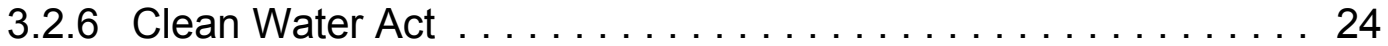

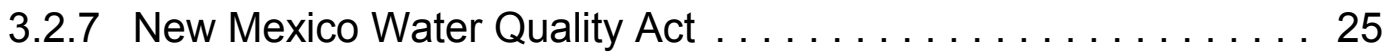

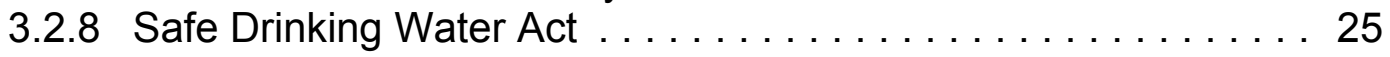

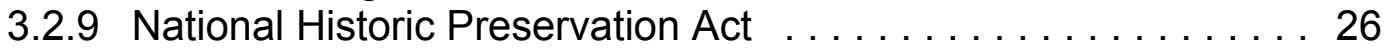

3.2.10 Hazardous Materials Transportation Act . . . . . . . . . 26

3.2.11 Packaging and Transporting Radioactive Materials . . . . . 27

3.2.12 Toxic Substances Control Act . . . . . . . . . . . . . . 28

3.3 Other Significant Accomplishments and Ongoing Compliance

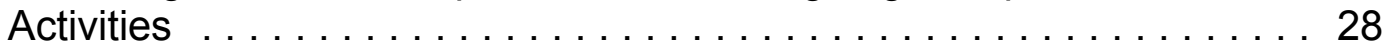

3.3.1 Environmental Compliance Assessment Program . . . . . . 28

3.3.2 Environmental Management System . . . . . . . . . . . 30 
3.3.3 Pollution Prevention Committee $\ldots \ldots \ldots \ldots \ldots \ldots \ldots \ldots .31$

3.3.4 Environmental Training ................... 33

CHAPTER 4 - ENVIRONMENTAL RADIOLOGICAL PROGRAM INFORMATION . 47

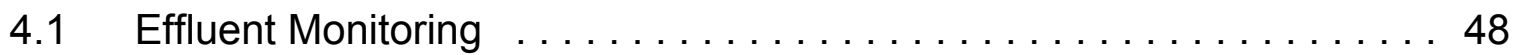

$4.2 \quad$ Airborne Gross Alpha/Beta $\ldots \ldots \ldots \ldots \ldots \ldots \ldots \ldots \ldots \ldots . \ldots 48$

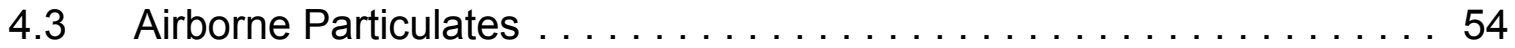

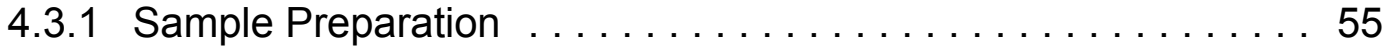

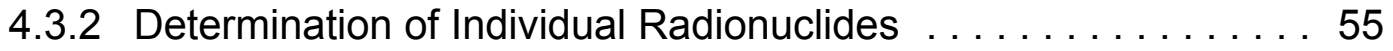

4.3.3 Results and Discussions . . . . . . . . . . . . . . . . . 55

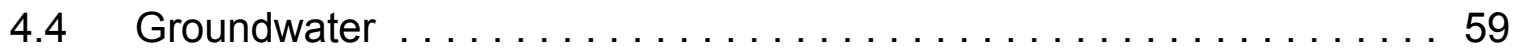

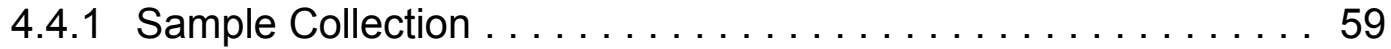

4.4.2 Determination of Individual Radionuclides ... . . . . . . . 59

4.4 .3 Results and Discussions . . . . . . . . . . . . . . . . . 59

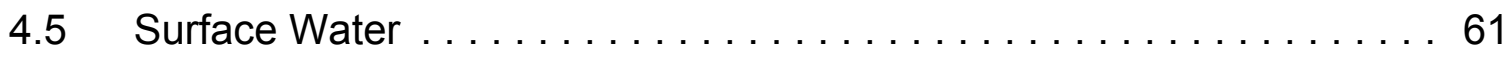

4.5.1 Sample Collection . . . . . . . . . . . . . . . . . 61

4.5.2 Determination of Individual Radionuclides ........... 62

4.5.3 Results and Discussions . . . . . . . . . . . . . . . . 63

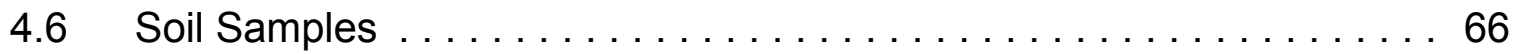

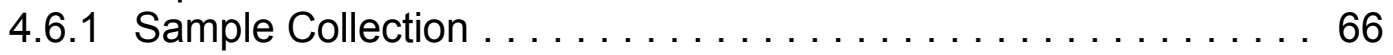

4.6.2 Sample Preparation . . . . . . . . . . . . . . . 66

4.6.3 Determination of Individual Radionuclides . . . . . . . . . 66

4.6.4 Results and Discussions . . . . . . . . . . . . . . . . . . 67

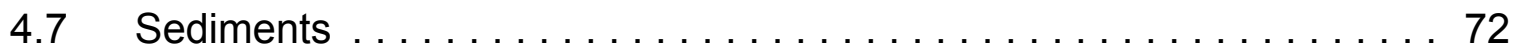

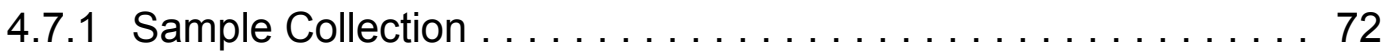

4.7 .2 Sample Preparation . . . . . . . . . . . . . . . 72

4.7.3 Determination of Individual Radionuclides . . . . . . . . . . 73

4.7.4 Results and Discussions . . . . . . . . . . . . . . . . . 73

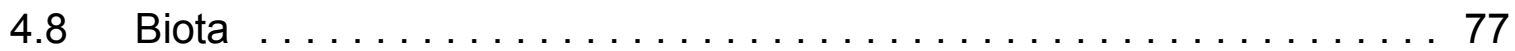

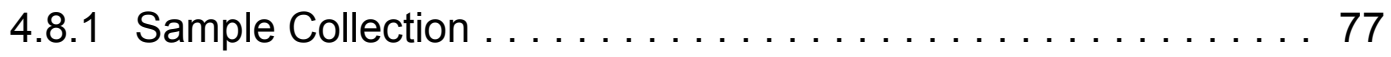

4.8 .2 Sample Preparation $\ldots \ldots \ldots \ldots \ldots \ldots \ldots \ldots \ldots \ldots . \ldots \ldots$

4.8.3 Results and Discussions . . . . . . . . . . . . . . . . . 77

4.9 Summary and Conclusion $\ldots \ldots \ldots \ldots \ldots \ldots \ldots \ldots \ldots \ldots \ldots$

CHAPTER 5 - ENVIRONMENTAL NONRADIOLOGICAL PROGRAM

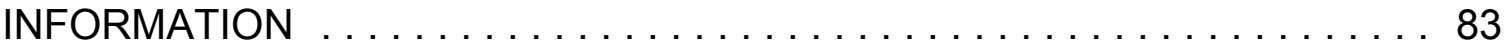

$5.1 \quad$ Principal Functions of Nonradiological Sampling . . . . . . . . . 83

$5.2 \quad$ WIPP Raptor Research Program $\ldots \ldots \ldots \ldots \ldots \ldots \ldots \ldots \ldots . \ldots 3$

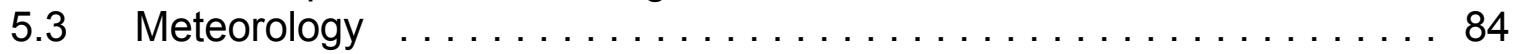

5.3 .1 Climatic Data . . . . . . . . . . . . . . . . . . 85

5.3.2 Wind Direction and Wind Speed ................ 85

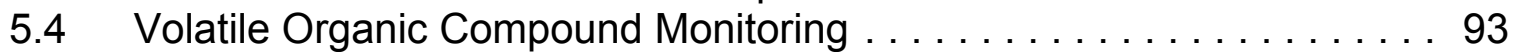

$5.5 \quad$ Seismic Activity . . . . . . . . . . . . . . . . . . . . 95

5.6 Liquid Effluent Monitoring $\ldots \ldots \ldots \ldots \ldots \ldots \ldots \ldots \ldots \ldots$ 
CHAPTER 6 - GROUNDWATER MONITORING . . . . . . . . . . . . . . . . . . 99

6.1 Groundwater Quality Sampling . . . . . . . . . . . . . . . . . 100

6.2 Groundwater Level Surveillance . . . . . . . . . . . . . . . . . . . . . . . . 102

6.3 Well Maintenance Activities . . . . . . . . . . . . . . . . . . . . . . . . . . 104

6.4 Shallow Subsurface Water Monitoring Program . . . . . . . . . . . . . . 105

6.4.1 Shallow Subsurface Water Quality Sampling . . . . . . . . . . . . . . 106

6.4.2 Shallow Subsurface Water Level Surveillance . . . . . . . . . . . 106

CHAPTER 7 - RADIOLOGICAL DOSE ASSESSMENT . . . . . . . . . . . . . . . 159

7.1 Introduction and Dose Limits . . . . . . . . . . . . . . . . 159

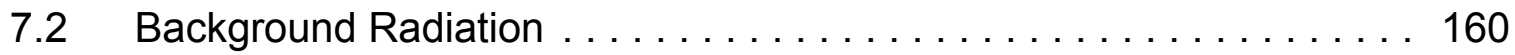

7.3 Dose from Air Emissions . . . . . . . . . . . . . . . . . . . 161

7.4 Total Potential Dose from WIPP Operations . . . . . . . . . . . . . . . 161

7.4.1 Potential Dose from Water Ingestion Pathway . . . . . . . . . . . 162

7.4.2 Potential Dose from Wild Game Ingestion . . . . . . . . . . . . . 162

7.4.3 Total Potential Dose from All Pathways . . . . . . . . . . . . . . . 162

7.5 Dose to Nonhuman Biota . . . . . . . . . . . . . . . . . . . . 163

7.6 Release of Property Containing Residual Radioactive Material . . . 164

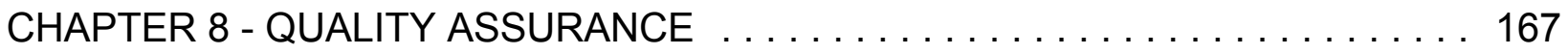

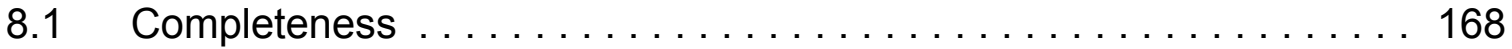

8.2 Precision . . . . . . . . . . . . . . . . . . . . 168

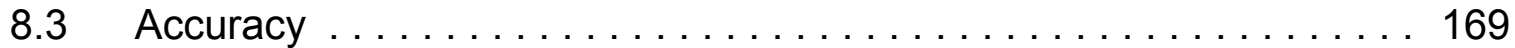

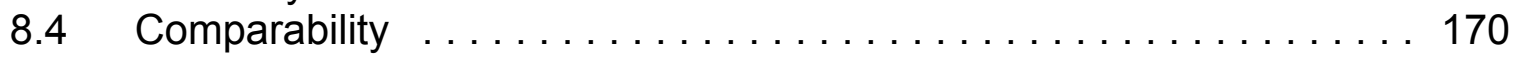

8.5 Representativeness . . . . . . . . . . . . . . . . . 171

REFERENCES . . . . . . . . . . . . . . . . . . . . . . . . . . . 189

Appendix A - Acronyms, Abbreviations, and Symbols . . . . . . . . . . . A-1

Appendix B - Location Codes . . . . . . . . . . . . . . . . . . B-1

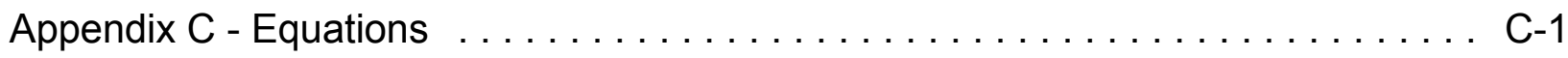

Appendix D - Concentrations of Alpha and Beta Activities in Air Particulates . . . . . D-1

Appendix E - Air Sampling Data: Mass and Volume of Composite Air Samples ... E-1

Appendix F - Time Trend Plots for Detectable Constituents in Groundwater . . . . . F-1

Appendix G - Air Sampling Data: Concentrations of Radionuclides . . . . . . . . . . G-1 
This page intentionally left blank 


\section{LIST OF TABLES}

Table 2.1 - Sampling Schedule for the WIPP Environmental Monitoring

Program ........................... 10

Table 3.1 - Permit Modification Requests Submitted During Calendar

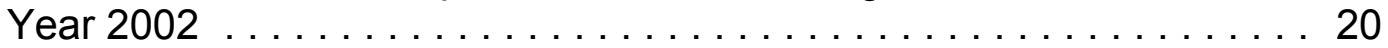

Table 3.2 - Materials Recycled at WIPP in $2002 \ldots \ldots \ldots \ldots$. . . . . . . . . . . . 32

Table 3.3 - Activities Associated with Major Environmental Statutes Applicable to the WIPP Project in $2002 \ldots \ldots \ldots \ldots \ldots$. . . . . . . . . . . . . . . .

Table 3.4 - Primary DOE Orders Affecting the WIPP Environmental Program . . . 36

Table 3.5 - Active Environmental Permits and Approvals for the Waste Isolation Pilot Plant - April 1, $2003 \ldots \ldots \ldots \ldots \ldots \ldots \ldots \ldots \ldots \ldots$

Table 4.1 - Activity $(\mathrm{Bq})$ of Quarterly Composite Air Samples from Effluent Monitoring Stations A, B, and C ............... 49

Table 4.2 - Mean Gross Alpha and Gross Beta Activity Concentrations $\left(\mathrm{Bq} / \mathrm{m}^{3}\right)$ Found in Weekly Air Particulate Samples . . . . . . . . . . . 53

Table 4.3 - Minimum, Maximum and Average Radionuclide Concentrations $\left(\mathrm{Bq} / \mathrm{m}^{3}\right)$ in Air Filter Composites from Stations Surrounding the WIPP Site

Table 4.4 - Results of Duplicate Composite Air Filter Sampling . . . . . . . . . 58

Table 4.5 - Preliminary Quarterly Average Radionuclide Concentrations $\left(\mathrm{Bq} / \mathrm{m}^{3}\right)$ Measured in Air Particulate Samples by the Environmental Evaluation Group in $2002 \ldots \ldots \ldots \ldots \ldots \ldots$. . . . . . . . . . 58

Table 4.6 - Average Radionuclide Concentrations (Bq/L) in Groundwater from Wells at the WIPP Site . . . . . . . . . . . . . . . . . 60

Table 4.7 - Uranium Concentrations $(\mathrm{Bq} / \mathrm{L})$ in Surface Water Near the WIPP Site

Table 4.8 - Americium and Plutonium Concentrations (Bq/L) in Surface Water Near the WIPP Site

Table 4.9 - Selected Radionuclide Concentrations (Bq/L) in Surface Water Near

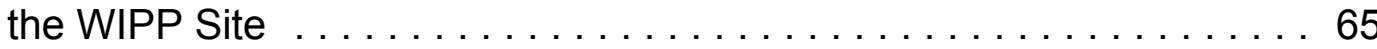

Table 4.10 - Results of Duplicate Surface Water Sample Analysis . . . . . . . . . . 66 


\section{Waste Isolation Pilot Plant 2002 Site Environmental Report DOE/WIPP 03-2225}

Table 4.11 - Uranium Concentrations $(\mathrm{Bq} / \mathrm{g})$ in Soil Near the WIPP Site. . . . . . . 68

Table 4.12 - Americium and Plutonium Concentrations $(\mathrm{Bq} / \mathrm{g})$ in Soil Near the WIPP Site . . . . . . . . . . . . . . . . . . . . . . . . . . . . . 69

Table 4.13 - Selected Radionuclide Concentrations $(\mathrm{Bq} / \mathrm{g})$ in Soil Near the WIPP Site . . . . . . . . . . . . . . . . . . . . . . . 71

Table 4.14 - Results of Duplicate Soil Sample Analysis . . . . . . . . . . . . . 72

Table 4.15 - Uranium Concentrations $(\mathrm{Bq} / \mathrm{g})$ in Sediment Near the WIPP Site . . . . 74

Table 4.16 - Americium and Plutonium Concentrations $(\mathrm{Bq} / \mathrm{g})$ in Sediment Near the WIPP Site . . . . . . . . . . . . . . . . . . . . . . . . . . . . 74

Table 4.17 - Selected Radionuclide Concentrations $(\mathrm{Bq} / \mathrm{g})$ in Sediment Near the WIPP Site

Table 4.18 - Results of Duplicate Sediment Sample Analysis . . . . . . . . . 76

Table 4.19 - Radionuclide Concentrations (Bq/g Wet Mass) in Vegetation Near the WIPP Site . . . . . . . . . . . . . . . . . . . . . . . . 78

Table 4.20 - Results of Duplicate Vegetation Sample Analysis . . . . . . . . . . . 79

Table 4.21 - Radionuclide Concentrations (Bq/g Wet Mass) in Deer and Quail Near the WIPP Site . . . . . . . . . . . . . . . . . . . . . . . . . . . 79

Table 4.22 - Radionuclide Concentrations (Bq/g Wet Mass) in Fish Near the WIPP Site

Table 5.1 - A Summary of 2002 Temperature Observations at 2-Meter Height $\ldots 87$

Table 5.2 - A Summary of 2002 Temperature Observations at 10-Meter Height . . 88

Table 5.3 - A Summary of 2002 Temperature Observations at 50-Meter Height . . 89

Table 5.4 - 2002 Wind Frequencies at 2-Meter Height, Stratified by Direction

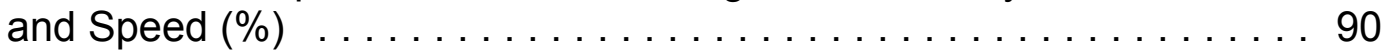

Table 5.5 - 2002 Wind Frequencies at 10-Meter Height, Stratified by Direction and Speed $(\%) \ldots \ldots \ldots \ldots \ldots$

Table 5.6 - 2002 Wind Frequencies at 50-Meter Height, Stratified by Direction

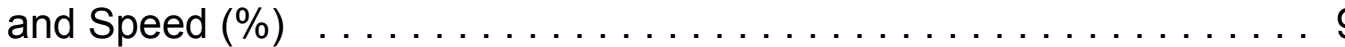


Table 5.7 - Concentrations of Concern for Volatile Organic Compounds, from Attachment $\mathrm{N}$ of the HWFP . . . . . . . . . . . . . . . 93

Table 5.8 - Volatile Organic Compound Sample Pair Differences Measured at

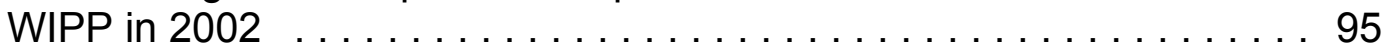

Table 6.1 - Pressure Density Survey for $2002 \ldots \ldots \ldots$. . . . . . . . . . . . . 104

Table 6.2 - Analytical Parameters for Which Groundwater Was Analyzed . . . . 112

Table 6.3 - Analytical Results for Groundwater Sampled from Well WQSP-1 . . 113

Table 6.4 - Analytical Results for Groundwater Sampled from Well WQSP-2 . . . 115

Table 6.5 - Analytical Results for Groundwater Sampled from Well WQSP-3 . . . 117

Table 6.6 - Analytical Results for Groundwater Sampled from Well WQSP-4 . . . 119

Table 6.7 - Analytical Results for Groundwater Sampled from Well WQSP-5 . . . 121

Table 6.8 - Analytical Results for Groundwater Sampled from Well WQSP-6 . . . 123

Table 6.9 - Analytical Results for Groundwater Sampled from Well WQSP-6A . 124

Table 6.10 - Summary of 2002 DOE Sitewide Groundwater Monitoring Program .......................... 127

Table 6.11 - Groundwater Level Measurement Results for 2002 . . . . . . . . . 128

Table 6.12 - Shallow Subsurface Water Analyses . . . . . . . . . . . . . . . 153

Table 6.13 - Shallow Subsurface Water Level Measurements . . . . . . . . . . . 155

Table 7.1 - Annual Estimated Average Radiation Dose Received by a Member of the Population of the United States from Naturally Occurring Radiation Sources . . . . . . . . . . . . . . . . . . . . 161

Table 7.2 - WIPP Radiological Dose and Release Summary . . . . . . . . . . 163

Table 7.3 - General Screening Results for Potential Radiation Dose to Nonhuman Biota from Radionuclide Concentrations in Surface Water $(\mathrm{Bq} / \mathrm{L})$, Sediment $(\mathrm{Bq} / \mathrm{g})$, and Soil $(\mathrm{Bq} / \mathrm{g})$ Near the WIPP Site 165

Table 8.1 - Comparison of Duplicate Air Monitoring Results (First Quarter of 2002) from WIPP Laboratories Data from Carlsbad (CBD) Sampling Location 
Table 8.2 - Comparison of Duplicate Air Monitoring Results

(Second Quarter of 2002) from WIPP Laboratories Data from

Southeast Control (SEC) Sampling Location ............... 174

Table 8.3 - Comparison of Duplicate Air Monitoring Results

(Third Quarter of 2002) from WIPP Laboratories Data from WIPP

Far Field (WFF) Sampling Location . . . . . . . . . . . . . . . . 175

Table 8.4 - Comparison of Duplicate Air Monitoring Results

(Fourth Quarter of 2002) from WIPP Laboratories Data from WIPP

East (WEE) Sampling Location . . . . . . . . . . . . . . . . 176

Table 8.5 - Environmental Measurements Laboratory Assessments for

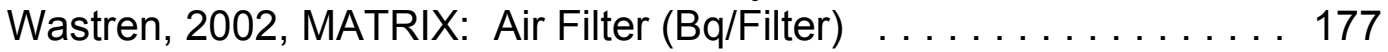

Table 8.6 - Environmental Measurements Laboratory Assessments for

Wastren, 2002, MATRIX: Soil $(\mathrm{Bq} / \mathrm{kg}) \ldots \ldots \ldots \ldots \ldots \ldots$

Table 8.7 - Environmental Measurements Laboratory Assessments for

Wastren, 2002, MATRIX: Vegetation $(\mathrm{Bq} / \mathrm{kg}) \ldots \ldots \ldots \ldots \ldots \ldots$

Table 8.8 - Environmental Measurements Laboratory Assessments for

Wastren, 2002, MATRIX: Water $(\mathrm{Bq} / \mathrm{L}) \ldots \ldots \ldots \ldots \ldots \ldots \ldots$

Table 8.9 - Environmental Resource Associates $®$ for Wastren, 2002

MATRIX: Water $(\mathrm{pCi} / \mathrm{L}) \ldots \ldots \ldots \ldots \ldots \ldots \ldots \ldots \ldots \ldots \ldots$

Table 8.10 - NRIP for WIPP Laboratories, 2002 . . . . . . . . . . . . . . . . . . . . 179

Table 8.11 - Environmental Measurements Laboratory Assessments for WIPP Laboratories, 2002, MATRIX: Air Filter (Bq/Filter) . . . . . . . 180

Table 8.12 - Environmental Measurements Laboratory Assessments for WIPP Laboratories, 2002, MATRIX: Soil $(\mathrm{Bq} / \mathrm{kg}) \ldots \ldots \ldots \ldots \ldots 180$

Table 8.13 - Environmental Measurements Laboratory Assessments for WIPP Laboratories, 2002, MATRIX: Vegetation $(\mathrm{Bq} / \mathrm{kg}) \ldots \ldots \ldots 181$

Table 8.14 - Environmental Measurements Laboratory Assessments for WIPP Laboratories, 2002, MATRIX: Water (Bq/L)

Table 8.15 - Environmental Resource Associates $₫$ Assessment of Air Toxics, Ltd., WP-93, December 9, 2002, for Volatile Organic Compounds

Table 8.16 - AbsoluteGrade PT Program Assessment of Trace Analysis, Inc. March - November, 2002. 
Waste Isolation Pilot Plant 2002 Site Environmental Report DOE/WIPP 03-2225

Table 8.17 - AbsoluteGrade PT Program Assessment of Trace Analysis, Inc., Petroleum March - November, $2002 \ldots \ldots \ldots \ldots \ldots \ldots \ldots \ldots \ldots$

Table 8.18 - AbsoluteGrade PT Program Assessment of Trace Analysis, Inc., Pesticides March - November, 2002 . . . . . . . . . . . . . . . 188 
This page intentionally left blank 


\section{LIST OF FIGURES}

Figure 1.1 - WIPP Stratigraphy $\ldots \ldots \ldots \ldots \ldots \ldots \ldots \ldots \ldots \ldots \ldots \ldots \ldots \ldots$

Figure 1.2 - WIPP Location $\ldots \ldots \ldots \ldots \ldots \ldots \ldots \ldots \ldots \ldots \ldots \ldots \ldots \ldots \ldots \ldots \ldots \ldots$

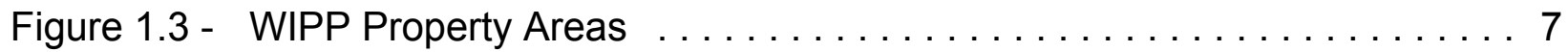

Figure 4.1 - Air Sampling Locations on and Near the WIPP Facility ........ 51

Figure 4.2 - Gross Alpha Activity Concentration Measured in Air Particulates Each Week in 2002. . . . . . . . . . . . . . . . . . . . . . 52

Figure 4.3 - Gross Beta Activity Concentration Measured in Air Particulates Each Week in $2002 \ldots \ldots \ldots \ldots \ldots \ldots \ldots \ldots \ldots \ldots \ldots \ldots \ldots \ldots \ldots \ldots$

Figure 4.4 - Average Gross Alpha and Beta Activity Concentrations Measured in Air Particulates in Four Consecutive Years. . . . . . . . . . . . . . 54

Figure 4.5 - Routine Surface Water Sampling Locations . . . . . . . . . . . 62

Figure 4.6 - Routine Soil and Vegetation Sampling Areas . . . . . . . . . . 67

Figure 4.7 - Sediment Sampling Sites $\ldots \ldots \ldots \ldots \ldots \ldots \ldots \ldots \ldots \ldots \ldots \ldots \ldots \ldots \ldots \ldots$

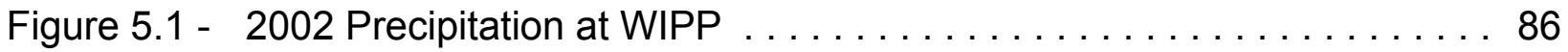

Figure 5.2 - 2002 WIPP Site Temperature at 2-Meter Height . . . . . . . . . . . 87

Figure 5.3 - 2002 WIPP Site Temperature at 10-Meter Height . . . . . . . . . . . 88

Figure 5.4 - 2002 WIPP Site Temperature at 50-Meter Height . . . . . . . . . . . . 89

Figure 5.5 - 2002 WIPP Site Wind Rose at 2-Meter Height . . . . . . . . . . . . 90

Figure 5.6 - 2002 WIPP Site Wind Rose at 10-Meter Height . . . . . . . . . . . 91

Figure 5.7 - 2002 WIPP Site Wind Rose at 50-Meter Height $\ldots \ldots \ldots \ldots \ldots . . \ldots 2$

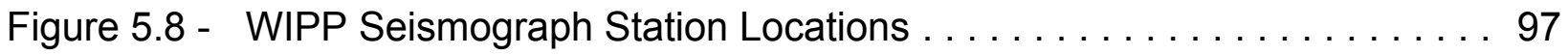

Figure 6.1 - Water Quality Sampling Program Wells ... . . . . . . . . . . 100

Figure 6.2 - Groundwater Level Surveillance Wells . . . . . . . . . . . . . 101 
Figure 6.3 - Potentiometric Surface, Adjusted to Equivalent Freshwater Head, of the Culebra Dolomite Member of the Rustler Formation Near the WIPP Site, December 2002 . . . . . . . . . . . . . . . . 107

Figure 6.4 - Flow Rte and Direction of Groundwater Flowing Across the WIPP Site from the Culebra Formation, December $2002 \ldots \ldots \ldots \ldots .108$

Figure 6.5 - Units Commonly Encountered During Shallow Drilling at WIPP . . . . 109

Figure 6.6 - Locations of SSW Wells (Piezometers PZ-1 through 12, C-2811,

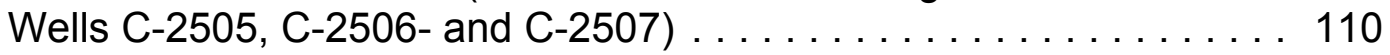

Figure 6.7 - Contour Plot of the SSW Potentionmetric Surface in the Santa Rosa Formation: December 2002 . . . . . . . . . . . . . . . . . . . . . . . . . 111 


\section{CHAPTER 1 - INTRODUCTION}

Located in southeastern New Mexico, WIPP is the world's first underground repository permitted to safely and permanently dispose of TRU radioactive and mixed waste (as defined in the WIPP LWA) generated through the research and production of nuclear weapons and other activities related to the national defense of the United States. TRU waste is defined in the WIPP LWA as radioactive waste containing more than 100 nanocuries $(3,700$ becquerels $[\mathrm{Bq}])$ of alpha-emitting elements having atomic numbers greater than uranium-92 per gram of waste, with half-lives greater than 20 years. Most TRU waste is contaminated industrial trash, such as rags, old tools, sludges from solidified liquids; and glass, metal, and other materials from dismantled buildings.

There are certain exceptions to the WIPP LWA definition of TRU waste, including high-level radioactive waste; waste that the Secretary of Energy has determined, with the concurrence of the Administrator of the EPA, does not need the degree of isolation required by 40 CFR Part 191 ("Environmental Radiation Protection Standards for the Management and Disposal of Spent Nuclear Fuel, High-Level and Transuranic Radioactive Wastes") disposal regulations; or waste that the NRC has approved for disposal on a case-by-case basis in accordance with 10 CFR Part 61.

WIPP's legislative mandate is to demonstrate the safe disposal of TRU wastes from national defense activities and programs. To fulfill this mandate, WIPP has been designed to safely handle, store, and dispose of TRU waste in a fully operational disposal facility. When waste arrives at WIPP, it is placed in excavated storage rooms, carved from rock salt, $655 \mathrm{~m}$ [meters] $(2,150 \mathrm{ft}$ [feet]) below the earth's surface. The nature of the salt is such that after a storage room has been filled, the salt will slowly fill the remaining spaces, thus isolating the waste safely for thousands of years.

WIPP is the world's first underground repository with the necessary permits and certifications for safe and permanent disposal of TRU radioactive and mixed waste generated by defense-related activities. A TRU waste is eligible for disposal at WIPP if it has been generated in whole or in part by one or more of the activities listed in the Nuclear Waste Policy Act of 1982 (42 United States Code [U.S.C.] §10101), including naval reactors development, weapons activities, verification and control technology, defense nuclear materials production, defense nuclear waste and materials by-products management, defense nuclear materials security and safeguards and security investigations, and defense research and development.

The WIPP Project is authorized by the DOE National Security and Military Applications of Nuclear Energy Authorization Act of 1980 (Pub. L. 96-164). WIPP's legislative mandate is to demonstrate the safe disposal of TRU wastes from national defense activities and programs. To fulfill this mandate, WIPP has been designed to safely handle, store, and dispose of TRU waste in a fully operational disposal facility. After more than 20 years of scientific study, public input, and regulatory research, WIPP received its first shipment of waste on March 26, 1999. 


\section{Waste Isolation Pilot Plant 2002 Site Environmental Report DOE/WIPP 03-2225}

When TRU waste arrives at WIPP, it is transported into the Waste Handling Building. The waste containers are removed from the shipping containers, placed on the waste

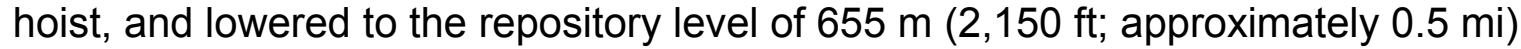
below the surface. During the disposal phase, the containers of waste are removed from the hoist and placed in excavated storage rooms in the Salado Formation, a thick sequence of salt beds deposited approximately 250 million years ago (Figure 1.1). Once a disposal area has been filled with waste, specially designed closures will be placed in the excavated disposal rooms, and seals will be placed in the shafts. Salt under pressure is relatively plastic, and mine openings will be allowed to creep closed for final disposal, encapsulating and isolating the waste.

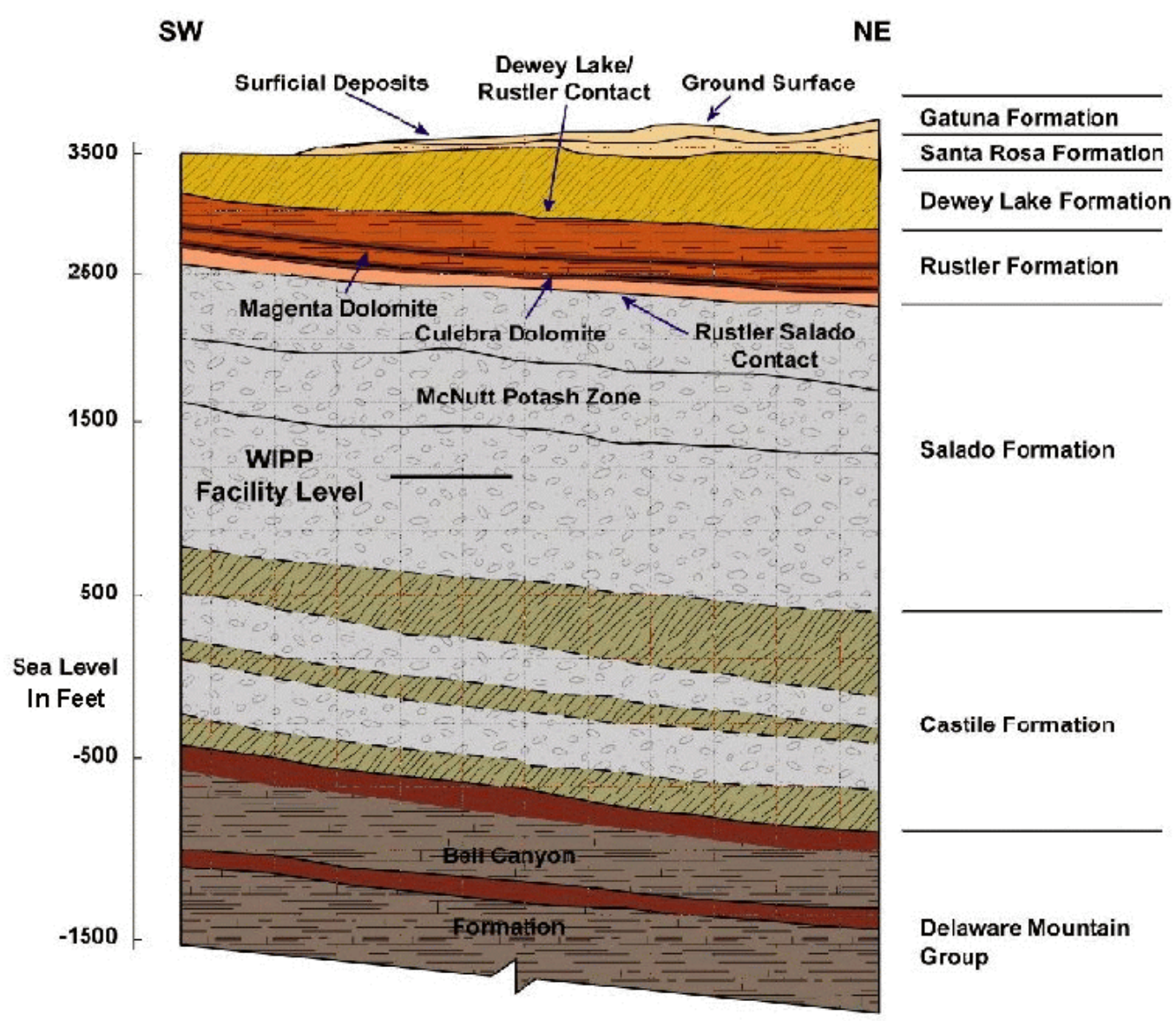

Figure 1.1 - WIPP Stratigraphy 


\subsection{WIPP History}

Government officials and scientists initiated the WIPP site selection process in the 1950s. At that time, the National Academy of Sciences conducted a nationwide search for stable geological formations to contain wastes for thousands of years. In 1955, after extensive study, salt deposits were recommended as a promising medium for the disposal of radioactive waste.

Salt was chosen as the material for the planned disposal of nuclear waste for several reasons. Most deposits of salt are found in stable geological areas with very little earthquake activity, assuring the stability of a waste repository. Salt deposits also demonstrate the absence of flowing fresh water that could move waste to the surface. Water, if it had been or were present, would have dissolved the salt beds. In addition, salt is relatively easy to mine. Finally, rock salt heals its own fractures because it is relatively plastic. This means salt formations will slowly and progressively move in to fill mined areas and will safely seal radioactive waste from the environment.

Government scientists searched for an appropriate site for the disposal of radioactive waste throughout the 1960s, and finally tested the area of southeastern New Mexico in the early 1970s. Salt formations at WIPP were deposited in thick beds during the evaporation of an ancient ocean, the Permian Sea. These geologic formations consist mainly of sodium chloride, the same substance as table salt. However, at WIPP, the salt is not granular, but is in the form of solid rock. The main salt formation at WIPP is about $610-\mathrm{m}(2,000-\mathrm{ft})$ thick, and begins $259 \mathrm{~m}$ (850 ft) below the earth's surface. Formed about 225 million years ago during the Permian Age, the large expanses of uninterrupted salt beds provide a repository that has been stable and free from the disturbances of large earthquakes for more than 200 million years. This proven stability over such a long time span offers the predictability that the salt will remain stable for the comparatively short 10,000 -year period that WIPP is mandated to isolate the waste from the human environment.

In 1979, Congress authorized the construction of WIPP, and the DOE constructed the facility during the 1980s. In late 1993, the DOE created the Carlsbad Area Office (CAO) (now CBFO) to lead the TRU waste disposal efforts. The CBFO coordinates the TRU program at waste-generating sites and national laboratories.

In 1999, WIPP received its first waste shipment. On March 25, the first waste bound for WIPP departed Los Alamos National Laboratory in New Mexico; it arrived at WIPP the following morning, and the first wastes were placed underground later that day. On April 17, WIPP celebrated its official grand opening. Ten days later, on April 27, the first out-of-state shipment arrived at WIPP, from the Idaho National Engineering and Environmental Laboratory. Later in the year, on October 27, the Secretary of the NMED issued a WIPP HWFP, which allows WIPP to manage, store, and dispose of CH TRU mixed waste. Mixed waste is waste contaminated by both hazardous and radioactive substances. "Contact-handled mixed waste" is TRU mixed waste with a surface dose rate less than 200 mrem per hour. 


\section{$1.2 \quad$ WIPP's Mission}

Current temporary radioactive waste storage facilities at 23 locations across the United States were never intended to provide permanent disposal. WIPP is the nation's first operating underground repository for defense-generated TRU waste and is a critical step toward solving the nation's nuclear waste disposal problem. Its mission is to provide for the safe, permanent, and environmentally sound disposal of TRU radioactive waste left from research, development, and production of nuclear weapons. Over the next 35 years, WIPP is expected to receive about 37,000 shipments of waste from locations across the United States.

The mission of the CBFO is to protect human health and the environment by opening and operating WIPP for safe disposal of TRU waste and by establishing an effective system for management of TRU waste from generation to disposal.

\subsection{WIPP Location}

Located in Eddy County in the remote Chihuahuan Desert of southeastern New Mexico (Figure 1.2), the WIPP site encompasses approximately 41.1 square kilometers $\left(\mathrm{km}^{2}\right)$, or 16 square miles $\left(\mathrm{mi}^{2}\right)$. The site is $42 \mathrm{~km}$ (26 mi) east of Carlsbad in a region known as Los Medaños. This part of New Mexico is relatively flat and is sparsely inhabited, with little surface water. The WIPP site boundary extends a minimum of $1.6 \mathrm{~km}(1 \mathrm{mi})$ beyond any of the WIPP underground developments. The WIPP LWA was signed into law on October 30,1992, transferring the land from the U.S. Department of the Interior to the DOE. With the exception of facilities within the boundaries of the posted $5.7 \mathrm{~km}^{2}$ $\left(2.2 \mathrm{mi}^{2}\right)$ Off-Limits Area, the surface land uses remain largely unchanged from pre-1992 uses, and are managed in accordance with accepted practices for multiple land use. However, mining and drilling for purposes other than those which support WIPP are prohibited within the WIPP site.

The majority of the lands in the immediate vicinity of WIPP are managed by the U.S. Department of the Interior's Bureau of Land Management (BLM). Land uses in the surrounding area include livestock grazing; potash mining; oil and gas exploration and production; and recreational activities such as hunting, camping, hiking, and bird watching. The region is home to diverse populations of animals and plants. 


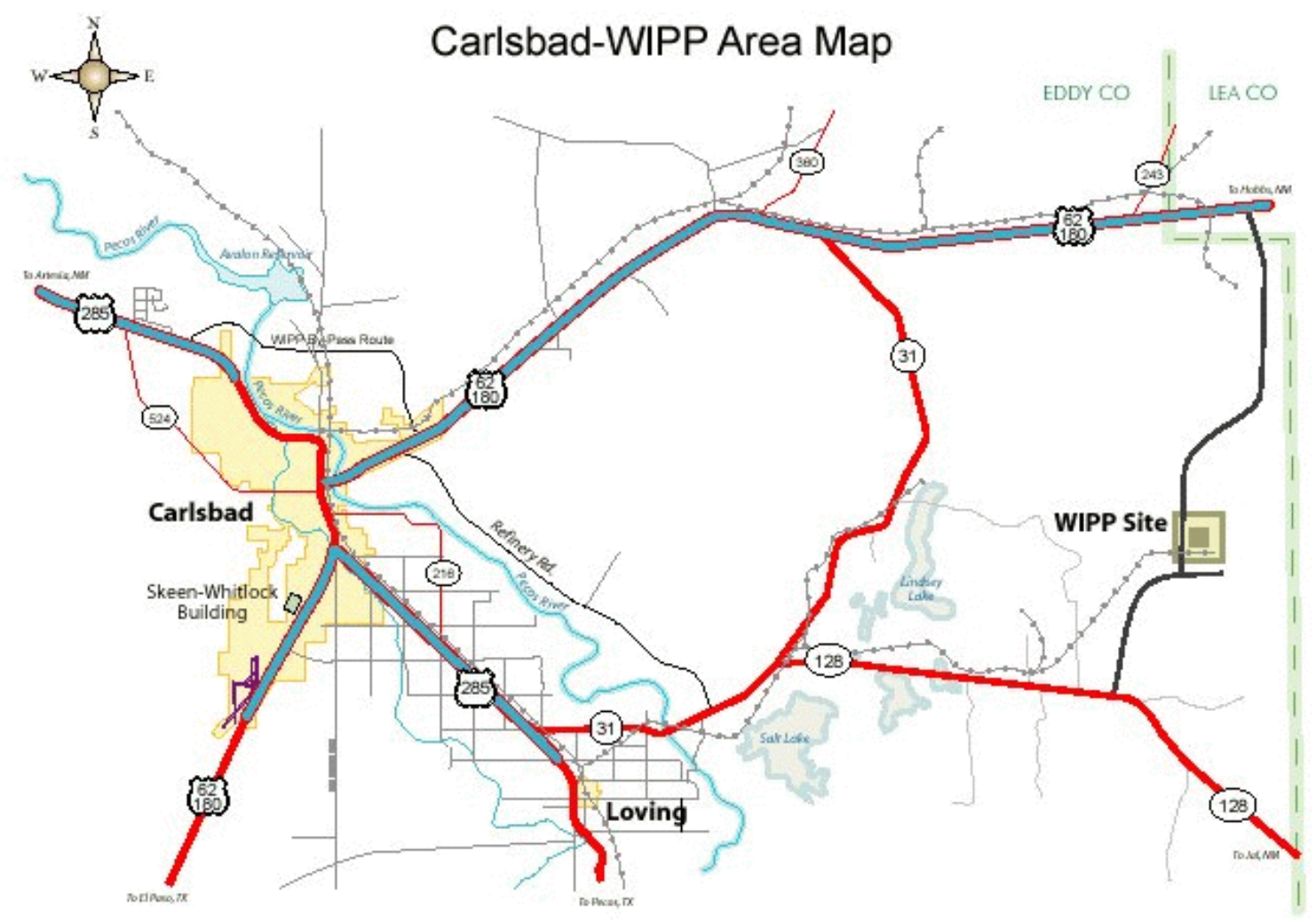

Figure 1.2 - WIPP Location

\subsubsection{WIPP Property Areas}

Five types of property areas are found within WIPP's boundary (Figure 1.3).

\section{Property Protection Area}

The interior core of the facility encompasses approximately $0.129 \mathrm{~km}^{2}\left(0.05 \mathrm{mi}^{2}\right)$ $(\approx 35$ acres) surrounded by a chain link fence. This area is under tight security and uniformed security personnel are on duty 24 hours a day.

\section{Exclusive Use Area}

The Exclusive Use Area comprises $1.12 \mathrm{~km}^{2}\left(0.432 \mathrm{mi}^{2}\right)(\approx 277$ acres$)$. It is surrounded by a five-strand barbed wire fence and is restricted exclusively for the use of the DOE and its contractors and subcontractors in support of the project. In addition, this area is defined as the point of closest public access for the purpose of analyzing accident consequences to the general public in the Waste Isolation Pilot Plant Contact-Handled (CH) Safety Analysis Report (DOE/WIPP 95-2065). This area is marked by DOE 
warning (e.g., "no trespassing") signs and is patrolled by WIPP security personnel to prevent unauthorized activities or uses.

\section{Off-Limits Area}

Managed as an area where unauthorized entry and introduction of weapons and/or dangerous materials is prohibited, the Off-Limits Area includes $5.7 \mathrm{~km}^{2}\left(2.2 \mathrm{mi}^{2}\right)$ $(\approx 1,421$ acres $)$. Pertinent prohibitions are posted at consistent intervals along the perimeter. Grazing and public thoroughfare will continue in this area until such time that these activities present a threat to the security, safety, or environmental quality of WIPP. This sector is patrolled by WIPP security personnel to prevent unauthorized activity or use.

\section{WIPP Land Withdrawal Area}

The WIPP site boundary delineates the perimeter of the $41.4 \mathrm{~km}^{2}\left(16 \mathrm{mi}^{2}\right)$ $(\approx 10,240$ acres) WIPP Land Withdrawal Area (WLWA). This tract includes properties outlying the Property Protection Area, the Exclusive Use Area, and the Off-Limits Area. This sector is designated as a Multiple Land Use Area, and is managed accordingly.

\section{$\underline{\text { Special Management Areas }}$}

Certain properties used in the operation of WIPP (e.g., reclamation sites, well pads, roads) are, or may be, identified as Special Management Areas (SMA). A SMA designation is made due to values, resources, and/or circumstances that meet criteria for protection and management under special management designations. Unique resources of value that are in danger of being lost or damaged, areas where ongoing construction is occurring, fragile plant and/or animal communities, sites of archaeological significance, locations containing safety hazards, or sectors that may receive an unanticipated elevated security status would be suitable for designation as a SMA. Accordingly, the subject sector would receive special management emphasis under this stipulation. Special Management Areas will be posted against trespass and will be safeguarded commensurate with applicable laws governing property protection. WIPP security personnel patrol these areas to prevent unauthorized access or use. 


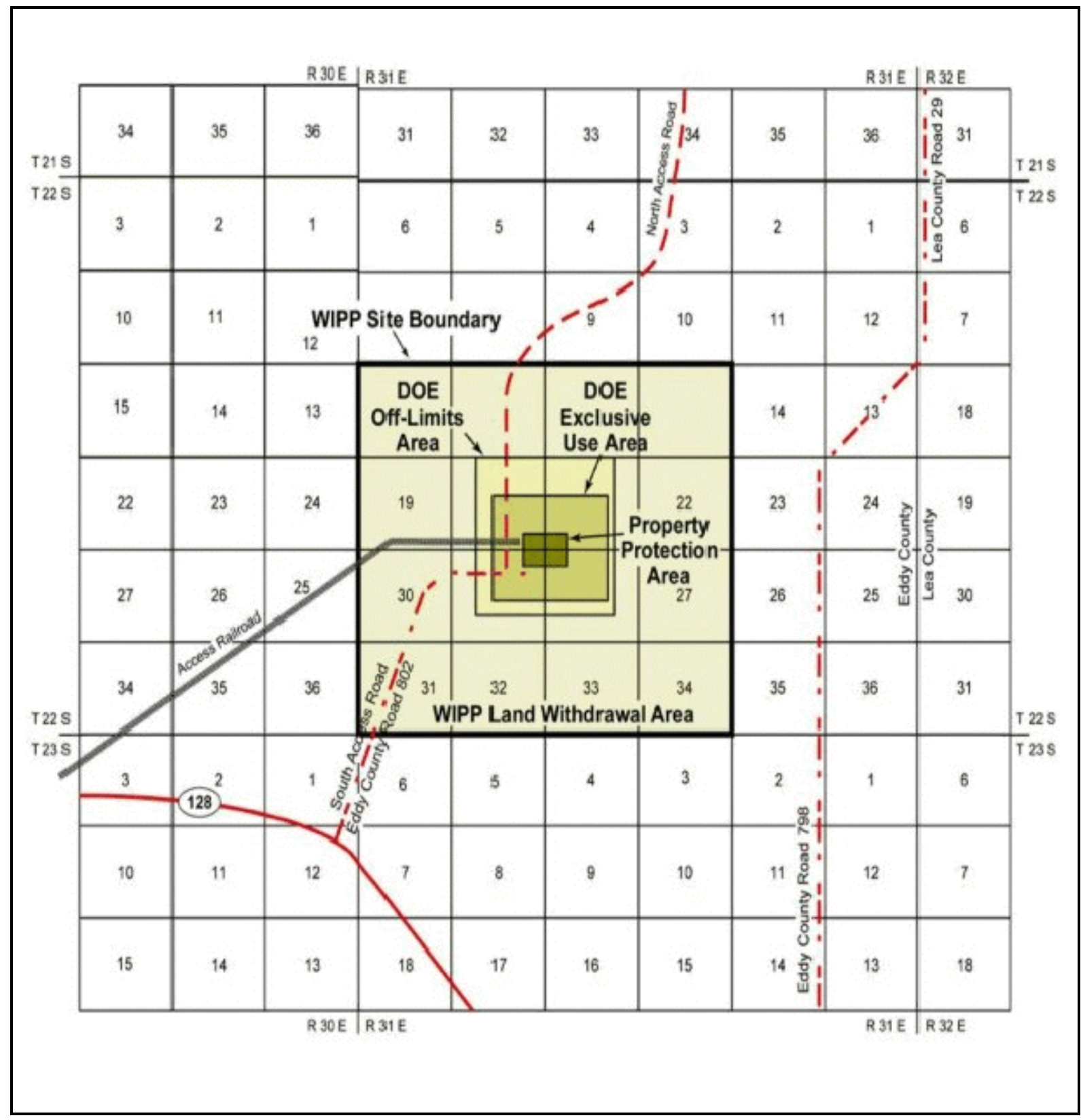

Figure 1.3 - WIPP Property Areas

\subsubsection{Population}

Approximately 26 residents live within $16 \mathrm{~km}(10 \mathrm{mi})$ of the WIPP site. The population within $16 \mathrm{~km}(10 \mathrm{mi})$ of WIPP is associated with ranching, oil and gas exploration/ production, and potash mining. There are two nearby ranch residences (Smith Ranch and Mills Ranch) which are continuously monitored as part of the EMP.

The majority of the local population within $80.5 \mathrm{~km}(50 \mathrm{mi})$ of WIPP is concentrated in and around the communities of Carlsbad, Hobbs, Eunice, Loving, Jal, Lovington, and Artesia, New Mexico. The nearest community is the village of Loving (current estimated 
population 1,326), $29 \mathrm{~km}(18 \mathrm{mi})$ west-southwest of WIPP. The nearest major populated area is Carlsbad, $42 \mathrm{~km}$ (26 mi) west of WIPP. The current estimated population of Carlsbad is approximately 25,625 .

\section{$1.4 \quad$ Environmental Performance}

The DOE's Environmental Policy Statement (DOE Order 5400.1) describes the DOE's commitment to environmental protection and pledges to conduct operations "in an environmentally safe and sound manner. . . in compliance with the letter and spirit of applicable environmental statutes, regulations, and standards." The Statement also affirms the DOE's commitment to "good environmental management in all of its programs and at all of its facilities in order to correct existing environmental problems and to anticipate and address potential environmental problems before they pose a threat to the quality of the environment or public welfare." Additionally, it states, "It is DOE's policy that efforts to meet environmental obligations be carried out consistently across all operations and among all field organizations and programs. . ."

The DOE used laboratory tests, field tests, and computer models to demonstrate WIPP's expected 10,000-year performance as a permanent disposal site. The EPA certified, in May 1998, WIPP's ability to protect the environment and human health, while assuring continued compliance through periodic recertification.

WTS conducted the Environmental Monitoring Program at WIPP in 2002 to monitor for any potential radiological effects of WIPP on people and the environment. Other organizations that oversee the WIPP program, include the EPA, which is responsible for certifying whether radioactive material disposal requirements are met; the state of New Mexico, which regulates the handling of the hazardous components of mixed wastes; and the Environmental Evaluation Group (EEG), an independent technical oversight group that participates in and comments on various WIPP issues and activities. The Carlsbad Environmental Monitoring and Research Center conducts a supplementary environmental monitoring program around WIPP. Several other agencies, committees, and panels monitor progress at WIPP and contribute to the project's development through regulation, review, and comment at the state and federal levels.

This Waste Isolation Pilot Plant 2002 Site Environmental Report was prepared in accordance with DOE Order 231.1. This report documents WIPP's radiological and nonradiological monitoring programs and their results for 2002. 


\section{Waste Isolation Pilot Plant 2002 Site Environmental Report DOE/WIPP 03-2225}

\section{CHAPTER 2 - ENVIRONMENTAL PROGRAM INFORMATION}

The DOE's policy for the management of WIPP is to conduct its operations in a manner commensurate with applicable environmental laws and regulations, and to safeguard the integrity of the southeastern New Mexico environment. This is accomplished through radiological and nonradiological environmental monitoring, environmental compliance, and land management programs, which include monitoring wildlife populations, the WRRP, and reclamation of disturbed lands. The purpose of these programs is to obtain land use permits, implement selected compliance functions such as NEPA compliance, collect data needed to detect and quantify possible impacts WIPP may have on the surrounding ecosystem and, when necessary, provide technical support in the disciplines of environmental science and land management to the DOE's CBFO.

Environmental monitoring activities at WIPP generally fall into four categories: collecting environmental samples from various matrices and analyzing them for specific radionuclides; preparing and publishing documents showing compliance with federal, state, and local regulations; evaluating whether WIPP activities cause any environmental impacts; and taking corrective action when an adverse effect on the environment is identified.

\subsection{Environmental Monitoring Plan}

WIPP's EMP outlines the programs that monitor the environment on, and immediately surrounding, the WIPP site. It discusses major environmental monitoring and surveillance activities at WIPP and reflects the importance of monitoring as a critical element of an effective environmental protection program. The EMP also discusses the WIPP QA/QC program as it relates to environmental monitoring. The purpose of the EMP is to outline the programs that evaluate WIPP's effect on the local ecosystem. Effluent and environmental monitoring also provide the data necessary to demonstrate compliance with applicable environmental protection regulations. The EMP sampling schedule is provided in Table 2.1.

The EMP describes the monitoring of naturally occurring and specific anthropogenic (human-made) radionuclides. The geographic scope of radiological sampling is based on projections of potential release pathways from the waste stored at WIPP. Airborne radioactivity is also monitored at Carlsbad, New Mexico, and local ranches.

The EMP also describes monitoring of VOCs, wildlife populations, meteorological data, groundwater chemistry, and other nonradiological environmental parameters. In general nonradiological monitoring is conducted within or near the WIPP boundary.

Results and discussions pertaining to the monitoring programs prescribed by the EMP are provided in Chapter 4, Environmental Radiological Program Information; and Chapter 5, Environmental Nonradiological Program Information. DOE Order 5400.1 requires the EMP to be reviewed internally every year and updated every three years. The EMP was updated in September 2002. 
Waste Isolation Pilot Plant 2002 Site Environmental Report DOE/WIPP 03-2225

Table 2.1 - Sampling Schedule for the WIPP Environmental Monitoring Program

\begin{tabular}{lcc}
\hline Type of Sample & $\begin{array}{c}\text { Number of Sampling } \\
\text { Locations }\end{array}$ & Sampling Frequency \\
\hline Liquid effluent & 1 & Semiannual (oversight) \\
Liquid effluent & 4 & Quarterly (DP 831 permit $^{\text {a }}$ ) \\
Airborne effluent & 3 & Periodic/Confirmatory \\
Meteorology & 2 & Continuous \\
Atmospheric particulate & 7 & Weekly \\
Vegetation & 6 & Annual \\
Beef/Deer/Game Birds/Rabbits & Sitewide & Annual \\
Soil & 6 & Annual \\
Surface water & 14 & Annual \\
Groundwater & 7 & Semiannual \\
Fish & 3 & Annual \\
Sediment & 12 & Annual \\
Aerial photography & Sitewide & As needed \\
Volatile organic compounds (VOCs) & 2 & Semiweekly \\
\hline a Monitoring compliance with the Discharge Plan, DP-831. &
\end{tabular}

\subsection{WIPP Environmental Monitoring Program}

It is the policy of the DOE to conduct effluent monitoring and environmental surveillance programs that are appropriate for determining adequate protection of the public and the environment during WIPP operations, and to ensure operations comply with DOE and other applicable federal or state radiation standards and requirements. It is the DOE's objective that all DOE operations properly and accurately measure radionuclides in effluent streams and in the ambient environmental media. The goal of the WIPP Environmental Monitoring Program is to determine if the local ecosystem has been impacted during the predisposal and disposal phases of WIPP, and, if so, to evaluate the severity, geographic extent, and environmental significance of those impacts. The program fulfills DOE Orders 5400.1 and 5400.5 .

The Environmental Monitoring Program monitors pathways by which WIPP-related radionuclides and other contaminants could reach the environment surrounding the WIPP site. The pathways measured include air, surface water, groundwater, sediments, soils, and biota (e.g., vegetation, select mammals, game birds, and fish). In addition, the program monitors groundwater quality and the overall health of the local environment. Nonradiological portions of the program focus on the area immediately surrounding the site while radiological surveillance generally covers a broader geographical area.

In addition to monitoring for radionuclides contained in WIPP wastes, background radiation (naturally occurring radioactivity and radioactivity associated with worldwide fallout from historic weapons testing) is also monitored. The geographic scope of 


\section{Waste Isolation Pilot Plant 2002 Site Environmental Report DOE/WIPP 03-2225}

radiological sampling is based on projections of potential release pathways for the types of radionuclides in WIPP wastes. Also, Carlsbad, New Mexico, and local ranches are monitored, even though release scenarios involving radiation doses to residents of these population centers are improbable.

The atmospheric pathway, which can lead to the inhalation of radionuclides, has been determined to be the most likely exposure pathway to the public from WIPP. Therefore, airborne particulate sampling for alpha-emitting radionuclides is emphasized. Air sampling results are used to trend environmental radiological levels and determine if there has been a deviation from established baseline concentrations.

Nonradiological environmental monitoring activities at WIPP consist of a comprehensive set of sampling programs designed to detect and quantify impacts of construction and operational activities. The ecological monitoring program focuses on nonradiological effects of WIPP, such as habitat disturbance.

WIPP has collected preoperational radiological and nonradiological environmental data. Baseline conditions were initially characterized by the Radiological Baseline Program. When the first shipment of waste arrived at WIPP, this program became an operational monitoring program.

Preoperational studies must be considered during environmental evaluations. These assessments have contributed to baseline data gathered during the construction phase and provided much of the foundation for long-term monitoring programs. Below are listed examples of such investigations.

- $\quad$ The WIPP Site Characterization Program was instituted in 1976 by Sandia National Laboratories to monitor air quality, background radiation levels, and groundwater quality.

- $\quad$ The WIPP Biology Program began in 1975 with site characterization studies of climate, soils, vegetation, arthropods, and vertebrates.

- Investigations of site geohydrology were conducted by the U.S. Geological Survey at the request of the DOE. In addition, the NRC issued a contract to Columbia University to perform a study of radionuclide mobility in the highly saline groundwaters of the Delaware Basin.

- $\quad$ Radiological monitoring of air, water, and biological media was conducted by the U.S. Atomic Energy Commission before and after the Project Gnome nuclear detonation in 1961.

\subsection{Land Management Programs}

On October 30, 1992, the WIPP LWA became law. This act transferred the responsibility for the management of the WLWA from the Secretary of the Interior to the 


\section{Waste Isolation Pilot Plant 2002 Site Environmental Report DOE/WIPP 03-2225}

Secretary of Energy. In accordance with Sections 3(a)(1) and (3) of the act, these lands:

... are withdrawn from all forms of entry, appropriation, and disposal under the public land laws . . . and are reserved for the use of the Secretary of Energy ... for the construction, experimentation, operation, repair and maintenance, disposal, shutdown, monitoring, decommissioning, and other activities associated with the purposes of WIPP as set forth in Section 213 of the DOE National Security and Military Application of the Nuclear Energy Act of 1980 (Pub. L. 96-164); 93 Stat. 1259, 1265, and this Act.

The DOE developed the LMP as required by Section 4 of the LWA. The LMP was developed to identify resource values, promote multiple-use management, and identify long-term goals for the management of WIPP lands until the culmination of the decommissioning phase. This plan was developed in consultation and cooperation with the BLM and the state of New Mexico. Changes or amendments to the plan require the involvement of the BLM, the state of New Mexico, and affected stakeholders, as appropriate.

The LMP encourages direct communication among stakeholders, including federal and state agencies, involved in managing the resources within, or activities impacting the areas adjacent to, the WLWA. It sets forth cooperative arrangements and protocols for addressing WIPP-related land management actions. Commitments contained in current permits, agreements, or concurrent MOUs with other agencies will be respected when addressing and evaluating land use management activities and future amendments that affect the management of WIPP lands.

\subsubsection{Land Use Requests}

Parties who wish to conduct activities that may impact lands under the jurisdiction of WIPP, but outside the secured fence area of the facility designated as the Property Protection Area, are required by the LMP to prepare a Land Use Request (LUR). A LUR consists of a narrative description of the project, a completed environmental review, and a map depicting the location of the proposed activity. The LUR, and associated NEPA checklists, are used to determine if applicable regulatory requirements have been met prior to the approval of a proposed project. A LUR may be submitted to the land use coordinator by any WIPP organization or outside entity wishing to complete any construction, right-of-way, pipeline easement, or similar action within the WIPP boundary or on lands used in the operation of WIPP, under the jurisdiction of the DOE. During 2002, twelve LURs were submitted for review and approval; all met applicable criteria and were approved. 


\section{Waste Isolation Pilot Plant 2002 Site Environmental Report DOE/WIPP 03-2225}

\subsubsection{Wildlife Population Monitoring}

Southeastern New Mexico is home to diverse populations of plants and wildlife. Shrubs and grasses are the most prominent components of the local flora. Dominant trees include shinnery oak (Quercus havardii), honey mesquite (Prosopis glandulosa), and western soapberry (Sapindus drummondii). Much of the area is composed of combined dune and grassland habitats that include perennial grasses and shrubs.

According to the BLM's Resource Management Plan for the WIPP area, 15 percent of the identified wildlife species use the shinnery oak habitat, while 30 percent occupy areas consisting primarily of grasses. The combination of shinnery oak/dune with grassland habitat has resulted in a diverse wildlife population.

Southeastern New Mexico supports an abundant and diverse population of mammals, including black-tailed jackrabbits (Lepus californicus), desert cottontails (Sylvilagus audoboni), desert mule deer (Odocoileus hemionus), coyotes (Canis latrans), gray foxes (Urocyon cinereoargenteus), badgers (Taxidea taxis), and striped skunks (Mephitis mephitis).

The habitat diversity of the Los Medaños region of southeastern New Mexico also accounts for a wide assortment of bird species. Scaled quail (Callipepla squamata), mourning doves (Zenaida macroura), loggerhead shrikes (Lanius ludovicianus), blackthroated sparrows (Amphispiza bilineata), Chihuahuan ravens (Corvus cryptoleucus), and a unique desert subspecies of the northern bobwhite (Colinus virginianus) are but a few examples of the array of avian inhabitants. Due to a scarcity of surface waters in the immediate vicinity of WIPP, migrating or breeding waterfowl are not common.

In addition, this area supports a particularly abundant and diverse population of raptors, or birds of prey. Harris' hawks (Parabuteo unicinctus), Swainson's hawks (Buteo swainsoni), and great horned owls (Bubo virginianus) are species commonly found nesting in the area. Northern harriers (Cicus cyaneus), burrowing owls (Athene cunicularia), barn owls (Tyto alba), and American kestrels (Falco sparverius) are also found around the site.

Reptiles and amphibians are also found in great numbers in southeastern New Mexico. Representative of the no fewer than ten native amphibians are the tiger salamander (Ambystoma tigrinum), green toad (Bufo debilis), plain's spadefoot (Spea bombifrons), red-spotted toad (Bufo punctatus), and New Mexico spadefoot (Spea muliplicata). Their significance is seldom recognized until spring or summer rains, at which time they appear in extraordinary numbers.

Reptiles are more conspicuous due to their diurnal nature. Characteristic reptiles in the region include the ornate box turtles (Terrapene ornata), side-blotched lizards (Uta stansburiana), western whiptails (Cnemidophorus tigris), bullsnakes (Pituophis melanoleucus), prairie rattlesnakes (Crotalus viridis), and Texas horned lizards (Phrynosoma cornutum), a federal notice-of-review species listed under the Endangered Species Act (16 U.S.C. §1531 et seq.). 


\section{Waste Isolation Pilot Plant 2002 Site Environmental Report DOE/WIPP 03-2225}

WTS personnel manage several wildlife research projects and conduct a number of general wildlife management activities. Specific wildlife populations are monitored and researched in accordance with applicable laws, agreements, and regulations. Each activity is mandated and/or supported by state and federal guidelines or by way of commitments created through interagency agreements and MOUs. Wildlife within the WLWA are given consideration by way of the WIPP LUR process during planning stages of projects that may disturb or encroach on wildlife habitat.

In 1995, the U.S. Department of the Interior, Fish and Wildlife Service, provided an updated list of threatened and endangered species for Eddy and Lea Counties, New Mexico. Included were 18 species that may be present on WIPP lands. A comprehensive evaluation in support of the second Supplemental Environmental Impact Statement (SEIS-II) (DOE/EIS-0026-S-2) was conducted in 1996 to determine the presence or absence of threatened or endangered species in the vicinity of WIPP and WIPP's effect on these species. Results indicated that activities associated with the operation of WIPP had no impact on any threatened or endangered species. The protection of threatened and endangered species is taken into consideration when planning and administering projects on WIPP lands.

The DOE, the BLM, and other government agencies are keenly aware of the value and importance of protecting and monitoring raptor populations. To assist in this effort at WIPP, the BLM and the DOE established the WRRP in the early 1990s to monitor, protect, and educate about raptors on the WIPP site. The WRRP is administered by the WIPP Environmental Monitoring Program with input from the BLM and others. Scientific consultation, research direction, and field operations were conducted in 2002 by scientists from Hawks Aloft, a nonprofit biological consultant group in Albuquerque, New Mexico. This research continued on long term studies of productivity and population demographics of the raptor community in and around WIPP. These studies are described in greater detail in Chapter 5.

\subsubsection{Reclamation of Disturbed Lands}

The DOE recognizes its responsibility pursuant to federal, state, and local environmental regulations to enhance and restore areas affected by WIPP activities, including disturbed lands accepted as part of the land transfer from the BLM.

WIPP reclamation activities are conducted in accordance with DOE Order 5400.1 ; the DOE Organization Act (42 U.S.C. §7112); the Federal Land Policy and Management Act of 1976 (43 U.S.C. $\$ 1751$ et seq.); the WIPP Disposal Phase SEIS-II; the SEIS-I (DOE/EIS-0026-FS); the Final Environmental Impact Statement (FEIS) (DOE/EIS-0026); and all applicable reclamation requirements by federal laws and regulations, Executive Orders, MOUs, DOE Orders, and state and local laws.

Without an active reclamation program for disturbed areas, the establishment of stable ecological conditions in arid environments may require decades or centuries to achieve stability, depending on the disturbances and environmental conditions present. Reclamation activities are intended to reduce soil erosion, increase the rate of plant 


\section{Waste Isolation Pilot Plant 2002 Site Environmental Report}

DOE/WIPP 03-2225

colonization and succession, and provide habitat for wildlife in disturbed areas. Reclamation ultimately serves to mitigate the effects of WIPP-related activities on affected plant and animal communities. The objective of the reclamation program is to reclaim lands used in the operation of WIPP that are no longer commissioned for WIPP operations. The DOE will also establish reclamation guidelines for land use requesters on a case-by-case basis.

In accordance with the LMP, WIPP follows a reclamation program and a long-range reclamation plan. As locations are identified for reclamation, WIPP personnel reclaim these areas by using the best acceptable reclamation practices. Seed mixes used reflect those species indigenous to the area with priority given to those plant species which are conducive to soil stabilization, wildlife, and livestock needs.

\subsubsection{Oil and Gas Surveillance}

The oil and gas industry is well established in southeastern New Mexico. Nearly all phases of oil and gas activities have occurred in the vicinity of WIPP, including seismic exploration, exploratory drilling, field development (comprised of production and injection wells), and other activities associated with hydrocarbon extraction.

The Los Medaños region, where WIPP is located, is part of the Delaware Basin. Although the Delaware Basin accounts for approximately 32 percent of lands in Eddy County, approximately 20 percent of the oil and gas wells are located within its boundaries. During 1995, oil and gas reserves in the immediate vicinity of the WLWA were evaluated by the New Mexico Bureau of Mines and Mineral Resources.

One aspect of the WIPP land withdrawal, unique to most DOE facilities, was the intent to maintain a multiple land use concept in the management of the property. However, an exception to a global multiple use strategy was required to reduce likelihood of inadvertent intrusion on the repository and to safeguard the surface infrastructure. Accordingly, all drilling and mining on the WIPP site has been prohibited. Oil and gas activities within $1.6 \mathrm{~km}(1 \mathrm{mi})$ of the WIPP boundary are monitored twice monthly to identify new activities associated with oil and gas exploration and production, including:

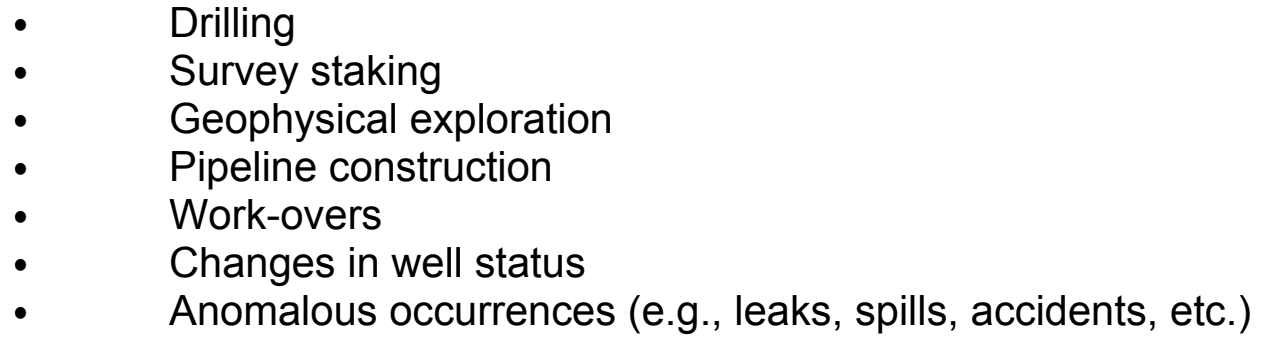

During 2002, WIPP surveillance teams conducted 24 scheduled surveillances with more than 100 cursory field inspections.

One exception to the prohibition of mining and drilling on the WIPP site involved two mineral leases. Under a provision contained in the LWA, these two mineral leases, 
consisting of 129 hectares (320 acres) each, were not appropriated in the proceedings. Both tracts, located in Township 22 South, Range 31 East, Section 31, prohibit drilling within the first $1,830 \mathrm{~m}(6,000 \mathrm{ft})$ of the surface. 


\section{CHAPTER 3 - COMPLIANCE SUMMARY}

WIPP is required to comply with applicable federal and state laws and DOE Orders. Documentation of requisite federal and state permits, notifications, well permits, and applications for approval is maintained by the Site Environmental Compliance Department. Regulatory requirements are incorporated into facility plans and implementing procedures. The primary method for maintaining compliance with environmental requirements is through the use of environmental professionals, routine training of facility personnel, and ongoing self-assessments.

\subsection{Compliance Overview}

In 2002, WIPP maintained compliance with applicable federal and state environmental regulations. The following sections describes the site compliance posture for 2002. Section 3.2 contains a listing of environmental statutes/regulations applicable to WIPP. Section 3.3 describes significant accomplishments and ongoing compliance activities relative to the regulations most pertinent to WIPP's development. A detailed breakdown of WIPP's compliance with environmental regulations is available in the Waste Isolation Pilot Plant Biennial Environmental Compliance Report (DOE/WIPP 02-2171).

\subsection{Compliance Status}

A summary of WIPP's compliance with major environmental regulations is presented in Table 3.3. Applicable DOE Orders are found in Table 3.4, and a list of WIPP permits appears in Table 3.5.

\subsubsection{Comprehensive Environmental Response, Compensation, and Liability Act}

No release sites have been identified at WIPP that would require cleanup under the provisions of the Comprehensive Environmental Response, Compensation, and Liability Act (CERCLA) (42 U.S.C. §9601. CERCLA establishes a comprehensive federal strategy for responding to, and establishing liability for, releases of hazardous substances from a facility to the environment. Any spills of hazardous substances that exceed a reportable quantity must be reported to the National Response Center under the provisions of CERCLA and 40 CFR Part 302. Hazardous substance cleanup procedures are specified in the National Oil and Hazardous Substances Pollution Contingency Plan (40 CFR Part 300).

\section{Superfund Amendments and Reauthorization Act of 1986}

WIPP is required by Superfund Amendments and Reauthorization Act of 1986 (SARA) Title III (also known as the Emergency Planning and Community Right-to-Know Act) to submit (1) a list of hazardous chemicals for which an MSDS is required, and (2) an Emergency and Hazardous Chemical Inventory Form (Tier II Form), which identifies the inventory of hazardous chemicals present during the preceding year to the State 


\section{Waste Isolation Pilot Plant 2002 Site Environmental Report DOE/WIPP 03-2225}

Emergency Response Commission, the Local Emergency Planning Committee, and the fire departments with jurisdiction over the facility.

Section 313, "Toxic Chemical Release Form," identifies requirements for facilities to submit a toxic chemical release report to the EPA in the resident state if toxic chemicals are used at the facility in excess of established threshold amounts.

The list of chemicals provides external emergency responders with information they may need when responding to a hazardous chemical emergency at WIPP. The Tier II Form, due on March 1 of each year, provides information to the public about hazardous chemicals that a facility has on-site at any time during the year above threshold planning quantities. WIPP submits the list of chemicals and the Tier II Form to each fire department with which the CBFO maintains an MOU. WIPP also provides the list of chemicals and the Tier II Form to the LEPC and SERC, as well as the fire departments that have MOUs with WIPP.

\section{Accidental Releases of Reportable Quantities of Hazardous Substances}

During 2002, there were no releases of hazardous substances exceeding the reportable quantity limits.

\subsubsection{Federal Acquisition, Recycling, and Pollution Prevention}

In July 1995, WIPP adopted a systematic and cost-effective affirmative procurement plan for the promotion and procurement of products containing recovered materials. Affirmative procurement is designed to "close a loop" in the waste minimization and recycling processes by supporting the market for materials collected through recycling and salvage operations.

Affirmative procurement programs are mandated by the RCRA, which requires federal procuring departments to establish material preference programs targeted to purchase recycled materials. Executive Order (E.O.) 13101 and EPA guidelines in 40 CFR Part 247, provide additional guidance for implementing affirmative procurement programs at federal facilities.

Affirmative procurement programs must include four elements: (1) a preference program, (2) a promotion program, (3) an estimation, certification, and verification procedure, and (4) annual review and monitoring procedures. The purchase and use of recycled products at WIPP will help foster markets for recovered materials and reduce the amount of solid waste requiring disposal.

WIPP's Affirmative Procurement Program Plan is defined in WP 02-EC.07, Waste Isolation Pilot Plant Affirmative Procurement Plan. In 2002, WTS purchased 99.98 percent of the items identified in the EPA guidelines through this program. WTS also purchased numerous items which were not required by the EPA program but, nevertheless, contained recovered materials. 


\subsubsection{Resource Conservation and Recovery Act}

The RCRA was enacted in 1976. Implementing regulations were promulgated in May 1980. This body of regulations ensures that hazardous waste is managed and disposed of in a way that protects human health and the environment. The Hazardous and Solid Waste Amendments of 1984 prohibit land disposal of hazardous waste unless treatment standards are met. The amendments also place increased emphasis on waste minimization activities and serve as a mechanism to enforce RCRA cleanup requirements.

Title 40 CFR Part 280 addresses underground storage tanks (USTs) containing petroleum products or hazardous chemicals. Requirements for UST management pertain to the design, construction, installation, and operation of USTs, as well as notification and corrective action requirements in the event of a release and actions required for out-of-service USTs. The NMED was authorized by the EPA to regulate USTs. The annual registration fee for two USTs is submitted by July 1 of each year.

The NMED is authorized by the EPA to implement the RCRA program in New Mexico pursuant to the New Mexico Hazardous Waste Act. The technical standards for treatment storage and disposal facilities are outlined in 20.4.1.500 NMAC (incorporating 40 CFR Part 264). The hazardous waste management permitting program is administered through 20.4.1.900 NMAC (incorporating 40 CFR Part 270), which outlines the administrative aspects for processing permit applications and modifications.

WIPP was issued the HWFP on October 27, 1999. The operating conditions set forth in the permit were effective November 26, 1999. The HWFP authorized WIPP to receive, store, and dispose of $\mathrm{CH}$ TRU waste. Specifically, two storage units (the Parking Area and Waste Handling Building) and three underground Hazardous Waste Disposal Units are permitted for the management of $\mathrm{CH}$ TRU waste.

The 2002 HWFP modifications submitted to the NMED in accordance with 20.4.1.900 NMAC are listed in the table below. These modifications, shown in Table 3.1, were processed to support economic and operational efficiencies at WIPP. These innovative technologies will simplify waste characterization and reduce employee exposure at the DOE TRU waste generator sites. 
Waste Isolation Pilot Plant 2002 Site Environmental Report

DOE/WIPP 03-2225

Table 3.1 - Permit Modification Requests Submitted During Calendar Year 2002

\begin{tabular}{|c|r|r|l|c|}
\hline ID & $\begin{array}{c}\text { Submittal } \\
\text { Date }\end{array}$ & Class & \multicolumn{1}{|c|}{ Name } & $\begin{array}{c}\text { Number of } \\
\text { Items }\end{array}$ \\
\hline 35 & $2 / 4 / 02$ & 1 & $\begin{array}{l}\text { ASTM (American Society for Testing and Materials) Type I } \\
\text { Water }\end{array}$ & 1 \\
\hline 36 & $2 / 28 / 02$ & 1 & Updating the RCRA Emergency Coordinator List - 2 & 1 \\
\hline 37 & $3 / 1 / 02$ & 1 & Headspace Gas Sampling Needle Insertion & 1 \\
\hline 38 & $3 / 21 / 02$ & 1 & $\begin{array}{l}\text { Filter Vent Location on Standard Waste Boxes and Ten-Drum } \\
\text { Overpacks }\end{array}$ & 1 \\
\hline 39 & $5 / 30 / 02$ & 1 & Update Contingency Plan and Revised Part A & 10 \\
\hline 40 & $6 / 10 / 02$ & $1^{*}$ & Remove Booster Fans & 1 \\
\hline 41 & $6 / 27 / 02$ & 2 & $\begin{array}{l}\text { Waste Characterization Updates and Other Process } \\
\text { Improvements }\end{array}$ & 5 \\
\hline 42 & $6 / 27 / 02$ & 2 & Add Waste Containers & 1 \\
\hline 43 & $6 / 27 / 02$ & 3 & Data Management Requirements & 2 \\
\hline 44 & $7 / 3 / 02$ & 3 & Remote Handled Transuranic Waste & 1 \\
\hline 46 & $10 / 7 / 02$ & 3 & Panel Closure Redesign & 1 \\
\hline 47 & $11 / 21 / 02$ & $1^{*}$ & Panel Closure Schedule & 1 \\
\hline 51 & $12 / 27 / 02$ & 1 & Name Change \\
\hline
\end{tabular}

Several RCRA regulatory inspections took place at the WIPP site during 2002. There was an NMED inspection on January 3, 2002. No violations were noted and the inspection report was closed. On January 7, 2002, the NMED sent Compliance Order HWB 01-08. Compliance Order HWB 01-08 alleged that WTS and the DOE had violated the HWFP, citing findings identified by the WIPP audit team during a recertification audit of the TRU waste characterization program at the Los Alamos National Laboratory. The NMED initially sought a civil penalty of $\$ 210,450.00$. The DOE and WTS agreed to pay $\$ 25,000.00$ to settle the matter. On February 14,2002 , WTS, the DOE, and the NMED executed a Settlement Agreement resolving Compliance Order HWB 01-08. On September 24, 2002, the NMED witnessed the test concrete pour for the monolith for Panel 1 closure. No issues were noted from that visit.

\section{Hazardous Waste Generator Compliance}

Nonradioactive hazardous waste is currently generated through normal facility operations, and is managed in Satellite Accumulation Areas and a "less-than-90-day" storage area. In addition, hazardous waste generated at WIPP is characterized, packaged, labeled, and manifested to off-site treatment, storage, and disposal facilities in accordance with the requirements codified in 40 CFR Part 262.

\section{WIPP Solid Waste Management Units and Areas of Concern}

Module VII of the HWFP contains the requirements for corrective action for the WIPP SWMUs and Areas of Concern (AOCs). The HWFP identified fifteen SWMUs requiring a RCRA Facility Investigation (RFI), three SWMUs not requiring a RFI (the Hazardous 
Waste Management Units), and eight AOCs in the 4,146 hectares (16 $\left.\mathrm{mi}^{2}\right)$ WLWA. There was no SWMU classification change during 2002.

Solid Waste Management Units

The 15 SWMUs included in the HWFP that require a RFI are listed below:

SWMU 001g (H-14/P-1 Mud Pits)
SWMU 001h (H-15/P-2 Mud Pits)
SWMU 001j (P-3 Mud Pit)
SWMU 001k (P-4 Mud Pit)
SWMU 001I (WIPP-12/P-5 Drilling Mud Pits)
SWMU 001m (P-6 Mud Pit)
SWMU 001n (P-15 Mud Pit)
SWMU 0010 (Badger Unit Drilling Mud Pits)
SWMU 001p (Cotton Baby Drilling Mud Pits)
SWMU 001q (DOE-1 Drilling Mud Pits)
SWMU 001s (ERDA 9 Mud Pit)
SWMU 001t (IMC 347 Mud Pit)
SWMU 001x (WIPP-13 Drilling Mud Pits)
SWMU 004a (Portacamp Storage Yard, West Side)
SWMU 007b (SW Evaporation Pond)

\section{Areas of Concern}

Following are the eight AOCs included in the HWFP.
AOC 001r (D-123 Mud Pit)
AOC 001u (IMC-376 Mud Pit)
AOC 001v (IMC-456 Mud Pit)
AOC 001w (IMC-457 Mud Pit)
AOC 001ac (DSP-207 Mud Pit)
AOC 001ae (IMC-377 Mud Pit)
AOC 010b (Waste Handling Shaft Sump)
AOC 010c (Exhaust Shaft Sump)

The SWMU program at WIPP began in 1994 under EPA regulatory authority. The NMED subsequently received regulatory authority from the EPA. A Phase $1 \mathrm{RFI}$ was completed at WIPP during 1996 as part of a Voluntary Release Assessment.

The fifteen SWMUs and eight AOCs identified in the permit are associated with natural resource exploration activities prior to the development of the WIPP, early WIPP mineral assessment and geologic studies to support facility, or facility construction. 


\section{Program Deliverables and Schedule}

As required by Module VII, Table 1 RFI/CMS (Corrective Measures Study) Schedule of Compliance, WIPP is in compliance with the Permit reporting requirements. The key Permit deliverables and their dates of submittal as contained in Module VII, Table 1, include: (1) the first initiating activity, SWMU sampling plan approval and subsequent sampling, occurred in August of 2001; and (2) the first Quarterly Report was submitted in November 2001. Quarterly progress reports have been submitted through

February 2003.

The Sampling and Analysis Plan addresses the current permit requirements for an RFI of SWMUs and AOCs. It uses the results of previous investigations performed at WIPP and expands the investigations as required by the permit. As an alternative to the RFI specified in Module VII of the permit, current NMED guidance identifies an Accelerated Corrective Action Approach (ACAA) that may be used for all SWMUs and AOCs. This ACAA is used to replace the standard RFI Work Plan and Report sequence for all current SWMUs and AOCs with a more flexible decision-making approach. The ACAA process allows a facility to proceed on an accelerated time line. The ACAA process can be entered either before or after an RFI Work Plan. According to the NMED's guidance, a facility can, and has, prepared an RFI Work Plan or ACAA for any SWMU or AOC. The NMED recognized that the facility was using the ACAA in lieu of the standard RFI in 2001. The required RFI work plan was superseded by the ACAA and the ACAA is used as a basis for the No Further Action (NFA) petition.

The ACAA process was used to produce an NFA report and petition, which was submitted to the NMED in October 2002. The NMED is reviewing the NFA petition and, if comments are given, WIPP will respond to them. When an NFA petition is granted, WIPP will proceed with an HWFP modification and remove the 15 SWMUs and 8 AOCs from the HWFP.

A revised facility work plan was submitted on February 13, 2002.

\subsubsection{National Environmental Policy Act}

The NEPA requires the federal government to use all practicable means to consider potential environmental impacts of proposed projects as part of the decision-making process. The NEPA dictates the public shall be allowed to review and comment on proposed projects that have the potential to significantly affect the environment. The NEPA also directs the federal government to use all practicable means to improve and coordinate federal plans, functions, programs, and resources relating to human health and the environment.

NEPA procedural objectives and public involvement requirements are detailed in the Council on Environmental Quality regulations implementing NEPA in 40 CFR Parts 1500 through 1508. The DOE codified its requirements for implementing the council's regulations in 10 CFR Part 1021. Further procedural NEPA compliance guidance is provided in DOE Order 451.1B. Title 10 CFR $\$ 1021.331$ requires that, 


\section{Waste Isolation Pilot Plant 2002 Site Environmental Report DOE/WIPP 03-2225}

following completion of each EIS and its associated ROD, the DOE shall prepare a mitigation action plan that addresses mitigation commitments expressed in the ROD. To fulfill this DOE Order requirement, the CBFO issued the 2002 Annual Mitigation Report for the Waste Isolation Pilot Plant in July 2002.

Day-to-day operational compliance with the NEPA at WIPP is achieved through implementation of the WIPP National Environmental Policy Act Compliance Plan (WP 02-EC.08) and the WIPP NEPA compliance procedure. These documents describe the roles and responsibilities of both the DOE NEPA Compliance Officer and the WRES NEPA Coordinator to evaluate the impacts of proposed projects at the site. A NEPA Database is used to track all proposed projects at the site. Proposed projects are pre-screened by the WRES NEPA Coordinator and the DOE NEPA Compliance Officer gives concurrence prior to project commencement. Every project at WIPP must be approved in this manner. Approximately 211 projects were approved in 2002. These projects primarily were performed as routine maintenance of equipment, to enhance efficiency and upgrade equipment at the WIPP site.

In June 2002, the DOE issued an EA and Finding of No Significant Impact for the proposed use of the Carlsbad Environmental Monitoring and Research Center for conducting actinide chemistry experiments in support of WIPP (DOE/EA-1404, Environmental Assessment for Actinide Chemistry and Repository Science Laboratory).

In November 2002, the DOE issued a supplement analysis that addressed the impacts of disposal of additional plutonium bearing materials from Rocky Flats that were not included in the original SEIS-II waste inventory at WIPP.

\subsubsection{Clean Air Act}

The Clean Air Act (CAA) (42 U.S.C. $\$ 7401$ et seq.) provides for the preservation, protection, and enhancement of air quality, particularly at locations of special interest such as areas of natural, recreational, scenic, or historic value. Authority for the implementation and enforcement of the CAA has been delegated to New Mexico through the approval of their State Implementation Plan by EPA Region VI. Regulations to ensure compliance with the CAA have been developed and administered by the NMED.

Under the CAA, the EPA established the National Ambient Air Quality Standards for six "criteria" pollutants: sulfur dioxide, total suspended particulates, carbon monoxide, ozone, nitrogen oxides, and lead. These standards establish primary and secondary criteria for ambient air quality that the EPA considers necessary to protect public health and welfare.

The initial 1993 WIPP air emissions inventory was developed as a baseline document to calculate maximum potential hourly and annual emissions of both hazardous and criteria pollutants. Based on the current air emissions inventory, WIPP operations do not exceed the 10-ton-per-year emission limit for any individual hazardous air pollutant or the 25-ton-per-year limit for any combination of hazardous air pollutant emissions 


\section{Waste Isolation Pilot Plant 2002 Site Environmental Report DOE/WIPP 03-2225}

established in Subpart A of NESHAP. Proposed facility modifications are reviewed to determine if they will create new air emission sources and require permit applications.

Based on the initial 1993 air emissions inventory, the WIPP site is not required to obtain federal CAA permits. WIPP, in consultation with the NMED Air Quality Bureau, working in concert with data provided in the first air emissions inventory, was required to obtain a New Mexico Air Quality Control Regulation 702, Operating Permit (recodified in 1997 as 20.2.72 NMAC, "Construction Permits") for two primary backup diesel generators at the site. During 2002, the backup diesel generators were operated for approximately 15 of the 480 hours allowed by the permit. There have been no activities or modifications to the operating conditions of the diesel generators that would require reporting under the conditions of the permit.

WIPP's normal operations do not involve or entail any planned or expected releases of airborne radioactive materials to the workplace or the environment. Waste containers accepted for disposal at WIPP are required to meet the 10 CFR Part 835 external contamination limits. To ensure compliance, the containers are surveyed both prior to release from the generator sites and as the TRUPACT-II containers are opened at WIPP.

Since radioactive material remains in the waste containers, there are no emissions of radionuclides to the ambient air from DOE facilities during normal WIPP waste handling, and the public is not subjected to radioactivity from the WIPP facility. The WIPP 2002 NESHAP report concluded that WIPP was operated in compliance with the release standards of 40 CFR Part 191, Subpart A, and 40 CFR Part 61, Subpart H.

External doses to workers from the handling of $\mathrm{CH}$ waste containers were estimated to be well within the DOE's "as low as reasonably achievable" goals and well below regulatory limits. Similarly, consequences to the public and workers as a result of the release of VOCs during disposal phase normal operations were shown to be many orders of magnitude below health-based limits.

\subsubsection{Clean Water Act}

The Clean Water Act (33 U.S.C. $\S \$ 1251$ through 1376) establishes provisions for the issuance of permits for discharges into waters of the United States. The regulation defining the scope of the permitting process is contained in 40 CFR Part 122, Subpart A, Section (b)(1), and states that ". . National Pollutant Discharge Elimination System (NPDES) program requires permits for the discharge of 'pollutants' from any 'point source' into waters of the United States."

On August 29, 1997, WIPP submitted to the EPA a Notice of Intent (NOI) for Storm Water Discharges Associated with Industrial Activity under a NPDES Multi-Sector General Permit. Permit NMR05A823 was issued February 23, 1998. Since WIPP does not discharge storm water to the waters of the United States, a Notice of Termination was submitted to the EPA on December 19, 2001, and coverage under the Storm Water Multi-Sector Permit was terminated on January 9, 2002. 


\section{Waste Isolation Pilot Plant 2002 Site Environmental Report DOE/WIPP 03-2225}

The NPDES sewage sludge regulations promulgated in 40 CFR Part 503 require all facilities that generate or dispose of sewage sludge to submit an information package describing sewage sludge management and disposal practices. WIPP did not dispose of any sewage sludge from the wastewater treatment systems during 2002.

\subsubsection{New Mexico Water Quality Act}

On January 16, 1992, the NMED issued the original discharge plan (DP-831) for the WIPP sewage facility. DP-831, as amended through December 2001, allows the disposal of 23,000 gallons per day (gpd) of sewage effluent to five lagoons; 2,000 gpd of nonhazardous brine water to the north evaporation cell; $8,000 \mathrm{gpd}$ of nonhazardous brine water to the $\mathrm{H}-19$ Evaporation Pond; and 100 gallons per year of neutralized acid to the domestic wastewater lagoons. A Discharge Plan Renewal was submitted to the NMED on June 5, 2002.

The DOE submits quarterly discharge monitoring reports to the NMED to demonstrate compliance with the inspection, monitoring, and reporting requirements identified in the plan.

DP-831 requires quarterly sampling and analysis of the sewage system influent for nitrate, total Kjeldahl nitrogen, total dissolved solids (TDS), ${ }^{238} \mathrm{Pu},{ }^{239+240} \mathrm{Pu},{ }^{241} \mathrm{Am},{ }^{234} \mathrm{U}$, ${ }^{235} \mathrm{U},{ }^{238} \mathrm{U}$, and ${ }^{90} \mathrm{Sr}$. Characterization samples are collected to appropriately disposition brine wastes prior to discharge into the $\mathrm{H}-19$ Evaporation Pond.

An NOI was submitted to the NMED Water Quality Bureau on October 30, 2002. This $\mathrm{NOI}$ was submitted to update the information provided in an NOI submitted on April 20, 1983, related to the salt pile and Salt Pile Evaporation Pond. The NMED notified WIPP on December 30, 2002, that a Discharge Plan, as defined in 6.2.1101 NMAC, is required for the WIPP salt pile operations. The discharge plan modification application was submitted to the NMED on April 25, 2003.

\subsubsection{Safe Drinking Water Act}

The Safe Drinking Water Act (SDWA) (42 U.S.C. §300f, et seq.) provides the regulatory strategy for protecting public water supply systems and underground sources of drinking water. The NMED notified WIPP in a September 9, 1992, letter that the WIPP public water supply was categorized as a nontransient, noncommunity system for reporting and testing requirements.

New Mexico water supply regulations mandate that when a public water supply system supplements other systems, that water system is treated as a single system for compliance sampling purposes. The Carlsbad municipal water supply system is contracted to provide "raw" water to WIPP from city-owned wells $50 \mathrm{~km}$ (31 mi) north of the site.

In a letter dated August 28, 1996, the NMED set the frequency for sampling lead and copper in the drinking water supply at ten samples every three years. The required 


\section{Waste Isolation Pilot Plant 2002 Site Environmental Report DOE/WIPP 03-2225}

samples were collected in July 2002 and the results were submitted to the NMED. All samples were below action levels as specified by New Mexico monitoring requirements for lead and copper in tap water. The next lead and copper sampling period will be in July 2005.

Bacterial samples were collected and reported monthly throughout 2002. All bacteriological/analytical results were below the SDWA regulatory limits.

\subsubsection{National Historic Preservation Act}

The NHPA was enacted to protect the nation's cultural resources and establish the National Register of Historic Places. Federal agencies are required to coordinate NEPA compliance with the responsibilities of the NHPA to ensure that historic and cultural properties are given proper consideration in the preparation of NEPA documentation. Agency obligations under the NHPA, however, are independent from NEPA and must be complied with even when no additional NEPA documentation is required (i.e., for proposed projects not classified as major federal actions with significant environmental impacts, the DOE must still consider impacts to historic properties and sites). Where both NEPA and the NHPA are applicable, EAs and EISs must integrate NHPA considerations along with other environmental impact analyses and studies (see 40 CFR §1502.25).

During 2002, one archaeological investigation was conducted to assess cultural resources for installation of livestock corrals as a range improvement activity within the WLWA. No artifacts were encountered.

\subsubsection{Hazardous Materials Transportation Act}

The HMTA is one of the major transportation-related statutes that affects the DOE at WIPP. It provides for safe transportation of hazardous materials, including radioactive materials. The DOE complies with applicable U.S. Department of Transportation (DOT) regulations, corresponding NRC regulations, and DOE Orders 460.1B, Packaging and Transportation Safety; and 460.2, Departmental Materials Transportation and Packaging Management, for the transportation of hazardous materials. DOE Orders require the development of a transportation plan, and implementing procedures to ensure that the DOT regulations and requirements of each NRC-certified package are met. DOE Order 460.2 also requires the use of the DOE TRANSCOM system to monitor shipments.

Other federal transportation regulations applicable to WIPP include:

- $\quad$ Title 10 CFR Part 71, NRC requirements for packaging, design, construction, certification, and payload control

- $\quad$ Title 40 CFR Part 262, Subpart B, requirements for use of the hazardous waste manifest 
The WTS Shipping Coordination Section implements applicable DOT and EPA regulations and DOE Orders for the transport of hazardous waste and hazardous materials from WIPP through the use of a transportation plan and implementing procedures. These implementing procedures address the classification, labeling, marking, placarding, and the shipping documentation needed to transport these materials in a safe and regulatory compliant manner.

\subsubsection{Packaging and Transporting Radioactive Materials}

Regulations for transportation of radioactive materials, under the authority of the DOT, are found in 49 CFR Parts 171 through 178. If the quantity of radioactive material exceeds certain limits, as determined by 49 CFR $\S 173.431$, a Type B shipping container (packaging) must be used. The specific requirements for the shipment of radioactive materials and requirements applicable to the Type B packages to be used to transport waste to the WIPP facility are detailed in 49 CFR Parts 171 through 173, and the NRC Certificate of Compliance ( $\mathrm{C}$ of $\mathrm{C}$ ) for the package. Regulations for Type $\mathrm{B}$ packaging, under the authority of the NRC, are found in 10 CFR Part 71, "Packaging and Transportation of Radioactive Materials." The WIPP LWA requires that TRU waste containers shipped to WIPP shall be transported using packages which have had the design certified by the NRC and which have been determined by the NRC to satisfy its QA requirements.

Additional transportation requirements for the mixed waste shipments (i.e., TRU mixed wastes) are detailed in 40 CFR Part 262. The appendix to Part 262 provides an example of a uniform hazardous waste manifest and instructions to waste generators and shippers of hazardous wastes.

$\mathrm{CH}$ TRU waste is shipped in the TRUPACT-II and the HalfPACT. The HalfPACT is a shorter version of the TRUPACT-II; it was designed to transport heavier CH TRU waste containers. The NRC certified the TRUPACT-II container on August 30, 1989. Since 1989, expansion of the TRUPACT-II payload envelope has been accomplished through applications to the NRC for revisions of the TRUPACT-II Safety Analysis Report for Packaging (NRC-Docket-71-9218) and the C of C, when applicable. The TRUPACT-II C of C, No. 14, expires June 30, 2004. The HalfPACT C of $C$ was revised August 16, 2002, and expires October 31, 2005.

$\mathrm{RH}$ waste is not yet approved for disposal at WIPP; when this occurs, $\mathrm{RH}$ waste will be shipped in the $\mathrm{RH}-72 \mathrm{~B}$ and the CNS 10-160B casks. The current $\mathrm{C}$ of $\mathrm{C}$ for the $\mathrm{RH}-72 \mathrm{~B}$ cask expires February 8,2005 . The current revision of the $C$ of $C$ for the $10-160 B$ expires October 31, 2005.

Emergency response for transportation of TRU waste is addressed by defense in depth. The first line of defense is the packaging itself. The NRC-certified packagings are able to survive "hypothetical" accident conditions without loss of contents. The testing 


\section{Waste Isolation Pilot Plant 2002 Site Environmental Report DOE/WIPP 03-2225}

process subjects the package to forces that are more severe than those that would be experienced in a vehicular accident.

The second line of defense rests with the driver. The qualifications for the drivers are set at a high mark. The driver's record is reviewed for at least five years. The driver must be accident free and moving violation free in this time period. In addition to prior skills, the driver must attend and pass WIPP-specified training.

In the event an incident should occur, the DOE has trained emergency responders and hospital personnel along the transportation routes to mitigate the incident. In addition to the training provided to the first responders, the DOE and the states have conducted "WIPPTREXes" (training exercises) to provide emergency response personnel the opportunity to put into practice the training they receive. In addition to the training, the DOE has an Incident/Accident Response Team that is on standby to respond to an incident to assist the on-scene Incident Commander in the mitigation of the incident.

\subsubsection{Toxic Substances Control Act}

In 2002, the CBFO began to pursue the ability to dispose of PCB (polychlorinated biphenyl)-contaminated mixed waste under the Toxic Substances Control Act of 1974 (15 U.S.C. $\$ 2601$ et seq.). In addition, the NMED determined that WIPP is exempt from the solid waste regulations for the purpose of disposal of asbestos waste and, therefore, is exempt from the registration and permitting requirements in accordance with 20.9.1 NMAC, "Solid Waste Management."

\subsection{Other Significant Accomplishments and Ongoing Compliance Activities}

\subsubsection{Environmental Compliance Assessment Program}

The Environmental Compliance Assessment Program plays a major role in the overall program for environmental protection activities at WIPP. The program was developed to determine if impactive or potentially impactive facility activities protect human health and the environment and if these activities are in compliance with applicable federal, state, and local requirements; permit conditions and requirements; and best management practices.

The QA manager and the Environmental Compliance Coordinator develop an assessment schedule based upon the results of the grading process identified in (1) WP 13-QA.03, Quality Assurance Independent Assessment Program, Attachment 8; (2) the amount of previous oversight; (3) customer input trending data; and (4) historical approval. Following is a summary of the assessments performed in 2002 and the results.

An assessment of Construction and Demolition Debris Landfill Requirements (Assessment No. ECA 02-002) was performed on January 22, 23, 24, and 25, 2002. The purpose of this assessment was to evaluate the effectiveness of WIPP procedures, 


\section{Waste Isolation Pilot Plant 2002 Site Environmental Report}

DOE/WIPP 03-2225

policies, and practices for compliance with applicable Construction and Demolition Debris Landfill requirements specified in 20.9.1 NMAC.

The assessment identified weaknesses in the implementation of certain aspects of the Construction and Demolition Debris Landfill process. When considering how well all other aspects of the program are performing, the overall implementation of the process is acceptable. Even when viewed in the aggregate, the assessment findings do not significantly affect the overall quality of the Construction and Demolition Debris Landfill Program.

The assessment resulted in two findings and no observations. The weaknesses noted by the two findings were related to incomplete documentation and departure from procedure requirements.

An assessment of WIPP Hazardous Waste Management and Land Disposal Restrictions (Assessment No. ECA 02-003) was performed on April 9, 10, 11, and 15, 2002. The purpose of this assessment was to evaluate the effectiveness of WIPP procedures, policies, and practices for compliance with applicable Hazardous Waste Management and Land Disposal Restriction requirements specified in 40 CFR Part 262, Subpart B, "The Manifest," and 40 CFR Part 268, "Land Disposal Restrictions."

The results of this assessment noted that implementation of the Hazardous Waste Management and Land Disposal Restriction program processes was acceptable. All Transportation Engineer training records indicated up-to-date qualifications. The Land Disposal Restriction forms were present and completed for all hazardous waste shipments, as required. The Hazardous Waste Shipment portfolios contained the documentation required by WP 08-NT3103, Shipment of Nonradioactive Waste. An evaluation has determined that the one assessment finding and one observation do not significantly affect the overall quality of the program.

The assessment resulted in one finding and one observation. The weakness noted by the finding was related to deviation from WP 15-PR, WIPP Records Management Program. The observation noted inconsistencies in completion of the Hazardous Waste Manifest.

An assessment of the WIPP Low Volume Air Sampling Program (Assessment No. ECA 02-004) was conducted on June 18, 19, 20, 24, 25, and 27, 2002. The purpose of this assessment was to evaluate the effectiveness of WIPP procedures, policies, and practices for compliance with applicable low volume airborne particulate sampling requirements specified in the DOE Environment, Safety, and Health Environmental Regulatory Guide for Radiological Effluent Monitoring and Environmental Surveillance, EH-0173T, January 1991; DOE/WIPP 99-2194; and EPA 402-R-97-01, Guidance for the Implementation of EPA's Standards for Management and Storage of Transuranic Waste at WIPP.

The assessment resulted in three exemplary practices, three findings, two observations, and three recommendations. All three exemplary practices were attributed to the 


\section{Waste Isolation Pilot Plant 2002 Site Environmental Report}

DOE/WIPP 03-2225

Environmental Monitoring staff for their thoroughness and professionalism. The weaknesses noted by the findings were related to records management, inadequate procedure, and personnel error. The observations identified insufficient personnel qualifications and a possible disconnect in the processes used to handle, transport, and dispose of loaded sample filters. The recommendations pertained to procedure revisions, sampler locations, and vendor calibrations.

An assessment of the Surface Water and Sediment Sampling Program (Assessment No. ECA 02-005) was conducted on August 19, 20, 21, 23, and 26, 2002. The purpose of this assessment was to evaluate the effectiveness of WIPP procedures, policies, and practices for compliance with applicable surface water and sediment sampling requirements specified in the EH-0173T and DOE/WIPP 99-2194.

The assessment resulted in three findings (one which was corrected during the course of the assessment) and two observations. The weaknesses noted by the findings pertained to documentation of environmental monitoring guidance exemptions, personnel qualifications, and incomplete documentation. The observations identified a failure to document pre-job safety briefings and a procedure violation.

\subsubsection{Environmental Management System}

WTS has established and implemented an EMS as a proactive approach to achieve environmental protection at WIPP through good environmental stewardship, regulatory compliance, pollution prevention/waste minimization, and continuous improvement. The WTS EMS is described in WP 02-EC.0.

WP 02-EC.0 incorporates the requirements of E.O. 13148, using the format of ISO 14001. The document also addresses the administrative control programs necessary to implement Management Policy (MP) 1.14, Environmental Management.

WTS has a number of programmatic and administrative documents that define how operational, safety, radiological, and environmental controls are implemented at WIPP. This includes controls to avoid hazards and enhance prevention such as pollution prevention options. The controls also include immediate protective actions in the WTS stop-work policy (MP 1.2, Work Suspension and Stop-Work Direction), as well as overall programmatic controls in MP 1.12, Worker Protection Policy.

The WTS EMS conforms to the ISO 14001 standard and is integrated with the ISMS as described in DOE/CBFO 98-2276. An annual review of the WTS EMS was conducted in December 2002. No nonconformance or findings were identified. The EMS registrar recommended continuous registration of the WTS EMS.

In 2002, WTS met its annual goal of zero reportable releases in all media as well as the established annual pollution prevention/waste reduction objectives. The WTS environmental performance measures and indicators for 2002 are identified in WP 02-EC.0 and WP 02-EC.11, Waste Isolation Pilot Plant Pollution Prevention Program Plan. The WP 02-EC.0, Environmental Management System Description 


\section{Waste Isolation Pilot Plant 2002 Site Environmental Report DOE/WIPP 03-2225}

Document, describes the WTS policies, plans, and procedures that make up the WTS EMS. The WTS EMS is also integrated in the ISMS as described in DOE/CBFO 98-2276, Integrated Safety Management System Description.

\section{EMS Performance Measures}

Site responsibilities for the P2 Program are an integral part of the WIPP EMS. These values are prescribed by the DOE Secretary of Energy, waste stream reduction goals from routine operations must be decreased by the following percentages by FY 2005:

$\begin{array}{ll}\text { Hazardous } & 90 \text { percent } \\ \text { Low-level radioactive } & 80 \text { percent } \\ \text { Low-level mixed radioactive } & 80 \text { percent } \\ \text { TRU } & 80 \text { percent }\end{array}$

The following are 2002 waste volumes and the reduction goals for 2005.

$\begin{array}{lcc}\text { Waste Type } & \begin{array}{c}\mathbf{2 0 0 2} \\ \text { Actual (Metric Tons) }\end{array} & \begin{array}{c}\text { FY 2005 Reduction Goal } \\ \text { (Metric Tons) }\end{array} \\ \text { RCRA (Hazardous) } & 0.34 & .51 \\ \text { RCRA Leaded Brine (1995 baseline) } & 7.73 & 5.86 \\ \text { Low-level radioactive (2000 baseline) } & 0.43 & .16 \\ \text { Low-level mixed radioactive (2000 baseline) } & 0.02 & .004 \\ \text { Sanitary } & 99.61 & 673 \\ \text { Medical } & 0.06 & \text { N/A, No required waste } \\ & & \text { stream reduction }\end{array}$

The DOE Secretary of Energy's new goals for fiscal year (FY) 2005 and beyond are to recycle 45 percent of sanitary wastes from all operations by FY 2005 and 50 percent by FY 2010, based on the 1993 baseline.

\subsubsection{Pollution Prevention Committee}

The P2 Committee was formed in 1993 with a representative from each department. The primary purpose of this committee is to foster recycling activities at WIPP. The committee prepared a waste minimization charter, which outlines the committee's responsibilities.

The identified primary areas for pollution prevention are reductions in the generation of the following waste streams: lead brine, sanitary waste, RCRA waste, low-level mixed waste, and low-level radioactive waste. Other waste minimization efforts at WIPP include recycling of, but are not limited to, used oil, pallets, scrap metal, fire extinguishers, wet batteries, ethylene glycol, Safety-Kleen solvent, computer equipment, aluminum cans, toner cartridges, paper, etc.. Actual WIPP materials recycled in metric tons for 2002 are shown in WP 02-EC.11. Actual WIPP performance against the established reportable release and P2 goals were reported to WTS senior management and to the CBFO through the ISMS process. 
On Earth Day 2002, the committee conducted activities to heighten employee awareness of xeriscaping and its efficient use of water. WIPP also participated in the River Blitz 2002 project in April as part of Earth Day activities.

The WIPP P2 Committee celebrated America Recycles Day in November 2002, using a display showing products made from recycled materials. The WIPP P2 Committee also participated in the city of Carlsbad activities for America Recycles Day by sponsoring a fashion show featuring items of clothing made from "trash."

During October 2002, Energy Month was celebrated with posters being hung around the site emphasizing the importance of saving energy.

\section{Pollution Prevention Programs}

The P2 program during 2002 included the following Pollution Prevention Opportunity Assessment (PPOA) activities:

- $\quad$ PPOA 2000-01 - Chemical Use Reduction. Implementation of this activity continued in 2002. Issues addressed included implementing an online, electronic MSDS system at WIPP, and increasing product substitution. This chemical use reduction is an ongoing PPOA activity. To date, 37 hazardous products have been eliminated or replaced by less hazardous products.

Noteworthy P2 activities during 2002 included the following:

- WTS continues to promote affirmative procurement strategies in the following ways: evaluate ways to improve data collection of affirmative program items on-line, WIPPtoday articles, and America Recycles Day activities.

- $\quad$ Recycling - WIPP continued its mandatory recycling program. Table 3.2 identifies the volume of materials recycled at WIPP in 2002.

Table 3.2 - Materials Recycled at WIPP in 2002

\begin{tabular}{|l|c|}
\hline \multicolumn{1}{|c|}{ Recycled Material } & 2002 Actual (Metric Tons) \\
\hline Paper & 20.80 \\
\hline Aluminum cans & 0.36 \\
\hline Cardboard & 6.42 \\
\hline Toner cartridges & 0.80 \\
\hline Pallets & 0.80 \\
\hline Oil & 3.99 \\
\hline Fluorescent bulbs/high-pressure sodium bulbs & 0.60 \\
\hline Wet batteries & 2.36 \\
\hline Silver & 0.10 \\
\hline Ethylene glycol (RCRA) & 0 \\
\hline Safety-Kleen solvent (RCRA) & 0.10 \\
\hline Scrap metal & 54.47 \\
\hline
\end{tabular}


Waste Isolation Pilot Plant 2002 Site Environmental Report

DOE/WIPP 03-2225

Table 3.2 - Materials Recycled at WIPP in 2002

\begin{tabular}{|l|c|}
\hline \multicolumn{1}{|c|}{ Recycled Material } & 2002 Actual (Metric Tons) \\
\hline Plastic & 0.24 \\
\hline Fire extinguishers & 0 \\
\hline Computer equipment & 7.46 \\
\hline Total Sanitary and RCRA Materials Recycled & 98.50 \\
\hline Total Sanitary and RCRA Materials Generated & 198.11 \\
\hline PERCENT RECYCLED & $49.7 \%$ \\
\hline
\end{tabular}

- WTS implemented an online, electronic MSDS system. Employees now have access to all MSDSs on their desktop computers. This reduced the number of paper copies generated and the amount of paper used and discarded at the WIPP site.

\subsubsection{Environmental Training}

Environmental training was provided to personnel associated with environmental operations at WIPP. Training courses included technical topics (e.g., RCRA sampling), EMS, basic environmental safety and health training, and general sitewide training such as the required General Employee Training module. These courses were conducted both on-site by WIPP personnel and off-site by various contractors. 
Waste Isolation Pilot Plant 2002 Site Environmental Report

DOE/WIPP 03-2225

Table 3.3 - Activities Associated with Major Environmental Statutes Applicable to the WIPP Project in 2002

\begin{tabular}{|c|c|}
\hline Statute/Regulation & Related Activity \\
\hline Clean Air Act of 1980 (42 U.S.C. $§ 7401$ et seq.) & Monitoring/reporting began upon first receipt of waste, March 26, 1999. \\
\hline Clean Water Act of 1970 (33 U.S.C. §1251 et seq.) & $\begin{array}{l}\text { Notice of Termination for the Multi-Sector Storm Water Discharge Permit was submitted on December 19, } \\
\text { 2001. Storm Water Multi-Sector Discharge Permit was terminated by the EPA on January 9, } 2002 .\end{array}$ \\
\hline $\begin{array}{l}\text { Comprehensive Environmental Response, } \\
\text { Compensation, and Liability Act/Superfund Amendments } \\
\text { and Reauthorization Act (SARA) } \\
\text { (42 U.S.C. §9601 et seq.) }\end{array}$ & $\begin{array}{l}\text { No CERCLA site cleanup activity performed. Reports filed as required under SARA for hazardous } \\
\text { substances are maintained on-site. }\end{array}$ \\
\hline $\begin{array}{l}\text { Endangered Species Act of } 1973 \\
\text { (16 U.S.C. } \$ 1531 \text { et seq.) (7 U.S.C. } \$ 136)\end{array}$ & $\begin{array}{l}\text { In November 1996, WIPP completed the } 1996 \text { Threatened and Endangered Species Survey. The survey is } \\
\text { part of the analysis required for the SEIS-II. There were no threatened or endangered species located on } \\
\text { WIPP land. Individual permits to collect biological samples and to band nonendangered species of raptors } \\
\text { are maintained. Consultation with federal and state agencies is not required. }\end{array}$ \\
\hline $\begin{array}{l}\text { Federal Land Policy and Management Act of } 1976 \\
\text { (43 U.S.C. } \$ 1751 \text { et seq.) }\end{array}$ & $\begin{array}{l}\text { An MOU between the DOE and the BLM was issued in July 1994. This MOU outlines the responsibilities the } \\
\text { BLM and the DOE have with regard to land use management for the withdrawal area. }\end{array}$ \\
\hline $\begin{array}{l}\text { Federal Insecticide, Fungicide, and Rodenticide Act } \\
\text { (7 U.S.C. } \$ 136-136 y[1996])\end{array}$ & All pesticides must be approved by Industrial Safety and Hygiene. \\
\hline $\begin{array}{l}\text { Hazardous Materials Transportation Act of } 1974 \\
\text { (49 U.S.C §5101 et seq.) }\end{array}$ & $\begin{array}{l}\text { Appropriate shipping papers accompany hazardous materials and hazardous wastes shipped off-site to } \\
\text { ensure compliance with the act. }\end{array}$ \\
\hline \multirow[t]{2}{*}{$\begin{array}{l}\text { National Environmental Policy Act of } 1969 \text { (as } \\
\text { supplemented by DOE Order 451.1B, and } \\
10 \text { CFR Part 1021) (42 U.S.C. } § \$ 4321-4347)\end{array}$} & $\begin{array}{l}\text { The } 2002 \text { Annual Mitigation Report for the Waste Isolation Pilot Plant (NEPA ID\# WIP:00:002) was issued } \\
\text { July 2002, in accordance with the requirement of DOE Order 451.1B, National Environmental Policy Act } \\
\text { Compliance Program. This order requires DOE facilities to track and annually report progress in } \\
\text { implementing a commitment for environmental impact mitigation that is essential to render the impacts of a } \\
\text { proposed action nonsignificant or that is made in the ROD. }\end{array}$ \\
\hline & $\begin{array}{l}\text { In June 2002, the DOE issued an EA and Finding of No Significant Impact for the proposed use of the } \\
\text { Carlsbad Environmental Monitoring and Research Center for conducting actinide chemistry experiments in } \\
\text { support of WIPP (DOE/EA-1404, Environmental Assessment for Actinide Chemistry and Repository Science } \\
\text { Laboratory). This Environmental Assessment was required to support a congressional directive to make } \\
\text { maximum use of existing WIPP facilities to further the scientific missions assigned to the DOE by Congress. }\end{array}$ \\
\hline $\begin{array}{l}\text { National Historic Preservation Act of } 1996 \\
(16 \text { U.S.C. §470) }\end{array}$ & $\begin{array}{l}\text { Activities requiring excavation in previously undisturbed areas are surveyed by licensed, permitted } \\
\text { archaeologists. Required reports are submitted to the New Mexico State Historic Preservation Officer. } \\
\text { There was one archeological clearance for installation of livestock corrals performed in 2002, resulting in no } \\
\text { findings or encounters. }\end{array}$ \\
\hline
\end{tabular}




\section{Waste Isolation Pilot Plant 2002 Site Environmental Report}

\section{DOE/WIPP 03-2225}

Table 3.3 - Activities Associated with Major Environmental Statutes Applicable to the WIPP Project in 2002

\begin{tabular}{|c|c|}
\hline Statute/Regulation & Related Activity \\
\hline $\begin{array}{l}\text { New Mexico Air Quality Control Act (§§74-2-1 to 74-2-22 } \\
\text { NMSA 1978) }\end{array}$ & $\begin{array}{l}\text { During } 2002 \text {, the backup diesel generators were operated for approximately } 15 \text { of the } 480 \text { hours allowed by } \\
\text { the permit. There were no malfunctions or abnormal conditions of operation that would cause a violation of } \\
\text { the permit. }\end{array}$ \\
\hline $\begin{array}{l}\text { New Mexico Water Quality Act of } 1978 \text { (§§74-6-1 to } \\
74-6-17 \text { NMSA 1978) }\end{array}$ & $\begin{array}{l}\text { An application for the renewal of Discharge Plan (DP-831) for the disposal of site-generated wastewater was } \\
\text { submitted on June } 5,2002 \text {. An NOI was submitted to the NMED to update information submitted in a } 1983 \\
\text { NOI for WIPP mining activities. The DOE submits quarterly discharge monitoring reports to the NMED } \\
\text { Groundwater Quality Bureau to comply with the requirements of DP-831. }\end{array}$ \\
\hline $\begin{array}{l}\text { New Mexico Wildlife Conservation Act }(\S \S 17-2-37 \text { to } \\
17-2-46 \text { NMSA 1978) }\end{array}$ & See "Endangered Species Act." \\
\hline $\begin{array}{l}\text { Resource Conservation and Recovery Act of } 1976 \\
\text { (42 U.S.C. } \$ 6901 \text { et seq.) }\end{array}$ & $\begin{array}{l}\text { Hazardous-waste generator compliance: All site-generated hazardous wastes were transported off-site } \\
\text { within the 90-day accumulation period. Permit compliance: NMED granted RCRA permit NM4890139088 } \\
\text { effective November } 26,1999 \text {. Underground Storage Tanks: Annual registration fee paid. }\end{array}$ \\
\hline $\begin{array}{l}\text { Toxic Substances Control Act of } 1974 \text { (15 U.S.C. §2601 } \\
\text { et seq.) }\end{array}$ & $\begin{array}{l}\text { Procurement of PCB-containing materials not allowed. The CBFO began to pursue the ability to dispose of } \\
\text { PCB-contaminated mixed waste at WIPP. Mixed waste containing asbestos waste is currently being } \\
\text { disposed of at WIPP. }\end{array}$ \\
\hline $\begin{array}{l}\text { Safe Drinking Water Act of } 1974 \text { (42 U.S.C. §300f } \\
\text { et seq.) }\end{array}$ & $\begin{array}{l}\text { The WIPP public water system is characterized as a nontransient, noncommunity system (NMED, } \\
\text { September } 9,1992) \text {. Drinking water is piped from the Carlsbad, New Mexico, municipal system. }\end{array}$ \\
\hline $\begin{array}{l}\text { Waste Isolation Pilot Plant Land Withdrawal Act of } 1992 \\
\text { (Pub. L. 102-579) }\end{array}$ & The Biennial Environmental Compliance Report was published in September 2002. \\
\hline
\end{tabular}




\section{Waste Isolation Pilot Plant 2002 Site Environmental Report}

\section{DOE/WIPP 03-2225}

Table 3.4 - Primary DOE Orders Affecting the WIPP Environmental Program

\begin{tabular}{|c|c|c|}
\hline Order No. & Title & Annotation \\
\hline DOE Order 5400.1 & $\begin{array}{l}\text { General Environmental } \\
\text { Protection Program }\end{array}$ & $\begin{array}{l}\text { Establishes environmental protection program requirements, authorities, and responsibilities for } \\
\text { DOE operations for ensuring compliance with federal and state environmental protection laws } \\
\text { and regulations, federal executive orders, and internal department policies. }\end{array}$ \\
\hline $\begin{array}{l}\text { DOE Order } 5400.5 \text { Paragraph } 1 \text { a } \\
\text { (3)(a) of Chapter II is canceled by } \\
\text { DOE O } 231.1\end{array}$ & $\begin{array}{l}\text { Radiation Protection of } \\
\text { the Public and the } \\
\text { Environment }\end{array}$ & $\begin{array}{l}\text { Establishes standards and requirements for operations of the DOE and DOE contractors with } \\
\text { respect to protection of the public and the environment against undue risk from radiation. }\end{array}$ \\
\hline DOE O 231.1 & $\begin{array}{l}\text { Environmental, Safety, and } \\
\text { Health Reporting }\end{array}$ & Ensures collecting and reporting on operations information. \\
\hline $\begin{array}{l}\text { DOE O } 225.1 \mathrm{~A} \text {, cancels } \\
\text { DOE O } 225.1\end{array}$ & Accident Investigation & $\begin{array}{l}\text { Prescribes requirements for conducting investigations of accidents and preventing recurrence of } \\
\text { such accidents. }\end{array}$ \\
\hline DOE O 414.1A & Quality Assurance & Promotes effective management through performance requirements and technical standards. \\
\hline DOE O 435.1 & $\begin{array}{l}\text { Radioactive Waste } \\
\text { Management }\end{array}$ & $\begin{array}{l}\text { Promotes radioactive waste management in a manner that is protective of workers, public health } \\
\text { and safety, and the environment. }\end{array}$ \\
\hline DOE O 451.1B & $\begin{array}{l}\text { National Environmental } \\
\text { Policy Act Compliance } \\
\text { Program }\end{array}$ & Establishes DOE policy for implementation of the NEPA of 1969 (Pub. L. 91-190). \\
\hline DOE O 460.1A & $\begin{array}{l}\text { Packaging and } \\
\text { Transportation Safety }\end{array}$ & $\begin{array}{l}\text { Establishes safety requirements for the proper packaging and transporting of DOE off-site } \\
\text { shipments and on-site transfers of hazardous materials and for model transportation. }\end{array}$ \\
\hline DOE O 460.2 & $\begin{array}{l}\text { Transportation and } \\
\text { Packaging }\end{array}$ & Prescribes requirements for materials transportation and packaging. \\
\hline DOE O 151.1A & $\begin{array}{l}\text { Comprehensive Emergency } \\
\text { Management System }\end{array}$ & $\begin{array}{l}\text { Establishes requirements for comprehensive planning, preparedness, response, and recovery } \\
\text { activities of emergency management programs for the DOE and for programs requiring DOE } \\
\text { assistance. }\end{array}$ \\
\hline DOE O 430.1A & $\begin{array}{l}\text { Life-Cycle Assessment } \\
\text { Management }\end{array}$ & $\begin{array}{l}\text { Establishes procedures to plan, acquire, operate, maintain, and dispose of physical assets as } \\
\text { valuable national resources. }\end{array}$ \\
\hline
\end{tabular}


Waste Isolation Pilot Plant 2002 Site Environmental Report DOE/WIPP 03-2225

Table 3.5 - Active Environmental Permits and Approvals for the Waste Isolation Pilot Plant - April 1, 2003

(Does Not Include Hazardous Waste Facility Permit)

\begin{tabular}{|c|c|c|c|c|c|c|c|c|c|}
\hline & Granting Agency & Type of Permit & $\begin{array}{l}\text { Permit } \\
\text { Number }\end{array}$ & Date & Expiration & $\begin{array}{c}\text { Current } \\
\text { Permit Status }\end{array}$ & WTS Owner & Signed By/Title & $\begin{array}{l}\text { Signed } \\
\text { For }\end{array}$ \\
\hline 1 & $\begin{array}{l}\text { Department of the Interior, } \\
\text { Bureau of Land } \\
\text { Management }\end{array}$ & $\begin{array}{l}\text { Right-of-Way for Water } \\
\text { Pipeline }\end{array}$ & NM53809 & $8 / 17 / 83$ & In Perpetuity & Active & \begin{tabular}{|l} 
Environmental \\
Monitoring
\end{tabular} & $\begin{array}{l}\text { Issued by BLM - WIPP } \\
\text { signature not required }\end{array}$ & $\mathrm{DOE}$ \\
\hline 2 & $\begin{array}{l}\text { Department of the Interior, } \\
\text { Bureau of Land } \\
\text { Management }\end{array}$ & $\begin{array}{l}\text { Right-of-Way for the } \\
\text { North Access Road }\end{array}$ & NM55676 & $8 / 24 / 83$ & None & Active & $\begin{array}{l}\text { Environmental } \\
\text { Monitoring }\end{array}$ & $\begin{array}{l}\text { Issued by BLM - WIPP } \\
\text { signature not required }\end{array}$ & DOE \\
\hline 3 & $\begin{array}{l}\text { Department of the Interior, } \\
\text { Bureau of Land } \\
\text { Management }\end{array}$ & Right-of-Way for Railroad & NM55699 & $9 / 27 / 83$ & None & Active & \begin{tabular}{|l} 
Environmental \\
Monitoring
\end{tabular} & $\begin{array}{l}\text { Issued by BLM - WIPP } \\
\text { signature not required }\end{array}$ & DOE \\
\hline 4 & $\begin{array}{l}\text { Department of the Interior, } \\
\text { Bureau of Land } \\
\text { Management }\end{array}$ & $\begin{array}{l}\text { Right-of-Way for } \\
\text { Dosimetry and Aerosol } \\
\text { Sampling Sites }\end{array}$ & NM63136 & $7 / 31 / 86$ & $7 / 31 / 11$ & Active & $\begin{array}{l}\text { Environmental } \\
\text { Monitoring }\end{array}$ & $\begin{array}{l}\text { Issued by BLM - WIPP } \\
\text { signature not required }\end{array}$ & $\mathrm{DOE}$ \\
\hline 5 & $\begin{array}{l}\text { Department of the Interior, } \\
\text { Bureau of Land } \\
\text { Management }\end{array}$ & $\begin{array}{l}\text { Right-of-Way for Seven } \\
\text { Subsidence Monuments }\end{array}$ & NM65801 & $11 / 7 / 86$ & None & Active & \begin{tabular}{|l} 
Environmental \\
Monitoring
\end{tabular} & $\begin{array}{l}\text { Issued by BLM - WIPP } \\
\text { signature not required }\end{array}$ & $\mathrm{DOE}$ \\
\hline 6 & $\begin{array}{l}\text { Department of the Interior, } \\
\text { Bureau of Land } \\
\text { Management }\end{array}$ & $\begin{array}{l}\text { Right-of-Way for Aerosol } \\
\text { Sampling Site }\end{array}$ & NM77921 & $8 / 18 / 89$ & $8 / 18 / 19$ & Active & \begin{tabular}{|l} 
Environmental \\
Monitoring
\end{tabular} & $\begin{array}{l}\text { Issued by BLM - WIPP } \\
\text { signature not required }\end{array}$ & $\mathrm{DOE}$ \\
\hline 7 & $\begin{array}{l}\text { Department of the Interior, } \\
\text { Bureau of Land } \\
\text { Management }\end{array}$ & $\begin{array}{l}\text { Right-of-Way for } 2 \text { Survey } \\
\text { Monuments }\end{array}$ & NM82245 & $12 / 13 / 89$ & $12 / 13 / 19$ & Active & \begin{tabular}{|l} 
Environmental \\
Monitoring
\end{tabular} & $\begin{array}{l}\text { Issued by BLM - WIPP } \\
\text { signature not required }\end{array}$ & DOE \\
\hline 8 & $\begin{array}{l}\text { Department of the Interior, } \\
\text { Bureau of Land } \\
\text { Management }\end{array}$ & $\begin{array}{l}\text { Right-of-Way for } \\
\text { telephone cable }\end{array}$ & NM46029 & $7 / 3 / 90$ & $9 / 4 / 11$ & Active & $\begin{array}{l}\text { Environmental } \\
\text { Monitoring }\end{array}$ & $\begin{array}{l}\text { Issued by BLM - WIPP } \\
\text { signature not required }\end{array}$ & DOE \\
\hline 9 & $\begin{array}{l}\text { Department of the Interior, } \\
\text { Bureau of Land } \\
\text { Management }\end{array}$ & $\begin{array}{l}\text { Right-of-Way for SPS } \\
\text { Powerline }\end{array}$ & NM43203 & $2 / 20 / 96$ & $10 / 19 / 11$ & Active & $\begin{array}{l}\text { Environmental } \\
\text { Monitoring }\end{array}$ & $\begin{array}{l}\text { Issued by BLM - WIPP } \\
\text { signature not required }\end{array}$ & DOE \\
\hline 10 & $\begin{array}{l}\text { Department of the Interior, } \\
\text { Bureau of Land } \\
\text { Management }\end{array}$ & $\begin{array}{l}\text { Right-of-Way for South } \\
\text { Access Road }\end{array}$ & NM46130 & $9 / 26 / 94$ & $8 / 17 / 31$ & Active & $\begin{array}{l}\text { Environmental } \\
\text { Monitoring }\end{array}$ & $\begin{array}{l}\text { Issued by BLM - WIPP } \\
\text { signature not required }\end{array}$ & DOE \\
\hline 11 & $\begin{array}{l}\text { Department of the Interior, } \\
\text { Bureau of Land } \\
\text { Management }\end{array}$ & $\begin{array}{l}\text { Right-of-Way for Duval } \\
\text { Telephone Line }\end{array}$ & NM60174 & $11 / 6 / 96$ & $3 / 8 / 15$ & Active & $\begin{array}{l}\text { Environmental } \\
\text { Monitoring }\end{array}$ & $\begin{array}{l}\text { Issued by BLM - WIPP } \\
\text { signature not required }\end{array}$ & DOE \\
\hline
\end{tabular}


Waste Isolation Pilot Plant 2002 Site Environmental Report DOE/WIPP 03-2225

Table 3.5 - Active Environmental Permits and Approvals for the Waste Isolation Pilot Plant - April 1, 2003 (Does Not Include Hazardous Waste Facility Permit)

\begin{tabular}{|c|c|c|c|c|c|c|c|c|c|}
\hline & Granting Agency & Type of Permit & $\begin{array}{l}\text { Permit } \\
\text { Number }\end{array}$ & Date & Expiration & $\begin{array}{c}\text { Current } \\
\text { Permit Status }\end{array}$ & WTS Owner & Signed By/Title & $\begin{array}{l}\text { Signed } \\
\text { For }\end{array}$ \\
\hline 12 & $\begin{array}{l}\text { Department of the Interior, } \\
\text { Bureau of Land } \\
\text { Management }\end{array}$ & $\begin{array}{l}\text { Right-of-Way for Wells } \\
\text { AEC-7 \& AEC-8 }\end{array}$ & NM108365 & $8 / 30 / 02$ & $8 / 30 / 32$ & Active & \begin{tabular}{|l} 
Environmental \\
Monitoring
\end{tabular} & $\begin{array}{l}\text { Issued by BLM - WIPP } \\
\text { signature not required }\end{array}$ & DOE \\
\hline 13 & $\begin{array}{l}\text { Department of the Interior, } \\
\text { Bureau of Land } \\
\text { Management }\end{array}$ & Right-of-Way for ERDA-6 & NM108365 & $8 / 30 / 02$ & $8 / 30 / 32$ & Active & $\begin{array}{l}\text { Environmental } \\
\text { Monitoring }\end{array}$ & $\begin{array}{l}\text { Issued by BLM - WIPP } \\
\text { signature not required }\end{array}$ & DOE \\
\hline 14 & $\begin{array}{l}\text { Department of the Interior, } \\
\text { Bureau of Land } \\
\text { Management }\end{array}$ & $\begin{array}{l}\text { Right-of-Way for Well } \\
\text { C-2756 (P-18) }\end{array}$ & NM108365 & $8 / 30 / 02$ & $8 / 30 / 32$ & Active & \begin{tabular}{|l} 
Environmental \\
Monitoring
\end{tabular} & $\begin{array}{l}\text { Issued by BLM - WIPP } \\
\text { signature not required }\end{array}$ & DOE \\
\hline 15 & $\begin{array}{l}\text { Department of the Interior, } \\
\text { Bureau of Land } \\
\text { Management }\end{array}$ & $\begin{array}{l}\text { Right-of-Way for } \\
\text { Monitoring Well C-2664 } \\
\text { (Cabin Baby) }\end{array}$ & NM107944 & $4 / 23 / 02$ & $4 / 23 / 32$ & Active & $\begin{array}{l}\text { Environmental } \\
\text { Monitoring }\end{array}$ & $\begin{array}{l}\text { Issued by BLM - WIPP } \\
\text { signature not required }\end{array}$ & DOE \\
\hline 16 & $\begin{array}{l}\text { Department of the Interior, } \\
\text { Bureau of Land } \\
\text { Management }\end{array}$ & $\begin{array}{l}\text { Right-of-Way for Seismic } \\
\text { Monitoring Station }\end{array}$ & NM85426 & $9 / 23 / 91$ & None & Active & $\begin{array}{l}\text { Environmental } \\
\text { Monitoring }\end{array}$ & $\begin{array}{l}\text { Issued by BLM - WIPP } \\
\text { signature not required }\end{array}$ & $\mathrm{DOE}$ \\
\hline 17 & $\begin{array}{l}\text { Department of the Interior, } \\
\text { Bureau of Land } \\
\text { Management }\end{array}$ & $\begin{array}{l}\text { Right-of-Way for Wells } \\
\text { C-2725 (H-4A), C-2775 } \\
(\mathrm{H}-4 \mathrm{~B}), \text { \& } \mathrm{C}-2776(\mathrm{H}-4 \mathrm{C})\end{array}$ & NM108365 & $8 / 30 / 02$ & $8 / 30 / 32$ & Active & \begin{tabular}{|l} 
Environmental \\
Monitoring
\end{tabular} & $\begin{array}{l}\text { Issued by BLM - WIPP } \\
\text { signature not required }\end{array}$ & DOE \\
\hline 18 & $\begin{array}{l}\text { Department of the Interior, } \\
\text { Bureau of Land } \\
\text { Management }\end{array}$ & $\begin{array}{l}\text { Right-of-Way for } \\
\text { Monitoring Wells C-2723 } \\
\text { (WIPP-25), C-2724 } \\
\text { (WIPP-26), C-2722 } \\
\text { (WIPP-27), C-2636 } \\
\text { (WIPP-28), C-2743 } \\
\text { (WIPP-29), \& C-2727 } \\
\text { (WIPP-30) }\end{array}$ & NM108365 & $8 / 30 / 02$ & $8 / 30 / 32$ & Active & \begin{tabular}{|l} 
Environmental \\
Monitoring
\end{tabular} & $\begin{array}{l}\text { Issued by BLM - WIPP } \\
\text { signature not required }\end{array}$ & $\mathrm{DOE}$ \\
\hline 19 & $\begin{array}{l}\text { Department of the Interior, } \\
\text { Bureau of Land } \\
\text { Management }\end{array}$ & $\begin{array}{l}\text { Right-of-Way for Aerosol } \\
\text { Sampling Sites }\end{array}$ & NM77921 & $10 / 3 / 89$ & $8 / 18 / 19$ & Active & $\begin{array}{l}\text { Environmental } \\
\text { Monitoring }\end{array}$ & $\begin{array}{l}\text { Issued by BLM - WIPP } \\
\text { signature not required }\end{array}$ & DOE \\
\hline 20 & $\begin{array}{l}\text { Department of the Interior, } \\
\text { Bureau of Land } \\
\text { Management }\end{array}$ & $\begin{array}{l}\text { Right-of-way Easement } \\
\text { for Accessing State Trust } \\
\text { Lands in Eddy and Lea } \\
\text { Counties }\end{array}$ & NM25430 & $2 / 29 / 00$ & $9 / 28 / 04$ & Active & $\begin{array}{l}\text { Environmental } \\
\text { Monitoring }\end{array}$ & $\begin{array}{l}\text { Issued by BLM - WIPP } \\
\text { signature not required }\end{array}$ & DOE \\
\hline
\end{tabular}


Waste Isolation Pilot Plant 2002 Site Environmental Report DOE/WIPP 03-2225

Table 3.5 - Active Environmental Permits and Approvals for the Waste Isolation Pilot Plant - April 1, 2003 (Does Not Include Hazardous Waste Facility Permit)

\begin{tabular}{|c|c|c|c|c|c|c|c|c|c|}
\hline & Granting Agency & Type of Permit & $\begin{array}{l}\text { Permit } \\
\text { Number }\end{array}$ & Date & Expiration & $\begin{array}{c}\text { Current } \\
\text { Permit Status }\end{array}$ & WTS Owner & Signed By/Title & $\begin{array}{l}\text { Signed } \\
\text { For }\end{array}$ \\
\hline 21 & $\begin{array}{l}\text { U.S. Department of the } \\
\text { Interior, Fish and Wildlife } \\
\text { Service }\end{array}$ & $\begin{array}{l}\text { Concurrence that WIPP } \\
\text { Construction Activities } \\
\text { Will Have No Significant } \\
\text { Impact on Federally- } \\
\text { Listed Threatened or } \\
\text { Endangered Species }\end{array}$ & None & $5 / 29 / 80$ & None & Active & $\begin{array}{l}\text { Environmental } \\
\text { Monitoring }\end{array}$ & $\mathrm{N} / \mathrm{A}$ & N/A \\
\hline 22 & $\begin{array}{l}\text { New Mexico Environment } \\
\text { Department Groundwater } \\
\text { Bureau }\end{array}$ & Discharge Permit & DP-831 & $7 / 3 / 97$ & $\begin{array}{c}7 / 3 / 02 \\
\text { (Comments } \\
\text { on draft } \\
\text { renewal } \\
\text { submitted } \\
4 / 10 / 03 \text { ) } \\
\end{array}$ & Active & $\begin{array}{l}\text { Environmental } \\
\text { Monitoring and } \\
\text { Facility } \\
\text { Operations }\end{array}$ & $\begin{array}{l}\text { G. E. Dials, Manager } \\
\text { 12/16/96 }\end{array}$ & DOE \\
\hline 23 & $\begin{array}{l}\text { New Mexico Environment } \\
\text { Department Air Quality } \\
\text { Bureau }\end{array}$ & $\begin{array}{l}\text { Operating Permit for two } \\
\text { backup diesel generators }\end{array}$ & $310-M-2$ & $12 / 7 / 93$ & None & Active & $\begin{array}{l}\text { Facility } \\
\text { Operations }\end{array}$ & $\begin{array}{l}\text { A. E. Hunt Project } \\
\text { Manager } \\
6 / 18 / 93\end{array}$ & DOE \\
\hline 24 & $\begin{array}{l}\text { New Mexico Department } \\
\text { of Game and Fish }\end{array}$ & $\begin{array}{l}\text { Concurrence that WIPP } \\
\text { construction activities will } \\
\text { have no significant impact } \\
\text { on state-listed threatened } \\
\text { or endangered species } \\
\end{array}$ & $\begin{array}{l}\text { None } \\
7 / 25 / 83 \\
\\
\end{array}$ & $5 / 26 / 89$ & None & Active & \begin{tabular}{|l} 
Environmental \\
Monitoring
\end{tabular} & $\mathrm{N} / \mathrm{A}$ & $\mathrm{N} / \mathrm{A}$ \\
\hline 25 & $\begin{array}{l}\text { New Mexico Environment } \\
\text { Department-UST Bureau }\end{array}$ & $\begin{array}{l}\text { Underground Storage } \\
\text { Tanks }\end{array}$ & $\begin{array}{l}\text { NMED11811 } \\
\text { (Number } \\
\text { changes } \\
\text { annually) }\end{array}$ & $7 / 1 / 02$ & $\begin{array}{c}6 / 30 / 03 \\
(2003 \\
\text { registration } \\
\text { submitted } \\
6 / 18 / 02) \\
\end{array}$ & Active & $\begin{array}{l}\text { Facility } \\
\text { Operations }\end{array}$ & $\begin{array}{l}\text { V. Daub, } \\
\text { Deputy Project Site } \\
\text { Manager } \\
6 / 18 / 92 \text { (Initial UST } \\
\text { registration) } \\
\end{array}$ & DOE \\
\hline 26 & $\begin{array}{l}\text { New Mexico State } \\
\text { Engineer Office }\end{array}$ & $\begin{array}{l}\text { Monitoring Well Exhaust } \\
\text { Shaft Exploratory } \\
\text { Borehole }\end{array}$ & C-2801 & $2 / 23 / 01$ & None & Active & EM\&H & H. E. Johnson, DOE & DOE \\
\hline 27 & $\begin{array}{l}\text { New Mexico State } \\
\text { Engineer Office }\end{array}$ & $\begin{array}{l}\text { Monitoring Well Exhaust } \\
\text { Shaft Exploratory } \\
\text { Borehole }\end{array}$ & C-2802 & $2 / 23 / 01$ & None & Active & EM\&H & $\begin{array}{l}\text { E. K. Hunter, Asst. } \\
\text { Manager ONTWO } \\
9 / 10 / 97\end{array}$ & DOE \\
\hline 28 & $\begin{array}{l}\text { New Mexico State } \\
\text { Engineer Office }\end{array}$ & $\begin{array}{l}\text { Monitoring Well Exhaust } \\
\text { Shaft Exploratory } \\
\text { Borehole }\end{array}$ & C-2803 & $2 / 23 / 01$ & None & Active & EM\&H & $\begin{array}{l}\text { E. K. Hunter, Asst. } \\
\text { Manager ONTWO } \\
\text { 9/10/97 }\end{array}$ & DOE \\
\hline
\end{tabular}


Waste Isolation Pilot Plant 2002 Site Environmental Report DOE/WIPP 03-2225

Table 3.5 - Active Environmental Permits and Approvals for the Waste Isolation Pilot Plant - April 1, 2003

(Does Not Include Hazardous Waste Facility Permit)

\begin{tabular}{|c|c|c|c|c|c|c|c|c|c|}
\hline & Granting Agency & Type of Permit & $\begin{array}{l}\text { Permit } \\
\text { Number }\end{array}$ & Date & Expiration & $\begin{array}{c}\text { Current } \\
\text { Permit Status }\end{array}$ & WTS Owner & Signed By/Title & $\begin{array}{l}\text { Signed } \\
\text { For }\end{array}$ \\
\hline 29 & $\begin{array}{l}\text { New Mexico State } \\
\text { Engineer Office }\end{array}$ & Monitoring Well & C-2811 & $3 / 2 / 02$ & None & Active & EM\&H & H. E. Johnson, DOE & DOE \\
\hline 30 & $\begin{array}{l}\text { New Mexico State } \\
\text { Engineer Office }\end{array}$ & $\begin{array}{l}\text { Appropriation: WQSP-1 } \\
\text { Well }\end{array}$ & C-2413 & $10 / 21 / 96$ & None & Active & EM\&H & $\begin{array}{l}\text { E. K. Hunter, Asst. } \\
\text { Manager ONTWO } \\
\text { 7/3/96 DOE }\end{array}$ & DOE \\
\hline 31 & $\begin{array}{l}\text { New Mexico State } \\
\text { Engineer Office }\end{array}$ & $\begin{array}{l}\text { Appropriation: WQSP-2 } \\
\text { Well }\end{array}$ & C-2414 & $10 / 21 / 96$ & None & Active & EM\&H & $\begin{array}{l}\text { E. K. Hunter, Asst. } \\
\text { Manager ONTWO } \\
7 / 3 / 96\end{array}$ & DOE \\
\hline 32 & $\begin{array}{l}\text { New Mexico State } \\
\text { Engineer Office }\end{array}$ & $\begin{array}{l}\text { Appropriation: WQSP-3 } \\
\text { Well }\end{array}$ & C-2415 & $10 / 21 / 96$ & None & Active & EM\&H & $\begin{array}{l}\text { E. K. Hunter, Asst. } \\
\text { Manager ONTWO } \\
7 / 3 / 96\end{array}$ & $\mathrm{DOE}$ \\
\hline 33 & $\begin{array}{l}\text { New Mexico State } \\
\text { Engineer Office }\end{array}$ & $\begin{array}{l}\text { Appropriation: WQSP-4 } \\
\text { Well }\end{array}$ & C-2416 & $10 / 21 / 96$ & None & Active & EM\&H & $\begin{array}{l}\text { E. K. Hunter, Asst. } \\
\text { Manager ONTWO } \\
7 / 3 / 96\end{array}$ & DOE \\
\hline 34 & $\begin{array}{l}\text { New Mexico State } \\
\text { Engineer Office }\end{array}$ & $\begin{array}{l}\text { Appropriation: WQSP-5 } \\
\text { Well }\end{array}$ & C-2417 & $10 / 21 / 96$ & None & Active & EM\&H & $\begin{array}{l}\text { E. K. Hunter, Asst. } \\
\text { Manager ONTWO } \\
7 / 3 / 96\end{array}$ & $\mathrm{DOE}$ \\
\hline 35 & $\begin{array}{l}\text { New Mexico State } \\
\text { Engineer Office }\end{array}$ & $\begin{array}{l}\text { Appropriation: WQSP-6 } \\
\text { Well }\end{array}$ & C-2418 & $10 / 21 / 96$ & None & Active & EM\&H & $\begin{array}{l}\text { E. K. Hunter, Asst. } \\
\text { Manager ONTWO } \\
7 / 3 / 96\end{array}$ & $\mathrm{DOE}$ \\
\hline 36 & $\begin{array}{l}\text { New Mexico State } \\
\text { Engineer Office }\end{array}$ & $\begin{array}{l}\text { Appropriation: WQSP-6a } \\
\text { Well }\end{array}$ & C-2419 & $10 / 21 / 96$ & None & Active & EM\&H & $\begin{array}{l}\text { E. K. Hunter, Asst. } \\
\text { Manager ONTWO } \\
7 / 3 / 96\end{array}$ & DOE \\
\hline 37 & $\begin{array}{l}\text { New Mexico State } \\
\text { Engineer Office } \\
\end{array}$ & Monitoring Well AEC-7 & $\mathrm{C}-2742$ & $11 / 6 / 00$ & None & Active & EM\&H & D. C. Lynn, 10/23/00 & DOE \\
\hline 38 & $\begin{array}{l}\text { New Mexico State } \\
\text { Engineer Office }\end{array}$ & Monitoring Well AEC-8 & C-2744 & $11 / 6 / 00$ & None & Active & EM\&H & D. C. Lynn, 10/23/00 & DOE \\
\hline 39 & $\begin{array}{l}\text { New Mexico State } \\
\text { Engineer Office }\end{array}$ & $\begin{array}{l}\text { Monitoring Well Cabin } \\
\text { Baby }\end{array}$ & C-2664 & $7 / 30 / 99$ & None & Active & EM\&H & $\begin{array}{l}\text { Richard A. Jepson, } \\
\text { Sandia National } \\
\text { Laboratories } 7 / 29 / 99 \\
\end{array}$ & $\mathrm{DOE}$ \\
\hline 40 & $\begin{array}{l}\text { New Mexico State } \\
\text { Engineer Office }\end{array}$ & $\begin{array}{l}\text { Monitoring Well D-268 } \\
\text { Plugged to } 220^{\prime} \\
\text { Livestock watering }\end{array}$ & C-2638 & $1 / 12 / 99$ & None & Active & EM\&H & $\begin{array}{l}\text { G. T. Basabilvaso, } \\
\text { DOE 12/10/98 }\end{array}$ & DOE \\
\hline
\end{tabular}


Waste Isolation Pilot Plant 2002 Site Environmental Report DOE/WIPP 03-2225

Table 3.5 - Active Environmental Permits and Approvals for the Waste Isolation Pilot Plant - April 1, 2003 (Does Not Include Hazardous Waste Facility Permit)

\begin{tabular}{|c|c|c|c|c|c|c|c|c|c|}
\hline & Granting Agency & Type of Permit & $\begin{array}{l}\text { Permit } \\
\text { Number }\end{array}$ & Date & Expiration & $\begin{array}{c}\text { Current } \\
\text { Permit Status }\end{array}$ & WTS Owner & Signed By/Title & $\begin{array}{l}\text { Signed } \\
\text { For }\end{array}$ \\
\hline 41 & $\begin{array}{l}\text { New Mexico State } \\
\text { Engineer Office }\end{array}$ & Monitoring Well DOE-1 & C-2757 & $11 / 6 / 00$ & None & Active & EM\&H & D. C. Lynn, 10/23/00 & $\mathrm{DOE}$ \\
\hline 42 & $\begin{array}{l}\text { New Mexico State } \\
\text { Engineer Office }\end{array}$ & Monitoring Well DOE-2 & C-2682 & $4 / 17 / 00$ & None & Active & EM\&H & D. C. Lynn, 10/23/00 & DOE \\
\hline 43 & $\begin{array}{l}\text { New Mexico State } \\
\text { Engineer Office }\end{array}$ & Monitoring Well ERDA-9 & C-2752 & $11 / 6 / 00$ & None & Active & EM\&H & D. C. Lynn, 10/23/00 & DOE \\
\hline 44 & $\begin{array}{l}\text { New Mexico State } \\
\text { Engineer Office }\end{array}$ & Monitoring Well H-1 & C-2765 & $11 / 6 / 00$ & None & $P \& A^{*}$ & EM\&H & D. C. Lynn, 10/23/00 & DOE \\
\hline 45 & $\begin{array}{l}\text { New Mexico State } \\
\text { Engineer Office }\end{array}$ & Monitoring Well $\mathrm{H}-2 \mathrm{~A}$ & C-2762 & $11 / 6 / 00$ & None & Active & EM\&H & D. C. Lynn, 10/23/00 & DOE \\
\hline 46 & $\begin{array}{l}\text { New Mexico State } \\
\text { Engineer Office } \\
\end{array}$ & Monitoring Well H-2B1 & C-2758 & $11 / 6 / 00$ & None & Active & EM\&H & D. C. Lynn, 10/23/00 & DOE \\
\hline 47 & $\begin{array}{l}\text { New Mexico State } \\
\text { Engineer Office }\end{array}$ & Monitoring Well H-2B2 & C-2763 & $11 / 6 / 00$ & None & Active & EM\&H & D. C. Lynn, 10/23/00 & DOE \\
\hline 48 & $\begin{array}{l}\text { New Mexico State } \\
\text { Engineer Office }\end{array}$ & Monitoring Well $\mathrm{H}-2 \mathrm{C}$ & C-2759 & $11 / 6 / 00$ & None & Active & EM\&H & D. C. Lynn, 10/23/00 & DOE \\
\hline 49 & $\begin{array}{l}\text { New Mexico State } \\
\text { Engineer Office }\end{array}$ & Monitoring Well H-3B1 & C-2764 & $11 / 6 / 00$ & None & Active & EM\&H & D. C. Lynn, 10/23/00 & DOE \\
\hline 50 & $\begin{array}{l}\text { New Mexico State } \\
\text { Engineer Office }\end{array}$ & Monitoring Well H-3B2 & C-2760 & $11 / 6 / 00$ & None & Active & EM\&H & D. C. Lynn, 10/23/00 & DOE \\
\hline 51 & $\begin{array}{l}\text { New Mexico State } \\
\text { Engineer Office }\end{array}$ & Monitoring Well H-3B3 & C-2761 & $11 / 6 / 00$ & None & Active & EM\&H & D. C. Lynn, 10/23/00 & DOE \\
\hline 52 & $\begin{array}{l}\text { New Mexico State } \\
\text { Engineer Office }\end{array}$ & Monitoring Well H-3D & Pending & $11 / 6 / 00$ & None & Active & EM\&H & D. C. Lynn, 10/23/00 & DOE \\
\hline 53 & $\begin{array}{l}\text { New Mexico State } \\
\text { Engineer Office }\end{array}$ & Monitoring Well H-4A & C-2725 & $11 / 6 / 00$ & None & $P \& A$ & EM\&H & D. C. Lynn, 10/23/00 & DOE \\
\hline 54 & $\begin{array}{l}\text { New Mexico State } \\
\text { Engineer Office }\end{array}$ & Monitoring Well H-4B & C-2775 & $11 / 6 / 00$ & None & Active & EM\&H & D. C. Lynn, 10/23/00 & DOE \\
\hline 55 & $\begin{array}{l}\text { New Mexico State } \\
\text { Engineer Office }\end{array}$ & Monitoring Well $\mathrm{H}-4 \mathrm{C}$ & C-2776 & $11 / 6 / 00$ & None & Active & EM\&H & D. C. Lynn, 10/23/00 & DOE \\
\hline 56 & $\begin{array}{l}\text { New Mexico State } \\
\text { Engineer Office }\end{array}$ & Monitoring Well $\mathrm{H}-5 \mathrm{~A}$ & C-2746 & $11 / 6 / 00$ & None & Active & EM\&H & D. C. Lynn, 10/23/00 & DOE \\
\hline
\end{tabular}


Waste Isolation Pilot Plant 2002 Site Environmental Report DOE/WIPP 03-2225

Table 3.5 - Active Environmental Permits and Approvals for the Waste Isolation Pilot Plant - April 1, 2003

(Does Not Include Hazardous Waste Facility Permit)

\begin{tabular}{|c|c|c|c|c|c|c|c|c|c|}
\hline & Granting Agency & Type of Permit & $\begin{array}{l}\text { Permit } \\
\text { Number }\end{array}$ & Date & Expiration & \begin{tabular}{|c|} 
Current \\
Permit Status
\end{tabular} & WTS Owner & Signed By/Title & $\begin{array}{l}\text { Signed } \\
\text { For }\end{array}$ \\
\hline 57 & $\begin{array}{l}\text { New Mexico State } \\
\text { Engineer Office }\end{array}$ & Monitoring Well H-5B & C-2745 & $11 / 6 / 00$ & None & Active & EM\&H & D. C. Lynn, 10/23/00 & DOE \\
\hline 58 & $\begin{array}{l}\text { New Mexico State } \\
\text { Engineer Office }\end{array}$ & Monitoring Well H-5C & C-2747 & $11 / 6 / 00$ & None & Active & EM\&H & D. C. Lynn, 10/23/00 & DOE \\
\hline 59 & $\begin{array}{l}\text { New Mexico State } \\
\text { Engineer Office }\end{array}$ & Monitoring Well H-6A & C-2751 & $11 / 6 / 00$ & None & Active & EM\&H & D. C. Lynn, 10/23/00 & DOE \\
\hline 60 & $\begin{array}{l}\text { New Mexico State } \\
\text { Engineer Office }\end{array}$ & Monitoring Well H-6B & C-2749 & $11 / 6 / 00$ & None & Active & EM\&H & D. C. Lynn, 10/23/00 & DOE \\
\hline 61 & $\begin{array}{l}\text { New Mexico State } \\
\text { Engineer Office }\end{array}$ & Monitoring Well H-6C & C-2750 & $11 / 6 / 00$ & None & Active & EM\&H & D. C. Lynn, 10/23/00 & DOE \\
\hline 62 & $\begin{array}{l}\text { New Mexico State } \\
\text { Engineer Office }\end{array}$ & Monitoring Well H-7A & C-2694 & $4 / 17 / 00$ & None & $P \& A$ & EM\&H & D. C. Lynn, 10/23/00 & DOE \\
\hline 63 & $\begin{array}{l}\text { New Mexico State } \\
\text { Engineer Office }\end{array}$ & Monitoring Well H-7B1 & C-2770 & $11 / 6 / 00$ & None & Active & EM\&H & D. C. Lynn, 10/23/00 & DOE \\
\hline 64 & $\begin{array}{l}\text { New Mexico State } \\
\text { Engineer Office }\end{array}$ & Monitoring Well H-7B2 & C-2771 & $11 / 6 / 00$ & None & Active & EM\&H & D. C. Lynn, 10/23/00 & DOE \\
\hline 65 & $\begin{array}{l}\text { New Mexico State } \\
\text { Engineer Office }\end{array}$ & Monitoring Well H-7C & C-2772 & $11 / 6 / 00$ & None & Active & EM\&H & D. C. Lynn, 10/23/00 & DOE \\
\hline 66 & $\begin{array}{l}\text { New Mexico State } \\
\text { Engineer Office }\end{array}$ & Monitoring Well H-8A & $\mathrm{C}-2780$ & $11 / 6 / 00$ & None & Active & EM\&H & D. C. Lynn, 10/23/00 & DOE \\
\hline 67 & $\begin{array}{l}\text { New Mexico State } \\
\text { Engineer Office }\end{array}$ & Monitoring Well H-8B & $\mathrm{C}-2781$ & $11 / 6 / 00$ & None & Active & EM\&H & D. C. Lynn, 10/23/00 & DOE \\
\hline 68 & $\begin{array}{l}\text { New Mexico State } \\
\text { Engineer Office }\end{array}$ & Monitoring Well H-8C & C-2782 & $11 / 6 / 00$ & None & Active & EM\&H & D. C. Lynn, 10/23/00 & DOE \\
\hline 69 & $\begin{array}{l}\text { New Mexico State } \\
\text { Engineer Office }\end{array}$ & Monitoring Well H-9A & C-2785 & $11 / 6 / 00$ & None & $P \& A$ & EM\&H & D. C. Lynn, 10/23/00 & DOE \\
\hline 70 & $\begin{array}{l}\text { New Mexico State } \\
\text { Engineer Office }\end{array}$ & Monitoring Well H-9B & C-2783 & $11 / 6 / 00$ & None & Active & EM\&H & D. C. Lynn, 10/23/00 & DOE \\
\hline 71 & $\begin{array}{l}\text { New Mexico State } \\
\text { Engineer Office }\end{array}$ & Monitoring Well H-9C & $\mathrm{C}-2784$ & $11 / 6 / 00$ & None & Active & EM\&H & D. C. Lynn, 10/23/00 & DOE \\
\hline 72 & $\begin{array}{l}\text { New Mexico State } \\
\text { Engineer Office }\end{array}$ & Monitoring Well H-10A & C-2779 & $11 / 6 / 00$ & None & Active & EM\&H & D. C. Lynn, 10/23/00 & DOE \\
\hline
\end{tabular}


Waste Isolation Pilot Plant 2002 Site Environmental Report DOE/WIPP 03-2225

Table 3.5 - Active Environmental Permits and Approvals for the Waste Isolation Pilot Plant - April 1, 2003 (Does Not Include Hazardous Waste Facility Permit)

\begin{tabular}{|c|c|c|c|c|c|c|c|c|c|}
\hline & Granting Agency & Type of Permit & $\begin{array}{l}\text { Permit } \\
\text { Number }\end{array}$ & Date & Expiration & $\begin{array}{c}\text { Current } \\
\text { Permit Status }\end{array}$ & WTS Owner & Signed By/Title & $\begin{array}{l}\text { Signed } \\
\text { For }\end{array}$ \\
\hline 73 & $\begin{array}{l}\text { New Mexico State } \\
\text { Engineer Office }\end{array}$ & Monitoring Well H-10B & C-2778 & $11 / 6 / 00$ & None & P\&A & EM\&H & D. C. Lynn, 10/23/00 & $\mathrm{DOE}$ \\
\hline 74 & $\begin{array}{l}\text { New Mexico State } \\
\text { Engineer Office }\end{array}$ & Monitoring Well $\mathrm{H}-10 \mathrm{C}$ & C-2695 & $4 / 17 / 00$ & None & Active & EM\&H & D. C. Lynn, 10/23/00 & DOE \\
\hline 75 & $\begin{array}{l}\text { New Mexico State } \\
\text { Engineer Office }\end{array}$ & Monitoring Well H-11B1 & C-2767 & $11 / 6 / 00$ & None & Active & EM\&H & D. C. Lynn, 10/23/00 & DOE \\
\hline 76 & $\begin{array}{l}\text { New Mexico State } \\
\text { Engineer Office }\end{array}$ & Monitoring Well H-11B2 & C-2687 & $4 / 17 / 00$ & None & Active & EM\&H & D. C. Lynn, 10/23/00 & DOE \\
\hline 77 & $\begin{array}{l}\text { New Mexico State } \\
\text { Engineer Office }\end{array}$ & Monitoring Well H-11B3 & C-2768 & $11 / 6 / 00$ & None & Active & EM\&H & D. C. Lynn, 10/23/00 & DOE \\
\hline 78 & $\begin{array}{l}\text { New Mexico State } \\
\text { Engineer Office } \\
\end{array}$ & Monitoring Well H-11B4 & C-2769 & $11 / 6 / 00$ & None & Active & EM\&H & D. C. Lynn, 10/23/00 & DOE \\
\hline 79 & $\begin{array}{l}\text { New Mexico State } \\
\text { Engineer Office }\end{array}$ & Monitoring Well H-12 & C-2777 & $11 / 6 / 00$ & None & Active & EM\&H & D. C. Lynn, 10/23/00 & DOE \\
\hline 80 & $\begin{array}{l}\text { New Mexico State } \\
\text { Engineer Office }\end{array}$ & Monitoring Well H-14 & C-2766 & $11 / 6 / 00$ & None & Active & EM\&H & D. C. Lynn, 10/23/00 & DOE \\
\hline 81 & $\begin{array}{l}\text { New Mexico State } \\
\text { Engineer Office }\end{array}$ & Monitoring Well H-15 & C-2685 & $4 / 17 / 00$ & None & Active & EM\&H & D. C. Lynn, 10/23/00 & DOE \\
\hline 82 & $\begin{array}{l}\text { New Mexico State } \\
\text { Engineer Office }\end{array}$ & Monitoring Well H-16 & C-2753 & $11 / 6 / 00$ & None & Active & EM\&H & D. C. Lynn, 10/23/00 & DOE \\
\hline 83 & $\begin{array}{l}\text { New Mexico State } \\
\text { Engineer Office }\end{array}$ & Monitoring Well H-17 & C-2773 & $11 / 6 / 00$ & None & Active & EM\&H & D. C. Lynn, 10/23/00 & DOE \\
\hline 84 & $\begin{array}{l}\text { New Mexico State } \\
\text { Engineer Office }\end{array}$ & Monitoring Well H-18 & C-2683 & $4 / 17 / 00$ & None & Active & EM\&H & D. C. Lynn, 10/23/00 & DOE \\
\hline 85 & $\begin{array}{l}\text { New Mexico State } \\
\text { Engineer Office }\end{array}$ & Monitoring Well H-19B0 & C-2420 & $1 / 25 / 95$ & $1 / 31 / 98$ & $\begin{array}{c}\text { Inactive - } \\
\text { Renew when } \\
\text { necessary }\end{array}$ & EM\&H & $\begin{array}{l}\text { Harold F. Klaus, Jr. } \\
\text { DOE 11/9/94 }\end{array}$ & $\mathrm{DOE}$ \\
\hline 86 & $\begin{array}{l}\text { New Mexico State } \\
\text { Engineer Office }\end{array}$ & Monitoring Well H-19B1 & C-2420 & $1 / 25 / 95$ & $1 / 31 / 98$ & $\begin{array}{c}\text { Inactive - } \\
\text { Renew when } \\
\text { necessary }\end{array}$ & EM\&H & $\begin{array}{l}\text { Harold F. Klaus, Jr. } \\
\text { DOE 11/9/94 }\end{array}$ & DOE \\
\hline 87 & $\begin{array}{l}\text { New Mexico State } \\
\text { Engineer Office }\end{array}$ & Monitoring Well H-19B2 & C-2421 & $1 / 25 / 95$ & $1 / 31 / 98$ & $\begin{array}{c}\text { Inactive - } \\
\text { Renew when } \\
\text { necessary }\end{array}$ & EM\&H & $\begin{array}{l}\text { Harold F. Klaus, Jr. } \\
\text { DOE 11/9/94 }\end{array}$ & DOE \\
\hline
\end{tabular}


Waste Isolation Pilot Plant 2002 Site Environmental Report DOE/WIPP 03-2225

Table 3.5 - Active Environmental Permits and Approvals for the Waste Isolation Pilot Plant - April 1, 2003

(Does Not Include Hazardous Waste Facility Permit)

\begin{tabular}{|c|c|c|c|c|c|c|c|c|c|}
\hline & Granting Agency & Type of Permit & $\begin{array}{l}\text { Permit } \\
\text { Number }\end{array}$ & Date & Expiration & $\begin{array}{c}\text { Current } \\
\text { Permit Status }\end{array}$ & WTS Owner & Signed By/Title & $\begin{array}{l}\text { Signed } \\
\text { For }\end{array}$ \\
\hline 88 & $\begin{array}{l}\text { New Mexico State } \\
\text { Engineer Office }\end{array}$ & Monitoring Well H-19B3 & C-2422 & $1 / 25 / 95$ & $1 / 31 / 98$ & $\begin{array}{c}\text { Inactive - } \\
\text { Renew when } \\
\text { necessary }\end{array}$ & EM\&H & $\begin{array}{l}\text { Harold F. Klaus, Jr. } \\
\text { DOE 11/9/94 }\end{array}$ & DOE \\
\hline 89 & $\begin{array}{l}\text { New Mexico State } \\
\text { Engineer Office }\end{array}$ & Monitoring Well H-19B4 & C-2423 & $1 / 25 / 95$ & $1 / 31 / 98$ & $\begin{array}{c}\text { Inactive - } \\
\text { Renew when } \\
\text { necessary }\end{array}$ & EM\&H & $\begin{array}{l}\text { Harold F. Klaus, Jr. } \\
\text { DOE 11/9/94 }\end{array}$ & $\mathrm{DOE}$ \\
\hline 90 & $\begin{array}{l}\text { New Mexico State } \\
\text { Engineer Office }\end{array}$ & Monitoring Well H-19B5 & C-2424 & $1 / 25 / 95$ & $1 / 31 / 98$ & $\begin{array}{c}\text { Inactive - } \\
\text { Renew when } \\
\text { necessary }\end{array}$ & EM\&H & $\begin{array}{l}\text { Harold F. Klaus, Jr. } \\
\text { DOE 11/9/94 }\end{array}$ & $\mathrm{DOE}$ \\
\hline 91 & $\begin{array}{l}\text { New Mexico State } \\
\text { Engineer Office }\end{array}$ & Monitoring Well H-19B6 & C-2425 & $1 / 25 / 95$ & $1 / 31 / 98$ & $\begin{array}{c}\text { Inactive - } \\
\text { Renew when } \\
\text { necessary }\end{array}$ & EM\&H & $\begin{array}{l}\text { Harold F. Klaus, Jr. } \\
\text { DOE 11/9/94 }\end{array}$ & $\mathrm{DOE}$ \\
\hline 92 & $\begin{array}{l}\text { New Mexico State } \\
\text { Engineer Office }\end{array}$ & Monitoring Well H-19B7 & C-2426 & $1 / 25 / 95$ & $1 / 31 / 98$ & $\begin{array}{c}\text { Inactive - } \\
\text { Renew when } \\
\text { necessary }\end{array}$ & EM\&H & $\begin{array}{l}\text { Harold F. Klaus, Jr. } \\
\text { DOE 11/9/94 }\end{array}$ & DOE \\
\hline 93 & $\begin{array}{l}\text { New Mexico State } \\
\text { Engineer Office }\end{array}$ & Monitoring Well P-14 & C-2637 & $1 / 2 / 99$ & None & $P \& A^{*}$ & EM\&H & $\begin{array}{l}\text { G. T. Basabilvaso, } \\
\text { DOE } 11 / 17 / 98\end{array}$ & $\mathrm{DOE}$ \\
\hline 94 & $\begin{array}{l}\text { New Mexico State } \\
\text { Engineer Office }\end{array}$ & Monitoring Well P-15 & C-2686 & $4 / 17 / 00$ & None & $P \& A^{*}$ & EM\&H & D. C. Lynn, 10/23/00 & DOE \\
\hline 95 & $\begin{array}{l}\text { New Mexico State } \\
\text { Engineer Office }\end{array}$ & Monitoring Well P-17 & C-2774 & $11 / 6 / 00$ & None & Active & EM\&H & D. C. Lynn, 10/23/00 & DOE \\
\hline 96 & $\begin{array}{l}\text { New Mexico State } \\
\text { Engineer Office }\end{array}$ & Monitoring Well P-18 & C-2756 & $11 / 6 / 00$ & None & $P \& A^{*}$ & EM\&H & D. C. Lynn, 10/23/00 & DOE \\
\hline 97 & $\begin{array}{l}\text { New Mexico State } \\
\text { Engineer Office }\end{array}$ & Monitoring Well WIPP-12 & C-2639 & $1 / 12 / 99$ & None & Active & EM\&H & $\begin{array}{l}\text { G. T. Basabilvaso, } \\
\text { DOE } 11 / 17 / 98\end{array}$ & DOE \\
\hline 98 & $\begin{array}{l}\text { New Mexico State } \\
\text { Engineer Office }\end{array}$ & Monitoring Well WIPP-13 & C-2748 & $11 / 6 / 00$ & None & Active & EM\&H & D. C. Lynn, 10/23/00 & DOE \\
\hline 99 & $\begin{array}{l}\text { New Mexico State } \\
\text { Engineer Office } \\
\end{array}$ & Monitoring Well WIPP-18 & C-2684 & $4 / 17 / 00$ & None & Active & EM\&H & D. C. Lynn, 10/23/00 & DOE \\
\hline 100 & $\begin{array}{l}\text { New Mexico State } \\
\text { Engineer Office }\end{array}$ & Monitoring Well WIPP-19 & C-2755 & $11 / 6 / 00$ & None & Active & EM\&H & D. C. Lynn, 10/23/00 & DOE \\
\hline 101 & $\begin{array}{l}\text { New Mexico State } \\
\text { Engineer Office }\end{array}$ & Monitoring Well WIPP-21 & C-2754 & $11 / 6 / 00$ & None & Active & EM\&H & D. C. Lynn, 10/23/00 & DOE \\
\hline
\end{tabular}




\section{Waste Isolation Pilot Plant 2002 Site Environmental Report}

$$
\text { DOE/WIPP 03-2225 }
$$

Table 3.5 - Active Environmental Permits and Approvals for the Waste Isolation Pilot Plant - April 1, 2003 (Does Not Include Hazardous Waste Facility Permit)

\begin{tabular}{|c|c|c|c|c|c|c|c|c|c|}
\hline & Granting Agency & Type of Permit & $\begin{array}{l}\text { Permit } \\
\text { Number }\end{array}$ & Date & Expiration & $\begin{array}{c}\text { Current } \\
\text { Permit Status }\end{array}$ & WTS Owner & Signed By/Title & $\begin{array}{l}\text { Signed } \\
\text { For }\end{array}$ \\
\hline 102 & $\begin{array}{l}\text { New Mexico State } \\
\text { Engineer Office }\end{array}$ & Monitoring Well WIPP-25 & C-2723 & $7 / 26 / 00$ & None & Active & EM\&H & D. C. Lynn, 10/23/00 & DOE \\
\hline 103 & $\begin{array}{l}\text { New Mexico State } \\
\text { Engineer Office }\end{array}$ & Monitoring Well WIPP-26 & C-2724 & $11 / 6 / 00$ & None & Active & EM\&H & D. C. Lynn, 10/23/00 & DOE \\
\hline 104 & $\begin{array}{l}\text { New Mexico State } \\
\text { Engineer Office }\end{array}$ & Monitoring Well WIPP-27 & C-2722 & $11 / 6 / 00$ & None & Active & EM\&H & D. C. Lynn, 7/24/00 & DOE \\
\hline 105 & $\begin{array}{l}\text { New Mexico State } \\
\text { Engineer Office }\end{array}$ & Monitoring Well WIPP-28 & C-2636 & $1 / 12 / 99$ & None & $\mathrm{P} \& \mathrm{~A}^{*}$ & EM\&H & $\begin{array}{l}\text { G. T. Basabilvaso, } \\
\text { DOE } 11 / 17 / 98\end{array}$ & DOE \\
\hline 106 & $\begin{array}{l}\text { New Mexico State } \\
\text { Engineer Office }\end{array}$ & Monitoring Well WIPP-29 & C-2743 & $11 / 6 / 00$ & None & Active & EM\&H & D. C. Lynn, 10/23/00 & DOE \\
\hline 107 & $\begin{array}{l}\text { New Mexico State } \\
\text { Engineer Office }\end{array}$ & Monitoring Well WIPP-30 & C-2727 & $8 / 4 / 00$ & None & Active & EM\&H & $\begin{array}{l}\text { G. T. Basabilvaso, } \\
\text { DOE } 7 / 31 / 00\end{array}$ & DOE \\
\hline
\end{tabular}

* Plugged and abandoned 
This page intentionally left blank 


\section{CHAPTER 4 - ENVIRONMENTAL RADIOLOGICAL PROGRAM INFORMATION}

Radionuclides present in the environment, whether naturally occurring or human-made, contribute to radiation doses to humans. Therefore, environmental monitoring around nuclear facilities is imperative to characterize radiological conditions, detect releases, and determine their effects, should they occur. Because of this, the DOE requires an environmental monitoring program for nuclear facilities (DOE Order 5400.1).

The WIPP Environmental Monitoring Program monitors air, groundwater, surface water, soils, sediments and biota to characterize the radiation environment around the WIPP facility. This program is carried out in accordance with the EMP. The WIPP Effluent Monitoring Program monitors the air from the underground storage areas and the Waste Handling Building to detect potential releases from WIPP activities.

The radiological environment near WIPP includes natural radioactivity, global fallout and, potentially, radioactive contamination from the Project Gnome. A nuclear device was detonated underground in bedded salt on December 10, 1961. The test site for Project Gnome was located approximately $9 \mathrm{~km}$ (5.4 miles) southwest of the WIPP site. The Project Gnome shot vented into the drift and up the shaft to the atmosphere. Therefore, most environmental samples are expected to contain small amounts of natural radioactivity and fission products.

Throughout this chapter, radionuclides were considered "detected" in a sample if the measured concentration or activity is greater than 2 sigma total propagated uncertainty ( 2 sigma TPU or $2 \times$ TPU) and the minimum detectable concentration (MDC). The MDC was determined by the different analytical laboratories based on the natural background radiation, the analytical technique, and inherent characteristics of the analytical equipment. The MDC represents the minimum concentration of a radionuclide detectable in a given sample using the given equipment and techniques with a specific statistical confidence (usually 95 percent).

Total propagated uncertainty is an estimate of the uncertainty in the measurement due to all sources, including counting error, measurement error, chemical recovery error, detector efficiency, randomness of radioactive decay and any other sources of uncertainty.

Comparisons of radionuclide concentrations were made between years and locations using the statistical procedure, ANOVA [Analysis of Variance]. When this, or another statistical test, was used, the p-value was reported. The $p$-value is the probability under the null hypothesis of observing a value as unlikely or more unlikely than the value of the test statistic. In many cases, scientists have accepted a value of $p<0.05$ as indicative of a difference between samples. However, interpretation of $p$ requires some judgment on the part of the reader; individual readers may choose to defend higher or lower values of $p$ as their cutoff value. For this report, $p<0.05$ was used. 


\subsection{Effluent Monitoring}

The WIPP facility has three effluent emission points, Stations A, B, and C, that may release airborne radionuclides to the atmosphere. Station $A$ samples the unfiltered underground exhaust air. Station B samples the underground exhaust air after HEPA (high-efficiency particulate air) filtration and, sometimes, nonfiltered air during maintenance. Station $\mathrm{C}$ samples the air from the Waste Handling Building after HEPA filtration. Each station employs one or more fixed air samplers, collecting particulates from the effluent air stream using a Versapore filter.

During 2002, 347 samples were collected from Station A for a total air volume sampled of $25,872 \mathrm{~m}^{3}\left(913,667 \mathrm{ft}^{3}\right)$. Because only a small fraction of the air released through Station $A$ is sampled, the activity on the filter is normalized to the total air flow through Station A. Sixty-six samples were collected from Station B for a total air volume sampled of $29,960 \mathrm{~m}^{3}\left(1,058,049 \mathrm{ft}^{3}\right)$, and 53 samples were collected from Station $\mathrm{C}$ for a total air volume sampled of $8,682.7 \mathrm{~m}^{3}\left(306,630 \mathrm{ft}^{3}\right)$. Samples were composited each quarter for stations $B$ and $C$. Because of the large number of samples from Station $A$, these samples were composited monthly. Samples were analyzed radiochemically for ${ }^{241} \mathrm{Am},{ }^{238} \mathrm{Pu},{ }^{239+240} \mathrm{Pu}$, and ${ }^{90} \mathrm{Sr}$, the components of the $\mathrm{CH}$ waste at WIPP expected to produce 98 percent of the potential radiation dose to humans.

Out of 80 total composite samples, no sample had detectable radioactivity (Table 4.1). For the 80 samples, the WIPP Laboratories reported an activity less than $2 \times$ TPU and the MDC. It was conservatively assumed that the actual activity was equal to the MDC for the WIPP 2002 Annual Periodic Confirmatory Measurement Compliance Report (40 CFR Part 61, Subpart H), and for other effluent reporting requirements.

In reference to Table 4.1, the WIPP Laboratories reports the radionuclide results in units of picoCurie/sample ( $\mathrm{pCi} / \mathrm{sample}$ ). The laboratory results are converted from $\mathrm{pCi} /$ sample to becquerels $(\mathrm{Bq}) /$ sample. The laboratory results are converted to $\mathrm{Bq} / \mathrm{sample}$ by multiplying the laboratory results by 0.037 .

Results from Stations A, B, and C were used as input for the dose assessment presented in Chapter 7.

Additional sampling was routinely performed in the underground using fixed air samplers and continuous air monitors. Evaluation of the samples from both indicate there were no detectable releases above background activity from the WIPP facility.

\subsection{Airborne Gross Alpha/Beta}

Gross alpha and beta measurements in airborne particulates are used as a screening technique to provide timely information on levels of radioactivity in the environment around the WIPP site. Airborne particulate samples were collected by the WRES Environmental Monitoring group from seven different locations around WIPP: Southeast Control (SEC), Carlsbad (CBD), J. C. Mills Ranch (MLR), Smith Ranch (SMR), WIPP East (WEE), WIPP South (WSS), and WIPP Far Field (WFF) (Figure 4.1). 


\section{Waste Isolation Pilot Plant 2002 Site Environmental Report DOE/WIPP 03-2225}

Each week at each station, approximately $600 \mathrm{~m}^{3}\left(21,200 \mathrm{ft}^{3}\right)$ of air was filtered through a 4.7-cm (centimeters) (1.85-in.) diameter glass microfiber filter using a low-volume continuous air sampler. The samples were collected at a height of 1.5-2 m (5-6.6 ft) to closely match the height at which air is inhaled by humans. Filters were counted for gross alpha and beta only after being stored for three days in the laboratory to ensure that the short-lived radon progeny had decayed.

Blank filters were also counted for gross alpha and beta activities so that background corrections (activities present in the blank filters) could be made in the gross alpha and beta measurements of the air samples. Blanks were counted weekly along with the samples. The gross alpha and beta activities per cubic meter of air were then determined by dividing the total activity of gross alpha and beta found in each weekly sample by the amount of air pulled through each sample. The results are given in Appendix D. The mass and volume of air collected each week are reported in Appendix E.

As expected, weekly gross alpha activity concentrations measured in 2002 varied by an order of magnitude throughout the year at each location (Figure 4.2). Measured concentrations ranged from a minimum of $1.47 \times 10^{-5} \pm 1.27 \times 10^{-5} \mathrm{~Bq} / \mathrm{m}^{3}\left(3.97 \times 10^{-4} \pm\right.$ $\left.3.43 \times 10^{-4} \mathrm{pCi} / \mathrm{m}^{3}\right)$ to a maximum of $2.35 \times 10^{-4} \pm 5.35 \times 10^{-5} \mathrm{~Bq} / \mathrm{m}^{3}\left(6.35 \times 10^{-3} \pm\right.$ $1.44 \times 10^{-3} \mathrm{pCi} / \mathrm{m}^{3}$ ) (Table 4.2). However, the annual mean concentrations of gross alpha activities found at all locations were similar, ranging from $7.19 \times 10^{-5} \pm 6.59 \times 10^{-5}$ to $8.16 \times 10^{-5} \pm 7.10 \times 10^{-5} \mathrm{~Bq} / \mathrm{m}^{3}\left(1.94 \times 10^{-3} \pm 1.78 \times 10^{-3}\right.$ to $\left.2.20 \times 10^{-3} \pm 1.92 \times 10^{-3} \mathrm{pCi} / \mathrm{m}^{3}\right)$. ANOVA indicated no statistically significant difference between sampling stations $(p=0.908)$.

Table 4.1 - Activity (Bq) of Quarterly Composite Air Samples from Effluent Monitoring Stations A, B, and C

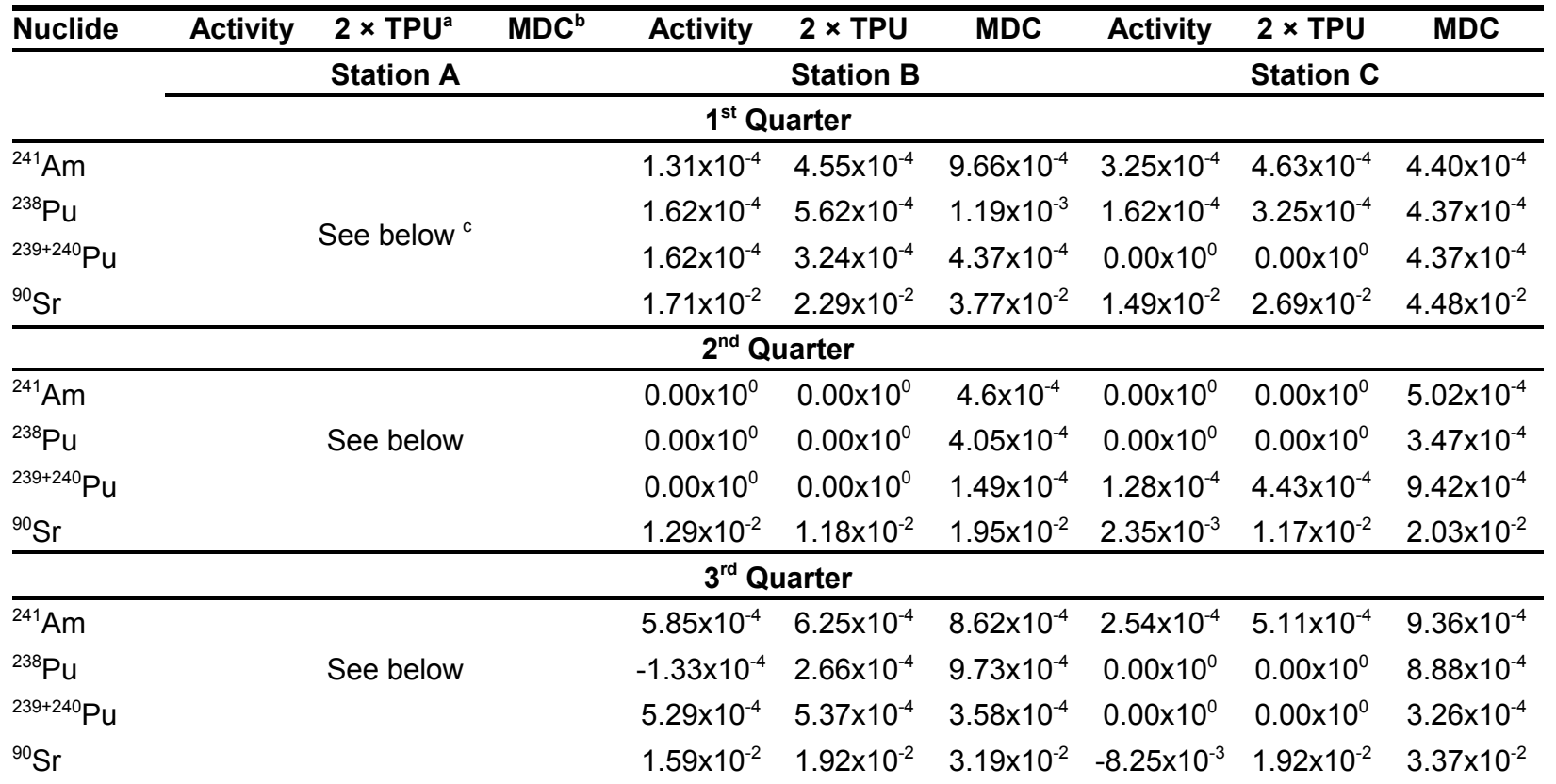


Waste Isolation Pilot Plant 2002 Site Environmental Report

DOE/WIPP 03-2225

Table 4.1 - Activity (Bq) of Quarterly Composite Air Samples from

Effluent Monitoring Stations A, B, and C

\begin{tabular}{|c|c|c|c|c|c|c|c|c|c|}
\hline Nuclide & Activity & $2 \times$ TPU $^{\mathrm{a}}$ & $\mathrm{MDC}^{\mathrm{b}}$ & Activity & $2 \times$ TPU & MDC & Activity & $2 \times$ TPU & MDC \\
\hline \multicolumn{10}{|c|}{$4^{\text {th }}$ Quarter } \\
\hline${ }^{241} \mathrm{Am}$ & & & & $0.00 \times 10^{0}$ & $0.00 \times 10^{0}$ & $7.73 \times 10^{-4}$ & $1.15 \times 10^{-4}$ & $4 \times 10^{-4}$ & $8.47 \times 10^{-4}$ \\
\hline${ }^{238} \mathrm{Pu}$ & \multirow{2}{*}{\multicolumn{3}{|c|}{ See below }} & $0.00 \times 10^{0}$ & $0.00 \times 10^{0}$ & $3.28 \times 10^{-4}$ & $2.32 \times 10^{-4}$ & $4.66 \times 10^{-4}$ & $6.29 \times 10^{-4}$ \\
\hline${ }^{239+240} \mathrm{Pu}$ & & & & $4.85 \times 10^{-4}$ & $4.92 \times 10^{-4}$ & $3.28 \times 10^{-4}$ & $0.00 \times 10^{0}$ & $0.00 \times 10^{0}$ & $1.71 \times 10^{-3}$ \\
\hline \multirow[t]{3}{*}{${ }^{90} \mathrm{Sr}$} & & & & $1.82 \times 10^{-3}$ & $2.25 \times 10^{-2}$ & $3.85 \times 10^{-2}$ & $1.80 \times 10^{-2}$ & $2.30 \times 10^{-2}$ & $3.81 \times 10^{-2}$ \\
\hline & \multirow{2}{*}{\multicolumn{3}{|c|}{ Station A }} & $1^{\text {st }} Q \mathrm{c}$ & uarter & Monthly $^{c}$ & & & \\
\hline & & & & \multicolumn{3}{|c|}{ February } & \multicolumn{3}{|c|}{ March } \\
\hline${ }^{241} \mathrm{Am}$ & $1.19 \times 10^{-4}$ & $2.40 \times 10^{-4}$ & $3.24 \times 10^{-4}$ & $4.29 \times 10^{-4}$ & $6.48 \times 10^{-4}$ & $1.06 \times 10^{-3}$ & $4.33 \times 10^{-4}$ & $4.37 \times 10^{-4}$ & $2.92 \times 10^{-4}$ \\
\hline${ }^{238} \mathrm{Pu}$ & $0.00 \times 10^{0}$ & $0.00 \times 10^{0}$ & $3.53 \times 10^{-4}$ & $0.00 \times 10^{0}$ & $0.00 \times 10^{0}$ & $8.77 \times 10^{-4}$ & $2.17 \times 10^{-4}$ & $3.09 \times 10^{-4}$ & $2.93 \times 10^{-4}$ \\
\hline${ }^{239+240} \mathrm{Pu}$ & $1.30 \times 10^{-4}$ & $2.61 \times 10^{-4}$ & $3.53 \times 10^{-4}$ & $3.57 \times 10^{-4}$ & $4.14 \times 10^{-4}$ & $3.22 \times 10^{-4}$ & $1.08 \times 10^{-4}$ & $3.74 \times 10^{-4}$ & $7.96 \times 10^{-4}$ \\
\hline \multirow[t]{3}{*}{${ }^{90} \mathrm{Sr}$} & $9.99 \times 10^{-3}$ & $2.23 \times 10^{-2}$ & $3.74 \times 10^{-2}$ & $-4.55 \times 10^{-3}$ & $2.33 \times 10^{-2}$ & $4.03 \times 10^{-2}$ & $5.70 \times 10^{-3}$ & $2.46 \times 10^{-2}$ & $4.18 \times 10^{-2}$ \\
\hline & \multirow{2}{*}{\multicolumn{3}{|c|}{ Station A }} & \multicolumn{2}{|c|}{$\mathbf{2}^{\text {nd }}$ Quarter } & Monthly & & & \\
\hline & & & & & May & & \multicolumn{3}{|c|}{ June } \\
\hline${ }^{241} \mathrm{Am}$ & $2.6 \times 10^{-5}$ & $5.23 \times 10^{-5}$ & $7.05 \times 10^{-5}$ & $0.00 \times 10^{0}$ & $0.00 \times 10^{0}$ & $1.93 \times 10^{-4}$ & $2.40 \times 10^{-5}$ & $4.82 \times 10^{-5}$ & $6.5 \times 10^{-5}$ \\
\hline${ }^{238} \mathrm{Pu}$ & $1.33 \times 10^{-4}$ & $2.67 \times 10^{-4}$ & $4.87 \times 10^{-4}$ & $-6.33 \times 10^{-5}$ & $1.27 \times 10^{-4}$ & $4.65 \times 10^{-4}$ & $1.51 \times 10^{-4}$ & $2.15 \times 10^{-4}$ & $2.03 \times 10^{-4}$ \\
\hline${ }^{239+240} \mathrm{Pu}$ & $6.62 \times 10^{-5}$ & $1.33 \times 10^{-4}$ & $1.9 \times 10^{-4}$ & $1.89 \times 10^{-4}$ & $2.20 \times 10^{-4}$ & $1.72 \times 10^{-4}$ & $0.00 \times 10^{0}$ & $0.00 \times 10^{0}$ & $2.03 \times 10^{-4}$ \\
\hline \multirow[t]{3}{*}{${ }^{90} \mathrm{Sr}$} & $-2.85 \times 10^{-3}$ & $1.09 \times 10^{-2}$ & $1.92 \times 10^{-2}$ & $1.10 \times 10^{-2}$ & $1.16 \times 10^{-2}$ & $1.95 \times 10^{-2}$ & $-4.10 \times 10^{-3}$ & $1.10 \times 10^{-2}$ & $1.95 \times 10^{-2}$ \\
\hline & \multirow{2}{*}{\multicolumn{3}{|c|}{ Station A }} & \multicolumn{2}{|c|}{$3^{\text {rd }}$ Quarter } & Monthly & & & \\
\hline & & & & & August & & \multicolumn{3}{|c|}{ September } \\
\hline${ }^{241} \mathrm{Am}$ & $5.85 \times 10^{-4}$ & $8.29 \times 10^{-4}$ & $7.92 \times 10^{-4}$ & $5.88 \times 10^{-4}$ & $8.36 \times 10^{-4}$ & $7.96 \times 10^{-4}$ & $6.70 \times 10^{-4}$ & $6.81 \times 10^{-4}$ & $4.51 \times 10^{-4}$ \\
\hline${ }^{238} \mathrm{Pu}$ & $-3.15 \times 10^{-4}$ & $6.33 \times 10^{-4}$ & $2.32 \times 10^{-3}$ & $2.97 \times 10^{-4}$ & $5.96 \times 10^{-4}$ & $8.03 \times 10^{-4}$ & $0.00 \times 10^{0}$ & $0.00 \times 10^{0}$ & $5.03 \times 10^{-4}$ \\
\hline${ }^{239+240} \mathrm{Pu}$ & $0.00 \times 10^{0}$ & $0.00 \times 10^{0}$ & $8.51 \times 10^{-4}$ & $5.92 \times 10^{-4}$ & $8.44 \times 10^{-4}$ & $8.03 \times 10^{-4}$ & $1.86 \times 10^{-4}$ & $3.74 \times 10^{-4}$ & $5.03 \times 10^{-4}$ \\
\hline \multirow[t]{3}{*}{${ }^{90} \mathrm{Sr}$} & $1.81 \times 10^{-3}$ & $1.82 \times 10^{-2}$ & $3.13 \times 10^{-2}$ & $-3.96 \times 10^{-3}$ & $1.70 \times 10^{-2}$ & $2.98 \times 10^{-2}$ & $-6.73 \times 10^{-3}$ & $1.89 \times 10^{-2}$ & $3.31 \times 10^{-2}$ \\
\hline & \multirow{2}{*}{\multicolumn{3}{|c|}{ Station A }} & \multicolumn{2}{|c|}{$4^{\text {th }}$ Quarter } & Monthly & & & \\
\hline & & & & & November & & \multicolumn{3}{|c|}{ December } \\
\hline${ }^{241} \mathrm{Am}$ & $4.40 \times 10^{-4}$ & $6.29 \times 10^{-4}$ & $5.96 \times 10^{-4}$ & $1.22 \times 10^{-4}$ & $2.45 \times 10^{-4}$ & $3.31 \times 10^{-4}$ & $1.32 \times 10^{-4}$ & $4.55 \times 10^{-4}$ & $9.69 \times 10^{-4}$ \\
\hline${ }^{238} \mathrm{Pu}$ & $-1.34 \times 10^{-4}$ & $2.70 \times 10^{-4}$ & $9.88 \times 10^{-4}$ & $-1.20 \times 10^{-3}$ & $1.21 \times 10^{-3}$ & $8.84 \times 10^{-3}$ & $0.00 \times 10^{0}$ & $0.00 \times 10^{0}$ & $1.28 \times 10^{-3}$ \\
\hline${ }^{239+240} \mathrm{Pu}$ & $1.34 \times 10^{-4}$ & $2.69 \times 10^{-4}$ & $3.63 \times 10^{-4}$ & $0.00 \times 10^{0}$ & $0.00 \times 10^{0}$ & $3.25 \times 10^{-3}$ & $0.00 \times 10^{0}$ & $0.00 \times 10^{0}$ & $4.74 \times 10^{-4}$ \\
\hline${ }^{90} \mathrm{Sr}$ & $-7.66 \times 10^{-3}$ & $2.38 \times 10^{-2}$ & $4.22 \times 10^{-2}$ & $6.29 \times 10^{-3}$ & $2.16 \times 10^{-2}$ & $3.7 \times 10^{-2}$ & $4.59 \times 10^{-3}$ & $2.18 \times 10^{-2}$ & $3.74 \times 10^{-2}$ \\
\hline
\end{tabular}

a Total propagated uncertainty

${ }^{\mathrm{b}}$ Minimum detectable concentration

${ }^{c}$ Station A - composited monthly due to the large number of samples

Note: An anomaly in the Canberra software for the alpha spectrometer prevents it from calculating uncertainty when the activity is 0 . 


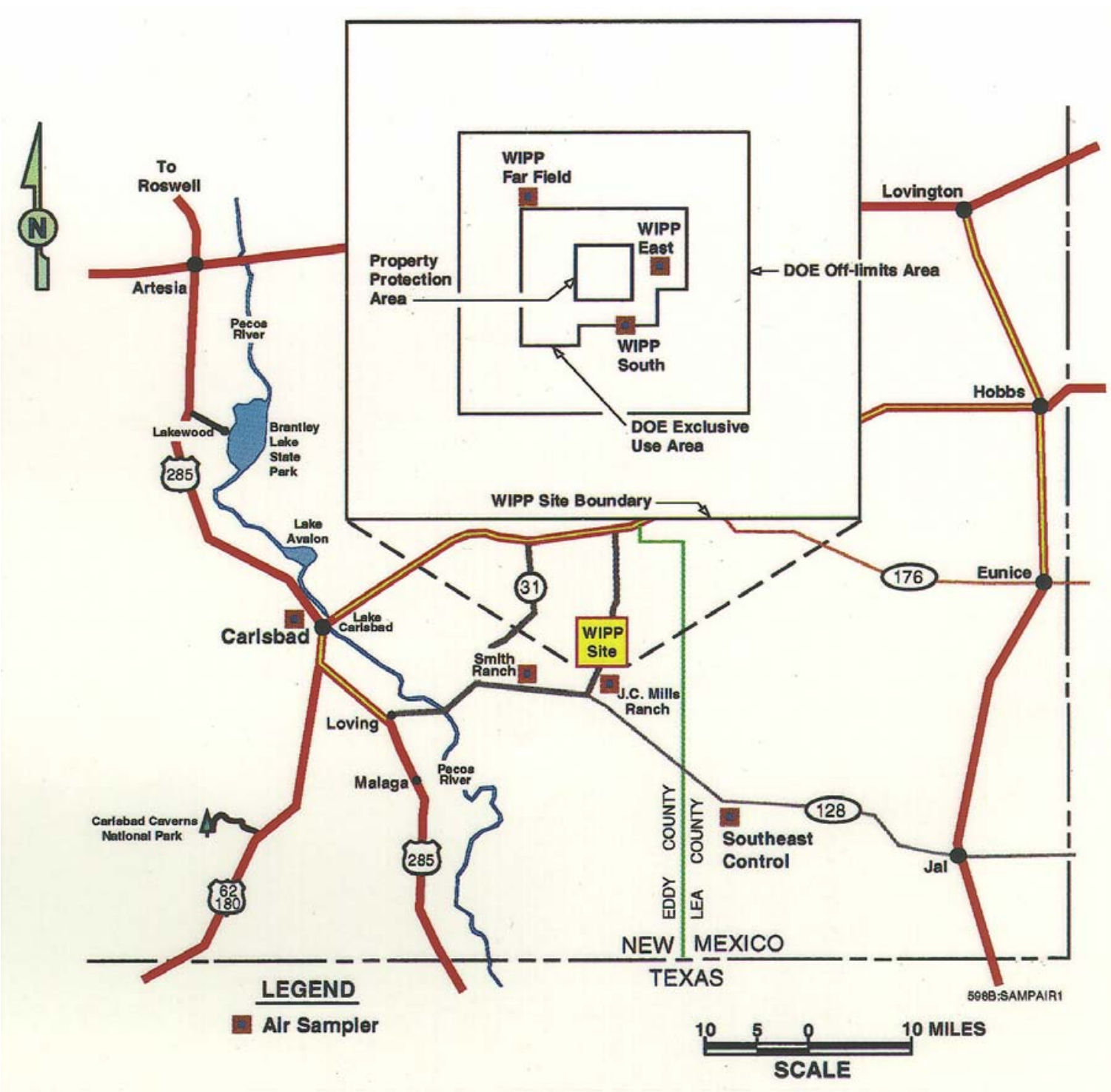

Figure 4.1 - Air Sampling Locations on and Near the WIPP Facility

In 2002, the weekly gross beta concentrations also varied throughout the year at each station (Figure 4.3). Stations tended to vary together, showing a strong annual pattern.

Concentrations ranged over almost an order of magnitude, from a minimum of $4.82 \times 10^{-4}$ $\pm 7.81 \times 10^{-5} \mathrm{~Bq} / \mathrm{m}^{3}\left(1.30 \times 10^{-2} \pm 2.11 \times 10^{-3} \mathrm{pCi} / \mathrm{m}^{3}\right)$ to a maximum of $1.77 \times 10^{-3} \pm$ $2.10 \times 10^{-4} \mathrm{~Bq} / \mathrm{m}^{3}\left(4.78 \times 10^{-2} \pm 5.67 \times 10^{-3} \mathrm{pCi} / \mathrm{m}^{3}\right)($ Table 4.2$)$. However, the annual mean concentrations of gross beta activities found at all locations were similar, ranging from $9.60 \times 10^{-4} \pm 4.67 \times 10^{-4}$ to $1.01 \times 10^{-3} \pm 4.78 \times 10^{-4} \mathrm{~Bq} / \mathrm{m}^{3}\left(2.59 \times 10^{-2} \pm 1.26 \times 10^{-2}\right.$ to $2.73 \times 10^{-2}$ $\left.\pm 1.29 \times 10^{-2} \mathrm{pCi} / \mathrm{m}^{3}\right)$. There was no significant difference between sampling stations (ANOVA, $p=0.923$ ). 


\section{Waste Isolation Pilot Plant 2002 Site Environmental Report DOE/WIPP 03-2225}

Gross alpha and gross beta activity concentrations in four consecutive years were compared to determine whether they had increased since waste began to be received at WIPP (Figure 4.4). There was no significant difference in measured gross alpha $(p=0.098)$ or gross beta $(p=0.056)$ activity concentration between years for the same location comparison. The gross alpha and gross beta activity concentrations measured in 2002 were within the $95 \%$ confidence interval ranges of preoperational radiological baseline report covering the period from 1985 to 1989 (DOE/WIPP 92-037).

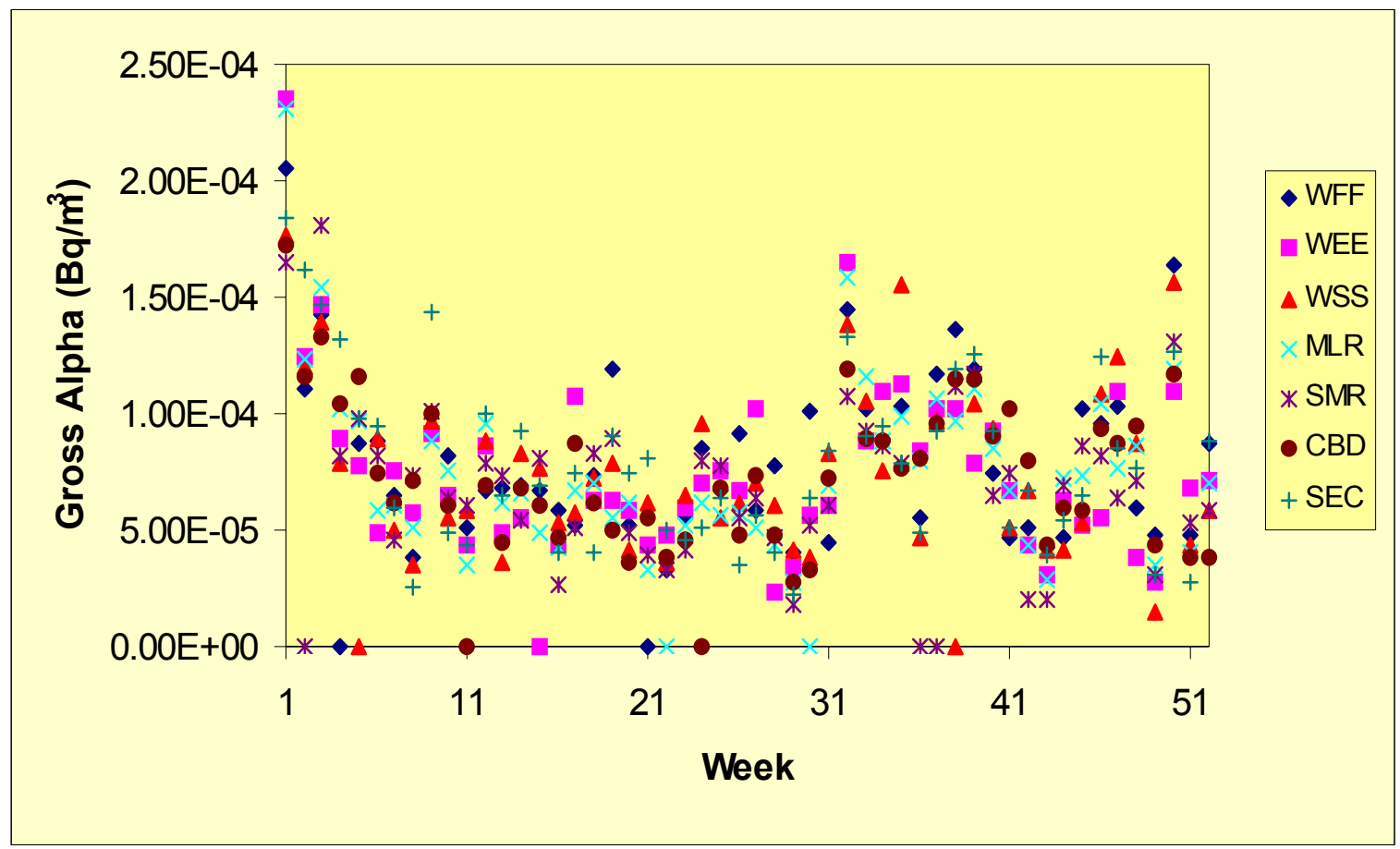

Figure 4.2 - Gross Alpha Activity Concentration Measured in Air Particulates Each Week in 2002. See Appendix B for sampling station locations.

One duplicate sample was collected every quarter by rotating the portable sampler from one location to another: CBD in the first quarter, SEC in the second quarter, WFF in the third quarter, and WEE in the fourth quarter. The samples were collected by both samplers in identical conditions at all four locations. Duplicate samples were collected and analyzed for the QC of (1) air sampling technique, (2) determination of gross alpha and beta activities, and (3) analysis of the individual radionuclides in airborne particulate. Relative Error Ratios (RER) (see Appendix C) were less than one in all of the weekly gross alpha and 98 percent of the weekly gross beta measurements. An RER less than one indicates good agreement between duplicates. The duplicate data are provided in Appendix D. 


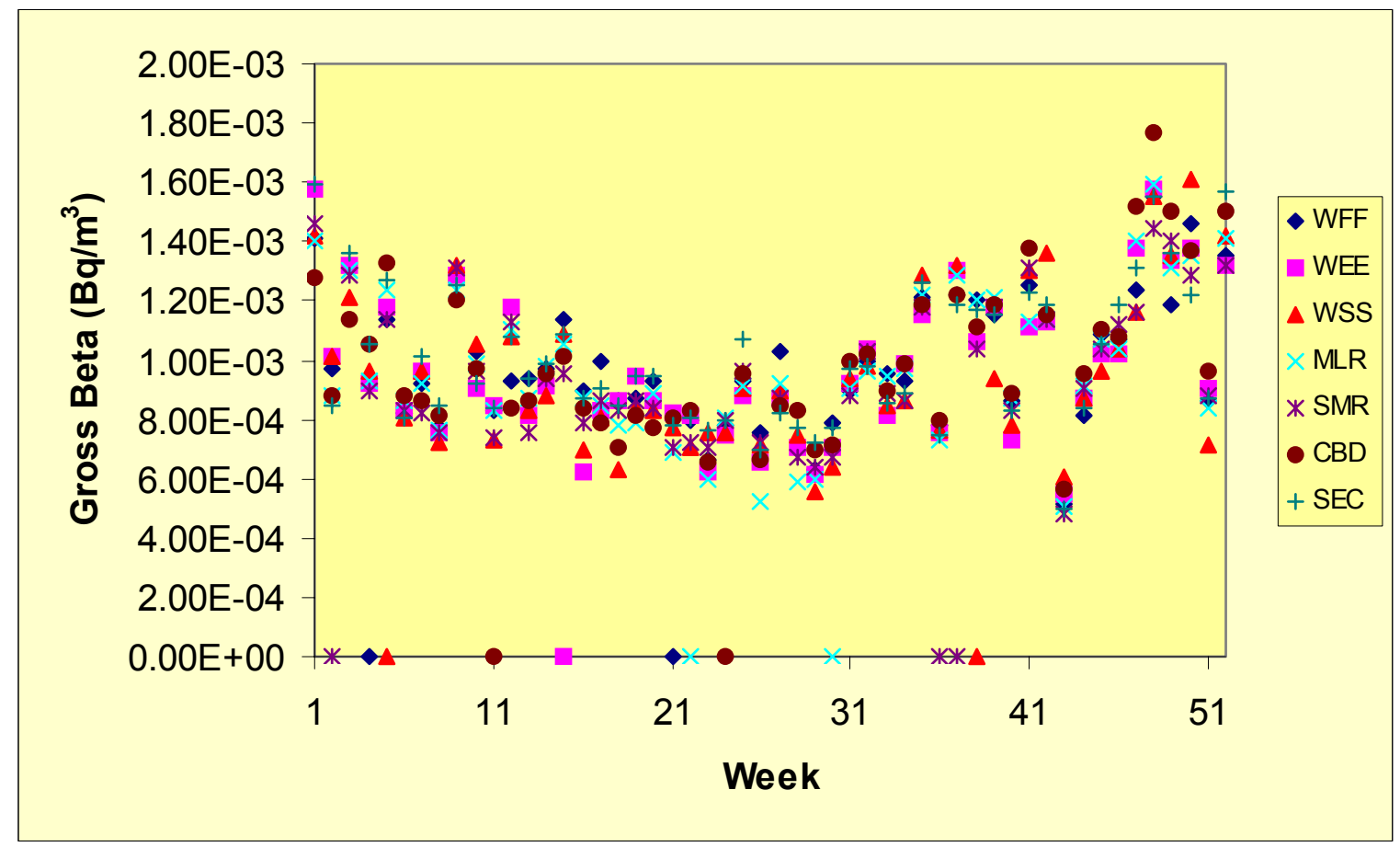

Figure 4.3 - Gross Beta Activity Concentration Measured in Air Particulates Each Week in 2002. See Appendix B for sampling station locations.

Table 4.2 - Mean Gross Alpha and Gross Beta Activity Concentrations (Bq/ $\left.\mathrm{m}^{3}\right)$ Found in Weekly Air Particulate Samples (See Appendix B for sample locations.)

\begin{tabular}{|c|c|c|c|c|c|c|}
\hline Location & Minimum & $2 \times \mathrm{TPU}^{\mathrm{a}}$ & Maximum & $2 \times$ TPU & Mean & $2 \times S D^{b}$ \\
\hline \multicolumn{7}{|c|}{ Gross Alpha } \\
\hline CBD & $2.76 \times 10^{-5}$ & $1.88 \times 10^{-5}$ & $1.72 \times 10^{-4}$ & $4.47 \times 10^{-5}$ & $7.54 \times 10^{-5}$ & $6.08 \times 10^{-5}$ \\
\hline MLR & $2.72 \times 10^{-5}$ & $1.95 \times 10^{-5}$ & $2.31 \times 10^{-4}$ & $5.35 \times 10^{-5}$ & $7.70 \times 10^{-5}$ & $7.44 \times 10^{-5}$ \\
\hline SEC & $2.28 \times 10^{-5}$ & $1.76 \times 10^{-5}$ & $1.84 \times 10^{-4}$ & $4.73 \times 10^{-5}$ & $7.87 \times 10^{-5}$ & $7.46 \times 10^{-5}$ \\
\hline SMR & $1.76 \times 10^{-5}$ & $1.59 \times 10^{-5}$ & $1.81 \times 10^{-4}$ & $4.81 \times 10^{-5}$ & $7.19 \times 10^{-5}$ & $6.59 \times 10^{-5}$ \\
\hline WEE & $2.36 \times 10^{-5}$ & $1.82 \times 10^{-5}$ & $2.35 \times 10^{-4}$ & $5.35 \times 10^{-5}$ & $7.63 \times 10^{-5}$ & $7.49 \times 10^{-5}$ \\
\hline WFF & $3.33 \times 10^{-5}$ & $2.04 \times 10^{-5}$ & $2.05 \times 10^{-4}$ & $5.02 \times 10^{-5}$ & $8.16 \times 10^{-5}$ & $7.10 \times 10^{-5}$ \\
\hline WSS & $1.47 \times 10^{-5}$ & $1.27 \times 10^{-5}$ & $1.77 \times 10^{-4}$ & $4.60 \times 10^{-5}$ & $7.63 \times 10^{-5}$ & $7.09 \times 10^{-5}$ \\
\hline \multicolumn{7}{|c|}{ Gross Beta } \\
\hline CBD & $5.62 \times 10^{-4}$ & $8.66 \times 10^{-5}$ & $1.77 \times 10^{-3}$ & $2.10 \times 10^{-4}$ & $1.00 \times 10^{-3}$ & $5.14 \times 10^{-4}$ \\
\hline MLR & $5.07 \times 10^{-4}$ & $8.14 \times 10^{-5}$ & $1.59 \times 10^{-3}$ & $1.92 \times 10^{-4}$ & $9.83 \times 10^{-4}$ & $5.00 \times 10^{-4}$ \\
\hline SEC & $4.94 \times 10^{-4}$ & $8.01 \times 10^{-5}$ & $1.59 \times 10^{-3}$ & $1.93 \times 10^{-4}$ & $1.01 \times 10^{-3}$ & $4.78 \times 10^{-4}$ \\
\hline SMR & $4.82 \times 10^{-4}$ & $7.81 \times 10^{-5}$ & $1.46 \times 10^{-3}$ & $1.80 \times 10^{-4}$ & $9.60 \times 10^{-4}$ & $4.67 \times 10^{-4}$ \\
\hline WEE & $5.48 \times 10^{-4}$ & $8.55 \times 10^{-5}$ & $1.58 \times 10^{-3}$ & $1.91 \times 10^{-4}$ & $9.73 \times 10^{-4}$ & $4.99 \times 10^{-4}$ \\
\hline WFF & $5.15 \times 10^{-4}$ & $8.11 \times 10^{-5}$ & $1.55 \times 10^{-3}$ & $1.88 \times 10^{-4}$ & $9.99 \times 10^{-4}$ & $4.44 \times 10^{-4}$ \\
\hline WSS & $5.55 \times 10^{-4}$ & $8.57 \times 10^{-5}$ & $1.61 \times 10^{-3}$ & $2.06 \times 10^{-4}$ & $9.60 \times 10^{-4}$ & $5.25 \times 10^{-4}$ \\
\hline
\end{tabular}

a Total propagated uncertainty

${ }^{\mathrm{b}}$ Standard deviation of the mean 

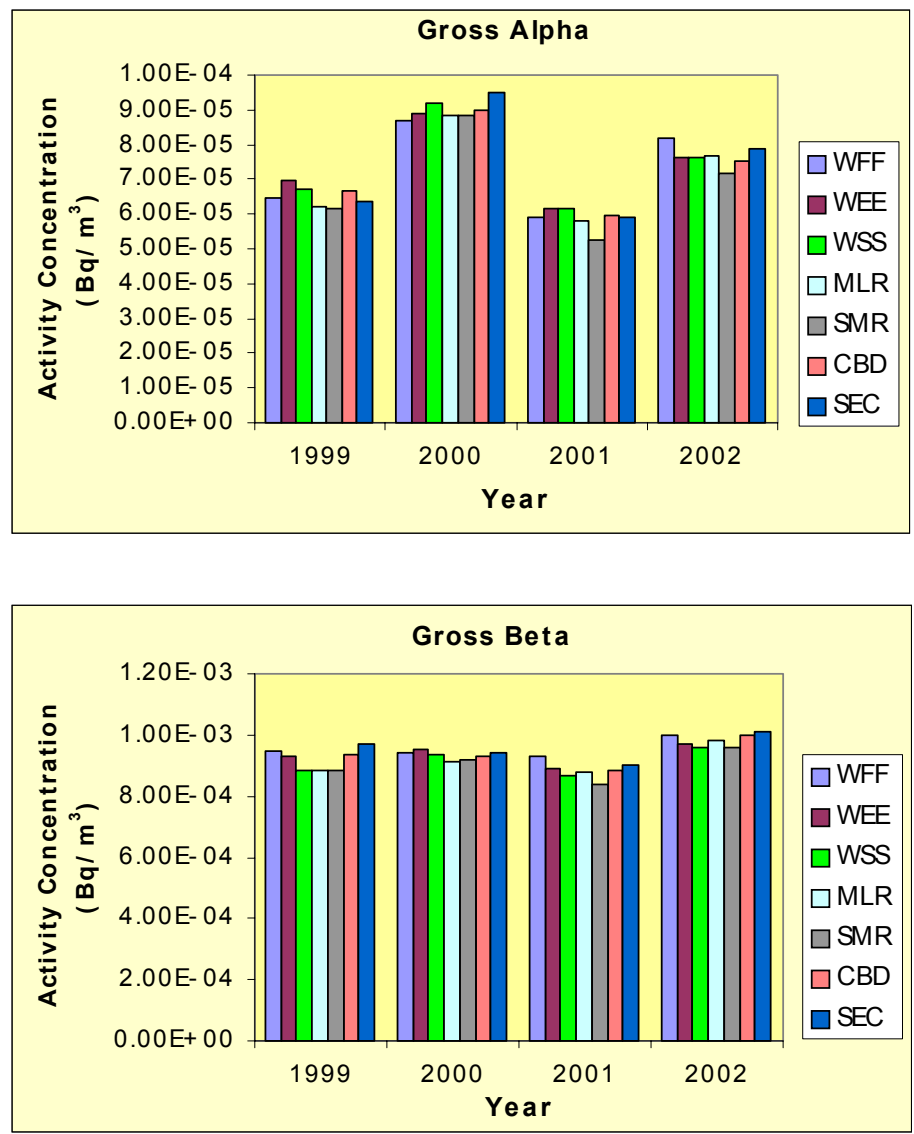

Figure 4.4 - Average Gross Alpha and Beta Activity Concentrations Measured in Air Particulates in Four Consecutive Years. (The year 1999 was the first year in which TRU waste was stored in WIPP. See Appendix B for sampling station locations.)

\subsection{Airborne Particulates}

The major pathways for the intake of radioactive materials into the human body are from the inhalation of dust particles and the ingestion of food and drinking water. Plutonium is the major constituent of the TRU wastes to be disposed at the WIPP site.

Accordingly, plutonium and other radionuclides of interest were determined in air particulate samples around the WIPP site.

Isotopes of plutonium and americium were analyzed because they are the most significant alpha-emitting radionuclides among the constituents of TRU wastes received at the WIPP site. Uranium isotopes were analyzed because they are prominent alpha-emitting radionuclides in the natural environment.

WIPP analyzed samples for ${ }^{90} \mathrm{Sr},{ }^{60} \mathrm{Co}$, and ${ }^{137} \mathrm{Cs}$ in order to demonstrate the ability to quantify these beta and gamma-emitting contaminants should they appear in the TRU waste stream. These radionuclides have been the subject of background studies at 


\section{Waste Isolation Pilot Plant 2002 Site Environmental Report DOE/WIPP 03-2225}

WIPP prior to 1999 and continue to be monitored. Potassium-40, a natural gammaemitting radionuclide which is ubiquitous in the earth's crust, was also monitored because of its possible enhancement in southeastern New Mexico due to potash mining.

Gross alpha and gross beta measurements are used as a screening technique and to identify any seasonal trends. The results are compared to historical values. Any result above the 2 sigma TPU warning limit is investigated for sampling error, instrument problems, and any other steps involved in the gross alpha and gross beta analysis. If the above-mentioned were ruled out as a contribution to the high result, a destructive analysis is performed to identify the specific nuclide contributing to the activity.

\subsubsection{Sample Preparation}

Weekly air particulate samples were collected as described in Section 4.2 and composited for each quarter. The composites were transferred into a Pyrex beaker, spiked with appropriate tracers, and heated in a Muffle furnace at $250^{\circ} \mathrm{C}\left(482^{\circ} \mathrm{F}\right)$ for two hours, followed by two hours at $375^{\circ} \mathrm{C}\left(707^{\circ} \mathrm{F}\right)$ and six hours at $525^{\circ} \mathrm{C}\left(977^{\circ} \mathrm{F}\right)$.

The ash was cooled, transferred quantitatively into a Teflon beaker by rinsing with concentrated nitric acid, and heated with concentrated hydrofluoric acid until completely dissolved. Hydrofluoric acid was removed by evaporating to dryness.

Approximately $25 \mathrm{ml}$ (milliliters) (0.845 oz [ounce]) of concentrated nitric acid and one gram $(0.0353 \mathrm{oz})$ of boric acid were added, heated, and finally evaporated to dryness. The residue was dissolved in $8 \mathrm{M}$ (molar) nitric acid for gamma spectrometry and determinations of ${ }^{90} \mathrm{Sr}$ and alpha-emitting radionuclides.

\subsubsection{Determination of Individual Radionuclides}

Gamma-emitting radionuclides were measured in the air filters by gamma spectrometry. Strontium-90 and alpha-emitting radionuclides were determined by sequential separation and counting. Determination of actinides involved co-precipitation, ion exchange separation, and alpha spectrometry.

\subsubsection{Results and Discussions}

The minimum, maximum, and average for all stations combined are reported in Table 4.3. Detailed data for each station are reported in Appendix G (Table G.1). Natural uranium isotopes were detected in every composite sample. Concentrations of

${ }^{234} \mathrm{U}$ ranged from $2.11 \times 10^{-6} \pm 5.07 \times 10^{-7} \mathrm{~Bq} / \mathrm{m}^{3}\left(5.70 \times 10^{-5} \pm 1.37 \times 10^{-5} \mathrm{pCi} / \mathrm{m}^{3}\right)$ at SEC in the fourth quarter to $4.74 \times 10^{-6} \pm 1.57 \times 10^{-6} \mathrm{~Bq} / \mathrm{m}^{3}\left(1.28 \times 10^{-4} \pm 4.24 \times 10^{-5} \mathrm{pCi} / \mathrm{m}^{3}\right)$ at CBD in the first quarter (Appendix G, Table G.1). There was no significant difference between concentrations measured in 2001 and 2002 (ANOVA, $p=0.853$ ). 
Table 4.3 - Minimum, Maximum and Average Radionuclide Concentrations $\left(\mathrm{Bq} / \mathrm{m}^{3}\right)$ in Air Filter Composites from Stations Surrounding the WIPP Site. See Appendix G for supporting data.

\begin{tabular}{|c|c|c|c|c|}
\hline \multicolumn{2}{|c|}{ Radionuclide } & {$[\mathrm{RN}]^{\mathrm{a}}$} & $2 \times T^{\prime} U^{b}$ & MDC $^{\mathrm{c}}$ \\
\hline \multirow[t]{3}{*}{${ }^{241} \mathrm{Am}$} & Minimum & $0.00 \times 10^{0}$ & $0.00 \times 10^{0}$ & $3.85 \times 10^{-8}$ \\
\hline & Maximum & $9.48 \times 10^{-8}$ & $9.07 \times 10^{-8}$ & $1.55 \times 10^{-7}$ \\
\hline & Average $^{d}$ & $4.66 \times 10^{-8}$ & $4.98 \times 10^{-8}$ & $9.64 \times 10^{-8}$ \\
\hline \multirow[t]{3}{*}{${ }^{238} \mathrm{Pu}$} & Minimum & $-6.80 \times 10^{-7}$ & $1.37 \times 10^{-6}$ & $3.89 \times 10^{-8}$ \\
\hline & Maximum & $2.69 \times 10^{-6}$ & $5.42 \times 10^{-6}$ & $9.88 \times 10^{-6}$ \\
\hline & Average & $3.60 \times 10^{-7}$ & $1.63 \times 10^{-6}$ & $1.30 \times 10^{-6}$ \\
\hline \multirow[t]{3}{*}{${ }^{239+240} \mathrm{Pu}$} & Minimum & $-6.77 \times 10^{-7}$ & $1.36 \times 10^{-6}$ & $3.89 \times 10^{-8}$ \\
\hline & Maximum & $5.97 \times 10^{-6}$ & $6.15 \times 10^{-6}$ & $7.96 \times 10^{-5}$ \\
\hline & Average & $4.39 \times 10^{-7}$ & $2.46 \times 10^{-6}$ & $3.64 \times 10^{-6}$ \\
\hline \multirow[t]{3}{*}{${ }^{234} \mathrm{U}$} & Minimum & $2.11 \times 10^{-6}$ & $5.07 \times 10^{-7}$ & $3.60 \times 10^{-8}$ \\
\hline & Maximum & $4.74 \times 10^{-6}$ & $1.57 \times 10^{-6}$ & $1.51 \times 10^{-7}$ \\
\hline & Average & $3.00 \times 10^{-6}$ & $1.45 \times 10^{-6}$ & $6.29 \times 10^{-8}$ \\
\hline \multirow[t]{3}{*}{${ }^{235} \mathrm{U}$} & Minimum & $2.07 \times 10^{-8}$ & $4.16 \times 10^{-8}$ & $4.44 \times 10^{-8}$ \\
\hline & Maximum & $2.29 \times 10^{-7}$ & $1.41 \times 10^{-7}$ & $1.86 \times 10^{-7}$ \\
\hline & Average & $1.07 \times 10^{-7}$ & $1.22 \times 10^{-7}$ & $7.28 \times 10^{-8}$ \\
\hline \multirow[t]{3}{*}{${ }^{238} \mathrm{U}$} & Minimum & $1.74 \times 10^{-6}$ & $4.52 \times 10^{-7}$ & $3.58 \times 10^{-8}$ \\
\hline & Maximum & $4.22 \times 10^{-6}$ & $8.21 \times 10^{-7}$ & $4.14 \times 10^{-7}$ \\
\hline & Average & $2.69 \times 10^{-6}$ & $1.24 \times 10^{-6}$ & $7.41 \times 10^{-8}$ \\
\hline \multirow[t]{3}{*}{${ }^{40} \mathrm{~K}$} & Minimum & $1.12 \times 10^{-4}$ & $2.93 \times 10^{-4}$ & $1.23 \times 10^{-4}$ \\
\hline & Maximum & $6.69 \times 10^{-4}$ & $3.31 \times 10^{-4}$ & $4.30 \times 10^{-4}$ \\
\hline & Average & $2.68 \times 10^{-4}$ & $2.30 \times 10^{-4}$ & $2.60 \times 10^{-4}$ \\
\hline \multirow[t]{3}{*}{${ }^{60} \mathrm{Co}$} & Minimum & $-1.28 \times 10^{-5}$ & $2.12 \times 10^{-5}$ & $2.12 \times 10^{-5}$ \\
\hline & Maximum & $3.72 \times 10^{-5}$ & $3.50 \times 10^{-5}$ & $4.30 \times 10^{-5}$ \\
\hline & Average & $1.06 \times 10^{-5}$ & $2.88 \times 10^{-5}$ & $3.01 \times 10^{-5}$ \\
\hline \multirow[t]{3}{*}{${ }^{90} \mathrm{Sr}$} & Minimum & $-2.28 \times 10^{-6}$ & $2.79 \times 10^{-6}$ & $2.93 \times 10^{-6}$ \\
\hline & Maximum & $4.02 \times 10^{-6}$ & $2.50 \times 10^{-6}$ & $6.35 \times 10^{-6}$ \\
\hline & Average & $7.01 \times 10^{-7}$ & $3.76 \times 10^{-6}$ & $4.96 \times 10^{-6}$ \\
\hline \multirow[t]{3}{*}{${ }^{137} \mathrm{Cs}$} & Minimum & $-5.99 \times 10^{-5}$ & $3.74 \times 10^{-5}$ & $1.70 \times 10^{-5}$ \\
\hline & Maximum & $2.13 \times 10^{-5}$ & $2.57 \times 10^{-5}$ & $3.99 \times 10^{-5}$ \\
\hline & Average & $-9.11 \times 10^{-6}$ & $4.55 \times 10^{-5}$ & $2.62 \times 10^{-5}$ \\
\hline
\end{tabular}

${ }^{a}$ Radionuclide concentration

${ }^{\mathrm{b}}$ Total propagated uncertainty

${ }^{\mathrm{c}}$ Minimum detectable concentration

${ }^{d}$ Arithmetic average for concentration and MDC; average TPU equals the standard deviation of the mean. Note: An anomaly in the Canberra software for the alpha spectrometer prevents it from calculating uncertainty when the activity is 0 .

The activity concentration of ${ }^{235} \mathrm{U}$ in the natural environment is very low compared to the concentrations of ${ }^{234} \mathrm{U}$ and ${ }^{238} \mathrm{U}(1 \mu \mathrm{gg}$ of natural uranium contains $12.2 \mathrm{mBq}$ [millibecquerel] [0.33 pCi] of ${ }^{238} \mathrm{U}, 0.56 \mathrm{mBq}$ [0.01 pCi] of ${ }^{235} \mathrm{U}$, and $12.8 \mathrm{mBq}$ [0.35 pCi] of ${ }^{234} \mathrm{U}$ ); therefore, the amount of ${ }^{235} \mathrm{U}$ in air particulate samples is expected to be lower. Uranium-235 was detected in approximately 46 percent of the quarterly composite samples. The lowest concentration $\left(2.07 \times 10^{-8} \pm 4.16 \times 10^{-8} \mathrm{~Bq} / \mathrm{m}^{3}\left[5.59 \times 10^{-7} \pm\right.\right.$ $\left.1.12 \times 10^{-6} \mathrm{pCi} / \mathrm{m}^{3}\right]$ ) was measured at MLR in the fourth quarter and the highest 
concentration $\left(2.29 \times 10^{-7} \pm 1.41 \times 10^{-7} \mathrm{~Bq} / \mathrm{m}^{3}\left[6.18 \times 10^{-6} \pm 3.08 \times 10^{-6} \mathrm{pCi} / \mathrm{m}^{3}\right]\right)$ was found at SEC in the second quarter (Table G.1). There was a significant difference between years (ANOVA, $p=0.041$ ), with 2001 having higher concentration than 2002.

Uranium-238 was also, as expected, detected in 100 percent of the composite air filters. Concentrations ranged from $1.74 \times 10^{-6} \pm 4.52 \times 10^{-7} \mathrm{~Bq} / \mathrm{m}^{3}\left(4.70 \times 10^{-5} \pm 1.22 \times 10^{-5} \mathrm{pCi} / \mathrm{m}^{3}\right)$ at WFF in the fourth quarter to $4.22 \times 10^{-6} \pm 8.21 \times 10^{-7} \mathrm{~Bq} / \mathrm{m}^{3}\left(1.14 \times 10^{-4} \pm\right.$ $2.22 \times 10^{-5} \mathrm{pCi} / \mathrm{m}^{3}$ ) at WEE in the first quarter (Table G.1). There was no significant difference between concentrations measured in 2001 and 2002 (ANOVA, $p=0.205$ ). The concentrations of uranium isotopes in 2002 were within the 95 percent confidence interval ranges of preoperational radiological baseline report covering the period from 1985 to 1989 (DOE/WIPP 92-037).

Neither ${ }^{238} \mathrm{Pu}$ nor ${ }^{241} \mathrm{Am}$ were detected in any sample in 2002. Plutonium-239+240 was detected once with concentration of $9.99 \times 10^{-8} \pm 8.31 \times 10^{-8} \mathrm{~Bq} / \mathrm{m}^{3}\left(2.70 \times 10^{-6} \pm\right.$ $2.24 \times 10^{-6} \mathrm{pCi} / \mathrm{m}^{3}$ ) at WSS in the fourth quarter composite.

Concentrations of ${ }^{40} \mathrm{~K}$ (Table G.1) were detected in approximately 64 percent of the samples. The minimum $\left(1.12 \times 10^{-4} \pm 2.93 \times 10^{-4} \mathrm{~Bq} / \mathrm{m}^{3}\left[3.02 \times 10^{-3} \pm 7.91 \times 10^{-3} \mathrm{pCi} / \mathrm{m}^{3}\right]\right)$ was found at MLR in the second quarter, while the maximum $\left(6.69 \times 10^{-4} \pm\right.$ $\left.3.31 \times 10^{-4} \mathrm{~Bq} / \mathrm{m}^{3}\left[1.81 \times 10^{-2} \pm 8.94 \times 10^{-3} \mathrm{pCi} / \mathrm{m}^{3}\right]\right)$ was found at WFF in the third quarter.

Cesium-137, ${ }^{60} \mathrm{Co}$ and ${ }^{90} \mathrm{Sr}$ were detected once in the quarterly composite samples in 2002. All of these detected concentrations were within the 95 percent confidence interval range of the preoperational radiological baseline report covering the period from 1985 to 1989 (DOE/WIPP 92-037).

Duplicate air particulate samples were collected by rotating the portable sampler from one location to another every quarter: CBD in the first quarter, SEC in the second quarter, WFF in the third quarter, and WEE in the fourth quarter. The samples were collected by both samplers in identical conditions at all four locations. The duplicate samples were analyzed to check the reproducibility of the data. The results are given in Table 4.4. The original and duplicate results for ${ }^{234} \mathrm{U},{ }^{238} \mathrm{U}$, and ${ }^{40} \mathrm{~K}$ were compared using the RER. The results for all other radionuclides were excluded because of insufficient detections for a meaningful test. Relative Error Ratios were less than one for all results shown in Table 4.4.

The results obtained for the concentrations of ${ }^{238} \mathrm{Pu}$, ${ }^{239+240} \mathrm{Pu}$, and ${ }^{241} \mathrm{Am}$ in air particulates compared favorably with those measured by the EEG (Table 4.5). The annual mean concentrations of these radionuclides were very low, and most samples collected by either WIPP or EEG did not contain detectable concentrations. 


\section{Waste Isolation Pilot Plant 2002 Site Environmental Report DOE/WIPP 03-2225}

Table 4.4 - Results of Duplicate Composite Air Filter Sampling. Units are Bq/m $\mathbf{m}^{3}$. See Appendix B for sampling stations.

\begin{tabular}{|c|c|c|c|c|c|}
\hline \multirow[b]{2}{*}{ Location } & \multirow[b]{2}{*}{ Quarter } & {$[\mathrm{RN}]^{\mathrm{a}}$} & $2 \times T_{P U}^{b}$ & $M^{\prime} C^{c}$ & RER $^{d}$ \\
\hline & & \multicolumn{4}{|c|}{${ }^{40} \mathrm{~K}$} \\
\hline CBD & 1 & $4.07 \times 10^{-4}$ & $3.32 \times 10^{-4}$ & $3.89 \times 10^{-4}$ & 0.235 \\
\hline CBD Dup. & 1 & $3.21 \times 10^{-4}$ & $1.58 \times 10^{-4}$ & $2.12 \times 10^{-4}$ & \\
\hline SEC & 2 & $1.33 \times 10^{-4}$ & $8.51 \times 10^{-5}$ & $1.23 \times 10^{-4}$ & 0.889 \\
\hline SEC Dup. & 2 & $3.37 \times 10^{-4}$ & $2.13 \times 10^{-4}$ & $2.86 \times 10^{-4}$ & \\
\hline WFF & 3 & $6.69 \times 10^{-4}$ & $3.31 \times 10^{-4}$ & $3.90 \times 10^{-4}$ & 0.805 \\
\hline WFF Dup. & 3 & $3.07 \times 10^{-4}$ & $3.04 \times 10^{-4}$ & $3.49 \times 10^{-4}$ & \\
\hline WEE & 4 & $4.15 \times 10^{-4}$ & $1.71 \times 10^{-4}$ & $2.36 \times 10^{-4}$ & 0.068 \\
\hline \multirow[t]{2}{*}{ WEE Dup. } & 4 & $3.97 \times 10^{-4}$ & $2.01 \times 10^{-4}$ & $2.69 \times 10^{-4}$ & \\
\hline & & \multicolumn{4}{|c|}{${ }^{234} U$} \\
\hline CBD & 1 & $4.74 \times 10^{-6}$ & $1.57 \times 10^{-6}$ & $1.51 \times 10^{-7}$ & 0.733 \\
\hline CBD Dup. & 1 & $3.47 \times 10^{-6}$ & $7.40 \times 10^{-7}$ & $1.31 \times 10^{-7}$ & \\
\hline SEC & 2 & $3.05 \times 10^{-6}$ & $6.36 \times 10^{-7}$ & $3.89 \times 10^{-8}$ & 0.044 \\
\hline SEC Dup. & 2 & $3.01 \times 10^{-6}$ & $6.40 \times 10^{-7}$ & $3.96 \times 10^{-8}$ & \\
\hline WFF & 3 & $2.22 \times 10^{-6}$ & $5.51 \times 10^{-7}$ & $5.15 \times 10^{-8}$ & 0.616 \\
\hline WFF Dup. & 3 & $2.75 \times 10^{-6}$ & $6.61 \times 10^{-7}$ & $5.21 \times 10^{-8}$ & \\
\hline WEE & 4 & $2.12 \times 10^{-6}$ & $5.26 \times 10^{-7}$ & $4.78 \times 10^{-8}$ & 0.103 \\
\hline \multirow[t]{2}{*}{ WEE Dup. } & 4 & $2.20 \times 10^{-6}$ & $5.72 \times 10^{-7}$ & $5.64 \times 10^{-8}$ & \\
\hline & & \multicolumn{4}{|c|}{${ }^{238} U$} \\
\hline CBD & 1 & $3.05 \times 10^{-6}$ & $1.12 \times 10^{-6}$ & $1.50 \times 10^{-7}$ & 0.361 \\
\hline CBD Dup. & 1 & $3.54 \times 10^{-6}$ & $7.51 \times 10^{-7}$ & $4.81 \times 10^{-8}$ & \\
\hline SEC & 2 & $2.63 \times 10^{-6}$ & $5.66 \times 10^{-7}$ & $3.85 \times 10^{-8}$ & 0.559 \\
\hline SEC Dup. & 2 & $3.12 \times 10^{-6}$ & $6.59 \times 10^{-7}$ & $3.96 \times 10^{-8}$ & \\
\hline WFF & 3 & $1.93 \times 10^{-6}$ & $4.97 \times 10^{-7}$ & $5.13 \times 10^{-8}$ & 0.687 \\
\hline WFF Dup. & 3 & $2.47 \times 10^{-6}$ & $6.09 \times 10^{-7}$ & $5.19 \times 10^{-8}$ & \\
\hline WEE & 4 & $1.90 \times 10^{-6}$ & $4.85 \times 10^{-7}$ & $4.76 \times 10^{-8}$ & 0.792 \\
\hline WEE Dup. & 4 & $2.53 \times 10^{-6}$ & $6.31 \times 10^{-7}$ & $5.61 \times 10^{-8}$ & \\
\hline
\end{tabular}

Table 4.5 - Preliminary Quarterly Average Radionuclide Concentrations $\left(\mathrm{Bq} / \mathrm{m}^{3}\right)$ Measured in Air Particulate Samples by the Environmental Evaluation Group in 2002

\begin{tabular}{|c|c|c|c|c|}
\hline & \multicolumn{4}{|c|}{ Quarter } \\
\hline & 1 & 2 & 3 & 4 \\
\hline & \multicolumn{4}{|c|}{${ }^{241} \mathrm{Am}$} \\
\hline Concentration & $9.77 \times 10^{-9}$ & $8.00 \times 10^{-9}$ & $7.22 \times 10^{-9}$ & $\mathrm{NR}^{\mathrm{b}}$ \\
\hline \multirow[t]{2}{*}{$2 \times \mathrm{SD}^{\mathrm{a}}$} & $1.65 \times 10^{-8}$ & $3.55 \times 10^{-8}$ & $7.80 \times 10^{-9}$ & NR \\
\hline & \multicolumn{4}{|c|}{${ }^{238} \mathrm{Pu}$} \\
\hline Concentration & $5.08 \times 10^{-9}$ & $4.17 \times 10^{-9}$ & $2.90 \times 10^{-10}$ & NR \\
\hline \multirow[t]{2}{*}{$2 \times S D$} & $9.06 \times 10^{-9}$ & $5.51 \times 10^{-9}$ & $4.82 \times 10^{-9}$ & NR \\
\hline & \multicolumn{4}{|c|}{${ }^{239+240} \mathrm{Pu}$} \\
\hline Concentration & $1.52 \times 10^{-8}$ & $2.06 \times 10^{-8}$ & $1.21 \times 10^{-8}$ & NR \\
\hline $2 \times S D$ & $9.70 \times 10^{-9}$ & $7.76 \times 10^{-9}$ & $9.71 \times 10^{-9}$ & NR \\
\hline
\end{tabular}




\subsection{Groundwater}

\subsubsection{Sample Collection}

Groundwater samples were collected from seven different wells around the WIPP site as shown in Figure 6.1. Approximately three bore volumes (approximately 3,800 liters $[1,000$ gallons]) of water were pumped out of each well before collecting approximately 38 liters (10 gallons) of water samples. The water samples were collected from depths ranging from 180-270 $\mathrm{m}$ (600-900 ft) from six wells (WQSP-1 to WQSP-6), and from a depth of $69 \mathrm{~m}(225 \mathrm{ft})$ from WQSP-6A. Samples were collected twice in 2002. Approximately 8 liters ( 2 gallons) of water were sent to the laboratory for the determination of radionuclides of interest. The rest of the samples were used to analyze for nonradiological parameters or were put into storage. The samples were acidified to $\mathrm{pH} \leq 2$ by titrating concentrated nitric acid.

\subsubsection{Determination of Individual Radionuclides}

The acidified water samples were used for the determination of gamma-emitting radionuclides, such as ${ }^{40} \mathrm{~K},{ }^{60} \mathrm{Co}$, and ${ }^{137} \mathrm{Cs}$, by gamma spectrometry. An aliquot of approximately 0.5 liters $(16.9 \mathrm{oz})$ was used for the determination of ${ }^{90} \mathrm{Sr}$. Another aliquot was used for the sequential determinations of the uranium isotopes, the plutonium isotopes, and ${ }^{241} \mathrm{Am}$ by alpha spectrometry, which involved the co-precipitation of actinides with iron carrier, ion exchange chromatographic separation of individual radionuclides, source preparation by micro-precipitating, and alpha spectrometry.

\subsubsection{Results and Discussions}

Isotopes of naturally occurring uranium were detected in every well in 2002 (Table 4.6). The mean concentrations of ${ }^{234} \mathrm{U}$ ranged from $2.35 \times 10^{-1} \pm 3.17 \times 10^{-2} \mathrm{~Bq} / \mathrm{L}$ (becquerels per liter) $\left(6.35 \times 10^{0} \pm 8.56 \times 10^{-1} \mathrm{pCi} / \mathrm{L}\right)$ (picoCuries per liter) in WQSP-6A to $1.32 \times 10^{0} \pm$ $2.89 \times 10^{-1} \mathrm{~Bq} / \mathrm{L}\left(3.56 \times 10^{1} \pm 7.80 \times 10^{0} \mathrm{pCi} / \mathrm{L}\right)$ in WQSP-1. Uranium-235 ranged from $3.49 \times 10^{-3} \pm 7.11 \times 10^{-5} \mathrm{~Bq} / \mathrm{L}\left(9.42 \times 10^{-2} \pm 1.92 \times 10^{-3} \mathrm{pCi} / \mathrm{L}\right)$ in WQSP-3 to $1.69 \times 10^{-2} \pm$ $9.05 \times 10^{-3} \mathrm{~Bq} / \mathrm{L}\left(4.56 \times 10^{-1} \pm 2.44 \times 10^{-1} \mathrm{pCi} / \mathrm{L}\right)$ in WQSP-1. The mean concentration of ${ }^{238} \mathrm{U}$ ranged from $3.71 \times 10^{-2} \pm 9.90 \times 10^{-3} \mathrm{~Bq} / \mathrm{L}\left(1.00 \times 10^{0} \pm 2.67 \times 10^{-1} \mathrm{pCi} / \mathrm{L}\right)$ in WQSP-3 to $2.23 \times 10^{-1} \pm 5.69 \times 10^{-2} \mathrm{~Bq} / \mathrm{L}\left(6.02 \times 10^{0} \pm 1.54 \times 10^{0} \mathrm{pCi} / \mathrm{L}\right)$ in WQSP-1. 
Table 4.6 - Average Radionuclide Concentrations (Bq/L) in Groundwater from Wells at the WIPP Site. See Chapter 6 for the sampling locations.

\begin{tabular}{|c|c|c|c|c|c|c|c|c|c|}
\hline \multirow{2}{*}{ Location } & ean & $2 \times S D^{a}$ & $\boldsymbol{c}^{\mathbf{b}}$ & & $2 \times S D$ & MDC & & $2 \times \mathrm{SD}$ & MDC \\
\hline & & ${ }^{241} \mathrm{Am}$ & & \multicolumn{3}{|c|}{${ }^{238} \mathrm{Pu}$} & \multicolumn{3}{|c|}{${ }^{239+240} \mathrm{Pu}$} \\
\hline /QSP-1 & & $2.13 \times 10^{-4}$ & & & $3.20 \times 10^{-4}$ & $2.11 \times 10^{-4}$ & & $1.59 \times 10^{-4}$ & $.37 \times 10^{-4}$ \\
\hline QSP-2 & $1.58 \times 10^{-4}$ & $4.38 \times 10^{-4}$ & $7.45 \times 10^{-4}$ & & $2.48 \times 10^{-4}$ & $27 \times 10^{-4}$ & & $0.00 \times 10^{0}$ & $.84 \times 10^{-4}$ \\
\hline & & $29 \times 10^{-4}$ & 1. & & $41 x$ & & & $2.30 \times 10^{-4}$ & $62 \times 10^{-4}$ \\
\hline D-4 & & $.44 \times 10^{-4}$ & $1.17 \times 10^{-3}$ & & $42 \times 10^{-4}$ & & $00 \times 10^{0}$ & $0.00 \times 10^{0}$ & $10^{-3}$ \\
\hline QSP-5 & $1.15 \times 10^{-4}$ & $3.20 \times 10^{-4}$ & $7.73 \times 10^{-4}$ & $3.22 \times 10^{-5}$ & $4.24 \times 10^{-4}$ & $6.94 \times 10^{-4}$ & $.03 \times 10^{-5}$ & $1.67 \times 10^{-4}$ & $.13 \times 10^{-4}$ \\
\hline QSP-6 & $-1.61 \times 10^{-4}$ & $4.45 \times 10^{-4}$ & $1.21 \times 10^{-3}$ & $3.38 \times 10^{-4}$ & $1.14 \times 10^{-5}$ & $9.29 \times 10^{-4}$ & $3.37 \times 10^{-4}$ & $1.23 \times 10^{-5}$ & $3.80 \times 10^{-4}$ \\
\hline$C D G A$ & & $\frac{5.23 \times 10^{-4}}{{ }^{234} \mathrm{U}}$ & $6.19 \times 10^{-4}$ & & $\frac{1.48 \times 10^{-4}}{{ }^{235} \mathrm{U}}$ & & & $\frac{5.90 \times 10^{-4}}{{ }^{238} \mathrm{U}}$ & $32 \times 10^{-4}$ \\
\hline & & $2.89 \times 10^{-1}$ & $7.02 \times 10^{-4}$ & & $9.05 \times 10^{-3}$ & $5.62 \times 10^{-4}$ & & $5.69 \times 10^{-2}$ & $.04 \times 10$ \\
\hline P-2 & $1.13 \times 10^{0}$ & $3.64 \times 10^{-2}$ & $5.25 \times 10^{-4}$ & $1.63 \times 10^{-2}$ & $1.58 \times 10^{-2}$ & $6.49 \times 10^{-4}$ & $1.81 \times 10^{-1}$ & $1.88 \times 10^{-2}$ & $5.24 \times 10^{-4}$ \\
\hline QSP-3 & $2.50 \times 10^{-1}$ & $2.22 \times 10^{-2}$ & $3.19 \times 10^{-4}$ & $3.49 \times 10^{-3}$ & $7.11 \times 10^{-5}$ & $3.94 \times 10^{-4}$ & $1 \times 10^{-2}$ & $9.90 \times 10^{-3}$ & $.18 \times 10^{-4}$ \\
\hline QSP-4 & $5.70 \times 10^{-1}$ & $1.01 \times 10^{-1}$ & $1.40 \times 10^{-3}$ & $8.81 \times 10^{-3}$ & $8.73 \times 10^{-5}$ & $7.42 \times 10^{-4}$ & $9.93 \times 10^{-2}$ & $1.91 \times 10^{-2}$ & $4.75 \times 10^{-3}$ \\
\hline$P-5$ & $5.38 x$ & $5.78 \times 10^{-2}$ & $2.76 \times 10^{-4}$ & $6.93 \times 10^{-3}$ & $3.15 \times 10^{-3}$ & $3.41 \times 10^{-4}$ & $17 \times 10^{-2}$ & $3.09 \times 10^{-2}$ & $.75 \times 10^{-4}$ \\
\hline & $5.52 \times 10^{-1}$ & $4.82 \times 10^{-2}$ & $3.15 \times 10^{-4}$ & $6.90 \times 10^{-3}$ & $1.59 \times 10^{-3}$ & $3.88 \times 10^{-4}$ & $7.34 \times 10^{-2}$ & $2.59 \times 10^{-3}$ & $.13 \times 10^{-4}$ \\
\hline NQSP-6A & & $\frac{3.17 \times 10^{-2}}{{ }^{137} \mathrm{Cs}}$ & & & $\frac{1.32 \times 10^{-3}}{{ }^{60} \mathrm{Co}}$ & & & $\frac{2.22 \times 10^{-2}}{{ }^{40} \mathrm{~K}}$ & \\
\hline$P-1$ & & $3.85 \times 10^{-1}$ & $3.41 \times 1$ & & $5.75 \times 10^{-2}$ & $3.97 \times 10^{-1}$ & & $3.34 \times 10^{0}$ & $.76 \times 10^{0}$ \\
\hline P-2 & $-2.85 \times 10^{-1}$ & $8.71 \times 10^{-1}$ & $4.02 \times 10^{-1}$ & $6.31 \times 10^{-2}$ & $1.88 \times 10^{-1}$ & $4.20 \times 10^{-1}$ & $54 \times 10^{1}$ & $4.33 \times 10^{0}$ & $.99 \times 10^{0}$ \\
\hline$P-3$ & $1.17 \times 10^{-1}$ & $3.34 \times 10^{-1}$ & $4.19 \times 10^{-1}$ & $1.43 \times 10^{-1}$ & $2.85 \times 10^{-1}$ & $4.59 \times 10^{-1}$ & $4.94 \times 10^{1}$ & $1.47 \times 10^{0}$ & $3.69 \times 10^{0}$ \\
\hline & $3.85 \times 10^{-2}$ & $5.92 \times 10^{-1}$ & $4.11 \times 10^{-1}$ & $1.85 \times 10^{-1}$ & $4.28 \times 10^{-2}$ & $4.54 \times 10^{-1}$ & $2.52 \times 10^{1}$ & $4.03 \times 10^{0}$ & $3.20 \times 10^{0}$ \\
\hline & $-1.71 x$ & $1.08 \times 10^{-1}$ & $4.05 \times 10^{-1}$ & $2.32 \times 10^{-1}$ & $5.97 \times 10^{-1}$ & $4.42 \times 10^{-1}$ & $\times 10^{1}$ & $7.62 \times 10^{0}$ & $48 \times 10^{0}$ \\
\hline VQSP-6 & $-4.40 \times 10^{-1}$ & $1.46 \times 10^{-1}$ & $5.29 \times 10^{-1}$ & $4.48 \times 10^{-1}$ & $1.10 \times 10^{0}$ & $5.57 \times 10^{-1}$ & $04 \times 10^{0}$ & $5.31 \times 10^{0}$ & $.08 \times 10^{0}$ \\
\hline WQSP-6A & $-3.60 \times 10^{-1}$ & $\frac{4.47 \times 10^{-1}}{{ }^{90} \mathrm{Sr}}$ & $5.05 \times 10^{-1}$ & $040 \times 10-1$ & $\frac{3.98 \times 10^{-1}}{{ }^{226} \mathrm{Ra}}$ & $4.97 \times 10^{-1}$ & $.41 \times 10^{0}$ & $\frac{1.77 \times 10^{0}}{{ }^{228} \mathrm{Ra}}$ & $5.18 \times 10^{0}$ \\
\hline QSP-1 & $9.56 \times 10^{-3}$ & $1.28 \times 10^{-2}$ & $4.31 \times 10^{-2}$ & $5.52 \times 10^{0}$ & $4.79 \times 10^{-1}$ & $4.05 \times 10^{-2}$ & $1.04 \times 10^{0}$ & $1.39 \times 10^{-1}$ & $.07 \times 10^{-1}$ \\
\hline QSP-2 & $5.73 \times 10^{-3}$ & $1.24 \times 10^{-2}$ & $3.54 \times 10^{-2}$ & $3.72 \times 10^{0}$ & $8.21 \times 10^{-2}$ & $2.78 \times 10^{-2}$ & $4.95 \times 10^{-1}$ & $6.91 \times 10^{-2}$ & $1.06 \times 10^{-1}$ \\
\hline & $1.09 \times 10^{-2}$ & $3.62 \times 10^{-2}$ & $4.31 \times 10^{-2}$ & $7.00 \times 10^{0}$ & $1.37 \times 10^{0}$ & $4.02 \times 10^{-2}$ & $1.14 \times 10^{0}$ & $2.48 \times 10^{-1}$ & $1.06 \times 10^{-1}$ \\
\hline SP-4 & $-5.08 \times 10^{-3}$ & $2.08 \times 10^{-2}$ & $6.47 \times 10^{-2}$ & $9.07 \times 10^{0}$ & $9.04 \times 10^{-1}$ & $4.13 \times 10^{-2}$ & $1.41 \times 10^{0}$ & $4.68 \times 10^{-2}$ & $1.20 \times 10^{-1}$ \\
\hline SP-5 & $-7.03 \times 10^{-2}$ & $1.12 \times 10^{-2}$ & $4.89 \times 10^{-2}$ & $2.75 \times 10^{0}$ & $1.16 \times 10^{-1}$ & $2.37 \times 10^{-2}$ & $3.72 \times 10^{-1}$ & $2.00 \times 10^{-1}$ & $1.18 \times 10^{-1}$ \\
\hline$P-6$ & $-1.89 \times 10^{-3}$ & $4.71 \times 10^{-2}$ & $5.39 \times 10^{-2}$ & $1.23 \times 10^{0}$ & $2.24 \times 10^{-1}$ & $1.71 \times 10^{-2}$ & $1.46 \times 10^{-1}$ & $1.00 \times 10^{-1}$ & $1.06 \times 10^{-1}$ \\
\hline VQSP-6A & $-7.25 \times 10^{-5}$ & $1.51 \times 10^{-2}$ & $4.05 \times 10^{-2}$ & $-7.15 \times 10^{-4}$ & $7.25 \times 10^{-3}$ & $1.34 \times 10^{-2}$ & $-1.35 \times 10^{-2}$ & $1.29 \times 10^{-1}$ & $1.02 \times 10^{-1}$ \\
\hline
\end{tabular}

${ }^{a}$ Standard deviation of the mean

${ }^{\mathrm{b}}$ Minimum detectable concentration

Note: An anomaly in the Canberra software for the alpha spectrometer prevents it from calculating uncertainty when the activity is 0 .

The concentrations of uranium isotopes in water samples collected from these wells were compared between 2001 and 2002. There was no significant difference in the concentration of uranium isotopes between years (ANOVA, ${ }^{234} \mathrm{U} p=0.701$, ${ }^{235} \mathrm{U} p=0.113,{ }^{238} \mathrm{U} p=0.914$ ).

Plutonium-238, ${ }^{239+240} \mathrm{Pu}$, and ${ }^{241} \mathrm{Am}$ were also analyzed in these groundwater samples (Table 4.6). Neither ${ }^{239+240} \mathrm{Pu}$ nor ${ }^{241} \mathrm{Am}$ were detected in any sample. The mean concentration of ${ }^{238} \mathrm{Pu}$ was greater than the MDC in one sample from well WQSP-3 $\left(5.08 \times 10^{-4} \pm 4.41 \times 10^{-4} \mathrm{~Bq} / \mathrm{L} ; \mathrm{MDC}=4.62 \times 10^{-4} \mathrm{~Bq} / \mathrm{L}\left[1.37 \times 10^{-2} \pm 1.19 \times 10^{-2} \mathrm{pCi} / \mathrm{L} ; \mathrm{MDC}=\right.\right.$ 
$\left.\left.1.25 \times 10^{-2} \mathrm{pCi} / \mathrm{L}\right]\right)$. However, this result was very close to the MDC and the MDC falls within the error associated with the result. All wells' sample results and means were below the detection limit for ${ }^{239+240} \mathrm{Pu}$ and ${ }^{241} \mathrm{Am}$. Analysis of variance did not show significant differences in ${ }^{238} \mathrm{Pu},{ }^{239+240} \mathrm{Pu}$, or ${ }^{241} \mathrm{Am}$ (ANOVA ${ }^{238} \mathrm{Pu} \mathrm{p}=0.497,{ }^{239+240} \mathrm{Pu} p=$ $0.087,{ }^{241} \mathrm{Am} \mathrm{p}=0.599$ ) between 2001 and 2002.

The concentrations of ${ }^{241} \mathrm{Am}$, plutonium isotopes, and uranium isotopes in groundwater in 2002 were within the 95 percent confidence interval ranges of preoperational radiological baseline report covering the period from 1985 to 1989 (DOE/WIPP 92-037).

As discussed in the 2000 annual Site Environmental Report (DOE/WIPP 01-2225), groundwater results from wells WQSP-1, WQSP-3, and WQSP-4 had tendency to exhibit a pattern of activity above the MDC for ${ }^{238} \mathrm{Pu}$ and ${ }^{241} \mathrm{Am}$. To help explain these concentrations apparently above background, WIPP began analyzing groundwater for ${ }^{226} \mathrm{Ra}$ and ${ }^{228} \mathrm{Ra}$ during the fall sampling of 2000 . Radium-226 and ${ }^{228} \mathrm{Ra}$ were detected in 100 percent of the samples except for well WQSP-6A in 2002. The mean concentrations were all above the mean detection limits except for well WQSP-6A (Table 4.6). However, the concentrations of ${ }^{226} \mathrm{Ra}$ in water from wells WQSP-1, WQSP-3, and WQSP-4 were all lower than those reported in the 1995 annual Site Environmental Report $(6.0 \pm 0.06 \mathrm{~Bq} / \mathrm{L}, 7.8 \pm 0.06 \mathrm{~Bq} / \mathrm{L}$, and $9.1 \pm 0.07 \mathrm{~Bq} / \mathrm{L}$, respectively).

These results are important because one decay product of ${ }^{226} \mathrm{Ra},{ }^{222} \mathrm{Rn}$, emits alpha particles with an energy of $5.489 \mathrm{MeV}$ (million electron volts), very close to the most abundant alpha energy of ${ }^{241} \mathrm{Am}(5.486 \mathrm{MeV})$ and ${ }^{238} \mathrm{Pu}(5.499 \mathrm{MeV})$. Because these energies are close, the region of interest in the alpha spectrum from the groundwater samples likely contained counts originating from ${ }^{222} \mathrm{Rn}$ that were identified as ${ }^{238} \mathrm{Pu}$ or ${ }^{241} \mathrm{Am}$. Additional ${ }^{226} \mathrm{Ra}$ progeny were also likely present. The solubility of the components can vary, causing the ${ }^{222} \mathrm{Rn}$ activity and associated ${ }^{226} \mathrm{Ra}$ progeny to appear in some analyses, but not all. This phenomenon may explain the trend of seemingly high concentrations of ${ }^{238} \mathrm{Pu}$ and ${ }^{241} \mathrm{Am}$ observed in some groundwater samples over time.

Cesium-137 was not detected in any of the samples. Potassium- 40 was detected in all wells except for the fall sampling round of WQSP-6. Strontium-90 was detected once in the spring sampling round of WQSP-6.

\subsection{Surface Water}

\subsubsection{Sample Collection}

Fourteen different locations around the WIPP site, as shown in Figure 4.5, were identified for collecting the surface water samples (see Appendix B for location codes). Samples were collected once in 2002 from 13 sampling locations. If the surface water collection location was dry, sediment was collected. Sediment results are described in Section 4.7. This year, surface water was collected from all sites, including the FWT, RCP1, RCP2, and SOO. 


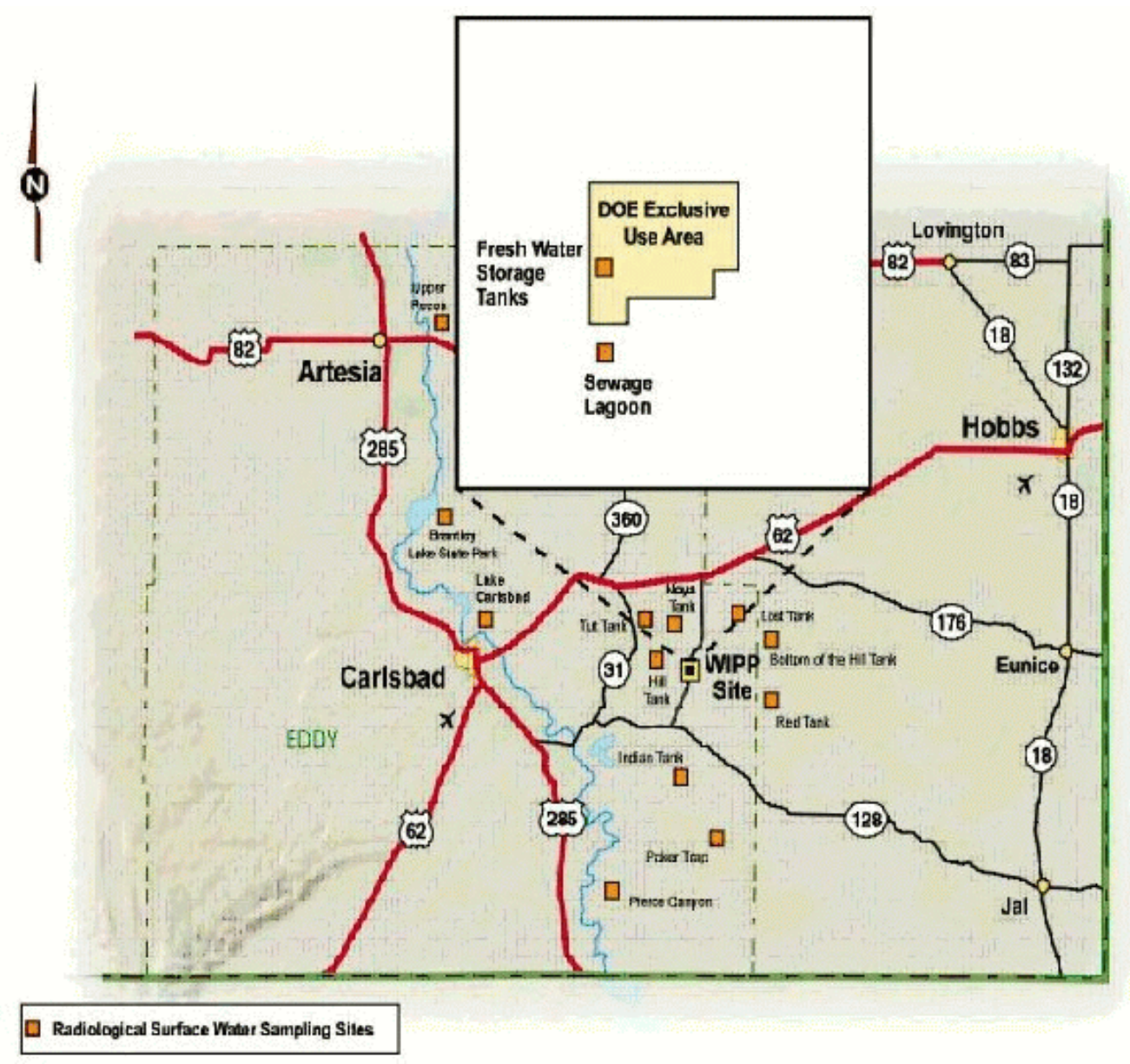

Figure 4.5 - Routine Surface Water Sampling Locations

Water from the sampling location was used to rinse 3.78-I (1-gallon) polyethylene containers several times. Approximately 3.78 I ( 1 gallon) of water was collected from each location. The samples were acidified immediately after collection with concentrated nitric acid to $\mathrm{pH} \leq 2$. Later, the samples were shipped to the laboratory for analysis. Chain of custody was maintained throughout the process.

\subsubsection{Determination of Individual Radionuclides}

Gamma-spectrometry was used for the determination of ${ }^{40} \mathrm{~K},{ }^{60} \mathrm{Co}$, and ${ }^{137} \mathrm{Cs}$. Strontium-90, a beta-emitting radionuclide, was determined by chemical separation and counting it on the gas proportional counter. Uranium, plutonium, and americium were determined by alpha spectrometry. These alpha-emitting radionuclides were separated from the bulk of water samples by co-precipitation with an iron carrier. Ion-exchange chromatography was used for the separation of individual radionuclides. Finally, the samples were counted by alpha spectrometry. 


\section{Waste Isolation Pilot Plant 2002 Site Environmental Report DOE/WIPP 03-2225}

\subsubsection{Results and Discussions}

Isotopes of natural uranium $\left({ }^{234} U\right.$ and $\left.{ }^{238} U\right)$ were detected in surface water at every sampling location (Table 4.7). Uranium-235 was detected in 65 percent of sampling locations except at IDN, PKR, RCP-1, RCP-2, RED, and SOO. Uranium-234 was lowest at Rainwater Catchment Pond 2 (RCP2) $\left(2.95 \times 10^{-3} \pm 1.22 \times 10^{-3} \mathrm{~Bq} / \mathrm{L}\left[7.97 \times 10^{-2} \pm\right.\right.$ $\left.\left.3.30 \times 10^{-2} \mathrm{pCi} / \mathrm{L}\right]\right)$ and highest at Pierce Canyon (PCN) $\left(2.29 \times 10^{-1} \pm 3.54 \times 10^{-2} \mathrm{~Bq} / \mathrm{L}\right.$ $\left.\left[6.18 \times 10^{0} \pm 9.56 \times 10^{-1} \mathrm{pCi} / \mathrm{L}\right]\right)$. Uranium-235 was detected in 65 percent of the samples. Concentrations ranged from $-4.73 \times 10^{-4} \pm 9.51 \times 10^{-4} \mathrm{~Bq} / \mathrm{L}\left(-1.28 \times 10^{-2} \pm 2.57 \times 10^{-2} \mathrm{pCi} / \mathrm{L}\right)$ at SOO to $6.14 \times 10^{-3} \pm 2.08 \times 10^{-3} \mathrm{~Bq} / \mathrm{L}\left(1.66 \times 10^{-1} \pm 5.62 \times 10^{-2} \mathrm{pCi} / \mathrm{L}\right)$ at $\mathrm{PCN}$. Concentrations of ${ }^{238} \mathrm{U}$, detected in all samples, ranged from $1.72 \times 10^{-3} \pm 8.81 \times 10^{-4} \mathrm{~Bq} / \mathrm{L}$ $\left(4.65 \times 10^{-2} \pm 2.38 \times 10^{-2} \mathrm{pCi} / \mathrm{L}\right)$ at RCP2 to $1.24 \times 10^{-1} \pm 1.96 \times 10^{-2} \mathrm{~Bq} / \mathrm{L}\left(3.35 \times 10^{0} \pm\right.$ $\left.5.30 \times 10^{-1} \mathrm{pCi} / \mathrm{L}\right)$ at $\mathrm{PCN}$.

Results for uranium concentrations in 2002 samples were compared with the uranium concentrations in 2001 samples. There was no significant difference in the concentration of any uranium isotope between years (ANOVA, ${ }^{234} U p=0.381$, $\left.{ }^{235} U p=0.339,{ }^{238} U p=0.425\right)$. The concentrations of uranium isotopes in surface water in 2002 were also within the 95 percent confidence interval ranges of preoperational radiological baseline report covering the period from 1985 to 1989 (DOE/WIPP 92-037).

Table 4.7 - Uranium Concentrations (Bq/L) in Surface Water Near the WIPP Site. See Appendix $B$ for the sampling locations.

\begin{tabular}{|c|c|c|c|c|c|c|c|c|c|}
\hline \multirow[b]{2}{*}{ Location } & {$[\mathrm{RN}]^{\mathrm{a}}$} & $2 \times$ TPU $^{b}$ & $M D^{c}$ & [RN] & $2 \times$ TPU & MDC & [RN] & $2 \times \mathrm{TPU}$ & MDC \\
\hline & \multicolumn{3}{|c|}{${ }^{234} U$} & \multicolumn{3}{|c|}{${ }^{235} \mathrm{U}$} & \multicolumn{3}{|c|}{${ }^{238} \mathrm{U}$} \\
\hline$\overline{\mathrm{BHT}}$ & $7.35 \times 10^{-3}$ & $2.15 \times 10^{-3}$ & $8.09 \times 10^{-4}$ & $6.77 \times 10^{-4}$ & $6.14 \times 10^{-4}$ & $3.67 \times 10^{-4}$ & $5.46 \times 10^{-3}$ & $1.76 \times 10^{-3}$ & $2.96 \times 10^{-4}$ \\
\hline BRA & $1.51 \times 10^{-1}$ & $2.59 \times 10^{-2}$ & $3.26 \times 10^{-4}$ & $4.88 \times 10^{-3}$ & $1.88 \times 10^{-3}$ & $4.03 \times 10^{-4}$ & $7.18 \times 10^{-2}$ & $1.30 \times 10^{-2}$ & $8.81 \times 10^{-4}$ \\
\hline CBD & $1.58 \times 10^{-1}$ & $2.80 \times 10^{-2}$ & $3.96 \times 10^{-4}$ & $3.96 \times 10^{-3}$ & $1.82 \times 10^{-3}$ & $4.88 \times 10^{-4}$ & $6.81 \times 10^{-2}$ & $1.30 \times 10^{-2}$ & $3.96 \times 10^{-4}$ \\
\hline FWT & $6.25 \times 10^{-2}$ & $1.34 \times 10^{-3}$ & $4.88 \times 10^{-4}$ & $1.11 \times 10^{-3}$ & $1.02 \times 10^{-3}$ & $6.03 \times 10^{-4}$ & $2.30 \times 10^{-2}$ & $5.92 \times 10^{-3}$ & $1.32 \times 10^{-3}$ \\
\hline HIL & $1.04 \times 10^{-2}$ & $2.73 \times 10^{-3}$ & $3.02 \times 10^{-4}$ & $1.10 \times 10^{-3}$ & $7.99 \times 10^{-4}$ & $3.74 \times 10^{-4}$ & $1.11 \times 10^{-2}$ & $2.87 \times 10^{-3}$ & $8.18 \times 10^{-4}$ \\
\hline IDN & $8.92 \times 10^{-3}$ & $2.50 \times 10^{-3}$ & $3.10 \times 10^{-4}$ & $1.41 \times 10^{-4}$ & $2.83 \times 10^{-4}$ & $3.81 \times 10^{-4}$ & $6.14 \times 10^{-3}$ & $1.96 \times 10^{-3}$ & $3.09 \times 10^{-4}$ \\
\hline LST & $2.68 \times 10^{-2}$ & $5.65 \times 10^{-3}$ & $3.35 \times 10^{-4}$ & $1.07 \times 10^{-3}$ & $8.24 \times 10^{-4}$ & $4.13 \times 10^{-4}$ & $2.15 \times 10^{-2}$ & $4.76 \times 10^{-3}$ & $3.33 \times 10^{-4}$ \\
\hline NOY & $8.40 \times 10^{-2}$ & $1.51 \times 10^{-2}$ & $3.42 \times 10^{-4}$ & $3.43 \times 10^{-3}$ & $1.62 \times 10^{-3}$ & $1.15 \times 10^{-3}$ & $8.18 \times 10^{-2}$ & $1.47 \times 10^{-2}$ & $9.29 \times 10^{-4}$ \\
\hline $\mathrm{PCN}$ & $2.29 \times 10^{-1}$ & $3.54 \times 10^{-2}$ & $8.14 \times 10^{-4}$ & $6.14 \times 10^{-3}$ & $2.08 \times 10^{-3}$ & $1.00 \times 10^{-3}$ & $1.24 \times 10^{-1}$ & $1.96 \times 10^{-2}$ & $2.98 \times 10^{-4}$ \\
\hline PKT & $1.41 \times 10^{-2}$ & $3.33 \times 10^{-3}$ & $2.92 \times 10^{-4}$ & $1.33 \times 10^{-4}$ & $4.63 \times 10^{-4}$ & $9.81 \times 10^{-4}$ & $1.21 \times 10^{-2}$ & $3.00 \times 10^{-3}$ & $7.92 \times 10^{-4}$ \\
\hline RCP1 & $1.07 \times 10^{-2}$ & $2.80 \times 10^{-3}$ & $3.13 \times 10^{-4}$ & $2.85 \times 10^{-4}$ & $4.07 \times 10^{-4}$ & $3.89 \times 10^{-4}$ & $7.14 \times 10^{-3}$ & $2.15 \times 10^{-3}$ & $3.12 \times 10^{-4}$ \\
\hline RCP2 & $2.95 \times 10^{-3}$ & $1.22 \times 10^{-3}$ & $7.51 \times 10^{-4}$ & $1.25 \times 10^{-4}$ & $2.52 \times 10^{-4}$ & $3.40 \times 10^{-4}$ & $1.72 \times 10^{-3}$ & $8.81 \times 10^{-4}$ & $2.75 \times 10^{-4}$ \\
\hline RED & $1.19 \times 10^{-2}$ & $2.95 \times 10^{-3}$ & $2.96 \times 10^{-4}$ & $2.69 \times 10^{-4}$ & $3.85 \times 10^{-4}$ & $3.65 \times 10^{-4}$ & $9.14 \times 10^{-3}$ & $2.46 \times 10^{-3}$ & $2.95 \times 10^{-4}$ \\
\hline soo & $3.45 \times 10^{-3}$ & $2.43 \times 10^{-3}$ & $1.04 \times 10^{-3}$ & $-4.73 \times 10^{-4}$ & $9.51 \times 10^{-4}$ & $3.48 \times 10^{-3}$ & $4.20 \times 10^{-3}$ & $2.71 \times 10^{-3}$ & $1.03 \times 10^{-3}$ \\
\hline SWL & $3.09 \times 10^{-2}$ & $6.85 \times 10^{-3}$ & $3.89 \times 10^{-4}$ & $1.24 \times 10^{-3}$ & $9.62 \times 10^{-4}$ & $4.81 \times 10^{-4}$ & $1.29 \times 10^{-2}$ & $3.52 \times 10^{-3}$ & $3.89 \times 10^{-4}$ \\
\hline TUT & $5.54 \times 10^{-2}$ & $9.68 \times 10^{-3}$ & $3.05 \times 10^{-4}$ & $1.80 \times 10^{-3}$ & $1.11 \times 10^{-3}$ & $1.02 \times 10^{-3}$ & $5.65 \times 10^{-2}$ & $9.85 \times 10^{-3}$ & $3.03 \times 10^{-3}$ \\
\hline UPR & $9.47 \times 10^{-2}$ & $1.64 \times 10^{-2}$ & $3.11 \times 10^{-4}$ & $3.26 \times 10^{-3}$ & $1.51 \times 10^{-3}$ & $1.04 \times 10^{-3}$ & $5.51 \times 10^{-2}$ & $1.01 \times 10^{-2}$ & $8.44 \times 10^{-4}$ \\
\hline
\end{tabular}

${ }^{a}$ Radionuclide concentration

b Total propagated uncertainty

${ }^{\mathrm{c}}$ Minimum detectable concentration 


\section{Waste Isolation Pilot Plant 2002 Site Environmental Report DOE/WIPP 03-2225}

These water samples were also analyzed for ${ }^{238} \mathrm{Pu},{ }^{239+240} \mathrm{Pu}$, and ${ }^{241} \mathrm{Am}$ (Table 4.8). Concentrations of ${ }^{241} \mathrm{Am},{ }^{238} \mathrm{Pu}$ and ${ }^{239+240} \mathrm{Pu}$ were either below the MDC or less than $2 \times$ TPU in every sample.

Potassium-40, ${ }^{60} \mathrm{Co},{ }^{90} \mathrm{Sr}$, and ${ }^{137} \mathrm{Cs}$ are ubiquitous in soils and might reasonably be expected in surface water samples due to leaching from sediments. As expected, ${ }^{40} \mathrm{~K}$ was detected in 47 percent of the surface water samples (Table 4.9). Its concentration ranged from $-1.05 \times 10^{0} \pm 3.61 \times 10^{\circ} \mathrm{Bq} / \mathrm{L}\left(-2.84 \times 10^{1} \pm 9.76 \times 10^{1} \mathrm{pCi} / \mathrm{L}\right)$ at Red Tank (RED) to $4.29 \times 10^{1} \pm 6.92 \times 10^{0} \mathrm{~Bq} / \mathrm{L}\left(1.16 \times 10^{3} \pm 1.87 \times 10^{2} \mathrm{pCi} / \mathrm{L}\right)$ at Sewage Lagoons (SWL). Cobalt-60, ${ }^{137} \mathrm{Cs}$, and ${ }^{90} \mathrm{Sr}$ were not detected in the samples.

Table 4.8 - Americium and Plutonium Concentrations (Bq/L) in Surface Water Near the WIPP Site. See Appendix $B$ for the sampling locations.

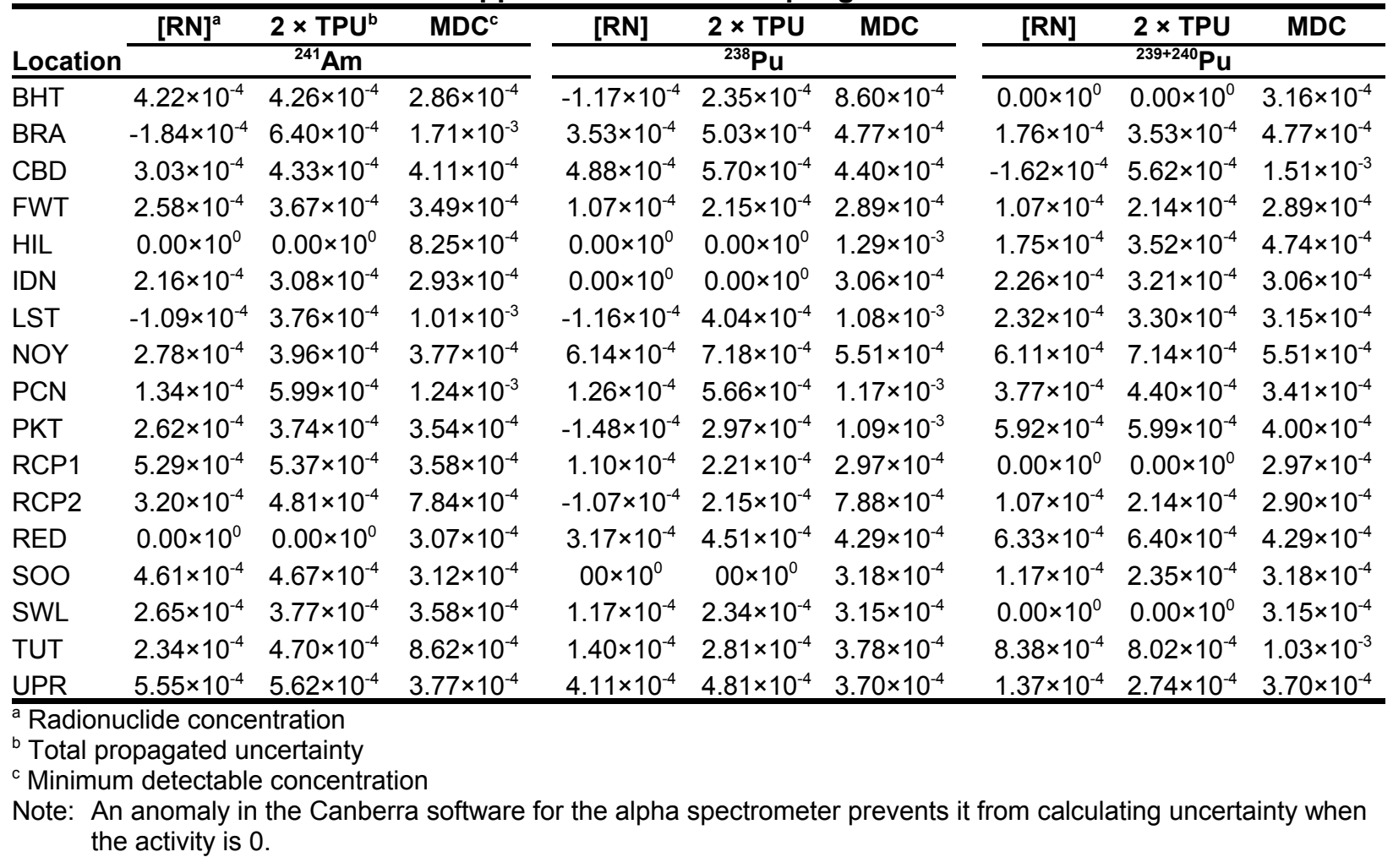


Table 4.9 - Selected Radionuclide Concentrations (Bq/L) in Surface Water Near the WIPP Site. See Appendix $B$ for the sampling locations.

\begin{tabular}{|c|c|c|c|c|c|c|}
\hline \multirow[b]{2}{*}{ Location } & {$[R N]^{a}$} & $2 \times$ TPU $^{b}$ & MDC $^{c}$ & [RN] & $2 \times$ TPU & MDC \\
\hline & \multicolumn{3}{|c|}{${ }^{137} \mathrm{Cs}$} & \multicolumn{3}{|c|}{${ }^{60} \mathrm{Co}$} \\
\hline$\overline{\mathrm{BHT}}$ & $7.51 \times 10^{-2}$ & $3.13 \times 10^{-1}$ & $3.59 \times 10^{-1}$ & $3.15 \times 10^{-3}$ & $3.53 \times 10^{-1}$ & $4.08 \times 10^{-1}$ \\
\hline BRA & $-5.92 \times 10^{-2}$ & $3.20 \times 10^{-1}$ & $3.54 \times 10^{-1}$ & $8.36 \times 10^{-2}$ & $3.64 \times 10^{-1}$ & $4.29 \times 10^{-1}$ \\
\hline CBD & $7.92 \times 10^{-2}$ & $3.22 \times 10^{-1}$ & $3.68 \times 10^{-1}$ & $2.73 \times 10^{-1}$ & $3.23 \times 10^{-1}$ & $4.07 \times 10^{-1}$ \\
\hline FWT & $1.60 \times 10^{-1}$ & $3.07 \times 10^{-1}$ & $3.58 \times 10^{-1}$ & $2.72 \times 10^{-1}$ & $3.43 \times 10^{-1}$ & $4.26 \times 10^{-1}$ \\
\hline HIL & $-8.18 \times 10^{-2}$ & $3.27 \times 10^{-1}$ & $3.60 \times 10^{-1}$ & $1.27 \times 10^{-1}$ & $3.31 \times 10^{-1}$ & $4.00 \times 10^{-1}$ \\
\hline IDN & $-1.35 \times 10^{-2}$ & $3.22 \times 10^{-1}$ & $3.61 \times 10^{-1}$ & $1.64 \times 10^{-1}$ & $3.44 \times 10^{-1}$ & $4.18 \times 10^{-1}$ \\
\hline LST & $-2.50 \times 10^{-1}$ & $2.44 \times 10^{-1}$ & $2.57 \times 10^{-1}$ & $7.13 \times 10^{-2}$ & $2.96 \times 10^{-1}$ & $3.45 \times 10^{-1}$ \\
\hline NOY & $-1.63 \times 10^{-1}$ & $3.38 \times 10^{-1}$ & $3.58 \times 10^{-1}$ & $-6.11 \times 10^{-2}$ & $3.64 \times 10^{-1}$ & $4.11 \times 10^{-1}$ \\
\hline $\mathrm{PCN}$ & $-4.63 \times 10^{-1}$ & $3.56 \times 10^{-1}$ & $3.43 \times 10^{-1}$ & $8.21 \times 10^{-2}$ & $3.50 \times 10^{-1}$ & $4.11 \times 10^{-1}$ \\
\hline PKT & $1.37 \times 10^{-3}$ & $3.31 \times 10^{-1}$ & $3.70 \times 10^{-1}$ & $-4.40 \times 10^{-1}$ & $3.61 \times 10^{-1}$ & $4.14 \times 10^{-1}$ \\
\hline RCP1 & $-2.70 \times 10^{-1}$ & $3.46 \times 10^{-1}$ & $3.57 \times 10^{-1}$ & $-8.81 \times 10^{-2}$ & $3.61 \times 10^{-1}$ & $4.03 \times 10^{-1}$ \\
\hline RCP2 & $1.19 \times 10^{-1}$ & $2.19 \times 10^{-1}$ & $2.66 \times 10^{-1}$ & $8.92 \times 10^{-2}$ & $2.74 \times 10^{-1}$ & $3.23 \times 10^{-1}$ \\
\hline RED & $2.21 \times 10^{-1}$ & $3.05 \times 10^{-1}$ & $3.59 \times 10^{-1}$ & $2.29 \times 10^{-1}$ & $3.50 \times 10^{-1}$ & $4.29 \times 10^{-1}$ \\
\hline soo & $-2.91 \times 10^{-1}$ & $4.67 \times 10^{-1}$ & $5.08 \times 10^{-1}$ & $4.75 \times 10^{-1}$ & $4.67 \times 10^{-1}$ & $5.53 \times 10^{-1}$ \\
\hline SWL & $-3.69 \times 10^{-2}$ & $2.33 \times 10^{-1}$ & $2.71 \times 10^{-1}$ & $8.95 \times 10^{-2}$ & $2.95 \times 10^{-1}$ & $3.44 \times 10^{-1}$ \\
\hline TUT & $-2.04 \times 10^{-2}$ & $3.21 \times 10^{-1}$ & $3.59 \times 10^{-1}$ & $-2.19 \times 10^{-1}$ & $3.86 \times 10^{-1}$ & $4.09 \times 10^{-1}$ \\
\hline \multirow[t]{2}{*}{ UPR } & $-4.29 \times 10^{-3}$ & $3.32 \times 10^{-1}$ & $3.70 \times 10^{-1}$ & $-1.54 \times 10^{-1}$ & $3.96 \times 10^{-1}$ & $4.29 \times 10^{-1}$ \\
\hline & \multicolumn{3}{|c|}{${ }^{90} \mathrm{Sr}$} & \multicolumn{3}{|c|}{${ }^{40} \mathrm{~K}$} \\
\hline BHT & $1.28 \times 10^{-3}$ & $2.15 \times 10^{-2}$ & $3.69 \times 10^{-2}$ & $4.42 \times 10^{0}$ & $3.45 \times 10^{0}$ & $4.48 \times 10^{0}$ \\
\hline BRA & $8.36 \times 10^{-3}$ & $2.11 \times 10^{-2}$ & $3.57 \times 10^{-2}$ & $4.88 \times 10^{0}$ & $3.17 \times 10^{0}$ & $4.26 \times 10^{0}$ \\
\hline CBD & $2.12 \times 10^{-3}$ & $2.21 \times 10^{-2}$ & $3.64 \times 10^{-2}$ & $4.66 \times 10^{0}$ & $3.25 \times 10^{0}$ & $4.29 \times 10^{0}$ \\
\hline FWT & $-1.02 \times 10^{-2}$ & $2.01 \times 10^{-2}$ & $3.54 \times 10^{-2}$ & $4.77 \times 10^{0}$ & $3.09 \times 10^{0}$ & $4.18 \times 10^{0}$ \\
\hline HIL & $8.40 \times 10^{-3}$ & $1.95 \times 10^{-2}$ & $3.30 \times 10^{-2}$ & $3.12 \times 10^{0}$ & $3.50 \times 10^{0}$ & $4.37 \times 10^{0}$ \\
\hline IDN & $2.70 \times 10^{-3}$ & $2.03 \times 10^{-2}$ & $3.47 \times 10^{-2}$ & $3.33 \times 10^{0}$ & $3.55 \times 10^{0}$ & $4.48 \times 10^{0}$ \\
\hline LST & $1.92 \times 10^{-3}$ & $2.24 \times 10^{-2}$ & $3.85 \times 10^{-2}$ & $2.16 \times 10^{0}$ & $2.69 \times 10^{0}$ & $3.31 \times 10^{0}$ \\
\hline NOY & $1.89 \times 10^{-3}$ & $3.85 \times 10^{-2}$ & $6.70 \times 10^{-2}$ & $3.85 \times 10^{0}$ & $2.29 \times 10^{0}$ & $3.34 \times 10^{0}$ \\
\hline $\mathrm{PCN}$ & $1.05 \times 10^{-2}$ & $2.06 \times 10^{-2}$ & $3.47 \times 10^{-2}$ & $3.49 \times 10^{0}$ & $2.39 \times 10^{0}$ & $3.59 \times 10^{0}$ \\
\hline PKT & $7.07 \times 10^{-3}$ & $2.10 \times 10^{-2}$ & $3.56 \times 10^{-2}$ & $2.12 \times 10^{0}$ & $1.48 \times 10^{0}$ & $2.15 \times 10^{0}$ \\
\hline RCP1 & $-9.69 \times 10^{-3}$ & $1.93 \times 10^{-2}$ & $3.38 \times 10^{-2}$ & $5.07 \times 10^{0}$ & $3.35 \times 10^{0}$ & $4.44 \times 10^{0}$ \\
\hline RCP2 & $1.37 \times 10^{-2}$ & $2.16 \times 10^{-2}$ & $3.63 \times 10^{-2}$ & $-1.28 \times 10^{-1}$ & $2.74 \times 10^{0}$ & $3.33 \times 10^{0}$ \\
\hline RED & $9.84 \times 10^{-3}$ & $2.16 \times 10^{-2}$ & $3.63 \times 10^{-2}$ & $-1.05 \times 10^{0}$ & $3.61 \times 10^{0}$ & $4.00 \times 10^{0}$ \\
\hline SOO & $-8.13 \times 10^{-4}$ & $2.03 \times 10^{-2}$ & $3.49 \times 10^{-2}$ & $4.07 \times 10^{0}$ & $4.39 \times 10^{0}$ & $5.02 \times 10^{0}$ \\
\hline SWL & $1.65 \times 10^{-2}$ & $2.36 \times 10^{-2}$ & $3.92 \times 10^{-2}$ & $2.19 \times 10^{1}$ & $6.92 \times 10^{0}$ & $2.91 \times 10^{0}$ \\
\hline TUT & $-1.03 \times 10^{-2}$ & $2.27 \times 10^{-2}$ & $3.99 \times 10^{-2}$ & $6.13 \times 10^{0}$ & $3.54 \times 10^{0}$ & $4.67 \times 10^{0}$ \\
\hline UPR & $2.21 \times 10^{-2}$ & $2.47 \times 10^{-2}$ & $4.07 \times 10^{-2}$ & $2.97 \times 10^{0}$ & $3.46 \times 10^{0}$ & $4.37 \times 10^{0}$ \\
\hline
\end{tabular}

${ }^{a}$ Radionuclide concentration

b Total propagated uncertainty

${ }^{\mathrm{c}}$ Minimum detectable concentration

Duplicate samples were collected from two locations (Indian Tank [IDN] and RED) to check the reproducibility of the sampling and the measurement techniques (Table 4.10). The RER values for all the isotopes in these samples were less than one, indicating no difference between duplicate samples. 
Table 4.10 - Results of Duplicate Surface Water Sample Analysis. Units are Bq/L. See Appendix $B$ for the sampling locations.

\begin{tabular}{|c|c|c|c|c|c|c|c|c|}
\hline \multirow[b]{2}{*}{ Location } & {$[\mathrm{RN}]^{\mathrm{a}}$} & $2 \times$ TPU $^{b}$ & MDC $^{c}$ & RER $^{\mathrm{d}}$ & [RN] & $2 \times T P U$ & MDC & RER \\
\hline & \multicolumn{4}{|c|}{${ }^{234} \mathrm{U}$} & \multicolumn{4}{|c|}{${ }^{235} U$} \\
\hline IDN & $8.92 \times 10^{-3}$ & $2.50 \times 10^{-3}$ & $3.10 \times 10^{-4}$ & 0.207 & $1.41 \times 10^{-4}$ & $2.83 \times 10^{-4}$ & $3.81 \times 10^{-4}$ & 0.901 \\
\hline IDN Dup. & $9.66 \times 10^{-3}$ & $2.56 \times 10^{-3}$ & $2.88 \times 10^{-4}$ & & $7.84 \times 10^{-4}$ & $6.55 \times 10^{-4}$ & $3.55 \times 10^{-4}$ & \\
\hline RED & $1.19 \times 10^{-2}$ & $2.95 \times 10^{-3}$ & $2.96 \times 10^{-4}$ & 0.02 & $2.69 \times 10^{-4}$ & $3.85 \times 10^{-4}$ & $3.65 \times 10^{-4}$ & 0.159 \\
\hline \multirow[t]{2}{*}{ RED Dup. } & $1.20 \times 10^{-2}$ & $2.83 \times 10^{-3}$ & $2.64 \times 10^{-4}$ & & $3.60 \times 10^{-4}$ & $4.22 \times 10^{-4}$ & $3.26 \times 10^{-4}$ & \\
\hline & \multicolumn{4}{|c|}{${ }^{238} U$} & \multicolumn{4}{|c|}{${ }^{40} \mathrm{~K}$} \\
\hline IDN & $6.14 \times 10^{-3}$ & $1.96 \times 10^{-3}$ & $3.09 \times 10^{-4}$ & 0.632 & $3.33 \times 10^{0}$ & $3.55 \times 10^{0}$ & $4.48 \times 10^{0}$ & 0.422 \\
\hline IDN Dup. & $8.03 \times 10^{-3}$ & $2.26 \times 10^{-3}$ & $2.87 \times 10^{-4}$ & & $1.23 \times 10^{0}$ & $3.49 \times 10^{0}$ & $4.18 \times 10^{0}$ & \\
\hline RED & $9.14 \times 10^{-3}$ & $2.46 \times 10^{-3}$ & $2.95 \times 10^{-4}$ & 0.691 & $-1.05 \times 10^{0}$ & $3.61 \times 10^{0}$ & $4.00 \times 10^{0}$ & 0.803 \\
\hline RED Dup. & $1.17 \times 10^{-2}$ & $2.77 \times 10^{-3}$ & $2.63 \times 10^{-4}$ & & $2.26 \times 10^{0}$ & $1.99 \times 10^{0}$ & $3.10 \times 10^{0}$ & \\
\hline
\end{tabular}

a Radionuclide concentration

${ }^{\mathrm{b}}$ Total propagated uncertainty

${ }^{\mathrm{c}}$ Minimum detectable concentration

${ }^{d}$ Relative error ratio

\subsection{Soil Samples}

\subsubsection{Sample Collection}

Soil samples were collected from near the low-volume air samplers at six different locations around the WIPP site: MLR, SEC, SMR, WEE, WFF, and WSS (Figure 4.6). Samples were collected from each location in three incremental profiles: surface soil (SS, 0-2 cm [0-0.8 in.]), intermediate soil (SI, $2-5 \mathrm{~cm}$ [0.8-2 in.]), and deep soil (SD, $5-10 \mathrm{~cm}[2-4 \mathrm{in}]$.$) . Measurements of radionuclides in depth profiles provide information$ about their vertical movements in the soil systems.

\subsubsection{Sample Preparation}

Soil samples were dried at $110^{\circ} \mathrm{C}\left(230^{\circ} \mathrm{F}\right)$ for several hours and homogenized by grinding to small particle sizes. One gram $(0.04 \mathrm{oz})$ of soil was dissolved by heating it with a mixture of nitric, hydrochloric, and hydrofluoric acids. Finally, it was heated with nitric and boric acids, and the residue was dissolved in hydrochloric acid for the determination of individual radionuclides.

\subsubsection{Determination of Individual Radionuclides}

Gamma-emitting radionuclides $\left({ }^{40} \mathrm{~K},{ }^{60} \mathrm{Co}\right.$, and $\left.{ }^{137} \mathrm{Cs}\right)$ were determined by counting an aliquot of well-homogenized ground soil samples by gamma-spectrometry. Strontium-90 was analyzed from an aliquot of the sample solution by separating it from other stable and radioactive elements using radiochemical techniques and beta counting. Another aliquot of the sample solution was used for the sequential determinations of alpha-emitting radionuclides, such as ${ }^{234} \mathrm{U},{ }^{235} \mathrm{U}$, and ${ }^{238} \mathrm{U}$; ${ }^{238} \mathrm{Pu}$ and ${ }^{239+240} \mathrm{Pu}$; and ${ }^{241} \mathrm{Am}$. These radionuclides were separated from the bulk of the inorganic materials present in the soil samples and from one another by radiochemical separations including co-precipitation and ion-exchange chromatography. Finally, the 


\section{Waste Isolation Pilot Plant 2002 Site Environmental Report DOE/WIPP 03-2225}

samples were micro-precipitated, filtered onto micro-filters, and counted on the alpha spectrometer.

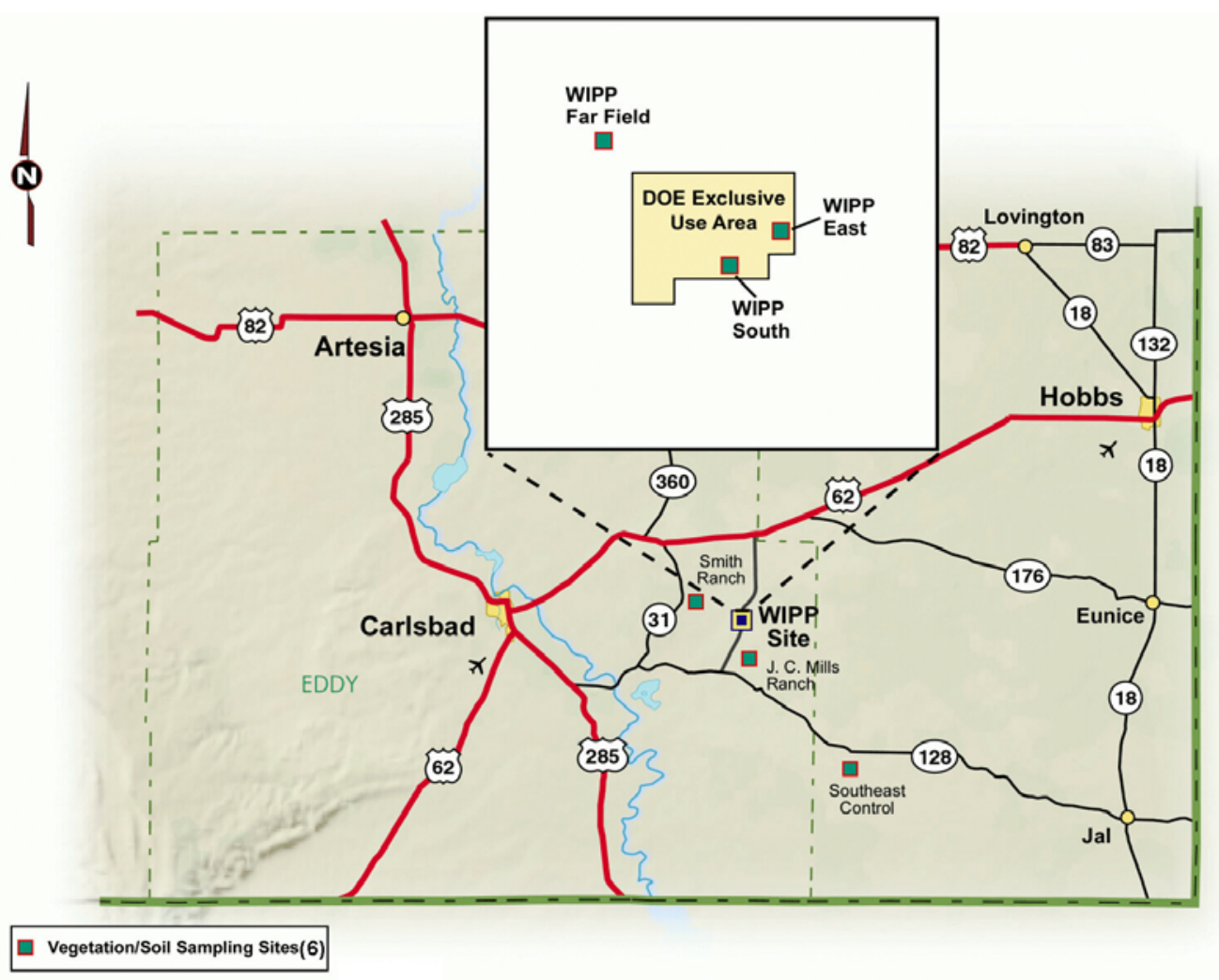

Figure 4.6 - Routine Soil and Vegetation Sampling Areas

\subsubsection{Results and Discussions}

Uranium-234, ${ }^{238} \mathrm{U}$, and ${ }^{235} \mathrm{U}$ were detected in every soil sample in 2002.

Concentrations of ${ }^{234} \mathrm{U}$ in surface soils $(0-2 \mathrm{~cm})$ ranged from a minimum of $8.77 \times 10^{-3} \pm$ $1.71 \times 10^{-3} \mathrm{~Bq} / \mathrm{g}\left(2.37 \times 10^{-1} \pm 4.62 \times 10^{-2} \mathrm{pCi} / \mathrm{g}\right)$ at WFF to a maximum of $2.75 \times 10^{-2} \pm$ $4.59 \times 10^{-3} \mathrm{~Bq} / \mathrm{g}\left(7.43 \times 10^{-1} \pm 1.24 \times 10^{-1} \mathrm{pCi} / \mathrm{g}\right)$ at MLR (Table 4.11). Concentrations of ${ }^{235} \mathrm{U}$ in the same samples ranged from $4.37 \times 10^{-4} \pm 3.00 \times 10^{-4} \mathrm{~Bq} / \mathrm{g}\left(1.18 \times 10^{-2} \pm 8.11 \times 10^{-3}\right.$ $\mathrm{pCi} / \mathrm{g})$ at WFF to $1.65 \times 10^{-3} \pm 5.33 \times 10^{-4} \mathrm{~Bq} / \mathrm{g}\left(4.46 \times 10^{-2} \pm 1.44 \times 10^{-2} \mathrm{pCi} / \mathrm{g}\right)$ at SMR. The concentration of ${ }^{238} \mathrm{U}$ in surface soils ranged from $9.40 \times 10^{-3} \pm 1.81 \times 10^{-3} \mathrm{~Bq} / \mathrm{g}\left(2.54 \times 10^{-1}\right.$ $\left.\pm 4.89 \times 10^{-2} \mathrm{pCi} / \mathrm{g}\right)$ at WFF to $2.85 \times 10^{-2} \pm 4.77 \times 10^{-3} \mathrm{~Bq} / \mathrm{g}\left(7.70 \times 10^{-1} \pm 1.29 \times 10^{-1} \mathrm{pCi} / \mathrm{g}\right)$ at MLR.

The results for uranium in intermediate depth $(2-5 \mathrm{~cm})$ soil samples are also given in Table 4.11. The concentration of ${ }^{234} U$ ranged from $6.96 \times 10^{-3} \pm 1.43 \times 10^{-3} \mathrm{~Bq} / \mathrm{g}$ $\left(1.88 \times 10^{-1} \pm 3.86 \times 10^{-2} \mathrm{pCi} / \mathrm{g}\right)$ at WFF to $2.66 \times 10^{-2} \pm 4.37 \times 10^{-3} \mathrm{~Bq} / \mathrm{g}\left(7.19 \times 10^{-1} \pm\right.$ $\left.1.18 \times 10^{-1} \mathrm{pCi} / \mathrm{g}\right)$ at MLR. Uranium-235 in these soils was lowest at WFF $\left(2.57 \times 10^{-4} \pm\right.$ $\left.1.99 \times 10^{-4} \mathrm{~Bq} / \mathrm{g}\left[6.95 \times 10^{-3} \pm 5.38 \times 10^{-3} \mathrm{pCi} / \mathrm{g}\right]\right)$ and highest at MLR $\left(1.38 \times 10^{-3} \pm 4.66 \times 10^{-4}\right.$ $\left.\mathrm{Bq} / \mathrm{g}\left[3.73 \times 10^{-2} \pm 1.26 \times 10^{-2} \mathrm{pCi} / \mathrm{g}\right]\right)$. The concentration of ${ }^{238} \mathrm{U}$ ranged from $8.66 \times 10^{-3} \pm$ 
$1.72 \times 10^{-3} \mathrm{~Bq} / \mathrm{g}\left(2.34 \times 10^{-1} \pm 4.65 \times 10^{-2} \mathrm{pCi} / \mathrm{g}\right)$ at WFF to $2.66 \times 10^{-2} \pm 4.40 \times 10^{-3} \mathrm{~Bq} / \mathrm{g}$ $\left(7.19 \times 10^{-1} \pm 1.19 \times 10^{-1} \mathrm{pCi} / \mathrm{g}\right)$ at MLR.

Table 4.11 - Uranium Concentrations (Bq/g) in Soil Near the WIPP Site.

See Appendix $B$ for the sampling locations.

\begin{tabular}{|c|c|c|c|c|c|c|c|c|c|c|}
\hline Location & $\begin{array}{l}\text { Depth } \\
\text { (cm) }\end{array}$ & {$[\mathrm{RN}]^{\mathrm{a}}$} & $\frac{2 \times \mathrm{TPU}^{\mathrm{b}}}{{ }^{234} \mathrm{U}}$ & $\mathrm{MDC}^{\mathrm{C}}$ & [RN] & $\frac{2 \times \text { TPU }}{{ }^{235} U}$ & MDC & [RN] & $\frac{2 \times \text { TPU }}{{ }^{238} U}$ & MDC \\
\hline MLR & $0-2$ & $2.75 \times 10^{-2}$ & $4.59 \times 10^{-3}$ & $7.25 \times 10^{-5}$ & $1.52 \times 10^{-3}$ & $5.07 \times 10^{-3}$ & $8.95 \times 10^{-5}$ & $2.85 \times 10^{-2}$ & $4.77 \times 10^{-3}$ & $7.22 \times 10^{-5}$ \\
\hline MLR & $2-5$ & $2.66 \times 10^{-2}$ & $4.37 \times 10^{-3}$ & $6.92 \times 10^{-5}$ & $1.38 \times 10^{-3}$ & $4.66 \times 10^{-4}$ & $8.51 \times 10^{-5}$ & $2.66 \times 10^{-2}$ & $4.40 \times 10^{-3}$ & $6.88 \times 10^{-5}$ \\
\hline MLR & $5-10$ & $2.52 \times 10^{-2}$ & $4.18 \times 10^{-3}$ & $1.93 \times 10^{-4}$ & $1.23 \times 10^{-3}$ & $4.51 \times 10^{-4}$ & $2.38 \times 10^{-4}$ & $2.57 \times 10^{-2}$ & $4.26 \times 10^{-3}$ & $7.07 \times 10^{-5}$ \\
\hline SEC & $0-2$ & $1.68 \times 10^{-2}$ & $3.05 \times 10^{-3}$ & $7.51 \times 10^{-5}$ & $7.88 \times 10^{-4}$ & $3.52 \times 10^{-4}$ & $9.25 \times 10^{-5}$ & $1.69 \times 10^{-2}$ & $3.05 \times 10^{-3}$ & $7.47 \times 10^{-5}$ \\
\hline SEC & $2-5$ & $1.73 \times 10^{-2}$ & $2.99 \times 10^{-3}$ & $7.29 \times 10^{-5}$ & $8.95 \times 10^{-4}$ & $3.70 \times 10^{-4}$ & $8.99 \times 10^{-5}$ & $1.83 \times 10^{-2}$ & $3.14 \times 10^{-3}$ & $7.25 \times 10^{-5}$ \\
\hline SEC & $5-10$ & $2.22 \times 10^{-2}$ & $3.89 \times 10^{-3}$ & $7.62 \times 10^{-5}$ & $1.18 \times 10^{-3}$ & $4.59 \times 10^{-4}$ & $2.56 \times 10^{-4}$ & $2.05 \times 10^{-2}$ & $3.62 \times 10^{-3}$ & $7.62 \times 10^{-5}$ \\
\hline SMR & $0-2$ & $2.43 \times 10^{-2}$ & $4.11 \times 10^{-3}$ & $6.96 \times 10^{-5}$ & $1.65 \times 10^{-3}$ & $5.33 \times 10^{-4}$ & $2.33 \times 10^{-4}$ & $2.54 \times 10^{-2}$ & $4.29 \times 10^{-3}$ & $6.92 \times 10^{-5}$ \\
\hline SMR & $2-5$ & $2.21 \times 10^{-2}$ & $3.77 \times 10^{-3}$ & $6.73 \times 10^{-5}$ & $1.31 \times 10^{-3}$ & $4.51 \times 10^{-4}$ & $8.29 \times 10^{-5}$ & $2.22 \times 10^{-2}$ & $3.77 \times 10^{-3}$ & $6.70 \times 10^{-5}$ \\
\hline SMR & $5-10$ & $2.63 \times 10^{-2}$ & $4.59 \times 10^{-3}$ & $7.84 \times 10^{-5}$ & $1.28 \times 10^{-3}$ & $4.77 \times 10^{-4}$ & $9.66 \times 10^{-5}$ & $2.73 \times 10^{-2}$ & $4.74 \times 10^{-3}$ & $7.81 \times 10^{-5}$ \\
\hline WEE & $0-2$ & $1.31 \times 10^{-2}$ & $2.38 \times 10^{-3}$ & $2.05 \times 10^{-4}$ & $5.85 \times 10^{-4}$ & $2.97 \times 10^{-4}$ & $9.29 \times 10^{-5}$ & $1.21 \times 10^{-2}$ & $2.21 \times 10^{-3}$ & $7.51 \times 10^{-5}$ \\
\hline WEE & $2-5$ & $1.51 \times 10^{-2}$ & $2.92 \times 10^{-3}$ & $8.77 \times 10^{-5}$ & $8.77 \times 10^{-4}$ & $4.03 \times 10^{-4}$ & $1.08 \times 10^{-4}$ & $1.45 \times 10^{-2}$ & $2.82 \times 10^{-3}$ & $2.99 \times 10^{-4}$ \\
\hline WEE & $5-10$ & $1.27 \times 10^{-2}$ & $2.39 \times 10^{-3}$ & $2.13 \times 10^{-4}$ & $6.40 \times 10^{-4}$ & $3.50 \times 10^{-4}$ & $3.31 \times 10^{-4}$ & $1.14 \times 10^{-2}$ & $2.18 \times 10^{-3}$ & $2.12 \times 10^{-4}$ \\
\hline WFF & $0-2$ & $8.77 \times 10^{-3}$ & $1.71 \times 10^{-3}$ & $2.18 \times 10^{-4}$ & $4.37 \times 10^{-4}$ & $3.00 \times 10^{-4}$ & $3.39 \times 10^{-4}$ & $9.40 \times 10^{-3}$ & $1.81 \times 10^{-3}$ & $2.17 \times 10^{-4}$ \\
\hline WFF & $2-5$ & $6.96 \times 10^{-3}$ & $1.43 \times 10^{-3}$ & $8.07 \times 10^{-5}$ & $2.57 \times 10^{-4}$ & $1.99 \times 10^{-4}$ & $9.95 \times 10^{-5}$ & $8.66 \times 10^{-3}$ & $1.72 \times 10^{-3}$ & $2.18 \times 10^{-4}$ \\
\hline WFF & $5-10$ & $9.73 \times 10^{-3}$ & $2.07 \times 10^{-3}$ & $1.06 \times 10^{-4}$ & $6.77 \times 10^{-4}$ & $3.81 \times 10^{-4}$ & $1.31 \times 10^{-4}$ & $1.03 \times 10^{-2}$ & $2.17 \times 10^{-3}$ & $1.06 \times 10^{-4}$ \\
\hline WSS & $0-2$ & $1.23 \times 10^{-2}$ & $2.15 \times 10^{-3}$ & $6.92 \times 10^{-5}$ & $5.66 \times 10^{-4}$ & $2.80 \times 10^{-4}$ & $8.55 \times 10^{-5}$ & $1.20 \times 10^{-2}$ & $2.09 \times 10^{-3}$ & $6.88 \times 10^{-5}$ \\
\hline WSS & $2-5$ & $1.09 \times 10^{-2}$ & $2.02 \times 10^{-3}$ & $7.29 \times 10^{-5}$ & $3.32 \times 10^{-4}$ & $2.16 \times 10^{-4}$ & $8.99 \times 10^{-5}$ & $1.11 \times 10^{-2}$ & $2.05 \times 10^{-3}$ & $7.25 \times 10^{-5}$ \\
\hline WSS & $5-10$ & $1.34 \times 10^{-2}$ & $2.44 \times 10^{-3}$ & $7.22 \times 10^{-5}$ & $4.26 \times 10^{-4}$ & $2.46 \times 10^{-4}$ & $8.92 \times 10^{-5}$ & $1.27 \times 10^{-2}$ & $2.33 \times 10^{-3}$ & $7.18 \times 10^{-5}$ \\
\hline
\end{tabular}

${ }^{a}$ Radionuclide concentration

b Total propagated uncertainty

${ }^{\mathrm{c}}$ Minimum detectable concentration

Concentrations of ${ }^{234} \mathrm{U},{ }^{235} \mathrm{U}$, and ${ }^{238} \mathrm{U}$ were also measured in deep soils $(5-10 \mathrm{~cm})$ (Table 4.11). Concentrations of ${ }^{234} \mathrm{U}$ varied from $9.73 \times 10^{-3} \pm 2.07 \times 10^{-3} \mathrm{~Bq} / \mathrm{g}\left(2.63 \times 10^{-1}\right.$ $\left.\pm 5.59 \times 10^{-2} \mathrm{pCi} / \mathrm{g}\right)$ at WFF to $2.63 \times 10^{-2} \pm 4.59 \times 10^{-3} \mathrm{~Bq} / \mathrm{g}\left(7.11 \times 10^{-1} \pm 1.24 \times 10^{-1} \mathrm{pCi} / \mathrm{g}\right)$ at SMR. The lowest concentration of ${ }^{235} \mathrm{U}$ in deep soils was found at WSS $\left(4.26 \times 10^{-4} \pm\right.$ $\left.2.46 \times 10^{-4} \mathrm{~Bq} / \mathrm{g}\left[1.15 \times 10^{-2} \pm 6.65 \times 10^{-3} \mathrm{pCi} / \mathrm{g}\right]\right)$ and the highest concentration was found at SMR $\left(1.28 \times 10^{-3} \pm 4.77 \times 10^{-4} \mathrm{~Bq} / \mathrm{g}\left[3.46 \times 10^{-2} \pm 1.29 \times 10^{-2} \mathrm{pCi} / \mathrm{g}\right]\right)$. Uranium-238 lowest concentration was $1.03 \times 10^{-2} \pm 2.17 \times 10^{-3} \mathrm{~Bq} / \mathrm{g}\left(2.78 \times 10^{-1} \pm 5.86 \times 10^{-2} \mathrm{pCi} / \mathrm{g}\right)$ at WFF and the highest was found $2.73 \times 10^{-2} \pm 4.74 \times 10^{-3} \mathrm{~Bq} / \mathrm{g}\left(7.38 \times 10^{-1} \pm 1.28 \times 10^{-1} \mathrm{pCi} / \mathrm{g}\right)$ at SMR.

No uranium isotope varied significantly for the same location comparisons between 2001 and 2002 (ANOVA, ${ }^{234} \mathrm{U} p=0.109,{ }^{238} \mathrm{U} p=0.174$ ). All maximum measured concentrations fell within the range of natural concentrations of uranium found in soils throughout the world. All these results suggest a pattern of natural variability consistent with the existence of natural uranium, without enhancement from artificial sources.

Plutonium-238, ${ }^{239+240} \mathrm{Pu}$, and ${ }^{241} \mathrm{Am}$ were also analyzed in these soil samples (Table 4.12). Plutonium-238 was not detected in any of the samples. The measured concentration of ${ }^{239+240} \mathrm{Pu}$ was greater than the MDC at location SEC and SMR at all 


\section{Waste Isolation Pilot Plant 2002 Site Environmental Report DOE/WIPP 03-2225}

three depths. Location MLR had detectable concentration for the surface depth $(0-2 \mathrm{~cm})$. Americium-241 was detected at MLR, 0-2 cm and 5-10 cm, SEC, 0-2 cm and 2-5 cm, and SMR, 2-5 cm and 5-10 cm. Historically, soil samples collected in the same locations have shown positive results on numerous occasions. Since 1997, soil samples collected by the Environmental Monitoring group at WEE, SEC, MLR, and SMR have shown levels of ${ }^{241} \mathrm{Am}$ and ${ }^{239+240} \mathrm{Pu}$ slightly above background. During this time period, three different analytical laboratories were used; all had similar results. The source of activity in WIPP samples could be due to natural transport of contaminated soil from the Gnome Site via wind. The Gnome Site lies about $9 \mathrm{~km}$ southwest of the WIPP boundary and was contaminated with fission products in 1961 when an underground test of a 3-kiloton ${ }^{239} \mathrm{Pu}$ device vented to the surface. Because there are elevated levels of radionuclides in the soil near the Gnome Site, there is potential for contamination of WIPP environmental samples. The levels of radionuclides remains relatively high around the Gnome Site despite remediation efforts.

Table 4.12 - Americium and Plutonium Concentrations (Bq/g) in Soil Near the WIPP Site. See Appendix $B$ for the sampling locations.

\begin{tabular}{|c|c|c|c|c|c|c|c|c|c|c|}
\hline \multirow{2}{*}{ Location } & \multirow{2}{*}{$\begin{array}{c}\text { Depth } \\
\text { (cm) }\end{array}$} & {$[\mathrm{RN}]^{\mathrm{a}}$} & $2 \times T^{T P U^{b}}$ & $M C^{c}$ & [RN] & $2 \times$ TPU & MDC & [RN] & $2 \times$ TPU & MDC \\
\hline & & & ${ }^{241} \mathrm{Am}$ & & \multicolumn{3}{|c|}{${ }^{238} \mathrm{Pu}$} & \multicolumn{3}{|c|}{${ }^{239+240} \mathrm{Pu}$} \\
\hline MLR & $0-2$ & $4.51 \times 10^{-4}$ & $2.96 \times 10^{-4}$ & $3.22 \times 10^{-4}$ & $2.50 \times 10^{-4}$ & $3.77 \times 10^{-4}$ & $6.14 \times 10^{-4}$ & $1.58 \times 10^{-3}$ & $8.40 \times 10^{-4}$ & $6.14 \times 10^{-4}$ \\
\hline MLR & $2-5$ & $1.54 \times 10^{-4}$ & $1.65 \times 10^{-4}$ & $2.27 \times 10^{-4}$ & $2.24 \times 10^{-4}$ & $2.14 \times 10^{-4}$ & $2.74 \times 10^{-4}$ & $1.49 \times 10^{-4}$ & $1.51 \times 10^{-4}$ & $1.01 \times 10^{-4}$ \\
\hline MLR & $5-10$ & $2.46 \times 10^{-4}$ & $1.79 \times 10^{-4}$ & $8.36 \times 10^{-5}$ & $1.25 \times 10^{-4}$ & $2.22 \times 10^{-4}$ & $3.89 \times 10^{-4}$ & $2.50 \times 10^{-4}$ & $2.39 \times 10^{-4}$ & $3.07 \times 10^{-4}$ \\
\hline SEC & $0-2$ & $2.34 \times 10^{-4}$ & $1.70 \times 10^{-4}$ & $7.92 \times 10^{-5}$ & $-1.45 \times 10^{-4}$ & $2.91 \times 10^{-4}$ & $7.81 \times 10^{-4}$ & $1.23 \times 10^{-3}$ & $6.48 \times 10^{-4}$ & $1.96 \times 10^{-4}$ \\
\hline SEC & $2-5$ & $3.06 \times 10^{-4}$ & $2.35 \times 10^{-4}$ & $2.85 \times 10^{-4}$ & $2.80 \times 10^{-4}$ & $4.22 \times 10^{-4}$ & $6.88 \times 10^{-4}$ & $8.40 \times 10^{-4}$ & $5.92 \times 10^{-4}$ & $2.52 \times 10^{-4}$ \\
\hline SEC & $5-10$ & $2.14 \times 10^{-4}$ & $2.06 \times 10^{-4}$ & $2.85 \times 10^{-4}$ & $3.70 \times 10^{-5}$ & $1.66 \times 10^{-4}$ & $3.44 \times 10^{-4}$ & $4.44 \times 10^{-4}$ & $2.87 \times 10^{-4}$ & $2.72 \times 10^{-4}$ \\
\hline SMR & $0-2$ & $1.04 \times 10^{-4}$ & $1.22 \times 10^{-4}$ & $9.44 \times 10^{-5}$ & $1.77 \times 10^{-4}$ & $2.52 \times 10^{-4}$ & $4.11 \times 10^{-4}$ & $4.00 \times 10^{-4}$ & $2.75 \times 10^{-4}$ & $1.20 \times 10^{-4}$ \\
\hline SMR & $2-5$ & $2.63 \times 10^{-4}$ & $2.12 \times 10^{-4}$ & $2.42 \times 10^{-4}$ & $0.00 \times 10^{0}$ & $0.00 \times 10^{0}$ & $2.93 \times 10^{-4}$ & $5.96 \times 10^{-4}$ & $3.24 \times 10^{-4}$ & $1.08 \times 10^{-4}$ \\
\hline SMR & $5-10$ & $3.25 \times 10^{-4}$ & $2.31 \times 10^{-4}$ & $2.40 \times 10^{-4}$ & $9.69 \times 10^{-5}$ & $1.45 \times 10^{-4}$ & $2.38 \times 10^{-4}$ & $6.77 \times 10^{-4}$ & $3.15 \times 10^{-4}$ & $8.73 \times 10^{-5}$ \\
\hline WEE & $0-2$ & $1.08 \times 10^{-4}$ & $1.09 \times 10^{-4}$ & $7.33 \times 10^{-5}$ & $6.29 \times 10^{-5}$ & $8.92 \times 10^{-5}$ & $8.51 \times 10^{-5}$ & $2.19 \times 10^{-4}$ & $1.91 \times 10^{-4}$ & $2.31 \times 10^{-4}$ \\
\hline WEE & $2-5$ & $8.47 \times 10^{-5}$ & $9.84 \times 10^{-5}$ & $7.62 \times 10^{-5}$ & $2.98 \times 10^{-5}$ & $5.99 \times 10^{-5}$ & $8.07 \times 10^{-5}$ & $1.19 \times 10^{-4}$ & $1.21 \times 10^{-4}$ & $8.07 \times 10^{-5}$ \\
\hline WEE & $5-10$ & $1.25 \times 10^{-4}$ & $1.26 \times 10^{-4}$ & $8.44 \times 10^{-5}$ & $2.80 \times 10^{-5}$ & $5.62 \times 10^{-5}$ & $7.59 \times 10^{-5}$ & $1.68 \times 10^{-4}$ & $1.61 \times 10^{-4}$ & $2.06 \times 10^{-4}$ \\
\hline WFF & $0-2$ & $9.77 \times 10^{-5}$ & $1.47 \times 10^{-4}$ & $2.40 \times 10^{-4}$ & $3.24 \times 10^{-5}$ & $6.51 \times 10^{-5}$ & $8.77 \times 10^{-5}$ & $9.73 \times 10^{-5}$ & $1.46 \times 10^{-4}$ & $2.39 \times 10^{-4}$ \\
\hline WFF & $2-5$ & $5.92 \times 10^{-5}$ & $8.44 \times 10^{-5}$ & $8.03 \times 10^{-5}$ & $3.89 \times 10^{-5}$ & $7.77 \times 10^{-5}$ & $1.05 \times 10^{-4}$ & $0.00 \times 10^{0}$ & $0.00 \times 10^{0}$ & $2.85 \times 10^{-4}$ \\
\hline WFF & $5-10$ & $6.07 \times 10^{-5}$ & $8.66 \times 10^{-5}$ & $8.21 \times 10^{-5}$ & $0.00 \times 10^{0}$ & $0.00 \times 10^{0}$ & $8.25 \times 10^{-5}$ & $0.00 \times 10^{0}$ & $0.00 \times 10^{0}$ & $8.25 \times 10^{-5}$ \\
\hline WSS & $0-2$ & $9.14 \times 10^{-5}$ & $1.62 \times 10^{-4}$ & $2.83 \times 10^{-4}$ & $-1.30 \times 10^{-4}$ & $2.30 \times 10^{-4}$ & $5.66 \times 10^{-4}$ & $1.30 \times 10^{-4}$ & $1.51 \times 10^{-4}$ & $1.17 \times 10^{-4}$ \\
\hline WSS & $2-5$ & $8.81 \times 10^{-5}$ & $1.32 \times 10^{-4}$ & $2.16 \times 10^{-4}$ & $1.04 \times 10^{-4}$ & $1.48 \times 10^{-4}$ & $1.40 \times 10^{-4}$ & $1.55 \times 10^{-4}$ & $1.82 \times 10^{-4}$ & $1.40 \times 10^{-4}$ \\
\hline WSS & $5-10$ & $1.15 \times 10^{-4}$ & $1.42 \times 10^{-4}$ & $2.12 \times 10^{-4}$ & $1.31 \times 10^{-4}$ & $1.54 \times 10^{-4}$ & $1.18 \times 10^{-4}$ & $1.75 \times 10^{-4}$ & $1.78 \times 10^{-4}$ & $1.18 \times 10^{-4}$ \\
\hline \multicolumn{11}{|c|}{$\begin{array}{l}{ }^{a} \text { Radionuclide concentration } \\
\text { b Total propagated uncertainty } \\
{ }^{\mathrm{c}} \text { Minimum detectable concentration }\end{array}$} \\
\hline
\end{tabular}

Potassium-40, as expected, was detected in every sample (Table 4.13). This naturally occurring gamma-emitting radionuclide is ubiquitous in soils. Concentrations in surface soils ranged from $1.74 \times 10^{-1} \pm 2.31 \times 10^{-2} \mathrm{~Bq} / \mathrm{g}\left(4.70 \times 10^{0} \pm 6.24 \times 10^{-1} \mathrm{pCi} / \mathrm{g}\right)$ at WFF to $6.73 \times 10^{-1} \pm 8.62 \times 10^{-2} \mathrm{~Bq} / \mathrm{g}\left(1.82 \times 10^{1} \pm 1.33 \times 10^{0} \mathrm{pCi} / \mathrm{g}\right)$ at SMR. In intermediate depth 
soils, concentrations of ${ }^{40} \mathrm{~K}$ varied from $1.93 \times 10^{-1} \pm 2.56 \times 10^{-2} \mathrm{~Bq} / \mathrm{g}\left(5.22 \times 10^{0} \pm\right.$ $\left.6.92 \times 10^{-1} \mathrm{pCi} / \mathrm{g}\right)$ at WFF to $6.99 \times 10^{-1} \pm 9.03 \times 10^{-2} \mathrm{~Bq} / \mathrm{g}\left(1.89 \times 10^{1} \pm 2.44 \times 10^{0} \mathrm{pCi} / \mathrm{g}\right)$ at SMR. Potassium-40 concentrations in deep soils were lowest at WFF $\left(1.81 \times 10^{-1} \pm\right.$ $2.39 \times 10^{-2} \mathrm{~Bq} / \mathrm{g}\left(4.89 \times 10^{0} \pm 6.46 \times 10^{-1} \mathrm{pCi} / \mathrm{g}\right)$ and highest at SMR $\left(6.81 \times 10^{-1} \pm 8.70 \times 10^{-2}\right.$ $\mathrm{Bq} / \mathrm{g}\left(1.84 \times 10^{1} \pm 2.35 \times 10^{0} \mathrm{pCi} / \mathrm{g}\right)$.

The concentration of ${ }^{40} \mathrm{~K}$ was not significantly different between 2001 and 2002 (ANOVA, $p=0.771$ ). The range of concentrations observed is consistent with the average natural ${ }^{40} \mathrm{~K}$ concentration in soils around the world $\left(4.00 \times 10^{-1} \mathrm{~Bq} / \mathrm{g}\right.$

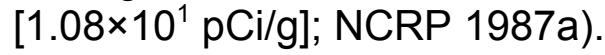

Cesium-137 was detected in 17 of the 18 soil samples (Table 4.13 ). In surface soils, concentrations ranged from $4.18 \times 10^{-4} \pm 1.72 \times 10^{-4} \mathrm{~Bq} / \mathrm{g}\left(1.13 \times 10^{-2} \pm 4.65 \times 10^{-3} \mathrm{pCi} / \mathrm{g}\right)$ at WFF to $1.09 \times 10^{-2} \pm 1.42 \times 10^{-3} \mathrm{~Bq} / \mathrm{g}\left(2.95 \times 10^{-1} \pm 3.84 \times 10^{-2} \mathrm{pCi} / \mathrm{g}\right)$ at MLR. The concentration in intermediate depth soils ranged from $4.00 \times 10^{-4} \pm 2.90 \times 10^{-4} \mathrm{~Bq} / \mathrm{g}$ $\left(1.08 \times 10^{-2} \pm 7.84 \times 10^{-3} \mathrm{pCi} / \mathrm{g}\right)$ at WFF to $1.30 \times 10^{-2} \pm 1.67 \times 10^{-3} \mathrm{~Bq} / \mathrm{g}\left(3.51 \times 10^{-1} \pm\right.$ $4.51 \times 10^{-2} \mathrm{pCi} / \mathrm{g}$ ) at SMR. In deep soils, the lowest concentrations of ${ }^{137} \mathrm{Cs}$ were found at WFF $\left(-1.42 \times 10^{-4} \pm 4.66 \times 10^{-4} \mathrm{~Bq} / \mathrm{g}\left[-3.84 \times 10^{-3} \pm 1.26 \times 10^{-2} \mathrm{pCi} / \mathrm{g}\right]\right)$ and the highest concentrations were found at SMR $\left(1.13 \times 10^{-2} \pm 1.46 \times 10^{-3} \mathrm{~Bq} / \mathrm{g}\left[3.05 \times 10^{-1} \pm\right.\right.$ $\left.\left.3.94 \times 10^{-2} \mathrm{pCi} / \mathrm{g}\right]\right)$.

Although ${ }^{137} \mathrm{Cs}$ is a fission product, it is ubiquitous in soils because of global fallout from atmospheric nuclear weapons testing. In 1998, prior to WIPP accepting any waste, the average concentration of ${ }^{137} \mathrm{Cs}$ in soils around WIPP was $4.3 \times 10^{-3} \mathrm{~Bq} / \mathrm{g}$ $\left(1.16 \times 10^{-1} \mathrm{pCi} / \mathrm{g}\right)$. There was no statistically significant difference between concentrations measured in 2001 and 2002 (ANOVA, $p=0.883$ ).

Strontium-90 and ${ }^{60} \mathrm{Co}$ were not detected at any locations (Table 4.13).

Soil samples collected from one location (SEC) were divided into two parts and analyzed separately (Table 4.14). Uranium-234, ${ }^{235} \mathrm{U},{ }^{238} \mathrm{U},{ }^{239+240} \mathrm{Pu},{ }^{40} \mathrm{~K}$, and ${ }^{137} \mathrm{Cs}$ were compared between the duplicates. Other radionuclides of interest had insufficient detections to allow a reasonable comparison. The RER was greater than one for ${ }^{234} U$ at depth $2-5 \mathrm{~cm}$ and for ${ }^{239+240} \mathrm{Pu}$ at depth $0-2 \mathrm{~cm}$. This circumstance may indicate a lack of precision in these analyses, primarily due to the nonhomogeneous distribution of radionuclides in soils. Because of small-scale differences in topography, soil type and structure, soil moisture, and other microenvironmental conditions, radionuclides are rarely homogeneously distributed in soils, and good agreement between duplicate samples is sometimes difficult to achieve. However, all the measurements were low, within the range of natural concentrations, and did not differ in time or space in such a way as to suggest WIPP-related contamination of the environment. 
Table 4.13 - Selected Radionuclide Concentrations (Bq/g) in Soil Near the WIPP Site. See Appendix B for the sampling locations.

\begin{tabular}{|c|c|c|c|c|c|c|c|}
\hline \multirow[b]{2}{*}{ Location } & \multirow{2}{*}{$\begin{array}{c}\text { Depth } \\
\text { (cm) }\end{array}$} & {$[R N]^{a}$} & $2 \times \mathrm{TPU}^{\mathrm{b}}$ & $\mathrm{MDC}^{\mathrm{C}}$ & [RN] & $2 \times \mathrm{TPU}$ & MDC \\
\hline & & \multicolumn{3}{|c|}{${ }^{137} \mathrm{Cs}$} & \multicolumn{3}{|c|}{${ }^{60} \mathrm{Co}$} \\
\hline MLR & $0-2$ & $1.09 \times 10^{-2}$ & $1.42 \times 10^{-3}$ & $4.00 \times 10^{-4}$ & $1.79 \times 10^{-4}$ & $5.37 \times 10^{-4}$ & $6.14 \times 10^{-4}$ \\
\hline MLR & $2-5$ & $2.30 \times 10^{-3}$ & $3.55 \times 10^{-4}$ & $2.95 \times 10^{-4}$ & $3.52 \times 10^{-4}$ & $4.81 \times 10^{-4}$ & $5.59 \times 10^{-4}$ \\
\hline MLR & $5-10$ & $1.09 \times 10^{-3}$ & $2.82 \times 10^{-4}$ & $5.07 \times 10^{-4}$ & $4.40 \times 10^{-4}$ & $4.96 \times 10^{-4}$ & $5.77 \times 10^{-4}$ \\
\hline SEC & $0-2$ & $4.92 \times 10^{-3}$ & $7.44 \times 10^{-4}$ & $5.25 \times 10^{-4}$ & $3.56 \times 10^{-4}$ & $3.96 \times 10^{-4}$ & $4.70 \times 10^{-4}$ \\
\hline SEC & $2-5$ & $5.07 \times 10^{-3}$ & $7.14 \times 10^{-4}$ & $3.53 \times 10^{-4}$ & $1.02 \times 10^{-4}$ & $3.96 \times 10^{-4}$ & $4.55 \times 10^{-4}$ \\
\hline SEC & $5-10$ & $2.86 \times 10^{-3}$ & $5.18 \times 10^{-4}$ & $5.07 \times 10^{-4}$ & $-1.95 \times 10^{-4}$ & $4.85 \times 10^{-4}$ & $5.33 \times 10^{-4}$ \\
\hline SMR & $0-2$ & $6.33 \times 10^{-3}$ & $9.10 \times 10^{-4}$ & $5.55 \times 10^{-4}$ & $1.11 \times 10^{-5}$ & $5.59 \times 10^{-4}$ & $6.33 \times 10^{-4}$ \\
\hline SMR & $2-5$ & $1.30 \times 10^{-2}$ & $1.67 \times 10^{-3}$ & $3.40 \times 10^{-4}$ & $2.25 \times 10^{-4}$ & $5.62 \times 10^{-4}$ & $6.40 \times 10^{-4}$ \\
\hline SMR & $5-10$ & $1.13 \times 10^{-2}$ & $1.46 \times 10^{-3}$ & $4.11 \times 10^{-4}$ & $-8.55 \times 10^{-5}$ & $5.88 \times 10^{-4}$ & $6.59 \times 10^{-4}$ \\
\hline WEE & $0-2$ & $1.88 \times 10^{-3}$ & $3.43 \times 10^{-4}$ & $3.15 \times 10^{-4}$ & $5.92 \times 10^{-5}$ & $3.89 \times 10^{-4}$ & $4.44 \times 10^{-4}$ \\
\hline WEE & $2-5$ & $1.66 \times 10^{-3}$ & $5.44 \times 10^{-4}$ & $7.66 \times 10^{-4}$ & $-7.59 \times 10^{-5}$ & $4.66 \times 10^{-4}$ & $5.22 \times 10^{-4}$ \\
\hline WEE & $5-10$ & $1.66 \times 10^{-3}$ & $3.50 \times 10^{-4}$ & $3.85 \times 10^{-4}$ & $2.53 \times 10^{-4}$ & $3.85 \times 10^{-4}$ & $4.51 \times 10^{-4}$ \\
\hline WFF & $0-2$ & $4.18 \times 10^{-4}$ & $1.72 \times 10^{-4}$ & $2.42 \times 10^{-4}$ & $1.63 \times 10^{-4}$ & $3.55 \times 10^{-4}$ & $4.14 \times 10^{-4}$ \\
\hline WFF & $2-5$ & $4.00 \times 10^{-4}$ & $2.90 \times 10^{-4}$ & $3.53 \times 10^{-4}$ & $2.77 \times 10^{-4}$ & $3.62 \times 10^{-4}$ & $4.29 \times 10^{-4}$ \\
\hline WFF & $5-10$ & $-1.42 \times 10^{-4}$ & $4.66 \times 10^{-4}$ & $5.11 \times 10^{-4}$ & $5.33 \times 10^{-5}$ & $4.33 \times 10^{-4}$ & $4.96 \times 10^{-4}$ \\
\hline WSS & $0-2$ & $1.18 \times 10^{-3}$ & $2.96 \times 10^{-4}$ & $3.62 \times 10^{-4}$ & $-2.23 \times 10^{-4}$ & $4.22 \times 10^{-4}$ & $4.51 \times 10^{-4}$ \\
\hline WSS & $2-5$ & $2.24 \times 10^{-3}$ & $4.55 \times 10^{-4}$ & $4.96 \times 10^{-4}$ & $-1.53 \times 10^{-4}$ & $4.74 \times 10^{-4}$ & $5.22 \times 10^{-4}$ \\
\hline \multirow[t]{2}{*}{ WSS } & $5-10$ & $1.77 \times 10^{-3}$ & $3.32 \times 10^{-4}$ & $3.15 \times 10^{-4}$ & $2.01 \times 10^{-4}$ & $3.92 \times 10^{-4}$ & $4.55 \times 10^{-4}$ \\
\hline & & \multicolumn{3}{|c|}{${ }^{90} \mathrm{Sr}$} & \multicolumn{3}{|c|}{${ }^{40} \mathrm{~K}$} \\
\hline MLR & $0-2$ & $-2.78 \times 10^{-3}$ & $7.81 \times 10^{-3}$ & $1.35 \times 10^{-2}$ & $4.33 \times 10^{-1}$ & $5.55 \times 10^{-2}$ & $5.77 \times 10^{-3}$ \\
\hline MLR & $2-5$ & $1.29 \times 10^{-2}$ & $1.04 \times 10^{-2}$ & $1.67 \times 10^{-2}$ & $4.11 \times 10^{-1}$ & $5.37 \times 10^{-2}$ & $5.66 \times 10^{-3}$ \\
\hline MLR & $5-10$ & $-9.47 \times 10^{-4}$ & $7.99 \times 10^{-3}$ & $1.38 \times 10^{-2}$ & $4.14 \times 10^{-1}$ & $5.37 \times 10^{-2}$ & $4.96 \times 10^{-3}$ \\
\hline SEC & $0-2$ & $3.18 \times 10^{-3}$ & $5.59 \times 10^{-3}$ & $9.21 \times 10^{-3}$ & $2.19 \times 10^{-1}$ & $2.89 \times 10^{-2}$ & $4.26 \times 10^{-3}$ \\
\hline SEC & $2-5$ & $1.38 \times 10^{-3}$ & $5.29 \times 10^{-3}$ & $8.84 \times 10^{-3}$ & $2.30 \times 10^{-1}$ & $3.03 \times 10^{-2}$ & $4.59 \times 10^{-3}$ \\
\hline SEC & $5-10$ & $4.66 \times 10^{-3}$ & $5.44 \times 10^{-3}$ & $8.81 \times 10^{-3}$ & $2.04 \times 10^{-1}$ & $2.70 \times 10^{-2}$ & $7.36 \times 10^{-3}$ \\
\hline SMR & $0-2$ & $4.22 \times 10^{-3}$ & $6.96 \times 10^{-3}$ & $1.14 \times 10^{-2}$ & $6.73 \times 10^{-1}$ & $8.62 \times 10^{-2}$ & $6.03 \times 10^{-3}$ \\
\hline SMR & $2-5$ & $2.18 \times 10^{-3}$ & $6.70 \times 10^{-3}$ & $1.11 \times 10^{-2}$ & $6.99 \times 10^{-1}$ & $9.03 \times 10^{-2}$ & $5.77 \times 10^{-3}$ \\
\hline SMR & $5-10$ & $-1.47 \times 10^{-4}$ & $5.48 \times 10^{-3}$ & $9.29 \times 10^{-3}$ & $6.81 \times 10^{-1}$ & $8.70 \times 10^{-2}$ & $6.40 \times 10^{-3}$ \\
\hline WEE & $0-2$ & $-1.88 \times 10^{-3}$ & $5.40 \times 10^{-3}$ & $9.44 \times 10^{-3}$ & $2.26 \times 10^{-1}$ & $2.98 \times 10^{-2}$ & $3.70 \times 10^{-3}$ \\
\hline WEE & $2-5$ & $7.62 \times 10^{-3}$ & $5.74 \times 10^{-3}$ & $9.36 \times 10^{-3}$ & $2.26 \times 10^{-1}$ & $2.96 \times 10^{-2}$ & $5.51 \times 10^{-3}$ \\
\hline WEE & $5-10$ & $1.20 \times 10^{-3}$ & $5.37 \times 10^{-3}$ & $9.18 \times 10^{-3}$ & $2.24 \times 10^{-1}$ & $2.95 \times 10^{-2}$ & $3.77 \times 10^{-3}$ \\
\hline WFF & $0-2$ & $4.33 \times 10^{-3}$ & $5.37 \times 10^{-3}$ & $8.95 \times 10^{-3}$ & $1.74 \times 10^{-1}$ & $2.31 \times 10^{-2}$ & $3.62 \times 10^{-3}$ \\
\hline WFF & $2-5$ & $-5.70 \times 10^{-4}$ & $5.40 \times 10^{-3}$ & $9.40 \times 10^{-3}$ & $1.93 \times 10^{-1}$ & $2.56 \times 10^{-2}$ & $3.69 \times 10^{-3}$ \\
\hline WFF & $5-10$ & $1.45 \times 10^{-3}$ & $5.51 \times 10^{-3}$ & $9.44 \times 10^{-3}$ & $1.81 \times 10^{-1}$ & $2.39 \times 10^{-2}$ & $5.66 \times 10^{-3}$ \\
\hline WSS & $0-2$ & $1.40 \times 10^{-3}$ & $5.59 \times 10^{-3}$ & $9.32 \times 10^{-3}$ & $2.25 \times 10^{-1}$ & $2.96 \times 10^{-2}$ & $3.74 \times 10^{-3}$ \\
\hline WSS & $2-5$ & $-5.00 \times 10^{-3}$ & $5.33 \times 10^{-3}$ & $9.36 \times 10^{-3}$ & $2.19 \times 10^{-1}$ & $2.87 \times 10^{-2}$ & $5.55 \times 10^{-3}$ \\
\hline WSS & $5-10$ & $4.77 \times 10^{-4}$ & $5.66 \times 10^{-3}$ & $9.55 \times 10^{-3}$ & $2.46 \times 10^{-1}$ & $3.24 \times 10^{-2}$ & $3.92 \times 10^{-3}$ \\
\hline
\end{tabular}

${ }^{a}$ Radionuclide concentration

b Total propagated uncertainty

${ }^{\mathrm{c}}$ Minimum detectable concentration 
Table 4.14 - Results of Duplicate Soil Sample Analysis. Units are Bq/g. See Appendix B for the sampling locations.

\begin{tabular}{|c|c|c|c|c|c|c|c|c|c|}
\hline \multirow[b]{2}{*}{ Location } & \multirow{2}{*}{$\begin{array}{c}\text { Depth } \\
\text { (cm) }\end{array}$} & {$[\mathrm{RN}]^{\mathrm{a}}$} & $2 \times T_{P U}^{b}$ & $\mathrm{MDC}^{\mathrm{C}}$ & RER $^{\text {d }}$ & [RN] & $2 \times T_{P U}^{a}$ & $M^{\prime b} C^{b}$ & RER $^{\text {c }}$ \\
\hline & & \multicolumn{4}{|c|}{${ }^{234} U$} & \multicolumn{4}{|c|}{${ }^{238} U$} \\
\hline$\overline{\text { SEC }}$ & $0-2$ & $1.68 \times 10^{-2}$ & $3.05 \times 10^{-3}$ & $7.51 \times 10^{-5}$ & 0.18 & $1.69 \times 10^{-2}$ & $3.05 \times 10^{-3}$ & $7.47 \times 10^{-5}$ & 0.13 \\
\hline SEC D & $0-2$ & $1.76 \times 10^{-2}$ & $3.14 \times 10^{-3}$ & $7.47 \times 10^{-5}$ & & $1.63 \times 10^{-2}$ & $2.93 \times 10^{-3}$ & $7.44 \times 10^{-5}$ & \\
\hline SEC & $2-5$ & $1.73 \times 10^{-2}$ & $2.99 \times 10^{-3}$ & $7.29 \times 10^{-5}$ & 1.08 & $1.83 \times 10^{-2}$ & $3.14 \times 10^{-3}$ & $7.25 \times 10^{-5}$ & 0.80 \\
\hline SEC D & $2-5$ & $2.27 \times 10^{-2}$ & $4.03 \times 10^{-3}$ & $7.70 \times 10^{-5}$ & & $2.23 \times 10^{-2}$ & $3.96 \times 10^{-3}$ & $7.66 \times 10^{-4}$ & \\
\hline SEC & $5-10$ & $2.22 \times 10^{-2}$ & $3.89 \times 10^{-3}$ & $7.62 \times 10^{-5}$ & 0.85 & $2.05 \times 10^{-2}$ & $3.62 \times 10^{-3}$ & $7.62 \times 10^{-5}$ & 0.70 \\
\hline \multirow[t]{2}{*}{ SEC D } & $5-10$ & $1.78 \times 10^{-2}$ & $3.34 \times 10^{-3}$ & $8.47 \times 10^{-5}$ & & $1.71 \times 10^{-2}$ & $3.22 \times 10^{-3}$ & $2.89 \times 10^{-4}$ & \\
\hline & & \multicolumn{4}{|c|}{${ }^{235} \mathrm{U}$} & \multicolumn{4}{|c|}{${ }^{239+240} \mathrm{Pu}$} \\
\hline SEC & $0-2$ & $7.88 \times 10^{-4}$ & $3.52 \times 10^{-4}$ & $9.25 \times 10^{-5}$ & 0.48 & $1.23 \times 10^{-3}$ & $6.48 \times 10^{-4}$ & $1.96 \times 10^{-4}$ & 1.05 \\
\hline SEC D & $0-2$ & $1.05 \times 10^{-3}$ & $4.37 \times 10^{-4}$ & $3.16 \times 10^{-4}$ & & $5.00 \times 10^{-4}$ & $2.47 \times 10^{-4}$ & $7.51 \times 10^{-5}$ & \\
\hline SEC & $2-5$ & $8.95 \times 10^{-4}$ & $3.70 \times 10^{-4}$ & $8.99 \times 10^{-5}$ & 0.03 & $8.40 \times 10^{-4}$ & $5.92 \times 10^{-4}$ & $2.52 \times 10^{-4}$ & 0.17 \\
\hline SEC D ${ }^{\mathrm{e}}$ & $2-5$ & $9.10 \times 10^{-4}$ & $3.89 \times 10^{-4}$ & $9.51 \times 10^{-5}$ & & $7.22 \times 10^{-4}$ & $3.16 \times 10^{-4}$ & $8.14 \times 10^{-5}$ & \\
\hline SEC & $5-10$ & $1.18 \times 10^{-3}$ & $4.59 \times 10^{-4}$ & $2.56 \times 10^{-4}$ & 0.49 & $4.44 \times 10^{-4}$ & $2.87 \times 10^{-4}$ & $2.72 \times 10^{-4}$ & 0.25 \\
\hline \multirow[t]{2}{*}{ SEC D } & $5-10$ & $8.88 \times 10^{-4}$ & $4.44 \times 10^{-4}$ & $1.04 \times 10^{-4}$ & & $5.44 \times 10^{-4}$ & $2.88 \times 10^{-4}$ & $9.25 \times 10^{-4}$ & \\
\hline & & \multicolumn{4}{|c|}{${ }^{40} \mathrm{~K}$} & \multicolumn{4}{|c|}{${ }^{137} \mathrm{Cs}$} \\
\hline SEC & $0-2$ & $2.19 \times 10^{-1}$ & $2.89 \times 10^{-2}$ & $4.26 \times 10^{-3}$ & 0.39 & $4.92 \times 10^{-3}$ & $7.44 \times 10^{-4}$ & $5.25 \times 10^{-4}$ & 0.04 \\
\hline SEC D & $0-2$ & $2.03 \times 10^{-1}$ & $2.68 \times 10^{-2}$ & $5.62 \times 10^{-3}$ & & $4.96 \times 10^{-3}$ & $7.18 \times 10^{-4}$ & $4.18 \times 10^{-4}$ & \\
\hline SEC & $2-5$ & $2.30 \times 10^{-1}$ & $3.03 \times 10^{-2}$ & $4.59 \times 10^{-3}$ & 0.03 & $5.07 \times 10^{-3}$ & $7.14 \times 10^{-4}$ & $3.53 \times 10^{-4}$ & 0.80 \\
\hline SEC D & $2-5$ & $2.31 \times 10^{-1}$ & $3.05 \times 10^{-2}$ & $3.77 \times 10^{-3}$ & & $4.33 \times 10^{-3}$ & $5.96 \times 10^{-4}$ & $2.51 \times 10^{-4}$ & \\
\hline SEC & $5-10$ & $2.04 \times 10^{-1}$ & $2.70 \times 10^{-2}$ & $7.36 \times 10^{-3}$ & 0.60 & $2.86 \times 10^{-3}$ & $5.18 \times 10^{-4}$ & $5.07 \times 10^{-4}$ & 0.38 \\
\hline SEC De & $5-10$ & $2.28 \times 10^{-1}$ & $2.99 \times 10^{-2}$ & $5.74 \times 10^{-3}$ & & $3.15 \times 10^{-3}$ & $5.59 \times 10^{-4}$ & $5.33 \times 10^{-4}$ & \\
\hline $\begin{array}{l}\text { a Radionuc } \\
\text { b } \text { Total pro } \\
{ }^{\mathrm{c}} \text { Minimum } \\
{ }^{\mathrm{d}} \text { Relative } \\
{ }^{\mathrm{e}} \text { Duplicate }\end{array}$ & clide col & centration & & & & & & & \\
\hline
\end{tabular}

\subsection{Sediments}

\subsubsection{Sample Collection}

Sediment samples were collected from 12 locations around the WIPP site, mostly from the same water bodies from which the surface water samples were collected (Figure 4.7, see Appendix B for location codes). The samples were collected in 1-I plastic containers from the top $15 \mathrm{~cm}$ (6 in.) of the sediments of the water bodies and shipped to the laboratory for the determination of individual radionuclides.

\subsubsection{Sample Preparation}

Sediment samples were dried at $110^{\circ} \mathrm{C}\left(230^{\circ} \mathrm{F}\right)$ for several hours and homogenized by grinding to smaller particle sizes. A $0.75 \mathrm{~g}(0.04 \mathrm{oz})$ aliquot was dissolved by heating it with a mixture of nitric, hydrochloric, and hydrofluoric acids. The residue was heated with nitric and boric acids to remove hydrofluoric acid quantitatively. Finally, the residue was dissolved in hydrochloric acid for the determination of individual radionuclides. 


\subsubsection{Determination of Individual Radionuclides}

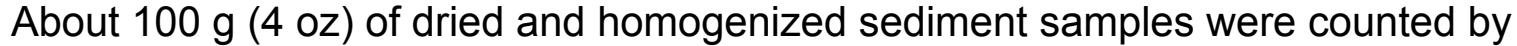
gamma-spectrometry for the determinations of ${ }^{40} \mathrm{~K},{ }^{60} \mathrm{Co}$, and ${ }^{137} \mathrm{Cs}$. Strontium-90 was determined from an aliquot of dissolved sediment samples by chemical separation and beta counting. Uranium, plutonium, and americium were determined by alpha spectrometry after chemical separations, micro-precipitating, and filtering onto micro filter papers.

\subsubsection{Results and Discussions}

Uranium-234, ${ }^{235} \mathrm{U}$, and ${ }^{238} \mathrm{U}$ were detected in every sediment sample (Table 4.15). The concentration of ${ }^{234} \mathrm{U}$ ranged from $1.68 \times 10^{-2} \pm 2.97 \times 10^{-3} \mathrm{~Bq} / \mathrm{g}\left(4.54 \times 10^{-1} \pm\right.$ $\left.8.02 \times 10^{-2} \mathrm{pCi} / \mathrm{g}\right)$ at NOY to $4.40 \times 10^{-2} \pm 7.25 \times 10^{-3} \mathrm{~Bq} / \mathrm{g}\left(1.19 \times 10^{0} \pm 1.96 \times 10^{-1} \mathrm{pCi} / \mathrm{g}\right)$ at CBD. The concentration of ${ }^{235} \mathrm{U}$ ranged from $9.92 \times 10^{-4} \pm 4.11 \times 10^{-4} \mathrm{~Bq} / \mathrm{g}\left(2.68 \times 10^{-2} \pm\right.$ $\left.1.11 \times 10^{-2} \mathrm{pCi} / \mathrm{g}\right)$ at RED to $2.06 \times 10^{-3} \pm 6.14 \times 10^{-4} \mathrm{~Bq} / \mathrm{g}\left(5.56 \times 10^{-2} \pm 1.66 \times 10^{-2} \mathrm{pCi} / \mathrm{g}\right)$ at IND. The concentration of ${ }^{238} \mathrm{U}$ was lowest at BHT $\left(1.84 \times 10^{-2} \pm 3.21 \times 10^{-3} \mathrm{~Bq} / \mathrm{g}\right.$ $\left.\left[4.97 \times 10^{-1} \pm 8.67 \times 10^{-2} \mathrm{pCi} / \mathrm{g}\right]\right)$ and highest at UPR $\left(3.15 \times 10^{-2} \pm 5.18 \times 10^{-3} \mathrm{~Bq} / \mathrm{g}\right.$ $\left.\left[8.51 \times 10^{-1} \pm 1.40 \times 10^{-1} \mathrm{pCi} / \mathrm{g}\right]\right)$. As expected, the ${ }^{235} \mathrm{U}$ concentration was much lower than the concentrations of ${ }^{234} \mathrm{U}$ and ${ }^{238} \mathrm{U}$. There was not a significant difference between 2001 and 2002 (ANOVA ${ }^{234} \mathrm{U} p=0.543,{ }^{235} \mathrm{U} p=0.935,{ }^{238} \mathrm{U} p=0.788$ ).

Plutonium-238 was detected in one sediment sample in 2002 at SOO (Table 4.16). Americium-241 was detected at CBD and PKT. Plutonium-239+240 was detected at 69 percent of sampling locations. The samples showed concentration barely above the MDC or 2xTPU and were within the normal background range as compared to the previous years.

Cesium-137 was detected in all the sediment samples except at $\mathrm{PCN}$, ranging from $5.77 \times 10^{-4} \pm 1.65 \times 10^{-4} \mathrm{~Bq} / \mathrm{g}\left(1.56 \times 10^{-2} \pm 4.46 \times 10^{-3} \mathrm{pCi} / \mathrm{g}\right)$ at UPR to $1.07 \times 10^{-2} \pm$ $1.42 \times 10^{-3} \mathrm{~Bq} / \mathrm{g}\left(2.89 \times 10^{0} \pm 3.83 \times 10^{-2} \mathrm{pCi} / \mathrm{g}\right)$ at SOO (Table 4.17). Cesium-137 did not differ statistically between sampling years 2001 and 2002 (ANOVA $p=0.258$ ).

Strontium-90 and ${ }^{60} \mathrm{Co}$ were not detected in any sediment samples. None of these radionuclides had sufficient detections to justify statistical comparisons between locations or years.

Potassium-40 was detected, as expected, in all sediment samples (Table 4.17). Its lowest concentration was found at BRA $\left(3.16 \times 10^{-1} \pm 4.14 \times 10^{-2} \mathrm{~Bq} / \mathrm{g}\left[8.53 \times 10^{0} \pm\right.\right.$ $\left.\left.1.12 \times 10^{0} \mathrm{pCi} / \mathrm{g}\right]\right)$ and its highest concentration was found at TUT $\left(9.66 \times 10^{-1} \pm 1.24 \times 10^{-1}\right.$ $\left.\mathrm{Bq} / \mathrm{g}\left[2.61 \times 10^{1} \pm 3.35 \times 10^{0} \mathrm{pCi} / \mathrm{g}\right]\right)$. Potassium- 40 did not vary significantly between years (ANOVA, $p=0.839$ ). Overall, the concentrations measured in 2002 were similar to the average concentration of ${ }^{40} \mathrm{~K}$ found in soils throughout the United States $\left(4.00 \times 10^{-1} \mathrm{~Bq} / \mathrm{g}\left[1.08 \times 10^{1} \mathrm{pCi} / \mathrm{g}\right] ;\right.$ NCRP, $\left.1987 \mathrm{a}\right)$.

Duplicate analyses were performed for all the radionuclides in sediment samples IDN and RED (Table 4.18). The RER was less than one for ${ }^{241} \mathrm{Am},{ }^{40} \mathrm{~K}$, and all uranium 


\section{Waste Isolation Pilot Plant 2002 Site Environmental Report DOE/WIPP 03-2225}

isotopes, indicating acceptable correspondence between the original and the duplicate samples. For ${ }^{137} \mathrm{Cs}$, it was greater than one for location RED. However, a t-test indicated no significant difference between any of these duplicate measurements for ${ }^{137} \mathrm{Cs}(p=0.377)$.

Table 4.15 - Uranium Concentrations (Bq/g) in Sediment Near the WIPP Site. See Appendix $B$ for the sampling locations.

\begin{tabular}{|c|c|c|c|c|c|c|c|c|c|}
\hline \multirow[b]{2}{*}{ Location } & {$[R N]^{a}$} & $2 \times \mathrm{TPU}^{\mathrm{b}}$ & $\mathrm{MDC}^{\mathrm{C}}$ & {$[R N]$} & $2 \times$ TPU & MDC & [RN] & $2 \times$ TPU & MDC \\
\hline & \multicolumn{3}{|c|}{${ }^{234} \mathrm{U}$} & \multicolumn{3}{|c|}{${ }^{235} \mathrm{U}$} & \multicolumn{3}{|c|}{${ }^{238} \mathrm{U}$} \\
\hline BRA & $2.87 \times 10^{-2}$ & $4.85 \times 10^{-3}$ & $6.18 \times 10^{-5}$ & $1.21 \times 10^{-3}$ & $4.18 \times 10^{-4}$ & $7.62 \times 10^{-5}$ & $2.72 \times 10^{-2}$ & $4.63 \times 10^{-3}$ & $1.68 \times 10^{-4}$ \\
\hline $\mathrm{BHT}$ & $1.79 \times 10^{-2}$ & $3.12 \times 10^{-3}$ & $1.62 \times 10^{-4}$ & $1.08 \times 10^{-3}$ & $3.85 \times 10^{-4}$ & $7.33 \times 10^{-5}$ & $1.84 \times 10^{-2}$ & $3.21 \times 10^{-3}$ & $1.61 \times 10^{-4}$ \\
\hline CBD & $4.40 \times 10^{-2}$ & $7.25 \times 10^{-3}$ & $6.92 \times 10^{-5}$ & $1.83 \times 10^{-3}$ & $5.66 \times 10^{-4}$ & $2.33 \times 10^{-4}$ & $3.00 \times 10^{-2}$ & $5.03 \times 10^{-3}$ & $6.92 \times 10^{-5}$ \\
\hline HIL & $2.20 \times 10^{-2}$ & $3.85 \times 10^{-3}$ & $6.44 \times 10^{-5}$ & $1.15 \times 10^{-3}$ & $4.11 \times 10^{-4}$ & $7.96 \times 10^{-5}$ & $2.20 \times 10^{-2}$ & $3.85 \times 10^{-3}$ & $6.44 \times 10^{-5}$ \\
\hline IDN & $2.21 \times 10^{-2}$ & $3.92 \times 10^{-3}$ & $1.90 \times 10^{-4}$ & $2.06 \times 10^{-3}$ & $6.14 \times 10^{-4}$ & $8.62 \times 10^{-5}$ & $2.45 \times 10^{-2}$ & $4.33 \times 10^{-3}$ & $6.96 \times 10^{-5}$ \\
\hline LST & $2.23 \times 10^{-2}$ & $4.00 \times 10^{-3}$ & $1.86 \times 10^{-4}$ & $1.99 \times 10^{-3}$ & $5.99 \times 10^{-4}$ & $8.44 \times 10^{-5}$ & $2.29 \times 10^{-2}$ & $4.07 \times 10^{-3}$ & $1.85 \times 10^{-4}$ \\
\hline NOY & $1.68 \times 10^{-2}$ & $2.97 \times 10^{-3}$ & $6.18 \times 10^{-5}$ & $1.47 \times 10^{-3}$ & $4.70 \times 10^{-4}$ & $7.62 \times 10^{-5}$ & $1.88 \times 10^{-2}$ & $3.28 \times 10^{-3}$ & $6.14 \times 10^{-5}$ \\
\hline PCN & $2.68 \times 10^{-2}$ & $4.40 \times 10^{-3}$ & $6.22 \times 10^{-5}$ & $1.36 \times 10^{-3}$ & $4.44 \times 10^{-4}$ & $7.70 \times 10^{-5}$ & $2.82 \times 10^{-2}$ & $4.63 \times 10^{-3}$ & $6.22 \times 10^{-5}$ \\
\hline PKT & $2.71 \times 10^{-2}$ & $4.37 \times 10^{-3}$ & $5.37 \times 10^{-5}$ & $1.20 \times 10^{-3}$ & $3.92 \times 10^{-4}$ & $1.80 \times 10^{-4}$ & $2.65 \times 10^{-2}$ & $4.29 \times 10^{-3}$ & $5.37 \times 10^{-5}$ \\
\hline RED & $2.04 \times 10^{-2}$ & $3.58 \times 10^{-3}$ & $8.07 \times 10^{-5}$ & $9.92 \times 10^{-4}$ & $4.11 \times 10^{-4}$ & $9.95 \times 10^{-5}$ & $1.95 \times 10^{-2}$ & $3.43 \times 10^{-3}$ & $8.03 \times 10^{-5}$ \\
\hline SOO & $2.39 \times 10^{-2}$ & $4.03 \times 10^{-3}$ & $6.40 \times 10^{-5}$ & $1.17 \times 10^{-3}$ & $4.11 \times 10^{-4}$ & $7.92 \times 10^{-5}$ & $2.43 \times 10^{-2}$ & $4.11 \times 10^{-3}$ & $6.40 \times 10^{-5}$ \\
\hline TUT & $2.47 \times 10^{-2}$ & $4.07 \times 10^{-3}$ & $1.52 \times 10^{-4}$ & $1.27 \times 10^{-3}$ & $4.14 \times 10^{-4}$ & $1.87 \times 10^{-4}$ & $2.70 \times 10^{-2}$ & $4.40 \times 10^{-3}$ & $5.55 \times 10^{-5}$ \\
\hline UPR & $2.97 \times 10^{-2}$ & $4.92 \times 10^{-3}$ & $5.99 \times 10^{-5}$ & $1.94 \times 10^{-3}$ & $5.51 \times 10^{-4}$ & $7.40 \times 10^{-5}$ & $3.15 \times 10^{-2}$ & $5.18 \times 10^{-3}$ & $5.96 \times 10^{-5}$ \\
\hline
\end{tabular}

Table 4.16 - Americium and Plutonium Concentrations (Bq/g) in Sediment Near the WIPP Site. See Appendix $B$ for the sampling locations.

\begin{tabular}{|c|c|c|c|c|c|c|c|c|c|}
\hline \multirow[b]{2}{*}{ Location } & {$[R N]^{a}$} & $2 \times \mathrm{TPU}^{b}$ & MDC $^{\mathrm{C}}$ & [RN] & $2 \times$ TPU & MDC & [RN] & $2 \times$ TPU & MDC \\
\hline & \multicolumn{3}{|c|}{${ }^{241} \mathrm{Am}$} & \multicolumn{3}{|c|}{${ }^{238} \mathrm{Pu}$} & \multicolumn{3}{|c|}{${ }^{239+240} \mathrm{Pu}$} \\
\hline BRA & $1.75 \times 10^{-4}$ & $3.52 \times 10^{-4}$ & $6.44 \times 10^{-4}$ & $0.00 \times 10^{0}$ & $0.00 \times 10^{0}$ & $4.81 \times 10^{-4}$ & $6.51 \times 10^{-5}$ & $1.31 \times 10^{-4}$ & $1.76 \times 10^{-4}$ \\
\hline $\mathrm{BHT}$ & $1.45 \times 10^{-4}$ & $1.56 \times 10^{-4}$ & $2.14 \times 10^{-4}$ & $9.14 \times 10^{-5}$ & $9.21 \times 10^{-5}$ & $6.18 \times 10^{-5}$ & $2.50 \times 10^{-4}$ & $1.80 \times 10^{-4}$ & $2.12 \times 10^{-4}$ \\
\hline CBD & $1.77 \times 10^{-4}$ & $1.62 \times 10^{-4}$ & $9.58 \times 10^{-5}$ & $7.47 \times 10^{-5}$ & $8.70 \times 10^{-5}$ & $6.73 \times 10^{-5}$ & $1.49 \times 10^{-4}$ & $1.24 \times 10^{-4}$ & $6.73 \times 10^{-5}$ \\
\hline -IIL & $0.00 \times 10^{0}$ & $0.00 \times 10^{0}$ & $7.10 \times 10^{-4}$ & $3.23 \times 10^{-5}$ & $1.12 \times 10^{-4}$ & $2.38 \times 10^{-4}$ & $1.61 \times 10^{-4}$ & $1.47 \times 10^{-4}$ & $8.73 \times 10^{-5}$ \\
\hline IDN & $9.66 \times 10^{-5}$ & $1.20 \times 10^{-4}$ & $1.78 \times 10^{-4}$ & $3.53 \times 10^{-5}$ & $1.22 \times 10^{-4}$ & $2.60 \times 10^{-4}$ & $3.17 \times 10^{-4}$ & $2.19 \times 10^{-4}$ & $9.55 \times 10^{-5}$ \\
\hline LST & $1.37 \times 10^{-4}$ & $1.82 \times 10^{-4}$ & $2.94 \times 10^{-4}$ & $0.00 \times 10^{0}$ & $0.00 \times 10^{0}$ & $1.57 \times 10^{-4}$ & $3.20 \times 10^{-4}$ & $1.72 \times 10^{-4}$ & $5.77 \times 10^{-5}$ \\
\hline NOY & $3.11 \times 10^{-5}$ & $1.08 \times 10^{-4}$ & $2.29 \times 10^{-4}$ & $9.73 \times 10^{-5}$ & $1.20 \times 10^{-4}$ & $1.79 \times 10^{-4}$ & $1.70 \times 10^{-4}$ & $1.31 \times 10^{-4}$ & $6.59 \times 10^{-5}$ \\
\hline $\mathrm{PCN}$ & $4.07 \times 10^{-5}$ & $5.77 \times 10^{-5}$ & $5.51 \times 10^{-5}$ & $1.00 \times 10^{-4}$ & $1.50 \times 10^{-4}$ & $2.46 \times 10^{-4}$ & $3.33 \times 10^{-5}$ & $6.70 \times 10^{-5}$ & $9.03 \times 10^{-5}$ \\
\hline PKT & $1.36 \times 10^{-4}$ & $1.24 \times 10^{-4}$ & $7.40 \times 10^{-5}$ & $8.25 \times 10^{-5}$ & $1.18 \times 10^{-4}$ & $1.12 \times 10^{-4}$ & $9.07 \times 10^{-4}$ & $4.22 \times 10^{-4}$ & $1.12 \times 10^{-4}$ \\
\hline RED & $1.02 \times 10^{-4}$ & $1.03 \times 10^{-4}$ & $6.92 \times 10^{-5}$ & $-1.25 \times 10^{-4}$ & $3.06 \times 10^{-4}$ & $7.47 \times 10^{-4}$ & $5.00 \times 10^{-4}$ & $3.69 \times 10^{-4}$ & $1.69 \times 10^{-4}$ \\
\hline SOO & $7.10 \times 10^{-5}$ & $1.07 \times 10^{-4}$ & $1.75 \times 10^{-4}$ & $1.53 \times 10^{-4}$ & $1.18 \times 10^{-4}$ & $5.92 \times 10^{-5}$ & $4.14 \times 10^{-4}$ & $2.01 \times 10^{-4}$ & $5.92 \times 10^{-5}$ \\
\hline TUT & $1.17 \times 10^{-4}$ & $1.45 \times 10^{-4}$ & $2.15 \times 10^{-4}$ & $6.99 \times 10^{-5}$ & $9.95 \times 10^{-5}$ & $9.44 \times 10^{-5}$ & $1.05 \times 10^{-4}$ & $1.22 \times 10^{-4}$ & $9.44 \times 10^{-5}$ \\
\hline UPR & $0.00 \times 10^{0}$ & $0.00 \times 10^{0}$ & $2.45 \times 10^{-4}$ & $-4.26 \times 10^{-5}$ & $8.58 \times 10^{-5}$ & $3.14 \times 10^{-4}$ & $1.28 \times 10^{-4}$ & $1.49 \times 10^{-4}$ & $1.15 \times 10^{-4}$ \\
\hline
\end{tabular}

${ }^{a}$ Radionuclide concentration

b Total propagated uncertainty

${ }^{\mathrm{c}}$ Minimum detectable concentration

Note: An anomaly in the Canberra software for the alpha spectrometer prevents it from calculating uncertainty when the activity is 0 . 
Table 4.17 - Selected Radionuclide Concentrations (Bq/g) in Sediment Near the WIPP Site. See Appendix $B$ for the sampling locations.

\begin{tabular}{|c|c|c|c|c|c|c|}
\hline \multirow[b]{2}{*}{ Location } & {$[R N]^{a}$} & $2 \times \operatorname{TPU}^{\mathrm{b}}$ & MDC $^{c}$ & [RN] & $2 \times \mathrm{TPU}$ & MDC \\
\hline & \multicolumn{3}{|c|}{${ }^{137} \mathrm{Cs}$} & \multicolumn{3}{|c|}{${ }^{60} \mathrm{Co}$} \\
\hline BRA & $8.33 \times 10^{-4}$ & $1.83 \times 10^{-4}$ & $2.84 \times 10^{-4}$ & $4.33 \times 10^{-4}$ & $4.66 \times 10^{-4}$ & $5.44 \times 10^{-4}$ \\
\hline BHT & $7.07 \times 10^{-3}$ & $1.10 \times 10^{-3}$ & $8.95 \times 10^{-4}$ & $-1.06 \times 10^{-5}$ & $6.33 \times 10^{-4}$ & $6.73 \times 10^{-4}$ \\
\hline CBD & $2.95 \times 10^{-3}$ & $4.33 \times 10^{-4}$ & $2.87 \times 10^{-4}$ & $1.18 \times 10^{-5}$ & $4.70 \times 10^{-4}$ & $5.29 \times 10^{-4}$ \\
\hline HIL & $1.57 \times 10^{-3}$ & $2.74 \times 10^{-4}$ & $3.27 \times 10^{-4}$ & $7.10 \times 10^{-5}$ & $5.51 \times 10^{-4}$ & $6.22 \times 10^{-4}$ \\
\hline IDN & $7.14 \times 10^{-3}$ & $9.51 \times 10^{-4}$ & $3.44 \times 10^{-4}$ & $1.82 \times 10^{-4}$ & $5.66 \times 10^{-4}$ & $6.44 \times 10^{-4}$ \\
\hline LST & $4.66 \times 10^{-3}$ & $6.44 \times 10^{-4}$ & $3.55 \times 10^{-4}$ & $-6.33 \times 10^{-5}$ & $5.66 \times 10^{-4}$ & $6.29 \times 10^{-4}$ \\
\hline NOY & $4.11 \times 10^{-3}$ & $5.77 \times 10^{-4}$ & $3.64 \times 10^{-4}$ & $1.32 \times 10^{-4}$ & $6.03 \times 10^{-4}$ & $6.77 \times 10^{-4}$ \\
\hline PCN & $1.20 \times 10^{-4}$ & $2.69 \times 10^{-4}$ & $5.00 \times 10^{-4}$ & $-1.52 \times 10^{-4}$ & $5.85 \times 10^{-4}$ & $6.44 \times 10^{-4}$ \\
\hline PKT & $7.40 \times 10^{-3}$ & $9.84 \times 10^{-4}$ & $3.96 \times 10^{-4}$ & $-6.18 \times 10^{-5}$ & $6.03 \times 10^{-4}$ & $6.48 \times 10^{-4}$ \\
\hline RED & $3.17 \times 10^{-3}$ & $4.92 \times 10^{-4}$ & $3.39 \times 10^{-4}$ & $4.88 \times 10^{-4}$ & $4.88 \times 10^{-4}$ & $5.70 \times 10^{-4}$ \\
\hline SOO & $1.07 \times 10^{-2}$ & $1.42 \times 10^{-3}$ & $5.37 \times 10^{-4}$ & $5.03 \times 10^{-4}$ & $5.40 \times 10^{-4}$ & $6.03 \times 10^{-4}$ \\
\hline TUT & $2.63 \times 10^{-3}$ & $5.48 \times 10^{-4}$ & $6.33 \times 10^{-4}$ & $5.03 \times 10^{-4}$ & $7.51 \times 10^{-4}$ & $8.07 \times 10^{-4}$ \\
\hline \multirow[t]{2}{*}{ UPR } & $5.77 \times 10^{-4}$ & $1.65 \times 10^{-4}$ & $3.20 \times 10^{-4}$ & $3.89 \times 10^{-4}$ & $5.33 \times 10^{-4}$ & $5.96 \times 10^{-4}$ \\
\hline & \multicolumn{3}{|c|}{${ }^{90} \mathrm{Sr}$} & \multicolumn{3}{|c|}{${ }^{40} \mathrm{~K}$} \\
\hline BRA & $3.23 \times 10^{-3}$ & $4.18 \times 10^{-3}$ & $7.10 \times 10^{-3}$ & $3.16 \times 10^{-1}$ & $4.14 \times 10^{-2}$ & $6.99 \times 10^{-3}$ \\
\hline BHT & $1.47 \times 10^{-3}$ & $3.61 \times 10^{-3}$ & $6.22 \times 10^{-3}$ & $4.92 \times 10^{-1}$ & $6.36 \times 10^{-2}$ & $6.81 \times 10^{-3}$ \\
\hline CBD & $1.85 \times 10^{-3}$ & $5.22 \times 10^{-3}$ & $9.07 \times 10^{-3}$ & $3.40 \times 10^{-1}$ & $4.44 \times 10^{-2}$ & $5.25 \times 10^{-3}$ \\
\hline $\mathrm{HIL}$ & $5.07 \times 10^{-3}$ & $4.85 \times 10^{-3}$ & $8.10 \times 10^{-3}$ & $7.14 \times 10^{-1}$ & $9.18 \times 10^{-2}$ & $6.07 \times 10^{-3}$ \\
\hline IDN & $1.34 \times 10^{-3}$ & $4.77 \times 10^{-3}$ & $8.29 \times 10^{-3}$ & $6.62 \times 10^{-1}$ & $8.55 \times 10^{-2}$ & $5.81 \times 10^{-3}$ \\
\hline LST & $4.92 \times 10^{-3}$ & $6.11 \times 10^{-3}$ & $1.03 \times 10^{-2}$ & $6.70 \times 10^{-1}$ & $8.62 \times 10^{-2}$ & $6.18 \times 10^{-3}$ \\
\hline NOY & $1.10 \times 10^{-3}$ & $3.96 \times 10^{-3}$ & $6.70 \times 10^{-3}$ & $8.58 \times 10^{-1}$ & $1.11 \times 10^{-1}$ & $6.99 \times 10^{-3}$ \\
\hline $\mathrm{PCN}$ & $-2.02 \times 10^{-3}$ & $4.85 \times 10^{-3}$ & $8.55 \times 10^{-3}$ & $6.88 \times 10^{-1}$ & $8.84 \times 10^{-2}$ & $5.55 \times 10^{-3}$ \\
\hline PKT & $1.82 \times 10^{-3}$ & $4.48 \times 10^{-3}$ & $7.59 \times 10^{-3}$ & $5.40 \times 10^{-1}$ & $7.62 \times 10^{-2}$ & $5.81 \times 10^{-2}$ \\
\hline RED & $1.11 \times 10^{-3}$ & $6.81 \times 10^{-3}$ & $1.18 \times 10^{-2}$ & $4.66 \times 10^{-1}$ & $6.03 \times 10^{-2}$ & $5.59 \times 10^{-3}$ \\
\hline SOO & $6.36 \times 10^{-3}$ & $6.66 \times 10^{-3}$ & $1.10 \times 10^{-2}$ & $4.03 \times 10^{-1}$ & $5.74 \times 10^{-2}$ & $5.85 \times 10^{-3}$ \\
\hline TUT & $1.93 \times 10^{-3}$ & $4.40 \times 10^{-3}$ & $7.47 \times 10^{-3}$ & $9.66 \times 10^{-1}$ & $1.24 \times 10^{-1}$ & $6.62 \times 10^{-3}$ \\
\hline UPR & $5.37 \times 10^{-3}$ & $5.14 \times 10^{-3}$ & $8.44 \times 10^{-3}$ & $3.44 \times 10^{-1}$ & $4.92 \times 10^{-2}$ & $5.70 \times 10^{-3}$ \\
\hline
\end{tabular}

a Radionuclide concentration

${ }^{\mathrm{b}}$ Total propagated uncertainty

${ }^{\mathrm{c}}$ Minimum detectable concentration

All of the radionuclides analyzed in sediment samples in 2002 were within the 95 percent confidence interval ranges of preoperational radiological baseline report covering the period from 1985 to 1989 (DOE/WIPP 92-037). 
Table 4.18 - Results of Duplicate Sediment Sample Analysis. Units are Bq/g. See Appendix B for the sampling locations.

\begin{tabular}{|c|c|c|c|c|c|c|c|c|}
\hline \multirow[b]{2}{*}{ Location } & {$[R N]^{a}$} & $2 \times T_{P U^{b}}$ & MDC $^{c}$ & RER $^{d}$ & [RN] & $2 \times T_{P U^{a}}$ & MDC $^{b}$ & RER $^{c}$ \\
\hline & \multicolumn{4}{|c|}{${ }^{241} \mathrm{Am}$} & \multicolumn{4}{|c|}{${ }^{137} \mathrm{Cs}$} \\
\hline IDN & $9.66 \times 10^{-5}$ & $1.20 \times 10^{-4}$ & $1.78 \times 10^{-4}$ & 0.55 & $7.14 \times 10^{-3}$ & $9.51 \times 10^{-4}$ & $3.44 \times 10^{-4}$ & 0 \\
\hline IDN Dup. & $1.99 \times 10^{-4}$ & $1.45 \times 10^{-4}$ & $6.73 \times 10^{-5}$ & & $7.14 \times 10^{-3}$ & $9.47 \times 10^{-4}$ & $3.45 \times 10^{-4}$ & \\
\hline RED & $1.02 \times 10^{-4}$ & $1.03 \times 10^{-4}$ & $6.92 \times 10^{-5}$ & 0.35 & $3.17 \times 10^{-3}$ & $4.92 \times 10^{-4}$ & $3.39 \times 10^{-4}$ & 5.55 \\
\hline \multirow[t]{2}{*}{ RED Dup. } & $5.11 \times 10^{-5}$ & $1.02 \times 10^{-4}$ & $1.88 \times 10^{-4}$ & & $3.61 \times 10^{-4}$ & $1.20 \times 10^{-4}$ & $2.43 \times 10^{-4}$ & \\
\hline & \multicolumn{4}{|c|}{${ }^{40} \mathrm{~K}$} & \multicolumn{4}{|c|}{${ }^{234} \mathrm{U}$} \\
\hline IDN & $6.62 \times 10^{-1}$ & $8.55 \times 10^{-2}$ & $5.81 \times 10^{-3}$ & 0 & $2.21 \times 10^{-2}$ & $3.92 \times 10^{-3}$ & $1.90 \times 10^{-4}$ & 0.56 \\
\hline IDN Dup. & $6.62 \times 10^{-1}$ & $8.55 \times 10^{-2}$ & $6.99 \times 10^{-3}$ & & $2.54 \times 10^{-2}$ & $4.59 \times 10^{-3}$ & $7.70 \times 10^{-5}$ & \\
\hline RED & $4.66 \times 10^{-1}$ & $6.03 \times 10^{-2}$ & $5.59 \times 10^{-3}$ & 0.21 & $2.04 \times 10^{-2}$ & $3.58 \times 10^{-3}$ & $8.07 \times 10^{-5}$ & 0.46 \\
\hline \multirow[t]{2}{*}{ RED Dup. } & $4.85 \times 10^{-1}$ & $6.29 \times 10^{-2}$ & $5.11 \times 10^{-3}$ & & $2.27 \times 10^{-2}$ & $3.77 \times 10^{-3}$ & $5.85 \times 10^{-5}$ & \\
\hline & \multicolumn{4}{|c|}{${ }^{235} U$} & \multicolumn{4}{|c|}{${ }^{238} \mathrm{U}$} \\
\hline IDN & $2.06 \times 10^{-3}$ & $6.14 \times 10^{-4}$ & $8.62 \times 10^{-5}$ & 0.99 & $2.45 \times 10^{-2}$ & $4.33 \times 10^{-3}$ & $6.96 \times 10^{-5}$ & 0.19 \\
\hline IDN Dup. & $1.30 \times 10^{-3}$ & $4.77 \times 10^{-4}$ & $9.47 \times 10^{-5}$ & & $2.57 \times 10^{-2}$ & $4.63 \times 10^{-3}$ & $7.66 \times 10^{-5}$ & \\
\hline RED & $9.92 \times 10^{-4}$ & $4.11 \times 10^{-4}$ & $9.95 \times 10^{-5}$ & 0.09 & $1.95 \times 10^{-2}$ & $3.43 \times 10^{-3}$ & $8.03 \times 10^{-5}$ & 0.91 \\
\hline RED Dup. & $1.04 \times 10^{-3}$ & $3.70 \times 10^{-4}$ & $7.25 \times 10^{-5}$ & & $2.43 \times 10^{-2}$ & $4.00 \times 10^{-3}$ & $1.59 \times 10^{-4}$ & \\
\hline
\end{tabular}

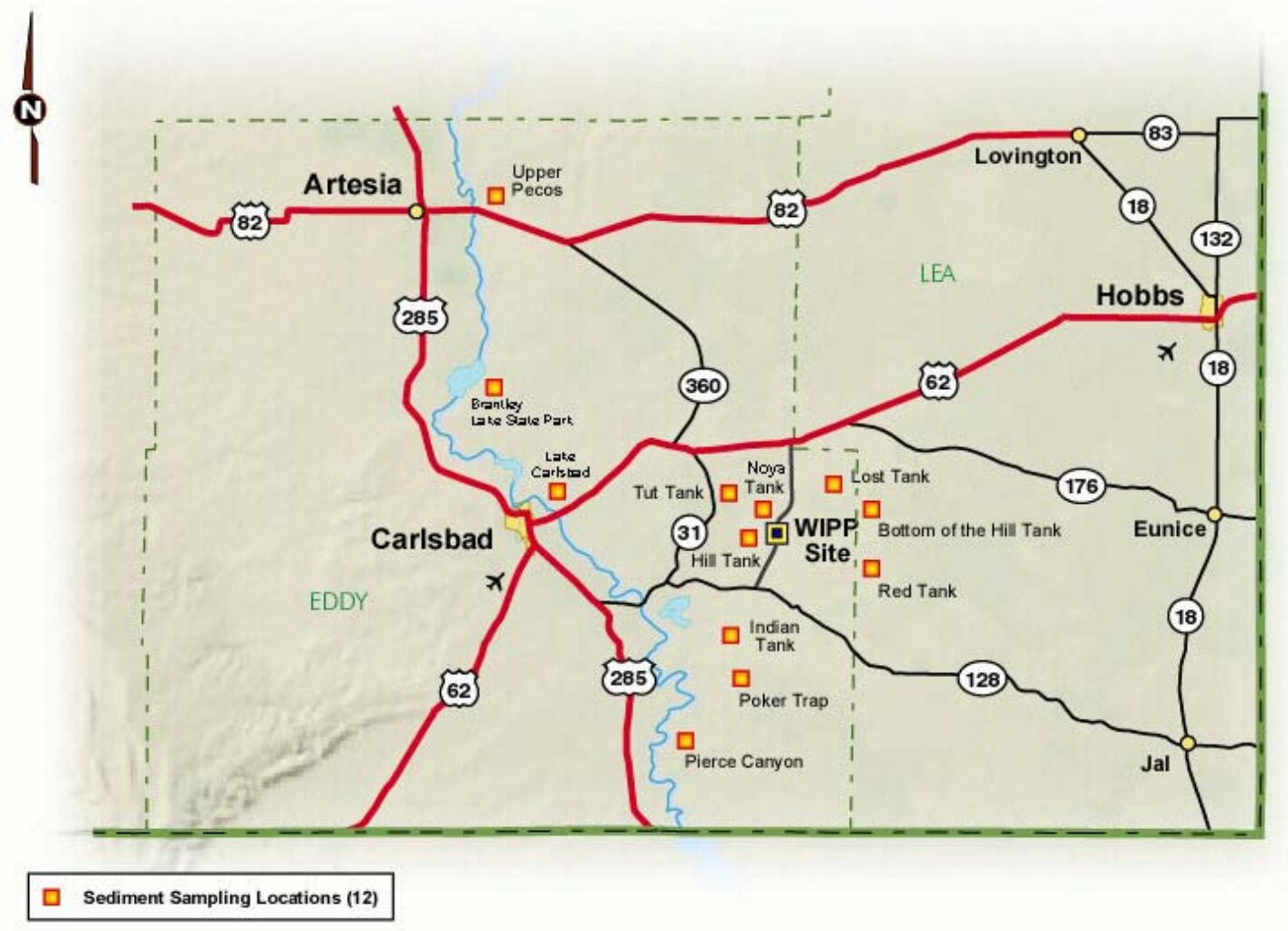

Figure 4.7 - Sediment Sampling Sites 


\subsection{Biota}

\subsubsection{Sample Collection}

The concentration of radionuclides in plants is an important factor in estimating the intake of individual radionuclides by humans through ingestion. Therefore, rangeland vegetation samples were collected from the same six locations from where the soil samples were collected (Figure 4.6). The vegetation samples were chopped into 2.5-5-cm (1-2-in)-pieces, mixed together well, air dried at room temperature, and analyzed. Also collected were muscle tissues from two road-killed deer and one quail, both species commonly consumed by humans. Fish is also consumed in large amounts; therefore, fish samples from BRA, PEC, and SOO (three different locations on the Pecos River) were collected. The muscle tissues from the deer, quail, and fish were also analyzed.

\subsubsection{Sample Preparation}

Weighed aliquots were taken from the bulk of the chopped vegetation samples and animal tissue samples from each location. The aliquots were transferred into separate containers and dried at $100^{\circ} \mathrm{C}\left(212^{\circ} \mathrm{F}\right)$. Gamma spectrometric determinations of ${ }^{40} \mathrm{~K}$, ${ }^{60} \mathrm{Co}$, and ${ }^{137} \mathrm{Cs}$ were performed directly from these aliquots. The samples were then dry-ashed, followed by wet-ashing and dissolution in $8 \mathrm{M}$ nitric acid. Aliquots from the dissolved samples were taken for the determinations of ${ }^{90} \mathrm{Sr},{ }^{234} \mathrm{U},{ }^{235} \mathrm{U},{ }^{238} \mathrm{U},{ }^{238} \mathrm{Pu}$, ${ }^{239+240} \mathrm{Pu}$, and ${ }^{241} \mathrm{Am}$.

\subsubsection{Results and Discussions}

\section{$\underline{\text { Vegetation }}$}

Uranium-234 was detected in all vegetation samples; because of its naturally low concentration, ${ }^{235} \mathrm{U}$ was not detected in any vegetation sample (Table 4.19). Concentrations of ${ }^{234} \mathrm{U}$ ranged from $2.90 \times 10^{-4} \pm 1.51 \times 10^{-4} \mathrm{~Bq} / \mathrm{g}\left(7.83 \times 10^{-3} \pm\right.$ $\left.4.08 \times 10^{-3} \mathrm{pCi} / \mathrm{g}\right)$ at SEC to $8.03 \times 10^{-4} \pm 3.07 \times 10^{-4} \mathrm{~Bq} / \mathrm{g}\left(2.17 \times 10^{-2} \pm 8.30 \times 10^{-3} \mathrm{pCi} / \mathrm{g}\right)$ at MLR. Uranium-238 was also detected in all the vegetation samples and varied between $2.51 \times 10^{-4} \pm 1.37 \times 10^{-4} \mathrm{~Bq} / \mathrm{g}\left(6.78 \times 10^{-3} \pm 3.70 \times 10^{-3} \mathrm{pCi} / \mathrm{g}\right)$ at WEE to $4.11 \times 10^{-4} \pm$ $2.02 \times 10^{-4} \mathrm{~Bq} / \mathrm{g}\left(1.11 \times 10^{-2} \pm 5.51 \times 10^{-3} \mathrm{pCi} / \mathrm{g}\right)$ at MLR. The concentration of ${ }^{234} \mathrm{U}$ and ${ }^{238} \mathrm{U}$ for the same location did not vary significantly between years 2001 and 2002 (ANOVA, ${ }^{234} \mathrm{U} p=0.727,{ }^{238} \mathrm{U} p=0.976$ ). The primary source for uranium in plant tissues is the soil, so this difference from the uranium results for soils may seem counterintuitive. However, uptake of radionuclides and contamination by resuspension are highly species dependent. Because of small-scale differences in soil type, shading, water availability, and other microenvironmental conditions, plants of the same species collected adjacent to one another will often have very different radionuclide concentrations.

Plutonium-238, ${ }^{239+240} \mathrm{Pu}$, and ${ }^{241} \mathrm{Am}$ were not detected in every vegetation sample (Table 4.19). 


\section{Waste Isolation Pilot Plant 2002 Site Environmental Report DOE/WIPP 03-2225}

Potassium-40 was detected in every vegetation sample (Table 4.19), ranging from $2.92 \times 10^{-1} \pm 4.55 \times 10^{-2} \mathrm{~Bq} / \mathrm{g}\left(7.89 \times 10^{0} \pm 1.23 \times 10^{0} \mathrm{pCi} / \mathrm{g}\right)$ at SEC to $8.47 \times 10^{-1} \pm$ $1.22 \times 10^{-1} \mathrm{~Bq} / \mathrm{g}\left(1.16 \times 10^{1} \pm 1.75 \times 10^{0} \mathrm{pCi} / \mathrm{g}\right)$ at SMR. The concentration of ${ }^{40} \mathrm{~K}$ in vegetation was not significantly different for the same location between years (ANOVA, $p=0.364)$. Like uranium, the primary source for potassium in plant tissues is the soil, and this difference from the ${ }^{40} \mathrm{~K}$ results for soil is probably due to the same factors. Cesium-137 and ${ }^{60} \mathrm{Co}$ were not detected in vegetation samples. Strontium-90 was detected at locations WEE, WFF, and WSS ranging from $9.36 \times 10^{-3} \pm 3.42 \times 10^{-3} \mathrm{~Bq} / \mathrm{g}$ $\left(2.53 \times 10^{-1} \pm 9.23 \times 10^{-2} \mathrm{pCi} / \mathrm{g}\right)$ to $1.54 \times 10^{-2} \pm 3.89 \times 10^{-3} \mathrm{~Bq} / \mathrm{g}\left(4.16 \times 10^{-1} \pm 1.05 \times 10^{-1}\right.$ $\mathrm{pCi} / \mathrm{g})$. There was no significant difference in ${ }^{90} \mathrm{Sr}$ concentration between 2001 and 2002 (ANOVA, $p=0.434$ ).

Table 4.19 - Radionuclide Concentrations (Bq/g Wet Mass) in Vegetation Near the WIPP Site. See Appendix $B$ for the sampling locations.

\begin{tabular}{|c|c|c|c|c|c|c|c|c|c|}
\hline \multirow[b]{2}{*}{ Location } & {$[\mathrm{RN}]^{\mathrm{a}}$} & $2 \times T_{P U}^{b}$ & $\mathrm{MDC}^{\mathrm{c}}$ & [RN] & $2 \times T P U$ & MDC & [RN] & $2 \times T P U$ & MDC \\
\hline & \multicolumn{3}{|c|}{${ }^{241} \mathrm{Am}$} & \multicolumn{3}{|c|}{${ }^{238} \mathrm{Pu}$} & \multicolumn{3}{|c|}{${ }^{239} \mathrm{Pu}$} \\
\hline MLR & $7.22 \times 10^{-5}$ & $8.44 \times 10^{-5}$ & $6.51 \times 10^{-5}$ & $3.74 \times 10^{-5}$ & $7.55 \times 10^{-5}$ & $1.38 \times 10^{-4}$ & $3.74 \times 10^{-5}$ & $5.33 \times 10^{-5}$ & $5.07 \times 10^{-5}$ \\
\hline SEC & $8.07 \times 10^{-5}$ & $8.66 \times 10^{-5}$ & $1.19 \times 10^{-3}$ & $4.11 \times 10^{-5}$ & $8.21 \times 10^{-5}$ & $1.51 \times 10^{-4}$ & $0.00 \times 10^{0}$ & $0.00 \times 10^{0}$ & $5.55 \times 10^{-5}$ \\
\hline SMR & $1.64 \times 10^{-5}$ & $5.70 \times 10^{-5}$ & $1.21 \times 10^{-4}$ & $0.00 \times 10^{0}$ & $0.00 \times 10^{0}$ & $2.20 \times 10^{-3}$ & $0.00 \times 10^{0}$ & $0.00 \times 10^{0}$ & $8.10 \times 10^{-5}$ \\
\hline WEE & $-1.94 \times 10^{-5}$ & $3.89 \times 10^{-5}$ & $1.42 \times 10^{-4}$ & $0.00 \times 10^{0}$ & $0.00 \times 10^{0}$ & $2.11 \times 10^{-4}$ & $2.86 \times 10^{-5}$ & $5.77 \times 10^{-5}$ & $7.77 \times 10^{-5}$ \\
\hline WFF & $4.14 \times 10^{-5}$ & $5.92 \times 10^{-5}$ & $5.62 \times 10^{-5}$ & $0.00 \times 10^{0}$ & $0.00 \times 10^{0}$ & $5.92 \times 10^{-5}$ & $4.37 \times 10^{-5}$ & $6.22 \times 10^{-5}$ & $5.92 \times 10^{-5}$ \\
\hline \multirow[t]{2}{*}{ WSS } & $8.70 \times 10^{-5}$ & $1.75 \times 10^{-4}$ & $3.20 \times 10^{-4}$ & $0.00 \times 10^{0}$ & $0.00 \times 10^{0}$ & $2.22 \times 10^{-4}$ & $0.00 \times 10^{0}$ & $0.00 \times 10^{0}$ & $2.22 \times 10^{-4}$ \\
\hline & \multicolumn{3}{|c|}{${ }^{234} \mathrm{U}$} & \multicolumn{3}{|c|}{${ }^{235} \mathrm{U}$} & \multicolumn{3}{|c|}{${ }^{238} \mathrm{U}$} \\
\hline MLR & $8.03 \times 10^{-4}$ & $3.07 \times 10^{-4}$ & $1.60 \times 10^{-4}$ & $2.68 \times 10^{-5}$ & $5.37 \times 10^{-5}$ & $7.25 \times 10^{-5}$ & $4.11 \times 10^{-4}$ & $2.02 \times 10^{-4}$ & $5.85 \times 10^{-5}$ \\
\hline SEC & $2.90 \times 10^{-4}$ & $1.51 \times 10^{-4}$ & $1.19 \times 10^{-4}$ & $7.96 \times 10^{-5}$ & $8.03 \times 10^{-5}$ & $5.37 \times 10^{-5}$ & $2.56 \times 10^{-4}$ & $1.35 \times 10^{-4}$ & $4.33 \times 10^{-5}$ \\
\hline SMR & $5.96 \times 10^{-4}$ & $2.50 \times 10^{-4}$ & $5.77 \times 10^{-5}$ & $5.25 \times 10^{-5}$ & $7.51 \times 10^{-5}$ & $7.10 \times 10^{-5}$ & $3.39 \times 10^{-4}$ & $1.81 \times 10^{-4}$ & $5.74 \times 10^{-5}$ \\
\hline WEE & $3.53 \times 10^{-4}$ & $1.65 \times 10^{-4}$ & $4.55 \times 10^{-5}$ & $0.00 \times 10^{0}$ & $0.00 \times 10^{0}$ & $1.53 \times 10^{-4}$ & $2.51 \times 10^{-4}$ & $1.37 \times 10^{-4}$ & $4.55 \times 10^{-5}$ \\
\hline WFF & $4.07 \times 10^{-4}$ & $1.72 \times 10^{-4}$ & $4.22 \times 10^{-5}$ & $1.92 \times 10^{-5}$ & $3.85 \times 10^{-5}$ & $5.22 \times 10^{-5}$ & $3.26 \times 10^{-4}$ & $1.52 \times 10^{-4}$ & $4.22 \times 10^{-5}$ \\
\hline \multirow[t]{2}{*}{ WSS } & $4.40 \times 10^{-4}$ & $1.82 \times 10^{-4}$ & $4.29 \times 10^{-4}$ & $0.00 \times 10^{0}$ & $0.00 \times 10^{0}$ & $5.29 \times 10^{-5}$ & $2.51 \times 10^{-4}$ & $1.32 \times 10^{-4}$ & $4.26 \times 10^{-5}$ \\
\hline & \multicolumn{3}{|c|}{${ }^{137} \mathrm{Cs}$} & \multicolumn{3}{|c|}{${ }^{60} \mathrm{Co}$} & & & \\
\hline MLR & $5.29 \times 10^{-4}$ & $1.18 \times 10^{-3}$ & $1.43 \times 10^{-3}$ & $-5.03 \times 10^{-3}$ & $1.68 \times 10^{-3}$ & $1.84 \times 10^{-3}$ & & & \\
\hline SEC & $9.47 \times 10^{-5}$ & $1.22 \times 10^{-3}$ & $1.44 \times 10^{-3}$ & $1.75 \times 10^{-3}$ & $1.51 \times 10^{-3}$ & $1.88 \times 10^{-3}$ & & & \\
\hline SMR & $-1.28 \times 10^{-3}$ & $2.00 \times 10^{-3}$ & $2.11 \times 10^{-3}$ & $1.49 \times 10^{-3}$ & $2.06 \times 10^{-3}$ & $2.55 \times 10^{-3}$ & & & \\
\hline WEE & $-1.91 \times 10^{-3}$ & $1.92 \times 10^{-3}$ & $1.95 \times 10^{-3}$ & $-9.51 \times 10^{-4}$ & $2.02 \times 10^{-3}$ & $2.22 \times 10^{-3}$ & & & \\
\hline WFF & $6.73 \times 10^{-4}$ & $1.21 \times 10^{-3}$ & $1.46 \times 10^{-3}$ & $1.62 \times 10^{-4}$ & $1.61 \times 10^{-3}$ & $1.84 \times 10^{-3}$ & & & \\
\hline \multirow[t]{2}{*}{ WSS } & $-2.10 \times 10^{-4}$ & $1.76 \times 10^{-3}$ & $1.96 \times 10^{-3}$ & $1.80 \times 10^{-3}$ & $1.83 \times 10^{-3}$ & $2.33 \times 10^{-3}$ & & & \\
\hline & \multicolumn{3}{|c|}{${ }^{90} \mathrm{Sr}$} & \multicolumn{3}{|c|}{${ }^{40} \mathrm{~K}$} & & & \\
\hline MLR & $4.26 \times 10^{-3}$ & $4.92 \times 10^{-3}$ & $8.10 \times 10^{-3}$ & $4.37 \times 10^{-1}$ & $6.51 \times 10^{-2}$ & $2.03 \times 10^{-2}$ & & & \\
\hline SEC & $3.27 \times 10^{-3}$ & $5.03 \times 10^{-3}$ & $8.40 \times 10^{-3}$ & $2.92 \times 10^{-1}$ & $4.55 \times 10^{-2}$ & $1.83 \times 10^{-2}$ & & & \\
\hline SMR & $3.32 \times 10^{-3}$ & $3.70 \times 10^{-3}$ & $6.11 \times 10^{-3}$ & $8.47 \times 10^{-1}$ & $1.22 \times 10^{-1}$ & $2.15 \times 10^{-2}$ & & & \\
\hline WEE & $1.04 \times 10^{-2}$ & $3.54 \times 10^{-3}$ & $5.22 \times 10^{-3}$ & $5.62 \times 10^{-1}$ & $8.36 \times 10^{-2}$ & $1.82 \times 10^{-2}$ & & & \\
\hline WFF & $1.54 \times 10^{-2}$ & $3.89 \times 10^{-3}$ & $5.37 \times 10^{-3}$ & $5.66 \times 10^{-1}$ & $8.25 \times 10^{-2}$ & $1.83 \times 10^{-2}$ & & & \\
\hline WSS & $9.36 \times 10^{-3}$ & $3.42 \times 10^{-3}$ & $5.11 \times 10^{-3}$ & $4.70 \times 10^{-1}$ & $7.03 \times 10^{-2}$ & $1.48 \times 10^{-2}$ & & & \\
\hline
\end{tabular}

${ }^{a}$ Radionuclide concentration

b Total propagated uncertainty

${ }^{\mathrm{C}}$ Minimum detectable concentration

Note: An anomaly in the Canberra software for the alpha spectrometer prevents it from calculating uncertainty when the activity is 0 .

A duplicate analysis of the vegetation sample from SEC was performed for all the radionuclides of interest (Table 4.20). Concentrations of ${ }^{234} \mathrm{U},{ }^{238} \mathrm{U}$, and ${ }^{40} \mathrm{~K}$ were above 


\section{Waste Isolation Pilot Plant 2002 Site Environmental Report DOE/WIPP 03-2225}

detection limits in the duplicate sample. Relative Error Ratio value exceeded one for ${ }^{40} \mathrm{~K}$, indicating a nonhomogenous sample.

Table 4.20 - Results of Duplicate Vegetation Sample Analysis. Units are Bq/g.

See Appendix $B$ for the sampling locations.

\begin{tabular}{|c|c|c|c|c|c|c|c|c|}
\hline \multirow[b]{2}{*}{ Location } & {$[\mathrm{RN}]^{\mathrm{a}}$} & $2 \times T^{\prime} U^{b}$ & $M^{\prime} C^{c}$ & RER $^{d}$ & [RN] & $2 \times$ TPU & MDC & RER \\
\hline & \multicolumn{4}{|c|}{${ }^{234} U$} & \multicolumn{4}{|c|}{${ }^{40} \mathrm{~K}$} \\
\hline SEC & $2.90 \times 10^{-4}$ & $1.51 \times 10^{-4}$ & $1.19 \times 10^{-4}$ & 0.7 & $2.92 \times 10^{-1}$ & $4.55 \times 10^{-2}$ & $1.83 \times 10^{-2}$ & 1.77 \\
\hline \multirow[t]{2}{*}{ SEC Dup. } & $4.55 \times 10^{-4}$ & $1.81 \times 10^{-4}$ & $4.11 \times 10^{-5}$ & & $4.33 \times 10^{-1}$ & $6.55 \times 10^{-2}$ & $1.71 \times 10^{-2}$ & \\
\hline & & ${ }^{238} \mathrm{U}$ & & & & & & \\
\hline SEC & $2.56 \times 10^{-4}$ & $1.35 \times 10^{-4}$ & $4.33 \times 10^{-5}$ & 0.92 & & & & \\
\hline SEC Dup. & $4.66 \times 10^{-4}$ & $1.84 \times 10^{-4}$ & $4.07 \times 10^{-5}$ & & & & & \\
\hline
\end{tabular}

${ }^{a}$ Radionuclide concentration

${ }^{\mathrm{b}}$ Total propagated uncertainty

${ }^{\mathrm{c}}$ Minimum detectable concentration

${ }^{\mathrm{d}}$ Relative error ratio

\section{$\underline{\text { Animals }}$}

Of the radionuclides of interest, ${ }^{234} \mathrm{U},{ }^{238} \mathrm{U}$, and ${ }^{40} \mathrm{~K}$ were detected in deer and quail tissue (Table 4.21). The mean concentrations were similar to year 2001. These results can be used only as a gross indication of uptakes, as the sample sizes are too small to provide a robust analysis.

Table 4.21 - Radionuclide Concentrations (Bq/g Wet Mass) in Deer and Quail Near the WIPP Site

\begin{tabular}{|c|c|c|c|c|c|c|c|c|c|}
\hline \multirow[b]{2}{*}{$\begin{array}{l}\text { Sample } \\
\text { Type }\end{array}$} & {$[\mathrm{RN}]^{\mathrm{a}}$} & $2 \times T_{P U^{b}}^{b}$ & $\mathrm{MDC}^{\mathrm{c}}$ & [RN] & $2 \times T P U$ & MDC & [RN] & $2 \times T P U$ & MDC \\
\hline & \multicolumn{3}{|c|}{${ }^{241} \mathrm{Am}$} & \multicolumn{3}{|c|}{${ }^{238} \mathrm{Pu}$} & \multicolumn{3}{|c|}{${ }^{239} \mathrm{Pu}$} \\
\hline Deer $^{d}$ & $7.01 \times 10^{-7}$ & $1.66 \times 10^{-6}$ & $1.15 \times 10^{-6}$ & $7.17 \times 10^{-7}$ & $6.68 \times 10^{-7}$ & $5.39 \times 10^{-7}$ & $1.20 \times 10^{-7}$ & $3.31 \times 10^{-7}$ & $5.39 \times 10^{-7}$ \\
\hline \multirow[t]{2}{*}{ Quail $^{\mathrm{e}}$} & $2.58 \times 10^{-6}$ & $2.01 \times 10^{-6}$ & $9.98 \times 10^{-7}$ & $0.00 \times 10^{0}$ & $0.00 \times 10^{0}$ & $1.75 \times 10^{-6}$ & $7.13 \times 10^{-7}$ & $8.32 \times 10^{-7}$ & $6.44 \times 10^{-7}$ \\
\hline & \multicolumn{3}{|c|}{${ }^{234} \mathrm{U}$} & \multicolumn{3}{|c|}{${ }^{235} U$} & \multicolumn{3}{|c|}{${ }^{238} \mathrm{U}$} \\
\hline Deer & $2.67 \times 10^{-6}$ & $9.70 \times 10^{-7}$ & $2.54 \times 10^{-7}$ & $1.86 \times 10^{-7}$ & $0.00 \times 10^{0}$ & $1.68 \times 10^{-7}$ & $2.91 \times 10^{-6}$ & $2.49 \times 10^{-6}$ & $2.53 \times 10^{-7}$ \\
\hline \multirow[t]{2}{*}{ Quail } & $6.07 \times 10^{-5}$ & $1.16 \times 10^{-5}$ & $5.39 \times 10^{-7}$ & $3.19 \times 10^{-6}$ & $1.84 \times 10^{-6}$ & $6.65 \times 10^{-7}$ & $5.65 \times 10^{-5}$ & $1.09 \times 10^{-5}$ & $1.46 \times 10^{-6}$ \\
\hline & & ${ }^{137} \mathrm{Cs}$ & & & ${ }^{60} \mathrm{Co}$ & & & & \\
\hline Deer & $3.39 \times 10^{-5}$ & $6.14 \times 10^{-5}$ & $1.51 \times 10^{-4}$ & $-3.06 \times 10^{-5}$ & $6.35 \times 10^{-5}$ & $1.99 \times 10^{-4}$ & & & \\
\hline \multirow[t]{2}{*}{ Quail } & $\frac{-}{4.22 \times 10^{-5}}$ & $5.88 \times 10^{-4}$ & $6.55 \times 10^{-4}$ & $2.49 \times 10^{-4}$ & $6.79 \times 10^{-4}$ & $8.07 \times 10^{-4}$ & & & \\
\hline & & ${ }^{90} \mathrm{Sr}$ & & & ${ }^{40} \mathrm{~K}$ & & & & \\
\hline Deer & $\begin{array}{c}- \\
3.97 \times 10^{-6}\end{array}$ & $8.51 \times 10^{-6}$ & $2.04 \times 10^{-6}$ & $1.18 \times 10^{-1}$ & $6.93 \times 10^{-3}$ & $2.04 \times 10^{-3}$ & & & \\
\hline Quail & $2.15 \times 10^{-4}$ & $1.02 \times 10^{-4}$ & $1.55 \times 10^{-4}$ & $1.12 \times 10^{-1}$ & $1.77 \times 10^{-2}$ & $7.41 \times 10^{-3}$ & & & \\
\hline
\end{tabular}

a Radionuclide concentration

b Total propagated uncertainty

${ }^{c}$ Minimum detectable concentration

${ }^{\mathrm{d}}$ Mean of two samples collected near WIPP. TPU represents the standard deviation of the mean.

e Single sample

Note: An anomaly in the Canberra software for the alpha spectrometer prevents it from calculating uncertainty when the activity is 0 .

Uranium-234 and ${ }^{238} \mathrm{U}$ were detected in all the fish samples. Uranium-235 was detected in 25 percent of the fish samples (Table 4.22). Neither ${ }^{238} \mathrm{Pu}$ or ${ }^{241} \mathrm{Am}$ isotope was detected in fish. Plutonium-239 was detected once in the fish samples. 


\section{Waste Isolation Pilot Plant 2002 Site Environmental Report DOE/WIPP 03-2225}

Cesium-137, ${ }^{60} \mathrm{Co}$, and ${ }^{90} \mathrm{Sr}$ were not detected in any of the fish samples (Table 4.22). Potassium-40 was detected in 88 percent of the fish (Table 4.22). It was lowest in the sample from BRA $\left(4.95 \times 10^{-2} \pm 2.12 \times 10^{-2} \mathrm{~Bq} / \mathrm{g}\left[1.34 \times 10^{0} \pm 5.72 \times 10^{-1} \mathrm{pCi} / \mathrm{g}\right]\right)$, and highest in the sample from SOO $\left(2.89 \times 10^{-1} \pm 4.77 \times 10^{-2} \mathrm{~Bq} / \mathrm{g}\left[7.80 \times 10^{0} \pm\right.\right.$ $\left.1.29 \times 10^{\circ} \mathrm{pCi} / \mathrm{g}\right]$ ).

Table 4.22 - Radionuclide Concentrations (Bq/g Wet Mass) in Fish Near the WIPP Site. See Appendix $B$ for the sampling locations.

\begin{tabular}{|c|c|c|c|c|c|c|c|c|c|}
\hline \multirow[b]{2}{*}{ Location } & {$[\mathbf{R N}]^{\mathrm{a}}$} & $2 \times T_{P U^{b}}$ & MDC $^{c}$ & [RN] & $2 \times T P U$ & MDC & [RN] & $2 \times T P U$ & MDC \\
\hline & \multicolumn{3}{|c|}{${ }^{241} \mathrm{Am}$} & \multicolumn{3}{|c|}{${ }^{238} \mathrm{Pu}$} & \multicolumn{3}{|c|}{${ }^{239} \mathrm{Pu}$} \\
\hline BRA & $4.33 \times 10^{-6}$ & $6.18 \times 10^{-6}$ & $5.85 \times 10^{-6}$ & $1.29 \times 10^{-5}$ & $1.94 \times 10^{-5}$ & $3.16 \times 10^{-5}$ & $0.00 \times 10^{0}$ & $0.00 \times 10^{0}$ & $1.16 \times 10^{-5}$ \\
\hline BRA & $2.12 \times 10^{-6}$ & $4.26 \times 10^{-6}$ & $5.74 \times 10^{-6}$ & $3.74 \times 10^{-5}$ & $3.85 \times 10^{-5}$ & $2.53 \times 10^{-5}$ & $0.00 \times 10^{0}$ & $0.00 \times 10^{0}$ & $2.53 \times 10^{-5}$ \\
\hline BRA & $3.01 \times 10^{-6}$ & $1.04 \times 10^{-5}$ & $2.22 \times 10^{-5}$ & $7.99 \times 10^{-6}$ & $9.29 \times 10^{-6}$ & $7.18 \times 10^{-6}$ & $0.00 \times 10^{0}$ & $0.00 \times 10^{0}$ & $7.18 \times 10^{-6}$ \\
\hline BRA & $5.33 \times 10^{-6}$ & $9.44 \times 10^{-6}$ & $1.65 \times 10^{-5}$ & $1.14 \times 10^{-6}$ & $2.28 \times 10^{-6}$ & $3.07 \times 10^{-6}$ & $1.25 \times 10^{-5}$ & $7.77 \times 10^{-6}$ & $3.07 \times 10^{-6}$ \\
\hline PEC & $2.91 \times 10^{-6}$ & $4.14 \times 10^{-6}$ & $3.92 \times 10^{-6}$ & $4.40 \times 10^{-6}$ & $8.88 \times 10^{-6}$ & $1.19 \times 10^{-5}$ & $0.00 \times 10^{0}$ & $0.00 \times 10^{0}$ & $1.19 \times 10^{-5}$ \\
\hline PEC & $5.74 \times 10^{-6}$ & $8.18 \times 10^{-6}$ & $7.77 \times 10^{-6}$ & $9.84 \times 10^{-5}$ & $2.02 \times 10^{-4}$ & $3.61 \times 10^{-4}$ & $0.00 \times 10^{0}$ & $0.00 \times 10^{0}$ & $1.33 \times 10^{-4}$ \\
\hline $\mathrm{SOO}^{\mathrm{d}}$ & $3.23 \times 10^{-6}$ & $4.59 \times 10^{-6}$ & $4.37 \times 10^{-6}$ & $6.55 \times 10^{-5}$ & $9.58 \times 10^{-5}$ & $1.52 \times 10^{-4}$ & $1.63 \times 10^{-5}$ & $3.32 \times 10^{-5}$ & $4.44 \times 10^{-5}$ \\
\hline \multirow[t]{2}{*}{$\mathrm{SOO}^{\mathrm{d}}$} & $4.86 \times 10^{-6}$ & $7.25 \times 10^{-6}$ & $1.19 \times 10^{-5}$ & $1.56 \times 10^{-6}$ & $5.40 \times 10^{-6}$ & $1.15 \times 10^{-5}$ & $0.00 \times 10^{0}$ & $0.00 \times 10^{0}$ & $4.22 \times 10^{-6}$ \\
\hline & \multicolumn{3}{|c|}{${ }^{234} \mathrm{U}$} & \multicolumn{3}{|c|}{${ }^{235} \mathrm{U}$} & \multicolumn{3}{|c|}{${ }^{238} \mathrm{U}$} \\
\hline BRA & $3.55 \times 10^{-4}$ & $7.51 \times 10^{-5}$ & $4.92 \times 10^{-6}$ & $6.70 \times 10^{-6}$ & $7.81 \times 10^{-6}$ & $6.07 \times 10^{-6}$ & $1.59 \times 10^{-4}$ & $4.18 \times 10^{-5}$ & $4.88 \times 10^{-6}$ \\
\hline BRA & $1.44 \times 10^{-4}$ & $4.11 \times 10^{-5}$ & $5.48 \times 10^{-6}$ & $-2.50 \times 10^{-6}$ & $5.03 \times 10^{-6}$ & $1.84 \times 10^{-5}$ & $1.01 \times 10^{-4}$ & $3.26 \times 10^{-5}$ & $5.48 \times 10^{-6}$ \\
\hline BRA & $2.67 \times 10^{-4}$ & $6.88 \times 10^{-5}$ & $2.01 \times 10^{-5}$ & $6.73 \times 10^{-6}$ & $1.35 \times 10^{-5}$ & $2.48 \times 10^{-5}$ & $1.11 \times 10^{-4}$ & $3.89 \times 10^{-5}$ & $7.36 \times 10^{-6}$ \\
\hline BRA & $3.66 \times 10^{-4}$ & $6.99 \times 10^{-5}$ & $3.19 \times 10^{-6}$ & $8.73 \times 10^{-6}$ & $8.33 \times 10^{-6}$ & $1.07 \times 10^{-5}$ & $2.12 \times 10^{-4}$ & $4.55 \times 10^{-5}$ & $3.18 \times 10^{-6}$ \\
\hline PEC & $9.99 \times 10^{-4}$ & $1.71 \times 10^{-4}$ & $8.88 \times 10^{-6}$ & $2.08 \times 10^{-5}$ & $1.16 \times 10^{-5}$ & $4.03 \times 10^{-6}$ & $4.40 \times 10^{-4}$ & $8.25 \times 10^{-5}$ & $3.26 \times 10^{-6}$ \\
\hline PEC & $2.60 \times 10^{-4}$ & $6.99 \times 10^{-5}$ & $8.40 \times 10^{-6}$ & $-3.81 \times 10^{-6}$ & $7.66 \times 10^{-6}$ & $2.82 \times 10^{-5}$ & $9.58 \times 10^{-5}$ & $3.85 \times 10^{-5}$ & $2.28 \times 10^{-5}$ \\
\hline $\mathrm{SOO}^{\mathrm{d}}$ & $8.55 \times 10^{-4}$ & $1.54 \times 10^{-4}$ & $1.16 \times 10^{-5}$ & $1.16 \times 10^{-5}$ & $1.11 \times 10^{-5}$ & $1.43 \times 10^{-5}$ & $3.60 \times 10^{-4}$ & $7.44 \times 10^{-5}$ & $1.15 \times 10^{-5}$ \\
\hline \multirow[t]{2}{*}{$\mathrm{SOO}^{\mathrm{d}}$} & $7.10 \times 10^{-4}$ & $1.23 \times 10^{-4}$ & $2.83 \times 10^{-6}$ & $1.67 \times 10^{-5}$ & $9.62 \times 10^{-6}$ & $3.49 \times 10^{-6}$ & $3.64 \times 10^{-4}$ & $6.88 \times 10^{-5}$ & $2.81 \times 10^{-6}$ \\
\hline & \multicolumn{3}{|c|}{${ }^{137} \mathrm{Cs}$} & \multicolumn{3}{|c|}{${ }^{60} \mathrm{Co}$} & & & \\
\hline BRA & $1.64 \times 10^{-3}$ & $8.33 \times 10^{-4}$ & $2.09 \times 10^{-3}$ & $-7.10 \times 10^{-4}$ & $4.59 \times 10^{-3}$ & $4.85 \times 10^{-3}$ & & & \\
\hline BRA & $1.49 \times 10^{-3}$ & $2.01 \times 10^{-3}$ & $2.49 \times 10^{-3}$ & $5.81 \times 10^{-4}$ & $2.81 \times 10^{-3}$ & $3.25 \times 10^{-3}$ & & & \\
\hline BRA & $-6.14 \times 10^{-}$ & $6.70 \times 10^{-3}$ & $6.62 \times 10^{-3}$ & $5.37 \times 10^{-3}$ & $6.51 \times 10^{-3}$ & $7.18 \times 10^{-3}$ & & & \\
\hline BRA & $-4.74 \times 10^{-}$ & $2.53 \times 10^{-3}$ & $2.86 \times 10^{-3}$ & $1.62 \times 10^{-3}$ & $2.66 \times 10^{-3}$ & $2.99 \times 10^{-3}$ & & & \\
\hline PEC & $3.08 \times 10^{-4}$ & $1.30 \times 10^{-3}$ & $1.55 \times 10^{-3}$ & $-3.63 \times 10^{-4}$ & $1.66 \times 10^{-3}$ & $1.84 \times 10^{-3}$ & & & \\
\hline PEC & $-9.73 ̧ \times 10^{-}$ & $7.96 \times 10^{-3}$ & $7.66 \times 10^{-3}$ & $-4.14 \times 10^{-3}$ & $8.18 \times 10^{-3}$ & $8.33 \times 10^{-3}$ & & & \\
\hline $\mathrm{SOO}^{d}$ & $-2.86 \times 10^{-}$ & $1.61 \times 10^{-4}$ & $1.86 \times 10^{-3}$ & $1.61 \times 10^{-3}$ & $1.97 \times 10^{-3}$ & $2.41 \times 10^{-3}$ & & & \\
\hline \multirow[t]{2}{*}{$\mathrm{SOO}^{d}$} & $8.95 \times 10^{-4}$ & $1.12 \times 10^{-3}$ & $1.37 \times 10^{-3}$ & $-3.77 \times 10^{-5}$ & $1.46 \times 10^{-3}$ & $1.65 \times 10^{-3}$ & & & \\
\hline & \multicolumn{3}{|c|}{${ }^{90} \mathrm{Sr}$} & \multicolumn{3}{|c|}{${ }^{40} \mathrm{~K}$} & & & \\
\hline BRA & $3.53 \times 10^{-4}$ & $2.87 \times 10^{-4}$ & $4.81 \times 10^{-4}$ & $1.54 \times 10^{-1}$ & $4.29 \times 10^{-2}$ & $5.40 \times 10^{-2}$ & & & \\
\hline BRA & $5.81 \times 10^{-5}$ & $3.40 \times 10^{-4}$ & $5.99 \times 10^{-4}$ & $4.59 \times 10^{-2}$ & $2.12 \times 10^{-2}$ & $2.97 \times 10^{-2}$ & & & \\
\hline BRA & $8.81 \times 10^{-4}$ & $5.44 \times 10^{-4}$ & $8.88 \times 10^{-4}$ & $9.77 \times 10^{-2}$ & $4.51 \times 10^{-2}$ & $6.62 \times 10^{-2}$ & & & \\
\hline BRA & $2.35 \times 10^{-4}$ & $1.98 \times 10^{-4}$ & $3.34 \times 10^{-4}$ & $1.22 \times 10^{-1}$ & $2.68 \times 10^{-2}$ & $2.81 \times 10^{-2}$ & & & \\
\hline PEC & $3.03 \times 10^{-4}$ & $2.08 \times 10^{-4}$ & $3.44 \times 10^{-4}$ & $1.94 \times 10^{-1}$ & $3.29 \times 10^{-2}$ & $2.05 \times 10^{-2}$ & & & \\
\hline PEC & $5.18 \times 10^{-4}$ & $5.07 \times 10^{-4}$ & $8.73 \times 10^{-4}$ & $6.40 \times 10^{-2}$ & $5.03 \times 10^{-2}$ & $7.88 \times 10^{-2}$ & & & \\
\hline $\mathrm{SOO}^{\mathrm{d}}$ & $3.34 \times 10^{-4}$ & $2.56 \times 10^{-4}$ & $4.29 \times 10^{-4}$ & $2.89 \times 10^{-1}$ & $4.77 \times 10^{-2}$ & $2.76 \times 10^{-2}$ & & & \\
\hline $\mathrm{SOO}^{\mathrm{d}}$ & $1.17 \times 10^{-4}$ & $1.75 \times 10^{-4}$ & $3.01 \times 10^{-4}$ & $1.99 \times 10^{-1}$ & $3.36 \times 10^{-2}$ & $2.21 \times 10^{-2}$ & & & \\
\hline \multicolumn{10}{|c|}{$\begin{array}{l}\text { a }[\mathrm{RN}]=\text { Radionuclide concentration } \\
\text { b Total propagated uncertainty } \\
{ }^{\mathrm{c}} \text { Minimum detectable concentration } \\
{ }^{\mathrm{d}} \text { Located at } 10-\text { mile dam }\end{array}$} \\
\hline
\end{tabular}


the activity is 0 .

\subsection{Summary and Conclusion}

The Environmental Monitoring Program collected samples of air particulates, soil, sediment, groundwater, surface water, and biota and analyzed them for radionuclides considered to be indicators of potential contamination from the WIPP facility, as well as other radionuclides of potential interest. Measured concentrations were examined for evidence of WIPP-related contamination, such as higher concentrations of TRU radionuclides after 1998, or higher concentrations in downwind or down gradient directions. Radionuclide concentrations observed were very small and were highly variable in space and time and between media. However, no time or space relationships related to WIPP were observed, and concentrations were consistent with background levels (DOE/WIPP 92-037). In no case, could environmental concentrations be attributed to WIPP releases. In addition, no events occurred at WIPP which would have led to a release. 
This page intentionally left blank 


\section{CHAPTER 5 - ENVIRONMENTAL NONRADIOLOGICAL PROGRAM INFORMATION}

This chapter discusses nonradiological environmental surveillance data collected between January 1 and December 31, 2002. Nonradiological programs at WIPP include wildlife population monitoring, meteorological monitoring, and seismic monitoring. In addition, VOCs were monitored to comply with the provisions of WIPP's hazardous waste permit, and liquid effluent monitoring was conducted in accordance with WIPP's Discharge Plan (DP-831).

\subsection{Principal Functions of Nonradiological Sampling}

The principal functions of the nonradiological environmental surveillance program are to:

- $\quad$ Assess the impacts of WIPP operations on the surrounding ecosystem;

- Monitor ecological conditions in the Los Medaños region;

- Investigate unusual or unexpected elements in the ecological databases;

- $\quad$ Provide environmental data which are important to the mission of the WIPP project, but which have not or will not be acquired by other programs; and

- $\quad$ Comply with applicable commitments identified with existing agreements (e.g., BLM/DOE MOU, Interagency Agreements, etc.).

\subsection{WIPP Raptor Research Program}

WIPP, and the region surrounding it, is widely recognized for its concentration and diversity of raptors. The area is home to several raptor species of special concern, including Harris' hawks, Swainson's hawks, burrowing owls, and barn owls, as well as other species.

The DOE, the BLM, and other government agencies are aware of the value and importance of protecting and monitoring raptor populations. To assist in this effort at WIPP, the BLM and the DOE established the WRRP in the early 1990s to monitor and protect raptors on the WIPP site, and to educate site workers and the public about these birds. The WRRP is administrated by the WIPP Environmental Monitoring Program with input from the BLM. During 2002, scientific consultation, research direction, and field operations were conducted by scientists from Hawks Aloft Incorporated, a nonprofit biological consultant group.

Raptor research at WIPP began in 1981 when the DOE commissioned a study of the social behavior of Harris' hawks by the University of New Mexico. Research results revealed the extent of the overall raptor population, and provided new information about raptor species in the area. In the late 1980s, the BLM designated the Los Medaños Raptor Area, which included the WIPP site, as a National Key Raptor Area. This 


\section{Waste Isolation Pilot Plant 2002 Site Environmental Report DOE/WIPP 03-2225}

designation served as a catalyst for the development of the WRRP. Simultaneously, the DOE reorganized its program to encompass expanded objectives.

The WRRP presently serves three significant functions:

- $\quad$ Wildlife Monitoring. The WRRP provides the DOE, the BLM, and other agencies with current information about the status of raptor populations in and around WIPP.

- $\quad$ Scientific Research. WRRP staff conduct research on topics that contribute to the understanding of raptors in the desert southwest.

- Interagency Cooperation. The WRRP is funded by the DOE, but works closely with several other federal and state agencies.

In 2002, long-term studies of productivity and population demographics of the raptor community in and around WIPP continued. The primary objective for the 2002 nesting season was to locate all raptor and raven nests within the $3000 \mathrm{~km}^{2}$ study area, centered on WIPP. Secondary objectives were to estimate raptor productivity in the area and to determine causes of raptor mortality.

Intensive ground searches for nesting raptors began on May 29, 2002, and ended September 12, 2002. Nest locations, activity, productivity, species, and behavioral data were collected and documented. Included in this research protocol were extended behavioral observations. These aided in assessments of group size, foraging behaviors, fledging success, and prey items. A total of 20 occupied Harris' hawk territories were observed. The mean brood size per active nest was $1.83(n=6)$. Territorial occupancy average was 2.75 with group size ranging from one to five individuals. Fifty-five percent of territorial occupancy consisted of pairs.

Electrocution by power poles continues to be an important cause of raptor mortality and is predicted to increase as oil and gas exploration increases in the area. To date, objective evidence indicates that electrocutions and random shootings comprise the most common mortality factors of adult Harris' hawks in the study area. Egg and nestling attrition are more naturally related to climatic conditions and prey availability.

\subsection{Meteorology}

The primary WIPP meteorological station is located $600 \mathrm{~m}(1,970 \mathrm{ft})$ northeast of the Waste Handling Building. The main function of the station is to provide data for atmospheric dispersion modeling. The station measures and records wind speed, wind direction, and temperature at elevations of 2,10 , and $50 \mathrm{~m}(6.5,33$, and $165 \mathrm{ft})$. The station records ground-level measurements of barometric pressure, relative humidity, precipitation, and solar radiation. 


\subsubsection{Climatic Data}

The precipitation at the WIPP site for 2002 was $286 \mathrm{~mm}$ (11.2 in.), which was $46 \mathrm{~mm}$ (1.8 in.) less than the previous year's rainfall. Figure 5.1 displays the monthly precipitation at WIPP.

The mean temperature for the WIPP area in 2002 was $17.2^{\circ} \mathrm{C}\left(62.3^{\circ} \mathrm{F}\right)$. The mean monthly temperatures for the WIPP area ranged from $6.1^{\circ} \mathrm{C}\left(43^{\circ} \mathrm{F}\right)$ during December to $28^{\circ} \mathrm{C}\left(82.4^{\circ} \mathrm{F}\right)$ in July. Generally, maximum temperatures occurred from May through September, while minimum temperatures occurred in January, November, and December, as illustrated in Figures 5.2, 5.3, and 5.4 and Tables 5.1, 5.2, and 5.3. The lowest recorded temperature was $-10.4^{\circ} \mathrm{C}\left(13.3^{\circ} \mathrm{F}\right)$ in March. The maximum recorded temperature was $40.82^{\circ} \mathrm{C}\left(105.5^{\circ} \mathrm{F}\right)$ in August. The minimum and maximum temperatures were recorded at the 2-m location on the meteorological tower.

\subsubsection{Wind Direction and Wind Speed}

Winds in the WIPP area in 2002 blew predominantly from the southeast. Seasonal weather systems move through this area, briefly altering the predominant southeasterly winds and sometimes resulting in violent convectional storms. Wind speed measured at the 10-m (33-ft) level were calm (less than 0.5 meters per second [m/s]) $(1.1$ miles per hour [mph]) about 19.3 percent of the time. At the $10-\mathrm{m}$ level, winds of 0.5 through $1.41 \mathrm{~m} / \mathrm{s}$ ( 1.12 to $3.15 \mathrm{mph}$ ) were the most prevalent over 2002, occurring 39.3 percent of the time. Figures 5.5, 5.6, and 5.7 and Tables 5.4, 5.5, and 5.6 display the annual wind data at WIPP for 2002. 
Waste Isolation Pilot Plant 2002 Site Environmental Report DOE/WIPP 03-2225

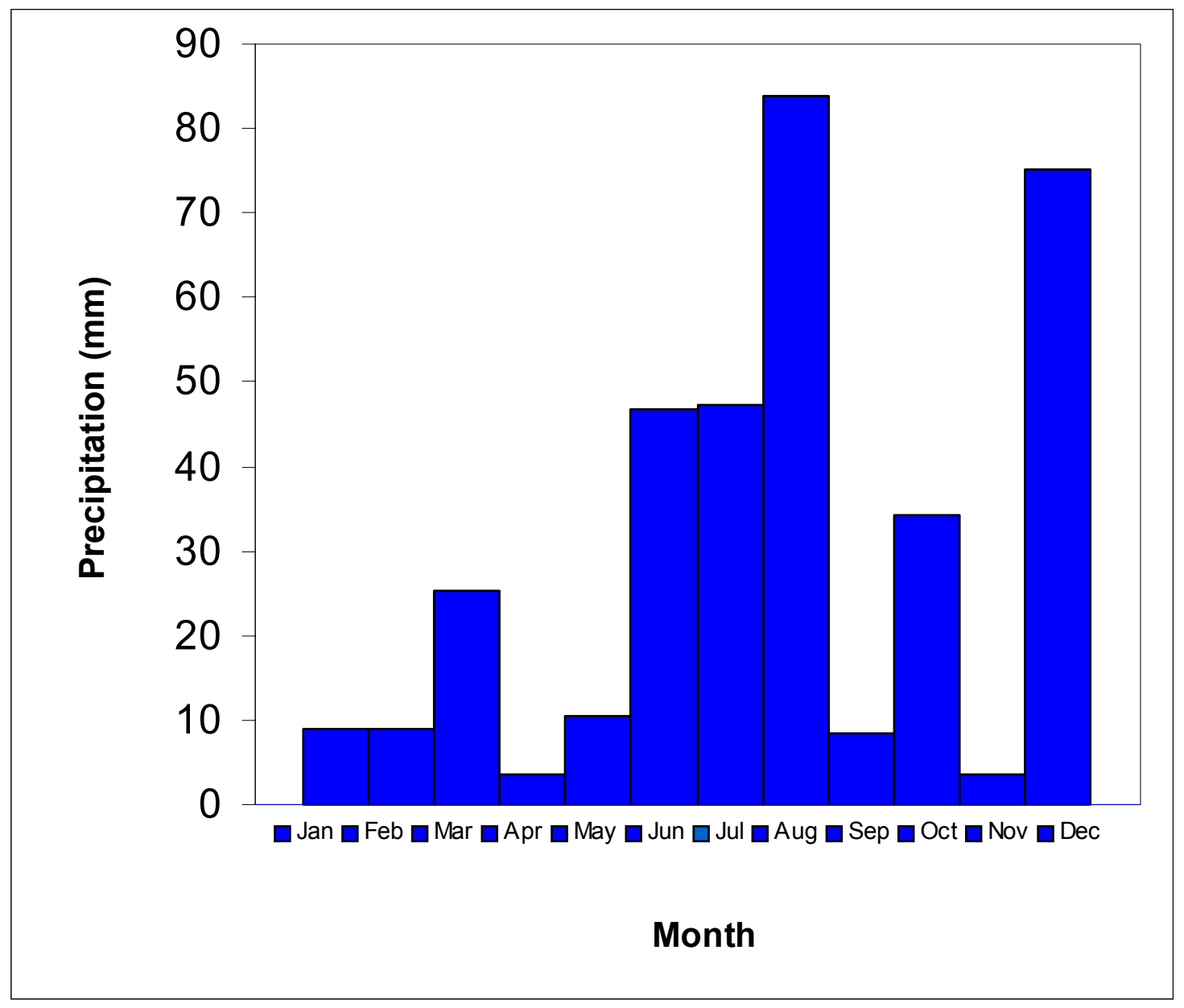

Figure 5.1 - 2002 Precipitation at WIPP 


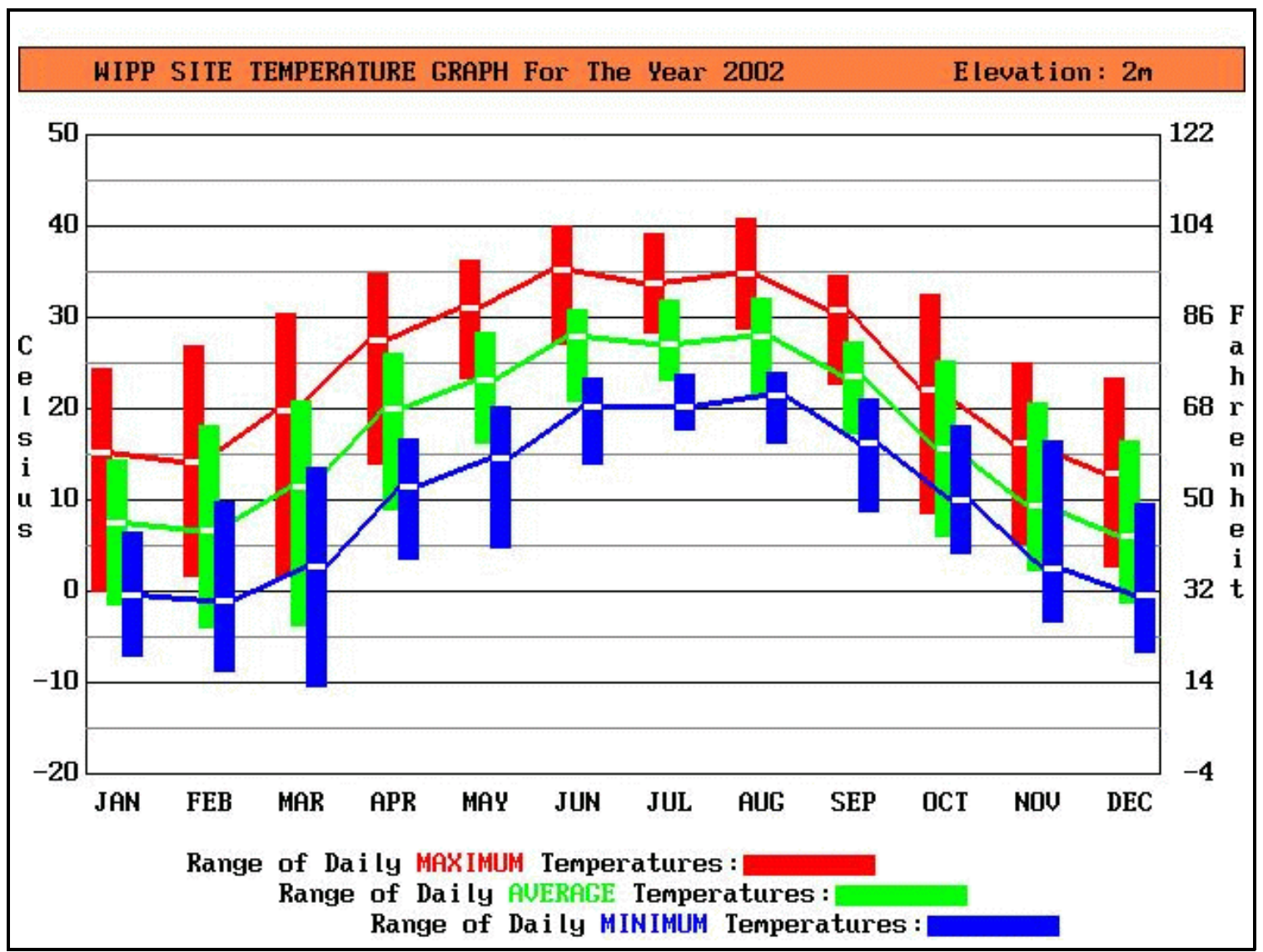

Figure 5.2 - 2002 WIPP Site Temperature at 2-Meter Height

Table 5.1 - A Summary of 2002 Temperature Observations at 2-Meter Height

\begin{tabular}{|c|c|c|c|c|c|c|c|c|c|}
\hline Month & $\begin{array}{c}\text { Max of } \\
\text { Daily } \\
\text { Highs } \\
\left({ }^{\circ} \mathrm{C}\right)\end{array}$ & $\begin{array}{l}\text { Avg of } \\
\text { Daily } \\
\text { Highs } \\
\left({ }^{\circ} \mathrm{C}\right) \\
\end{array}$ & $\begin{array}{c}\text { Min of } \\
\text { Daily } \\
\text { Highs } \\
\left({ }^{\circ} \mathrm{C}\right) \\
\end{array}$ & $\begin{array}{c}\text { Max } \\
\text { of Daily } \\
\text { Averages } \\
\left({ }^{\circ} \mathrm{C}\right) \\
\end{array}$ & $\begin{array}{c}\text { Avg of } \\
\text { Daily } \\
\text { Averages } \\
\left({ }^{\circ} \mathrm{C}\right) \\
\end{array}$ & $\begin{array}{c}\text { Min of } \\
\text { Daily } \\
\text { Averages } \\
\left({ }^{\circ} \mathrm{C}\right) \\
\end{array}$ & $\begin{array}{c}\text { Max of } \\
\text { Daily } \\
\text { Lows } \\
\left({ }^{\circ} \mathrm{C}\right) \\
\end{array}$ & $\begin{array}{l}\text { Avg of } \\
\text { Daily } \\
\text { Lows } \\
\left({ }^{\circ} \mathrm{C}\right) \\
\end{array}$ & $\begin{array}{l}\text { Min of } \\
\text { Daily } \\
\text { Lows } \\
\left({ }^{\circ} \mathrm{C}\right) \\
\end{array}$ \\
\hline Jan & 24.33 & 15.18 & -0.02 & 14.47 & 7.42 & -1.45 & 6.38 & -0.47 & -7.06 \\
\hline Feb & 26.95 & 14.13 & 1.75 & 18.11 & 6.67 & -4 & 9.89 & -1 & -8.82 \\
\hline Mar & 30.33 & 19.70 & 1.66 & 20.83 & 11.36 & -3.65 & 13.57 & 2.68 & -10.44 \\
\hline Apr & 34.8 & 27.49 & 14.04 & 26.11 & 19.9 & 8.86 & 16.72 & 11.53 & 3.56 \\
\hline May & 36.24 & 31.02 & 23.37 & 28.38 & 23.11 & 16.27 & 20.23 & 14.66 & 4.88 \\
\hline Jun & 40.01 & 35.19 & 26.98 & 30.87 & 27.9 & 20.9 & 23.36 & 20.31 & 14.02 \\
\hline Jul & 39.23 & 33.69 & 28.33 & 31.83 & 27.08 & 23.12 & 23.82 & 20.27 & 17.73 \\
\hline Aug & 40.82 & 34.79 & 28.82 & 32.16 & 27.95 & 21.69 & 23.9 & 21.36 & 16.29 \\
\hline Sept & 34.54 & 30.90 & 22.72 & 27.3 & 23.47 & 17.25 & 20.98 & 16.16 & 8.84 \\
\hline Oct & 32.6 & 22.01 & 8.62 & 25.14 & 15.56 & 5.99 & 18.18 & 9.96 & 4.17 \\
\hline Nov & 25.1 & 16.16 & 5.13 & 20.62 & 9.54 & 2.22 & 16.4 & 2.46 & -3.42 \\
\hline $\mathrm{Dec}$ & 23.28 & 12.93 & 2.77 & 16.48 & 6.02 & -1.31 & 9.6 & -0.33 & -6.64 \\
\hline Annual & 40.82 & 24.43 & -0.02 & 32.16 & 17.16 & -4 & 23.9 & 9.8 & -10.44 \\
\hline
\end{tabular}


Waste Isolation Pilot Plant 2002 Site Environmental Report DOE/WIPP 03-2225

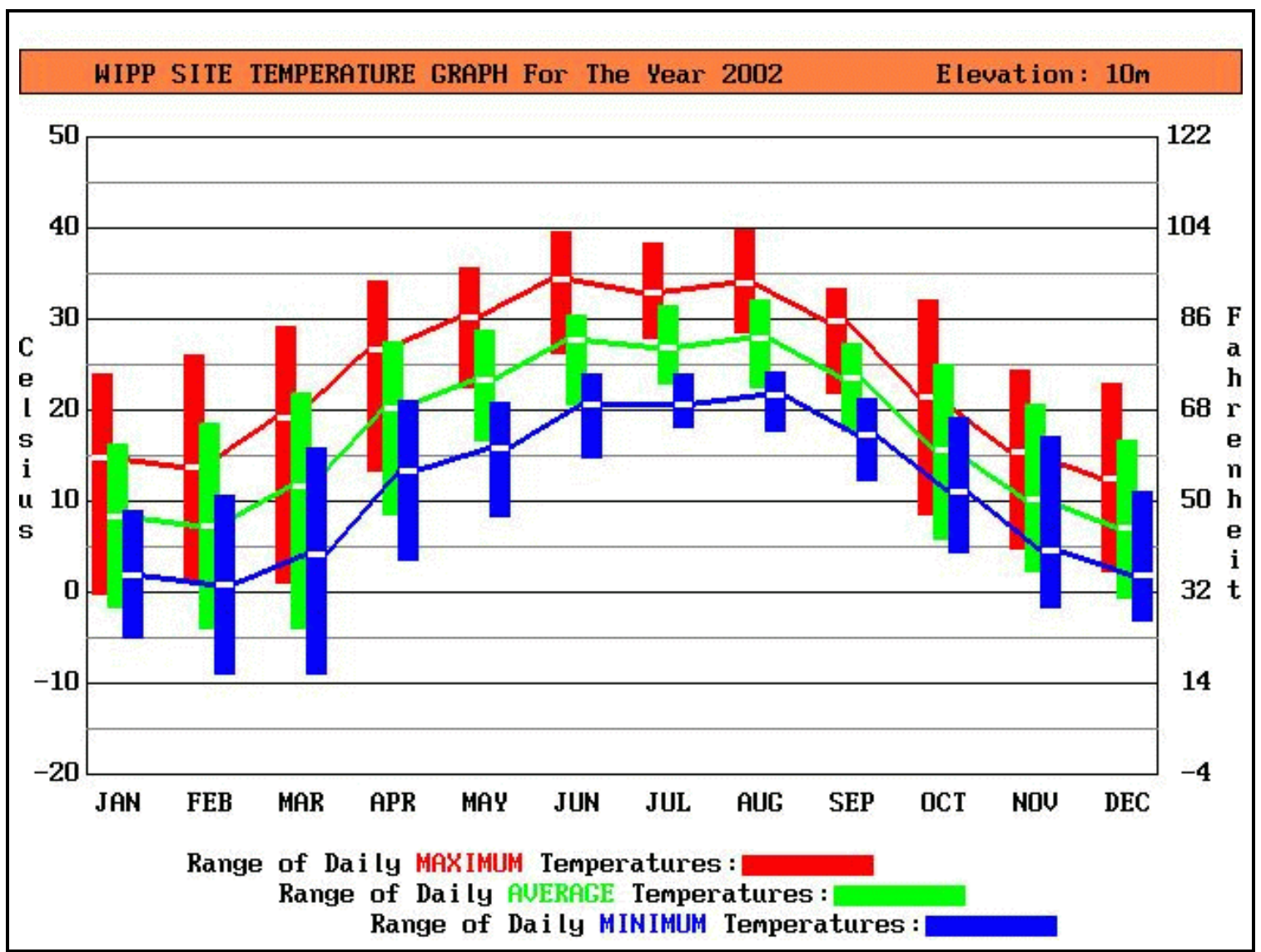

Figure 5.3 - 2002 WIPP Site Temperature at 10-Meter Height

Table 5.2 - A Summary of 2002 Temperature Observations at 10-Meter Height

\begin{tabular}{|c|c|c|c|c|c|c|c|c|c|}
\hline Month & $\begin{array}{l}\text { Max of } \\
\text { Daily } \\
\text { Highs } \\
\left({ }^{\circ} \mathrm{C}\right)\end{array}$ & $\begin{array}{l}\text { Avg of } \\
\text { Daily } \\
\text { Highs } \\
\left({ }^{\circ} \mathrm{C}\right)\end{array}$ & $\begin{array}{l}\text { Min of } \\
\text { Daily } \\
\text { Highs } \\
\left({ }^{\circ} \mathrm{C}\right)\end{array}$ & $\begin{array}{c}\text { Max of } \\
\text { Daily } \\
\text { Averages } \\
\left({ }^{\circ} \mathrm{C}\right)\end{array}$ & $\begin{array}{c}\text { Avg of } \\
\text { Daily } \\
\text { Averages } \\
\left({ }^{\circ} \mathrm{C}\right)\end{array}$ & $\begin{array}{c}\text { Min of } \\
\text { Daily } \\
\text { Averages } \\
\left({ }^{\circ} \mathrm{C}\right)\end{array}$ & $\begin{array}{l}\text { Max of } \\
\text { Daily } \\
\text { Lows } \\
\left({ }^{\circ} \mathrm{C}\right)\end{array}$ & $\begin{array}{l}\text { Avg of } \\
\text { Daily } \\
\text { Lows } \\
\left({ }^{\circ} \mathrm{C}\right)\end{array}$ & $\begin{array}{l}\text { Min of } \\
\text { Daily } \\
\text { Lows } \\
\left({ }^{\circ} \mathrm{C}\right)\end{array}$ \\
\hline Jan & 23.92 & 14.76 & -0.23 & 16.31 & 8.43 & -1.58 & 8.87 & 1.94 & -5.01 \\
\hline Feb & 26.04 & 13.67 & 1.20 & 18.52 & 7.3 & -4.03 & 10.67 & 0.9 & -8.87 \\
\hline Mar & 29.10 & 19.27 & 1.07 & 21.86 & 11.75 & -3.91 & 15.79 & 4.24 & -8.88 \\
\hline Apr & 34.16 & 26.67 & 13.31 & 27.46 & 20.18 & 8.5 & 21.14 & 13.4 & 3.54 \\
\hline May & 35.53 & 30.15 & 22.53 & 28.94 & 23.27 & 16.7 & 20.9 & 15.84 & 8.23 \\
\hline Jun & 39.57 & 34.34 & 26.15 & 30.51 & 27.65 & 20.56 & 23.87 & 20.63 & 14.89 \\
\hline Jul & 38.38 & 32.85 & 27.87 & 31.55 & 26.9 & 22.83 & 24.02 & 20.67 & 18.17 \\
\hline Aug & 39.81 & 34.05 & 28.51 & 32.12 & 27.89 & 22.4 & 24.14 & 21.77 & 17.76 \\
\hline Sep & 33.40 & 29.78 & 21.84 & 27.20 & 23.54 & 17.7 & 21.33 & 17.36 & 12.27 \\
\hline Oct & 32.04 & 21.40 & 8.52 & 24.91 & 15.71 & 5.75 & 19.19 & 11.01 & 4.28 \\
\hline Nov & 24.33 & 15.49 & 4.79 & 20.62 & 10.14 & 2.26 & 17.05 & 4.62 & -1.66 \\
\hline Dec & 22.82 & 12.45 & 2.33 & 16.76 & 7.13 & -0.72 & 10.98 & 1.92 & -3.19 \\
\hline Annual & 39.81 & 23.74 & -0.23 & 32.12 & 17.49 & -4.03 & 24.14 & 11.19 & -8.88 \\
\hline
\end{tabular}




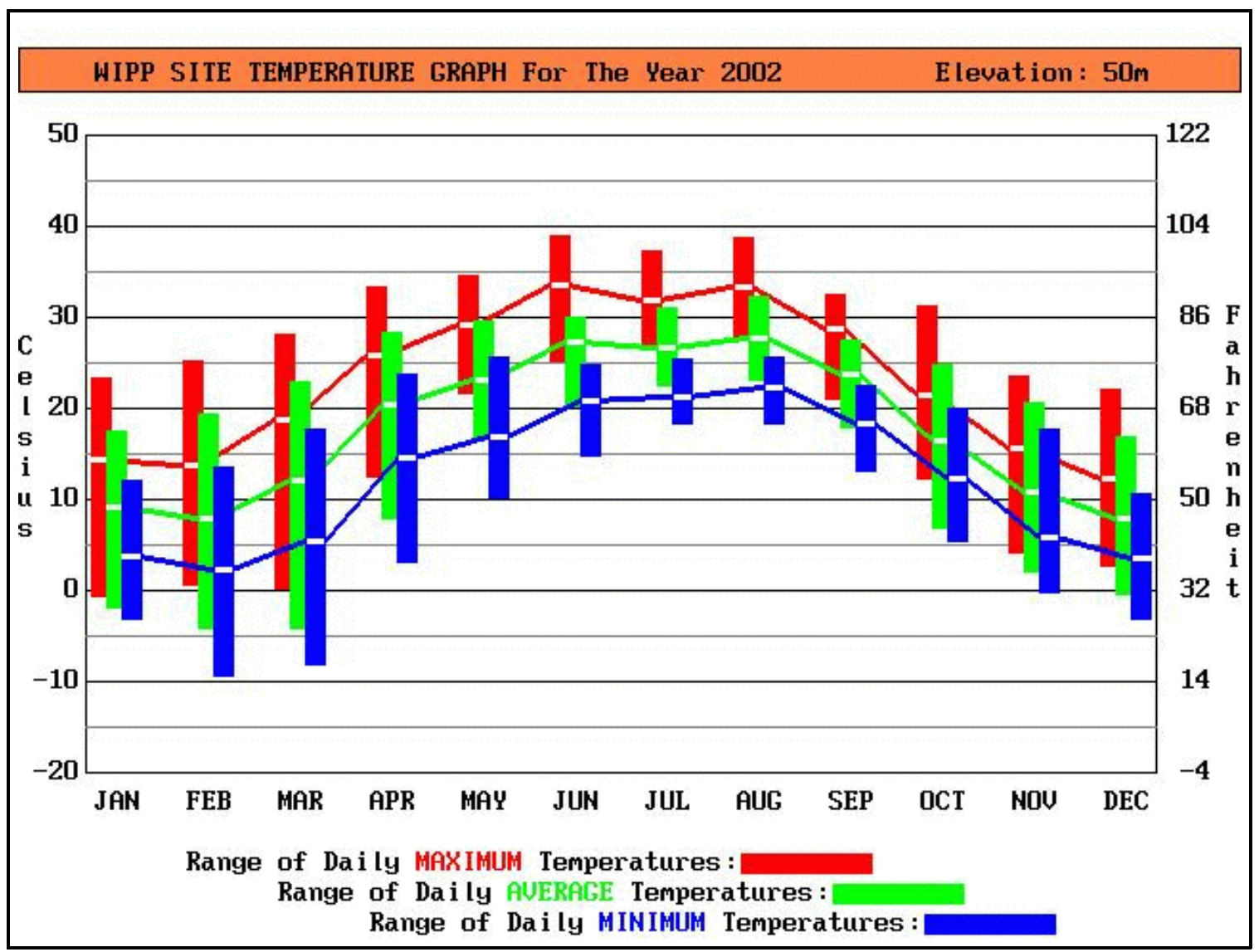

Figure 5.4 - 2002 WIPP Site Temperature at 50-Meter Height

Table 5.3 - A Summary of 2002 Temperature Observations at 50-Meter Height

\begin{tabular}{lccccccccc}
\hline Month & $\begin{array}{c}\text { Max of } \\
\text { Daily } \\
\text { Highs } \\
\left({ }^{\circ} \mathbf{C}\right)\end{array}$ & $\begin{array}{c}\text { Avg of } \\
\text { Daily } \\
\text { Highs } \\
\left({ }^{\circ} \mathbf{C}\right)\end{array}$ & $\begin{array}{c}\text { Min of } \\
\text { Daily } \\
\text { Highs } \\
\left({ }^{\circ} \mathbf{C}\right)\end{array}$ & $\begin{array}{c}\text { Max of } \\
\text { Daily } \\
\text { Averages } \\
\left({ }^{\circ} \mathbf{C}\right)\end{array}$ & $\begin{array}{c}\text { Avg of } \\
\text { Daily } \\
\text { Averages } \\
\left({ }^{\circ} \mathbf{C}\right)\end{array}$ & $\begin{array}{c}\text { Min of } \\
\text { Daily } \\
\text { Averages } \\
\left({ }^{\circ} \mathbf{C}\right)\end{array}$ & $\begin{array}{c}\text { Max of } \\
\text { Daily } \\
\text { Lows } \\
\left({ }^{\circ} \mathbf{C}\right)\end{array}$ & $\begin{array}{c}\text { Avg of } \\
\text { Daily } \\
\text { Lows } \\
\left({ }^{\circ} \mathbf{C}\right)\end{array}$ & $\begin{array}{c}\text { Min of } \\
\text { Daily } \\
\text { Lows } \\
\left({ }^{\circ} \mathbf{C}\right)\end{array}$ \\
\hline Jan & 23.23 & 14.33 & -0.68 & 17.58 & 9.19 & -1.87 & 12.14 & 3.69 & -3.11 \\
Feb & 25.14 & 13.67 & 0.66 & 19.36 & 7.84 & -4.13 & 13.47 & 2.26 & -9.35 \\
Mar & 28.12 & 18.78 & 0.29 & 22.85 & 12.15 & -4.27 & 17.71 & 5.39 & -8.14 \\
Apr & 33.25 & 25.91 & 12.46 & 28.31 & 20.35 & 7.98 & 23.7 & 14.56 & 3.20 \\
May & 34.61 & 29.25 & 21.61 & 29.48 & 23.22 & 16.75 & 25.66 & 16.91 & 10.31 \\
Jun & 38.95 & 33.47 & 25.31 & 30.02 & 27.29 & 20.14 & 24.73 & 20.85 & 14.71 \\
Jul & 37.39 & 31.95 & 27.17 & 31.11 & 26.66 & 22.41 & 25.34 & 21.18 & 18.39 \\
Aug & 38.73 & 33.23 & 27.98 & 32.3 & 27.78 & 23.07 & 25.63 & 22.22 & 18.38 \\
Sep & 32.52 & 28.84 & 21.09 & 27.59 & 23.74 & 17.88 & 22.59 & 18.3 & 13.11 \\
Oct & 31.35 & 21.43 & 12.36 & 24.74 & 16.45 & 6.96 & 20.05 & 12.23 & 5.36 \\
Nov & 23.61 & 15.53 & 4.15 & 20.53 & 10.87 & 2.04 & 17.76 & 5.79 & -0.24 \\
Dec & 22.16 & 12.19 & 2.65 & 16.85 & 7.96 & -0.5 & 10.72 & 3.6 & -3.14 \\
\hline Annual & 38.95 & 23.22 & -0.68 & 32.3 & 17.79 & -4.27 & 25.66 & 12.25 & -9.35 \\
\hline
\end{tabular}




\section{Waste Isolation Pilot Plant 2002 Site Environmental Report DOE/WIPP 03-2225}

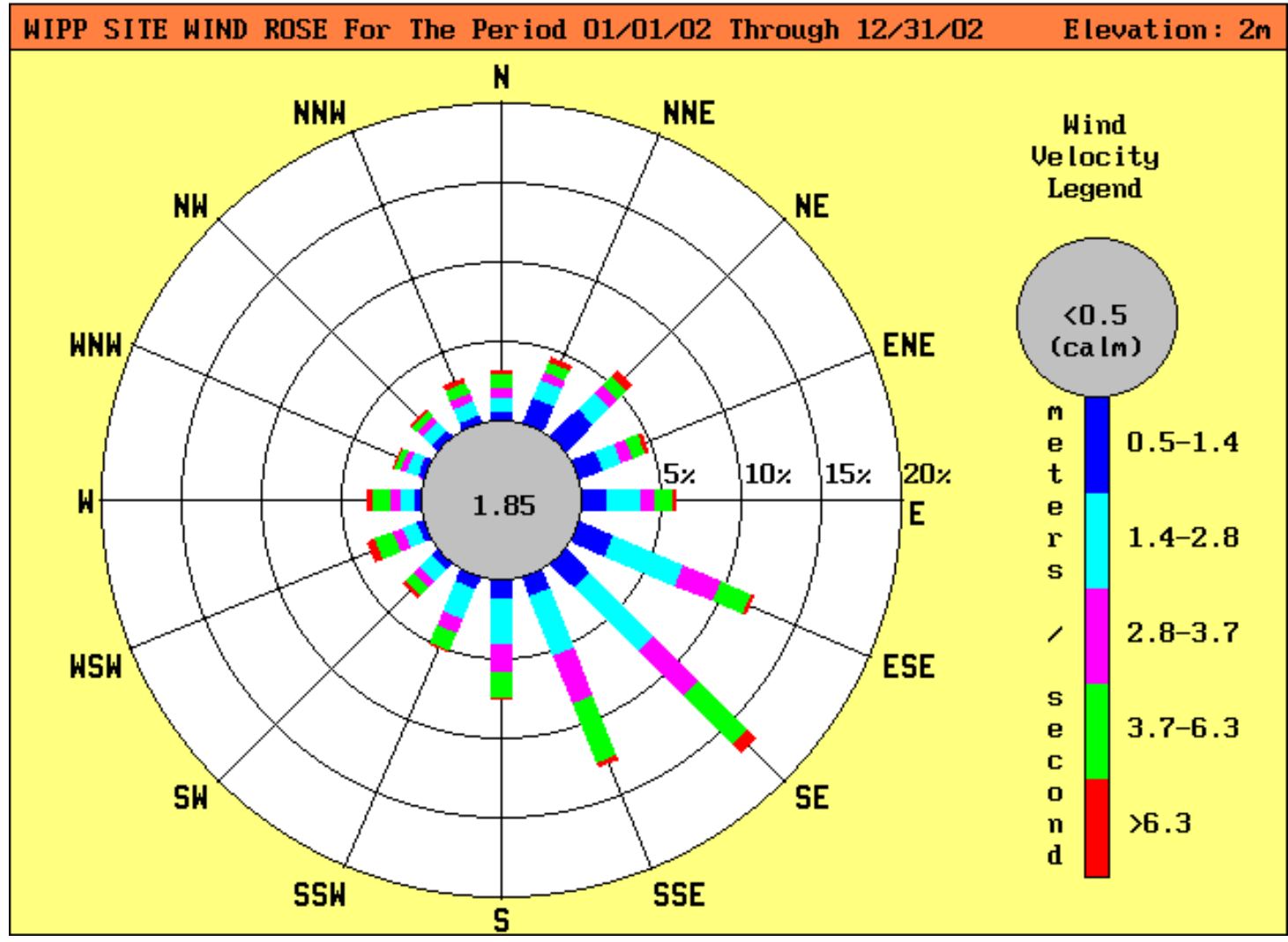

Figure 5.5 - 2002 WIPP Site Wind Rose at 2-Meter Height

Table 5.4 - 2002 Wind Frequencies at 2-Meter Height, Stratified by Direction and Speed (\%)

\begin{tabular}{|c|c|c|c|c|c|c|c|}
\hline \multirow[b]{2}{*}{ Direction } & \multicolumn{6}{|c|}{ Wind Speed Range, Meters/Second } & \multirow[b]{2}{*}{ Totals } \\
\hline & $<0.5$ & $0.5-1.41$ & $1.4-2.8$ & 2.8-3.7 & $3.7-6.3$ & $>6.3$ & \\
\hline $\mathrm{N}$ & 0.075 & 0.518 & 0.999 & 0.645 & 0.919 & 0.196 & 3.352 \\
\hline NNE & 0.150 & 1.728 & 1.296 & 0.521 & 0.853 & 0.274 & 4.821 \\
\hline NE & 0.236 & 2.480 & 1.593 & 0.625 & 0.939 & 0.475 & 6.348 \\
\hline ENE & 0.297 & 1.573 & 1.342 & 0.783 & 0.999 & 0.144 & 5.138 \\
\hline $\mathrm{E}$ & 0.228 & 1.575 & 2.215 & 0.936 & 1.195 & 0.23 & 6.379 \\
\hline ESE & 0.158 & 2.281 & 4.807 & 2.511 & 2.172 & 0.127 & 12.056 \\
\hline SE & 0.181 & 2.065 & 5.826 & 3.966 & 4.467 & 0.685 & 17.191 \\
\hline SSE & 0.112 & 1.333 & 4.107 & 3.358 & 4.101 & 0.256 & 13.269 \\
\hline$S$ & 0.089 & 1.178 & 2.915 & 1.861 & 1.653 & 0.009 & 7.704 \\
\hline SSW & 0.072 & 0.781 & 2.013 & 1.017 & 1.164 & 0.072 & 5.118 \\
\hline SW & 0.035 & 0.446 & 1.241 & 0.547 & 0.781 & 0.181 & 3.231 \\
\hline WSW & 0.04 & 0.418 & 1.045 & 0.668 & 1.319 & 0.452 & 3.943 \\
\hline W & 0.023 & 0.412 & 0.901 & 0.665 & 1.181 & 0.314 & 3.496 \\
\hline WNW & 0.026 & 0.386 & 0.809 & 0.452 & 0.389 & 0.066 & 2.128 \\
\hline NW & 0.046 & 0.452 & 0.948 & 0.495 & 0.504 & 0.164 & 2.609 \\
\hline NNW & 0.078 & 0.420 & 1.063 & 0.611 & 0.752 & 0.291 & 3.214 \\
\hline Total & 1.846 & 18.047 & 33.121 & 19.662 & 23.386 & 3.937 & 100 \\
\hline
\end{tabular}




\section{Waste Isolation Pilot Plant 2002 Site Environmental Report DOE/WIPP 03-2225}

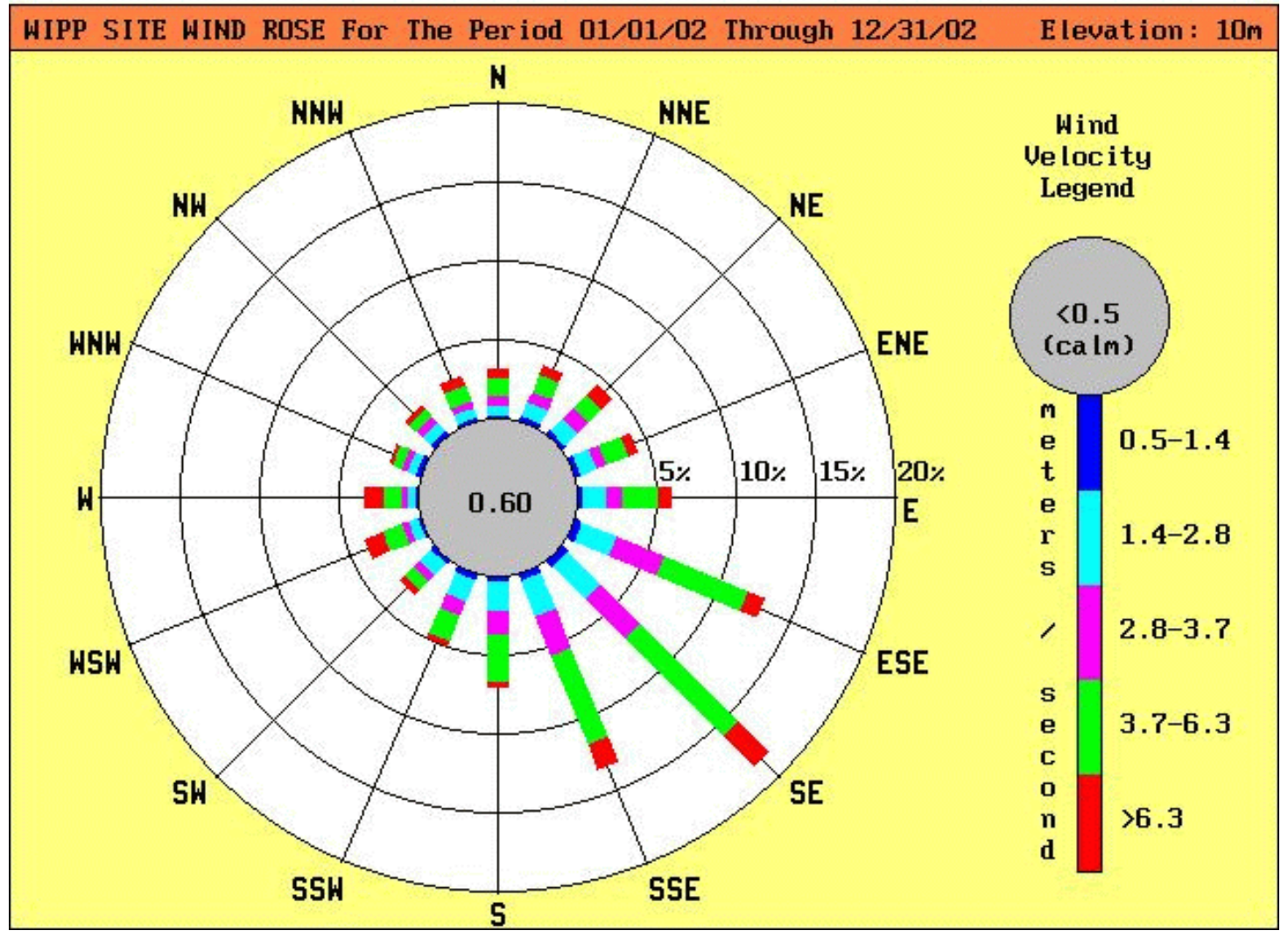

Figure 5.6 - 2002 WIPP Site Wind Rose at 10-Meter Height

Table 5.5 - 2002 Wind Frequencies at 10-Meter Height, Stratified by Direction and Speed (\%)

\begin{tabular}{|c|c|c|c|c|c|c|c|}
\hline \multirow[b]{2}{*}{ Direction } & \multicolumn{6}{|c|}{ Wind Speed Range, Meters/Second } & \multirow[b]{2}{*}{ Totals } \\
\hline & $<0.5$ & $0.5-1.41$ & $1.4-2.8$ & 2.8-3.7 & $3.7-6.3$ & $>6.3$ & \\
\hline $\mathrm{N}$ & 0.037 & 0.181 & 0.709 & 0.628 & 1.227 & 0.593 & 3.375 \\
\hline NNE & 0.04 & 0.291 & 1.069 & 0.757 & 1.241 & 0.688 & 4.087 \\
\hline $\mathrm{NE}$ & 0.052 & 0.305 & 1.166 & 0.925 & 1.247 & 1.04 & 4.735 \\
\hline ENE & 0.040 & 0.354 & 1.135 & 0.709 & 1.584 & 0.596 & 4.418 \\
\hline $\mathrm{E}$ & 0.035 & 0.366 & 1.538 & 1.112 & 2.353 & 0.870 & 6.273 \\
\hline ESE & 0.066 & 0.484 & 2.439 & 3.260 & 5.864 & 1.014 & 13.128 \\
\hline SE & 0.066 & 0.504 & 2.961 & 3.591 & 8.753 & 2.733 & 18.608 \\
\hline SSE & 0.020 & 0.469 & 2.624 & 2.696 & 6.215 & 1.717 & 13.741 \\
\hline S & 0.049 & 0.363 & 1.970 & 1.575 & 3.013 & 0.308 & 7.278 \\
\hline SSW & 0.035 & 0.348 & 1.555 & 1.008 & 1.823 & 0.346 & 5.115 \\
\hline SW & 0.014 & 0.325 & 1.057 & 0.562 & 0.979 & 0.475 & 3.413 \\
\hline WSW & 0.029 & 0.245 & 0.709 & 0.533 & 1.256 & 1.213 & 3.983 \\
\hline W & 0.026 & 0.222 & 0.605 & 0.406 & 1.204 & 1.207 & 3.669 \\
\hline WNW & 0.037 & 0.265 & 0.749 & 0.403 & 0.662 & 0.187 & 2.304 \\
\hline NW & 0.026 & 0.271 & 0.766 & 0.553 & 0.685 & 0.340 & 2.641 \\
\hline NNW & 0.023 & 0.179 & 0.703 & 0.588 & 1.051 & 0.688 & 3.231 \\
\hline Total & 0.596 & 5.173 & 21.753 & 19.305 & 39.158 & 14.015 & 100 \\
\hline
\end{tabular}




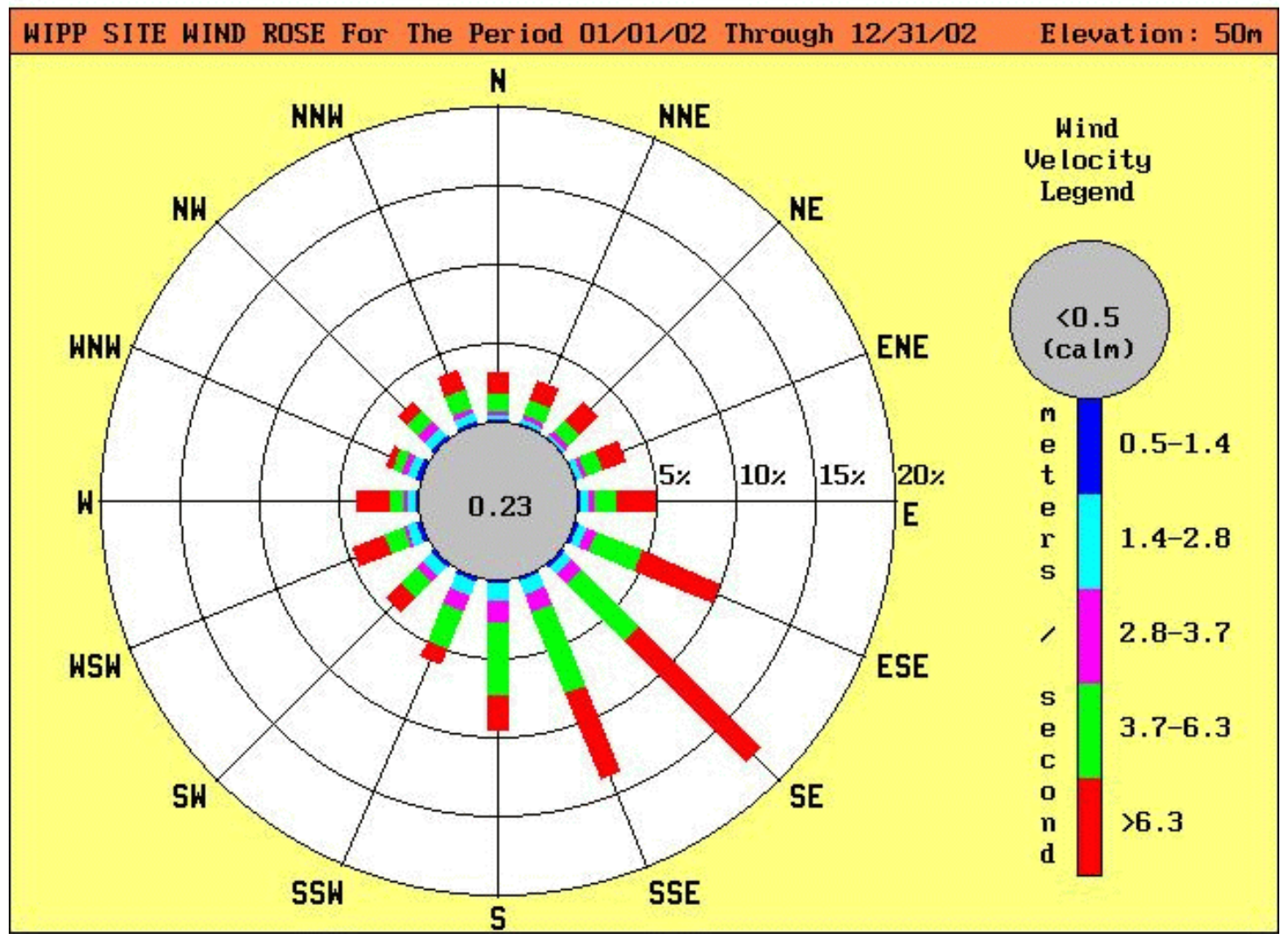

Figure 5.7 - 2002 WIPP Site Wind Rose at 50-Meter Height

Table 5.6 - 2002 Wind Frequencies at 50-Meter Height, Stratified by Direction and Speed (\%)

\begin{tabular}{|c|c|c|c|c|c|c|c|}
\hline \multirow[b]{2}{*}{ Direction } & \multicolumn{6}{|c|}{ Wind Speed Range, Meters/Second } & \multirow[b]{2}{*}{ Totals } \\
\hline & $<0.5$ & $0.5-1.41$ & $1.4-2.8$ & 2.8-3.7 & 3.7-6.3 & $>6.3$ & \\
\hline $\mathrm{N}$ & 0.02 & 0.124 & 0.412 & 0.348 & 1.247 & 1.331 & 3.482 \\
\hline NNE & 0.014 & 0.124 & 0.380 & 0.305 & 1.057 & 1.339 & 3.220 \\
\hline $\mathrm{NE}$ & 0.009 & 0.104 & 0.360 & 0.297 & 1.040 & 1.737 & 3.545 \\
\hline ENE & 0.017 & 0.112 & 0.392 & 0.363 & 1.189 & 1.624 & 3.698 \\
\hline $\mathrm{E}$ & 0.009 & 0.156 & 0.559 & 0.481 & 1.449 & 2.425 & 5.078 \\
\hline ESE & 0.012 & 0.138 & 0.662 & 0.691 & 3.136 & 5.351 & 9.991 \\
\hline SE & 0.017 & 0.193 & 0.783 & 0.821 & 5.187 & 10.933 & 17.934 \\
\hline SSE & 0.014 & 0.190 & 1.028 & 1.236 & 5.726 & 5.795 & 13.989 \\
\hline S & 0.014 & 0.239 & 1.21 & 1.380 & 4.640 & 2.160 & 9.643 \\
\hline SSW & 0.009 & 0.245 & 1.115 & 1.227 & 2.609 & 1.060 & 6.264 \\
\hline SW & 0.014 & 0.173 & 0.899 & 0.622 & 1.380 & 1.270 & 4.358 \\
\hline WSW & 0.009 & 0.253 & 0.749 & 0.363 & 1.264 & 2.163 & 4.801 \\
\hline W & 0.014 & 0.199 & 0.622 & 0.331 & 0.896 & 2.042 & 4.104 \\
\hline WNW & 0.026 & 0.302 & 0.723 & 0.441 & 0.68 & 0.392 & 2.563 \\
\hline NW & 0.020 & 0.207 & 0.815 & 0.565 & 1.04 & 0.827 & 3.473 \\
\hline NNW & 0.012 & 0.153 & 0.585 & 0.423 & 1.348 & 1.336 & 3.856 \\
\hline Total & 0.23 & 2.912 & 11.293 & 9.893 & 33.887 & 41.785 & 100 \\
\hline
\end{tabular}




\subsection{Volatile Organic Compound Monitoring}

VOC monitoring was implemented on April 21, 1997, in accordance with WP12-VC.01, Confirmatory Volatile Organic Compound Monitoring Program. This program was implemented as a requirement of the HWFP, Module IV, Section D and Attachment N, and is intended to demonstrate that regulated VOCs are not being emitted by the waste at concentrations in excess of concentrations of concern as defined in the permit.

Nine target compounds, which contribute approximately 99 percent of the calculated human health risks from RCRA constituents, were chosen for monitoring. These target compounds are 1,1-dichloroethylene, methylene chloride, chloroform, 1,1,1-trichloroethane, carbon tetrachloride, 1,2-dichloroethane, toluene, chlorobenzene, and 1,1,2,2-tetrachloroethane.

Sampling for target compounds is performed at two air monitoring stations. The stations are identified as VOC-A, located downstream from hazardous waste disposal unit Panel 1 in Drift E300, and VOC-B, located upstream from Panel 1. In 2002, VOC-B was located in Drift S1950. As waste is placed in new panels, VOC-B will be relocated to ensure that it samples underground air before it passes the waste panels. The location of VOC-A is not anticipated to change.

Target compounds found in VOC-B represent air found in the underground before the air passes through the panels containing waste. The VOC concentrations measured at this location are the sum of background concentrations entering the mine through the air intake shaft plus additional concentrations contributed by facility operations upstream of the waste panels. Concentrations measured at VOC-A will be equal to those found at VOC-B plus any contributions from the waste panels. Differences measured between the two stations will then represent any VOC contributions from the waste panels. Any concentration differences between the two stations must be less than the concentrations of concern listed in Attachment $\mathrm{N}$ of the HWFP (Table 5.7).

Table 5.7 - Concentrations of Concern for Volatile Organic Compounds, from Attachment N of the HWFP (No. NM4890139088)

\begin{tabular}{lc}
\hline \multicolumn{1}{c}{ Compound } & Concentration of Concern ppbv $^{\mathbf{a}}$ \\
\hline 1,1,1-Trichloroethane & 590 \\
1,1,2,2-Tetrachloroethane & 50 \\
1,1-Dichloroethylene & 100 \\
1,2-Dichloroethane & 45 \\
Carbon tetrachloride & 165 \\
Chlorobenzene & 220 \\
Chloroform & 180 \\
Methylene chloride & 1930 \\
Toluene & 190 \\
\hline
\end{tabular}

${ }^{a}$ Parts per billion by volume 


\section{Waste Isolation Pilot Plant 2002 Site Environmental Report DOE/WIPP 03-2225}

Sample pair differences are calculated by subtracting the concentration of a compound of interest observed at VOC-B from that measured at VOC-A for the given sampling period (Table 5.8). Negative values indicate ambient air concentrations of a compound (VOC-B) were greater than concentrations in the air passing out of the panel (VOC-A). Negative values could be caused by emissions from normal mining activities near VOC-B which quickly dispersed in the mine ventilation flow and were not detected at VOC-A. The annual averages shown in Table 5.8 were calculated by averaging all sample pair differences from January 1, 2002, to December 31, 2002.

During 2002, three of the nine target compounds (1,1,1-trichloroethane, methylene chloride, and toluene) were measured above the $0.5 \mathrm{ppbv} \mathrm{MDL}$ (minimum detection limit). For each of the detected target compounds, the annual average was less than 0.2 percent of the respective concentration of concern listed in Table 5.7 and were, therefore, at insignificant levels with respect to human health and the environment.

Positive sample pair differences for methylene chloride were found in 26 of 105 sample pairs. The 2002 annual average sample pair difference for methylene chloride was $0.11 \mathrm{ppbv}$, with a minimum difference value of $-1.06 \mathrm{ppbv}$ and a maximum value of $7.53 \mathrm{ppbv}$. Methylene chloride, a common laboratory contaminant, can also be found in paint remover, aerosol propellant, degreasing and metal cleaning agents, and adhesives.

Positive sample pair differences for toluene were found in 32 of the 105 sample pairs. The overall 2002 average for toluene sample pair differences was 0.26 ppbv, with a minimum difference value of -2.69 and a maximum difference value of $3.3 \mathrm{ppbv}$. Possible sources of toluene contamination could be products of incomplete combustion of diesel fuel, cleaning solvents, or paint.

Positive sample pair differences for 1,1,1-trichloroethane were found in 14 of the 105 samples pairs. The overall 2002 average for 1,1,1-trichloroethane sample pair differences was $0.16 \mathrm{ppbv}$, with a minimum difference value of -1.09 and a maximum difference value of $3.09 \mathrm{ppbv}$. This compound is a common constituent in cleaning solutions and is also one of the main VOC components in the waste stream.

The routine laboratory reporting limit was 5.0 ppbv for 1,1,1-trichloroethane, 1,1-dichloroethylene, methylene chloride, and toluene and $2.0 \mathrm{ppbv}$ for 1,1,2,2-tetrachloroethane, 1,2-dichloroethane, carbon tetrachloride, chlorobenzene, and chloroform. For dilution factors greater than one, the $5.0 \mathrm{ppbv}$ and $2.0 \mathrm{ppbv}$ values are multiplied by the dilution factor to calculate the laboratory reporting limits for the diluted sample.

The MDL is defined as the minimum concentration of a substance that can be measured and reported with a 99 percent confidence to be greater than zero. Values were estimated for constituents detected at concentrations less than the laboratory reporting limits but above the $0.5 \mathrm{ppbv}$ MDL. 


\section{Waste Isolation Pilot Plant 2002 Site Environmental Report DOE/WIPP 03-2225}

VOC sampling reported in this section was performed using guidance included in Compendium Method TO-14A, Compendium Methods for the Determination of Toxic Organic Compounds in Ambient Air (EPA, 1999). The samples were analyzed using gas chromatography/mass spectrometry under an established QA/QC program. Laboratory analytical procedures were developed based on the concepts contained in both TO-14A and the draft EPA Contract Laboratory Program Volatile Organics Analysis of Ambient Air in Canisters (EPA 1994). The results of year 2002 VOC monitoring indicated an increase in the number of detections of 1,1,1-trichloroethane in air downstream of Panel 1.

Table 5.8 - Volatile Organic Compound Sample Pair Differences Measured at WIPP in 2002

\begin{tabular}{lcccc}
\hline \multicolumn{1}{c}{ Compound } & $\begin{array}{c}\text { No. of Sample } \\
\text { Pairs } \\
\text { (A and B) }\end{array}$ & $\begin{array}{c}\text { 2002 Annual } \\
\text { Average of Sample } \\
\text { Pair Differences } \\
\left(\mathbf{p p b v}^{\mathbf{a}}\right)\end{array}$ & $\begin{array}{c}\text { Minimum of } \\
\text { Sample Pair } \\
\text { Differences } \\
\left(\mathbf{p p b v}^{\mathbf{2}}\right)\end{array}$ & $\begin{array}{c}\text { Maximum of } \\
\text { Sample Pair } \\
\text { Differences } \\
\left(\mathbf{p p b v}^{\mathbf{a}}\right)\end{array}$ \\
\hline 1,1,1-Trichloroethane & 105 & 0.16 & -1.09 & 3.09 \\
1,1,2,2-Tetrachloroethane & 105 & 0 & 0 & 0 \\
1,1-Dichloroethylene & 105 & 0 & 0 & 0 \\
1,2-Dichloroethane & 105 & 0 & 0 & 0 \\
Carbon Tetrachloride & 105 & 0 & 0 & 0 \\
Chlorobenzene & 105 & 0 & 0 & 0 \\
Chloroform & 105 & 0 & 0 & 0 \\
Methylene Chloride & 105 & 0.11 & -1.06 & 7.53 \\
Toluene & 105 & 0.26 & -2.69 & 3.3 \\
\hline
\end{tabular}

${ }^{\text {a }}$ Parts per billion by volume

\subsection{Seismic Activity}

WIPP is located about 60 miles east of the western margin of the Permian Basin. The geologic structure and tectonic pattern of the Permian Basin are chiefly the result of large-scale subsidence and uplift during the Paleozoic era. The broad basin is divided into a series of subbasins which passed through their last stage of significant subsidence during the Late Permian age. The Delaware subbasin occupies the southwestern portion of the Permian Basin and hosts the WIPP site. It is bordered by the Roosevelt Uplift to the north, the Marathon Thrust Belt to the south, the Central (Permian) Basin Platform to the east, and the Sierra Diablo Platform and Guadalupe and Sacramento Mountains to the west. The Delaware Basin contains a thick sequence of evaporite layers.

All major tectonic elements of the Delaware Basin were essentially formed before deposition of the Permian evaporites, and the region has been relatively stable since then. Deep-seated faults are rare, except along the western and eastern basin margins, and there is no evidence of young, deep-seated faults inside the basin.

Researchers suspect that some low-magnitude earthquakes may result from secondary oil recovery (water flooding). Their foci are about as deep as the bottom of relatively shallow hydrocarbon wells. 
Significant recent seismic events near WIPP on January 2, 1992, and April 14, 1995, had magnitudes of 5.0 and 5.3 respectively. The January 2, 1992, Rattlesnake Canyon earthquake had an epicenter $60 \mathrm{~km}$ (36 mi) east-southeast of the WIPP site, while an April 14, 1995, event's epicenter was located about $240 \mathrm{~km}$ (144 mi) southwest of WIPP, near Alpine, Texas. Neither earthquake had any effect on WIPP structures, as documented by post-event inspections by WIPP staff and the NMED. The magnitudes of both events were within the parameters used to develop the seismic risk assessment of the WIPP structures.

Seismic information for the WIPP region before 1962 was derived from chronicles of the effects of those tremors on people, structures, and surface features. Seismicity in New Mexico reported prior to 1962 was mostly limited to the corridor between Albuquerque and Socorro, part of a structure known as the Rio Grande Rift. Since 1962, most seismic information has been based on instrumental data recorded at various seismograph stations.

Currently, seismicity within $300 \mathrm{~km}$ (186 mi) of the WIPP site is being monitored by the New Mexico Institute of Mining and Technology (NMIMT), using data from a seven-station network approximately centered on the site (Figure 5.14). Station signals are transmitted to the NMIMT Seismological Observatory in Socorro. When appropriate, readings from the WIPP network stations are combined with readings from an additional NMIMT network in the central Rio Grande Rift. Occasionally, data are also exchanged with the University of Texas at EI Paso and Texas Tech University in Lubbock, both of which operate stations in west Texas.

The mean operational efficiency of the WIPP seismic monitoring stations during 2002 was approximately 97.1 percent. From January 1 through December 31, 2002, locations for 104 seismic events were recorded within $300 \mathrm{~km}(186 \mathrm{mi})$ of WIPP. These data included origin times, epicenter coordinates, and magnitudes. The strongest recorded event (magnitude 3.4) occurred on September 17 and was located approximately $86 \mathrm{~km}(53 \mathrm{mi})$ west-northwest of the site. The closest event to the site had a magnitude of 1.5. These events had no effect on WIPP structures. 


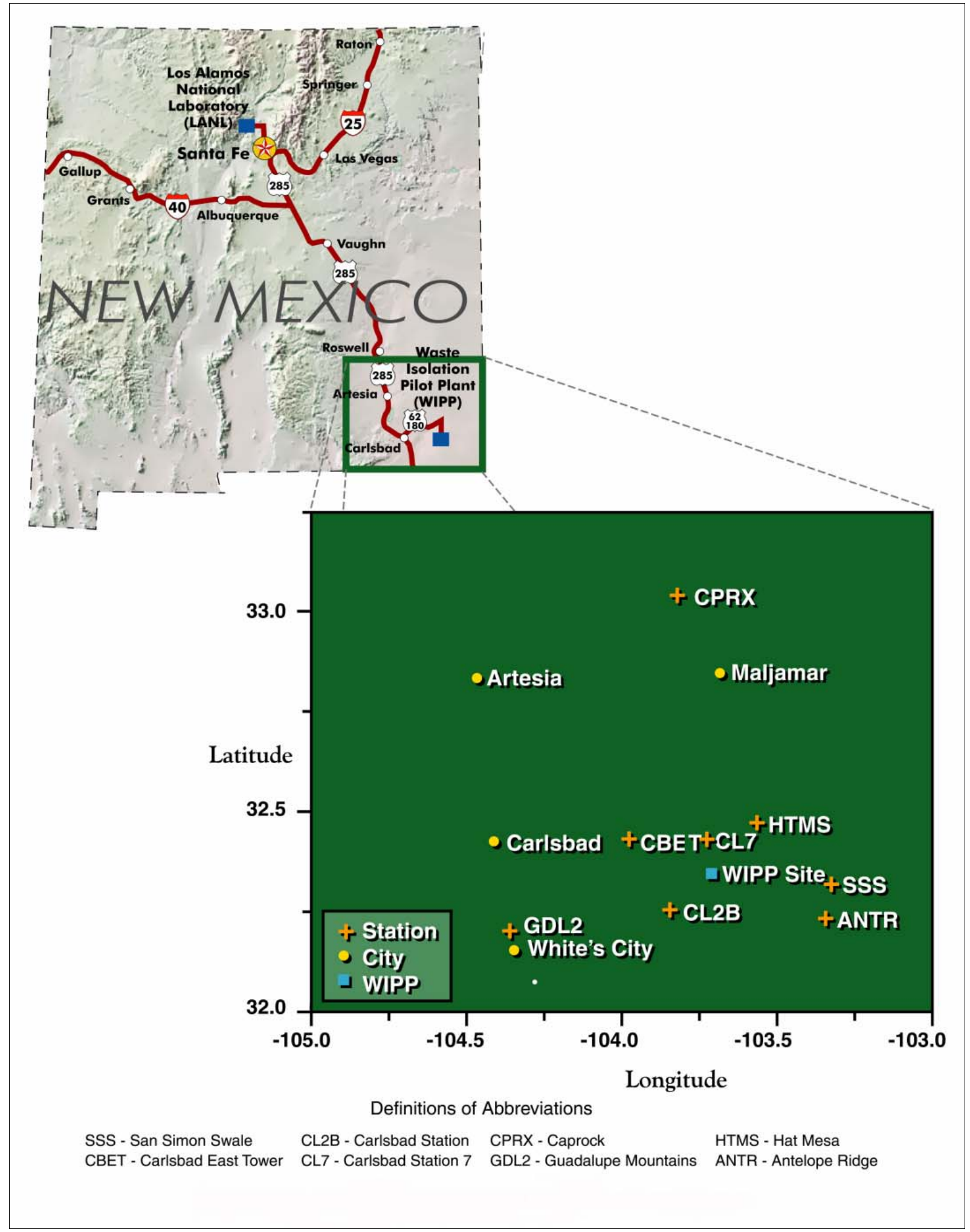

Figure 5.8 - WIPP Seismograph Station Locations 


\subsection{Liquid Effluent Monitoring}

The WIPP sewage lagoon system is a zero-discharge facility consisting of two primary settling lagoons, two polishing lagoons, and three evaporation basins. The entire facility is lined with 30-mil synthetic liners and is designed to dispose of domestic sewage as well as site-generated brine waters from observation well pumping and underground dewatering activities at the site.

The WIPP sewage facility is operated under DP-831, issued by the state of New Mexico; New Mexico Water Quality Control Regulations (20.6.2 NMAC, Ground and Surface Water Protection); and applicable WIPP procedures. These requirements provide the framework for disposal of domestic sewage, site-generated brine waters, and nonhazardous waste waters.

DP-831 allows for the disposal of up to $23,000 \mathrm{gpd}$ of sewage effluent and 7,570 liters (2,000 gallons) of nonhazardous brine water to the North Evaporation and at the sewage lagoon system. An additional 30,283 liters (8,000 gallons) per day of nonhazardous brine waters are permitted for disposal in the H-19 Evaporation Pond. Quarterly discharge monitoring reports are submitted to the NMED to demonstrate compliance with the inspection monitoring and reporting requirements identified in the plan. The quarterly discharge monitoring reports summarize the volumes of water discharged and the analytical results for quarterly monitoring required by DP-831. Because the facility is designed to not have any discharges to the environment, no effluent limits were established in DP-831. 


\section{CHAPTER 6 - GROUNDWATER MONITORING}

Current groundwater monitoring activities at WIPP are outlined in the WIPP Groundwater Monitoring Program Plan (WP 02-1). This is a QA document containing program plans for each activity performed by groundwater monitoring personnel. In addition, WIPP has detailed procedures for performing specific activities, such as pumping system installations, field parameter analyses and documentation, and QA records management. Groundwater monitoring activities are also defined in the EMP.

The objectives of the Groundwater Monitoring Program are to:

- Determine the physical and chemical characteristics of groundwater;

- Maintain surveillance of groundwater levels surrounding the WIPP facility, both before and throughout the operational lifetime of the facility;

- Document and identify effects, if any, of WIPP operations on groundwater parameters; and

- $\quad$ Fulfill the requirements of the HWFP, the EPA Compliance Certification Application, and DOE Order 5400.1.

The data obtained by the WIPP Groundwater Monitoring Program supported two major programs at WIPP: (1) the RCRA Detection Monitoring Program supporting the RCRA Part B Permit in compliance with 40 CFR Part 264 and 20.4.1 NMAC (HWFP Module V), and (2) performance assessment supporting the Compliance Certification Application (DOE/CAO 96-2184, 40 CFR Part 191 Compliance Certification Application for the Waste Isolation Pilot Plant) in compliance with 40 CFR Part 191 and 40 CFR Part 194. Each of these programs requires a unique set of analyses and data. Particular sample needs are defined by each program.

Background data were collected from 1995 through 1997 and reported in the Waste Isolation Pilot Plant RCRA Background Groundwater Quality Baseline Report (DOE/WIPP 98-2285). The background data were expanded in 2000 to include ten rounds of sampling instead of five. The data were published in Addendum 1, Waste Isolation Pilot Plant RCRA Background Groundwater Quality Baseline Update Report (IT Corporation, 2000). These background data will be compared to water quality data collected throughout the operational life of the facility.

Groundwater monitoring activities during 2002 included groundwater quality sampling and groundwater level surveillance. Groundwater quality data were gathered from six wells completed in the Culebra Member of the Rustler Formation (wells WQSP-1 through WQSP-6) and one well completed in the Dewey Lake Redbeds Formation (well WQSP-6A; Figure 6.1). Groundwater surface elevation data were gathered from 76 well bores, four of which were equipped with production-inflated packers to allow groundwater level surveillance of more than one producing zone through the same well bore (Figure 6.2). 


\subsection{Groundwater Quality Sampling}

The HWFP Module $V$ requires groundwater quality sampling twice a year, from March through May (Round 14 for 2002) and, again, from September through November (Round 15 for 2002). Sampling for groundwater quality was performed at seven well sites during 2002 (Figure 6.1). Field analysis for Eh (Intensity Factor: an indicator of oxidation or reduction of chemical species), specific gravity, specific conductance, acidity or alkalinity, chloride, divalent cations, and total iron were performed periodically during the sampling.

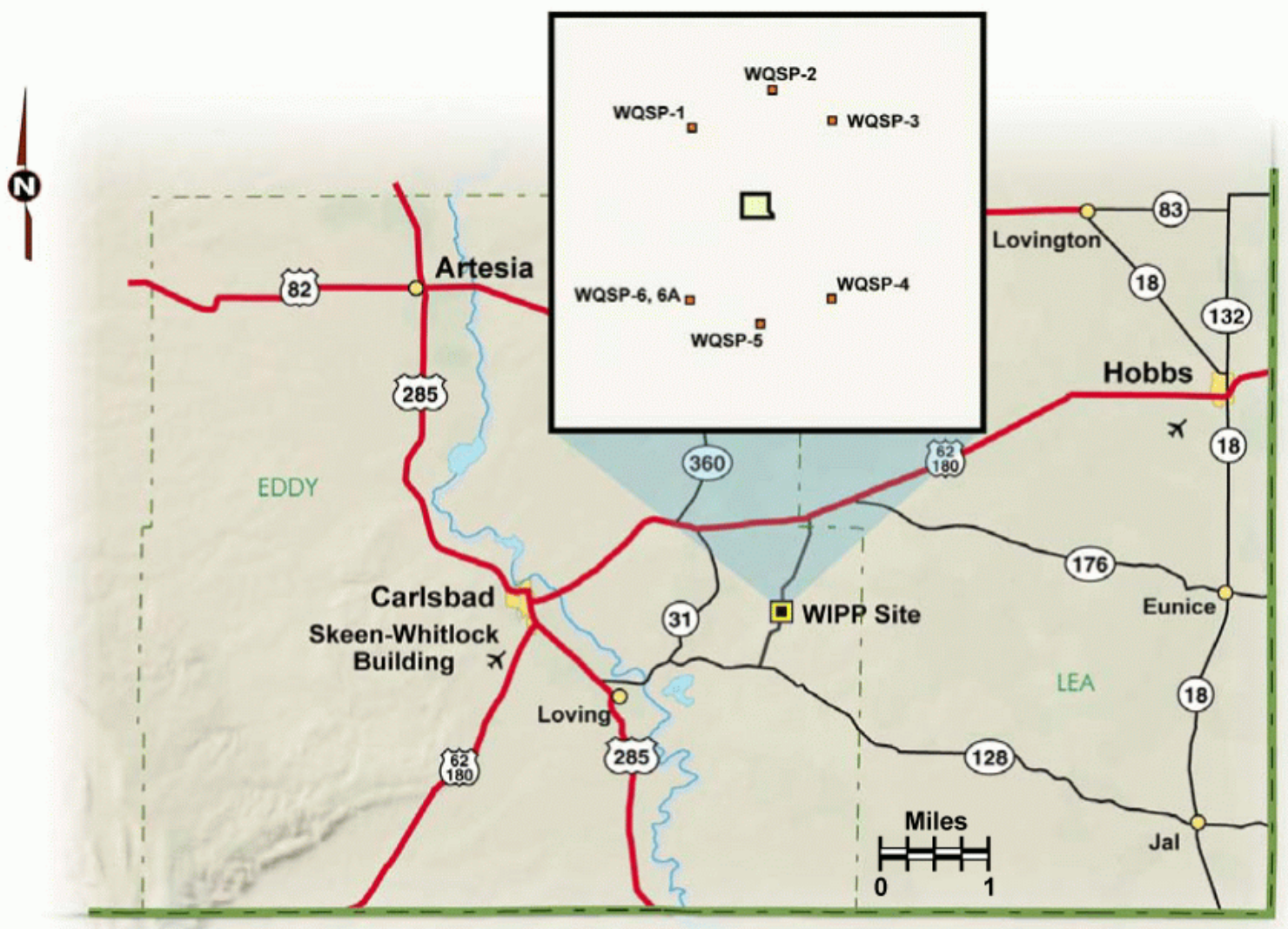

Figure 6.1 - Water Quality Sampling Program Wells (Inset represents the locations of the DMP wells in the four-square-mile area of the WIPP site [Land Withdrawal Area].) 


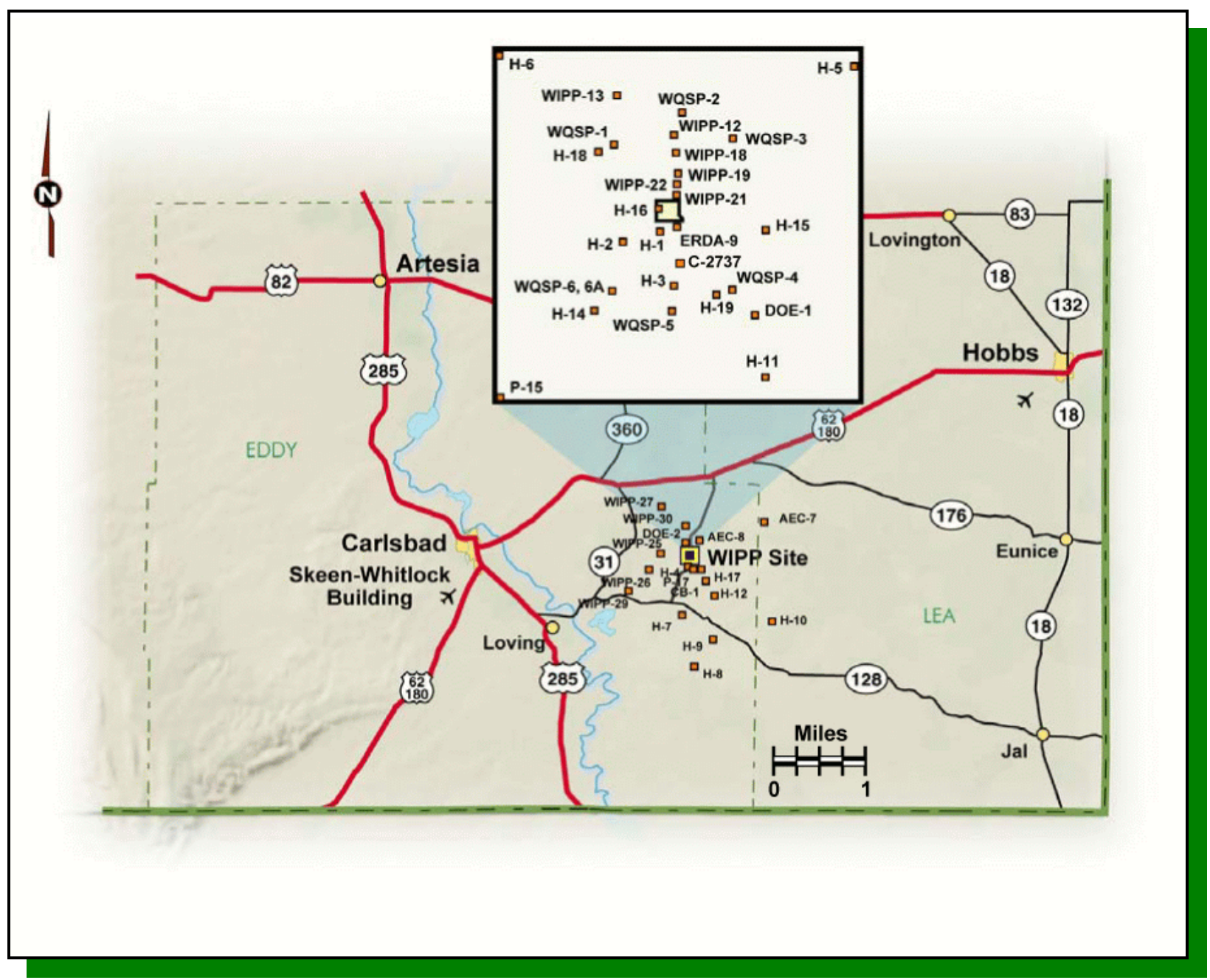

Figure 6.2 - Groundwater Level Surveillance Wells (Inset represents the locations of the groundwater surveillance wells in the four-square-mile area of the WIPP site [Land Withdrawal Area].)

Table 6.2 lists the analytical parameters included in the year 2002 groundwater sampling program.

During 2002, groundwater surveillance activities removed approximately 14,560 gallons (55,116 liters) of water from the Culebra Member of the Rustler Formation and 3,269 gallons (12,375 liters) from the Dewey Lake Redbeds Formation. The quality of the Culebra water sampled near WIPP is naturally poor and not suitable for human consumption or for agricultural purposes. The groundwater of the Culebra is considered to be Class III water by EPA guidelines.

Water quality measurements performed in the Dewey Lake Redbeds Formation indicate the waters are considerably better quality than the Culebra water. The TDS values were less than $5,000 \mathrm{mg} / \mathrm{L}$ (milligrams per liter). The water is suitable for livestock consumption, and classified as Class II water according to EPA guidance. Saturation of 
the Dewey Lake Redbeds Formation in the area of WIPP is discontinuous. No hydrologic connection has been established that would indicate WIPP activities have had an impact on naturally occurring groundwater in the Dewey Lake Redbeds Formation. However, anthropogenic shallow subsurface water (SSW) has been encountered in the upper Dewey Lake Redbeds Formation at the Santa Rosa Formation contact. To date there are no data that indicate the SSW has commingled with the naturally occurring groundwater in the lower Dewey Lake Redbeds Formation (see Section 6.4).

Because of the highly variable transmissivity and TDS values within the Culebra, baseline groundwater quality was defined for each individual well. Tables 6.3 through 6.9 summarize the results of analyses for each parameter or constituent for the two sampling sessions in 2002 (rounds 14 and 15).

In these tables, either the $95^{\text {th }}$ upper tolerance limit value (UTLV) or the $95^{\text {th }}$ percentile value is presented depending on the type of distribution exhibited by the parameter. Both values represent the value beneath which 95 percent of the values in a population are expected to occur. The UTLVs were calculated for data that exhibited a normal or a lognormal distribution. The $95^{\text {th }}$ percentile was determined for data that were considered nonparametric; having neither a normal nor a lognormal distribution. Due to the large number of nondetectable concentrations of organic compounds, the limits for organic compounds were considered nonparametric and based on the method detection limit reported by the laboratory. These values have been recomputed after baseline sampling was completed in 2000, and were used for sampling rounds 14 and 15 to evaluate potential contamination of the groundwater wells.

The analytical results for detectable constituents are plotted as Time Trend Plots compared to the baseline established prior to 2000 (Appendix F, Figures F.1 through F.98).

In a few isolated cases, reported concentrations of some parameters, such as potassium and total organic halogens slightly exceeded the calculated $95^{\text {th }}$ percentile or the $95^{\text {th }}$ UTLV. Such exceedences do not indicate the presence of contamination. The $95^{\text {th }}$ UTLV or percentile is a value representing where 5 percent of the concentration in the population will be greater than the UTLV or percentile. WIPP groundwater in the Culebra Dolomite Member of the Rustler Formation has very high concentrations of dissolved solids. The contract analytical laboratory has had some difficulty performing the analyses for some of the cations found in the highly concentrated brines.

Table 6.10 summarizes the overall Groundwater Sampling Program.

\subsection{Groundwater Level Surveillance}

Groundwater surface elevations in the vicinity of WIPP may be influenced by localized disturbances, such as pumping tests for site characterization, water quality sampling, or shaft sealing. Other influences on groundwater surface elevations may be caused by natural groundwater level fluctuations and industrial influences from agriculture, mining, and resource exploration. 
Well bores were used to perform surveillance of eight water-bearing zones in the WIPP area (Figure 6.2). The two zones of primary interest were the Culebra and Magenta Members of the Rustler Formation (see Figure 1.1). Throughout the year, forty-eight measurements were taken in the Culebra and eleven in the Magenta. Two measurements were taken in the Dewey Lake Redbeds Formation. Two measurements were taken in the Bell Canyon Formation. One measurement each was taken in the Forty-niner and Rustler/Salado contact. In 2002, groundwater level measurements were taken monthly in at least one accessible well bore at each well site for each available formation. Redundant well bores (well bores located on well pads with multiple wells completed in the same formation) at each well site were measured on a quarterly basis (Table 6.11).

Four well bores (WIPP-30 Culebra/Magenta, Cabin Baby Culebra/Bell Canyon, C-2737 Culebra/Magenta, and WIPP-25 Culebra/Magenta) were completed at multiple depths. By using packers, these well bores can monitor more than one formation.

Groundwater elevation measurements in the Culebra Member indicated the generalized directional flow of groundwater was north to south at the center of the WIPP site (Figure 6.3). Regionally, the flow is from the north to the southwest. Water elevation trend analysis was performed in 46 of 48 wells completed in the Culebra. Rising water level trends were noted in 39 wells while 7 of the wells had falling trends.

A total rise in groundwater level of more than $0.6 \mathrm{~m}(2 \mathrm{ft})$ occurred this year in seven wells completed to the Culebra. WIPP-30 had a steady methodical increase totaling $2.36 \mathrm{ft}$, which is similar to regional Culebra water level rise. The remaining six wells WQSP-3, $\mathrm{H}-10 \mathrm{c}, \mathrm{H}-11 \mathrm{~b} 1, \mathrm{H}-11 \mathrm{~b} 4$, Cabin Baby, and $\mathrm{C} 2737$ had water level increases of more than $2 \mathrm{ft}$, which directly correlates to well maintenance activities in their immediate vicinity (see Section 6.3). Many of these wells were cleaned and developed during 2002. The increase in water levels is most likely due to the equilibration of water levels to pre-cleaning elevations.

During the year, a program was planned to determine the reasons for the rising water levels. Additional monitoring wells will be installed in 2003 to evaluate different hypotheses for this trend. Sandia National Laboratories will be performing a series of tests, analyses, and modeling to evaluate the hypotheses.

Groundwater level data were transmitted on a monthly basis to the NMED, EEG, Sandia National Laboratories, the CBFO Technical Assistance Contractor, and technical subcontractors as requested by the CBFO. A copy of the data was placed in the operating record for inspection by authorized agencies.

Culebra flow rates across the Land Withdrawal Area were determined using numerical modeling techniques calibrated to current groundwater head elevations. Flow rates ranged from $3.5 \times 10^{-5} \mathrm{ft}$ per day (ft/d) to $6 \times 10^{-4} \mathrm{ft} / \mathrm{d}$ in the southwestern and west sections of the Land Withdrawal Area. Flow rates in the central portion of the Land Withdrawal Area ranged from $3.4 \times 10^{-4} \mathrm{ft} / \mathrm{d}$ to $4.3 \times 10^{-4} \mathrm{ft} / \mathrm{d}$. Centrally, the flow rate ranged from $1.1 \times 10^{-4} \mathrm{ft} / \mathrm{d}$ to $8.2 \times 10^{-4} \mathrm{ft} / \mathrm{d}$ (Figure 6.4). 


\section{Waste Isolation Pilot Plant 2002 Site Environmental Report DOE/WIPP 03-2225}

The interpretation of groundwater data collected in 2002 is similar to previous years. To date there is no indication WIPP operations have had a measurable or significant impact on either the elevation or the quality of naturally occurring groundwater in the Dewey Lake Redbeds, Magenta, and Culebra Formations (see Section 6.4).

Culebra groundwater in the vicinity of WIPP exhibits highly variable TDS concentrations. These variable TDS concentrations are reflected in a commensurate variability in groundwater density. Each year the WIPP conducts a program to measure the density of well-bore fluids in water level monitoring wells. Due to the high concentration of TDS in WIPP groundwater, density must be taken into account to accurately determine relative water levels between wells. Measured water levels are adjusted to equivalent fresh-water head values, considering fluid density differences between measuring points.

For the year 2002, the Pressure-Density Survey measured well-bore fluid density in eleven wells, as shown in Table 6.1.

Table 6.1 - Pressure Density Survey for 2002

\begin{tabular}{|c|c|c|c|}
\hline WELL NAME & DATE & FORMATION & DENSITY \\
\hline DOE-1 & $11 / 18 / 02$ & Culebra & $1.0902 \mathrm{~g} / \mathrm{cc}$ \\
\hline $\mathrm{H}-03 \mathrm{~b} 2$ & $11 / 7 / 02$ & Culebra & $1.000 \mathrm{~g} / \mathrm{cc}$ \\
\hline $\mathrm{H}-19 \mathrm{~b} 2$ & $10 / 4 / 02$ & Culebra & $1.0632 \mathrm{~g} / \mathrm{cc}$ \\
\hline $\mathrm{H}-11 \mathrm{~b} 4$ & $11 / 19 / 02$ & Culebra & $1.0638 \mathrm{~g} / \mathrm{cc}$ \\
\hline $\mathrm{H}-17$ & $10 / 7 / 02$ & Culebra & $1.1350 \mathrm{~g} / \mathrm{cc}$ \\
\hline $\mathrm{H}-09 \mathrm{c}$ & $12 / 18 / 02$ & Culebra & $1.0029 \mathrm{~g} / \mathrm{cc}$ \\
\hline $\mathrm{H}-10 \mathrm{c}$ & $9 / 26 / 02$ & Culebra & $1.000 \mathrm{~g} / \mathrm{cc}$ \\
\hline $\mathrm{H}-\mathrm{C}-2737$ & $7 / 12 / 02$ & Culebra & $1.0013 \mathrm{~g} / \mathrm{cc}$ \\
\hline $\mathrm{WIPP}-19$ & $10 / 22 / 02$ & Culebra & $1.0506 \mathrm{~g} / \mathrm{cc}$ \\
\hline WIPP-12 & $10 / 29 / 02$ & Culebra & $1.0987 \mathrm{~g} / \mathrm{cc}$ \\
\hline WIPP-22 & $10 / 15 / 02$ & Culebra & $1.0614 \mathrm{~g} / \mathrm{cc}$ \\
\hline
\end{tabular}

\subsection{Well Maintenance Activities}

Maintenance activities were performed on eighteen wells in 2002. Maintenance is performed to prepare wells for future experiments, repair nonfunctioning wells, recomplete wells to monitor additional zones of interest, and plug and abandon wells that are no longer useful.

Evaluations were performed to determine the condition of the well casing and the wells' ability to yield useful data. The wells were first cleaned with a casing scraper and circulated with fresh water to remove the scale. After cleaning, ultrasonic imaging logs were performed to determine the condition of the casing and the cement seal behind the casing. If the wells were determined to be in good condition, they were returned to service. Alternatively, if problems were found, the well bores were plugged and abandoned. 
Plugging and abandonment (P\&A) activities in 2002 took place at $\mathrm{H}-9 \mathrm{a}$ in January; at $\mathrm{H}-10 \mathrm{~b}, \mathrm{P}-15$, and $\mathrm{P}-18$ in February; and at $\mathrm{H}-11 \mathrm{~b} 3$ in March. After cleaning and logging, the well bores were cemented from the bottom of the well to the surface and a monument was placed at the surface in the top of the well casing.

Nine wells were cleaned and returned to service between January and March 2002. These wells are:

$\begin{array}{ll}\text { H-3b1 } & \text { February } \\ \mathrm{H}-3 \mathrm{~b} 2 & \text { February } \\ \mathrm{H}-3 \mathrm{b3} & \text { February } \\ \mathrm{H}-10 \mathrm{a} & \text { February } \\ \mathrm{H}-7 \mathrm{~b} 1 & \text { March } \\ \mathrm{H}-7 \mathrm{~b} 2 & \text { March } \\ \mathrm{H}-7 \mathrm{c} & \text { March } \\ \mathrm{H}-11 \mathrm{~b} 1 & \text { March } \\ \mathrm{H}-11 \mathrm{~b} 4 & \text { March }\end{array}$

In addition to the nine wells returned to service, $\mathrm{H}-9 \mathrm{~b}$ had also been cleaned and returned to service; however, during $\mathrm{P} \& \mathrm{~A}$ activities at $\mathrm{H}-9 \mathrm{a}$, cement migrated to $\mathrm{H}-9 \mathrm{~b}$ and consequently plugged the Culebra. The well was subsequently removed from service, but not plugged. $\mathrm{H}-9 \mathrm{c}$ was reconfigured as a Magenta monitoring well in January after the evaluation process was completed.

$\mathrm{H}-10 \mathrm{c}$ was reconfigured as a Culebra monitoring well in February after $\mathrm{H}-10 \mathrm{~b}$ was removed from service and plugged and abandoned.

\subsection{Shallow Subsurface Water Monitoring Program}

Shallow subsurface water occurs beneath the WIPP site at a depth of less than $100 \mathrm{ft}$ below ground surface (bgs) at the contact between the lower Santa Rosa Formation and the upper Dewey Lake Redbeds Formation. This SSW yields generally less than one gallon per minute in monitoring wells and piezometers and contains high concentrations of TDS and chlorides. The origin of this water is believed to be primarily from anthropogenic causes, with some contribution from natural sources. The SSW occurs not only under the WIPP site surface facilities but also to the south as indicated by the recent encounter in drill hole C-2737 about a half mile south of the Waste Shaft (Figure 6.6). Natural shallow groundwater occurs in the middle part of the Dewey Lake Redbeds Formation at the southern portion of the WIPP site and to the south of the WIPP site. To date, there is no indication that the SSW has affected the naturally occurring groundwater in the Dewey Lake Redbeds Formation.

Since discovery of the SSW in the late 1990's, 12 piezometers and four wells (C-2505, C-2506, C-2507, and C-2811) have been part of a monitoring program to monitor spatial and temporal changes in SSW water levels and water quality. Shallow subsurface water (SSW) monitoring activities during 2002 included SSW quality sampling and SSW level surveillance at these 16 locations (Figure 6.6). 


\subsubsection{Shallow Subsurface Water Quality Sampling}

One round of water-quality samples from 15 wells/piezometers was collected in year 2002 from the SSW monitoring program. Wells in this monitoring system are poor producers, yielding less than two gallons per minute when developed. The quality of SSW sampled near the WIPP is poor and not suitable for human consumption. TDS concentrations measured in the SSW ranged from 2,160 mg/L to $135,000 \mathrm{mg} / \mathrm{L}$

(Table 6.12). Four sample locations have TDS concentrations less than 10,000 mg/L: (C-2507, C-2811, PZ-2, and PZ-10); all other locations have TDS values in excess of $10,000 \mathrm{mg} / \mathrm{L}$.

\subsubsection{Shallow Subsurface Water Level Surveillance}

Sixteen wells were used to perform surveillance of the shallow subsurface water-bearing horizon in the Santa Rosa Formation and the upper Dewey Lake Redbeds Formation. Water levels were collected monthly for all locations presented in Figure 6.6. Fluctuations in water level have varied less than one-half a foot during the year. Water levels have indicated a decreasing trend during the year in response to decreased precipitation resulting in less recharge to the shallow subsurface (Table 6.13). Piezometer PZ-8 has historically been dry.

Groundwater elevation measurements in the SSW indicate that flow moves radially away from a potentiometric high located near PZ-7 adjacent to the Salt Pile Evaporation Pond (Figure 6.7). A potentiometric low is located near PZ-12. A second low is located east of PZ-8, located east of the site, which has historically been a dry hole. Investigations are under way in 2003 to characterize the conditions of the SSW south of the site. 


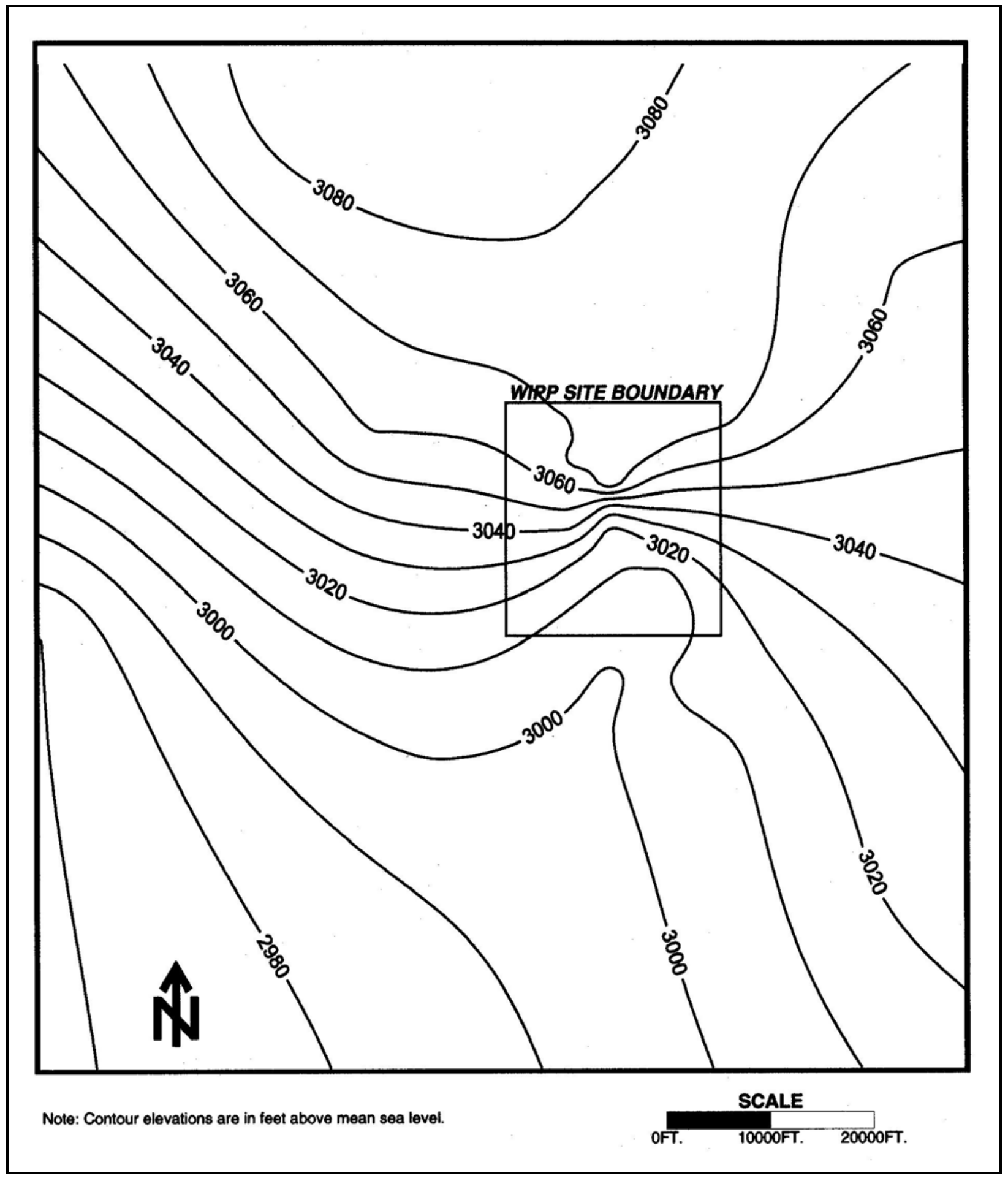

Figure 6.3 - Potentiometric Surface, Adjusted to Equivalent Freshwater Head, of the Culebra Dolomite Member of the Rustler Formation Near the WIPP Site, December 2002 


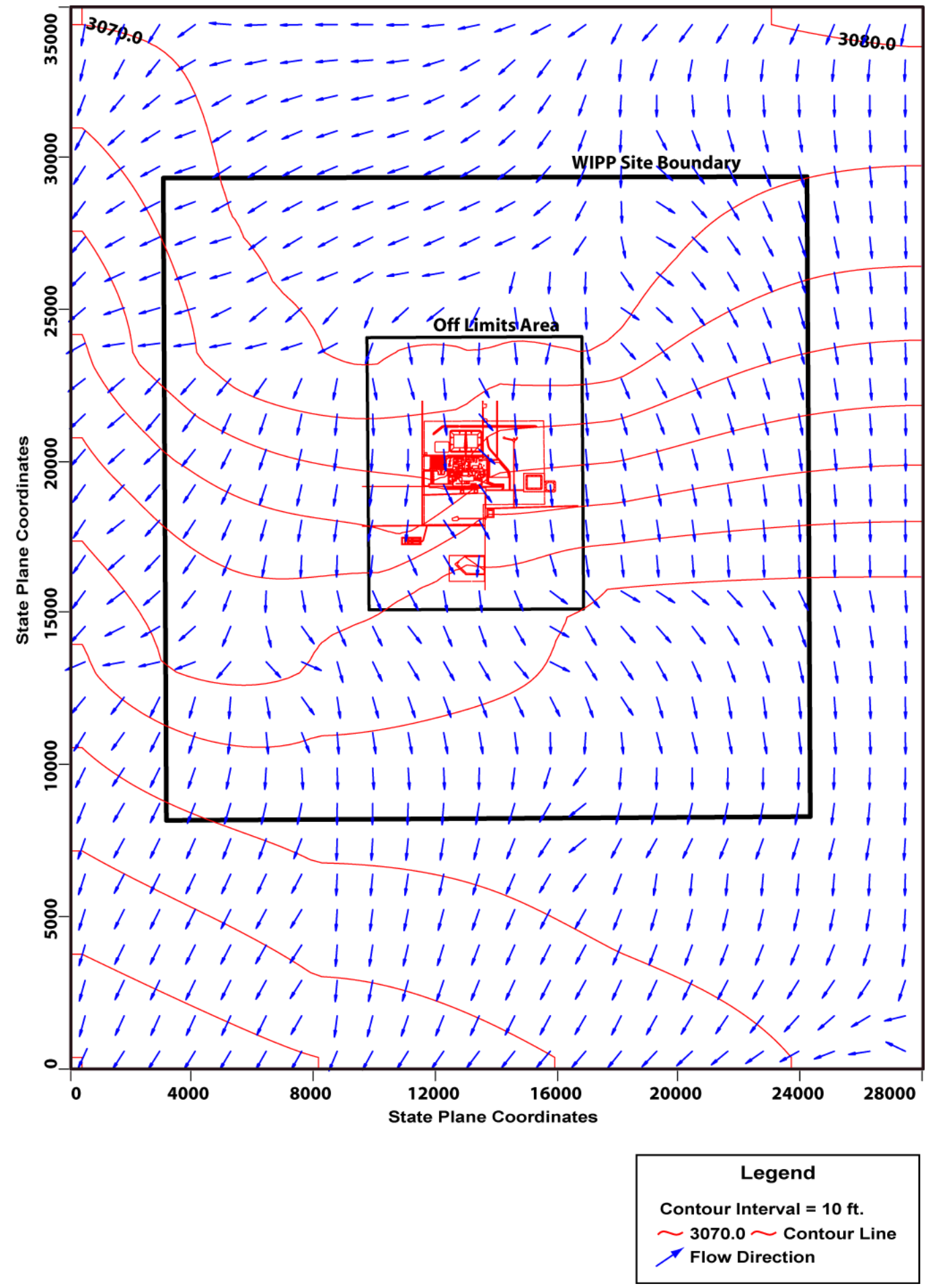

Figure 6.4 - Flow Rte and Direction of Groundwater Flowing Across the WIPP Site from the Culebra Formation, December 2002 
<smiles>[C]1C=CC=C1</smiles> 


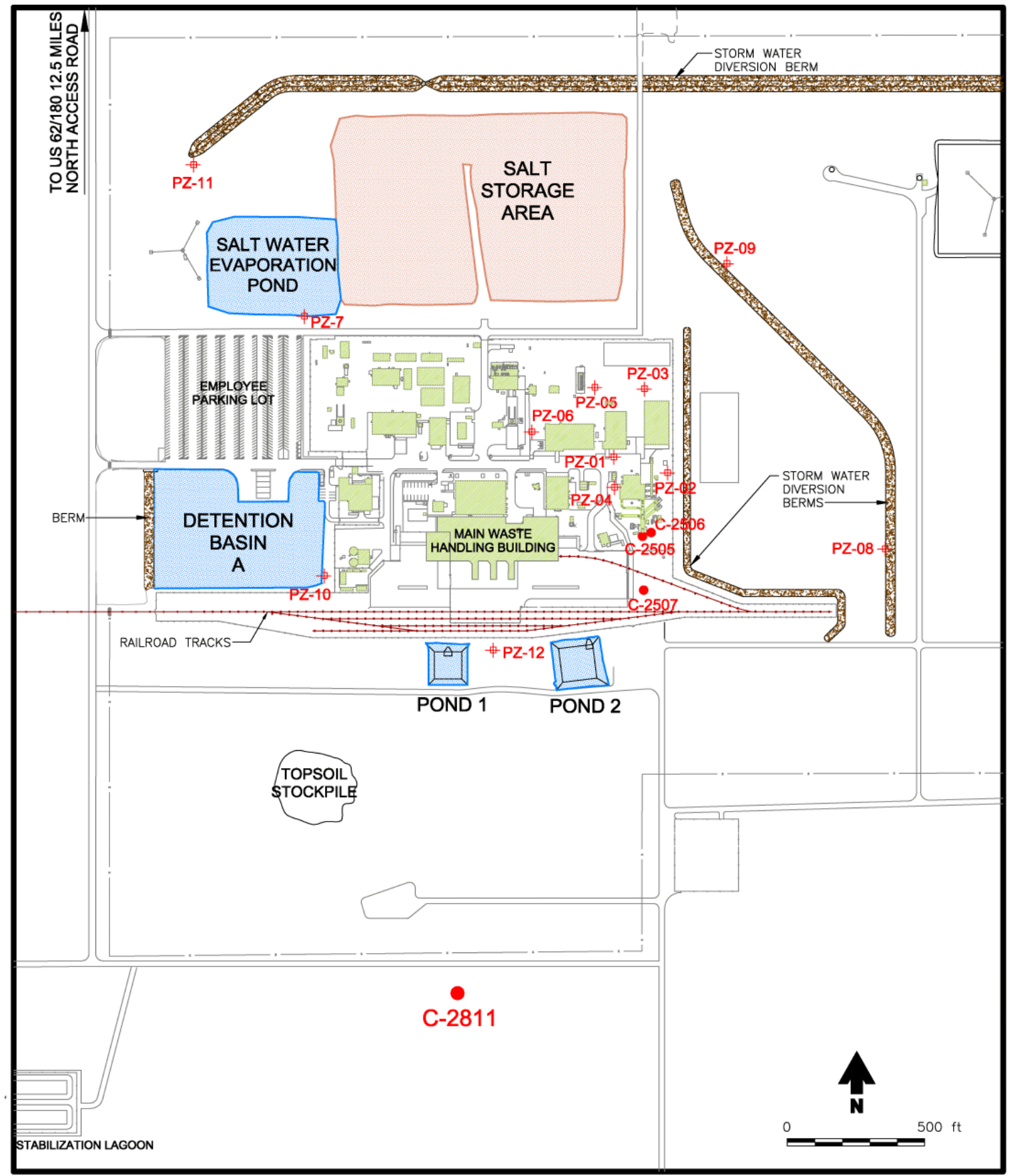

Figure 6.6 - Locations of SSW Wells (Piezometers PZ-1 through 12, C-2811, Wells C-2505, C-2506- and C-2507) 
Waste Isolation Pilot Plant 2002 Site Environmental Report DOE/WIPP 03-2225

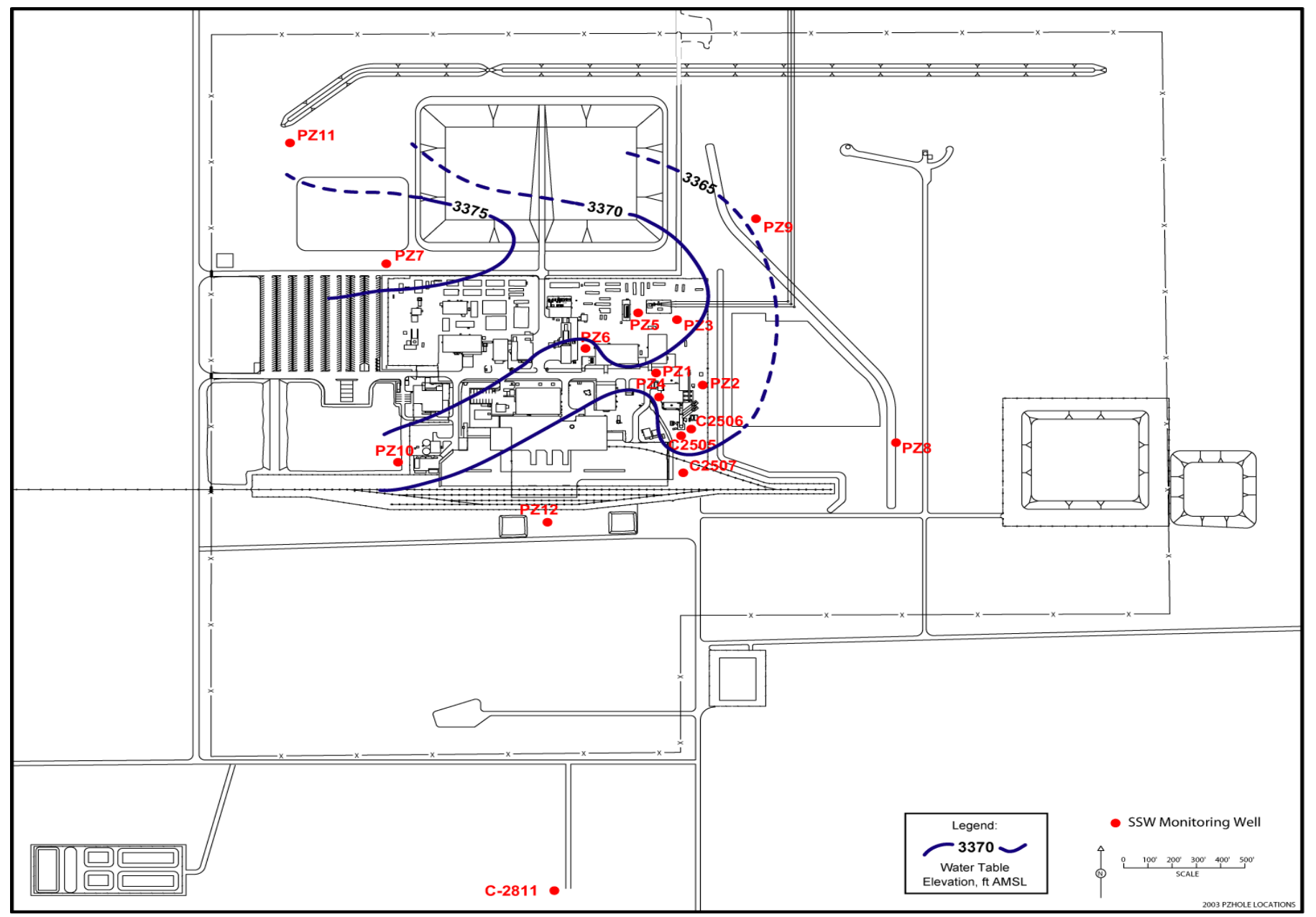

Figure 6.7 - Contour Plot of the SSW Potentionmetric Surface in the Santa Rosa Formation: December 2002 
Waste Isolation Pilot Plant 2002 Site Environmental Report DOE/WIPP 03-2225

Table 6.2 - Analytical Parameters for Which Groundwater Was Analyzed

\begin{tabular}{|c|c|c|c|c|c|}
\hline CAS No. ${ }^{a}$ & Parameter & $\begin{array}{c}\text { EPA } \\
\text { Method } \\
\text { Number }\end{array}$ & CAS No. & Parameter & $\begin{array}{c}\text { EPA } \\
\text { Method } \\
\text { Number }\end{array}$ \\
\hline $71-55-6$ & 1,1,1-Trichloroethane & $8260 \mathrm{~B}$ & $7782-50-5$ & Chloride & 300 \\
\hline $79-34-5$ & 1,1,2,2-Tetrachloroethane & $8260 \mathrm{~B}$ & & Density $^{\mathrm{b}}$ & \\
\hline $79-00-5$ & 1,1,2-Trichloroethane & $8260 B$ & $7727-37-9$ & Nitrate (as N) & 300 \\
\hline 75-34-3 & 1,1-Dichloroethane & $8260 \mathrm{~B}$ & & $\mathrm{pH}$ & 150.1 \\
\hline $75-35-4$ & 1,1-Dichloroethylene & $8260 \mathrm{~B}$ & & Specific conductance & 120.1 \\
\hline $107-06-2$ & 1,2-Dichloroethane & $8260 \mathrm{~B}$ & & Sulfate & 300 \\
\hline $56-23-5$ & Carbon tetrachloride & $8260 \mathrm{~B}$ & & Total dissolved solids (TDS) & 160.1 \\
\hline $108-90-7$ & Chlorobenzene & $8260 B$ & & Total organic carbon (TOC) & 415.1 \\
\hline $67-66-3$ & Chloroform & $8260 \mathrm{~B}$ & & Total organic halogen $(\mathrm{TOH})$ & $9020 \mathrm{~B}$ \\
\hline $540-59-0$ & cis-1,2-Dichloroethylene & $8260 \mathrm{~B}$ & & Total suspended solids (TSS) & 160.2 \\
\hline $540-59-0$ & trans-1, 2-Dichloroethylene & $8260 \mathrm{~B}$ & & & \\
\hline $78-93-3$ & Methyl ethyl ketone & $8260 \mathrm{~B}$ & & & \\
\hline $75-09-2$ & Methylene chloride & $8260 \mathrm{~B}$ & & & \\
\hline $127-18-4$ & Tetrachloroethylene & $8260 B$ & $7440-36-0$ & Alkalinity & 310.1 \\
\hline $108-88-3$ & Toluene & $8260 B$ & $7440-38-2$ & Antimony & $6010 \mathrm{~B}$ \\
\hline $79-01-6$ & Trichloroethylene & $8260 \mathrm{~B}$ & $7440-39-3$ & Arsenic & $6010 \mathrm{~B}$ \\
\hline $75-69-4$ & Trichlorofluoromethane & $8260 \mathrm{~B}$ & $7440-41-7$ & Barium & $6010 \mathrm{~B}$ \\
\hline $75-01-4$ & Vinyl chloride & $8260 \mathrm{~B}$ & $7440-43-9$ & Beryllium & $6010 \mathrm{~B}$ \\
\hline $1330-20-7$ & Xylene & $8260 \mathrm{~B}$ & $7440-70-2$ & Cadmium & $6010 \mathrm{~B}$ \\
\hline $95-50-1$ & 1,2-Dichlorobenzene & $8270 \mathrm{C}$ & $7440-47-3$ & Calcium & $6010 B$ \\
\hline $106-46-7$ & 1,4-Dichlorobenzene & $8270 \mathrm{C}$ & $7439-89-6$ & Chromium & 6010B \\
\hline $51-28-5$ & 2,4-Dinitrophenol & $8270 \mathrm{C}$ & $7439-92-1$ & Iron & $6010 \mathrm{~B}$ \\
\hline $121-14-2$ & 2,4-Dinitrotoluene & $8270 \mathrm{C}$ & $7439-95-4$ & Lead & $6010 \mathrm{~B}$ \\
\hline $95-48-7$ & 2-Methylphenol & $8270 \mathrm{C}$ & $7439-97-6$ & Magnesium & $6010 \mathrm{~B}$ \\
\hline \multirow{2}{*}{$\begin{array}{l}108-39-4 / \\
106-44-5\end{array}$} & \multirow{2}{*}{$\begin{array}{l}\text { 3-Methylphenol/ } \\
\text { 4-Methylphenol }\end{array}$} & \multirow[t]{2}{*}{$8270 \mathrm{C}$} & 2023473 & Mercury & $7470 \mathrm{~A}$ \\
\hline & & & 2023692 & Nickel & $6010 \mathrm{~B}$ \\
\hline $118-74-1$ & Hexachlorobenzene & $8270 \mathrm{C}$ & $7782-49-2$ & Potassium & $6010 \mathrm{~B}$ \\
\hline $67-72-1$ & Hexachloroethane & $8270 \mathrm{C}$ & $7440-22-4$ & Selenium & $6010 \mathrm{~B}$ \\
\hline $98-95-3$ & Nitrobenzene & $8270 \mathrm{C}$ & $7440-23-5$ & Silver & $6010 \mathrm{~B}$ \\
\hline $87-86-5$ & Pentachlorophenol & $8270 \mathrm{C}$ & $7440-28-0$ & Sodium & $6010 \mathrm{~B}$ \\
\hline $110-86-1$ & Pyridine & $8270 \mathrm{C}$ & $7440-62-2$ & Thallium & $6010 \mathrm{~B}$ \\
\hline $78-83-1$ & Isobutanol & 8015B & $7440-66-6$ & Vanadium & $6010 \mathrm{~B}$ \\
\hline
\end{tabular}


Table 6.3 - Analytical Results for Groundwater Sampled from Well WQSP-1

\begin{tabular}{|c|c|c|c|c|c|c|c|c|}
\hline \multirow[b]{3}{*}{ Parameter } & \multicolumn{7}{|c|}{ Concentration } & \multirow[b]{3}{*}{$\begin{array}{c}95^{\text {th }} \\
\text { UTLV }\end{array}$} \\
\hline & \multicolumn{2}{|c|}{ Round 14} & \multicolumn{2}{|c|}{ Round 15} & \multirow[b]{2}{*}{ Units } & \multicolumn{2}{|c|}{ Reporting Limit } & \\
\hline & Sample & Dup. & Sample & Dup. & & $\begin{array}{c}\text { Round } \\
14\end{array}$ & $\begin{array}{c}\text { Round } \\
15\end{array}$ & \\
\hline 1,1,1-Trichloroethane & $<1$ & $<1$ & $<1$ & $<1$ & $\mu g / L$ & 1 & 1 & $<\mathrm{RL}^{\mathrm{b}}$ \\
\hline 1,1,2,2-Tetrachloroethane & $<1$ & $<1$ & $<1$ & $<1$ & $\mu \mathrm{g} / \mathrm{L}$ & 1 & 1 & $<R L$ \\
\hline 1,1,2-Trichloroethane & $<1$ & $<1$ & $<1$ & $<1$ & $\mu g / L$ & 1 & 1 & $<R L$ \\
\hline 1,1-Dichloroethane & $<1$ & $<1$ & $<1$ & $<1$ & $\mu g / L$ & 1 & 1 & $<R L$ \\
\hline 1,1-Dichloroethylene & $<1$ & $<1$ & $<1$ & $<1$ & $\mu g / L$ & 1 & 1 & $<R L$ \\
\hline 1,2-Dichloroethane & $<1$ & $<1$ & $<1$ & $<1$ & $\mu g / L$ & 1 & 1 & $<R L$ \\
\hline Carbon tetrachloride & $<1$ & $<1$ & $<1$ & $<1$ & $\mu g / L$ & 1 & 1 & $<R L$ \\
\hline Chlorobenzene & $<1$ & $<1$ & $<1$ & $<1$ & $\mu g / L$ & 1 & 1 & $<\mathrm{RL}$ \\
\hline Chloroform & $<1$ & $<1$ & $<1$ & $<1$ & $\mu g / L$ & 1 & 1 & $<R L$ \\
\hline cis-1,2-Dichloroethylene & $<1$ & $<1$ & $<1$ & $<1$ & $\mu g / L$ & 1 & 1 & $<R L$ \\
\hline trans-1, 2-Dichloroethylene & $<1$ & $<1$ & $<1$ & $<1$ & $\mu g / L$ & 1 & 1 & $<R L$ \\
\hline Methyl ethyl ketone & $<5$ & $<5$ & $<5$ & $<5$ & $\mu g / L$ & 5 & 5 & $<\mathrm{RL}$ \\
\hline Methylene chloride & $<5$ & $<5$ & $<5$ & $<5$ & $\mu g / L$ & 5 & 5 & $<R L$ \\
\hline Tetrachloroethylene & $<1$ & $<1$ & $<1$ & $<1$ & $\mu g / L$ & 1 & 1 & $<R L$ \\
\hline Toluene & $<1$ & $<1$ & $<1$ & $<1$ & $\mu g / L$ & 1 & 1 & $<\mathrm{RL}$ \\
\hline Trichloroethylene & $<1$ & $<1$ & $<1$ & $<1$ & $\mu g / L$ & 1 & 1 & $<R L$ \\
\hline Trichlorofluoromethane & $<1$ & $<1$ & $<1$ & $<1$ & $\mu g / L$ & 1 & 1 & $<R L$ \\
\hline Vinyl chloride & $<1$ & $<1$ & $<1$ & $<1$ & $\mu g / L$ & 1 & 1 & $<\mathrm{RL}$ \\
\hline Xylene & $<1$ & $<1$ & $<1$ & $<1$ & $\mu g / L$ & 1 & 1 & $<R L$ \\
\hline 1,2-Dichlorobenzene & $<5$ & $<5$ & $<5$ & $<5$ & $\mu g / L$ & 5 & 5 & $<R L$ \\
\hline 1,4-Dichlorobenzene & $<5$ & $<5$ & $<5$ & $<5$ & $\mu g / L$ & 5 & 5 & $<\mathrm{RL}$ \\
\hline 2,4-Dinitrophenol & $<5$ & $<5$ & $<5$ & $<5$ & $\mu g / L$ & 5 & 5 & $<R L$ \\
\hline 2,4-Dinitrotoluene & $<5$ & $<5$ & $<5$ & $<5$ & $\mu g / L$ & 5 & 5 & $<R L$ \\
\hline 2-Methylphenol & $<5$ & $<5$ & $<5$ & $<5$ & $\mu g / L$ & 5 & 5 & $<\mathrm{RL}$ \\
\hline $\begin{array}{l}\text { 3-Methylphenol/ } \\
\text { 4-Methylphenol }\end{array}$ & $<5$ & $<5$ & $<5$ & $<5$ & $\mu g / L$ & 5 & 5 & $<R L$ \\
\hline Hexachlorobenzene & $<5$ & $<5$ & $<5$ & $<5$ & $\mu g / L$ & 5 & 5 & $<R L$ \\
\hline Hexachloroethane & $<5$ & $<5$ & $<5$ & $<5$ & $\mu g / L$ & 5 & 5 & $<R L$ \\
\hline Nitrobenzene & $<5$ & $<5$ & $<5$ & $<5$ & $\mu g / L$ & 5 & 5 & $<R L$ \\
\hline Pentachlorophenol & $<5$ & $<5$ & $<5$ & $<5$ & $\mu g / L$ & 5 & 5 & $<R L$ \\
\hline Pyridine & $<5$ & $<5$ & $<5$ & $<5$ & $\mu g / L$ & 5 & 5 & $<R L$ \\
\hline Isobutanol & $<5$ & $<5$ & $<5$ & $<5$ & $\mu g / L$ & 5 & 5 & $<R L$ \\
\hline Alkalinity & 50 & 48 & 49 & 51 & $\mathrm{mg} / \mathrm{L}$ & 4 & 4 & 55.7 \\
\hline Chloride & 36600 & 32300 & 35400 & 37800 & $\mathrm{mg} / \mathrm{L}$ & 0.5 & 2 & 40472 \\
\hline Density & 1.035 & 1.037 & 1.049 & 1.046 & $\mathrm{~g} / \mathrm{mL}$ & $N / A^{c}$ & $\mathrm{~N} / \mathrm{A}$ & 1.072 \\
\hline Nitrate (as N) & $<.10$ & $<.10$ & $<.10$ & $<.10$ & $\mathrm{mg} / \mathrm{L}$ & 0.1 & 0.1 & $<10$ \\
\hline $\mathrm{pH}$ & 7.1 & 7.1 & 7.2 & 7.2 & $S U^{d}$ & $\mathrm{~N} / \mathrm{A}$ & $\mathrm{N} / \mathrm{A}$ & 6.89-7.65 \\
\hline Specific conductance & 99400 & 99000 & 77700 & 71800 & $\mu \mathrm{mhos} / \mathrm{cm}$ & $\mathrm{N} / \mathrm{A}$ & N/A & 175000 \\
\hline Sulfate & 4270 & 4010 & 5110 & 5640 & $\mathrm{mg} / \mathrm{L}$ & 0.5 & 2 & 5757 \\
\hline
\end{tabular}


Waste Isolation Pilot Plant 2002 Site Environmental Report DOE/WIPP 03-2225

Table 6.3 - Analytical Results for Groundwater Sampled from Well WQSP-1

\begin{tabular}{|c|c|c|c|c|c|c|c|c|}
\hline \multirow[b]{3}{*}{ Parameter } & \multicolumn{7}{|c|}{ Concentration } & \multirow[b]{3}{*}{$\begin{array}{l}95^{\text {th }} \\
\text { UTLV }^{\mathrm{a}}\end{array}$} \\
\hline & \multicolumn{2}{|c|}{ Round 14} & \multicolumn{2}{|c|}{ Round 15} & \multirow[b]{2}{*}{ Units } & \multicolumn{2}{|c|}{ Reporting Limit } & \\
\hline & Sample & Dup. & Sample & Dup. & & $\begin{array}{c}\text { Round } \\
14 \\
\end{array}$ & $\begin{array}{c}\text { Round } \\
15 \\
\end{array}$ & \\
\hline Total dissolved solids & 60500 & 60600 & 64500 & 63900 & $\mathrm{mg} / \mathrm{L}$ & 10 & 10 & 80700 \\
\hline Total organic carbon & $<1.0$ & $<1.0$ & $<1.0$ & $<1.0$ & $\mathrm{mg} / \mathrm{L}$ & 1 & 1 & $<5.0$ \\
\hline Total organic halogen & 2.6 & 2.2 & 3.3 & 3.7 & $\mathrm{mg} / \mathrm{L}$ & N/A & 0.005 & 14.6 \\
\hline Total suspended solids & $<1.0$ & $<1.0$ & $<1.0$ & $<1.0$ & $\mathrm{mg} / \mathrm{L}$ & 1 & 1 & 33.5 \\
\hline Antimony & $<0.025$ & $<0.025$ & $<0.125$ & $<0.125$ & $\mathrm{mg} / \mathrm{L}$ & 0.025 & 0.025 & 0.33 \\
\hline Arsenic & $<0.05$ & $<0.05$ & $<0.25$ & $<0.25$ & $\mathrm{mg} / \mathrm{L}$ & 0.05 & 0.05 & $<0.1$ \\
\hline Barium & $<0.05$ & $<0.05$ & $<0.50$ & $<0.50$ & $\mathrm{mg} / \mathrm{L}$ & 0.05 & 0.05 & $<1.0$ \\
\hline Beryllium & $<0.01$ & $<0.01$ & $<0.0125$ & $<0.0125$ & $\mathrm{mg} / \mathrm{L}$ & 0.01 & 0.0125 & $<0.02$ \\
\hline Cadmium & $<0.050$ & $<0.050$ & $<0.005$ & $<0.005$ & $\mathrm{mg} / \mathrm{L}$ & 0.05 & 0.005 & $<0.2$ \\
\hline Calcium & 1620 & 1580 & 1700 & 1620 & $\mathrm{mg} / \mathrm{L}$ & 0.2 & 0.5 & 2,087 \\
\hline Chromium & $<0.05$ & $<0.05$ & $<0.05$ & $<0.051$ & $\mathrm{mg} / \mathrm{L}$ & 0.05 & 0.05 & $<0.5$ \\
\hline Iron & $<0.20$ & $<0.20$ & 0.358 & 0.253 & $\mathrm{mg} / \mathrm{L}$ & 0.2 & 0.5 & 1.32 \\
\hline Lead & $<0.10$ & $<0.10$ & $<0.01$ & $<0.01$ & $\mathrm{mg} / \mathrm{L}$ & 0.1 & 0.01 & 0.105 \\
\hline Magnesium & 1240 & 1220 & 1120 & 1040 & $\mathrm{mg} / \mathrm{L}$ & 0.2 & 0.5 & 1,247 \\
\hline Mercury & $<0.0002$ & $<0.0002$ & $<0.0002$ & $<0.0002$ & $\mathrm{mg} / \mathrm{L}$ & 0 & 0 & $<0.002$ \\
\hline Nickel & $<0.10$ & $<0.10$ & $<0.125$ & $<0.125$ & $\mathrm{mg} / \mathrm{L}$ & 0.1 & 0.125 & 0.490 \\
\hline Potassium & 695 & 721 & 681 & 691 & $\mathrm{mg} / \mathrm{L}$ & 0.2 & 0.5 & 799 \\
\hline Selenium & $<0.05$ & $<0.05$ & $<0.25$ & $<0.25$ & $\mathrm{mg} / \mathrm{L}$ & 0.05 & 0.25 & 0.15 \\
\hline Silver & $<0.0125$ & $<0.0125$ & $<0.0625$ & $<0.0625$ & $\mathrm{mg} / \mathrm{L}$ & 0.013 & 0.0625 & $<0.50$ \\
\hline Sodium & 18400 & 19600 & 18600 & 15100 & $\mathrm{mg} / \mathrm{L}$ & 0.2 & 0.5 & 22,090 \\
\hline Thallium & $<0.20$ & $<0.20$ & $<0.25$ & $<0.25$ & $\mathrm{mg} / \mathrm{L}$ & 0.2 & 0.25 & 0.980 \\
\hline Vanadium & $<0.10$ & $<0.10$ & $<0.125$ & $<0.125$ & $\mathrm{mg} / \mathrm{L}$ & 0.1 & 0.125 & $<0.1$ \\
\hline \multicolumn{9}{|c|}{$\begin{array}{l}\text { A } 95^{\text {th }} \text { Upper tolerance limit value, equivalent to } 95 \% \text { confidence limit } \\
\text { b Reporting limit } \\
\text { ' Not applicable } \\
\text { d Standard unit }\end{array}$} \\
\hline
\end{tabular}


Table 6.4 - Analytical Results for Groundwater Sampled from Well WQSP-2

\begin{tabular}{|c|c|c|c|c|c|c|c|c|}
\hline \multirow[b]{3}{*}{ Parameter } & \multicolumn{7}{|c|}{ Concentration } & \multirow[b]{3}{*}{$\begin{array}{l}95^{\text {th }} \\
\text { UTLV }\end{array}$} \\
\hline & \multicolumn{2}{|c|}{ Round 14} & \multicolumn{2}{|c|}{ Round 15} & \multirow[b]{2}{*}{ Units } & \multicolumn{2}{|c|}{ Reporting Limit } & \\
\hline & Sample & Dup. & Sample & Dup. & & $\begin{array}{c}\text { Round } \\
14\end{array}$ & $\begin{array}{c}\text { Round } \\
15\end{array}$ & \\
\hline 1,1,1-Trichloroethane & $<1$ & $<1$ & $<1$ & $<1$ & $\mu g / L$ & 1 & 1 & $<\mathrm{RL}^{\mathrm{b}}$ \\
\hline 1,1,2,2-Tetrachloroethane & $<1$ & $<1$ & $<1$ & $<1$ & $\mu g / L$ & 1 & 1 & $<R L$ \\
\hline 1,1,2-Trichloroethane & $<1$ & $<1$ & $<1$ & $<1$ & $\mu g / L$ & 1 & 1 & $<R L$ \\
\hline 1,1-Dichloroethane & $<1$ & $<1$ & $<1$ & $<1$ & $\mu g / L$ & 1 & 1 & $<\mathrm{RL}$ \\
\hline 1,1-Dichloroethylene & $<1$ & $<1$ & $<1$ & $<1$ & $\mu g / L$ & 1 & 1 & $<\mathrm{RL}$ \\
\hline 1,2-Dichloroethane & $<1$ & $<1$ & $<1$ & $<1$ & $\mu g / L$ & 1 & 1 & $<R L$ \\
\hline Carbon tetrachloride & $<1$ & $<1$ & $<1$ & $<1$ & $\mu g / L$ & 1 & 1 & $<R L$ \\
\hline Chlorobenzene & $<1$ & $<1$ & $<1$ & $<1$ & $\mu g / L$ & 1 & 1 & $<\mathrm{RL}$ \\
\hline Chloroform & $<1$ & $<1$ & $<1$ & $<1$ & $\mu g / L$ & 1 & 1 & $<R L$ \\
\hline cis-1,2-Dichloroethylene & $<1$ & $<1$ & $<1$ & $<1$ & $\mu g / L$ & 1 & 1 & $<R L$ \\
\hline trans-1,2-Dichloroethylene & $<1$ & $<1$ & $<1$ & $<1$ & $\mu g / L$ & 1 & 1 & $<\mathrm{RL}$ \\
\hline Methyl ethyl ketone & $<5$ & $<5$ & $<5$ & $<5$ & $\mu g / L$ & 5 & 5 & $<R L$ \\
\hline Methylene chloride & $<5$ & $<5$ & $<5$ & $<5$ & $\mu g / L$ & 5 & 5 & $<R L$ \\
\hline Tetrachloroethylene & $<1$ & $<1$ & $<1$ & $<1$ & $\mu g / L$ & 1 & 1 & $<\mathrm{RL}$ \\
\hline Toluene & $<1$ & $<1$ & $<1$ & $<1$ & $\mu g / L$ & 1 & 1 & $<R L$ \\
\hline Trichloroethylene & $<1$ & $<1$ & $<1$ & $<1$ & $\mu g / L$ & 1 & 1 & $<R L$ \\
\hline Trichlorofluoromethane & $<1$ & $<1$ & $<1$ & $<1$ & $\mu g / L$ & 1 & 1 & $<R L$ \\
\hline Vinyl chloride & $<1$ & $<1$ & $<1$ & $<1$ & $\mu \mathrm{g} / \mathrm{L}$ & 1 & 1 & $<R L$ \\
\hline Xylene & $<1$ & $<1$ & $<1$ & $<1$ & $\mu g / L$ & 1 & 1 & $<R L$ \\
\hline 1,2-Dichlorobenzene & $<5$ & $<5$ & $<5$ & $<5$ & $\mu g / L$ & 5 & 5 & $<R L$ \\
\hline 1,4-Dichlorobenzene & $<5$ & $<5$ & $<5$ & $<5$ & $\mu \mathrm{g} / \mathrm{L}$ & 5 & 5 & $<R L$ \\
\hline 2,4-Dinitrophenol & $<5$ & $<5$ & $<5$ & $<5$ & $\mu g / L$ & 5 & 5 & $<R L$ \\
\hline 2,4-Dinitrotoluene & $<5$ & $<5$ & $<5$ & $<5$ & $\mu g / L$ & 5 & 5 & $<R L$ \\
\hline 2-Methylphenol & $<5$ & $<5$ & $<5$ & $<5$ & $\mu g / L$ & 5 & 5 & $<R L$ \\
\hline $\begin{array}{l}\text { 3-Methylphenol/ } \\
\text { 4-Methylphenol }\end{array}$ & $<5$ & $<5$ & $<5$ & $<5$ & $\mu g / L$ & 5 & 5 & $<\mathrm{RL}$ \\
\hline Hexachlorobenzene & $<5$ & $<5$ & $<5$ & $<5$ & $\mu \mathrm{g} / \mathrm{L}$ & 5 & 5 & $<R L$ \\
\hline Hexachloroethane & $<5$ & $<5$ & $<5$ & $<5$ & $\mu g / L$ & 5 & 5 & $<\mathrm{RL}$ \\
\hline Nitrobenzene & $<5$ & $<5$ & $<5$ & $<5$ & $\mu g / L$ & 5 & 5 & $<\mathrm{RL}$ \\
\hline Pentachlorophenol & $<5$ & $<5$ & $<5$ & $<5$ & $\mu g / L$ & 5 & 5 & $<R L$ \\
\hline Pyridine & $<5$ & $<5$ & $<5$ & $<5$ & $\mu g / L$ & 5 & 5 & $<R L$ \\
\hline Isobutanol & $<5$ & $<5$ & $<5$ & $<5$ & $\mu g / L$ & 5 & 5 & $<R L$ \\
\hline Alkalinity & 48 & 46 & 42 & 44 & $\mathrm{mg} / \mathrm{L}$ & 4 & 4 & 70.3 \\
\hline Chloride & 34500 & 33900 & 36100 & 34100 & $\mathrm{mg} / \mathrm{L}$ & 2 & 2 & 39670 \\
\hline Density & 1.0467 & 1.0409 & 1.04 & 1.043 & $\mathrm{~g} / \mathrm{mL}$ & $N / A^{d}$ & $\mathrm{~N} / \mathrm{A}$ & 1.06 \\
\hline Nitrate (as N) & $<0.1$ & $<0.1$ & $<0.1$ & $<0.1$ & $\mathrm{mg} / \mathrm{L}$ & 0.1 & 0.1 & $<10$ \\
\hline $\mathrm{pH}$ & 7.2 & 7.2 & 7.1 & 7.1 & $S u^{e}$ & $\mathrm{~N} / \mathrm{A}$ & $\mathrm{N} / \mathrm{A}$ & $7.00-7.60$ \\
\hline Specific conductance & 75600 & 79300 & 76870 & 74060 & $\mu \mathrm{mhos} / \mathrm{cm}$ & $\mathrm{N} / \mathrm{A}$ & $\mathrm{N} / \mathrm{A}$ & 124000 \\
\hline Sulfate & 5570 & 5650 & 6310 & 5560 & $\mathrm{mg} / \mathrm{L}$ & 2 & 2 & 6590 \\
\hline
\end{tabular}


Waste Isolation Pilot Plant 2002 Site Environmental Report DOE/WIPP 03-2225

Table 6.4 - Analytical Results for Groundwater Sampled from Well WQSP-2

\begin{tabular}{|c|c|c|c|c|c|c|c|c|}
\hline \multirow[b]{3}{*}{ Parameter } & \multicolumn{5}{|c|}{ Concentration } & & & \multirow[b]{3}{*}{$\begin{array}{l}95^{\text {th }} \\
\text { UTLV }^{\mathrm{a}}\end{array}$} \\
\hline & \multicolumn{2}{|c|}{ Round 14} & \multicolumn{2}{|c|}{ Round 15} & \multirow[b]{2}{*}{ Units } & \multicolumn{2}{|c|}{ Reporting Limit } & \\
\hline & Sample & Dup. & Sample & Dup. & & $\begin{array}{c}\text { Round } \\
14 \\
\end{array}$ & $\begin{array}{c}\text { Round } \\
15\end{array}$ & \\
\hline Total dissolved solids & 59800 & 59600 & 67700 & 67600 & $\mathrm{mg} / \mathrm{L}$ & 10 & 10 & 80500 \\
\hline Total organic carbon & 1.59 & 2.02 & $<1.0$ & $<1.0$ & $\mathrm{mg} / \mathrm{L}$ & 1 & 1 & 7.97 \\
\hline Total organic halogen & 3.2 & 3.2 & 2.6 & 2.7 & $\mathrm{mg} / \mathrm{L}$ & 0.01 & 0.01 & 63.8 \\
\hline Total suspended solids & $<1.0$ & $<1.0$ & $<1.0$ & $<1.0$ & $\mathrm{mg} / \mathrm{L}$ & 1 & 1 & 43 \\
\hline Antimony & $<0.025$ & $<0.025$ & $<0.025$ & $<0.025$ & $\mathrm{mg} / \mathrm{L}$ & 0.025 & 0.025 & $<0.50$ \\
\hline Arsenic & $<0.05$ & $<0.05$ & $<0.05$ & $<0.05$ & $\mathrm{mg} / \mathrm{L}$ & 0.05 & 0.05 & 0.062 \\
\hline Barium & $<0.10$ & $<0.10$ & $<0.10$ & $<0.10$ & $\mathrm{mg} / \mathrm{L}$ & 0.1 & 0.1 & $<1.0$ \\
\hline Beryllium & $<0.0025$ & $<0.0025$ & $<0.0025$ & $<0.0025$ & $\mathrm{mg} / \mathrm{L}$ & 0 & 0 & $<1.0$ \\
\hline Cadmium & $<0.005$ & $<0.005$ & $<0.00$ & $<0.00$ & $\mathrm{mg} / \mathrm{L}$ & 0.01 & 0.01 & $<0.5$ \\
\hline Calcium & 1662 & 1624 & 1510 & 1450 & $\mathrm{mg} / \mathrm{L}$ & 0.5 & 0.5 & 1,827 \\
\hline Chromium & $<0.01$ & $<0.01$ & $<0.01$ & $<0.01$ & $\mathrm{mg} / \mathrm{L}$ & 0.01 & 0.01 & $<0.5$ \\
\hline Iron & $<0.50$ & $<0.50$ & $<0.05$ & $<0.05$ & $\mathrm{mg} / \mathrm{L}$ & 0.50 & 0.05 & 1.32 \\
\hline Lead & $<0.01$ & $<0.01$ & $<0.01$ & $<0.01$ & $\mathrm{mg} / \mathrm{L}$ & 0.01 & 0.01 & 0.163 \\
\hline Magnesium & 1093 & 1074 & 1080 & 1030 & $\mathrm{mg} / \mathrm{L}$ & 0.5 & 0.5 & 1,244 \\
\hline Mercury & $<0.0002$ & $<0.0002$ & $<0.0002$ & $<0.0002$ & $\mathrm{mg} / \mathrm{L}$ & 0 & 0 & $<0.002$ \\
\hline Nickel & $<0.025$ & $<0.025$ & $<0.025$ & $<0.025$ & $\mathrm{mg} / \mathrm{L}$ & 0.025 & 0.025 & 0.490 \\
\hline Potassium & 759 & 797 & 852 & 813 & $\mathrm{mg} / \mathrm{L}$ & 0.5 & 0.5 & 845 \\
\hline Selenium & $<0.05$ & $<0.05$ & 0.051 & $<0.05$ & $\mathrm{mg} / \mathrm{L}$ & 0.05 & 0.05 & 0.150 \\
\hline Silver & $<0.0125$ & $<0.0125$ & $<0.0125$ & $<0.0125$ & $\mathrm{mg} / \mathrm{L}$ & 0.013 & 0.013 & $<0.50$ \\
\hline Sodium & 20240 & 20490 & 15900 & 16500 & $\mathrm{mg} / \mathrm{L}$ & 0.5 & 0.5 & 21,900 \\
\hline Thallium & $<0.05$ & $<0.05$ & $<0.05$ & $<0.05$ & $\mathrm{mg} / \mathrm{L}$ & 0.05 & 0.05 & 0.98 \\
\hline Vanadium & $<0.025$ & $<0.025$ & $<0.025$ & $<0.025$ & $\mathrm{mg} / \mathrm{L}$ & 0.025 & 0.025 & $<0.1$ \\
\hline $\begin{array}{l}\text { A } 95^{\text {th }} \text { Upper tolerance lir } \\
\text { b Reporting limit } \\
{ }^{\circ} \text { Not reported by the lab } \\
\text { d Not applicable } \\
\text { e Standard unit }\end{array}$ & $\begin{array}{l}\text { value, equ } \\
\text { tory }\end{array}$ & ivalent to 9 & $\%$ confider & ce limit & & & & \\
\hline
\end{tabular}


Table 6.5 - Analytical Results for Groundwater Sampled from Well WQSP-3

\begin{tabular}{|c|c|c|c|c|c|c|c|c|}
\hline \multirow[b]{3}{*}{ Parameter } & \multicolumn{7}{|c|}{ Concentration } & \multirow[b]{3}{*}{$\begin{array}{l}9^{\text {th }} \\
\text { UTLV }^{\text {a }}\end{array}$} \\
\hline & \multicolumn{2}{|c|}{ Round 14} & \multicolumn{2}{|c|}{ Round 15} & \multirow[b]{2}{*}{ Units } & \multicolumn{2}{|c|}{ Reporting Limit } & \\
\hline & Sample & Dup. & Sample & Dup. & & $\begin{array}{c}\text { Round } \\
14 \\
\end{array}$ & $\begin{array}{c}\text { Round } \\
15\end{array}$ & \\
\hline 1,1,1-Trichloroethane & $<1$ & $<1$ & $<1$ & $<1$ & $\mu \mathrm{g} / \mathrm{L}$ & 1 & 1 & $<\mathrm{RL}^{\mathrm{b}}$ \\
\hline 1,1,2,2-Tetrachloroethane & $<1$ & $<1$ & $<1$ & $<1$ & $\mu g / L$ & 1 & 1 & $<R L$ \\
\hline 1,1,2-Trichloroethane & $<1$ & $<1$ & $<1$ & $<1$ & $\mu g / L$ & 1 & 1 & $<R L$ \\
\hline 1,1-Dichloroethane & $<1$ & $<1$ & $<1$ & $<1$ & $\mu g / L$ & 1 & 1 & $<R L$ \\
\hline 1,1-Dichloroethylene & $<1$ & $<1$ & $<1$ & $<1$ & $\mu g / L$ & 1 & 1 & $<R L$ \\
\hline 1,2-Dichloroethane & $<1$ & $<1$ & $<1$ & $<1$ & $\mu g / L$ & 1 & 1 & $<R L$ \\
\hline Carbon tetrachloride & $<1$ & $<1$ & $<1$ & $<1$ & $\mu g / L$ & 1 & 1 & $<R L$ \\
\hline Chlorobenzene & $<1$ & $<1$ & $<1$ & $<1$ & $\mu g / L$ & 1 & 1 & $<R L$ \\
\hline Chloroform & $<1$ & $<1$ & $<1$ & $<1$ & $\mu g / L$ & 1 & 1 & $<R L$ \\
\hline cis-1,2-Dichloroethylene & $<1$ & $<1$ & $<1$ & $<1$ & $\mu g / L$ & 1 & 1 & $<\mathrm{RL}$ \\
\hline trans-1,2-Dichloroethylene & $<1$ & $<1$ & $<1$ & $<1$ & $\mu g / L$ & 1 & 1 & $<R L$ \\
\hline Methyl ethyl ketone & $<5$ & $<5$ & $<5$ & $<5$ & $\mu g / L$ & 5 & 5 & $<R L$ \\
\hline Methylene chloride & $<5$ & $<5$ & $<5$ & $<5$ & $\mu g / L$ & 5 & 5 & $<\mathrm{RL}$ \\
\hline Tetrachloroethylene & $<1$ & $<1$ & $<1$ & $<1$ & $\mu g / L$ & 1 & 1 & $<R L$ \\
\hline Toluene & $<1$ & $<1$ & $<1$ & $<1$ & $\mu g / L$ & 1 & 1 & $<R L$ \\
\hline Trichloroethylene & $<1$ & $<1$ & $<1$ & $<1$ & $\mu g / L$ & 1 & 1 & $<R L$ \\
\hline Trichlorofluoromethane & $<1$ & $<1$ & $<1$ & $<1$ & $\mu g / L$ & 1 & 1 & $<R L$ \\
\hline Vinyl chloride & $<1$ & $<1$ & $<1$ & $<1$ & $\mu g / L$ & 1 & 1 & $<R L$ \\
\hline Xylene & $<1$ & $<1$ & $<1$ & $<1$ & $\mu g / L$ & 1 & 1 & $<R L$ \\
\hline 1,2-Dichlorobenzene & $<5$ & $<5$ & $<5$ & $<5$ & $\mu g / L$ & 5 & 5 & $<R L$ \\
\hline 1,4-Dichlorobenzene & $<5$ & $<5$ & $<5$ & $<5$ & $\mu g / L$ & 5 & 5 & $<R L$ \\
\hline 2,4-Dinitrophenol & $<5$ & $<5$ & $<5$ & $<5$ & $\mu g / L$ & 5 & 5 & $<R L$ \\
\hline 2,4-Dinitrotoluene & $<5$ & $<5$ & $<5$ & $<5$ & $\mu g / L$ & 5 & 5 & $<R L$ \\
\hline 2-Methylphenol & $<5$ & $<5$ & $<5$ & $<5$ & $\mu g / L$ & 5 & 5 & $<R L$ \\
\hline $\begin{array}{l}\text { 3-Methylphenol/ } \\
\text { 4-Methylphenol }\end{array}$ & $<5$ & $<5$ & $<5$ & $<5$ & $\mu g / L$ & 5 & 5 & $<\mathrm{RL}$ \\
\hline Hexachlorobenzene & $<5$ & $<5$ & $<5$ & $<5$ & $\mu g / L$ & 5 & 5 & $<R L$ \\
\hline Hexachloroethane & $<5$ & $<5$ & $<5$ & $<5$ & $\mu g / L$ & 5 & 5 & $<R L$ \\
\hline Nitrobenzene & $<5$ & $<5$ & $<5$ & $<5$ & $\mu g / L$ & 5 & 5 & $<R L$ \\
\hline Pentachlorophenol & $<5$ & $<5$ & $<5$ & $<5$ & $\mu g / L$ & 5 & 5 & $<R L$ \\
\hline Pyridine & $<5$ & $<5$ & $<5$ & $<5$ & $\mu g / L$ & 5 & 5 & $<R L$ \\
\hline Isobutanol & $<5$ & $<5$ & $<5$ & $<5$ & $\mu g / L$ & 5 & 5 & $<R L$ \\
\hline Alkalinity & 36 & 38 & 32 & 33 & $\mathrm{mg} / \mathrm{L}$ & 4 & 4 & 54.5 \\
\hline Chloride & 125000 & 126000 & 128600 & 124800 & $\mathrm{mg} / \mathrm{L}$ & 2 & 2 & 149100 \\
\hline Density & 1.144 & 1.142 & 1.14 & 1.14 & $\mathrm{~g} / \mathrm{mL}$ & $N / A^{d}$ & $N / A$ & 1.17 \\
\hline Nitrate (as N) & $<0.10$ & $<0.10$ & $<0.10$ & $<0.10$ & $\mathrm{mg} / \mathrm{L}$ & 0.1 & 0.1 & $<12$ \\
\hline $\mathrm{pH}$ & 6.8 & 6.8 & 6.8 & 6.8 & $S U^{e}$ & $\mathrm{~N} / \mathrm{A}$ & N/A & $6.6-7.2$ \\
\hline Specific conductance & 232000 & 233000 & 186000 & 187000 & $\mu \mathrm{mhos} / \mathrm{cm}$ & $\mathrm{N} / \mathrm{A}$ & $\mathrm{N} / \mathrm{A}$ & 517000 \\
\hline Sulfate & 7540 & 7150 & 7640 & 7270 & $\mathrm{mg} / \mathrm{L}$ & 2 & 2 & 8015 \\
\hline
\end{tabular}


Waste Isolation Pilot Plant 2002 Site Environmental Report

DOE/WIPP 03-2225

Table 6.5 - Analytical Results for Groundwater Sampled from Well WQSP-3

\begin{tabular}{|c|c|c|c|c|c|c|c|c|}
\hline \multirow[b]{3}{*}{ Parameter } & \multicolumn{5}{|c|}{ Concentration } & & & \multirow[b]{3}{*}{$\begin{array}{c}95^{\text {th }} \\
\text { UTLV }^{\text {a }}\end{array}$} \\
\hline & \multicolumn{2}{|c|}{ Round 14} & \multicolumn{2}{|c|}{ Round 15} & \multirow[b]{2}{*}{ Units } & \multicolumn{2}{|c|}{ Reporting Limit } & \\
\hline & Sample & Dup. & Sample & Dup. & & $\begin{array}{c}\text { Round } \\
14\end{array}$ & $\begin{array}{c}\text { Round } \\
15 \\
\end{array}$ & \\
\hline Total dissolved solids & 228000 & 230000 & 228000 & 216000 & $\mathrm{mg} / \mathrm{L}$ & 10 & 10 & 261000 \\
\hline Total organic carbon & $<1.0$ & $<1.0$ & $<1.0$ & $<1.0$ & $\mathrm{mg} / \mathrm{L}$ & 1 & 1 & $<5.0$ \\
\hline Total organic halogen & 8.4 & 11 & 3.2 & 3.5 & $\mathrm{mg} / \mathrm{L}$ & 0.005 & 0.005 & 55 \\
\hline Total suspended solids & 6 & 6 & $<1.0$ & $<1.0$ & $\mathrm{mg} / \mathrm{L}$ & 1 & 1 & 107 \\
\hline Antimony & $<0.025$ & $<0.025$ & $<0.625$ & $<0.625$ & $\mathrm{mg} / \mathrm{L}$ & 0.025 & 0.625 & $<1.0$ \\
\hline Arsenic & $<0.05$ & $<0.05$ & $<1.25$ & $<1.25$ & $\mathrm{mg} / \mathrm{L}$ & 0.05 & 1.25 & 0.207 \\
\hline Barium & $<0.10$ & $<0.10$ & $<2.50$ & $<2.50$ & $\mathrm{mg} / \mathrm{L}$ & 0.1 & 2.5 & $<1.0$ \\
\hline Beryllium & $<0.0025$ & $<0.0025$ & $<0.0625$ & $<0.0625$ & $\mathrm{mg} / \mathrm{L}$ & 0.003 & 0.0625 & $<0.1$ \\
\hline Cadmium & $<0.005$ & $<0.005$ & $<0.125$ & $<0.125$ & $\mathrm{mg} / \mathrm{L}$ & 0.005 & 0.125 & $<0.5$ \\
\hline Calcium & 1500 & 1560 & 1460 & 1420 & $\mathrm{mg} / \mathrm{L}$ & 0.5 & 0.5 & 1,680 \\
\hline Chromium & $<0.01$ & $<0.01$ & $<0.25$ & $<0.25$ & $\mathrm{mg} / \mathrm{L}$ & 0.01 & 0.25 & $<2.0$ \\
\hline Iron & $<0.25$ & $<0.25$ & $<1.25$ & $<1.25$ & $\mathrm{mg} / \mathrm{L}$ & 0.25 & 1.25 & $<1.0$ \\
\hline Lead & $<0.01$ & $<0.012$ & 0.669 & 0.654 & $\mathrm{mg} / \mathrm{L}$ & 0.01 & 0.02 & 0.80 \\
\hline Magnesium & 2270 & 2400 & 2300 & 2280 & $\mathrm{mg} / \mathrm{L}$ & 0.5 & 0.5 & 2,625 \\
\hline Mercury & $<0.0002$ & $<0.0002$ & $<0.0002$ & $<0.0002$ & $\mathrm{mg} / \mathrm{L}$ & 0 & 0 & $<0.002$ \\
\hline Nickel & $<0.025$ & $<0.025$ & $<0.625$ & $<0.625$ & $\mathrm{mg} / \mathrm{L}$ & 0.025 & 0.625 & $<5.00$ \\
\hline Potassium & 1960 & 1950 & 2430 & 2210 & $\mathrm{mg} / \mathrm{L}$ & 0.5 & 0.5 & 3,438 \\
\hline Selenium & $<0.05$ & $<0.05$ & $<1.250$ & $<1.250$ & $\mathrm{mg} / \mathrm{L}$ & 0.05 & 1.25 & $<2.00$ \\
\hline Silver & $<0.0125$ & $<0.0125$ & $<0.312$ & $<0.312$ & $\mathrm{mg} / \mathrm{L}$ & 0.0125 & 0.312 & 0.31 \\
\hline Sodium & 73200 & 75100 & 77200 & 76500 & $\mathrm{mg} / \mathrm{L}$ & 0.5 & 0.5 & 140,400 \\
\hline Thallium & $<0.05$ & $<0.05$ & $<1.25$ & $<1.25$ & $\mathrm{mg} / \mathrm{L}$ & 0.05 & 1.25 & 5.800 \\
\hline Vanadium & $<0.025$ & $<0.025$ & $<0.625$ & $<0.625$ & $\mathrm{mg} / \mathrm{L}$ & 0.025 & 0.625 & $<5.00$ \\
\hline
\end{tabular}


Table 6.6 - Analytical Results for Groundwater Sampled from Well WQSP-4

\begin{tabular}{|c|c|c|c|c|c|c|c|c|}
\hline \multirow[b]{3}{*}{ Parameter } & \multicolumn{7}{|c|}{ Concentration } & \multirow[b]{3}{*}{$\begin{array}{l}95^{\text {th }} \\
\text { UTLV }\end{array}$} \\
\hline & \multicolumn{2}{|c|}{ Round 14} & \multicolumn{2}{|c|}{ Round 15} & \multirow[b]{2}{*}{ Units } & \multicolumn{2}{|c|}{ Reporting Limit } & \\
\hline & Sample & Dup. & Sample & Dup. & & $\begin{array}{c}\text { Round } \\
14\end{array}$ & $\begin{array}{c}\text { Round } \\
15\end{array}$ & \\
\hline 1,1,1-Trichloroethane & $<1$ & $<1$ & $<1$ & $<1$ & $\mu g / L$ & 1 & 1 & $<\mathrm{RL}^{\mathrm{b}}$ \\
\hline 1,1,2,2-Tetrachloroethane & $<1$ & $<1$ & $<1$ & $<1$ & $\mu \mathrm{g} / \mathrm{L}$ & 1 & 1 & $<R L$ \\
\hline 1,1,2-Trichloroethane & $<1$ & $<1$ & $<1$ & $<1$ & $\mu g / L$ & 1 & 1 & $<R L$ \\
\hline 1,1-Dichloroethane & $<1$ & $<1$ & $<1$ & $<1$ & $\mu g / L$ & 1 & 1 & $<\mathrm{RL}$ \\
\hline 1,1-Dichloroethylene & $<1$ & $<1$ & $<1$ & $<1$ & $\mu g / L$ & 1 & 1 & $<R L$ \\
\hline 1,2-Dichloroethane & $<1$ & $<1$ & $<1$ & $<1$ & $\mu g / L$ & 1 & 1 & $<R L$ \\
\hline Carbon tetrachloride & $<1$ & $<1$ & $<1$ & $<1$ & $\mu g / L$ & 1 & 1 & $<\mathrm{RL}$ \\
\hline Chlorobenzene & $<1$ & $<1$ & $<1$ & $<1$ & $\mu g / L$ & 1 & 1 & $<R L$ \\
\hline Chloroform & $<1$ & $<1$ & $<1$ & $<1$ & $\mu g / L$ & 1 & 1 & $<R L$ \\
\hline cis-1,2-Dichloroethylene & $<1$ & $<1$ & $<1$ & $<1$ & $\mu g / L$ & 1 & 1 & $<R L$ \\
\hline trans-1,2-Dichloroethylene & $<1$ & $<1$ & $<1$ & $<1$ & $\mu g / L$ & 1 & 1 & $<R L$ \\
\hline Methyl ethyl ketone & $<5$ & $<5$ & $<5$ & $<5$ & $\mu g / L$ & 5 & 5 & $<R L$ \\
\hline Methylene chloride & $<5$ & $<5$ & $<5$ & $<5$ & $\mu g / L$ & 5 & 5 & $<R L$ \\
\hline Tetrachloroethylene & $<1$ & $<1$ & $<1$ & $<1$ & $\mu \mathrm{g} / \mathrm{L}$ & 1 & 1 & $<R L$ \\
\hline Toluene & $<1$ & $<1$ & $<1$ & $<1$ & $\mu g / L$ & 1 & 1 & $<R L$ \\
\hline Trichloroethylene & $<1$ & $<1$ & $<1$ & $<1$ & $\mu g / L$ & 1 & 1 & $<R L$ \\
\hline Trichlorofluoromethane & $<1$ & $<1$ & $<1$ & $<1$ & $\mu \mathrm{g} / \mathrm{L}$ & 1 & 1 & $<R L$ \\
\hline Vinyl chloride & $<1$ & $<1$ & $<1$ & $<1$ & $\mu g / L$ & 1 & 1 & $<R L$ \\
\hline Xylene & $<1$ & $<1$ & $<1$ & $<1$ & $\mu g / L$ & 1 & 1 & $<R L$ \\
\hline 1,2-Dichlorobenzene & $<5$ & $<5$ & $<5$ & $<5$ & $\mu \mathrm{g} / \mathrm{L}$ & 5 & 5 & $<R L$ \\
\hline 1,4-Dichlorobenzene & $<5$ & $<5$ & $<5$ & $<5$ & $\mu g / L$ & 5 & 5 & $<R L$ \\
\hline 2,4-Dinitrophenol & $<5$ & $<5$ & $<5$ & $<5$ & $\mu \mathrm{g} / \mathrm{L}$ & 5 & 5 & $<R L$ \\
\hline 2,4-Dinitrotoluene & $<5$ & $<5$ & $<5$ & $<5$ & $\mu \mathrm{g} / \mathrm{L}$ & 5 & 5 & $<R L$ \\
\hline 2-Methylphenol & $<5$ & $<5$ & $<5$ & $<5$ & $\mu g / L$ & 5 & 5 & $<\mathrm{RL}$ \\
\hline $\begin{array}{l}\text { 3-Methylphenol/ } \\
\text { 4-Methylphenol }\end{array}$ & $<5$ & $<5$ & $<5$ & $<5$ & $\mu g / L$ & 5 & 5 & $<R L$ \\
\hline Hexachlorobenzene & $<5$ & $<5$ & $<5$ & $<5$ & $\mu g / L$ & 5 & 5 & $<\mathrm{RL}$ \\
\hline Hexachloroethane & $<5$ & $<5$ & $<5$ & $<5$ & $\mu g / L$ & 5 & 5 & $<R L$ \\
\hline Nitrobenzene & $<5$ & $<5$ & $<5$ & $<5$ & $\mu g / L$ & 5 & 5 & $<R L$ \\
\hline Pentachlorophenol & $<5$ & $<5$ & $<5$ & $<5$ & $\mu g / L$ & 5 & 5 & $<\mathrm{RL}$ \\
\hline Pyridine & $<5$ & $<5$ & $<5$ & $<5$ & $\mu g / L$ & 5 & 5 & $<R L$ \\
\hline Isobutanol & $<5$ & $<5$ & $<5$ & $<5$ & $\mu g / L$ & 5 & 5 & $<\mathrm{RL}$ \\
\hline Alkalinity & 42 & 40 & 38 & 40 & $\mathrm{mg} / \mathrm{L}$ & 4 & 4 & 47.1 \\
\hline Chloride & 49700 & 50500 & 56400 & 53900 & $\mathrm{mg} / \mathrm{L}$ & 2 & 2 & 63960 \\
\hline Density & 1.07 & 1.075 & 1.066 & 1.073 & $\mathrm{~g} / \mathrm{mL}$ & $N / A^{c}$ & $N / A$ & 1.1 \\
\hline Nitrate (as N) & $<0.10$ & $<0.10$ & $<0.10$ & $<0.10$ & $\mathrm{mg} / \mathrm{L}$ & 0.1 & 0.1 & $<10$ \\
\hline $\mathrm{pH}$ & 7.1 & 7.1 & 7.1 & 7.1 & $S U^{d}$ & $N / A$ & $\mathrm{~N} / \mathrm{A}$ & $6.80-7.61$ \\
\hline Specific conductance & 109630 & 111823 & 109700 & 110900 & $\mu \mathrm{mhos} / \mathrm{cm}$ & $N / A$ & $\mathrm{~N} / \mathrm{A}$ & 319800 \\
\hline Sulfate & 6560 & 6400 & 6960 & 6760 & $\mathrm{mg} / \mathrm{L}$ & 2 & 2 & 7927 \\
\hline
\end{tabular}


Waste Isolation Pilot Plant 2002 Site Environmental Report

DOE/WIPP 03-2225

Table 6.6 - Analytical Results for Groundwater Sampled from Well WQSP-4

\begin{tabular}{|c|c|c|c|c|c|c|c|c|}
\hline \multirow[b]{3}{*}{ Parameter } & \multicolumn{7}{|c|}{ Concentration } & \multirow[b]{3}{*}{$\begin{array}{l}9^{\text {th }} \\
\text { UTLV }^{\mathrm{a}}\end{array}$} \\
\hline & \multicolumn{2}{|c|}{ Round 14} & \multicolumn{2}{|c|}{ Round 15} & \multirow[b]{2}{*}{ Units } & \multicolumn{2}{|c|}{ Reporting Limit } & \\
\hline & Sample & Dup. & Sample & Dup. & & $\begin{array}{c}\text { Round } \\
14\end{array}$ & $\begin{array}{c}\text { Round } \\
15\end{array}$ & \\
\hline Total dissolved solids & 101000 & 104000 & 115400 & 113600 & $\mathrm{mg} / \mathrm{L}$ & 10 & 10 & 123500 \\
\hline Total organic carbon & 1.39 & 1.75 & $<1.0$ & 1.14 & $\mathrm{mg} / \mathrm{L}$ & 1 & 1 & $<5.0$ \\
\hline Total organic halogen & 2.6 & 2.7 & 3 & 1.8 & $\mathrm{mg} / \mathrm{L}$ & $N R^{e}$ & 0.01 & 17 \\
\hline Total suspended solids & $<1.0$ & $<1.0$ & $<1.0$ & $<1.0$ & $\mathrm{mg} / \mathrm{L}$ & 1 & 1 & 57 \\
\hline Antimony & $<0.025$ & $<0.025$ & $<0.025$ & $<0.025$ & $\mathrm{mg} / \mathrm{L}$ & 0.025 & 0.025 & 0.8 \\
\hline Arsenic & $<0.05$ & $<0.05$ & $<0.05$ & $<0.05$ & $\mathrm{mg} / \mathrm{L}$ & 0.05 & 0.05 & $<0.50$ \\
\hline Barium & $<0.10$ & $<0.10$ & $<0.10$ & $<0.10$ & $\mathrm{mg} / \mathrm{L}$ & 0.1 & 0.1 & $<1.0$ \\
\hline Beryllium & $<0.0025$ & $<0.0025$ & $<0.0025$ & $<0.0025$ & $\mathrm{mg} / \mathrm{L}$ & 0.003 & 0 & 0.25 \\
\hline Cadmium & $<0.005$ & $<0.005$ & $<0.005$ & $<0.005$ & $\mathrm{mg} / \mathrm{L}$ & 0.005 & 0.01 & $<0.50$ \\
\hline Calcium & 1610 & 1590 & 1530 & 1640 & $\mathrm{mg} / \mathrm{L}$ & 0.5 & 0.5 & 1,834 \\
\hline Chromium & $<0.010$ & $<0.010$ & $<0.010$ & $<0.010$ & $\mathrm{mg} / \mathrm{L}$ & 0.01 & 0.01 & $<2.0$ \\
\hline Iron & $<0.50$ & $<0.50$ & 0.078 & 0.0736 & $\mathrm{mg} / \mathrm{L}$ & 0.5 & 0.5 & $<4.0$ \\
\hline Lead & $<0.01$ & $<0.01$ & 0.029 & 0.0169 & $\mathrm{mg} / \mathrm{L}$ & 0.01 & 0.02 & 0.525 \\
\hline Magnesium & 1260 & 1200 & 1110 & 1230 & $\mathrm{mg} / \mathrm{L}$ & 0.5 & 0.5 & 1,472 \\
\hline Mercury & $<0.0002$ & $<0.0002$ & $<0.0002$ & $<0.0002$ & $\mathrm{mg} / \mathrm{L}$ & 0 & 0 & $<0.002$ \\
\hline Nickel & $<0.025$ & $<0.025$ & $<0.250$ & $<0.250$ & $\mathrm{mg} / \mathrm{L}$ & 0.025 & 0.25 & $<5.00$ \\
\hline Potassium & 1220 & 1230 & 1030 & 1120 & $\mathrm{mg} / \mathrm{L}$ & 0.5 & 0.5 & 1,648 \\
\hline Selenium & $<0.05$ & $<0.05$ & $<0.05$ & $<0.05$ & $\mathrm{mg} / \mathrm{L}$ & 0.05 & 0.05 & 2.009 \\
\hline Silver & $<0.0125$ & $<0.0125$ & $<0.0125$ & $<0.0125$ & $\mathrm{mg} / \mathrm{L}$ & 0.0125 & 0.013 & 0.519 \\
\hline Sodium & 27200 & 31600 & 33900 & 35400 & $\mathrm{mg} / \mathrm{L}$ & 0.5 & 0.5 & 38,790 \\
\hline Thallium & $<0.050$ & $<0.050$ & 0.125 & 0.0882 & $\mathrm{mg} / \mathrm{L}$ & 0.05 & 0.013 & 1.00 \\
\hline Vanadium & $<0.025$ & $<0.025$ & $<0.250$ & $<0.250$ & $\mathrm{mg} / \mathrm{L}$ & 0.025 & 0.025 & $<5.00$ \\
\hline
\end{tabular}

A $95^{\text {th }}$ Upper tolerance limit value, equivalent to $95 \%$ confidence limit

${ }^{\mathrm{b}}$ Reporting limit

${ }^{\mathrm{c}}$ Not applicable

${ }^{\mathrm{d}}$ Standard unit

${ }^{\mathrm{e}}$ Not reported by the laboratory 
Table 6.7 - Analytical Results for Groundwater Sampled from Well WQSP-5

\begin{tabular}{|c|c|c|c|c|c|c|c|c|}
\hline \multirow[b]{3}{*}{ Parameter } & \multicolumn{7}{|c|}{ Concentration } & \multirow[b]{3}{*}{$\begin{array}{l}95^{\text {th }} \\
\text { UTLV }^{\text {a }}\end{array}$} \\
\hline & \multicolumn{2}{|c|}{ Round 14} & \multicolumn{2}{|c|}{ Round 15} & \multirow[b]{2}{*}{ Units } & \multicolumn{2}{|c|}{ Reporting Limit } & \\
\hline & Sample & Dup. & Sample & Dup. & & $\begin{array}{c}\text { Round } \\
14 \\
\end{array}$ & $\begin{array}{c}\text { Round } \\
15\end{array}$ & \\
\hline 1,1,1-Trichloroethane & $<1$ & $<1$ & $<1$ & $<1$ & $\mu \mathrm{g} / \mathrm{L}$ & 1 & 1 & $<\mathrm{RL}^{\mathrm{b}}$ \\
\hline 1,1,2,2-Tetrachloroethane & $<1$ & $<1$ & $<1$ & $<1$ & $\mu g / L$ & 1 & 1 & $<\mathrm{RL}$ \\
\hline 1,1,2-Trichloroethane & $<1$ & $<1$ & $<1$ & $<1$ & $\mu g / L$ & 1 & 1 & $<R L$ \\
\hline 1,1-Dichloroethane & $<1$ & $<1$ & $<1$ & $<1$ & $\mu g / L$ & 1 & 1 & $<R L$ \\
\hline 1,1-Dichloroethylene & $<1$ & $<1$ & $<1$ & $<1$ & $\mu g / L$ & 1 & 1 & $<R L$ \\
\hline 1,2-Dichloroethane & $<1$ & $<1$ & $<1$ & $<1$ & $\mu g / L$ & 1 & 1 & $<R L$ \\
\hline Carbon tetrachloride & $<1$ & $<1$ & $<1$ & $<1$ & $\mu g / L$ & 1 & 1 & $<R L$ \\
\hline Chlorobenzene & $<1$ & $<1$ & $<1$ & $<1$ & $\mu g / L$ & 1 & 1 & $<R L$ \\
\hline Chloroform & $<1$ & $<1$ & $<1$ & $<1$ & $\mu g / L$ & 1 & 1 & $<R L$ \\
\hline cis-1,2-Dichloroethylene & $<1$ & $<1$ & $<1$ & $<1$ & $\mu g / L$ & 1 & 1 & $<R L$ \\
\hline trans-1,2-Dichloroethylene & $<1$ & $<1$ & $<1$ & $<1$ & $\mu g / L$ & 1 & 1 & $<R L$ \\
\hline Methyl ethyl ketone & $<5$ & $<5$ & $<5$ & $<5$ & $\mu g / L$ & 5 & 5 & $<R L$ \\
\hline Methylene chloride & $<5$ & $<5$ & $<5$ & $<5$ & $\mu g / L$ & 5 & 5 & $<\mathrm{RL}$ \\
\hline Tetrachloroethylene & $<1$ & $<1$ & $<1$ & $<1$ & $\mu g / L$ & 1 & 1 & $<R L$ \\
\hline Toluene & $<1$ & $<1$ & $<1$ & $<1$ & $\mu g / L$ & 1 & 1 & $<R L$ \\
\hline Trichloroethylene & $<1$ & $<1$ & $<1$ & $<1$ & $\mu g / L$ & 1 & 1 & $<R L$ \\
\hline Trichlorofluoromethane & $<1$ & $<1$ & $<1$ & $<1$ & $\mu g / L$ & 1 & 1 & $<R L$ \\
\hline Vinyl chloride & $<1$ & $<1$ & $<1$ & $<1$ & $\mu g / L$ & 1 & 1 & $<R L$ \\
\hline Xylene & $<1$ & $<1$ & $<1$ & $<1$ & $\mu g / L$ & 1 & 1 & $<R L$ \\
\hline 1,2-Dichlorobenzene & $<5$ & $<5$ & $<5$ & $<5$ & $\mu g / L$ & 5 & 5 & $<R L$ \\
\hline 1,4-Dichlorobenzene & $<5$ & $<5$ & $<5$ & $<5$ & $\mu g / L$ & 5 & 5 & $<R L$ \\
\hline 2,4-Dinitrophenol & $<5$ & $<5$ & $<5$ & $<5$ & $\mu g / L$ & 5 & 5 & $<R L$ \\
\hline 2,4-Dinitrotoluene & $<5$ & $<5$ & $<5$ & $<5$ & $\mu g / L$ & 5 & 5 & $<R L$ \\
\hline 2-Methylphenol & $<5$ & $<5$ & $<5$ & $<5$ & $\mu g / L$ & 5 & 5 & $<R L$ \\
\hline $\begin{array}{l}\text { 3-Methylphenol/ } \\
\text { 4-Methylphenol }\end{array}$ & $<5$ & $<5$ & $<5$ & $<5$ & $\mu g / L$ & 5 & 5 & $<R L$ \\
\hline Hexachlorobenzene & $<5$ & $<5$ & $<5$ & $<5$ & $\mu g / L$ & 5 & 5 & $<R L$ \\
\hline Hexachloroethane & $<5$ & $<5$ & $<5$ & $<5$ & $\mu g / L$ & 5 & 5 & $<R L$ \\
\hline Nitrobenzene & $<5$ & $<5$ & $<5$ & $<5$ & $\mu g / L$ & 5 & 5 & $<R L$ \\
\hline Pentachlorophenol & $<5$ & $<5$ & $<5$ & $<5$ & $\mu g / L$ & 5 & 5 & $<R L$ \\
\hline Pyridine & $<5$ & $<5$ & $<5$ & $<5$ & $\mu g / L$ & 5 & 5 & $<R L$ \\
\hline Isobutanol & $<5$ & $<5$ & $<5$ & $<5$ & $\mu g / L$ & 5 & 5 & $<\mathrm{RL}$ \\
\hline Alkalinity & 46 & 48 & 50 & 48 & $\mathrm{mg} / \mathrm{L}$ & 4 & 4 & 56 \\
\hline Chloride & 15900 & 15200 & 14300 & 14100 & $\mathrm{mg} / \mathrm{L}$ & 2 & 2 & 18100 \\
\hline Density & 1.027 & 1.0195 & 1.02 & 1.015 & $\mathrm{~g} / \mathrm{mL}$ & $N / A^{d}$ & $\mathrm{~N} / \mathrm{A}$ & 1.04 \\
\hline Nitrate (as N) & $<0.1$ & $<0.1$ & $<0.10$ & $<0.10$ & $\mathrm{mg} / \mathrm{L}$ & 0.1 & 0.1 & $<10$ \\
\hline $\mathrm{pH}$ & 7.6 & 7.6 & 7.5 & 7.5 & $S U^{e}$ & $\mathrm{~N} / \mathrm{A}$ & $\mathrm{N} / \mathrm{A}$ & $7.40-7.90$ \\
\hline Specific conductance & 39200 & 38810 & 43680 & 43760 & $\mu \mathrm{mhos} / \mathrm{cm}$ & N/A & $\mathrm{N} / \mathrm{A}$ & 67700 \\
\hline Sulfate & 5230 & 5250 & 4700 & 4730 & $\mathrm{mg} / \mathrm{L}$ & 2 & 2 & 6129 \\
\hline
\end{tabular}


Waste Isolation Pilot Plant 2002 Site Environmental Report DOE/WIPP 03-2225

Table 6.7 - Analytical Results for Groundwater Sampled from Well WQSP-5

\begin{tabular}{|c|c|c|c|c|c|c|c|c|}
\hline \multirow[b]{3}{*}{ Parameter } & \multicolumn{7}{|c|}{ Concentration } & \multirow[b]{3}{*}{$\begin{array}{l}95^{\text {th }} \\
\text { UTLV }^{\mathrm{a}}\end{array}$} \\
\hline & \multicolumn{2}{|c|}{ Round 14} & \multicolumn{2}{|c|}{ Round 15} & \multirow[b]{2}{*}{ Units } & \multicolumn{2}{|c|}{ Reporting Limit } & \\
\hline & Sample & Dup. & Sample & Dup. & & $\begin{array}{c}\text { Round } \\
14\end{array}$ & $\begin{array}{c}\text { Round } \\
15\end{array}$ & \\
\hline Total dissolved solids & 33600 & 33300 & 32500 & 32700 & $\mathrm{mg} / \mathrm{L}$ & 10 & 10 & 43950 \\
\hline Total organic carbon & $<1.0$ & $<1.0$ & $<1.0$ & $<1.0$ & $\mathrm{mg} / \mathrm{L}$ & 1 & 1 & $<5.0$ \\
\hline Total organic halogen & 1.7 & 2.2 & 3.6 & 4 & $\mathrm{mg} / \mathrm{L}$ & 0.005 & 0.005 & 8.37 \\
\hline Total suspended solids & $<1.0$ & $<1.0$ & $<1.0$ & $<1.0$ & $\mathrm{mg} / \mathrm{L}$ & 1 & 1 & $<10.0$ \\
\hline Antimony & $<0.025$ & $<0.025$ & $<0.025$ & $<0.025$ & $\mathrm{mg} / \mathrm{L}$ & 0.025 & 0.025 & 0.073 \\
\hline Arsenic & $<0.05$ & $<0.05$ & $<0.05$ & $<0.05$ & $\mathrm{mg} / \mathrm{L}$ & 0.05 & 0.05 & $<0.50$ \\
\hline Barium & $<0.10$ & $<0.10$ & $<0.10$ & $<0.10$ & $\mathrm{mg} / \mathrm{L}$ & 0.1 & 0.1 & $<1.0$ \\
\hline Beryllium & $<0.0025$ & $<0.0025$ & $<0.0025$ & $<0.0025$ & $\mathrm{mg} / \mathrm{L}$ & 0.003 & 0.003 & 0.02 \\
\hline Cadmium & $<0.005$ & $<0.005$ & $<0.005$ & $<0.005$ & $\mathrm{mg} / \mathrm{L}$ & 0.005 & 0.005 & $<0.050$ \\
\hline Calcium & 1010 & 1080 & 928 & 947 & $\mathrm{mg} / \mathrm{L}$ & 0.5 & 0.5 & 1,303 \\
\hline Chromium & $<0.01$ & $<0.01$ & $<0.01$ & $<0.01$ & $\mathrm{mg} / \mathrm{L}$ & 0.01 & 0.01 & $<0.50$ \\
\hline Iron & $<0.25$ & 0.49 & 0.0761 & 0.077 & $\mathrm{mg} / \mathrm{L}$ & 0.5 & 0.5 & 0.795 \\
\hline Lead & $<0.01$ & $<0.01$ & 0.0263 & 0.028 & $\mathrm{mg} / \mathrm{L}$ & 0.01 & 0.02 & $<0.05$ \\
\hline Magnesium & 451 & 457 & 426 & 443 & $\mathrm{mg} / \mathrm{L}$ & 0.5 & 0.5 & 547.0 \\
\hline Mercury & $<0.0002$ & $<0.0002$ & $<0.0002$ & $<0.0002$ & $\mathrm{mg} / \mathrm{L}$ & 0 & 0 & $<0.002$ \\
\hline Nickel & $<0.025$ & $<0.025$ & $<0.025$ & $<0.025$ & $\mathrm{mg} / \mathrm{L}$ & 0.025 & 0.025 & $<0.10$ \\
\hline Potassium & 398 & 422 & 357 & 251 & $\mathrm{mg} / \mathrm{L}$ & 0.5 & 0.5 & 622.0 \\
\hline Selenium & $<0.05$ & $<0.05$ & $<0.05$ & $<0.05$ & $\mathrm{mg} / \mathrm{L}$ & 0.05 & 0.05 & $<0.10$ \\
\hline Silver & $<0.0125$ & $<0.0125$ & $<0.0125$ & $<0.0125$ & $\mathrm{mg} / \mathrm{L}$ & 0.0125 & 0.0125 & $<0.50$ \\
\hline Sodium & 8740 & 7750 & 7660 & 7410 & $\mathrm{mg} / \mathrm{L}$ & 0.5 & 0.5 & 11,190 \\
\hline Thallium & $<0.05$ & $<0.05$ & $<0.05$ & $<0.05$ & $\mathrm{mg} / \mathrm{L}$ & 0.05 & 0.05 & 0.209 \\
\hline Vanadium & $<0.025$ & $<0.025$ & $<0.025$ & $<0.025$ & $\mathrm{mg} / \mathrm{L}$ & 0.025 & 0.025 & 2.70 \\
\hline
\end{tabular}

a $95^{\text {th }}$ Upper tolerance limit value, equivalent to $95 \%$ confidence limit

${ }^{b}$ Reporting limit

${ }^{c}$ Not reported by the laboratory

${ }^{\mathrm{d}}$ Not applicable

e Standard unit 
Table 6.8 - Analytical Results for Groundwater Sampled from Well WQSP-6

\begin{tabular}{|c|c|c|c|c|c|c|c|c|}
\hline \multirow[b]{3}{*}{ Parameter } & \multicolumn{7}{|c|}{ Concentration } & \multirow[b]{3}{*}{$\begin{array}{l}95^{\text {th }} \\
\text { UTLV }\end{array}$} \\
\hline & \multicolumn{2}{|c|}{ Round 14} & \multicolumn{2}{|c|}{ Round 15} & \multirow[b]{2}{*}{ Units } & \multicolumn{2}{|c|}{ Reporting Limit } & \\
\hline & Sample & Dup. & Sample & Dup. & & $\begin{array}{c}\text { Round } \\
14\end{array}$ & $\begin{array}{c}\text { Round } \\
15\end{array}$ & \\
\hline 1,1,1-Trichloroethane & $<1$ & $<1$ & $<1$ & $<1$ & $\mu \mathrm{g} / \mathrm{L}$ & 1 & 1 & $<\mathrm{RL}^{\mathrm{b}}$ \\
\hline 1,1,2,2-Tetrachloroethane & $<1$ & $<1$ & $<1$ & $<1$ & $\mu \mathrm{g} / \mathrm{L}$ & 1 & 1 & $<\mathrm{RL}$ \\
\hline 1,1,2-Trichloroethane & $<1$ & $<1$ & $<1$ & $<1$ & $\mu g / L$ & 1 & 1 & $<R L$ \\
\hline 1,1-Dichloroethane & $<1$ & $<1$ & $<1$ & $<1$ & $\mu g / L$ & 1 & 1 & $<\mathrm{RL}$ \\
\hline 1,1-Dichloroethylene & $<1$ & $<1$ & $<1$ & $<1$ & $\mu \mathrm{g} / \mathrm{L}$ & 1 & 1 & $<\mathrm{RL}$ \\
\hline 1,2-Dichloroethane & $<1$ & $<1$ & $<1$ & $<1$ & $\mu g / L$ & 1 & 1 & $<R L$ \\
\hline Carbon tetrachloride & $<1$ & $<1$ & $<1$ & $<1$ & $\mu g / L$ & 1 & 1 & $<R L$ \\
\hline Chlorobenzene & $<1$ & $<1$ & $<1$ & $<1$ & $\mu g / L$ & 1 & 1 & $<R L$ \\
\hline Chloroform & $<1$ & $<1$ & $<1$ & $<1$ & $\mu g / L$ & 1 & 1 & $<R L$ \\
\hline cis-1,2-Dichloroethylene & $<1$ & $<1$ & $<1$ & $<1$ & $\mu g / L$ & 1 & 1 & $<R L$ \\
\hline trans-1,2-Dichloroethylene & $<1$ & $<1$ & $<1$ & $<1$ & $\mu \mathrm{g} / \mathrm{L}$ & 1 & 1 & $<R L$ \\
\hline Methyl ethyl ketone & $<5$ & $<5$ & $<5$ & $<5$ & $\mu \mathrm{g} / \mathrm{L}$ & 5 & 5 & $<R L$ \\
\hline Methylene chloride & $<5$ & $<5$ & $<5$ & $<5$ & $\mu g / L$ & 5 & 5 & $<R L$ \\
\hline Tetrachloroethylene & $<1$ & $<1$ & $<1$ & $<1$ & $\mu g / L$ & 1 & 1 & $<R L$ \\
\hline Toluene & $<1$ & $<1$ & $<1$ & $<1$ & $\mu \mathrm{g} / \mathrm{L}$ & 1 & 1 & $<R L$ \\
\hline Trichloroethylene & $<1$ & $<1$ & $<1$ & $<1$ & $\mu g / L$ & 1 & 1 & $<R L$ \\
\hline Trichlorofluoromethane & $<1$ & $<1$ & $<1$ & $<1$ & $\mu g / L$ & 1 & 1 & $<R L$ \\
\hline Vinyl chloride & $<1$ & $<1$ & $<1$ & $<1$ & $\mu \mathrm{g} / \mathrm{L}$ & 1 & 1 & $<R L$ \\
\hline Xylene & $<1$ & $<1$ & $<1$ & $<1$ & $\mu g / L$ & 1 & 1 & $<R L$ \\
\hline 1,2-Dichlorobenzene & $<5$ & $<5$ & $<5$ & $<5$ & $\mu g / L$ & 5 & 5 & $<R L$ \\
\hline 1,4-Dichlorobenzene & $<5$ & $<5$ & $<5$ & $<5$ & $\mu g / L$ & 5 & 5 & $<R L$ \\
\hline 2,4-Dinitrophenol & $<5$ & $<5$ & $<5$ & $<5$ & $\mu g / L$ & 5 & 5 & $<R L$ \\
\hline 2,4-Dinitrotoluene & $<5$ & $<5$ & $<5$ & $<5$ & $\mu g / L$ & 5 & 5 & $<R L$ \\
\hline 2-Methylphenol & $<5$ & $<5$ & $<5$ & $<5$ & $\mu g / L$ & 5 & 5 & $<R L$ \\
\hline $\begin{array}{l}\text { 3-Methylphenol/ } \\
\text { 4-Methylphenol }\end{array}$ & $<5$ & $<5$ & $<5$ & $<5$ & $\mu g / L$ & 5 & 5 & $<\mathrm{RL}$ \\
\hline Hexachlorobenzene & $<5$ & $<5$ & $<5$ & $<5$ & $\mu g / L$ & 5 & 5 & $<R L$ \\
\hline Hexachloroethane & $<5$ & $<5$ & $<5$ & $<5$ & $\mu g / L$ & 5 & 5 & $<R L$ \\
\hline Nitrobenzene & $<5$ & $<5$ & $<5$ & $<5$ & $\mu g / L$ & 5 & 5 & $<R L$ \\
\hline Pentachlorophenol & $<5$ & $<5$ & $<5$ & $<5$ & $\mu g / L$ & 5 & 5 & $<R L$ \\
\hline Pyridine & $<5$ & $<5$ & $<5$ & $<5$ & $\mu g / L$ & 5 & 5 & $<R L$ \\
\hline Isobutanol & $<5$ & $<5$ & $<5$ & $<5$ & $\mu g / L$ & 5 & 5 & $<R L$ \\
\hline Alkalinity & 46 & 46 & 48 & 50 & $\mathrm{mg} / \mathrm{L}$ & 4 & 4 & 55.8 \\
\hline Chloride & 4990 & 4950 & 5020 & 4940 & $\mathrm{mg} / \mathrm{L}$ & 2 & 2 & 6200 \\
\hline Density & 1.0121 & 1.0145 & 1.009 & 1.006 & $\mathrm{~g} / \mathrm{mL}$ & $N / A^{d}$ & $\mathrm{~N} / \mathrm{A}$ & 1.02 \\
\hline Nitrate (as N) & $<0.10$ & $<0.10$ & $<0.10$ & $<0.10$ & $\mathrm{mg} / \mathrm{L}$ & 0.1 & 0.1 & 7.45 \\
\hline $\mathrm{pH}$ & 7.7 & 7.7 & 7.8 & 7.8 & $S U^{e}$ & $\mathrm{~N} / \mathrm{A}$ & $\mathrm{N} / \mathrm{A}$ & $7.50-7.90$ \\
\hline Specific conductance & 21060 & 21040 & 19200 & 18900 & $\mu \mathrm{mhos} / \mathrm{cm}$ & $\mathrm{N} / \mathrm{A}$ & $\mathrm{N} / \mathrm{A}$ & 27660 \\
\hline Sulfate & 4640 & 4600 & 4720 & 4740 & $\mathrm{mg} / \mathrm{L}$ & 2 & 2 & 5557 \\
\hline
\end{tabular}


Table 6.8 - Analytical Results for Groundwater Sampled from Well WQSP-6

\begin{tabular}{|c|c|c|c|c|c|c|c|c|}
\hline \multirow[b]{3}{*}{ Parameter } & \multicolumn{7}{|c|}{ Concentration } & \multirow[b]{3}{*}{$\begin{array}{l}95^{\text {th }} \\
\text { UTLV }\end{array}$} \\
\hline & \multicolumn{2}{|c|}{ Round 14} & \multicolumn{2}{|c|}{ Round 15} & \multirow[b]{2}{*}{ Units } & \multicolumn{2}{|c|}{ Reporting Limit } & \\
\hline & Sample & Dup. & Sample & Dup. & & $\begin{array}{c}\text { Round } \\
14 \\
\end{array}$ & $\begin{array}{c}\text { Round } \\
15 \\
\end{array}$ & \\
\hline Total dissolved solids & 15800 & 15000 & 15820 & 16260 & $\mathrm{mg} / \mathrm{L}$ & 10 & 10 & 22500 \\
\hline Total organic carbon & 1.53 & $<1.0$ & $<1.0$ & $<1.0$ & $\mathrm{mg} / \mathrm{L}$ & 1 & 1 & 10.14 \\
\hline Total organic halogen & 2.8 & 1.8 & 3.6 & 3.3 & $\mathrm{mg} / \mathrm{L}$ & 0.005 & 0.005 & 1.54 \\
\hline Total suspended solids & $<1.0$ & $<1.0$ & $<1.0$ & $<1.0$ & $\mathrm{mg} / \mathrm{L}$ & 1 & 1 & 14.8 \\
\hline Antimony & $<0.025$ & $<0.025$ & $<0.025$ & $<0.025$ & $\mathrm{mg} / \mathrm{L}$ & 0.025 & 0.025 & 0.14 \\
\hline Arsenic & $<0.05$ & $<0.05$ & $<0.05$ & $<0.05$ & $\mathrm{mg} / \mathrm{L}$ & 0.05 & 0.05 & $<0.50$ \\
\hline Barium & $<0.10$ & $<0.10$ & $<0.10$ & $<0.10$ & $\mathrm{mg} / \mathrm{L}$ & 0.1 & 0.1 & $<1.0$ \\
\hline Beryllium & $<0.0025$ & $<0.0025$ & $<0.0025$ & $<0.0025$ & $\mathrm{mg} / \mathrm{L}$ & 0.003 & 0.003 & $<0.020$ \\
\hline Cadmium & $<0.005$ & $<0.005$ & $<0.005$ & $<0.005$ & $\mathrm{mg} / \mathrm{L}$ & 0.005 & 0.005 & $<0.050$ \\
\hline Calcium & 738 & 735 & 647 & 616 & $\mathrm{mg} / \mathrm{L}$ & 0.5 & 0.5 & 796 \\
\hline Chromium & $<0.010$ & $<0.010$ & $<0.010$ & $<0.010$ & $\mathrm{mg} / \mathrm{L}$ & 0.01 & 0.01 & $<0.50$ \\
\hline Iron & $<0.050$ & $<0.050$ & 0.0698 & 0.069 & $\mathrm{mg} / \mathrm{L}$ & 0.05 & 0.05 & 3.105 \\
\hline Lead & $<0.01$ & $<0.01$ & 0.0447 & 0.046 & $\mathrm{mg} / \mathrm{L}$ & 0.01 & 0.02 & 0.150 \\
\hline Magnesium & 238 & 238 & 234 & 239 & $\mathrm{mg} / \mathrm{L}$ & 0.5 & 0.5 & 255 \\
\hline Mercury & $<0.0002$ & $<0.0002$ & $<0.0002$ & $<0.0002$ & $\mathrm{mg} / \mathrm{L}$ & 0 & 0 & $<0.002$ \\
\hline Nickel & $<0.025$ & $<0.025$ & $<0.025$ & $<0.025$ & $\mathrm{mg} / \mathrm{L}$ & 0.025 & 0.025 & $<0.50$ \\
\hline Potassium & 221 & 223 & 231 & 205 & $\mathrm{mg} / \mathrm{L}$ & 0.5 & 0.5 & 270 \\
\hline Selenium & $<0.050$ & $<0.050$ & $<0.050$ & $<0.050$ & $\mathrm{mg} / \mathrm{L}$ & 0.05 & 0.05 & $<0.10$ \\
\hline Silver & $<0.0125$ & $<0.0125$ & $<0.0125$ & $<0.0125$ & $\mathrm{mg} / \mathrm{L}$ & 0.0125 & 0.0125 & $<0.50$ \\
\hline Sodium & 3870 & 3860 & 4210 & 3850 & $\mathrm{mg} / \mathrm{L}$ & 0.5 & 0.5 & 6,290 \\
\hline Thallium & $<0.050$ & $<0.050$ & $<0.050$ & $<0.050$ & $\mathrm{mg} / \mathrm{L}$ & 0.05 & 0.05 & 0.560 \\
\hline Vanadium & $<0.025$ & $<0.025$ & $<0.025$ & $<0.025$ & $\mathrm{mg} / \mathrm{L}$ & 0.025 & 0.025 & $<0.10$ \\
\hline
\end{tabular}

Table 6.9 - Analytical Results for Groundwater Sampled from Well WQSP-6A

\begin{tabular}{|c|c|c|c|c|c|c|c|c|}
\hline \multicolumn{9}{|c|}{ Concentration } \\
\hline \multirow[b]{2}{*}{ Parameter } & \multicolumn{2}{|c|}{ Round 14} & \multicolumn{2}{|c|}{ Round 15} & \multirow[b]{2}{*}{ Units } & \multicolumn{2}{|c|}{ Reporting Limit } & \multirow[b]{2}{*}{$\begin{array}{l}95^{\text {th }} \\
\text { UTLV }\end{array}$} \\
\hline & Sample & Dup. & Sample & Dup. & & $\begin{array}{c}\text { Round } \\
14\end{array}$ & $\begin{array}{c}\text { Round } \\
15\end{array}$ & \\
\hline 1,1,1-Trichloroethane & $<1$ & $<1$ & $<1$ & $<1$ & $\mu g / L$ & 1 & 1 & $<\mathrm{RL}^{\mathrm{b}}$ \\
\hline 1,1,2,2-Tetrachloroethane & $<1$ & $<1$ & $<1$ & $<1$ & $\mu g / L$ & 1 & 1 & $<\mathrm{RL}$ \\
\hline 1,1,2-Trichloroethane & $<1$ & $<1$ & $<1$ & $<1$ & $\mu g / L$ & 1 & 1 & $<R L$ \\
\hline 1,1-Dichloroethane & $<1$ & $<1$ & $<1$ & $<1$ & $\mu g / L$ & 1 & 1 & $<R L$ \\
\hline 1,1-Dichloroethylene & $<1$ & $<1$ & $<1$ & $<1$ & $\mu g / L$ & 1 & 1 & $<R L$ \\
\hline 1,2-Dichloroethane & $<1$ & $<1$ & $<1$ & $<1$ & $\mu \mathrm{g} / \mathrm{L}$ & 1 & 1 & $<R L$ \\
\hline
\end{tabular}


Table 6.9 - Analytical Results for Groundwater Sampled from Well WQSP-6A

\begin{tabular}{|c|c|c|c|c|c|c|c|c|}
\hline \multirow[b]{3}{*}{ Parameter } & \multicolumn{7}{|c|}{ Concentration } & \multirow[b]{3}{*}{$\begin{array}{l}95^{\text {th }} \\
\text { UTLV }\end{array}$} \\
\hline & \multicolumn{2}{|c|}{ Round 14} & \multicolumn{2}{|c|}{ Round 15} & \multirow[b]{2}{*}{ Units } & \multicolumn{2}{|c|}{ Reporting Limit } & \\
\hline & Sample & Dup. & Sample & Dup. & & $\begin{array}{c}\text { Round } \\
14\end{array}$ & $\begin{array}{c}\text { Round } \\
15\end{array}$ & \\
\hline Carbon tetrachloride & $<1$ & $<1$ & $<1$ & $<1$ & $\mu \mathrm{g} / \mathrm{L}$ & 1 & 1 & $<\mathrm{RL}$ \\
\hline Chlorobenzene & $<1$ & $<1$ & $<1$ & $<1$ & $\mu g / L$ & 1 & 1 & $<\mathrm{RL}$ \\
\hline Chloroform & $<1$ & $<1$ & $<1$ & $<1$ & $\mu g / L$ & 1 & 1 & $<R L$ \\
\hline cis-1,2-Dichloroethylene & $<1$ & $<1$ & $<1$ & $<1$ & $\mu g / L$ & 1 & 1 & $<\mathrm{RL}$ \\
\hline trans-1,2-Dichloroethylene & $<1$ & $<1$ & $<1$ & $<1$ & $\mu g / L$ & 1 & 1 & $<\mathrm{RL}$ \\
\hline Methyl ethyl ketone & $<5$ & $<5$ & $<5$ & $<5$ & $\mu g / L$ & 5 & 5 & $<\mathrm{RL}$ \\
\hline Methylene chloride & $<5$ & $<5$ & $<5$ & $<5$ & $\mu g / L$ & 5 & 5 & $<\mathrm{RL}$ \\
\hline Tetrachloroethylene & $<1$ & $<1$ & $<1$ & $<1$ & $\mu g / L$ & 1 & 1 & $<\mathrm{RL}$ \\
\hline Toluene & $<1$ & $<1$ & $<1$ & $<1$ & $\mu g / L$ & 1 & 1 & $<\mathrm{RL}$ \\
\hline Trichloroethylene & $<1$ & $<1$ & $<1$ & $<1$ & $\mu g / L$ & 1 & 1 & $<\mathrm{RL}$ \\
\hline Trichlorofluoromethane & $<1$ & $<1$ & $<1$ & $<1$ & $\mu g / L$ & 1 & 1 & $<\mathrm{RL}$ \\
\hline Vinyl chloride & $<1$ & $<1$ & $<1$ & $<1$ & $\mu g / L$ & 1 & 1 & $<\mathrm{RL}$ \\
\hline Xylene & $<1$ & $<1$ & $<1$ & $<1$ & $\mu g / L$ & 1 & 1 & $<\mathrm{RL}$ \\
\hline 1,2-Dichlorobenzene & $<5$ & $<5$ & $<5$ & $<5$ & $\mu g / L$ & 5 & 5 & $<\mathrm{RL}$ \\
\hline 1,4-Dichlorobenzene & $<5$ & $<5$ & $<5$ & $<5$ & $\mu g / L$ & 5 & 5 & $<\mathrm{RL}$ \\
\hline 2,4-Dinitrophenol & $<5$ & $<5$ & $<5$ & $<5$ & $\mu g / L$ & 5 & 5 & $<\mathrm{RL}$ \\
\hline 2,4-Dinitrotoluene & $<5$ & $<5$ & $<5$ & $<5$ & $\mu g / L$ & 5 & 5 & $<\mathrm{RL}$ \\
\hline 2-Methylphenol & $<5$ & $<5$ & $<5$ & $<5$ & $\mu g / L$ & 5 & 5 & $<\mathrm{RL}$ \\
\hline $\begin{array}{l}\text { 3-Methylphenol/ } \\
\text { 4-Methylphenol }\end{array}$ & $<5$ & $<5$ & $<5$ & $<5$ & $\mu g / L$ & 5 & 5 & $<\mathrm{RL}$ \\
\hline Hexachlorobenzene & $<5$ & $<5$ & $<5$ & $<5$ & $\mu \mathrm{g} / \mathrm{L}$ & 5 & 5 & $<R L$ \\
\hline Hexachloroethane & $<5$ & $<5$ & $<5$ & $<5$ & $\mu g / L$ & 5 & 5 & $<\mathrm{RL}$ \\
\hline Nitrobenzene & $<5$ & $<5$ & $<5$ & $<5$ & $\mu g / L$ & 5 & 5 & $<\mathrm{RL}$ \\
\hline Pentachlorophenol & $<5$ & $<5$ & $<5$ & $<5$ & $\mu g / L$ & 5 & 5 & $<\mathrm{RL}$ \\
\hline Pyridine & $<5$ & $<5$ & $<5$ & $<5$ & $\mu g / L$ & 5 & 5 & $<\mathrm{RL}$ \\
\hline Isobutanol & $<5$ & $<5$ & $<5$ & $<5$ & $\mathrm{mg} / \mathrm{L}$ & 5 & 5 & $<\mathrm{RL}$ \\
\hline Alkalinity & 106 & 104 & 100 & 102 & $\mathrm{mg} / \mathrm{L}$ & 4 & 4 & 113 \\
\hline Chloride & 487 & 400 & 419 & 417 & $\mathrm{mg} / \mathrm{L}$ & 2 & 2 & 1040 \\
\hline Density & 1.0028 & 0.9993 & 1.0020 & 1.0040 & $\mathrm{~g} / \mathrm{mL}$ & $N / A^{c}$ & N/A & 1.01 \\
\hline Nitrate (as N) & 5.52 & 5.42 & 5.61 & 5.28 & $\mathrm{mg} / \mathrm{L}$ & 0.1 & 0.1 & 12.2 \\
\hline $\mathrm{pH}$ & 7.4 & 7.4 & 7.7 & 7.7 & $S U^{d}$ & N/A & N/A & $6.80-8.00$ \\
\hline Specific conductance & 4210 & 4220 & 4050 & 4050 & $\mu \mathrm{mhos} / \mathrm{cm}$ & $\mathrm{N} / \mathrm{A}$ & $\mathrm{N} / \mathrm{A}$ & 5192 \\
\hline Sulfate & 1930 & 1940 & 2090 & 2090 & $\mathrm{mg} / \mathrm{L}$ & 2 & 2 & 2543 \\
\hline Total dissolved solids & 3540 & 3700 & 3685 & 3545 & $\mathrm{mg} / \mathrm{L}$ & 10 & 10 & 4600 \\
\hline Total organic carbon & $<1.0$ & 1.16 & 1.59 & $<1.0$ & $\mathrm{mg} / \mathrm{L}$ & 1 & 1 & 15.45 \\
\hline Total organic halogen & 0.44 & 0.29 & 2.3 & 2.2 & $\mathrm{mg} / \mathrm{L}$ & 0.005 & 0.005 & 0.19 \\
\hline Total suspended solids & $<1.0$ & $<1.0$ & $<1.0$ & $<1.0$ & $\mathrm{mg} / \mathrm{L}$ & 1 & 1 & 91 \\
\hline Antimony & $<0.025$ & $<0.025$ & $<0.025$ & $<0.025$ & $\mathrm{mg} / \mathrm{L}$ & 0.025 & 0.025 & 0.48 \\
\hline Arsenic & $<0.05$ & $<0.05$ & $<0.05$ & $<0.05$ & $\mathrm{mg} / \mathrm{L}$ & 0.05 & 0.05 & 0.50 \\
\hline
\end{tabular}


Waste Isolation Pilot Plant 2002 Site Environmental Report DOE/WIPP 03-2225

Table 6.9 - Analytical Results for Groundwater Sampled from Well WQSP-6A

\begin{tabular}{|c|c|c|c|c|c|c|c|c|}
\hline \multirow[b]{3}{*}{ Parameter } & \multicolumn{7}{|c|}{ Concentration } & \multirow[b]{3}{*}{$\begin{array}{l}95^{\text {th }} \\
\text { UTLV }\end{array}$} \\
\hline & \multicolumn{2}{|c|}{ Round 14} & \multicolumn{2}{|c|}{ Round 15} & \multirow[b]{2}{*}{ Units } & \multicolumn{2}{|c|}{ Reporting Limit } & \\
\hline & Sample & Dup. & Sample & Dup. & & $\begin{array}{c}\text { Round } \\
14\end{array}$ & $\begin{array}{c}\text { Round } \\
15\end{array}$ & \\
\hline Barium & $<0.10$ & $<0.10$ & $<0.10$ & $<0.10$ & $\mathrm{mg} / \mathrm{L}$ & 0.10 & 0.10 & 0.10 \\
\hline Beryllium & $<0.0025$ & $<0.0025$ & $<0.0025$ & $<0.0025$ & $\mathrm{mg} / \mathrm{L}$ & 0.0025 & 0.0025 & 0.010 \\
\hline Cadmium & $<0.005$ & $<0.005$ & $<0.005$ & $<0.005$ & $\mathrm{mg} / \mathrm{L}$ & 0.005 & 0.005 & 0.05 \\
\hline Calcium & 573 & 552 & 588 & 574 & $\mathrm{mg} / \mathrm{L}$ & 0.5 & 0.5 & 733 \\
\hline Chromium & $<0.01$ & $<0.01$ & $<0.01$ & $<0.01$ & $\mathrm{mg} / \mathrm{L}$ & 0.01 & 0.01 & 0.5 \\
\hline Iron & $<0.05$ & $<0.05$ & $<0.05$ & $<0.05$ & $\mathrm{mg} / \mathrm{L}$ & 0.5 & 0.5 & 1.0 \\
\hline Lead & $<0.01$ & $<0.01$ & $<0.01$ & $<0.01$ & $\mathrm{mg} / \mathrm{L}$ & 0.01 & 0.01 & 0.05 \\
\hline Magnesium & 151 & 154 & 170 & 153 & $\mathrm{mg} / \mathrm{L}$ & 0.50 & 0.50 & 188 \\
\hline Mercury & $<0.0002$ & $<0.0002$ & $<0.0002$ & $<0.0002$ & $\mathrm{mg} / \mathrm{L}$ & 0.0002 & 0.0002 & 0.002 \\
\hline Nickel & $<0.025$ & $<0.025$ & $<0.025$ & $<0.025$ & $\mathrm{mg} / \mathrm{L}$ & 0.025 & 0.025 & 0.284 \\
\hline Potassium & 7.27 & 7.49 & 6.15 & 5.96 & $\mathrm{mg} / \mathrm{L}$ & 0.50 & 0.50 & 10.1 \\
\hline Selenium & $<0.05$ & $<0.05$ & $<0.05$ & $<0.05$ & $\mathrm{mg} / \mathrm{L}$ & 0.05 & 0.05 & 0.22 \\
\hline Silver & $<0.0125$ & $<0.0125$ & $<0.0125$ & $<0.0125$ & $\mathrm{mg} / \mathrm{L}$ & 0.0125 & 0.0125 & 0.50 \\
\hline Sodium & 253 & 254 & 279 & 281 & $\mathrm{mg} / \mathrm{L}$ & 0.50 & 0.50 & 369.0 \\
\hline Thallium & $<0.05$ & $<0.05$ & $<0.05$ & $<0.05$ & $\mathrm{mg} / \mathrm{L}$ & 0.05 & 0.05 & 0.058 \\
\hline Vanadium & $<0.025$ & $<0.025$ & 0.0482 & 0.0384 & $\mathrm{mg} / \mathrm{L}$ & 0.025 & 0.025 & 0.50 \\
\hline
\end{tabular}

A $95^{\text {th }}$ Upper tolerance limit value, equivalent to $95 \%$ confidence limit

${ }^{\mathrm{b}}$ Reporting limit

c Not applicable

d Standard unit

${ }^{\mathrm{e}}$ Not reported by the laboratory 
Waste Isolation Pilot Plant 2002 Site Environmental Report

DOE/WIPP 03-2225

Table 6.10 - Summary of 2002 DOE Sitewide Groundwater Monitoring Program

\begin{tabular}{|c|c|c|c|c|}
\hline & \multicolumn{4}{|c|}{ Purposes for Which Monitoring was Performed } \\
\hline & Remediation & $\begin{array}{c}\text { Waste } \\
\text { Management }\end{array}$ & $\begin{array}{l}\text { Environmental } \\
\text { Surveillance }\end{array}$ & $\begin{array}{c}\text { Other } \\
\text { Drivers }\end{array}$ \\
\hline Number of Active Wells Monitored & N/A & N/A & 7 & $\mathrm{~N} / \mathrm{A}$ \\
\hline Number of Samples Taken & N/A & $\mathrm{N} / \mathrm{A}$ & 14 & $\mathrm{~N} / \mathrm{A}$ \\
\hline Number of Analyses Performed & N/A & $\mathrm{N} / \mathrm{A}$ & 1512 & $\mathrm{~N} / \mathrm{A}$ \\
\hline$\%$ of Analyses that are Non-Detects & $\mathrm{N} / \mathrm{A}$ & $\mathrm{N} / \mathrm{A}$ & $83 \% *$ & $\mathrm{~N} / \mathrm{A}$ \\
\hline
\end{tabular}


Waste Isolation Pilot Plant 2002 Site Environmental Report DOE/WIPP 03-2225

Table 6.11 - Groundwater Level Measurement Results for 2002

\begin{tabular}{|c|c|c|c|c|c|c|c|c|}
\hline $\begin{array}{l}\text { Well } \\
\text { Number }\end{array}$ & Zone & $\begin{array}{l}\text { Top of } \\
\text { Casing } \\
\text { Elevation }\end{array}$ & Date & $\begin{array}{l}\text { Measured } \\
\text { Depth From } \\
\text { Top of Casing }\end{array}$ & $\begin{array}{c}\text { Measured } \\
\text { Depth in Meters }\end{array}$ & $\begin{array}{l}\text { Elevation in } \\
\text { Feet AMSL* }\end{array}$ & $\begin{array}{l}\text { Elevation in } \\
\text { Meters }\end{array}$ & $\begin{array}{c}\text { Elevation Adjusted } \\
\text { to Equivalent Fresh } \\
\text { Water Head }\end{array}$ \\
\hline AEC-7 & CUL & 3657.25 & $01 / 15 / 02$ & 619.16 & 188.72 & 3038.09 & 926.01 & 3061.03 \\
\hline AEC-7 & CUL & 3657.25 & $02 / 06 / 02$ & 619.14 & 188.71 & 3038.11 & 926.02 & 3061.05 \\
\hline AEC-7 & CUL & 3657.25 & $03 / 12 / 02$ & 619.08 & 188.70 & 3038.17 & 926.03 & 3061.12 \\
\hline AEC-7 & CUL & 3657.25 & $04 / 09 / 02$ & 619.15 & 188.72 & 3038.10 & 926.01 & 3061.04 \\
\hline AEC-7 & CUL & 3657.25 & $05 / 08 / 02$ & 618.95 & 188.66 & 3038.30 & 926.07 & 3061.26 \\
\hline AEC-7 & CUL & 3657.25 & $06 / 12 / 02$ & 619.01 & 188.67 & 3038.24 & 926.06 & 3061.19 \\
\hline AEC-7 & CUL & 3657.25 & $07 / 15 / 02$ & 619.16 & 188.72 & 3038.09 & 926.01 & 3061.03 \\
\hline AEC-7 & CUL & 3657.25 & $08 / 13 / 02$ & 618.92 & 188.65 & 3038.33 & 926.08 & 3061.29 \\
\hline AEC-7 & CUL & 3657.25 & $09 / 09 / 02$ & 619.04 & 188.68 & 3038.21 & 926.05 & 3061.16 \\
\hline AEC-7 & CUL & 3657.25 & $10 / 09 / 02$ & 619.19 & 188.73 & 3038.06 & 926.00 & 3061.00 \\
\hline AEC-7 & CUL & 3657.25 & $11 / 05 / 02$ & 619.13 & 188.71 & 3038.12 & 926.02 & 3061.06 \\
\hline AEC-7 & CUL & 3657.25 & $12 / 03 / 02$ & 619.12 & 188.71 & 3038.13 & 926.02 & 3061.07 \\
\hline AEC-8 & $B / C$ & 3537.10 & $01 / 15 / 02$ & 491.52 & 149.82 & 3045.58 & 928.29 & $\mathrm{~N} / \mathrm{A}$ \\
\hline AEC-8 & $B / C$ & 3537.10 & $02 / 06 / 02$ & 490.39 & 149.47 & 3046.71 & 928.64 & $\mathrm{~N} / \mathrm{A}$ \\
\hline AEC-8 & $B / C$ & 3537.10 & $03 / 12 / 02$ & 488.94 & 149.03 & 3048.16 & 929.08 & $\mathrm{~N} / \mathrm{A}$ \\
\hline AEC-8 & $B / C$ & 3537.10 & $04 / 09 / 02$ & 487.65 & 148.64 & 3049.45 & 929.47 & $\mathrm{~N} / \mathrm{A}$ \\
\hline AEC-8 & $B / C$ & 3537.10 & $05 / 08 / 02$ & 486.36 & 148.24 & 3050.74 & 929.87 & N/A \\
\hline AEC-8 & $B / C$ & 3537.10 & $06 / 13 / 02$ & 484.84 & 147.78 & 3052.26 & 930.33 & $\mathrm{~N} / \mathrm{A}$ \\
\hline AEC-8 & $B / C$ & 3537.10 & $07 / 15 / 02$ & 482.53 & 147.08 & 3054.57 & 931.03 & $\mathrm{~N} / \mathrm{A}$ \\
\hline AEC-8 & $B / C$ & 3537.10 & $08 / 13 / 02$ & 480.20 & 146.36 & 3056.90 & 931.74 & $\mathrm{~N} / \mathrm{A}$ \\
\hline AEC-8 & $B / C$ & 3537.10 & 09/10/02 & 478.22 & 145.76 & 3058.88 & 932.35 & $\mathrm{~N} / \mathrm{A}$ \\
\hline AEC-8 & $B / C$ & 3537.10 & $10 / 09 / 02$ & 476.71 & 145.30 & 3060.39 & 932.81 & N/A \\
\hline AEC-8 & $\mathrm{B} / \mathrm{C}$ & 3537.10 & $11 / 05 / 02$ & 475.66 & 144.98 & 3061.44 & 933.13 & $\mathrm{~N} / \mathrm{A}$ \\
\hline AEC-8 & $\mathrm{B} / \mathrm{C}$ & 3537.10 & $12 / 03 / 02$ & 474.75 & 144.70 & 3062.35 & 933.40 & N/A \\
\hline C-2505 & $\mathrm{SR} / \mathrm{D}$ & 3413.05 & $08 / 15 / 02$ & 45.61 & 13.90 & 3367.44 & 1026.40 & N/A \\
\hline C-2505 & SR/D & 3413.05 & $09 / 12 / 02$ & 45.49 & 13.87 & 3367.56 & 1026.43 & N/A \\
\hline C-2505 & $S R / D$ & 3413.05 & $10 / 10 / 02$ & 45.55 & 13.88 & 3367.50 & 1026.41 & $\mathrm{~N} / \mathrm{A}$ \\
\hline C-2505 & SR/D & 3413.05 & $11 / 06 / 02$ & 45.64 & 13.91 & 3367.41 & 1026.39 & N/A \\
\hline
\end{tabular}


Waste Isolation Pilot Plant 2002 Site Environmental Report DOE/WIPP 03-2225

Table 6.11 - Groundwater Level Measurement Results for 2002

\begin{tabular}{|c|c|c|c|c|c|c|c|c|}
\hline $\begin{array}{l}\text { Well } \\
\text { Number }\end{array}$ & Zone & $\begin{array}{l}\text { Top of } \\
\text { Casing } \\
\text { Elevation }\end{array}$ & Date & $\begin{array}{c}\text { Measured } \\
\text { Depth From } \\
\text { Top of Casing } \\
\end{array}$ & $\begin{array}{c}\text { Measured } \\
\text { Depth in Meters }\end{array}$ & $\begin{array}{l}\text { Elevation in } \\
\text { Feet AMSL* }\end{array}$ & $\begin{array}{l}\text { Elevation in } \\
\text { Meters }\end{array}$ & $\begin{array}{c}\text { Elevation Adjusted } \\
\text { to Equivalent Fresh } \\
\text { Water Head }\end{array}$ \\
\hline C-2505 & SR/D & 3413.05 & $12 / 04 / 02$ & 45.53 & 13.88 & 3367.52 & 1026.42 & N/A \\
\hline C-2506 & SR/D & 3412.87 & $08 / 15 / 02$ & 45.00 & 13.72 & 3367.87 & 1026.53 & N/A \\
\hline C-2506 & SR/D & 3412.87 & $09 / 12 / 02$ & 44.89 & 13.68 & 3367.98 & 1026.56 & N/A \\
\hline C-2506 & SR/D & 3412.87 & $10 / 10 / 02$ & 44.93 & 13.69 & 3367.94 & 1026.55 & N/A \\
\hline C-2506 & SR/D & 3412.87 & $11 / 06 / 02$ & 45.01 & 13.72 & 3367.86 & 1026.52 & N/A \\
\hline C-2506 & SR/D & 3412.87 & $12 / 04 / 02$ & 44.90 & 13.69 & 3367.97 & 1026.56 & N/A \\
\hline C-2507 & SR/D & 3410.01 & $08 / 15 / 02$ & 45.85 & 13.98 & 3364.16 & 1025.40 & $\mathrm{~N} / \mathrm{A}$ \\
\hline C-2507 & SR/D & 3410.01 & $09 / 12 / 02$ & 45.62 & 13.90 & 3364.39 & 1025.47 & $\mathrm{~N} / \mathrm{A}$ \\
\hline C-2507 & SR/D & 3410.01 & $10 / 10 / 02$ & 45.59 & 13.90 & 3364.42 & 1025.48 & $\mathrm{~N} / \mathrm{A}$ \\
\hline C-2507 & SR/D & 3410.01 & $11 / 06 / 02$ & 45.64 & 13.91 & 3364.37 & 1025.46 & N/A \\
\hline C-2507 & SR/D & 3410.01 & $12 / 04 / 02$ & 45.60 & 13.90 & 3364.41 & 1025.47 & $\mathrm{~N} / \mathrm{A}$ \\
\hline C-2737 (ANNULUS) & MAG & 3399.30 & $01 / 16 / 02$ & 254.49 & 77.57 & 3144.81 & 958.54 & $\mathrm{~N} / \mathrm{A}$ \\
\hline C-2737 (ANNULUS) & MAG & 3399.30 & $02 / 05 / 02$ & 254.63 & 77.61 & 3144.67 & 958.50 & $\mathrm{~N} / \mathrm{A}$ \\
\hline C-2737 (ANNULUS) & MAG & 3399.30 & $03 / 12 / 02$ & 255.26 & 77.80 & 3144.04 & 958.3 & $\mathrm{~N} / \mathrm{A}$ \\
\hline C-2737 (ANNULUS) & MAG & 3399.30 & $04 / 08 / 02$ & 255.47 & 77.87 & 3143.83 & 958.24 & $\mathrm{~N} / \mathrm{A}$ \\
\hline C-2737 (ANNULUS) & MAG & 3399.30 & 05/07/02 & 256.06 & 78.05 & 3143.24 & 958.06 & $\mathrm{~N} / \mathrm{A}$ \\
\hline C-2737 (ANNULUS) & MAG & 3399.30 & $06 / 10 / 02$ & 256.33 & 78.13 & 3142.97 & 957.98 & N/A \\
\hline C-2737 (ANNULUS) & MAG & 3399.30 & $07 / 16 / 02$ & 256.87 & 78.29 & 3142.43 & 957.81 & $\mathrm{~N} / \mathrm{A}$ \\
\hline C-2737 (ANNULUS) & MAG & 3399.30 & $08 / 13 / 02$ & 256.95 & 78.32 & 3142.35 & 957.79 & $\mathrm{~N} / \mathrm{A}$ \\
\hline C-2737 (ANNULUS) & MAG & 3399.30 & $09 / 12 / 02$ & 257.23 & 78.40 & 3142.07 & 957.70 & $\mathrm{~N} / \mathrm{A}$ \\
\hline C-2737 (ANNULUS) & MAG & 3399.30 & $10 / 09 / 02$ & 257.35 & 78.44 & 3141.95 & 957.67 & $\mathrm{~N} / \mathrm{A}$ \\
\hline C-2737 (ANNULUS) & MAG & 3399.30 & $11 / 06 / 02$ & 257.63 & 78.53 & 3141.67 & 957.58 & $\mathrm{~N} / \mathrm{A}$ \\
\hline C-2737 (ANNULUS) & MAG & 3399.30 & $12 / 04 / 02$ & 257.69 & 78.54 & 3141.61 & 957.56 & $\mathrm{~N} / \mathrm{A}$ \\
\hline C-2737 (PIP) & CUL & 3399.30 & $01 / 16 / 02$ & 384.86 & 117.31 & 3014.44 & 918.80 & 3014.44 \\
\hline C-2737 (PIP) & CUL & 3399.30 & $02 / 05 / 02$ & 384.75 & 117.27 & 3014.55 & 918.83 & 3014.55 \\
\hline C-2737 (PIP) & CUL & 3399.30 & $03 / 12 / 02$ & 383.25 & 116.81 & 3016.05 & 919.29 & 3016.05 \\
\hline C-2737 (PIP) & CUL & 3399.30 & $04 / 08 / 02$ & 382.98 & 116.73 & 3016.32 & 919.37 & 3016.32 \\
\hline C-2737 (PIP) & CUL & 3399.30 & $05 / 07 / 02$ & 382.93 & 116.72 & 3016.37 & 919.39 & 3016.37 \\
\hline
\end{tabular}


Waste Isolation Pilot Plant 2002 Site Environmental Report DOE/WIPP 03-2225

Table 6.11 - Groundwater Level Measurement Results for 2002

\begin{tabular}{|c|c|c|c|c|c|c|c|c|}
\hline $\begin{array}{l}\text { Well } \\
\text { Number }\end{array}$ & Zone & $\begin{array}{l}\text { Top of } \\
\text { Casing } \\
\text { Elevation }\end{array}$ & Date & $\begin{array}{l}\text { Measured } \\
\text { Depth From } \\
\text { Top of Casing }\end{array}$ & $\begin{array}{c}\text { Measured } \\
\text { Depth in Meters }\end{array}$ & $\begin{array}{l}\text { Elevation in } \\
\text { Feet AMSL* }\end{array}$ & $\begin{array}{c}\text { Elevation in } \\
\text { Meters }\end{array}$ & $\begin{array}{c}\text { Elevation Adjusted } \\
\text { to Equivalent Fresh } \\
\text { Water Head }\end{array}$ \\
\hline C-2737 (PIP) & CUL & 3399.30 & 06/10/02 & 382.58 & 116.61 & 3016.72 & 919.50 & 3016.72 \\
\hline C-2737 (PIP) & CUL & 3399.30 & $07 / 15 / 02$ & 382.6 & 116.62 & 3016.70 & 919.49 & 3016.70 \\
\hline C-2737 (PIP) & CUL & 3399.30 & $08 / 13 / 02$ & 382.29 & 116.52 & 3017.01 & 919.58 & 3017.01 \\
\hline C-2737 (PIP) & CUL & 3399.30 & $09 / 12 / 02$ & 382.26 & 116.51 & 3017.04 & 919.59 & 3017.04 \\
\hline C-2737 (PIP) & CUL & 3399.30 & $10 / 09 / 02$ & 382.14 & 116.48 & 3017.16 & 919.63 & 3017.16 \\
\hline C-2737 (PIP) & CUL & 3399.30 & $11 / 06 / 02$ & 382.52 & 116.59 & 3016.78 & 919.51 & 3016.78 \\
\hline C-2737 (PIP) & CUL & 3399.30 & $12 / 04 / 02$ & 382.39 & 116.55 & 3016.91 & 919.55 & 3016.91 \\
\hline C-2811 & SR/D & 3398.92 & $08 / 15 / 02$ & 61.35 & 18.70 & 3337.57 & 1017.29 & $\mathrm{~N} / \mathrm{A}$ \\
\hline C-2811 & SR/D & 3398.92 & $09 / 12 / 02$ & 61.24 & 18.67 & 3337.68 & 1017.32 & $\mathrm{~N} / \mathrm{A}$ \\
\hline C-2811 & SR/D & 3398.92 & $10 / 10 / 02$ & 60.92 & 18.57 & 3338.00 & 1017.42 & $\mathrm{~N} / \mathrm{A}$ \\
\hline C-2811 & SR/D & 3398.92 & $11 / 06 / 02$ & 60.93 & 18.57 & 3337.99 & 1017.42 & $\mathrm{~N} / \mathrm{A}$ \\
\hline C-2811 & SR/D & 3398.92 & $12 / 04 / 02$ & 60.76 & 18.52 & 3338.16 & 1017.47 & $\mathrm{~N} / \mathrm{A}$ \\
\hline CB-1 & CUL & 3328.38 & $01 / 15 / 02$ & 48.03 & 14.64 & 3280.35 & 999.85 & 3293.47 \\
\hline CB-1 & CUL & 3328.38 & $02 / 05 / 02$ & 45.24 & 13.79 & 3283.14 & 1000.70 & 3296.34 \\
\hline CB-1 & CUL & 3328.38 & $04 / 10 / 02$ & 36.72 & 11.19 & 3291.66 & 1003.30 & 3305.13 \\
\hline CB-1 & CUL & 3328.38 & $04 / 10 / 02$ & 36.72 & 11.19 & 3291.66 & 1003.30 & 3305.13 \\
\hline CB-1 & CUL & 3328.38 & $07 / 16 / 02$ & 440.22 & 134.18 & 2888.16 & 880.31 & 2889.12 \\
\hline CB-1 & CUL & 3328.38 & $08 / 14 / 02$ & 422.88 & 128.89 & 2905.50 & 885.60 & 2907.00 \\
\hline CB-1 & CUL & 3328.38 & $10 / 09 / 02$ & 392.90 & 119.76 & 2935.48 & 894.73 & 2937.90 \\
\hline CB-1 & CUL & 3328.38 & $11 / 06 / 02$ & 379.61 & 115.71 & 2948.77 & 898.79 & 2951.61 \\
\hline CB-1 & CUL & 3328.38 & $03 / 13 / 02$ & 40.37 & 12.30 & 3288.01 & 1002.19 & 3301.36 \\
\hline CB-1 & CUL & 3328.38 & $06 / 11 / 02$ & 463.65 & 141.32 & 2864.73 & 873.17 & 2864.96 \\
\hline CB-1 & CUL & 3328.38 & $09 / 12 / 02$ & 406.85 & 124.01 & 2921.53 & 890.48 & 2923.52 \\
\hline CB-1 & CUL & 3328.38 & $12 / 04 / 02$ & 367.12 & 111.90 & 2961.26 & 902.59 & 2964.48 \\
\hline CB-1 (PIP) & $\mathrm{B} / \mathrm{C}$ & 3328.38 & $01 / 15 / 02$ & 313.73 & 95.62 & 3014.65 & 918.87 & $\mathrm{~N} / \mathrm{A}$ \\
\hline CB-1 (PIP) & $B / C$ & 3328.38 & $02 / 05 / 02$ & 313.73 & 95.62 & 3014.65 & 918.87 & $\mathrm{~N} / \mathrm{A}$ \\
\hline CB-1 (PIP) & $B / C$ & 3328.38 & $03 / 13 / 02$ & 313.58 & 95.58 & 3014.80 & 918.91 & $\mathrm{~N} / \mathrm{A}$ \\
\hline CB-1 (PIP) & $B / C$ & 3328.38 & $04 / 10 / 02$ & 313.76 & 95.63 & 3014.62 & 918.86 & $\mathrm{~N} / \mathrm{A}$ \\
\hline
\end{tabular}


Waste Isolation Pilot Plant 2002 Site Environmental Report DOE/WIPP 03-2225

Table 6.11 - Groundwater Level Measurement Results for 2002

\begin{tabular}{|c|c|c|c|c|c|c|c|c|}
\hline $\begin{array}{l}\text { Well } \\
\text { Number }\end{array}$ & Zone & $\begin{array}{l}\text { Top of } \\
\text { Casing } \\
\text { Elevation }\end{array}$ & Date & $\begin{array}{l}\text { Measured } \\
\text { Depth From } \\
\text { Top of Casing }\end{array}$ & $\begin{array}{c}\text { Measured } \\
\text { Depth in Meters }\end{array}$ & $\begin{array}{l}\text { Elevation in } \\
\text { Feet AMSL* }\end{array}$ & $\begin{array}{l}\text { Elevation in } \\
\text { Meters }\end{array}$ & $\begin{array}{c}\text { Elevation Adjusted } \\
\text { to Equivalent Fresh } \\
\text { Water Head }\end{array}$ \\
\hline CB-1 (PIP) & $B / C$ & 3328.38 & 04/10/02 & 313.76 & 95.63 & 3014.62 & 918.86 & N/A \\
\hline CB-1 (PIP) & $\mathrm{B} / \mathrm{C}$ & 3328.38 & $06 / 11 / 02$ & 313.64 & 95.60 & 3014.74 & 918.89 & N/A \\
\hline CB-1 (PIP) & $\mathrm{B} / \mathrm{C}$ & 3328.38 & $07 / 16 / 02$ & 313.83 & 95.66 & 3014.55 & 918.83 & N/A \\
\hline CB-1 (PIP) & $\mathrm{B} / \mathrm{C}$ & 3328.38 & $08 / 14 / 02$ & 313.78 & 95.64 & 3014.60 & 918.85 & N/A \\
\hline CB-1 (PIP) & $\mathrm{B} / \mathrm{C}$ & 3328.38 & 09/12/02 & 313.83 & 95.66 & 3014.55 & 918.83 & N/A \\
\hline CB-1 (PIP) & $\mathrm{B} / \mathrm{C}$ & 3328.38 & $10 / 09 / 02$ & 313.81 & 95.65 & 3014.57 & 918.84 & $\mathrm{~N} / \mathrm{A}$ \\
\hline CB-1 (PIP) & $\mathrm{B} / \mathrm{C}$ & 3328.38 & $11 / 06 / 02$ & 313.95 & 95.69 & 3014.43 & 918.80 & $\mathrm{~N} / \mathrm{A}$ \\
\hline CB-1 (PIP) & $\mathrm{B} / \mathrm{C}$ & 3328.38 & $12 / 04 / 02$ & 313.87 & 95.67 & 3014.51 & 918.82 & $\mathrm{~N} / \mathrm{A}$ \\
\hline DOE-1 & CUL & 3466.04 & $01 / 16 / 02$ & 489.16 & 149.10 & 2976.88 & 907.35 & 3005.37 \\
\hline DOE-1 & CUL & 3466.04 & $02 / 05 / 02$ & 488.95 & 149.03 & 2977.09 & 907.42 & 3005.60 \\
\hline DOE-1 & CUL & 3466.04 & $03 / 13 / 02$ & 488.80 & 148.99 & 2977.24 & 907.46 & 3005.76 \\
\hline DOE-1 & CUL & 3466.04 & $04 / 10 / 02$ & 489.30 & 149.14 & 2976.74 & 907.31 & 3005.22 \\
\hline DOE-1 & CUL & 3466.04 & $05 / 07 / 02$ & 488.82 & 148.99 & 2977.22 & 907.46 & 3005.74 \\
\hline DOE-1 & CUL & 3466.04 & $06 / 11 / 02$ & 488.48 & 148.89 & 2977.56 & 907.56 & 3006.11 \\
\hline DOE-1 & CUL & 3466.04 & $07 / 15 / 02$ & 488.18 & 148.80 & 2977.86 & 907.65 & 3006.43 \\
\hline DOE-1 & CUL & 3466.04 & $08 / 14 / 02$ & 488.06 & 148.76 & 2977.98 & 907.69 & 3006.56 \\
\hline DOE-1 & CUL & 3466.04 & $09 / 11 / 02$ & 487.95 & 148.73 & 2978.09 & 907.72 & 3006.68 \\
\hline DOE-1 & CUL & 3466.04 & $10 / 07 / 02$ & 487.92 & 148.72 & 2978.12 & 907.73 & 3006.72 \\
\hline DOE-1 & CUL & 3466.04 & $11 / 06 / 02$ & 487.87 & 148.70 & 2978.17 & 907.75 & 3006.77 \\
\hline DOE-1 & CUL & 3466.04 & $12 / 04 / 02$ & 487.94 & 148.72 & 2978.10 & 907.72 & 3006.69 \\
\hline ERDA-9 & CUL & 3410.10 & $01 / 16 / 02$ & 401.70 & 122.44 & 3008.40 & 916.96 & 3023.84 \\
\hline ERDA-9 & CUL & 3410.10 & $02 / 05 / 02$ & 401.64 & 122.42 & 3008.46 & 916.98 & 3023.90 \\
\hline ERDA-9 & CUL & 3410.10 & $03 / 12 / 02$ & 401.57 & 122.40 & 3008.53 & 917.00 & 3023.98 \\
\hline ERDA-9 & CUL & 3410.10 & $04 / 08 / 02$ & 401.23 & 122.29 & 3008.87 & 917.10 & 3024.33 \\
\hline ERDA-9 & CUL & 3410.10 & 05/07/02 & 400.97 & 122.22 & 3009.13 & 917.18 & 3024.61 \\
\hline ERDA-9 & CUL & 3410.10 & $06 / 10 / 02$ & 400.62 & 122.11 & 3009.48 & 917.29 & 3024.97 \\
\hline ERDA-9 & CUL & 3410.10 & $07 / 15 / 02$ & 400.44 & 122.05 & 3009.66 & 917.34 & 3025.16 \\
\hline ERDA-9 & CUL & 3410.10 & $08 / 14 / 02$ & 400.23 & 121.99 & 3009.87 & 917.41 & 3025.38 \\
\hline
\end{tabular}


Waste Isolation Pilot Plant 2002 Site Environmental Report DOE/WIPP 03-2225

Table 6.11 - Groundwater Level Measurement Results for 2002

\begin{tabular}{|c|c|c|c|c|c|c|c|c|}
\hline $\begin{array}{l}\text { Well } \\
\text { Number }\end{array}$ & Zone & $\begin{array}{l}\text { Top of } \\
\text { Casing } \\
\text { Elevation }\end{array}$ & Date & $\begin{array}{l}\text { Measured } \\
\text { Depth From } \\
\text { Top of Casing }\end{array}$ & $\begin{array}{c}\text { Measured } \\
\text { Depth in Meters }\end{array}$ & $\begin{array}{l}\text { Elevation in } \\
\text { Feet AMSL* }\end{array}$ & $\begin{array}{l}\text { Elevation in } \\
\text { Meters }\end{array}$ & $\begin{array}{c}\text { Elevation Adjusted } \\
\text { to Equivalent Fresh } \\
\text { Water Head }\end{array}$ \\
\hline ERDA-9 & CUL & 3410.10 & 09/10/02 & 400.15 & 121.97 & 3009.95 & 917.43 & 3025.47 \\
\hline ERDA-9 & CUL & 3410.10 & $10 / 07 / 02$ & 400.11 & 121.95 & 3009.99 & 917.44 & 3025.51 \\
\hline ERDA-9 & CUL & 3410.10 & $11 / 04 / 02$ & 400.23 & 121.99 & 3009.87 & 917.41 & 3025.38 \\
\hline ERDA-9 & CUL & 3410.10 & $12 / 02 / 02$ & 400.27 & 122.00 & 3009.83 & 917.40 & 3025.34 \\
\hline $\mathrm{H}-02 \mathrm{a}$ & CUL & 3378.09 & $03 / 13 / 02$ & 340.01 & 103.64 & 3038.08 & 926.01 & 3041.61 \\
\hline $\mathrm{H}-02 \mathrm{a}$ & CUL & 3378.09 & $06 / 11 / 02$ & 339.79 & 103.57 & 3038.30 & 926.07 & 3041.83 \\
\hline $\mathrm{H}-02 \mathrm{a}$ & CUL & 3378.09 & 09/10/02 & 339.57 & 103.50 & 3038.52 & 926.14 & 3042.06 \\
\hline $\mathrm{H}-02 \mathrm{a}$ & CUL & 3378.09 & $12 / 04 / 02$ & 339.33 & 103.43 & 3038.76 & 926.21 & 3042.30 \\
\hline $\mathrm{H}-02 \mathrm{~b} 1$ & MAG & 3378.46 & $01 / 16 / 02$ & 231.31 & 70.50 & 3147.15 & 959.25 & $\mathrm{~N} / \mathrm{A}$ \\
\hline $\mathrm{H}-02 \mathrm{~b} 1$ & MAG & 3378.46 & $02 / 05 / 02$ & 231.29 & 70.50 & 3147.17 & 959.26 & N/A \\
\hline $\mathrm{H}-02 \mathrm{~b} 1$ & MAG & 3378.46 & $03 / 13 / 02$ & 231.31 & 70.50 & 3147.15 & 959.25 & $\mathrm{~N} / \mathrm{A}$ \\
\hline $\mathrm{H}-02 \mathrm{~b} 1$ & MAG & 3378.46 & $04 / 08 / 02$ & 231.25 & 70.49 & 3147.21 & 959.27 & N/A \\
\hline $\mathrm{H}-02 \mathrm{~b} 1$ & MAG & 3378.46 & 05/08/02 & 231.29 & 70.50 & 3147.17 & 959.26 & $\mathrm{~N} / \mathrm{A}$ \\
\hline $\mathrm{H}-02 \mathrm{~b} 1$ & MAG & 3378.46 & $06 / 11 / 02$ & 231.32 & 70.51 & 3147.14 & 959.25 & $\mathrm{~N} / \mathrm{A}$ \\
\hline $\mathrm{H}-02 \mathrm{~b} 1$ & MAG & 3378.46 & $07 / 16 / 02$ & 231.37 & 70.52 & 3147.09 & 959.23 & $\mathrm{~N} / \mathrm{A}$ \\
\hline $\mathrm{H}-02 \mathrm{~b} 1$ & MAG & 3378.46 & $08 / 13 / 02$ & 231.45 & 70.55 & 3147.01 & 959.21 & $\mathrm{~N} / \mathrm{A}$ \\
\hline $\mathrm{H}-02 \mathrm{~b} 1$ & MAG & 3378.46 & $09 / 10 / 02$ & 231.50 & 70.56 & 3146.96 & 959.19 & N/A \\
\hline $\mathrm{H}-02 \mathrm{~b} 1$ & MAG & 3378.46 & $10 / 08 / 02$ & 231.57 & 70.58 & 3146.89 & 959.17 & $\mathrm{~N} / \mathrm{A}$ \\
\hline $\mathrm{H}-02 \mathrm{~b} 1$ & MAG & 3378.46 & $11 / 05 / 02$ & 231.60 & 70.59 & 3146.86 & 959.16 & $\mathrm{~N} / \mathrm{A}$ \\
\hline $\mathrm{H}-02 \mathrm{~b} 1$ & MAG & 3378.46 & $12 / 04 / 02$ & 231.72 & 70.63 & 3146.74 & 959.13 & $\mathrm{~N} / \mathrm{A}$ \\
\hline $\mathrm{H}-02 \mathrm{~b} 2$ & CUL & 3378.31 & $01 / 16 / 02$ & 340.57 & 103.81 & 3037.74 & 925.90 & 3040.09 \\
\hline $\mathrm{H}-02 \mathrm{~b} 2$ & CUL & 3378.31 & $02 / 05 / 02$ & 340.46 & 103.77 & 3037.85 & 925.94 & 3040.2 \\
\hline $\mathrm{H}-02 \mathrm{~b} 2$ & CUL & 3378.31 & $03 / 13 / 02$ & 340.13 & 103.67 & 3038.18 & 926.04 & 3040.54 \\
\hline $\mathrm{H}-02 \mathrm{~b} 2$ & CUL & 3378.31 & $04 / 08 / 02$ & 340.00 & 103.63 & 3038.31 & 926.08 & 3040.67 \\
\hline $\mathrm{H}-02 \mathrm{~b} 2$ & CUL & 3378.31 & 05/08/02 & 339.89 & 103.60 & 3038.42 & 926.11 & 3040.78 \\
\hline $\mathrm{H}-02 \mathrm{~b} 2$ & CUL & 3378.31 & $06 / 11 / 02$ & 339.86 & 103.59 & 3038.45 & 926.12 & 3040.81 \\
\hline $\mathrm{H}-02 \mathrm{~b} 2$ & CUL & 3378.31 & $07 / 16 / 02$ & 339.90 & 103.60 & 3038.41 & 926.11 & 3040.77 \\
\hline $\mathrm{H}-02 \mathrm{~b} 2$ & CUL & 3378.31 & $08 / 13 / 02$ & 339.65 & 103.53 & 3038.66 & 926.18 & 3041.02 \\
\hline
\end{tabular}


Waste Isolation Pilot Plant 2002 Site Environmental Report DOE/WIPP 03-2225

Table 6.11 - Groundwater Level Measurement Results for 2002

\begin{tabular}{|c|c|c|c|c|c|c|c|c|}
\hline $\begin{array}{l}\text { Well } \\
\text { Number }\end{array}$ & Zone & $\begin{array}{l}\text { Top of } \\
\text { Casing } \\
\text { Elevation }\end{array}$ & Date & $\begin{array}{l}\text { Measured } \\
\text { Depth From } \\
\text { Top of Casing }\end{array}$ & $\begin{array}{c}\text { Measured } \\
\text { Depth in Meters }\end{array}$ & $\begin{array}{l}\text { Elevation in } \\
\text { Feet AMSL* }\end{array}$ & $\begin{array}{c}\text { Elevation in } \\
\text { Meters }\end{array}$ & $\begin{array}{c}\text { Elevation Adjusted } \\
\text { to Equivalent Fresh } \\
\text { Water Head }\end{array}$ \\
\hline $\mathrm{H}-02 \mathrm{~b} 2$ & CUL & 3378.31 & 09/10/02 & 339.66 & 103.53 & 3038.65 & 926.18 & 3041.01 \\
\hline $\mathrm{H}-02 \mathrm{~b} 2$ & CUL & 3378.31 & $10 / 08 / 02$ & 339.56 & 103.50 & 3038.75 & 926.21 & 3041.11 \\
\hline $\mathrm{H}-02 \mathrm{~b} 2$ & CUL & 3378.31 & $11 / 05 / 02$ & 339.38 & 103.44 & 3038.93 & 926.27 & 3041.29 \\
\hline $\mathrm{H}-02 \mathrm{~b} 2$ & CUL & 3378.31 & $12 / 04 / 02$ & 339.39 & 103.45 & 3038.92 & 926.26 & 3041.28 \\
\hline $\mathrm{H}-02 \mathrm{c}$ & CUL & 3378.41 & $03 / 13 / 02$ & 340.39 & 103.75 & 3038.02 & 925.99 & 3050.93 \\
\hline $\mathrm{H}-02 \mathrm{c}$ & CUL & 3378.41 & $06 / 11 / 02$ & 340.00 & 103.63 & 3038.41 & 926.11 & 3051.33 \\
\hline $\mathrm{H}-02 \mathrm{c}$ & CUL & 3378.41 & 09/10/02 & 339.73 & 103.55 & 3038.68 & 926.19 & 3051.62 \\
\hline $\mathrm{H}-02 \mathrm{c}$ & CUL & 3378.41 & $12 / 04 / 02$ & 339.46 & 103.47 & 3038.95 & 926.27 & 3051.90 \\
\hline $\mathrm{H}-03 \mathrm{~b} 1$ & MAG & 3390.64 & $01 / 16 / 02$ & 240.20 & 73.21 & 3150.44 & 960.25 & $\mathrm{~N} / \mathrm{A}$ \\
\hline $\mathrm{H}-03 \mathrm{~b} 1$ & MAG & 3390.64 & $02 / 05 / 02$ & 240.34 & 73.26 & 3150.30 & 960.21 & N/A \\
\hline $\mathrm{H}-03 \mathrm{~b} 1$ & MAG & 3390.64 & $03 / 18 / 02$ & 263.15 & 80.21 & 3127.49 & 953.26 & $\mathrm{~N} / \mathrm{A}$ \\
\hline $\mathrm{H}-03 \mathrm{~b} 1$ & MAG & 3390.64 & $04 / 09 / 02$ & 266.40 & 81.20 & 3124.24 & 952.27 & N/A \\
\hline $\mathrm{H}-03 \mathrm{~b} 1$ & MAG & 3390.64 & 05/08/02 & 260.01 & 79.25 & 3130.63 & 954.22 & $\mathrm{~N} / \mathrm{A}$ \\
\hline $\mathrm{H}-03 \mathrm{~b} 1$ & MAG & 3390.64 & $06 / 10 / 02$ & 259.18 & 79.00 & 3131.46 & 954.47 & $\mathrm{~N} / \mathrm{A}$ \\
\hline $\mathrm{H}-03 \mathrm{~b} 1$ & MAG & 3390.64 & $07 / 17 / 02$ & 257.53 & 78.50 & 3133.11 & 954.97 & $\mathrm{~N} / \mathrm{A}$ \\
\hline $\mathrm{H}-03 \mathrm{~b} 1$ & MAG & 3390.64 & $08 / 14 / 02$ & 257.41 & 78.46 & 3133.23 & 955.01 & $\mathrm{~N} / \mathrm{A}$ \\
\hline $\mathrm{H}-03 \mathrm{~b} 1$ & MAG & 3390.64 & $09 / 10 / 02$ & 257.79 & 78.57 & 3132.85 & 954.89 & N/A \\
\hline $\mathrm{H}-03 \mathrm{~b} 1$ & MAG & 3390.64 & $10 / 07 / 02$ & 259.16 & 78.99 & 3131.48 & 954.48 & $\mathrm{~N} / \mathrm{A}$ \\
\hline $\mathrm{H}-03 \mathrm{~b} 1$ & MAG & 3390.64 & $11 / 06 / 02$ & 259.29 & 79.03 & 3131.35 & 954.44 & $\mathrm{~N} / \mathrm{A}$ \\
\hline $\mathrm{H}-03 \mathrm{~b} 1$ & MAG & 3390.64 & $12 / 02 / 02$ & 260.25 & 79.32 & 3130.39 & 954.14 & $\mathrm{~N} / \mathrm{A}$ \\
\hline $\mathrm{H}-03 \mathrm{~b} 2$ & CUL & 3390.03 & $01 / 16 / 02$ & 390.68 & 119.08 & 2999.35 & 914.20 & 3010.71 \\
\hline $\mathrm{H}-03 \mathrm{~b} 2$ & CUL & 3390.03 & $02 / 05 / 02$ & 390.60 & 119.05 & 2999.43 & 914.23 & 3010.80 \\
\hline $\mathrm{H}-03 \mathrm{~b} 2$ & CUL & 3390.03 & $03 / 18 / 02$ & 390.88 & 119.14 & 2999.15 & 914.14 & 3010.50 \\
\hline $\mathrm{H}-03 \mathrm{~b} 2$ & CUL & 3390.03 & 04/09/02 & 390.88 & 119.14 & 2999.15 & 914.14 & 3010.50 \\
\hline $\mathrm{H}-03 \mathrm{~b} 2$ & CUL & 3390.03 & 05/07/02 & 390.96 & 119.16 & 2999.07 & 914.12 & 3010.42 \\
\hline $\mathrm{H}-03 \mathrm{~b} 2$ & CUL & 3390.03 & $06 / 10 / 02$ & 390.29 & 118.96 & 2999.74 & 914.32 & 3011.12 \\
\hline $\mathrm{H}-03 \mathrm{~b} 2$ & CUL & 3390.03 & $07 / 17 / 02$ & 390.31 & 118.97 & 2999.72 & 914.31 & 3011.10 \\
\hline $\mathrm{H}-03 \mathrm{~b} 2$ & CUL & 3390.03 & $08 / 14 / 02$ & 390.01 & 118.88 & 3000.02 & 914.41 & 3011.41 \\
\hline
\end{tabular}


Waste Isolation Pilot Plant 2002 Site Environmental Report DOE/WIPP 03-2225

Table 6.11 - Groundwater Level Measurement Results for 2002

\begin{tabular}{|c|c|c|c|c|c|c|c|c|}
\hline $\begin{array}{l}\text { Well } \\
\text { Number }\end{array}$ & Zone & $\begin{array}{l}\text { Top of } \\
\text { Casing } \\
\text { Elevation }\end{array}$ & Date & $\begin{array}{l}\text { Measured } \\
\text { Depth From } \\
\text { Top of Casing }\end{array}$ & $\begin{array}{c}\text { Measured } \\
\text { Depth in Meters }\end{array}$ & $\begin{array}{l}\text { Elevation in } \\
\text { Feet AMSL* }\end{array}$ & $\begin{array}{l}\text { Elevation in } \\
\text { Meters }\end{array}$ & $\begin{array}{c}\text { Elevation Adjusted } \\
\text { to Equivalent Fresh } \\
\text { Water Head }\end{array}$ \\
\hline $\mathrm{H}-03 \mathrm{~b} 2$ & CUL & 3390.03 & 09/10/02 & 389.98 & 118.87 & 3000.05 & 914.42 & 3011.44 \\
\hline $\mathrm{H}-03 \mathrm{~b} 2$ & CUL & 3390.03 & $10 / 07 / 02$ & 389.92 & 118.85 & 3000.11 & 914.43 & 3011.50 \\
\hline $\mathrm{H}-03 \mathrm{~b} 2$ & CUL & 3390.03 & $11 / 06 / 02$ & 390.60 & 119.05 & 2999.43 & 914.23 & 3010.80 \\
\hline $\mathrm{H}-03 \mathrm{~b} 2$ & CUL & 3390.03 & $12 / 02 / 02$ & 389.97 & 118.86 & 3000.06 & 914.42 & 3011.45 \\
\hline H-03b3 & CUL & 3388.67 & $03 / 18 / 02$ & 385.22 & 117.42 & 3003.45 & 915.45 & 3013.30 \\
\hline H-03b3 & CUL & 3388.67 & $06 / 10 / 02$ & 384.63 & 117.24 & 3004.04 & 915.63 & 3013.91 \\
\hline H-03b3 & CUL & 3388.67 & 09/10/02 & 384.26 & 117.12 & 3004.41 & 915.74 & 3014.29 \\
\hline $\mathrm{H}-03 \mathrm{~b} 3$ & CUL & 3388.67 & $12 / 02 / 02$ & 384.29 & 117.13 & 3004.38 & 915.74 & 3014.26 \\
\hline $\mathrm{H}-03 \mathrm{~d} / \mathrm{DL}$ (PVC) & $\mathrm{DL}$ & 3390.01 & $01 / 16 / 02$ & 315.91 & 96.29 & 3074.10 & 936.99 & $\mathrm{~N} / \mathrm{A}$ \\
\hline $\mathrm{H}-03 \mathrm{~d} / \mathrm{DL}$ (PVC) & $\mathrm{DL}$ & 3390.01 & $02 / 05 / 02$ & 315.80 & 96.26 & 3074.21 & 937.02 & $\mathrm{~N} / \mathrm{A}$ \\
\hline $\mathrm{H}-03 \mathrm{~d} / \mathrm{DL}$ (PVC) & $\mathrm{DL}$ & 3390.01 & 03/18/02 & 315.87 & 96.28 & 3074.14 & 937.00 & $\mathrm{~N} / \mathrm{A}$ \\
\hline $\mathrm{H}-03 \mathrm{~d} / \mathrm{DL}$ (PVC) & $\mathrm{DL}$ & 3390.01 & 04/09/02 & 315.80 & 96.26 & 3074.21 & 937.02 & $\mathrm{~N} / \mathrm{A}$ \\
\hline $\mathrm{H}-03 \mathrm{~d} / \mathrm{DL}$ (PVC) & DL & 3390.01 & $05 / 07 / 02$ & 315.68 & 96.22 & 3074.33 & 937.06 & $\mathrm{~N} / \mathrm{A}$ \\
\hline $\mathrm{H}-03 \mathrm{~d} / \mathrm{DL}$ (PVC) & $\mathrm{DL}$ & 3390.01 & $06 / 10 / 02$ & 315.57 & 96.19 & 3074.44 & 937.09 & $\mathrm{~N} / \mathrm{A}$ \\
\hline $\mathrm{H}-03 \mathrm{~d} / \mathrm{DL}$ (PVC) & $\mathrm{DL}$ & 3390.01 & $07 / 17 / 02$ & 315.50 & 96.16 & 3074.51 & 937.11 & $\mathrm{~N} / \mathrm{A}$ \\
\hline $\mathrm{H}-03 \mathrm{~d} / \mathrm{DL}$ (PVC) & DL & 3390.01 & $08 / 14 / 02$ & 315.41 & 96.14 & 3074.60 & 937.14 & $\mathrm{~N} / \mathrm{A}$ \\
\hline $\mathrm{H}-03 \mathrm{~d} / \mathrm{DL}$ (PVC) & DL & 3390.01 & $09 / 10 / 02$ & 315.33 & 96.11 & 3074.68 & 937.16 & N/A \\
\hline $\mathrm{H}-03 \mathrm{~d} / \mathrm{DL}$ (PVC) & $\mathrm{DL}$ & 3390.01 & $10 / 07 / 02$ & 315.25 & 96.09 & 3074.76 & 937.19 & $\mathrm{~N} / \mathrm{A}$ \\
\hline $\mathrm{H}-03 \mathrm{~d} / \mathrm{DL}$ (PVC) & $\mathrm{DL}$ & 3390.01 & $11 / 06 / 02$ & 315.17 & 96.06 & 3074.84 & 937.21 & $\mathrm{~N} / \mathrm{A}$ \\
\hline $\mathrm{H}-03 \mathrm{~d} / \mathrm{DL}$ (PVC) & $\mathrm{DL}$ & 3390.01 & $12 / 02 / 02$ & 315.09 & 96.04 & 3074.92 & 937.24 & $\mathrm{~N} / \mathrm{A}$ \\
\hline $\mathrm{H}-04 \mathrm{~b}$ & CUL & 3333.35 & $01 / 16 / 02$ & 332.11 & 101.23 & 3001.24 & 914.78 & 3004.83 \\
\hline $\mathrm{H}-04 \mathrm{~b}$ & CUL & 3333.35 & $02 / 05 / 02$ & 332.04 & 101.21 & 3001.31 & 914.80 & 3004.90 \\
\hline $\mathrm{H}-04 \mathrm{~b}$ & CUL & 3333.35 & $03 / 13 / 02$ & 331.69 & 101.10 & 3001.66 & 914.91 & 3005.26 \\
\hline $\mathrm{H}-04 \mathrm{~b}$ & CUL & 3333.35 & 04/09/02 & 331.83 & 101.14 & 3001.52 & 914.86 & 3005.11 \\
\hline $\mathrm{H}-04 \mathrm{~b}$ & CUL & 3333.35 & 05/08/02 & 331.49 & 101.04 & 3001.86 & 914.97 & 3005.46 \\
\hline $\mathrm{H}-04 \mathrm{~b}$ & CUL & 3333.35 & $07 / 16 / 02$ & 331.54 & 101.05 & 3001.81 & 914.95 & 3005.41 \\
\hline $\mathrm{H}-04 \mathrm{~b}$ & CUL & 3333.35 & $08 / 12 / 02$ & 331.43 & 101.02 & 3001.92 & 914.99 & 3005.52 \\
\hline $\mathrm{H}-04 \mathrm{~b}$ & CUL & 3333.35 & $09 / 11 / 02$ & 331.62 & 101.08 & 3001.73 & 914.93 & 3005.33 \\
\hline
\end{tabular}


Waste Isolation Pilot Plant 2002 Site Environmental Report DOE/WIPP 03-2225

Table 6.11 - Groundwater Level Measurement Results for 2002

\begin{tabular}{|c|c|c|c|c|c|c|c|c|}
\hline $\begin{array}{l}\text { Well } \\
\text { Number }\end{array}$ & Zone & $\begin{array}{l}\text { Top of } \\
\text { Casing } \\
\text { Elevation }\end{array}$ & Date & $\begin{array}{l}\text { Measured } \\
\text { Depth From } \\
\text { Top of Casing }\end{array}$ & $\begin{array}{c}\text { Measured } \\
\text { Depth in Meters }\end{array}$ & $\begin{array}{l}\text { Elevation in } \\
\text { Feet AMSL* }\end{array}$ & $\begin{array}{c}\text { Elevation in } \\
\text { Meters }\end{array}$ & $\begin{array}{c}\text { Elevation Adjusted } \\
\text { to Equivalent Fresh } \\
\text { Water Head }\end{array}$ \\
\hline $\mathrm{H}-04 \mathrm{~b}$ & CUL & 3333.35 & $10 / 07 / 02$ & 331.65 & 101.09 & 3001.70 & 914.92 & 3005.30 \\
\hline $\mathrm{H}-04 \mathrm{~b}$ & CUL & 3333.35 & $11 / 04 / 02$ & 331.55 & 101.06 & 3001.80 & 914.95 & 3005.40 \\
\hline $\mathrm{H}-04 \mathrm{~b}$ & CUL & 3333.35 & $12 / 02 / 02$ & 331.68 & 101.10 & 3001.67 & 914.91 & 3005.27 \\
\hline $\mathrm{H}-04 \mathrm{~b}$ & CUL & 3333.35 & $06 / 10 / 02$ & 331.34 & 100.99 & 3002.01 & 915.01 & 3005.61 \\
\hline $\mathrm{H}-04 \mathrm{c}$ & MAG & 3334.04 & $01 / 16 / 02$ & 189.73 & 57.83 & 3144.31 & 958.39 & N/A \\
\hline $\mathrm{H}-04 \mathrm{c}$ & MAG & 3334.04 & $02 / 05 / 02$ & 189.73 & 57.83 & 3144.31 & 958.39 & $\mathrm{~N} / \mathrm{A}$ \\
\hline $\mathrm{H}-04 \mathrm{c}$ & MAG & 3334.04 & $03 / 13 / 02$ & 189.60 & 57.79 & 3144.44 & 958.43 & $\mathrm{~N} / \mathrm{A}$ \\
\hline $\mathrm{H}-04 \mathrm{c}$ & MAG & 3334.04 & $04 / 08 / 02$ & 189.46 & 57.75 & 3144.58 & 958.47 & $\mathrm{~N} / \mathrm{A}$ \\
\hline $\mathrm{H}-04 \mathrm{C}$ & MAG & 3334.04 & $05 / 08 / 02$ & 189.44 & 57.74 & 3144.60 & 958.47 & $\mathrm{~N} / \mathrm{A}$ \\
\hline $\mathrm{H}-04 \mathrm{c}$ & MAG & 3334.04 & $06 / 10 / 02$ & 189.47 & 57.75 & 3144.57 & 958.46 & N/A \\
\hline $\mathrm{H}-04 \mathrm{c}$ & MAG & 3334.04 & $07 / 16 / 02$ & 189.51 & 57.76 & 3144.53 & 958.45 & $\mathrm{~N} / \mathrm{A}$ \\
\hline $\mathrm{H}-04 \mathrm{C}$ & MAG & 3334.04 & $08 / 12 / 02$ & 189.52 & 57.77 & 3144.52 & 958.45 & N/A \\
\hline $\mathrm{H}-04 \mathrm{c}$ & MAG & 3334.04 & $09 / 11 / 02$ & 189.65 & 57.81 & 3144.39 & 958.41 & $\mathrm{~N} / \mathrm{A}$ \\
\hline $\mathrm{H}-04 \mathrm{c}$ & MAG & 3334.04 & $10 / 07 / 02$ & 189.63 & 57.80 & 3144.41 & 958.42 & $\mathrm{~N} / \mathrm{A}$ \\
\hline $\mathrm{H}-04 \mathrm{C}$ & MAG & 3334.04 & $11 / 04 / 02$ & 190.13 & 57.95 & 3143.91 & 958.26 & $\mathrm{~N} / \mathrm{A}$ \\
\hline $\mathrm{H}-04 \mathrm{C}$ & MAG & 3334.04 & $12 / 02 / 02$ & 190.75 & 58.14 & 3143.29 & 958.07 & $\mathrm{~N} / \mathrm{A}$ \\
\hline $\mathrm{H}-05 \mathrm{a}$ & CUL & 3506.24 & $03 / 12 / 02$ & 474.90 & 144.75 & 3031.34 & 923.95 & 3071.29 \\
\hline $\mathrm{H}-05 \mathrm{a}$ & CUL & 3506.24 & $06 / 12 / 02$ & 474.74 & 144.70 & 3031.50 & 924.00 & 3071.47 \\
\hline $\mathrm{H}-05 a$ & CUL & 3506.24 & 09/10/02 & 474.83 & 144.73 & 3031.41 & 923.97 & 3071.37 \\
\hline $\mathrm{H}-05 \mathrm{a}$ & CUL & 3506.24 & $12 / 03 / 02$ & 474.62 & 144.66 & 3031.62 & 924.04 & 3071.60 \\
\hline $\mathrm{H}-05 \mathrm{~b}$ & CUL & 3506.04 & $01 / 16 / 02$ & 477.51 & 145.55 & 3028.53 & 923.10 & 3073.42 \\
\hline $\mathrm{H}-05 \mathrm{~b}$ & CUL & 3506.04 & $02 / 06 / 02$ & 477.46 & 145.53 & 3028.58 & 923.11 & 3073.48 \\
\hline $\mathrm{H}-05 \mathrm{~b}$ & CUL & 3506.04 & $03 / 12 / 02$ & 477.39 & 145.51 & 3028.65 & 923.13 & 3073.55 \\
\hline $\mathrm{H}-05 \mathrm{~b}$ & CUL & 3506.04 & 04/09/02 & 477.30 & 145.48 & 3028.74 & 923.16 & 3073.65 \\
\hline $\mathrm{H}-05 \mathrm{~b}$ & CUL & 3506.04 & 05/08/02 & 477.19 & 145.45 & 3028.85 & 923.19 & 3073.77 \\
\hline $\mathrm{H}-05 \mathrm{~b}$ & CUL & 3506.04 & $06 / 12 / 02$ & 477.20 & 145.45 & 3028.84 & 923.19 & 3073.76 \\
\hline $\mathrm{H}-05 \mathrm{~b}$ & CUL & 3506.04 & $07 / 15 / 02$ & 477.25 & 145.47 & 3028.79 & 923.18 & 3073.71 \\
\hline $\mathrm{H}-05 \mathrm{~b}$ & CUL & 3506.04 & $08 / 13 / 02$ & 477.18 & 145.44 & 3028.86 & 923.20 & 3073.79 \\
\hline
\end{tabular}


Waste Isolation Pilot Plant 2002 Site Environmental Report DOE/WIPP 03-2225

Table 6.11 - Groundwater Level Measurement Results for 2002

\begin{tabular}{|c|c|c|c|c|c|c|c|c|}
\hline $\begin{array}{l}\text { Well } \\
\text { Number }\end{array}$ & Zone & $\begin{array}{l}\text { Top of } \\
\text { Casing } \\
\text { Elevation }\end{array}$ & Date & $\begin{array}{c}\text { Measured } \\
\text { Depth From } \\
\text { Top of Casing } \\
\end{array}$ & $\begin{array}{c}\text { Measured } \\
\text { Depth in Meters }\end{array}$ & $\begin{array}{l}\text { Elevation in } \\
\text { Feet AMSL* }\end{array}$ & $\begin{array}{c}\text { Elevation in } \\
\text { Meters }\end{array}$ & $\begin{array}{c}\text { Elevation Adjusted } \\
\text { to Equivalent Fresh } \\
\text { Water Head }\end{array}$ \\
\hline $\mathrm{H}-05 \mathrm{~b}$ & CUL & 3506.04 & 09/10/02 & 477.27 & 145.47 & 3028.77 & 923.17 & 3073.69 \\
\hline $\mathrm{H}-05 \mathrm{~b}$ & CUL & 3506.04 & $10 / 09 / 02$ & 477.10 & 145.42 & 3028.94 & 923.22 & 3073.87 \\
\hline $\mathrm{H}-05 \mathrm{~b}$ & CUL & 3506.04 & $11 / 05 / 02$ & 477.16 & 145.44 & 3028.88 & 923.20 & 3073.81 \\
\hline $\mathrm{H}-05 \mathrm{~b}$ & CUL & 3506.04 & $12 / 03 / 02$ & 477.14 & 145.43 & 3028.90 & 923.21 & 3073.83 \\
\hline $\mathrm{H}-05 \mathrm{c}$ & MAG & 3506.04 & $01 / 16 / 02$ & 348.86 & 106.33 & 3157.18 & 962.31 & N/A \\
\hline $\mathrm{H}-05 \mathrm{c}$ & MAG & 3506.04 & 02/06/02 & 348.80 & 106.31 & 3157.24 & 962.33 & N/A \\
\hline $\mathrm{H}-05 \mathrm{c}$ & MAG & 3506.04 & $03 / 12 / 02$ & 348.79 & 106.31 & 3157.25 & 962.33 & N/A \\
\hline $\mathrm{H}-05 \mathrm{c}$ & MAG & 3506.04 & 04/09/02 & 348.77 & 106.31 & 3157.27 & 962.34 & $\mathrm{~N} / \mathrm{A}$ \\
\hline $\mathrm{H}-05 \mathrm{c}$ & MAG & 3506.04 & $05 / 08 / 02$ & 348.67 & 106.27 & 3157.37 & 962.37 & $\mathrm{~N} / \mathrm{A}$ \\
\hline $\mathrm{H}-05 \mathrm{c}$ & MAG & 3506.04 & $06 / 12 / 02$ & 348.74 & 106.30 & 3157.30 & 962.35 & N/A \\
\hline $\mathrm{H}-05 \mathrm{c}$ & MAG & 3506.04 & $07 / 15 / 02$ & 348.85 & 106.33 & 3157.19 & 962.31 & $\mathrm{~N} / \mathrm{A}$ \\
\hline $\mathrm{H}-05 \mathrm{c}$ & MAG & 3506.04 & 08/13/02 & 348.82 & 106.32 & 3157.22 & 962.32 & N/A \\
\hline $\mathrm{H}-05 \mathrm{c}$ & MAG & 3506.04 & 09/10/02 & 348.99 & 106.37 & 3157.05 & 962.27 & $\mathrm{~N} / \mathrm{A}$ \\
\hline $\mathrm{H}-05 \mathrm{c}$ & MAG & 3506.04 & $10 / 09 / 02$ & 348.89 & 106.34 & 3157.15 & 962.30 & $\mathrm{~N} / \mathrm{A}$ \\
\hline $\mathrm{H}-05 \mathrm{c}$ & MAG & 3506.04 & $11 / 05 / 02$ & 348.97 & 106.37 & 3157.07 & 962.27 & $\mathrm{~N} / \mathrm{A}$ \\
\hline $\mathrm{H}-05 \mathrm{c}$ & MAG & 3506.04 & $12 / 03 / 02$ & 349.04 & 106.39 & 3157.00 & 962.25 & $\mathrm{~N} / \mathrm{A}$ \\
\hline $\mathrm{H}-06 \mathrm{a}$ & CUL & 3348.11 & $03 / 11 / 02$ & 294.12 & 89.65 & 3053.99 & 930.86 & 3066.23 \\
\hline $\mathrm{H}-06 \mathrm{a}$ & CUL & 3348.11 & $06 / 10 / 02$ & 293.65 & 89.50 & 3054.46 & 931.00 & 3066.72 \\
\hline $\mathrm{H}-06 \mathrm{a}$ & CUL & 3348.11 & 09/09/02 & 293.39 & 89.43 & 3054.72 & 931.08 & 3066.99 \\
\hline $\mathrm{H}-06 \mathrm{a}$ & CUL & 3348.11 & $12 / 02 / 02$ & 293.10 & 89.34 & 3055.01 & 931.17 & 3067.29 \\
\hline $\mathrm{H}-06 \mathrm{~b}$ & CUL & 3348.25 & $01 / 16 / 02$ & 295.39 & 90.03 & 3052.86 & 930.51 & 3065.05 \\
\hline $\mathrm{H}-06 \mathrm{~b}$ & CUL & 3348.25 & $02 / 05 / 02$ & 295.26 & 90.00 & 3052.99 & 930.55 & 3065.18 \\
\hline $\mathrm{H}-06 \mathrm{~b}$ & CUL & 3348.25 & $03 / 11 / 02$ & 294.99 & 89.91 & 3053.26 & 930.63 & 3065.47 \\
\hline $\mathrm{H}-06 \mathrm{~b}$ & CUL & 3348.25 & $04 / 08 / 02$ & 294.76 & 89.84 & 3053.49 & 930.70 & 3065.70 \\
\hline $\mathrm{H}-06 \mathrm{~b}$ & CUL & 3348.25 & 05/06/02 & 294.70 & 89.82 & 3053.55 & 930.72 & 3065.77 \\
\hline $\mathrm{H}-06 \mathrm{~b}$ & CUL & 3348.25 & $06 / 10 / 02$ & 294.54 & 89.78 & 3053.71 & 930.77 & 3065.93 \\
\hline $\mathrm{H}-06 \mathrm{~b}$ & CUL & 3348.25 & $07 / 15 / 02$ & 294.37 & 89.72 & 3053.88 & 930.82 & 3066.11 \\
\hline $\mathrm{H}-06 \mathrm{~b}$ & CUL & 3348.25 & $08 / 12 / 02$ & 294.25 & 89.69 & 3054.00 & 930.86 & 3066.23 \\
\hline
\end{tabular}


Waste Isolation Pilot Plant 2002 Site Environmental Report DOE/WIPP 03-2225

Table 6.11 - Groundwater Level Measurement Results for 2002

\begin{tabular}{|c|c|c|c|c|c|c|c|c|}
\hline $\begin{array}{l}\text { Well } \\
\text { Number }\end{array}$ & Zone & $\begin{array}{l}\text { Top of } \\
\text { Casing } \\
\text { Elevation }\end{array}$ & Date & $\begin{array}{l}\text { Measured } \\
\text { Depth From } \\
\text { Top of Casing }\end{array}$ & $\begin{array}{c}\text { Measured } \\
\text { Depth in Meters }\end{array}$ & $\begin{array}{l}\text { Elevation in } \\
\text { Feet AMSL* }\end{array}$ & $\begin{array}{c}\text { Elevation in } \\
\text { Meters }\end{array}$ & $\begin{array}{c}\text { Elevation Adjusted } \\
\text { to Equivalent Fresh } \\
\text { Water Head }\end{array}$ \\
\hline $\mathrm{H}-06 \mathrm{~b}$ & CUL & 3348.25 & 09/09/02 & 294.31 & 89.71 & 3053.94 & 930.84 & 3066.17 \\
\hline $\mathrm{H}-06 \mathrm{~b}$ & CUL & 3348.25 & $10 / 07 / 02$ & 294.28 & 89.70 & 3053.97 & 930.85 & 3066.20 \\
\hline $\mathrm{H}-06 \mathrm{~b}$ & CUL & 3348.25 & $11 / 04 / 02$ & 294.06 & 89.63 & 3054.19 & 930.92 & 3066.43 \\
\hline $\mathrm{H}-06 \mathrm{~b}$ & CUL & 3348.25 & $12 / 02 / 02$ & 294.01 & 89.61 & 3054.24 & 930.93 & 3066.48 \\
\hline $\mathrm{H}-06 \mathrm{c}$ & MAG & 3348.52 & $01 / 16 / 02$ & 283.57 & 86.43 & 3064.95 & 934.20 & N/A \\
\hline $\mathrm{H}-06 \mathrm{c}$ & MAG & 3348.52 & $02 / 05 / 02$ & 283.50 & 86.41 & 3065.02 & 934.22 & N/A \\
\hline $\mathrm{H}-06 \mathrm{c}$ & MAG & 3348.52 & $03 / 11 / 02$ & 283.32 & 86.36 & 3065.20 & 934.27 & $\mathrm{~N} / \mathrm{A}$ \\
\hline $\mathrm{H}-06 \mathrm{c}$ & MAG & 3348.52 & $04 / 08 / 02$ & 283.09 & 86.29 & 3065.43 & 934.34 & $\mathrm{~N} / \mathrm{A}$ \\
\hline $\mathrm{H}-06 \mathrm{c}$ & MAG & 3348.52 & $05 / 06 / 02$ & 283.20 & 86.32 & 3065.32 & 934.31 & $\mathrm{~N} / \mathrm{A}$ \\
\hline $\mathrm{H}-06 \mathrm{c}$ & MAG & 3348.52 & $06 / 10 / 02$ & 283.10 & 86.29 & 3065.42 & 934.34 & N/A \\
\hline $\mathrm{H}-06 \mathrm{c}$ & MAG & 3348.52 & $07 / 15 / 02$ & 283.20 & 86.32 & 3065.32 & 934.31 & $\mathrm{~N} / \mathrm{A}$ \\
\hline $\mathrm{H}-06 \mathrm{c}$ & MAG & 3348.52 & $08 / 12 / 02$ & 283.13 & 86.30 & 3065.39 & 934.33 & N/A \\
\hline $\mathrm{H}-06 \mathrm{c}$ & MAG & 3348.52 & 09/09/02 & 283.23 & 86.33 & 3065.29 & 934.30 & $\mathrm{~N} / \mathrm{A}$ \\
\hline $\mathrm{H}-06 \mathrm{c}$ & MAG & 3348.52 & $10 / 07 / 02$ & 283.29 & 86.35 & 3065.23 & 934.28 & $\mathrm{~N} / \mathrm{A}$ \\
\hline $\mathrm{H}-06 \mathrm{c}$ & MAG & 3348.52 & $11 / 04 / 02$ & 283.15 & 86.30 & 3065.37 & 934.32 & $\mathrm{~N} / \mathrm{A}$ \\
\hline $\mathrm{H}-06 \mathrm{c}$ & MAG & 3348.52 & $12 / 02 / 02$ & 283.00 & 86.26 & 3065.52 & 934.37 & $\mathrm{~N} / \mathrm{A}$ \\
\hline $\mathrm{H}-07 \mathrm{~b} 1$ & CUL & 3164.17 & $03 / 11 / 02$ & 166.20 & 50.66 & 2997.97 & 913.78 & 2998.42 \\
\hline $\mathrm{H}-07 \mathrm{~b} 1$ & CUL & 3164.17 & $06 / 12 / 02$ & 166.29 & 50.69 & 2997.88 & 913.75 & 2998.33 \\
\hline $\mathrm{H}-07 \mathrm{~b} 1$ & CUL & 3164.17 & $09 / 11 / 02$ & 166.57 & 50.77 & 2997.60 & 913.67 & 2998.05 \\
\hline $\mathrm{H}-07 \mathrm{~b} 1$ & CUL & 3164.17 & $12 / 03 / 02$ & 166.44 & 50.73 & 2997.73 & 913.71 & 2998.18 \\
\hline $\mathrm{H}-07 \mathrm{~b} 2$ & CUL & 3164.40 & $01 / 14 / 02$ & 166.92 & 50.88 & 2997.48 & 913.63 & 2997.39 \\
\hline $\mathrm{H}-07 \mathrm{~b} 2$ & CUL & 3164.40 & $02 / 06 / 02$ & 166.85 & 50.86 & 2997.55 & 913.65 & 2997.46 \\
\hline $\mathrm{H}-07 \mathrm{~b} 2$ & CUL & 3164.40 & $03 / 11 / 02$ & 166.59 & 50.78 & 2997.81 & 913.73 & 2997.72 \\
\hline $\mathrm{H}-07 \mathrm{~b} 2$ & CUL & 3164.40 & $04 / 10 / 02$ & 166.89 & 50.87 & 2997.52 & 913.64 & 2997.43 \\
\hline $\mathrm{H}-07 \mathrm{~b} 2$ & CUL & 3164.40 & $04 / 10 / 02$ & 166.89 & 50.87 & 2997.52 & 913.64 & 2997.43 \\
\hline $\mathrm{H}-07 \mathrm{~b} 2$ & CUL & 3165.07 & $06 / 12 / 02$ & 167.44 & 51.04 & 2997.63 & 913.68 & 2997.54 \\
\hline $\mathrm{H}-07 \mathrm{~b} 2$ & CUL & 3164.40 & $07 / 16 / 02$ & 167.63 & 51.09 & 2996.77 & 913.42 & 2996.68 \\
\hline $\mathrm{H}-07 \mathrm{~b} 2$ & CUL & 3164.40 & $08 / 12 / 02$ & 167.57 & 51.08 & 2996.83 & 913.43 & 2996.74 \\
\hline
\end{tabular}


Waste Isolation Pilot Plant 2002 Site Environmental Report DOE/WIPP 03-2225

Table 6.11 - Groundwater Level Measurement Results for 2002

\begin{tabular}{|c|c|c|c|c|c|c|c|c|}
\hline $\begin{array}{l}\text { Well } \\
\text { Number }\end{array}$ & Zone & $\begin{array}{l}\text { Top of } \\
\text { Casing } \\
\text { Elevation }\end{array}$ & Date & $\begin{array}{l}\text { Measured } \\
\text { Depth From } \\
\text { Top of Casing }\end{array}$ & $\begin{array}{c}\text { Measured } \\
\text { Depth in Meters }\end{array}$ & $\begin{array}{l}\text { Elevation in } \\
\text { Feet AMSL* }\end{array}$ & $\begin{array}{c}\text { Elevation in } \\
\text { Meters }\end{array}$ & $\begin{array}{c}\text { Elevation Adjusted } \\
\text { to Equivalent Fresh } \\
\text { Water Head }\end{array}$ \\
\hline $\mathrm{H}-07 \mathrm{~b} 2$ & CUL & 3165.07 & $09 / 11 / 02$ & 167.73 & 51.12 & 2997.34 & 913.59 & 2997.25 \\
\hline $\mathrm{H}-07 \mathrm{~b} 2$ & CUL & 3165.07 & $10 / 08 / 02$ & 167.65 & 51.10 & 2997.42 & 913.61 & 2997.33 \\
\hline $\mathrm{H}-07 \mathrm{~b} 2$ & CUL & 3165.07 & $11 / 05 / 02$ & 167.66 & 51.10 & 2997.41 & 913.61 & 2997.32 \\
\hline $\mathrm{H}-07 \mathrm{~b} 2$ & CUL & 3165.07 & $12 / 03 / 02$ & 167.62 & 51.09 & 2997.45 & 913.62 & 2997.36 \\
\hline $\mathrm{H}-08 \mathrm{a}$ & MAG & 3432.99 & $01 / 15 / 02$ & 406.23 & 123.82 & 3026.76 & 922.56 & N/A \\
\hline $\mathrm{H}-08 \mathrm{a}$ & MAG & 3432.99 & 02/06/02 & 406.12 & 123.79 & 3026.87 & 922.59 & N/A \\
\hline $\mathrm{H}-08 \mathrm{a}$ & MAG & 3432.99 & $03 / 13 / 02$ & 406.09 & 123.78 & 3026.90 & 922.60 & $\mathrm{~N} / \mathrm{A}$ \\
\hline $\mathrm{H}-08 \mathrm{a}$ & MAG & 3432.99 & $04 / 10 / 02$ & 406.03 & 123.76 & 3026.96 & 922.62 & $\mathrm{~N} / \mathrm{A}$ \\
\hline $\mathrm{H}-08 \mathrm{a}$ & MAG & 3432.99 & $05 / 06 / 02$ & 405.98 & 123.74 & 3027.01 & 922.63 & $\mathrm{~N} / \mathrm{A}$ \\
\hline $\mathrm{H}-08 \mathrm{a}$ & MAG & 3432.99 & $06 / 11 / 02$ & 405.96 & 123.74 & 3027.03 & 922.64 & N/A \\
\hline $\mathrm{H}-08 \mathrm{a}$ & MAG & 3432.99 & $07 / 16 / 02$ & 406.10 & 123.78 & 3026.89 & 922.60 & $\mathrm{~N} / \mathrm{A}$ \\
\hline $\mathrm{H}-08 \mathrm{a}$ & MAG & 3432.99 & $08 / 13 / 02$ & 406.01 & 123.75 & 3026.98 & 922.62 & N/A \\
\hline $\mathrm{H}-08 \mathrm{a}$ & MAG & 3432.99 & $09 / 11 / 02$ & 406.02 & 123.75 & 3026.97 & 922.62 & $\mathrm{~N} / \mathrm{A}$ \\
\hline $\mathrm{H}-08 \mathrm{a}$ & MAG & 3432.99 & $10 / 09 / 02$ & 406.03 & 123.76 & 3026.96 & 922.62 & $\mathrm{~N} / \mathrm{A}$ \\
\hline $\mathrm{H}-08 \mathrm{a}$ & MAG & 3432.99 & $11 / 06 / 02$ & 406.03 & 123.76 & 3026.96 & 922.62 & $\mathrm{~N} / \mathrm{A}$ \\
\hline $\mathrm{H}-08 \mathrm{a}$ & MAG & 3432.99 & $12 / 03 / 02$ & 406.05 & 123.76 & 3026.94 & 922.61 & $\mathrm{~N} / \mathrm{A}$ \\
\hline $\mathrm{H}-08 \mathrm{c}$ & $\mathrm{R} / \mathrm{S}$ & 3432.90 & $01 / 15 / 02$ & 453.72 & 138.29 & 2979.18 & 908.05 & N/A \\
\hline $\mathrm{H}-08 \mathrm{c}$ & $R / S$ & 3432.90 & $02 / 06 / 02$ & 453.56 & 138.25 & 2979.34 & 908.10 & $\mathrm{~N} / \mathrm{A}$ \\
\hline $\mathrm{H}-08 \mathrm{c}$ & $R / S$ & 3432.90 & $03 / 13 / 02$ & 453.52 & 138.23 & 2979.38 & 908.12 & $\mathrm{~N} / \mathrm{A}$ \\
\hline $\mathrm{H}-08 \mathrm{c}$ & $R / S$ & 3432.90 & $04 / 10 / 02$ & 453.45 & 138.21 & 2979.45 & 908.14 & $\mathrm{~N} / \mathrm{A}$ \\
\hline $\mathrm{H}-08 \mathrm{c}$ & $R / S$ & 3432.90 & $05 / 06 / 02$ & 453.37 & 138.19 & 2979.53 & 908.16 & $\mathrm{~N} / \mathrm{A}$ \\
\hline $\mathrm{H}-08 \mathrm{c}$ & $R / S$ & 3432.90 & $06 / 11 / 02$ & 453.30 & 138.17 & 2979.60 & 908.18 & $\mathrm{~N} / \mathrm{A}$ \\
\hline $\mathrm{H}-08 \mathrm{c}$ & $\mathrm{R} / \mathrm{S}$ & 3432.90 & 07/16/02 & 453.24 & 138.15 & 2979.66 & 908.20 & $\mathrm{~N} / \mathrm{A}$ \\
\hline $\mathrm{H}-08 \mathrm{c}$ & $\mathrm{R} / \mathrm{S}$ & 3432.90 & $08 / 13 / 02$ & 453.23 & 138.14 & 2979.67 & 908.20 & $\mathrm{~N} / \mathrm{A}$ \\
\hline $\mathrm{H}-08 \mathrm{c}$ & $\mathrm{R} / \mathrm{S}$ & 3432.90 & $09 / 11 / 02$ & 453.19 & 138.13 & 2979.71 & 908.22 & N/A \\
\hline $\mathrm{H}-08 \mathrm{c}$ & $\mathrm{R} / \mathrm{S}$ & 3432.90 & $10 / 09 / 02$ & 453.14 & 138.12 & 2979.76 & 908.23 & $\mathrm{~N} / \mathrm{A}$ \\
\hline $\mathrm{H}-08 \mathrm{c}$ & $\mathrm{R} / \mathrm{S}$ & 3432.90 & $11 / 06 / 02$ & 453.10 & 138.10 & 2979.80 & 908.24 & $\mathrm{~N} / \mathrm{A}$ \\
\hline $\mathrm{H}-08 \mathrm{c}$ & $\mathrm{R} / \mathrm{S}$ & 3432.90 & $12 / 03 / 02$ & 453.09 & 138.10 & 2979.81 & 908.25 & $\mathrm{~N} / \mathrm{A}$ \\
\hline
\end{tabular}


Waste Isolation Pilot Plant 2002 Site Environmental Report DOE/WIPP 03-2225

Table 6.11 - Groundwater Level Measurement Results for 2002

\begin{tabular}{|c|c|c|c|c|c|c|c|c|}
\hline $\begin{array}{l}\text { Well } \\
\text { Number }\end{array}$ & Zone & $\begin{array}{l}\text { Top of } \\
\text { Casing } \\
\text { Elevation }\end{array}$ & Date & $\begin{array}{l}\text { Measured } \\
\text { Depth From } \\
\text { Top of Casing }\end{array}$ & $\begin{array}{c}\text { Measured } \\
\text { Depth in Meters }\end{array}$ & $\begin{array}{l}\text { Elevation in } \\
\text { Feet AMSL* }\end{array}$ & $\begin{array}{c}\text { Elevation in } \\
\text { Meters }\end{array}$ & $\begin{array}{c}\text { Elevation Adjusted } \\
\text { to Equivalent Fresh } \\
\text { Water Head }\end{array}$ \\
\hline $\mathrm{H}-10 \mathrm{a}$ & MAG & 3688.67 & $01 / 15 / 02$ & 526.59 & 160.50 & 3162.08 & 963.80 & N/A \\
\hline $\mathrm{H}-10 \mathrm{a}$ & MAG & 3688.67 & $02 / 06 / 02$ & 484.67 & 147.73 & 3204.00 & 976.58 & N/A \\
\hline $\mathrm{H}-10 \mathrm{a}$ & MAG & 3688.67 & $03 / 13 / 02$ & 468.88 & 142.91 & 3219.79 & 981.39 & N/A \\
\hline $\mathrm{H}-10 \mathrm{a}$ & MAG & 3688.67 & $04 / 10 / 02$ & 468.34 & 142.75 & 3220.33 & 981.56 & N/A \\
\hline $\mathrm{H}-10 \mathrm{a}$ & MAG & 3688.67 & 05/06/02 & 468.35 & 142.75 & 3220.32 & 981.55 & $\mathrm{~N} / \mathrm{A}$ \\
\hline $\mathrm{H}-10 \mathrm{a}$ & MAG & 3688.67 & $06 / 11 / 02$ & 468.47 & 142.79 & 3220.20 & 981.52 & $\mathrm{~N} / \mathrm{A}$ \\
\hline $\mathrm{H}-10 \mathrm{a}$ & MAG & 3688.67 & $07 / 16 / 02$ & 468.68 & 142.85 & 3219.99 & 981.45 & $\mathrm{~N} / \mathrm{A}$ \\
\hline $\mathrm{H}-10 \mathrm{a}$ & MAG & 3688.67 & $08 / 13 / 02$ & 468.70 & 142.86 & 3219.97 & 981.45 & $\mathrm{~N} / \mathrm{A}$ \\
\hline $\mathrm{H}-10 \mathrm{a}$ & MAG & 3688.67 & $09 / 11 / 02$ & 468.75 & 142.88 & 3219.92 & 981.43 & $\mathrm{~N} / \mathrm{A}$ \\
\hline $\mathrm{H}-10 \mathrm{a}$ & MAG & 3688.67 & $10 / 09 / 02$ & 468.75 & 142.88 & 3219.92 & 981.43 & N/A \\
\hline $\mathrm{H}-10 \mathrm{a}$ & MAG & 3688.67 & $11 / 06 / 02$ & 468.68 & 142.85 & 3219.99 & 981.45 & $\mathrm{~N} / \mathrm{A}$ \\
\hline $\mathrm{H}-10 \mathrm{a}$ & MAG & 3688.67 & $12 / 03 / 02$ & 468.63 & 142.84 & 3220.04 & 981.47 & N/A \\
\hline $\mathrm{H}-10 \mathrm{c}$ & CUL & 3688.64 & $04 / 22 / 02$ & 660.82 & 201.42 & 3027.82 & 922.88 & 3027.82 \\
\hline $\mathrm{H}-10 \mathrm{c}$ & CUL & 3688.64 & $05 / 07 / 02$ & 661.17 & 201.52 & 3027.47 & 922.77 & 3027.47 \\
\hline $\mathrm{H}-10 \mathrm{c}$ & CUL & 3688.64 & $06 / 11 / 02$ & 661.69 & 201.68 & 3026.95 & 922.61 & 3026.95 \\
\hline $\mathrm{H}-10 \mathrm{c}$ & CUL & 3688.64 & $07 / 16 / 02$ & 662.30 & 201.87 & 3026.34 & 922.43 & 3026.34 \\
\hline $\mathrm{H}-10 \mathrm{c}$ & CUL & 3688.64 & $08 / 13 / 02$ & 662.56 & 201.95 & 3026.08 & 922.35 & 3026.08 \\
\hline $\mathrm{H}-10 \mathrm{c}$ & CUL & 3688.64 & $09 / 11 / 02$ & 662.32 & 201.88 & 3026.32 & 922.42 & 3026.32 \\
\hline $\mathrm{H}-10 \mathrm{c}$ & CUL & 3688.64 & $10 / 09 / 02$ & 662.39 & 201.90 & 3026.25 & 922.40 & 3026.25 \\
\hline $\mathrm{H}-10 \mathrm{c}$ & CUL & 3688.64 & $11 / 06 / 02$ & 662.76 & 202.01 & 3025.88 & 922.29 & 3025.88 \\
\hline $\mathrm{H}-10 \mathrm{c}$ & CUL & 3688.64 & $12 / 03 / 02$ & 662.93 & 202.06 & 3025.71 & 922.24 & 3025.71 \\
\hline $\mathrm{H}-11 \mathrm{~b} 1$ & CUL & 3411.62 & $12 / 03 / 01$ & 430.39 & 131.18 & 2981.23 & 908.68 & 3004.41 \\
\hline $\mathrm{H}-11 \mathrm{~b} 1$ & CUL & 3411.62 & $06 / 11 / 02$ & 419.21 & 127.78 & 2992.41 & 912.09 & 3016.42 \\
\hline $\mathrm{H}-11 \mathrm{~b} 1$ & CUL & 3411.62 & $09 / 12 / 02$ & 419.03 & 127.72 & 2992.59 & 912.14 & 3016.61 \\
\hline $\mathrm{H}-11 \mathrm{~b} 1$ & CUL & 3411.62 & $12 / 04 / 02$ & 419.11 & 127.74 & 2992.51 & 912.12 & 3016.52 \\
\hline $\mathrm{H}-11 \mathrm{~b} 4$ & CUL & 3410.89 & $01 / 15 / 02$ & 426.35 & 129.95 & 2984.54 & 909.69 & 3004.64 \\
\hline $\mathrm{H}-11 \mathrm{~b} 4$ & CUL & 3410.89 & $02 / 05 / 02$ & 426.19 & 129.90 & 2984.70 & 909.74 & 3004.81 \\
\hline $\mathrm{H}-11 \mathrm{~b} 4$ & CUL & 3410.89 & $03 / 13 / 02$ & 434.32 & 132.38 & 2976.57 & 907.26 & 2996.15 \\
\hline
\end{tabular}


Waste Isolation Pilot Plant 2002 Site Environmental Report DOE/WIPP 03-2225

Table 6.11 - Groundwater Level Measurement Results for 2002

\begin{tabular}{|c|c|c|c|c|c|c|c|c|}
\hline $\begin{array}{l}\text { Well } \\
\text { Number }\end{array}$ & Zone & $\begin{array}{l}\text { Top of } \\
\text { Casing } \\
\text { Elevation }\end{array}$ & Date & $\begin{array}{l}\text { Measured } \\
\text { Depth From } \\
\text { Top of Casing }\end{array}$ & $\begin{array}{c}\text { Measured } \\
\text { Depth in Meters }\end{array}$ & $\begin{array}{l}\text { Elevation in } \\
\text { Feet AMSL* }\end{array}$ & $\begin{array}{l}\text { Elevation in } \\
\text { Meters }\end{array}$ & $\begin{array}{c}\text { Elevation Adjusted } \\
\text { to Equivalent Fresh } \\
\text { Water Head }\end{array}$ \\
\hline $\mathrm{H}-11 \mathrm{~b} 4$ & CUL & 3410.89 & 04/10/02 & 427.93 & 130.43 & 2982.96 & 909.21 & 3002.95 \\
\hline $\mathrm{H}-11 \mathrm{~b} 4$ & CUL & 3410.89 & $05 / 06 / 02$ & 427.43 & 130.28 & 2983.46 & 909.36 & 3003.49 \\
\hline $\mathrm{H}-11 \mathrm{~b} 4$ & CUL & 3410.89 & $06 / 11 / 02$ & 427.05 & 130.16 & 2983.84 & 909.47 & 3003.89 \\
\hline $\mathrm{H}-11 \mathrm{~b} 4$ & CUL & 3410.89 & $07 / 16 / 02$ & 426.98 & 130.14 & 2983.91 & 909.50 & 3003.97 \\
\hline $\mathrm{H}-11 \mathrm{~b} 4$ & CUL & 3410.89 & $08 / 14 / 02$ & 426.84 & 130.10 & 2984.05 & 909.54 & 3004.12 \\
\hline $\mathrm{H}-11 \mathrm{~b} 4$ & CUL & 3410.89 & $09 / 12 / 02$ & 426.80 & 130.09 & 2984.09 & 909.55 & 3004.16 \\
\hline $\mathrm{H}-11 \mathrm{~b} 4$ & CUL & 3410.89 & $10 / 09 / 02$ & 426.69 & 130.06 & 2984.20 & 909.58 & 3004.28 \\
\hline $\mathrm{H}-11 \mathrm{~b} 4$ & CUL & 3410.89 & $11 / 06 / 02$ & 426.80 & 130.09 & 2984.09 & 909.55 & 3004.16 \\
\hline $\mathrm{H}-11 \mathrm{~b} 4$ & CUL & 3410.89 & $12 / 04 / 02$ & 426.72 & 130.06 & 2984.17 & 909.58 & 3004.24 \\
\hline $\mathrm{H}-12$ & CUL & 3427.19 & $01 / 15 / 02$ & 457.57 & 139.47 & 2969.62 & 905.14 & 3006.87 \\
\hline $\mathrm{H}-12$ & CUL & 3427.19 & $02 / 06 / 02$ & 457.50 & 139.45 & 2969.69 & 905.16 & 3006.95 \\
\hline $\mathrm{H}-12$ & CUL & 3427.19 & $03 / 13 / 02$ & 457.12 & 139.33 & 2970.07 & 905.28 & 3007.37 \\
\hline $\mathrm{H}-12$ & CUL & 3427.19 & $04 / 10 / 02$ & 457.26 & 139.37 & 2969.93 & 905.23 & 3007.21 \\
\hline $\mathrm{H}-12$ & CUL & 3427.19 & $05 / 06 / 02$ & 457.00 & 139.29 & 2970.19 & 905.31 & 3007.50 \\
\hline $\mathrm{H}-12$ & CUL & 3427.19 & $06 / 11 / 02$ & 456.81 & 139.24 & 2970.38 & 905.37 & 3007.71 \\
\hline $\mathrm{H}-12$ & CUL & 3427.19 & $07 / 16 / 02$ & 456.90 & 139.26 & 2970.29 & 905.34 & 3007.61 \\
\hline $\mathrm{H}-12$ & CUL & 3427.19 & $08 / 13 / 02$ & 456.41 & 139.11 & 2970.78 & 905.49 & 3008.15 \\
\hline $\mathrm{H}-12$ & CUL & 3427.19 & $09 / 11 / 02$ & 456.69 & 139.20 & 2970.50 & 905.41 & 3007.84 \\
\hline $\mathrm{H}-12$ & CUL & 3427.19 & $10 / 09 / 02$ & 456.57 & 139.16 & 2970.62 & 905.44 & 3007.97 \\
\hline $\mathrm{H}-12$ & CUL & 3427.19 & $11 / 06 / 02$ & 456.59 & 139.17 & 2970.60 & 905.44 & 3007.95 \\
\hline $\mathrm{H}-12$ & CUL & 3427.19 & $12 / 03 / 02$ & 456.47 & 139.13 & 2970.72 & 905.48 & 3008.08 \\
\hline $\mathrm{H}-17$ & CUL & 3385.31 & $01 / 15 / 02$ & 423.28 & 129.02 & 2962.03 & 902.83 & 3011.27 \\
\hline $\mathrm{H}-17$ & CUL & 3385.31 & $02 / 05 / 02$ & 423.20 & 128.99 & 2962.11 & 902.85 & 3011.36 \\
\hline $\mathrm{H}-17$ & CUL & 3385.31 & $03 / 13 / 02$ & 422.69 & 128.84 & 2962.62 & 903.01 & 3011.96 \\
\hline $\mathrm{H}-17$ & CUL & 3385.31 & $04 / 10 / 02$ & 422.95 & 128.92 & 2962.36 & 902.93 & 3011.65 \\
\hline $\mathrm{H}-17$ & CUL & 3385.31 & $05 / 07 / 02$ & 422.60 & 128.81 & 2962.71 & 903.03 & 3012.06 \\
\hline $\mathrm{H}-17$ & CUL & 3385.31 & $06 / 11 / 02$ & 422.32 & 128.72 & 2962.99 & 903.12 & 3012.39 \\
\hline $\mathrm{H}-17$ & CUL & 3385.31 & $07 / 16 / 02$ & 422.36 & 128.74 & 2962.95 & 903.11 & 3012.34 \\
\hline
\end{tabular}


Waste Isolation Pilot Plant 2002 Site Environmental Report DOE/WIPP 03-2225

Table 6.11 - Groundwater Level Measurement Results for 2002

\begin{tabular}{|c|c|c|c|c|c|c|c|c|}
\hline $\begin{array}{l}\text { Well } \\
\text { Number }\end{array}$ & Zone & $\begin{array}{l}\text { Top of } \\
\text { Casing } \\
\text { Elevation }\end{array}$ & Date & $\begin{array}{l}\text { Measured } \\
\text { Depth From } \\
\text { Top of Casing }\end{array}$ & $\begin{array}{c}\text { Measured } \\
\text { Depth in Meters }\end{array}$ & $\begin{array}{l}\text { Elevation in } \\
\text { Feet AMSL* }\end{array}$ & $\begin{array}{l}\text { Elevation in } \\
\text { Meters }\end{array}$ & $\begin{array}{c}\text { Elevation Adjusted } \\
\text { to Equivalent Fresh } \\
\text { Water Head }\end{array}$ \\
\hline $\mathrm{H}-17$ & CUL & 3385.31 & $08 / 14 / 02$ & 422.19 & 128.68 & 2963.12 & 903.16 & 3012.54 \\
\hline $\mathrm{H}-17$ & CUL & 3385.31 & $09 / 12 / 02$ & 422.24 & 128.70 & 2963.07 & 903.14 & 3012.48 \\
\hline $\mathrm{H}-17$ & CUL & 3385.31 & $10 / 09 / 02$ & 422.17 & 128.68 & 2963.14 & 903.17 & 3012.56 \\
\hline $\mathrm{H}-17$ & CUL & 3385.31 & $11 / 06 / 02$ & 422.19 & 128.68 & 2963.12 & 903.16 & 3012.54 \\
\hline $\mathrm{H}-17$ & CUL & 3385.31 & $12 / 04 / 02$ & 422.16 & 128.67 & 2963.15 & 903.17 & 3012.57 \\
\hline $\mathrm{H}-19 \mathrm{b0}$ & CUL & 3418.38 & $01 / 16 / 02$ & 428.30 & 130.55 & 2990.08 & 911.38 & 3011.87 \\
\hline $\mathrm{H}-19 \mathrm{b0}$ & CUL & 3418.38 & $02 / 05 / 02$ & 428.19 & 130.51 & 2990.19 & 911.41 & 3011.99 \\
\hline $\mathrm{H}-19 \mathrm{~b} 0$ & CUL & 3418.38 & $03 / 13 / 02$ & 428.02 & 130.46 & 2990.36 & 911.46 & 3012.17 \\
\hline $\mathrm{H}-19 \mathrm{~b} 0$ & CUL & 3418.38 & $04 / 09 / 02$ & 428.30 & 130.55 & 2990.08 & 911.38 & 3011.87 \\
\hline $\mathrm{H}-19 \mathrm{~b} 0$ & CUL & 3418.38 & $05 / 07 / 02$ & 428.06 & 130.47 & 2990.32 & 911.45 & 3012.13 \\
\hline $\mathrm{H}-19 \mathrm{~b} 0$ & CUL & 3418.38 & $06 / 11 / 02$ & 427.60 & 130.33 & 2990.78 & 911.59 & 3012.62 \\
\hline $\mathrm{H}-19 \mathrm{~b} 0$ & CUL & 3418.38 & $07 / 15 / 02$ & 427.54 & 130.31 & 2990.84 & 911.61 & 3012.68 \\
\hline $\mathrm{H}-19 \mathrm{b0}$ & CUL & 3418.38 & $08 / 14 / 02$ & 427.40 & 130.27 & 2990.98 & 911.65 & 3012.83 \\
\hline $\mathrm{H}-19 \mathrm{~b} 0$ & CUL & 3418.38 & $09 / 10 / 02$ & 427.39 & 130.27 & 2990.99 & 911.65 & 3012.84 \\
\hline $\mathrm{H}-19 \mathrm{~b} 0$ & CUL & 3418.38 & $10 / 07 / 02$ & 427.32 & 130.25 & 2991.06 & 911.68 & 3012.92 \\
\hline H-19b0 & CUL & 3418.38 & $11 / 04 / 02$ & 427.63 & 130.34 & 2990.75 & 911.58 & 3012.59 \\
\hline $\mathrm{H}-19 \mathrm{b0}$ & CUL & 3418.38 & $12 / 04 / 02$ & 427.42 & 130.28 & 2990.96 & 911.64 & 3012.81 \\
\hline $\mathrm{H}-19 \mathrm{~b} 2$ & CUL & 3419.01 & $03 / 13 / 02$ & 429.33 & 130.86 & 2989.68 & 911.25 & 3011.55 \\
\hline $\mathrm{H}-19 \mathrm{~b} 2$ & CUL & 3419.01 & $06 / 11 / 02$ & 428.92 & 130.73 & 2990.09 & 911.38 & 3011.98 \\
\hline $\mathrm{H}-19 \mathrm{~b} 2$ & CUL & 3419.01 & 09/10/02 & 428.71 & 130.67 & 2990.30 & 911.44 & 3012.21 \\
\hline $\mathrm{H}-19 \mathrm{~b} 2$ & CUL & 3419.01 & $12 / 04 / 02$ & 428.72 & 130.67 & 2990.29 & 911.44 & 3012.20 \\
\hline $\mathrm{H}-19 \mathrm{~b} 3$ & CUL & 3419.09 & $03 / 13 / 02$ & 429.55 & 130.93 & 2989.54 & 911.21 & 3011.30 \\
\hline $\mathrm{H}-19 \mathrm{~b} 3$ & CUL & 3419.09 & $06 / 11 / 02$ & 429.14 & 130.80 & 2989.95 & 911.34 & 3011.74 \\
\hline $\mathrm{H}-19 \mathrm{~b} 3$ & CUL & 3419.09 & 09/10/02 & 428.91 & 130.73 & 2990.18 & 911.41 & 3011.98 \\
\hline $\mathrm{H}-19 \mathrm{~b} 3$ & CUL & 3419.09 & $12 / 04 / 02$ & 428.93 & 130.74 & 2990.16 & 911.40 & 3011.96 \\
\hline $\mathrm{H}-19 \mathrm{~b} 4$ & CUL & 3419.03 & $03 / 13 / 02$ & 428.79 & 130.70 & 2990.24 & 911.43 & 3011.89 \\
\hline $\mathrm{H}-19 \mathrm{~b} 4$ & CUL & 3419.03 & $06 / 11 / 02$ & 428.38 & 130.57 & 2990.65 & 911.55 & 3012.33 \\
\hline $\mathrm{H}-19 \mathrm{~b} 4$ & CUL & 3419.03 & $09 / 10 / 02$ & 428.14 & 130.50 & 2990.89 & 911.62 & 3012.59 \\
\hline
\end{tabular}


Waste Isolation Pilot Plant 2002 Site Environmental Report DOE/WIPP 03-2225

Table 6.11 - Groundwater Level Measurement Results for 2002

\begin{tabular}{|c|c|c|c|c|c|c|c|c|}
\hline $\begin{array}{l}\text { Well } \\
\text { Number }\end{array}$ & Zone & $\begin{array}{l}\text { Top of } \\
\text { Casing } \\
\text { Elevation }\end{array}$ & Date & $\begin{array}{l}\text { Measured } \\
\text { Depth From } \\
\text { Top of Casing }\end{array}$ & $\begin{array}{c}\text { Measured } \\
\text { Depth in Meters }\end{array}$ & $\begin{array}{l}\text { Elevation in } \\
\text { Feet AMSL* }\end{array}$ & $\begin{array}{l}\text { Elevation in } \\
\text { Meters }\end{array}$ & $\begin{array}{c}\text { Elevation Adjusted } \\
\text { to Equivalent Fresh } \\
\text { Water Head }\end{array}$ \\
\hline $\mathrm{H}-19 \mathrm{~b} 4$ & CUL & 3419.03 & $12 / 04 / 02$ & 428.19 & 130.51 & 2990.84 & 911.61 & 3012.53 \\
\hline $\mathrm{H}-19 \mathrm{b5}$ & CUL & 3418.63 & $03 / 13 / 02$ & 428.90 & 130.73 & 2989.73 & 911.27 & 3011.29 \\
\hline $\mathrm{H}-19 \mathrm{b5}$ & CUL & 3418.63 & $06 / 11 / 02$ & 428.49 & 130.60 & 2990.14 & 911.39 & 3011.73 \\
\hline $\mathrm{H}-19 \mathrm{~b} 5$ & CUL & 3418.63 & 09/10/02 & 428.27 & 130.54 & 2990.36 & 911.46 & 3011.96 \\
\hline H-19b5 & CUL & 3418.63 & $12 / 04 / 02$ & 428.28 & 130.54 & 2990.35 & 911.46 & 3011.95 \\
\hline H-19b6 & CUL & 3419.07 & 03/13/02 & 429.45 & 130.90 & 2989.62 & 911.24 & 3011.32 \\
\hline H-19b6 & CUL & 3419.07 & $06 / 11 / 02$ & 429.04 & 130.77 & 2990.03 & 911.36 & 3011.75 \\
\hline $\mathrm{H}-19 \mathrm{~b} 6$ & CUL & 3419.07 & 09/10/02 & 428.81 & 130.70 & 2990.26 & 911.43 & 3012.00 \\
\hline $\mathrm{H}-19 \mathrm{~b} 6$ & CUL & 3419.07 & $12 / 04 / 02$ & 428.85 & 130.71 & 2990.22 & 911.42 & 3011.96 \\
\hline $\mathrm{H}-19 \mathrm{~b} 7$ & CUL & 3418.99 & $03 / 13 / 02$ & 429.59 & 130.94 & 2989.40 & 911.17 & 3011.12 \\
\hline $\mathrm{H}-19 \mathrm{~b} 7$ & CUL & 3418.99 & $06 / 11 / 02$ & 429.16 & 130.81 & 2989.83 & 911.30 & 3011.58 \\
\hline $\mathrm{H}-19 \mathrm{~b} 7$ & CUL & 3418.99 & $09 / 10 / 02$ & 428.95 & 130.74 & 2990.04 & 911.36 & 3011.81 \\
\hline $\mathrm{H}-19 \mathrm{~b} 7$ & CUL & 3418.99 & $12 / 04 / 02$ & 428.96 & 130.75 & 2990.03 & 911.36 & 3011.80 \\
\hline $\mathrm{P}-17$ & CUL & 3337.24 & $01 / 15 / 02$ & 353.77 & 107.83 & 2983.47 & 909.36 & 2997.65 \\
\hline $\mathrm{P}-17$ & CUL & 3337.24 & $02 / 05 / 02$ & 353.71 & 107.81 & 2983.53 & 909.38 & 2997.72 \\
\hline $\mathrm{P}-17$ & CUL & 3337.24 & $03 / 13 / 02$ & 353.30 & 107.69 & 2983.94 & 909.50 & 2998.15 \\
\hline $\mathrm{P}-17$ & CUL & 3337.24 & $04 / 10 / 02$ & 353.45 & 107.73 & 2983.79 & 909.46 & 2997.99 \\
\hline $\mathrm{P}-17$ & CUL & 3337.24 & $05 / 07 / 02$ & 353.15 & 107.64 & 2984.09 & 909.55 & 2998.31 \\
\hline $\mathrm{P}-17$ & CUL & 3337.24 & $06 / 11 / 02$ & 352.92 & 107.57 & 2984.32 & 909.62 & 2998.56 \\
\hline $\mathrm{P}-17$ & CUL & 3337.24 & $07 / 16 / 02$ & 353.00 & 107.59 & 2984.24 & 909.60 & 2998.47 \\
\hline $\mathrm{P}-17$ & CUL & 3337.24 & $08 / 14 / 02$ & 352.87 & 107.55 & 2984.37 & 909.64 & 2998.61 \\
\hline $\mathrm{P}-17$ & CUL & 3337.24 & $09 / 12 / 02$ & 352.90 & 107.56 & 2984.34 & 909.63 & 2998.58 \\
\hline $\mathrm{P}-17$ & CUL & 3337.24 & $10 / 09 / 02$ & 352.83 & 107.54 & 2984.41 & 909.65 & 2998.65 \\
\hline $\mathrm{P}-17$ & CUL & 3337.24 & $11 / 06 / 02$ & 352.97 & 107.59 & 2984.27 & 909.61 & 2998.51 \\
\hline $\mathrm{P}-17$ & CUL & 3337.24 & $12 / 04 / 02$ & 352.85 & 107.55 & 2984.39 & 909.64 & 2998.63 \\
\hline PZ-01 & SR/D & 3413.41 & $08 / 15 / 02$ & 42.44 & 12.94 & 3370.97 & 1027.47 & $\mathrm{~N} / \mathrm{A}$ \\
\hline PZ-01 & SR/D & 3413.41 & $09 / 12 / 02$ & 42.51 & 12.96 & 3370.90 & 1027.45 & $\mathrm{~N} / \mathrm{A}$ \\
\hline PZ-01 & SR/D & 3413.41 & $10 / 10 / 02$ & 42.56 & 12.97 & 3370.85 & 1027.44 & $\mathrm{~N} / \mathrm{A}$ \\
\hline
\end{tabular}


Waste Isolation Pilot Plant 2002 Site Environmental Report DOE/WIPP 03-2225

Table 6.11 - Groundwater Level Measurement Results for 2002

\begin{tabular}{|c|c|c|c|c|c|c|c|c|}
\hline $\begin{array}{c}\text { Well } \\
\text { Number }\end{array}$ & Zone & $\begin{array}{l}\text { Top of } \\
\text { Casing } \\
\text { Elevation }\end{array}$ & Date & $\begin{array}{l}\text { Measured } \\
\text { Depth From } \\
\text { Top of Casing }\end{array}$ & $\begin{array}{c}\text { Measured } \\
\text { Depth in Meters }\end{array}$ & $\begin{array}{l}\text { Elevation in } \\
\text { Feet AMSL* }\end{array}$ & $\begin{array}{l}\text { Elevation in } \\
\text { Meters }\end{array}$ & $\begin{array}{c}\text { Elevation Adjusted } \\
\text { to Equivalent Fresh } \\
\text { Water Head }\end{array}$ \\
\hline PZ-01 & SR/D & 3413.41 & $11 / 06 / 02$ & 42.64 & 13.00 & 3370.77 & 1027.41 & $\mathrm{~N} / \mathrm{A}$ \\
\hline PZ-01 & SR/D & 3413.41 & $12 / 04 / 02$ & 42.55 & 12.97 & 3370.86 & 1027.44 & $\mathrm{~N} / \mathrm{A}$ \\
\hline PZ-02 & SR/D & 3413.42 & $08 / 15 / 02$ & 43.68 & 13.31 & 3369.74 & 1027.10 & $\mathrm{~N} / \mathrm{A}$ \\
\hline PZ-02 & SR/D & 3413.42 & $09 / 12 / 02$ & 43.85 & 13.37 & 3369.57 & 1027.04 & $\mathrm{~N} / \mathrm{A}$ \\
\hline PZ-02 & SR/D & 3413.42 & $10 / 10 / 02$ & 43.92 & 13.39 & 3369.50 & 1027.02 & $\mathrm{~N} / \mathrm{A}$ \\
\hline $\mathrm{PZ}-02$ & SR/D & 3413.42 & $11 / 06 / 02$ & 44.08 & 13.44 & 3369.34 & 1026.97 & $\mathrm{~N} / \mathrm{A}$ \\
\hline PZ-02 & $\mathrm{SR} / \mathrm{D}$ & 3413.42 & $12 / 04 / 02$ & 44.88 & 13.68 & 3368.54 & 1026.73 & $\mathrm{~N} / \mathrm{A}$ \\
\hline PZ-03 & $\mathrm{SR} / \mathrm{D}$ & 3416.15 & $08 / 15 / 02$ & 45.29 & 13.80 & 3370.86 & 1027.44 & $\mathrm{~N} / \mathrm{A}$ \\
\hline PZ-03 & SR/D & 3416.15 & $09 / 12 / 02$ & 45.44 & 13.85 & 3370.71 & 1027.39 & $\mathrm{~N} / \mathrm{A}$ \\
\hline PZ-03 & SR/D & 3416.15 & $10 / 10 / 02$ & 45.49 & 13.87 & 3370.66 & 1027.38 & $\mathrm{~N} / \mathrm{A}$ \\
\hline PZ-03 & SR/D & 3416.15 & $11 / 06 / 02$ & 45.63 & 13.91 & 3370.52 & 1027.33 & $\mathrm{~N} / \mathrm{A}$ \\
\hline PZ-03 & $S R / D$ & 3416.15 & $12 / 04 / 02$ & 45.45 & 13.85 & 3370.70 & 1027.39 & $\mathrm{~N} / \mathrm{A}$ \\
\hline PZ-04 & $S R / D$ & 3412.10 & $08 / 15 / 02$ & 47.74 & 14.55 & 3364.36 & 1025.46 & $\mathrm{~N} / \mathrm{A}$ \\
\hline PZ-04 & $S R / D$ & 3412.10 & $09 / 12 / 02$ & 47.62 & 14.51 & 3364.48 & 1025.49 & $\mathrm{~N} / \mathrm{A}$ \\
\hline PZ-04 & $S R / D$ & 3412.10 & $10 / 10 / 02$ & 47.63 & 14.52 & 3364.47 & 1025.49 & $\mathrm{~N} / \mathrm{A}$ \\
\hline PZ-04 & $S R / D$ & 3412.10 & $11 / 06 / 02$ & 47.74 & 14.55 & 3364.36 & 1025.46 & $\mathrm{~N} / \mathrm{A}$ \\
\hline PZ-04 & $\mathrm{SR} / \mathrm{D}$ & 3412.10 & $12 / 04 / 02$ & 47.61 & 14.51 & 3364.49 & 1025.50 & $\mathrm{~N} / \mathrm{A}$ \\
\hline PZ-05 & $S R / D$ & 3415.31 & $08 / 15 / 02$ & 43.12 & 13.14 & 3372.19 & 1027.84 & $\mathrm{~N} / \mathrm{A}$ \\
\hline PZ-05 & $S R / D$ & 3415.31 & $09 / 12 / 02$ & 43.27 & 13.19 & 3372.04 & 1027.80 & $\mathrm{~N} / \mathrm{A}$ \\
\hline PZ-05 & $S R / D$ & 3415.31 & $10 / 10 / 02$ & 43.33 & 13.21 & 3371.98 & 1027.78 & $\mathrm{~N} / \mathrm{A}$ \\
\hline PZ-05 & SR/D & 3415.31 & $11 / 06 / 02$ & 43.43 & 13.24 & 3371.88 & 1027.75 & $\mathrm{~N} / \mathrm{A}$ \\
\hline PZ-05 & SR/D & 3415.31 & $12 / 04 / 02$ & 43.26 & 13.19 & 3372.05 & 1027.80 & $\mathrm{~N} / \mathrm{A}$ \\
\hline PZ-06 & SR/D & 3413.49 & $08 / 15 / 02$ & 43.66 & 13.31 & 3369.83 & 1027.12 & $\mathrm{~N} / \mathrm{A}$ \\
\hline PZ-06 & SR/D & 3413.49 & $09 / 12 / 02$ & 43.65 & 13.30 & 3369.84 & 1027.13 & $\mathrm{~N} / \mathrm{A}$ \\
\hline PZ-06 & SR/D & 3413.49 & $10 / 10 / 02$ & 43.68 & 13.31 & 3369.81 & 1027.12 & $\mathrm{~N} / \mathrm{A}$ \\
\hline PZ-06 & SR/D & 3413.49 & $11 / 06 / 02$ & 43.74 & 13.33 & 3369.75 & 1027.10 & $\mathrm{~N} / \mathrm{A}$ \\
\hline PZ-06 & $S R / D$ & 3413.49 & $12 / 04 / 02$ & 43.65 & 13.30 & 3369.84 & 1027.13 & $\mathrm{~N} / \mathrm{A}$ \\
\hline PZ-07 & SR/D & 3413.99 & $08 / 15 / 02$ & 37.19 & 11.34 & 3376.80 & 1029.25 & $\mathrm{~N} / \mathrm{A}$ \\
\hline
\end{tabular}


Waste Isolation Pilot Plant 2002 Site Environmental Report DOE/WIPP 03-2225

Table 6.11 - Groundwater Level Measurement Results for 2002

\begin{tabular}{|c|c|c|c|c|c|c|c|c|}
\hline $\begin{array}{l}\text { Well } \\
\text { Number }\end{array}$ & Zone & $\begin{array}{l}\text { Top of } \\
\text { Casing } \\
\text { Elevation }\end{array}$ & Date & $\begin{array}{l}\text { Measured } \\
\text { Depth From } \\
\text { Top of Casing }\end{array}$ & $\begin{array}{c}\text { Measured } \\
\text { Depth in Meters }\end{array}$ & $\begin{array}{l}\text { Elevation in } \\
\text { Feet AMSL* }\end{array}$ & $\begin{array}{l}\text { Elevation in } \\
\text { Meters }\end{array}$ & $\begin{array}{c}\text { Elevation Adjusted } \\
\text { to Equivalent Fresh } \\
\text { Water Head }\end{array}$ \\
\hline PZ-07 & SR/D & 3413.99 & $09 / 12 / 02$ & 37.49 & 11.43 & 3376.50 & 1029.16 & N/A \\
\hline PZ-07 & SR/D & 3413.99 & $10 / 10 / 02$ & 37.58 & 11.45 & 3376.41 & 1029.13 & N/A \\
\hline PZ-07 & SR/D & 3413.99 & $11 / 06 / 02$ & 37.78 & 11.52 & 3376.21 & 1029.07 & N/A \\
\hline PZ-07 & SR/D & 3413.99 & $12 / 04 / 02$ & 37.61 & 11.46 & 3376.38 & 1029.12 & N/A \\
\hline PZ-09 & SR/D & 3421.21 & 08/15/02 & 57.59 & 17.55 & 3363.62 & 1025.23 & N/A \\
\hline PZ-09 & SR/D & 3421.21 & $09 / 12 / 02$ & 57.79 & 17.61 & 3363.42 & 1025.17 & N/A \\
\hline PZ-09 & SR/D & 3421.21 & $10 / 10 / 02$ & 57.75 & 17.60 & 3363.46 & 1025.18 & $\mathrm{~N} / \mathrm{A}$ \\
\hline PZ-09 & SR/D & 3421.21 & $11 / 06 / 02$ & 57.81 & 17.62 & 3363.40 & 1025.16 & $\mathrm{~N} / \mathrm{A}$ \\
\hline PZ-09 & SR/D & 3421.21 & $12 / 04 / 02$ & 57.26 & 17.45 & 3363.95 & 1025.33 & $\mathrm{~N} / \mathrm{A}$ \\
\hline PZ-10 & SR/D & 3405.80 & $08 / 15 / 02$ & 38.47 & 11.73 & 3367.33 & 1026.36 & N/A \\
\hline PZ-10 & SR/D & 3405.80 & $09 / 12 / 02$ & 38.31 & 11.68 & 3367.49 & 1026.41 & $\mathrm{~N} / \mathrm{A}$ \\
\hline PZ-10 & SR/D & 3405.80 & $10 / 10 / 02$ & 38.34 & 11.69 & 3367.46 & 1026.40 & N/A \\
\hline PZ-10 & SR/D & 3405.80 & $11 / 06 / 02$ & 38.36 & 11.69 & 3367.44 & 1026.40 & $\mathrm{~N} / \mathrm{A}$ \\
\hline PZ-10 & SR/D & 3405.80 & $12 / 04 / 02$ & 38.19 & 11.64 & 3367.61 & 1026.45 & $\mathrm{~N} / \mathrm{A}$ \\
\hline PZ-11 & SR/D & 3418.95 & $08 / 15 / 02$ & 45.30 & 13.81 & 3373.65 & 1028.29 & $\mathrm{~N} / \mathrm{A}$ \\
\hline PZ-11 & SR/D & 3418.95 & $09 / 12 / 02$ & 45.54 & 13.88 & 3373.41 & 1028.22 & $\mathrm{~N} / \mathrm{A}$ \\
\hline PZ-11 & SR/D & 3418.95 & $10 / 10 / 02$ & 45.56 & 13.89 & 3373.39 & 1028.21 & N/A \\
\hline PZ-11 & SR/D & 3418.95 & $11 / 06 / 02$ & 45.74 & 13.94 & 3373.21 & 1028.15 & $\mathrm{~N} / \mathrm{A}$ \\
\hline PZ-11 & SR/D & 3418.95 & $12 / 04 / 02$ & 45.63 & 13.91 & 3373.32 & 1028.19 & $\mathrm{~N} / \mathrm{A}$ \\
\hline PZ-12 & SR/D & 3408.99 & $08 / 15 / 02$ & 53.60 & 16.34 & 3355.39 & 1022.72 & $\mathrm{~N} / \mathrm{A}$ \\
\hline PZ-12 & SR/D & 3408.99 & $09 / 12 / 02$ & 53.15 & 16.20 & 3355.84 & 1022.86 & $\mathrm{~N} / \mathrm{A}$ \\
\hline PZ-12 & SR/D & 3408.99 & $10 / 10 / 02$ & 53.17 & 16.21 & 3355.82 & 1022.85 & N/A \\
\hline PZ-12 & SR/D & 3408.99 & $11 / 06 / 02$ & 53.40 & 16.28 & 3355.59 & 1022.78 & $\mathrm{~N} / \mathrm{A}$ \\
\hline $\mathrm{PZ}-12$ & SR/D & 3408.99 & $12 / 04 / 02$ & 53.28 & 16.24 & 3355.71 & 1022.82 & $\mathrm{~N} / \mathrm{A}$ \\
\hline WIPP-12 & CUL & 3472.06 & $01 / 16 / 02$ & 439.82 & 134.06 & 3032.24 & 924.23 & 3069.05 \\
\hline WIPP-12 & CUL & 3472.06 & $02 / 05 / 02$ & 439.68 & 134.01 & 3032.38 & 924.27 & 3069.2 \\
\hline WIPP-12 & CUL & 3472.06 & $03 / 12 / 02$ & 439.47 & 133.95 & 3032.59 & 924.33 & 3069.43 \\
\hline WIPP-12 & CUL & 3472.06 & $04 / 08 / 02$ & 439.23 & 133.88 & 3032.83 & 924.41 & 3069.7 \\
\hline
\end{tabular}


Waste Isolation Pilot Plant 2002 Site Environmental Report DOE/WIPP 03-2225

Table 6.11 - Groundwater Level Measurement Results for 2002

\begin{tabular}{|c|c|c|c|c|c|c|c|c|}
\hline $\begin{array}{l}\text { Well } \\
\text { Number }\end{array}$ & Zone & $\begin{array}{l}\text { Top of } \\
\text { Casing } \\
\text { Elevation }\end{array}$ & Date & $\begin{array}{l}\text { Measured } \\
\text { Depth From } \\
\text { Top of Casing }\end{array}$ & $\begin{array}{c}\text { Measured } \\
\text { Depth in Meters }\end{array}$ & $\begin{array}{l}\text { Elevation in } \\
\text { Feet AMSL* }\end{array}$ & $\begin{array}{l}\text { Elevation in } \\
\text { Meters }\end{array}$ & $\begin{array}{c}\text { Elevation Adjusted } \\
\text { to Equivalent Fresh } \\
\text { Water Head }\end{array}$ \\
\hline WIPP-12 & CUL & 3472.06 & $05 / 07 / 02$ & 439.10 & 133.84 & 3032.96 & 924.45 & 3069.84 \\
\hline WIPP-12 & CUL & 3472.06 & $06 / 10 / 02$ & 438.95 & 133.79 & 3033.11 & 924.49 & 3070 \\
\hline WIPP-12 & CUL & 3472.06 & $07 / 15 / 02$ & 438.90 & 133.78 & 3033.16 & 924.51 & 3070.06 \\
\hline WIPP-12 & CUL & 3472.06 & $08 / 13 / 02$ & 438.84 & 133.76 & 3033.22 & 924.53 & 3070.12 \\
\hline WIPP-12 & CUL & 3472.06 & 09/10/02 & 438.85 & 133.76 & 3033.21 & 924.52 & 3070.11 \\
\hline WIPP-12 & CUL & 3472.06 & $10 / 07 / 02$ & 438.82 & 133.75 & 3033.24 & 924.53 & 3070.15 \\
\hline WIPP-12 & CUL & 3472.06 & $11 / 04 / 02$ & 438.81 & 133.75 & 3033.25 & 924.53 & 3070.16 \\
\hline WIPP-12 & CUL & 3472.06 & $12 / 02 / 02$ & 438.77 & 133.74 & 3033.29 & 924.55 & 3070.20 \\
\hline WIPP-13 & CUL & 3405.71 & $01 / 15 / 02$ & 348.45 & 106.21 & 3057.26 & 931.85 & 3067.83 \\
\hline WIPP-13 & CUL & 3405.71 & $02 / 05 / 02$ & 348.46 & 106.21 & 3057.25 & 931.85 & 3067.82 \\
\hline WIPP-13 & CUL & 3405.71 & $03 / 11 / 02$ & 348.22 & 106.14 & 3057.49 & 931.92 & 3068.06 \\
\hline WIPP-13 & CUL & 3405.71 & $04 / 08 / 02$ & 348.07 & 106.09 & 3057.64 & 931.97 & 3068.22 \\
\hline WIPP-13 & CUL & 3405.71 & 05/06/02 & 348.04 & 106.08 & 3057.67 & 931.98 & 3068.25 \\
\hline WIPP-13 & CUL & 3405.71 & $06 / 11 / 02$ & 347.80 & 106.01 & 3057.91 & 932.05 & 3068.50 \\
\hline WIPP-13 & CUL & 3405.71 & $07 / 15 / 02$ & 347.87 & 106.03 & 3057.84 & 932.03 & 3068.42 \\
\hline WIPP-13 & CUL & 3405.71 & $08 / 13 / 02$ & 347.81 & 106.01 & 3057.90 & 932.05 & 3068.49 \\
\hline WIPP-13 & CUL & 3405.71 & 09/09/02 & 347.92 & 106.05 & 3057.79 & 932.01 & 3068.37 \\
\hline WIPP-13 & CUL & 3405.71 & $10 / 08 / 02$ & 347.73 & 105.99 & 3057.98 & 932.07 & 3068.57 \\
\hline WIPP-13 & CUL & 3405.71 & $11 / 05 / 02$ & 347.72 & 105.99 & 3057.99 & 932.08 & 3068.58 \\
\hline WIPP-13 & CUL & 3405.71 & $12 / 02 / 02$ & 347.71 & 105.98 & 3058.00 & 932.08 & 3068.59 \\
\hline WIPP-19 & CUL & 3435.14 & $01 / 16 / 02$ & 395.13 & 120.44 & 3040.01 & 926.60 & 3077.82 \\
\hline WIPP-19 & CUL & 3435.14 & $02 / 05 / 02$ & 395.01 & 120.40 & 3040.13 & 926.63 & 3077.95 \\
\hline WIPP-19 & CUL & 3435.14 & $03 / 12 / 02$ & 394.90 & 120.37 & 3040.24 & 926.67 & 3078.08 \\
\hline WIPP-19 & CUL & 3435.14 & $04 / 08 / 02$ & 394.62 & 120.28 & 3040.52 & 926.75 & 3078.38 \\
\hline WIPP-19 & CUL & 3435.14 & 05/07/02 & 394.50 & 120.24 & 3040.64 & 926.79 & 3078.52 \\
\hline WIPP-19 & CUL & 3435.14 & $06 / 10 / 02$ & 394.24 & 120.16 & 3040.90 & 926.87 & 3078.80 \\
\hline WIPP-19 & CUL & 3435.14 & $07 / 15 / 02$ & 394.26 & 120.17 & 3040.88 & 926.86 & 3078.78 \\
\hline WIPP-19 & CUL & 3435.14 & $08 / 13 / 02$ & 394.05 & 120.11 & 3041.09 & 926.92 & 3079.01 \\
\hline
\end{tabular}


Waste Isolation Pilot Plant 2002 Site Environmental Report DOE/WIPP 03-2225

Table 6.11 - Groundwater Level Measurement Results for 2002

\begin{tabular}{|c|c|c|c|c|c|c|c|c|}
\hline $\begin{array}{l}\text { Well } \\
\text { Number }\end{array}$ & Zone & $\begin{array}{l}\text { Top of } \\
\text { Casing } \\
\text { Elevation }\end{array}$ & Date & $\begin{array}{l}\text { Measured } \\
\text { Depth From } \\
\text { Top of Casing }\end{array}$ & $\begin{array}{c}\text { Measured } \\
\text { Depth in Meters }\end{array}$ & $\begin{array}{l}\text { Elevation in } \\
\text { Feet AMSL* }\end{array}$ & $\begin{array}{c}\text { Elevation in } \\
\text { Meters }\end{array}$ & $\begin{array}{c}\text { Elevation Adjusted } \\
\text { to Equivalent Fresh } \\
\text { Water Head }\end{array}$ \\
\hline WIPP-19 & CUL & 3435.14 & 09/10/02 & 394.08 & 120.12 & 3041.06 & 926.92 & 3078.98 \\
\hline WIPP-19 & CUL & 3435.14 & $10 / 07 / 02$ & 394.10 & 120.12 & 3041.04 & 926.91 & 3078.96 \\
\hline WIPP-19 & CUL & 3435.14 & $11 / 04 / 02$ & 394.02 & 120.10 & 3041.12 & 926.93 & 3079.04 \\
\hline WIPP-19 & CUL & 3435.14 & $12 / 02 / 02$ & 393.92 & 120.07 & 3041.22 & 926.96 & 3079.15 \\
\hline WIPP-21 & CUL & 3418.96 & $01 / 16 / 02$ & 402.99 & 122.83 & 3015.97 & 919.27 & 3040.11 \\
\hline WIPP-21 & CUL & 3418.96 & $02 / 05 / 02$ & 402.88 & 122.80 & 3016.08 & 919.30 & 3040.23 \\
\hline WIPP-21 & CUL & 3418.96 & $03 / 12 / 02$ & 402.80 & 122.77 & 3016.16 & 919.33 & 3040.31 \\
\hline WIPP-21 & CUL & 3418.96 & $04 / 08 / 02$ & 402.39 & 122.65 & 3016.57 & 919.45 & 3040.75 \\
\hline WIPP-21 & CUL & 3418.96 & $05 / 07 / 02$ & 402.16 & 122.58 & 3016.80 & 919.52 & 3041.00 \\
\hline WIPP-21 & CUL & 3418.96 & $06 / 10 / 02$ & 401.83 & 122.48 & 3017.13 & 919.62 & 3041.35 \\
\hline WIPP-21 & CUL & 3418.96 & $07 / 15 / 02$ & 401.71 & 122.44 & 3017.25 & 919.66 & 3041.48 \\
\hline WIPP-21 & CUL & 3418.96 & $08 / 13 / 02$ & 401.50 & 122.38 & 3017.46 & 919.72 & 3041.70 \\
\hline WIPP-21 & CUL & 3418.96 & 09/10/02 & 401.20 & 122.29 & 3017.76 & 919.81 & 3042.02 \\
\hline WIPP-21 & CUL & 3418.96 & $10 / 07 / 02$ & 401.58 & 122.40 & 3017.38 & 919.70 & 3041.62 \\
\hline WIPP-21 & CUL & 3418.96 & $11 / 04 / 02$ & 401.64 & 122.42 & 3017.32 & 919.68 & 3041.55 \\
\hline WIPP-21 & CUL & 3418.96 & $12 / 02 / 02$ & 401.63 & 122.42 & 3017.33 & 919.68 & 3041.56 \\
\hline WIPP-22 & CUL & 3428.12 & $01 / 16 / 02$ & 397.95 & 121.30 & 3030.17 & 923.60 & 3061.24 \\
\hline WIPP-22 & CUL & 3428.12 & $02 / 05 / 02$ & 397.86 & 121.27 & 3030.26 & 923.62 & 3061.34 \\
\hline WIPP-22 & CUL & 3428.12 & $03 / 12 / 02$ & 397.73 & 121.23 & 3030.39 & 923.66 & 3061.48 \\
\hline WIPP-22 & CUL & 3428.12 & 04/08/02 & 397.39 & 121.12 & 3030.73 & 923.77 & 3061.85 \\
\hline WIPP-22 & CUL & 3428.12 & $05 / 07 / 02$ & 397.28 & 121.09 & 3030.84 & 923.80 & 3061.97 \\
\hline WIPP-22 & CUL & 3428.12 & $06 / 10 / 02$ & 396.99 & 121.00 & 3031.13 & 923.89 & 3062.29 \\
\hline WIPP-22 & CUL & 3428.12 & $07 / 15 / 02$ & 396.23 & 120.77 & 3031.89 & 924.12 & 3063.11 \\
\hline WIPP-22 & CUL & 3428.12 & $08 / 13 / 02$ & 396.75 & 120.93 & 3031.37 & 923.96 & 3062.55 \\
\hline WIPP-22 & CUL & 3428.12 & 09/10/02 & 396.75 & 120.93 & 3031.37 & 923.96 & 3062.55 \\
\hline WIPP-22 & CUL & 3428.12 & $10 / 07 / 02$ & 396.75 & 120.93 & 3031.37 & 923.96 & 3062.55 \\
\hline WIPP-22 & CUL & 3428.12 & $11 / 04 / 02$ & 396.68 & 120.91 & 3031.44 & 923.98 & 3062.62 \\
\hline WIPP-22 & CUL & 3428.12 & $12 / 02 / 02$ & 396.61 & 120.89 & 3031.51 & 924.00 & 3062.70 \\
\hline
\end{tabular}


Waste Isolation Pilot Plant 2002 Site Environmental Report DOE/WIPP 03-2225

Table 6.11 - Groundwater Level Measurement Results for 2002

\begin{tabular}{|c|c|c|c|c|c|c|c|c|}
\hline $\begin{array}{l}\text { Well } \\
\text { Number }\end{array}$ & Zone & $\begin{array}{l}\text { Top of } \\
\text { Casing } \\
\text { Elevation }\end{array}$ & Date & $\begin{array}{l}\text { Measured } \\
\text { Depth From } \\
\text { Top of Casing }\end{array}$ & $\begin{array}{c}\text { Measured } \\
\text { Depth in Meters }\end{array}$ & $\begin{array}{l}\text { Elevation in } \\
\text { Feet AMSL* }\end{array}$ & $\begin{array}{l}\text { Elevation in } \\
\text { Meters }\end{array}$ & $\begin{array}{c}\text { Elevation Adjusted } \\
\text { to Equivalent Fresh } \\
\text { Water Head }\end{array}$ \\
\hline WIPP-25 (ANNULUS) & MAG & 3214.39 & $01 / 14 / 02$ & 163.78 & 49.92 & 3050.61 & 929.83 & N/A \\
\hline WIPP-25 (ANNULUS) & MAG & 3214.39 & 02/06/02 & 163.59 & 49.86 & 3050.80 & 929.88 & N/A \\
\hline WIPP-25 (ANNULUS) & MAG & 3214.39 & $03 / 11 / 02$ & 163.84 & 49.94 & 3050.55 & 929.81 & N/A \\
\hline WIPP-25 (ANNULUS) & MAG & 3214.39 & 04/09/02 & 163.17 & 49.73 & 3051.22 & 930.01 & N/A \\
\hline WIPP-25 (ANNULUS) & MAG & 3214.39 & 05/06/02 & 163.04 & 49.69 & 3051.35 & 930.05 & N/A \\
\hline WIPP-25 (ANNULUS) & MAG & 3214.39 & 06/10/02 & 162.97 & 49.67 & 3051.42 & 930.07 & N/A \\
\hline WIPP-25 (ANNULUS) & MAG & 3214.39 & $07 / 16 / 02$ & 162.72 & 49.60 & 3051.67 & 930.15 & $\mathrm{~N} / \mathrm{A}$ \\
\hline WIPP-25 (ANNULUS) & MAG & 3214.39 & $08 / 12 / 02$ & 162.62 & 49.57 & 3051.77 & 930.18 & $\mathrm{~N} / \mathrm{A}$ \\
\hline WIPP-25 (ANNULUS) & MAG & 3214.39 & $09 / 11 / 02$ & 162.56 & 49.55 & 3051.83 & 930.20 & $\mathrm{~N} / \mathrm{A}$ \\
\hline WIPP-25 (ANNULUS) & MAG & 3214.39 & $10 / 08 / 02$ & 162.49 & 49.53 & 3051.90 & 930.22 & $\mathrm{~N} / \mathrm{A}$ \\
\hline WIPP-25 (ANNULUS) & MAG & 3214.39 & $11 / 05 / 02$ & 162.14 & 49.42 & 3052.25 & 930.33 & $\mathrm{~N} / \mathrm{A}$ \\
\hline WIPP-25 (ANNULUS) & MAG & 3214.39 & $12 / 03 / 02$ & 162.30 & 49.47 & 3052.09 & 930.28 & $\mathrm{~N} / \mathrm{A}$ \\
\hline WIPP-25 (PIP) & CUL & 3214.39 & $01 / 14 / 02$ & 153.78 & 46.87 & 3060.61 & 932.87 & 3057.53 \\
\hline WIPP-25 (PIP) & CUL & 3214.39 & $02 / 06 / 02$ & 153.49 & 46.78 & 3060.90 & 932.96 & 3057.82 \\
\hline WIPP-25 (PIP) & CUL & 3214.39 & $03 / 11 / 02$ & 153.20 & 46.70 & 3061.19 & 933.05 & 3058.11 \\
\hline WIPP-25 (PIP) & CUL & 3214.39 & $04 / 09 / 02$ & 153.14 & 46.68 & 3061.25 & 933.07 & 3058.17 \\
\hline WIPP-25 (PIP) & CUL & 3214.39 & $05 / 06 / 02$ & 152.84 & 46.59 & 3061.55 & 933.16 & 3058.46 \\
\hline WIPP-25 (PIP) & CUL & 3214.39 & $06 / 10 / 02$ & 152.75 & 46.56 & 3061.64 & 933.19 & 3058.55 \\
\hline WIPP-25 (PIP) & CUL & 3214.39 & $07 / 16 / 02$ & 152.42 & 46.46 & 3061.97 & 933.29 & 3058.88 \\
\hline WIPP-25 (PIP) & CUL & 3214.39 & $08 / 12 / 02$ & 152.23 & 46.40 & 3062.16 & 933.35 & 3059.07 \\
\hline WIPP-25 (PIP) & CUL & 3214.39 & $09 / 11 / 02$ & 152.29 & 46.42 & 3062.10 & 933.33 & 3059.01 \\
\hline WIPP-25 (PIP) & CUL & 3214.39 & $10 / 08 / 02$ & 152.11 & 46.36 & 3062.28 & 933.38 & 3059.19 \\
\hline WIPP-25 (PIP) & CUL & 3214.39 & $11 / 05 / 02$ & 151.91 & 46.30 & 3062.48 & 933.44 & 3059.38 \\
\hline WIPP-25 (PIP) & CUL & 3214.39 & $12 / 03 / 02$ & 152.07 & 46.35 & 3062.32 & 933.40 & 3059.23 \\
\hline WIPP-26 & CUL & 3153.20 & $01 / 15 / 02$ & 131.48 & 40.08 & 3021.72 & 921.02 & 3021.85 \\
\hline WIPP-26 & CUL & 3153.20 & $02 / 06 / 02$ & 131.38 & 40.04 & 3021.82 & 921.05 & 3021.96 \\
\hline WIPP-26 & CUL & 3153.20 & $03 / 11 / 02$ & 131.36 & 40.04 & 3021.84 & 921.06 & 3021.98 \\
\hline WIPP-26 & CUL & 3153.20 & $04 / 09 / 02$ & 131.25 & 40.01 & 3021.95 & 921.09 & 3022.09 \\
\hline
\end{tabular}


Waste Isolation Pilot Plant 2002 Site Environmental Report DOE/WIPP 03-2225

Table 6.11 - Groundwater Level Measurement Results for 2002

\begin{tabular}{|c|c|c|c|c|c|c|c|c|}
\hline $\begin{array}{l}\text { Well } \\
\text { Number }\end{array}$ & Zone & $\begin{array}{l}\text { Top of } \\
\text { Casing } \\
\text { Elevation }\end{array}$ & Date & $\begin{array}{c}\text { Measured } \\
\text { Depth From } \\
\text { Top of Casing }\end{array}$ & $\begin{array}{c}\text { Measured } \\
\text { Depth in Meters }\end{array}$ & $\begin{array}{l}\text { Elevation in } \\
\text { Feet AMSL* }\end{array}$ & $\begin{array}{c}\text { Elevation in } \\
\text { Meters }\end{array}$ & $\begin{array}{c}\text { Elevation Adjusted } \\
\text { to Equivalent Fresh } \\
\text { Water Head }\end{array}$ \\
\hline WIPP-26 & CUL & 3153.20 & 05/06/02 & 131.06 & 39.95 & 3022.14 & 921.15 & 3022.28 \\
\hline WIPP-26 & CUL & 3153.20 & $06 / 12 / 02$ & 131.27 & 40.01 & 3021.93 & 921.08 & 3022.07 \\
\hline WIPP-26 & CUL & 3153.20 & 07/16/02 & 130.77 & 39.86 & 3022.43 & 921.24 & 3022.57 \\
\hline WIPP-26 & CUL & 3153.20 & $08 / 12 / 02$ & 130.81 & 39.87 & 3022.39 & 921.22 & 3022.53 \\
\hline WIPP-26 & CUL & 3153.20 & 09/11/02 & 131.34 & 40.03 & 3021.86 & 921.06 & 3022.00 \\
\hline WIPP-26 & CUL & 3153.20 & $10 / 08 / 02$ & 130.97 & 39.92 & 3022.23 & 921.18 & 3022.37 \\
\hline WIPP-26 & CUL & 3153.20 & $11 / 05 / 02$ & 130.25 & 39.70 & 3022.95 & 921.40 & 3023.09 \\
\hline WIPP-26 & CUL & 3153.20 & $12 / 03 / 02$ & 130.19 & 39.68 & 3023.01 & 921.41 & 3023.15 \\
\hline WIPP-27 (PIP) & CUL & 3178.98 & $01 / 14 / 02$ & 96.43 & 29.39 & 3082.55 & 939.56 & 3088.65 \\
\hline WIPP-27 (PIP) & CUL & 3178.98 & 02/06/02 & 96.33 & 29.36 & 3082.65 & 939.59 & 3088.75 \\
\hline WIPP-27 (PIP) & CUL & 3178.98 & $03 / 11 / 02$ & 96.19 & 29.32 & 3082.79 & 939.63 & 3088.90 \\
\hline WIPP-27 (PIP) & CUL & 3178.98 & 04/09/02 & 96.38 & 29.38 & 3082.60 & 939.58 & 3088.70 \\
\hline WIPP-27 (PIP) & CUL & 3178.98 & $05 / 06 / 02$ & 96.36 & 29.37 & 3082.62 & 939.58 & 3088.72 \\
\hline WIPP-27 (PIP) & CUL & 3178.98 & $06 / 10 / 02$ & 96.68 & 29.47 & 3082.30 & 939.49 & 3088.39 \\
\hline WIPP-27 (PIP) & CUL & 3178.98 & $07 / 16 / 02$ & 97.02 & 29.57 & 3081.96 & 939.38 & 3088.04 \\
\hline WIPP-27 (PIP) & CUL & 3178.98 & $08 / 12 / 02$ & 97.12 & 29.60 & 3081.86 & 939.35 & 3087.94 \\
\hline WIPP-27 (PIP) & CUL & 3178.98 & 09/10/02 & 97.30 & 29.66 & 3081.68 & 939.30 & 3087.76 \\
\hline WIPP-27 (PIP) & CUL & 3178.98 & $10 / 08 / 02$ & 97.37 & 29.68 & 3081.61 & 939.27 & 3087.68 \\
\hline WIPP-27 (PIP) & CUL & 3178.98 & $11 / 05 / 02$ & 97.06 & 29.58 & 3081.92 & 939.37 & 3088.00 \\
\hline WIPP-27 (PIP) & CUL & 3178.98 & $12 / 02 / 02$ & 96.59 & 29.44 & 3082.39 & 939.51 & 3088.49 \\
\hline WIPP-29 & CUL & 2978.26 & $01 / 14 / 02$ & 11.42 & 3.48 & 2966.84 & 904.29 & 2969.96 \\
\hline WIPP-29 & CUL & 2978.26 & $02 / 06 / 02$ & 11.11 & 3.39 & 2967.15 & 904.39 & 2970.33 \\
\hline WIPP-29 & CUL & 2978.26 & $03 / 11 / 02$ & 11.26 & 3.43 & 2967.00 & 904.34 & 2970.15 \\
\hline WIPP-29 & CUL & 2978.26 & $04 / 09 / 02$ & 11.01 & 3.36 & 2967.25 & 904.42 & 2970.45 \\
\hline WIPP-29 & CUL & 2978.26 & $05 / 06 / 02$ & 10.97 & 3.34 & 2967.29 & 904.43 & 2970.50 \\
\hline WIPP-29 & CUL & 2978.26 & $06 / 12 / 02$ & 11.19 & 3.41 & 2967.07 & 904.36 & 2970.24 \\
\hline WIPP-29 & CUL & 2978.26 & 07/16/02 & 11.16 & 3.40 & 2967.10 & 904.37 & 2970.27 \\
\hline WIPP-29 & CUL & 2978.26 & $08 / 12 / 02$ & 11.10 & 3.38 & 2967.16 & 904.39 & 2970.34 \\
\hline
\end{tabular}


Waste Isolation Pilot Plant 2002 Site Environmental Report DOE/WIPP 03-2225

Table 6.11 - Groundwater Level Measurement Results for 2002

\begin{tabular}{|c|c|c|c|c|c|c|c|c|}
\hline $\begin{array}{l}\text { Well } \\
\text { Number }\end{array}$ & Zone & $\begin{array}{l}\text { Top of } \\
\text { Casing } \\
\text { Elevation }\end{array}$ & Date & $\begin{array}{l}\text { Measured } \\
\text { Depth From } \\
\text { Top of Casing }\end{array}$ & $\begin{array}{c}\text { Measured } \\
\text { Depth in Meters }\end{array}$ & $\begin{array}{l}\text { Elevation in } \\
\text { Feet AMSL* }\end{array}$ & $\begin{array}{l}\text { Elevation in } \\
\text { Meters }\end{array}$ & $\begin{array}{c}\text { Elevation Adjusted } \\
\text { to Equivalent Fresh } \\
\text { Water Head }\end{array}$ \\
\hline WIPP-29 & CUL & 2978.26 & 09/11/02 & 11.19 & 3.41 & 2967.07 & 904.36 & 2970.24 \\
\hline WIPP-29 & CUL & 2978.26 & $10 / 08 / 02$ & 11.24 & 3.43 & 2967.02 & 904.35 & 2970.18 \\
\hline WIPP-29 & CUL & 2978.26 & $11 / 05 / 02$ & 11.00 & 3.35 & 2967.26 & 904.42 & 2970.46 \\
\hline WIPP-29 & CUL & 2978.26 & $12 / 03 / 02$ & 11.06 & 3.37 & 2967.20 & 904.40 & 2970.39 \\
\hline WIPP-30 (PIP) & CUL & 3429.05 & 01/15/02 & 360.79 & 109.97 & 3068.26 & 935.21 & 3075.33 \\
\hline WIPP-30 (PIP) & CUL & 3429.05 & 02/06/02 & 360.64 & 109.92 & 3068.41 & 935.25 & 3075.48 \\
\hline WIPP-30 (PIP) & CUL & 3429.05 & $03 / 11 / 02$ & 360.05 & 109.74 & 3069.00 & 935.43 & 3076.09 \\
\hline WIPP-30 (PIP) & CUL & 3429.05 & 04/09/02 & 359.89 & 109.69 & 3069.16 & 935.48 & 3076.25 \\
\hline WIPP-30 (PIP) & CUL & 3429.05 & $05 / 08 / 02$ & 359.35 & 109.53 & 3069.70 & 935.64 & 3076.81 \\
\hline WIPP-30 (PIP) & CUL & 3429.05 & $06 / 12 / 02$ & 359.11 & 109.46 & 3069.94 & 935.72 & 3077.05 \\
\hline WIPP-30 (PIP) & CUL & 3429.05 & $07 / 15 / 02$ & 359.03 & 109.43 & 3070.02 & 935.74 & 3077.13 \\
\hline WIPP-30 (PIP) & CUL & 3429.05 & $08 / 13 / 02$ & 358.82 & 109.37 & 3070.23 & 935.81 & 3077.35 \\
\hline WIPP-30 (PIP) & CUL & 3429.05 & 09/09/02 & 358.86 & 109.38 & 3070.19 & 935.79 & 3077.31 \\
\hline WIPP-30 (PIP) & CUL & 3429.05 & $10 / 08 / 02$ & 358.64 & 109.31 & 3070.41 & 935.86 & 3077.53 \\
\hline WIPP-30 (PIP) & CUL & 3429.05 & $11 / 05 / 02$ & 358.57 & 109.29 & 3070.48 & 935.88 & 3077.61 \\
\hline WIPP-30 (PIP) & CUL & 3429.05 & $12 / 03 / 02$ & 358.49 & 109.27 & 3070.56 & 935.91 & 3077.69 \\
\hline WQSP-1 & CUL & 3419.20 & $01 / 16 / 02$ & 365.31 & 111.35 & 3053.89 & 930.83 & 3070.58 \\
\hline WQSP-1 & CUL & 3419.20 & $02 / 05 / 02$ & 365.18 & 111.31 & 3054.02 & 930.87 & 3070.72 \\
\hline WQSP-1 & CUL & 3419.20 & $03 / 11 / 02$ & 364.83 & 111.20 & 3054.37 & 930.97 & 3071.09 \\
\hline WQSP-1 & CUL & 3419.20 & 04/08/02 & 364.58 & 111.12 & 3054.62 & 931.05 & 3071.35 \\
\hline WQSP-1 & CUL & 3419.20 & $05 / 06 / 02$ & 364.46 & 111.09 & 3054.74 & 931.08 & 3071.47 \\
\hline WQSP-1 & CUL & 3419.20 & $06 / 10 / 02$ & 364.24 & 111.02 & 3054.96 & 931.15 & 3071.71 \\
\hline WQSP-1 & CUL & 3419.20 & $07 / 15 / 02$ & 364.23 & 111.02 & 3054.97 & 931.15 & 3071.72 \\
\hline WQSP-1 & CUL & 3419.20 & $08 / 12 / 02$ & 364.07 & 110.97 & 3055.13 & 931.20 & 3071.88 \\
\hline WQSP-1 & CUL & 3419.20 & 09/09/02 & 364.18 & 111.00 & 3055.02 & 931.17 & 3071.77 \\
\hline WQSP-1 & CUL & 3419.20 & $10 / 07 / 02$ & 364.14 & 110.99 & 3055.06 & 931.18 & 3071.81 \\
\hline WQSP-1 & CUL & 3419.20 & $11 / 04 / 02$ & 364.01 & 110.95 & 3055.19 & 931.22 & 3071.95 \\
\hline WQSP-1 & CUL & 3419.20 & $12 / 02 / 02$ & 363.92 & 110.92 & 3055.28 & 931.25 & 3072.04 \\
\hline
\end{tabular}


Waste Isolation Pilot Plant 2002 Site Environmental Report DOE/WIPP 03-2225

Table 6.11 - Groundwater Level Measurement Results for 2002

\begin{tabular}{|c|c|c|c|c|c|c|c|c|}
\hline $\begin{array}{l}\text { Well } \\
\text { Number }\end{array}$ & Zone & $\begin{array}{l}\text { Top of } \\
\text { Casing } \\
\text { Elevation }\end{array}$ & Date & $\begin{array}{c}\text { Measured } \\
\text { Depth From } \\
\text { Top of Casing }\end{array}$ & $\begin{array}{c}\text { Measured } \\
\text { Depth in Meters }\end{array}$ & $\begin{array}{l}\text { Elevation in } \\
\text { Feet AMSL* }\end{array}$ & $\begin{array}{c}\text { Elevation in } \\
\text { Meters }\end{array}$ & $\begin{array}{c}\text { Elevation Adjusted } \\
\text { to Equivalent Fresh } \\
\text { Water Head }\end{array}$ \\
\hline WQSP-2 & CUL & 3463.90 & $01 / 16 / 02$ & 403.89 & 123.11 & 3060.01 & 932.69 & 3079.78 \\
\hline WQSP-2 & CUL & 3463.90 & $02 / 05 / 02$ & 403.67 & 123.04 & 3060.23 & 932.76 & 3080.01 \\
\hline WQSP-2 & CUL & 3463.90 & $03 / 12 / 02$ & 403.15 & 122.88 & 3060.75 & 932.92 & 3080.55 \\
\hline WQSP-2 & CUL & 3463.90 & 04/08/02 & 403.89 & 123.11 & 3060.01 & 932.69 & 3079.78 \\
\hline WQSP-2 & CUL & 3463.90 & 05/06/02 & 403.62 & 123.02 & 3060.28 & 932.77 & 3080.06 \\
\hline WQSP-2 & CUL & 3463.90 & 06/10/02 & 403.19 & 122.89 & 3060.71 & 932.90 & 3080.51 \\
\hline WQSP-2 & CUL & 3463.90 & 07/15/02 & 403.07 & 122.86 & 3060.83 & 932.94 & 3080.64 \\
\hline WQSP-2 & CUL & 3463.90 & $08 / 12 / 02$ & 402.73 & 122.75 & 3061.17 & 933.04 & 3080.99 \\
\hline WQSP-2 & CUL & 3463.90 & $09 / 09 / 02$ & 402.68 & 122.74 & 3061.22 & 933.06 & 3081.05 \\
\hline WQSP-2 & CUL & 3463.90 & $10 / 07 / 02$ & 403.55 & 123.00 & 3060.35 & 932.79 & 3080.13 \\
\hline WQSP-2 & CUL & 3463.90 & $11 / 04 / 02$ & 403.28 & 122.92 & 3060.62 & 932.88 & 3080.42 \\
\hline WQSP-2 & CUL & 3463.90 & $12 / 02 / 02$ & 403.01 & 122.84 & 3060.89 & 932.96 & 3080.70 \\
\hline WQSP-3 & CUL & 3480.30 & $01 / 16 / 02$ & 468.32 & 142.74 & 3011.98 & 918.05 & 3069.14 \\
\hline WQSP-3 & CUL & 3480.30 & $02 / 05 / 02$ & 468.08 & 142.67 & 3012.22 & 918.12 & 3069.41 \\
\hline WQSP-3 & CUL & 3480.30 & $03 / 12 / 02$ & 467.68 & 142.55 & 3012.62 & 918.25 & 3069.87 \\
\hline WQSP-3 & CUL & 3480.30 & 04/08/02 & 472.06 & 143.88 & 3008.24 & 916.91 & 3064.85 \\
\hline WQSP-3 & CUL & 3480.30 & $05 / 07 / 02$ & 468.25 & 142.72 & 3012.05 & 918.07 & 3069.22 \\
\hline WQSP-3 & CUL & 3480.30 & $06 / 10 / 02$ & 467.60 & 142.52 & 3012.70 & 918.27 & 3069.96 \\
\hline WQSP-3 & CUL & 3480.30 & $07 / 15 / 02$ & 467.40 & 142.46 & 3012.90 & 918.33 & 3070.19 \\
\hline WQSP-3 & CUL & 3480.30 & $08 / 12 / 02$ & 467.17 & 142.39 & 3013.13 & 918.40 & 3070.45 \\
\hline WQSP-3 & CUL & 3480.30 & 09/09/02 & 467.06 & 142.36 & 3013.24 & 918.44 & 3070.58 \\
\hline WQSP-3 & CUL & 3480.30 & $10 / 07 / 02$ & 473.79 & 144.41 & 3006.51 & 916.38 & 3062.87 \\
\hline WQSP-3 & CUL & 3480.30 & $11 / 04 / 02$ & 468.35 & 142.75 & 3011.95 & 918.04 & 3069.10 \\
\hline WQSP-3 & CUL & 3480.30 & $12 / 02 / 02$ & 467.69 & 142.55 & 3012.61 & 918.24 & 3069.86 \\
\hline WQSP-4 & CUL & 3433.00 & $01 / 16 / 02$ & 445.54 & 135.80 & 2987.46 & 910.58 & 3012.41 \\
\hline WQSP-4 & CUL & 3433.00 & $02 / 05 / 02$ & 445.42 & 135.76 & 2987.58 & 910.61 & 3012.54 \\
\hline WQSP-4 & CUL & 3433.00 & $03 / 13 / 02$ & 445.26 & 135.72 & 2987.74 & 910.66 & 3012.71 \\
\hline WQSP-4 & CUL & 3433.00 & $04 / 09 / 02$ & 445.54 & 135.80 & 2987.46 & 910.58 & 3012.41 \\
\hline
\end{tabular}


Waste Isolation Pilot Plant 2002 Site Environmental Report DOE/WIPP 03-2225

Table 6.11 - Groundwater Level Measurement Results for 2002

\begin{tabular}{|c|c|c|c|c|c|c|c|c|}
\hline $\begin{array}{l}\text { Well } \\
\text { Number }\end{array}$ & Zone & $\begin{array}{l}\text { Top of } \\
\text { Casing } \\
\text { Elevation }\end{array}$ & Date & $\begin{array}{c}\text { Measured } \\
\text { Depth From } \\
\text { Top of Casing } \\
\end{array}$ & $\begin{array}{c}\text { Measured } \\
\text { Depth in Meters }\end{array}$ & $\begin{array}{l}\text { Elevation in } \\
\text { Feet AMSL* }\end{array}$ & $\begin{array}{c}\text { Elevation in } \\
\text { Meters }\end{array}$ & $\begin{array}{c}\text { Elevation Adjusted } \\
\text { to Equivalent Fresh } \\
\text { Water Head }\end{array}$ \\
\hline WQSP-4 & CUL & 3433.00 & $05 / 07 / 02$ & 445.31 & 135.73 & 2987.69 & 910.65 & 3012.66 \\
\hline WQSP-4 & CUL & 3433.00 & $06 / 10 / 02$ & 444.89 & 135.60 & 2988.11 & 910.78 & 3013.11 \\
\hline WQSP-4 & CUL & 3433.00 & $07 / 15 / 02$ & 444.78 & 135.57 & 2988.22 & 910.81 & 3013.23 \\
\hline WQSP-4 & CUL & 3433.00 & $08 / 12 / 02$ & 444.53 & 135.49 & 2988.47 & 910.89 & 3013.50 \\
\hline WQSP-4 & CUL & 3433.00 & 09/09/02 & 444.55 & 135.50 & 2988.45 & 910.88 & 3013.47 \\
\hline WQSP-4 & CUL & 3433.00 & $10 / 07 / 02$ & 444.56 & 135.50 & 2988.44 & 910.88 & 3013.46 \\
\hline WQSP-4 & CUL & 3433.00 & $11 / 04 / 02$ & 444.82 & 135.58 & 2988.18 & 910.80 & 3013.18 \\
\hline WQSP-4 & CUL & 3433.00 & $12 / 02 / 02$ & 444.58 & 135.51 & 2988.42 & 910.87 & 3013.44 \\
\hline WQSP-5 & CUL & 3384.40 & $01 / 16 / 02$ & 381.43 & 116.26 & 3002.97 & 915.31 & 3010.03 \\
\hline WQSP-5 & CUL & 3384.40 & $02 / 05 / 02$ & 381.29 & 116.22 & 3003.11 & 915.35 & 3010.17 \\
\hline WQSP-5 & CUL & 3384.40 & $03 / 13 / 02$ & 381.30 & 116.22 & 3003.10 & 915.34 & 3010.16 \\
\hline WQSP-5 & CUL & 3384.40 & $04 / 09 / 02$ & 381.28 & 116.21 & 3003.12 & 915.35 & 3010.18 \\
\hline WQSP-5 & CUL & 3384.40 & 05/08/02 & 381.46 & 116.27 & 3002.94 & 915.30 & 3010.00 \\
\hline WQSP-5 & CUL & 3384.40 & $06 / 10 / 02$ & 380.77 & 116.06 & 3003.63 & 915.51 & 3010.71 \\
\hline WQSP-5 & CUL & 3384.40 & $07 / 15 / 02$ & 380.68 & 116.03 & 3003.72 & 915.53 & 3010.80 \\
\hline WQSP-5 & CUL & 3384.40 & $08 / 12 / 02$ & 380.40 & 115.95 & 3004.00 & 915.62 & 3011.09 \\
\hline WQSP-5 & CUL & 3384.40 & 09/09/02 & 380.36 & 115.93 & 3004.04 & 915.63 & 3011.13 \\
\hline WQSP-5 & CUL & 3384.40 & $10 / 07 / 02$ & 380.34 & 115.93 & 3004.06 & 915.64 & 3011.15 \\
\hline WQSP-5 & CUL & 3384.40 & $11 / 04 / 02$ & 381.67 & 116.33 & 3002.73 & 915.23 & 3009.78 \\
\hline WQSP-5 & CUL & 3384.40 & $12 / 02 / 02$ & 380.43 & 115.96 & 3003.97 & 915.61 & 3011.05 \\
\hline WQSP-6 & CUL & 3363.80 & $01 / 16 / 02$ & 347.61 & 105.95 & 3016.19 & 919.33 & 3019.92 \\
\hline WQSP-6 & CUL & 3363.80 & $02 / 05 / 02$ & 347.47 & 105.91 & 3016.33 & 919.38 & 3020.07 \\
\hline WQSP-6 & CUL & 3363.80 & $03 / 13 / 02$ & 347.07 & 105.79 & 3016.73 & 919.50 & 3020.47 \\
\hline WQSP-6 & CUL & 3363.80 & 04/09/02 & 347.20 & 105.83 & 3016.60 & 919.46 & 3020.34 \\
\hline WQSP-6 & CUL & 3363.80 & 05/08/02 & 346.83 & 105.71 & 3016.97 & 919.57 & 3020.72 \\
\hline WQSP-6 & CUL & 3363.80 & $06 / 10 / 02$ & 347.43 & 105.90 & 3016.37 & 919.39 & 3020.11 \\
\hline WQSP-6 & CUL & 3363.80 & $07 / 15 / 02$ & 347.06 & 105.78 & 3016.74 & 919.50 & 3020.48 \\
\hline WQSP-6 & CUL & 3363.80 & $08 / 12 / 02$ & 346.79 & 105.70 & 3017.01 & 919.58 & 3020.76 \\
\hline
\end{tabular}


Waste Isolation Pilot Plant 2002 Site Environmental Report DOE/WIPP 03-2225

Table 6.11 - Groundwater Level Measurement Results for 2002

\begin{tabular}{|c|c|c|c|c|c|c|c|c|}
\hline $\begin{array}{l}\text { Well } \\
\text { Number }\end{array}$ & Zone & $\begin{array}{l}\text { Top of } \\
\text { Casing } \\
\text { Elevation }\end{array}$ & Date & $\begin{array}{l}\text { Measured } \\
\text { Depth From } \\
\text { Top of Casing }\end{array}$ & $\begin{array}{c}\text { Measured } \\
\text { Depth in Meters }\end{array}$ & $\begin{array}{l}\text { Elevation in } \\
\text { Feet AMSL* }\end{array}$ & $\begin{array}{c}\text { Elevation in } \\
\text { Meters }\end{array}$ & $\begin{array}{c}\text { Elevation Adjusted } \\
\text { to Equivalent Fresh } \\
\text { Water Head }\end{array}$ \\
\hline WQSP-6 & CUL & 3363.80 & 09/09/02 & 346.71 & 105.68 & 3017.09 & 919.61 & 3020.84 \\
\hline WQSP-6 & CUL & 3363.80 & $10 / 07 / 02$ & 346.70 & 105.67 & 3017.10 & 919.61 & 3020.85 \\
\hline WQSP-6 & CUL & 3363.80 & $11 / 04 / 02$ & 346.54 & 105.63 & 3017.26 & 919.66 & 3021.01 \\
\hline WQSP-6 & CUL & 3363.80 & $12 / 02 / 02$ & 347.35 & 105.87 & 3016.45 & 919.41 & 3020.19 \\
\hline WQSP-6A & $\mathrm{DL}$ & 3364.70 & $01 / 16 / 02$ & 166.44 & 50.73 & 3198.26 & 974.83 & N/A \\
\hline WQSP-6A & $\mathrm{DL}$ & 3364.70 & $02 / 05 / 02$ & 166.46 & 50.74 & 3198.24 & 974.82 & N/A \\
\hline WQSP-6A & $\mathrm{DL}$ & 3364.70 & $03 / 13 / 02$ & 166.22 & 50.66 & 3198.48 & 974.90 & N/A \\
\hline WQSP-6A & $\mathrm{DL}$ & 3364.70 & $04 / 09 / 02$ & 166.67 & 50.80 & 3198.03 & 974.76 & $\mathrm{~N} / \mathrm{A}$ \\
\hline WQSP-6A & $\mathrm{DL}$ & 3364.70 & $05 / 08 / 02$ & 166.31 & 50.69 & 3198.39 & 974.87 & $\mathrm{~N} / \mathrm{A}$ \\
\hline WQSP-6A & $\mathrm{DL}$ & 3364.70 & 06/10/02 & 166.33 & 50.70 & 3198.37 & 974.86 & $\mathrm{~N} / \mathrm{A}$ \\
\hline WQSP-6A & DL & 3364.70 & $07 / 15 / 02$ & 166.49 & 50.75 & 3198.21 & 974.81 & N/A \\
\hline WQSP-6A & DL & 3364.70 & $08 / 12 / 02$ & 166.43 & 50.73 & 3198.27 & 974.83 & N/A \\
\hline WQSP-6A & DL & 3364.70 & 09/09/02 & 166.60 & 50.78 & 3198.10 & 974.78 & N/A \\
\hline WQSP-6A & DL & 3364.70 & $10 / 07 / 02$ & 166.73 & 50.82 & 3197.97 & 974.74 & $\mathrm{~N} / \mathrm{A}$ \\
\hline WQSP-6A & $\mathrm{DL}$ & 3364.70 & $11 / 04 / 02$ & 166.60 & 50.78 & 3198.10 & 974.78 & $\mathrm{~N} / \mathrm{A}$ \\
\hline WQSP-6A & $\mathrm{DL}$ & 3364.70 & $12 / 02 / 02$ & 166.48 & 50.74 & 3198.22 & 974.82 & $\mathrm{~N} / \mathrm{A}$ \\
\hline
\end{tabular}

$\mathrm{N} / \mathrm{A}=$ Not applicable

* Above mean sea level 


\section{Waste Isolation Pilot Plant 2002 Site Environmental Report}

DOE/WIPP 03-2225

Table 6.12 - Shallow Subsurface Water Analyses

\begin{tabular}{|c|c|c|c|c|c|c|}
\hline \multirow[b]{2}{*}{ Parameter } & \multicolumn{6}{|c|}{ Well ID } \\
\hline & C-2505 & $\mathrm{C} 2506$ & C-2507 & $\begin{array}{c}\text { C-2507 } \\
\text { (Dup.) }\end{array}$ & PZ-1 & PZ-2 \\
\hline Ammonium & 0.359 & 0.341 & 0.0641 & 0.0097 & 0.214 & $<0.004$ \\
\hline Arsenic & 0.0018 & 0.0018 & 0.0017 & 0.0017 & 0.0013 & 0.0019 \\
\hline Barium & 0.0885 & 0.0969 & 0.0453 & 0.044 & 0.173 & 0.0191 \\
\hline Boron & 0.2 & 0.078 & 0.27 & \begin{tabular}{l|l|}
0.25 \\
\end{tabular} & $<0.011$ & 0.18 \\
\hline Bromide & 10 & 6 & 4.4 & 4.3 & 2.9 & 7.4 \\
\hline Cadmium & $<0.001$ & 0.001 & 0.00012 & 0.0001 & 0.0014 & 0.00052 \\
\hline Calcium & 833 & 1150 & 446 & 444 & 5140 & 452 \\
\hline Chloride & 5920 & 8870 & 1520 & 1560 & 48500 & 1230 \\
\hline Chromium & 0.0201 & 0.0156 & 0.0421 & 0.0411 & 0.0179 & 0.0088 \\
\hline Iron & 0.0161 & $<0.014$ & 0.0019 & $<0.0014$ & $<0.014$ & $<0.0014$ \\
\hline Lead & $<0.001$ & $<0.001$ & 0.00052 & 0.00018 & $<0.001$ & 0.00011 \\
\hline Magnesium & 574 & 753 & 338 & 337 & 2700 & 338 \\
\hline Mercury & $<0.001$ & $<0.001$ & $<0.0002$ & $<0.0002$ & 0.0012 & $<0.0002$ \\
\hline Nitrate & 24.2 & 25.7 & 25.9 & 26.3 & 6.16 & 9.68 \\
\hline Nitrite & $<0.0061$ & $<0.0061$ & 0.0252 & 0.0307 & $<0.0061$ & $<0.0061$ \\
\hline $\mathrm{pH}$ & 7.21 & 7.09 & 7.15 & 7.17 & 6.8 & 7.43 \\
\hline Potassium & 11 & 14.6 & 6.7 & 6.6 & 41.3 & 7.2 \\
\hline Selenium & 0.0895 & 0.0911 & 0.0633 & 0.0646 & 0.0801 & 0.121 \\
\hline Silicon & 23.2 & 22.1 & 24.6 & 24.6 & 21 & 22.1 \\
\hline Silver & $<0.001$ & $<0.001$ & 0.00053 & 0.00015 & 0.0029 & $<0.0001$ \\
\hline Sodium & 2090 & 3240 & 348 & 343 & 19000 & 417 \\
\hline Specific Gravity & 1.01 & 1.012 & 1.006 & 1.006 & 1.058 & 1.004 \\
\hline Sulfate & 1200 & 1280 & 977 & 996 & 1790 & 1550 \\
\hline Total Dissolved Solids & 12000 & 17700 & 3650 & 3630 & 86700 & 4260 \\
\hline Total Inorganic Carbon & 53.5 & 49.1 & 82.7 & 83.8 & 25 & 56.2 \\
\hline Total Organic Carbon & 3.4 & 3.3 & 3.4 & 3.3 & 3.5 & 4 \\
\hline Total Suspended Solids & $<10$ & $<10$ & $<10$ & $<10$ & $<10$ & $<10$ \\
\hline Zinc & $<0.01$ & $<0.01$ & 0.0125 & 0.0021 & $<0.01$ & $<0.001$ \\
\hline Parameter & PZ-3 & PZ-4 & PZ-5 & PZ-6 & PZ-6 (Dup.) & PZ-7 \\
\hline Ammonium & 0.264 & 0.606 & 0.259 & 0.585 & 0.599 & 0.378 \\
\hline Arsenic & 0.0014 & 0.0015 & 0.00095 & 0.00088 & 0.00092 & 0.001 \\
\hline Barium & 0.0746 & 0.18 & 0.0882 & 0.108 & 0.108 & 0.0605 \\
\hline Boron & 0.093 & 0.064 & 0.035 & 0.063 & 0.034 & 0.054 \\
\hline \begin{tabular}{|l} 
Bromide \\
\end{tabular} & 7.2 & 6.1 & 15.2 & 5.2 & 5.2 & 10.9 \\
\hline Cadmium & $<0.001$ & 0.0011 & 0.0014 & 0.0018 & 0.0018 & 0.0017 \\
\hline Calcium & 933 & 2370 & 2500 & 2160 & 2150 & 3020 \\
\hline Chloride & 16100 & 39300 & 30900 & 48500 & 47400 & 33000 \\
\hline Chromium & 0.0141 & 0.0209 & 0.0155 & 0.0191 & 0.0192 & 0.0202 \\
\hline Iron & $<0.014$ & $<0.014$ & $<0.014$ & $<0.014$ & $<0.014$ & $<0.014$ \\
\hline Lead & $<0.001$ & $<0.001$ & $<0.001$ & $<0.001$ & $<0.001$ & $<0.001$ \\
\hline Magnesium & 635 & 1210 & 1480 & 1340 & 1340 & 1760 \\
\hline Mercury & $<0.001$ & $<0.001$ & $<0.001$ & $<0.001$ & $<0.001$ & $<0.001$ \\
\hline Nitrate & 14.9 & 16.3 & 13.2 & 25.5 & 25.5 & 19.9 \\
\hline Nitrite & $<0.0061$ & $<0.0061$ & $<0.0061$ & $<0.0061$ & $<0.0061$ & $<0.0061$ \\
\hline $\mathrm{pH}$ & 7.03 & 7.14 & 6.88 & 6.74 & 7.02 & 6.75 \\
\hline Potassium & 65.2 & 47.5 & 63.3 & 344 & 349 & 57.8 \\
\hline
\end{tabular}


Waste Isolation Pilot Plant 2002 Site Environmental Report DOE/WIPP 03-2225

Table 6.12 - Shallow Subsurface Water Analyses

\begin{tabular}{|c|c|c|c|c|c|c|}
\hline \multirow[b]{2}{*}{ Parameter } & \multicolumn{6}{|c|}{ Well ID } \\
\hline & C-2505 & C2506 & C-2507 & $\begin{array}{r}\text { C-2507 } \\
\text { (Dup.) }\end{array}$ & PZ-1 & PZ-2 \\
\hline Selenium & 0.123 & 0.0533 & 0.0839 & 0.0589 & 0.0579 & 0.0908 \\
\hline Silicon & 18.9 & 20.6 & 20 & 20.4 & 20.2 & 22.2 \\
\hline Silver & $<0.001$ & 0.0012 & $<0.001$ & 0.0012 & 0.0011 & 0.0011 \\
\hline Sodium & 7890 & 19000 & 13300 & 24600 & 24600 & 13600 \\
\hline Specific Gravity & 1.022 & 1.046 & 1.038 & 1.06 & 1.058 & 1.04 \\
\hline Sulfate & 1410 & 1420 & 1550 & 2550 & 2610 & 2040 \\
\hline Parameter & PZ-3 & $\mathrm{PZ}-4$ & PZ-5 & PZ-6 & PZ-6 (Dup.) & PZ-7 \\
\hline Total Dissolved Solids & 29700 & 69000 & 55200 & 86400 & 86400 & 61000 \\
\hline Total Inorganic Carbon & 40.3 & 43.7 & 33 & 43.6 & 44.3 & 40.4 \\
\hline Total Organic Carbon & 3.4 & 1.9 & 1.1 & 2.1 & 2.3 & 6.2 \\
\hline Total Suspended Solids & 11.8 & $<10$ & $<10$ & $<10$ & $<10$ & $<10$ \\
\hline Zinc & $<0.01$ & $<0.01$ & $<0.01$ & $<0.01$ & $<0.01$ & $<0.010$ \\
\hline
\end{tabular}

\begin{tabular}{|c|c|c|c|c|c|c|c|}
\hline Parameter & PZ-7 (Dup.) & PZ-9 & $P Z-10$ & $\mathrm{PZ}-11$ & $\mathrm{PZ}-12$ & PZ-12 (Dup.) & C-2811 \\
\hline Ammonium & 0.399 & 0.159 & 0.0145 & 0.116 & 0.826 & 0.854 & 0.0125 \\
\hline Arsenic & 0.00073 & $<0.0005$ & 0.0017 & 0.00088 & 0.0012 & 0.0014 & 0.0021 \\
\hline Barium & 0.0614 & 0.21 & 0.0484 & 0.229 & 0.116 & 0.113 & 0.102 \\
\hline \begin{tabular}{|l|} 
Boron \\
\end{tabular} & 0.03 & 0.082 & 0.29 & $<0.011$ & 0.13 & 0.097 & 0.17 \\
\hline Bromide & 9.1 & 35 & 2.2 & 17 & 4.2 & 4.1 & 1.9 \\
\hline Cadmium & 0.0017 & 0.005 & $<0.0001$ & 0.0047 & $<0.001$ & $<0.001$ & $<0.0001$ \\
\hline Calcium & 3030 & 3250 & 242 & 3430 & 769 & 771 & 272 \\
\hline Chloride & 33200 & 73800 & 445 & 55800 & 6250 & 6300 & 899 \\
\hline Chromium & 0.0209 & 0.0219 & 0.0019 & 0.0217 & 0.0166 & 0.0163 & 0.003 \\
\hline \begin{tabular}{|l|} 
Iron \\
\end{tabular} & $<0.014$ & $<0.014$ & 0.0042 & $<0.014$ & $<0.014$ & $<0.014$ & $<0.0014$ \\
\hline Lead & $<0.001$ & 0.004 & $<0.0001$ & 0.0014 & $<0.001$ & $<0.001$ & $<0.0001$ \\
\hline Magnesium & 1790 & 3360 & 163 & 2720 & 551 & 549 & 206 \\
\hline \begin{tabular}{|l|} 
Mercury \\
\end{tabular} & $<0.001$ & 0.0027 & $<0.0002$ & 0.0034 & $<0.001$ & $<0.001$ & $<0.0002$ \\
\hline \begin{tabular}{|l} 
Nitrate \\
\end{tabular} & 19.8 & 14 & 20.9 & 28.2 & 30.9 & 30.6 & 27.6 \\
\hline \begin{tabular}{|l|} 
Nitrite \\
\end{tabular} & $<0.0061$ & 0.0217 & 0.02 & $<0.0061$ & $<0.0061$ & 0.0207 & 0.0265 \\
\hline $\mathrm{PH}$ & 6.7 & 6.49 & 7.37 & 6.62 & 6.97 & 7.03 & 7.4 \\
\hline Potassium & 59 & 523 & 3.9 & 73.3 & 25 & 24.8 & 4.3 \\
\hline Selenium & 0.0904 & 0.0466 & 0.0256 & 0.0264 & 0.0372 & 0.0375 & 0.0246 \\
\hline Silicon & 22.2 & 14.8 & 21.7 & 18.2 & 21.3 & 21.2 & 21.8 \\
\hline Silver & 0.0011 & 0.0033 & $<0.0001$ & 0.0022 & $<0.001$ & $<0.001$ & $<0.0001$ \\
\hline Sodium & 13700 & 34800 & 178 & 26200 & 2280 & 2260 & 134 \\
\hline Specific Gravity & 1.042 & 1.086 & 1.004 & 1.068 & 1.01 & 1.012 & 1 \\
\hline Sulfate & 2010 & 3560 & 650 & 2410 & 815 & 809 & 355 \\
\hline Total Dissolved Solids & 59800 & 135000 & 2160 & 104000 & 12500 & 12500 & 2400 \\
\hline Total Inorganic Carbon & 39.5 & 41.4 & 99 & 34.5 & 71.6 & 72.3 & 50 \\
\hline Total Organic Carbon & 6 & 1.5 & 2.7 & 1.7 & 2.9 & 2.5 & 1.9 \\
\hline Total Suspended Solids & $<10$ & $<10$ & 29.3 & $<10$ & $<10$ & $<10$ & $<10$ \\
\hline Zinc & $<0.01$ & $<0.01$ & $<0.001$ & $<0.01$ & $<0.01$ & $<0.01$ & $<0.001$ \\
\hline
\end{tabular}

Note:

" $<$ " denotes concentration is below method detection limit of value indicated

All concentrations are reported in milligrams per liter ( $\mathrm{mg} / \mathrm{L})$ 


\section{Waste Isolation Pilot Plant 2002 Site Environmental Report DOE/WIPP 03-2225}

Table 6.13 - Shallow Subsurface Water Level Measurements

\begin{tabular}{|c|c|c|c|c|}
\hline Well Number & Date & $\begin{array}{l}\text { Casing Elevation } \\
\text { (AMSL*) }\end{array}$ & $\begin{array}{l}\text { Depth to Water } \\
\text { (Feet) }\end{array}$ & $\begin{array}{c}\text { Water Level } \\
\text { Elevation (AMSL) }\end{array}$ \\
\hline C-2505 & $1 / 31 / 02$ & 3413.05 & 45.81 & 3367.24 \\
\hline C-2505 & $2 / 28 / 02$ & 3413.05 & 45.54 & 3367.51 \\
\hline C-2505 & $3 / 25 / 02$ & 3413.05 & 45.73 & 3367.32 \\
\hline C-2505 & $4 / 29 / 02$ & 3413.05 & 45.65 & 3367.4 \\
\hline C-2505 & $5 / 30 / 02$ & 3413.05 & 45.73 & 3367.32 \\
\hline C-2505 & $6 / 25 / 02$ & 3413.05 & 45.96 & 3367.09 \\
\hline C-2505 & $7 / 29 / 02$ & 3413.05 & 45.77 & 3367.28 \\
\hline C-2505 & $8 / 15 / 02$ & 3413.05 & 45.61 & 3367.44 \\
\hline C-2505 & $9 / 12 / 02$ & 3413.05 & 45.49 & 3367.56 \\
\hline C-2505 & $10 / 10 / 02$ & 3413.05 & 45.55 & 3367.5 \\
\hline C-2505 & $11 / 6 / 02$ & 3413.05 & 45.64 & 3367.41 \\
\hline C-2505 & $12 / 4 / 02$ & 3413.05 & 45.53 & 3367.52 \\
\hline C-2506 & $1 / 31 / 02$ & 3412.87 & 45.2 & 3367.67 \\
\hline C-2506 & $2 / 28 / 02$ & 3412.87 & 44.86 & 3368.01 \\
\hline C-2506 & $3 / 25 / 02$ & 3412.87 & 45.09 & 3367.78 \\
\hline C-2506 & $4 / 29 / 02$ & 3412.87 & 45.02 & 3367.85 \\
\hline C-2506 & $5 / 30 / 02$ & 3412.87 & 45.06 & 3367.81 \\
\hline C-2506 & $6 / 25 / 02$ & 3412.87 & 45.32 & 3367.55 \\
\hline C-2506 & $7 / 29 / 02$ & 3412.87 & 45.13 & 3367.74 \\
\hline C-2506 & $8 / 15 / 02$ & 3412.87 & 45 & 3367.87 \\
\hline C-2506 & $9 / 12 / 02$ & 3412.87 & 44.89 & 3367.98 \\
\hline C-2506 & $10 / 10 / 02$ & 3412.87 & 44.93 & 3367.94 \\
\hline C-2506 & $11 / 6 / 02$ & 3412.87 & 45.01 & 3367.86 \\
\hline C-2506 & $12 / 4 / 02$ & 3412.87 & 44.9 & 3367.97 \\
\hline C-2507 & $1 / 31 / 02$ & 3410.01 & 46.12 & 3363.89 \\
\hline C-2507 & $2 / 28 / 02$ & 3410.01 & 45.88 & 3364.13 \\
\hline C-2507 & $3 / 25 / 02$ & 3410.01 & 46.1 & 3363.91 \\
\hline C-2507 & $4 / 29 / 02$ & 3410.01 & 46.02 & 3363.99 \\
\hline C-2507 & $5 / 30 / 02$ & 3410.01 & 46.01 & 3364 \\
\hline C-2507 & $6 / 25 / 02$ & 3410.01 & 46.22 & 3363.79 \\
\hline C-2507 & $7 / 29 / 02$ & 3410.01 & 46.02 & 3363.99 \\
\hline C-2507 & $8 / 15 / 02$ & 3410.01 & 45.85 & 3364.16 \\
\hline C-2507 & $9 / 12 / 02$ & 3410.01 & 45.62 & 3364.39 \\
\hline C-2507 & $10 / 10 / 02$ & 3410.01 & 45.59 & 3364.42 \\
\hline C-2507 & $111 / 6 / 02$ & 3410.01 & 45.64 & 3364.37 \\
\hline C-2507 & $12 / 4 / 02$ & 3410.01 & 45.6 & 3364.41 \\
\hline $\begin{array}{l}P Z-1 \\
\end{array}$ & $1 / 31 / 02$ & 3413.41 & 42.54 & 3370.87 \\
\hline PZ-1 & $2 / 28 / 02$ & 3413.41 & 42.13 & 3371.28 \\
\hline PZ-1 & $3 / 25 / 02$ & 3413.41 & 42.32 & 3371.09 \\
\hline PZ-1 & $4 / 29 / 02$ & 3413.41 & 42.29 & 3371.12 \\
\hline$P Z-1$ & $5 / 30 / 02$ & 3413.41 & 42.3 & 3371.11 \\
\hline $\begin{array}{l}\mathrm{PZZ}-1 \\
\end{array}$ & $6 / 25 / 02$ & 3413.41 & 42.5 & 3370.91 \\
\hline PZ-1 & $7 / 29 / 02$ & 3413.41 & 42.45 & 3370.96 \\
\hline PZ-1 & $8 / 15 / 02$ & 3413.41 & 42.44 & 3370.97 \\
\hline PZ-1 & $9 / 12 / 02$ & 3413.41 & 42.51 & 3370.9 \\
\hline PZ-1 & $10 / 10 / 02$ & 3413.41 & 42.56 & 3370.85 \\
\hline $\begin{array}{l}P Z-1 \\
\end{array}$ & $11 / 6 / 02$ & 3413.41 & 42.64 & 3370.77 \\
\hline PZ-1 & $12 / 4 / 02$ & 3413.41 & 42.55 & 3370.86 \\
\hline PZ-2 & $1 / 31 / 02$ & 3413.42 & 43.72 & 3369.7 \\
\hline PZ-2 & $2 / 28 / 02$ & 3413.42 & 43.45 & 3369.97 \\
\hline PZ-2 & $3 / 25 / 02$ & 3413.42 & 43.6 & 3369.82 \\
\hline
\end{tabular}




\section{Waste Isolation Pilot Plant 2002 Site Environmental Report DOE/WIPP 03-2225}

Table 6.13 - Shallow Subsurface Water Level Measurements

\begin{tabular}{|c|c|c|c|c|}
\hline Well Number & Date & $\begin{array}{c}\text { Casing Elevation } \\
\text { (AMSL*) }\end{array}$ & $\begin{array}{l}\text { Depth to Water } \\
\text { (Feet) }\end{array}$ & $\begin{array}{c}\text { Water Level } \\
\text { Elevation (AMSL) }\end{array}$ \\
\hline PZ-2 & $4 / 29 / 02$ & 3413.42 & 43.58 & 3369.84 \\
\hline PZ-2 & $5 / 30 / 02$ & 3413.42 & 43.6 & 3369.82 \\
\hline PZ-2 & $6 / 25 / 02$ & 3413.42 & 43.8 & 3369.62 \\
\hline PZ-2 & $7 / 29 / 02$ & 3413.42 & 43.72 & 3369.7 \\
\hline PZ-2 & $8 / 15 / 02$ & 3413.42 & 43.68 & 3369.74 \\
\hline PZ-2 & $9 / 12 / 02$ & 3413.42 & 43.85 & 3369.57 \\
\hline PZ-2 & $10 / 10 / 02$ & 3413.42 & 43.92 & 3369.5 \\
\hline PZ-2 & $11 / 6 / 02$ & 3413.42 & 44.08 & 3369.34 \\
\hline PZ-2 & $12 / 4 / 02$ & 3413.42 & 44.88 & 3368.54 \\
\hline PZ-3 & $1 / 31 / 02$ & 3416.15 & 45.51 & 3370.64 \\
\hline PZ-3 & $2 / 28 / 02$ & 3416.15 & 45.52 & 3370.63 \\
\hline PZ-3 & $3 / 25 / 02$ & 3416.15 & 45.44 & 3370.71 \\
\hline PZ-3 & $4 / 29 / 02$ & 3416.15 & 45.41 & 3370.74 \\
\hline PZ-3 & $5 / 30 / 02$ & 3416.15 & 45.71 & 3370.44 \\
\hline PZ-3 & $6 / 25 / 02$ & 3416.15 & 45.48 & 3370.67 \\
\hline PZ-3 & $7 / 29 / 02$ & 3416.15 & 45.34 & 3370.81 \\
\hline PZ-3 & $8 / 15 / 02$ & 3416.15 & 45.29 & 3370.86 \\
\hline PZ-3 & $9 / 12 / 02$ & 3416.15 & 45.44 & 3370.71 \\
\hline PZ-3 & $10 / 10 / 02$ & 3416.15 & 45.49 & 3370.66 \\
\hline PZ-3 & $11 / 6 / 02$ & 3416.15 & 45.63 & 3370.52 \\
\hline PZ-3 & $12 / 4 / 02$ & 3416.15 & 45.45 & 3370.7 \\
\hline PZ-4 & $1 / 31 / 02$ & 3412.1 & 48 & 3364.1 \\
\hline PZ-4 & $2 / 28 / 02$ & 3412.1 & 47.77 & 3364.33 \\
\hline PZ-4 & $3 / 25 / 02$ & 3412.1 & 48 & 3364.1 \\
\hline PZ-4 & $4 / 29 / 02$ & 3412.1 & 47.93 & 3364.17 \\
\hline PZ-4 & $5 / 30 / 02$ & 3412.1 & 47.93 & 3364.17 \\
\hline PZ-4 & $6 / 25 / 02$ & 3412.1 & 47.12 & 3364.98 \\
\hline PZ-4 & $7 / 29 / 02$ & 3412.1 & 46.91 & 3365.19 \\
\hline PZ-4 & $8 / 15 / 02$ & 3412.1 & 47.74 & 3364.36 \\
\hline PZ-4 & 9/12/02 & 3412.1 & 47.62 & 3364.48 \\
\hline PZ-4 & $10 / 10 / 02$ & 3412.1 & 47.63 & 3364.47 \\
\hline PZ-4 & $11 / 6 / 02$ & 3412.1 & 47.74 & 3364.36 \\
\hline PZ-4 & $12 / 4 / 02$ & 3412.1 & 47.61 & 3364.49 \\
\hline PZ-5 & $1 / 31 / 02$ & 3415.31 & 43.2 & 3372.11 \\
\hline PZ-5 & $2 / 28 / 02$ & 3415.31 & 42.9 & 3372.41 \\
\hline PZ-5 & $3 / 25 / 02$ & 3415.31 & 43.05 & 3372.26 \\
\hline PZ-5 & $4 / 29 / 02$ & 3415.31 & 43.05 & 3372.26 \\
\hline PZ-5 & $5 / 30 / 02$ & 3415.31 & 43.21 & 3372.1 \\
\hline PZ-5 & $6 / 25 / 02$ & 3415.31 & 43.22 & 3372.09 \\
\hline PZ-5 & $7 / 29 / 02$ & 3415.31 & 43.14 & 3372.17 \\
\hline PZ-5 & $8 / 15 / 02$ & 3415.31 & 43.12 & 3372.19 \\
\hline PZ-5 & $9 / 12 / 02$ & 3415.31 & 43.27 & 3372.04 \\
\hline PZ-5 & $10 / 10 / 02$ & 3415.31 & 43.33 & 3371.98 \\
\hline PZ-5 & $11 / 6 / 02$ & 3415.31 & 43.43 & 3371.88 \\
\hline PZ-5 & $12 / 4 / 02$ & 3415.31 & 43.26 & 3372.05 \\
\hline PZ-6 & $1 / 31 / 02$ & 3413.49 & 43.65 & 3369.84 \\
\hline PZ-6 & $2 / 28 / 02$ & 3413.49 & 43.4 & 3370.09 \\
\hline PZ-6 & $3 / 25 / 02$ & 3413.49 & 43.54 & 3369.95 \\
\hline PZ-6 & $4 / 29 / 02$ & 3413.49 & 43.59 & 3369.9 \\
\hline PZ-6 & $5 / 30 / 02$ & 3413.49 & 43.81 & 3369.68 \\
\hline PZ-6 & $6 / 25 / 02$ & 3413.49 & 43.84 & 3369.65 \\
\hline
\end{tabular}




\section{Waste Isolation Pilot Plant 2002 Site Environmental Report DOE/WIPP 03-2225}

Table 6.13 - Shallow Subsurface Water Level Measurements

\begin{tabular}{|c|c|c|c|c|}
\hline Well Number & Date & $\begin{array}{l}\text { Casing Elevation } \\
\text { (AMSL*) }\end{array}$ & $\begin{array}{l}\text { Depth to Water } \\
\text { (Feet) }\end{array}$ & $\begin{array}{c}\text { Water Level } \\
\text { Elevation (AMSL) }\end{array}$ \\
\hline PZ-6 & $7 / 29 / 02$ & 3413.49 & 43.74 & 3369.75 \\
\hline PZ-6 & $8 / 15 / 02$ & 3413.49 & 43.66 & 3369.83 \\
\hline PZ-6 & $9 / 12 / 02$ & 3413.49 & 43.65 & 3369.84 \\
\hline PZ-6 & $10 / 10 / 02$ & 3413.49 & 43.68 & 3369.81 \\
\hline PZ-6 & $11 / 6 / 02$ & 3413.49 & 43.74 & 3369.75 \\
\hline PZ-6 & $12 / 4 / 02$ & 3413.49 & 43.65 & 3369.84 \\
\hline PZ-7 & $1 / 31 / 02$ & 3413.99 & 37.32 & 3376.67 \\
\hline PZ-7 & $2 / 28 / 02$ & 3413.99 & 36.98 & 3377.01 \\
\hline PZ-7 & $3 / 25 / 02$ & 3413.99 & 37.07 & 3376.92 \\
\hline PZ-7 & $4 / 29 / 02$ & 3413.99 & 37.09 & 3376.9 \\
\hline PZ-7 & $5 / 30 / 02$ & 3413.99 & 37.06 & 3376.93 \\
\hline PZ-7 & $6 / 25 / 02$ & 3413.99 & 37.24 & 3376.75 \\
\hline PZ-7 & $7 / 29 / 02$ & 3413.99 & 37.24 & 3376.75 \\
\hline PZ-7 & $8 / 15 / 02$ & 3413.99 & 37.19 & 3376.8 \\
\hline PZ-7 & $9 / 12 / 02$ & 3413.99 & 37.49 & 3376.5 \\
\hline PZ-7 & $10 / 10 / 02$ & 3413.99 & 37.58 & 3376.41 \\
\hline PZ-7 & $11 / 6 / 02$ & 3413.99 & 37.78 & 3376.21 \\
\hline PZ-7 & $12 / 4 / 02$ & 3413.99 & 37.61 & 3376.38 \\
\hline PZ-9 & $1 / 31 / 02$ & 3421.21 & 57.87 & 3363.34 \\
\hline PZ-9 & $2 / 28 / 02$ & 3421.21 & 57.61 & 3363.6 \\
\hline PZ-9 & $3 / 25 / 02$ & 3421.21 & 57.78 & 3363.43 \\
\hline PZ-9 & $4 / 29 / 02$ & 3421.21 & 57.32 & 3363.89 \\
\hline PZ-9 & $5 / 30 / 02$ & 3421.21 & 57.6 & 3363.61 \\
\hline PZ-9 & $6 / 25 / 02$ & 3421.21 & 57.83 & 3363.38 \\
\hline PZ-9 & $7 / 29 / 02$ & 3421.21 & 57.67 & 3363.54 \\
\hline PZ-9 & $8 / 15 / 02$ & 3421.21 & 57.59 & 3363.62 \\
\hline PZ-9 & $9 / 12 / 02$ & 3421.21 & 57.79 & 3363.42 \\
\hline PZ-9 & $10 / 10 / 02$ & 3421.21 & 57.75 & 3363.46 \\
\hline PZ-9 & $11 / 6 / 02$ & 3421.21 & 57.81 & 3363.4 \\
\hline PZ-9 & $12 / 4 / 02$ & 3421.21 & 57.26 & 3363.95 \\
\hline PZ-10 & $1 / 31 / 02$ & 3405.8 & 38.15 & 3367.65 \\
\hline PZ-10 & $2 / 28 / 02$ & 3405.8 & 37.9 & 3367.9 \\
\hline PZ-10 & $3 / 25 / 02$ & 3405.8 & 38.17 & 3367.63 \\
\hline PZ-10 & $4 / 29 / 02$ & 3405.8 & 37.74 & 3368.06 \\
\hline PZ-10 & $5 / 30 / 02$ & 3405.8 & 38.28 & 3367.52 \\
\hline PZ-10 & $6 / 25 / 02$ & 3405.8 & 38.57 & 3367.23 \\
\hline PZ-10 & $7 / 29 / 02$ & 3405.8 & 38.68 & 3367.12 \\
\hline PZ-10 & $8 / 15 / 02$ & 3405.8 & 38.47 & 3367.33 \\
\hline PZ-10 & $9 / 12 / 02$ & 3405.8 & 38.31 & 3367.49 \\
\hline$P Z-10$ & $10 / 10 / 02$ & 3405.8 & 38.34 & 3367.46 \\
\hline$P Z-10$ & $11 / 6 / 02$ & 3405.8 & 38.36 & 3367.44 \\
\hline PZ-10 & $12 / 4 / 02$ & 3405.8 & 38.19 & 3367.61 \\
\hline $\mathrm{PZ}-11$ & $1 / 31 / 02$ & 3418.95 & 45.31 & 3373.64 \\
\hline $\mathrm{PZ}-11$ & $2 / 28 / 02$ & 3418.95 & 45.04 & 3373.91 \\
\hline PZ-11 & $3 / 25 / 02$ & 3418.95 & 45.16 & 3373.79 \\
\hline PZ-11 & $4 / 29 / 02$ & 3418.95 & 45.13 & 3373.82 \\
\hline PZ-11 & $5 / 30 / 02$ & 3418.95 & 45.11 & 3373.84 \\
\hline PZ-11 & $6 / 25 / 02$ & 3418.95 & 45.38 & 3373.57 \\
\hline PZ-11 & $7 / 29 / 02$ & 3418.95 & 45.37 & 3373.58 \\
\hline $\mathrm{PZ}-11$ & $8 / 15 / 02$ & 3418.95 & 45.3 & 3373.65 \\
\hline $\mathrm{PZ}-11$ & $9 / 12 / 02$ & 3418.95 & 45.54 & 3373.41 \\
\hline
\end{tabular}


Waste Isolation Pilot Plant 2002 Site Environmental Report DOE/WIPP 03-2225

Table 6.13 - Shallow Subsurface Water Level Measurements

\begin{tabular}{|c|r|r|r|r|}
\hline Well Number & \multicolumn{1}{|c|}{ Date } & $\begin{array}{c}\text { Casing Elevation } \\
\text { (AMSL*) }\end{array}$ & $\begin{array}{c}\text { Depth to Water } \\
\text { (Feet) }\end{array}$ & $\begin{array}{c}\text { Water Level } \\
\text { Elevation (AMSL) }\end{array}$ \\
\hline $\mathrm{PZ}-11$ & $10 / 10 / 02$ & 3418.95 & 45.56 & 3373.39 \\
\hline $\mathrm{PZ}-11$ & $11 / 6 / 02$ & 3418.95 & 45.74 & 3373.21 \\
\hline $\mathrm{PZ}-11$ & $12 / 4 / 02$ & 3418.95 & 54.63 & 3373.32 \\
\hline $\mathrm{PZ}-12$ & $1 / 31 / 02$ & 3408.99 & 53.87 & 3354.87 \\
\hline $\mathrm{PZ}-12$ & $2 / 28 / 02$ & 3408.99 & 54.26 & 3355.12 \\
\hline $\mathrm{PZ}-12$ & $3 / 25 / 02$ & 3408.99 & 54.15 & 3354.73 \\
\hline $\mathrm{PZ}-12$ & $4 / 29 / 02$ & 3408.99 & 54.03 & 3354.94 \\
\hline $\mathrm{PZ}-12$ & $5 / 30 / 02$ & 3408.99 & 54.44 & 3354.55 \\
\hline $\mathrm{PZ}-12$ & $6 / 25 / 02$ & 3408.99 & 53.97 & 3355.02 \\
\hline $\mathrm{PZ}-12$ & $7 / 29 / 02$ & 3408.99 & 53.6 & 3355.39 \\
\hline $\mathrm{PZ}-12$ & $8 / 15 / 02$ & 3408.99 & 53.15 & 3355.84 \\
\hline $\mathrm{PZ}-12$ & $9 / 12 / 02$ & 3408.99 & 53.17 & 3355.82 \\
\hline $\mathrm{PZ}-12$ & $10 / 10 / 02$ & 3408.99 & 53.4 & 3355.59 \\
\hline $\mathrm{PZ}-12$ & $11 / 6 / 02$ & 3408.99 & 53.28 & 3355.71 \\
\hline $\mathrm{PZ}-12$ & $12 / 4 / 02$ & 3408.99 & 61.7 & 3337.22 \\
\hline $\mathrm{C}-2811$ & $1 / 31 / 02$ & 3398.92 & 61.37 & 3337.55 \\
\hline $\mathrm{C}-2811$ & $2 / 28 / 02$ & 3398.92 & 61.68 & 3337.24 \\
\hline $\mathrm{C}-2811$ & $3 / 25 / 02$ & 3398.92 & 61.46 & 3337.46 \\
\hline $\mathrm{C}-2811$ & $4 / 29 / 02$ & 3398.92 & 61.41 & 3337.51 \\
\hline $\mathrm{C}-2811$ & $5 / 30 / 02$ & 3398.92 & 61.59 & 3337.33 \\
\hline $\mathrm{C}-2811$ & $6 / 25 / 02$ & 3398.92 & 61.53 & 3337.39 \\
\hline $\mathrm{C}-2811$ & $7 / 29 / 02$ & 3398.92 & 61.35 & 3337.57 \\
\hline $\mathrm{C}-2811$ & $8 / 15 / 02$ & 3398.92 & 60.92 & 3337.68 \\
\hline $\mathrm{C}-2811$ & $9 / 12 / 02$ & 3398.92 & 60.93 & 3338 \\
\hline $\mathrm{C}-2811$ & $10 / 10 / 02$ & 3398.92 & & 3337.99 \\
\hline $\mathrm{C}-2811$ & $11 / 6 / 02$ & 3398.92 & 3338.16 \\
\hline $\mathrm{C}-2811$ & $12 / 4 / 02$ & 3398.92 & & \\
\hline
\end{tabular}

* AMSL - Above mean sea level 


\section{CHAPTER 7 - RADIOLOGICAL DOSE ASSESSMENT}

It is the policy of DOE ". . . to conduct its operations in an environmentally safe and sound manner. Protection of the environment and the public are responsibilities of paramount importance and concern to DOE" (DOE Order 5400.1). In addition, DOE Order 5400.5 states, "It is also a DOE objective that potential exposures to members of the public be as far below the limits as is reasonably achievable. ..."

Chapter 4 of this report summarized the amount of radioactivity in air emissions and other media sampled in the WIPP environment in 2002. It is the purpose of this chapter to summarize the air emission levels in regard to the potential dose from WIPP operations.

Specifically, this chapter summarizes:

- Regulatory requirements on emissions of radionuclides, effective dose equivalents, and use of CAP88-PC computer model;

- The national average dose from naturally occurring sources of radiation;

- $\quad$ The estimated dose from air emissions from WIPP;

- The total potential dose from WIPP operations; and

- $\quad$ Potential doses to nonhuman biota from radioactivity measured near WIPP.

\subsection{Introduction and Dose Limits}

Title 40 CFR Part 61, Subpart H, "National Emission Standards for Emissions of Radionuclides Other than Radon from Department of Energy Facilities," states "Emissions of radionuclides to the ambient air from Department of Energy facilities shall not exceed those amounts that would cause any member of the public to receive in any year an effective dose equivalent of $10 \mathrm{mrem} /$ year."

Compliance with the above regulatory requirement is determined by measuring effluent flow rate; monitoring, extracting, collecting, and measuring radionuclides; and calculating the effective dose equivalent (EDE). The EDE is the weighted sum of the doses to the individual organs of the body. The dose to each organ is weighted according to the risk that dose represents. These organ doses are then added together, and that total is the effective dose equivalent. In this manner, the risk from different sources of radiation can be controlled by a single standard.

Calculating the EDE to members of the public requires the use of CAP88-PC or other EPA approved computer models and procedures. The WIPP Effluent Monitoring Program generally uses CAP88-PC. CAP88-PC is a set of computer programs, datasets and associated utility programs for estimation of dose and risk from radionuclide air emissions. CAP88-PC uses a Gaussian Plume dispersion model, which 
predicts air concentrations, deposition rates, concentrations in food, and intake rates for people. CAP88-PC estimates dose and risk to individuals and populations from multiple pathways. Dose and risk is calculated for ingestion, inhalation, ground level air immersion, and ground surface irradiation exposure pathways.

Environmental radiation protection standards for the management and disposal of TRU wastes set limits on the total annual radiation dose equivalent to members of the public at $0.25 \mathrm{mSv}(25 \mathrm{mrem})$ to the whole body and $0.75 \mathrm{mSv}$ (75 mrem) to any critical organ (40 CFR §191.03). National standards for emissions of radionuclides from DOE facilities state that the maximum annual dose equivalent to any member of the public from air emissions must be no greater than $0.1 \mathrm{mSv}$ (10 mrem) (40 CFR §61.92). The SDWA (40 CFR §141.16) states that average annual concentrations of beta- and gamma-emitting human-made radionuclides in drinking water shall not result in an annual dose equivalent greater than $0.04 \mathrm{mSv}(4 \mathrm{mrem})$. It is important to note that all of these dose equivalent limits are set for radionuclides released to the environment from DOE operations. They do not include, but are limits in addition to, doses from natural background radiation or from medical procedures.

\subsection{Background Radiation}

Radiation is a naturally occurring phenomenon that has been in the environment since the beginning of time. There are several sources of natural radiation: cosmic and cosmogenic radiation (from outer space and the earth's atmosphere), terrestrial radiation (from the earth's crust), and internal radiation (naturally occurring radiation in our bodies, such as ${ }^{40} \mathrm{~K}$ ). The most common sources of terrestrial radiation are uranium, thorium, and their decay products. Potassium-40 is another source of terrestrial radiation. While not a major radiation source, ${ }^{40} \mathrm{~K}$ may be enhanced in the southeastern New Mexico environment due to local potash mining. Radon gas, a decay product of uranium, is the most widely known naturally occurring terrestrial radionuclide. In addition to natural radioactivity, small amounts of radioactivity from above-ground nuclear weapons tests that occurred from 1945 through 1980 and the 1986 Chernobyl nuclear accident are also present in the environment. Together, these sources of radiation are called "background" radiation. Every human is constantly exposed to background radiation. Exposure to radioactivity from weapons testing fallout is quite small compared to natural radioactivity and continually gets smaller as radionuclides decay.

Naturally occurring radiation in our environment can deliver both internal and external doses. Internal dose is received as a result of the intake of radionuclides. The major routes of intake of radionuclides for members of the public are ingestion and inhalation. Ingestion includes the intake of the radionuclides from eating and drinking contaminated food or drink. Inhalation includes the intake of radionuclides through breathing dust particles containing radioactive materials or radon gas. External dose can occur from submersion in contaminated air or deposition of contaminants on surfaces. The average annual dose received by a member of the public from naturally occurring radionuclides is about $3 \mathrm{mSv}$ (300 mrem) (Table 7.1). 
Table 7.1 - Annual Estimated Average Radiation Dose Received by a Member of the Population of the United States from Naturally Occurring Radiation Sources (adapted from NCRP, 1987)

\begin{tabular}{|c|c|c|}
\hline \multirow[b]{2}{*}{ Source } & \multicolumn{2}{|c|}{ Average Annual Effective Dose Equivalent } \\
\hline & (mSv) & (mrem) \\
\hline Inhaled (Radon and Decay Products) & 2 & 200 \\
\hline Internal Radionuclides & 0.39 & 39 \\
\hline Terrestrial Radiation & 0.28 & 28 \\
\hline Cosmic Radiation & 0.27 & 27 \\
\hline Cosmogenic Radioactivity & 0.01 & 1 \\
\hline Rounded Total from Natural Sources & 3 & 300 \\
\hline
\end{tabular}

\subsection{Dose from Air Emissions}

The NESHAP issued by the EPA set limits for radionuclide emissions to air (40 CFR Part 61, Subpart H). Compliance procedures for DOE facilities (40 CFR §61.93[a]) require the use of CAP88-PC or AIRDOS-PC computer models, or an equivalent, to calculate dose to members of the public. For the determination of the radiation dose received by members of the public, WIPP used the computer model CAP88-PC, version 2.0. Source term input for the program was determined by radiochemical analyses of periodic air samples taken from the effluent Stations $A, B$, and $\mathrm{C}$ (see Section 4.1). Air samples were analyzed for ${ }^{241} \mathrm{Am},{ }^{239+240} \mathrm{Pu},{ }^{238} \mathrm{Pu}$, and ${ }^{90} \mathrm{Sr}$ because they constitute over 98 percent of the dose potential from $\mathrm{CH}$ waste. Measured activity values greater than the MDC were used as a part of the source term for the air emission pathway and, for measured results less than the MDC, the MDC value was used as part of the source term (see Table 4.1). CAP88-PC dose calculations are based on the assumption that exposed persons remain at home during the entire year and all vegetables, milk, and meat consumed are home produced. Thus, this dose calculation is a maximum potential dose which encompasses dose from inhalation, submersion, deposition, and ingestion of air emitted radionuclides.

For 2002, the CAP88-PC model predicted the highest dose to someone residing near WIPP to be at the Smith Ranch approximately $8 \mathrm{~km}(5 \mathrm{mi})$ west-northwest of WIPP. Results showed the whole body dose potentially received by someone residing at this location to be about $7.61 \times 10^{-8} \mathrm{mSv}\left(7.61 \times 10^{-6} \mathrm{mrem}\right)$ per year.

\subsection{Total Potential Dose from WIPP Operations}

The radiation dose equivalent received by members of the public as a result of the management and storage of TRU radioactive wastes at any disposal facility operated by the DOE is regulated under 40 CFR Part 191, Subpart A. Specific standards state that the combined annual dose equivalent to any member of the public in the general 
environment shall not exceed $0.25 \mathrm{mSv}(25 \mathrm{mrem})$ to the whole body and $0.75 \mathrm{mSv}$ (75 mrem) to any critical organ. Section 7.3 discussed the potential dose equivalent received from radionuclides released to the air from WIPP. The following sections discuss the potential dose equivalent through other pathways and the total potential dose equivalent a member of the public may have received from WIPP operations during 2002.

\subsubsection{Potential Dose from Water Ingestion Pathway}

The potential dose to individuals from the ingestion of WIPP-related radionuclides transported in water is estimated to be nonexistent for several reasons. Drinking water for communities near WIPP comes from groundwater sources which are not expected to be affected by potential WIPP contaminants based on current radionuclide transport scenarios summarized in DOE/WIPP 95-2065). The only credible pathway for contaminants from WIPP to accessible groundwater is through the Culebra Member of the Rustler Formation as stated in DOE/CAO 96-2184. Water from the Culebra is naturally not potable due to high levels of TDS. Water from the Dewey Lake Formation is suitable for livestock consumption having TDS values below 10,000 mg/L.

Groundwater and surface water samples collected around WIPP during 2002 did not contain radionuclide concentrations discernable from those in samples collected prior to WIPP receiving waste.

\subsubsection{Potential Dose from Wild Game Ingestion}

Game animals sampled during 2002 were mule deer, quail, and fish. The only radionuclides detected were not different from background levels measured prior to commencement of waste shipments to WIPP. Therefore, no dose from WIPP-related radionuclides is estimated to have been received by any individual from this pathway during 2002.

\subsubsection{Total Potential Dose from All Pathways}

The only pathway for which a dose could be estimated was that of air emissions. Air emissions from WIPP were not above background ambient air levels. Estimated concentrations of radionuclides in air emissions accounted for the calculable dose from WIPP operations during 2002. The effective dose equivalent potentially received by the maximally exposed individual residing $8 \mathrm{~km}(5 \mathrm{mi})$ west-northwest of WIPP was calculated to be $7.61 \times 10^{-8} \mathrm{mSv}\left(7.61 \times 10^{-6} \mathrm{mrem}\right)$ per year whole body. This value is in compliance with the requirements of $0.1 \mathrm{mSv}(10 \mathrm{mrem})$ per year as specified in 40 CFR §61.92. The total radiological dose and atmospheric release at WIPP in 2002 is summarized in Table 7.2. 
Waste Isolation Pilot Plant 2002 Site Environmental Report DOE/WIPP 03-2225

Table 7.2 - WIPP Radiological Dose and Release Summary

\begin{tabular}{|c|c|c|c|}
\hline \multicolumn{4}{|c|}{ WIPP Radiological Atmospheric Releases ${ }^{\text {a }}$ During 2002} \\
\hline${ }^{238} \mathrm{c}, \mathrm{cu}$ & ${ }^{239+240} \mathrm{Pu}$ & ${ }^{241} \mathrm{Am}$ & ${ }^{90} \mathrm{Sr}$ \\
\hline $1.30 \times 10^{-7} \mathrm{Ci}$ & $8.10 \times 10^{-8} \mathrm{Ci}$ & $7.10 \times 10^{-8} \mathrm{Ci}$ & $4.00 \times 10^{-6} \mathrm{Ci}$ \\
$4.81 \times 10^{3} \mathrm{~Bq}$ & $3.00 \times 10^{3} \mathrm{~Bq}$ & $2.63 \times 10^{3} \mathrm{~Bq}$ & $1.48 \times 10^{5} \mathrm{~Bq}$ \\
\hline
\end{tabular}

\begin{tabular}{|c|c|c|c|c|c|c|c|}
\hline \multicolumn{8}{|c|}{ WIPP Radiological Dose Reporting Table in 2002 per CFR $\$ 61.92$} \\
\hline \multirow[t]{2}{*}{ Pathway } & \multicolumn{2}{|c|}{$\begin{array}{c}\text { Effective Dose Equivalent } \\
\text { to the Maximally Exposed } \\
\text { Individual } \\
\text { at } 7500 \text { Meters WNW }\end{array}$} & \multirow[t]{2}{*}{$\begin{array}{c}\% \text { of EPA } \\
10-m r e m / \\
\text { year limit to } \\
\text { member of } \\
\text { the public }\end{array}$} & \multicolumn{2}{|c|}{$\begin{array}{l}\text { Estimated Population Dose } \\
\text { within } 50 \text { miles }\end{array}$} & \multirow[t]{2}{*}{$\begin{array}{l}\text { Estimated } \\
\text { Population } \\
\text { within } \\
50 \text { miles }\end{array}$} & \multirow{2}{*}{$\begin{array}{c}\begin{array}{c}\text { Estimated } \\
\text { Natural } \\
\text { Radiation } \\
\text { Population } \\
\text { Dose }^{d}\end{array} \\
\text { (person-rem) }\end{array}$} \\
\hline & (mrem/year) & (mSv/year) & & $\begin{array}{l}\text { (person- } \\
\text { rem/year) }\end{array}$ & $\begin{array}{l}\text { (person- } \\
\text { Sv/year) }\end{array}$ & & \\
\hline Air & $7.61 \times 10^{-6}$ & $7.61 \times 10^{-8}$ & $7.61 \times 10^{-5}$ & $1.66 \times 10^{-5}$ & $1.66 \times 10^{-7}$ & 78959 & 23688 \\
\hline
\end{tabular}

\begin{tabular}{|c|c|c|c|c|c|c|}
\hline \multicolumn{7}{|c|}{ WIPP Radiological Dose Reporting Table in 2002 per 40 CFR §191.03(b) } \\
\hline \multirow[t]{2}{*}{ Pathway } & \multicolumn{2}{|c|}{$\begin{array}{l}\text { Dose equivalent to the } \\
\text { receptor's whole body } \\
\text { resides year-round at WIPP } \\
\text { fence line } 350 \text { meters NW }\end{array}$} & \multirow[t]{2}{*}{$\begin{array}{c}\text { \% of EPA } \\
25-\text { mrem/year } \\
\text { whole body } \\
\text { limit }\end{array}$} & \multicolumn{2}{|c|}{$\begin{array}{l}\text { Dose equivalent to the } \\
\text { receptor's critical organ } \\
\text { resides year-round at WIPP } \\
\text { fence line } 350 \text { meters NW }\end{array}$} & \multirow[t]{2}{*}{$\begin{array}{c}\% \text { of EPA } \\
75 \text {-mrem/year } \\
\text { critical organ limit }\end{array}$} \\
\hline & (mrem/year) & (mSv/year) & & (mrem/year) & (mSv/year) & \\
\hline Air & $1.51 \times 10^{-4}$ & $1.51 \times 10^{-6}$ & $6.04 \times 10^{-4}$ & $2.46 \times 10^{-3}$ & $2.46 \times 10^{-5}$ & $3.28 \times 10^{-3}$ \\
\hline
\end{tabular}

${ }^{a}$ Total releases from the combination of Effluent Stations $A, B$, and C

${ }^{\mathrm{b}}$ Curies $=\mathrm{Ci}$

${ }^{\mathrm{C}}$ Becquerels $=\mathrm{Bq}$

${ }^{\mathrm{d}}$ Estimated natural radiation populations dose $=($ Estimated population within 50 miles $) \times(300 \mathrm{mrem} / \mathrm{year})$

In compliance with 40 CFR Part 191, Subpart A, the receptor selected resides year-round at the WIPP fence line located 350 meters in the NW sector. The dose to this receptor is estimated to be $1.51 \times 10^{-6} \mathrm{mSv}\left(1.51 \times 10^{-4} \mathrm{mrem}\right)$ per year whole body and $2.46 \times 10^{-5} \mathrm{mSv}\left(2.46 \times 10^{-3} \mathrm{mrem}\right)$ per year to the critical organ. These values are in compliance with the requirements of $0.25 \mathrm{mSv}(25 \mathrm{mrem})$ and $0.75 \mathrm{mSv}(75 \mathrm{mrem})$ per year to the critical organ as specified in 40 CFR §191.03(b).

\subsection{Dose to Nonhuman Biota}

DOE Order 5400.5 lists the environmental radiation protection requirements that WIPP must meet to protect aquatic animals. In addition, dose limits below which no deleterious effects on populations of aquatic and terrestrial organisms have been observed have been discussed in NCRP Report No. 109, Effects of lonizing Radiation on Aquatic Organisms, (NCRP, 1991) and the International Atomic Energy Agency (IAEA Technical Report Series No. 332). Those dose limits are:

- Aquatic animals - $10 \mathrm{mGy} / \mathrm{d}(1 \mathrm{rad} / \mathrm{d})$

- Terrestrial plants $-10 \mathrm{mGy} / \mathrm{d}(1 \mathrm{rad} / \mathrm{d})$

- Terrestrial animals $-1 \mathrm{mGy} / \mathrm{d}(0.1 \mathrm{rad} / \mathrm{d})$ 
The DOE has considered proposing these dose standards for aquatic and terrestrial biota under proposed rule 10 CFR Part 834, "Radiation Protection of the Public and the Environment" but has delayed until guidance for demonstrating compliance was developed. DOE-STD-1153-2002 was developed to meet this need. The DOE requires reporting of radiation doses to nonhuman biota in the annual SER using DOE-STD-1153-2002.

The new Technical Standard uses a multiphase approach, including an initial screening phase with conservative assumptions. Software is provided with the new Technical Standard to conduct the screening evaluation. In the initial screen, Biota Concentration Guides (BCGs) are derived using very conservative assumptions for a variety of generic organisms. Maximum concentrations of radionuclides detected in soil, sediment, and water during environmental monitoring are divided by the BCGs and the results are summed for each organism (DOE-STD-1153-2002). If the sum of these fractions is less than 1 , the site is deemed to have passed the screen and no further action is required. This screening evaluation is intended to provide a very conservative evaluation of whether the site is in compliance with the recommended limits.

This guidance was used to screen radionuclide concentrations observed around WIPP during 2002 using the maximum radionuclide concentrations listed in Table 7.3. The sum of fractions was less than one for all media, demonstrating compliance with the proposed rule. Radiation in the environment surrounding WIPP does not have a deleterious effect on populations of plants and animals.

\subsection{Release of Property Containing Residual Radioactive Material}

There was no release of radiologically contaminated materials or property in 2002 . The potential for release of contaminated materials or property at WIPP is based on DOE Order 5400.5, and contractor institutional controls. 


\section{Waste Isolation Pilot Plant 2002 Site Environmental Report DOE/WIPP 03-2225}

Table 7.3 - General Screening Results for Potential Radiation Dose to Nonhuman Biota from Radionuclide Concentrations in Surface Water (Bq/L), Sediment (Bq/g), and Soil (Bq/g) Near the WIPP Site. Maximum detected concentrations were compared with $B C G^{a}$ values to assess potential dose to biota. As long as the sum of the ratios between observed maximum concentrations and the associated BCG is below 1.0, no adverse effects on plant or animal populations are expected (DOE-STD-1153-2002).

\begin{tabular}{|c|c|c|c|c|}
\hline Medium & Radionuclide & $\begin{array}{c}\text { Maximum } \\
\text { Observed } \\
\text { Concentration }\end{array}$ & BCG & Concentration/BCG \\
\hline \multicolumn{5}{|c|}{ Aquatic System Evaluation } \\
\hline \multirow[t]{6}{*}{ Sediment $(\mathrm{Bq} / \mathrm{g})$} & ${ }^{60} \mathrm{Co}$ & $6.85 \times 10^{-4}$ & $5.00 \times 10^{1}$ & $1.37 \times 10^{-5}$ \\
\hline & ${ }^{137} \mathrm{Cs}$ & $4.59 \times 10^{-2}$ & $1.00 \times 10^{2}$ & $4.59 \times 10^{-4}$ \\
\hline & ${ }^{234} U$ & $4.96 \times 10^{-2}$ & $2.00 \times 10^{2}$ & $2.48 \times 10^{-4}$ \\
\hline & ${ }^{235} \mathrm{U}$ & $2.12 \times 10^{-3}$ & $1.00 \times 10^{2}$ & $2.12 \times 10^{-5}$ \\
\hline & ${ }^{238} \mathrm{U}$ & $3.35 \times 10^{-2}$ & $9.00 \times 10^{1}$ & $3.72 \times 10^{-4}$ \\
\hline & ${ }^{241} \mathrm{Am}$ & $7.10 \times 10^{-4}$ & $2.00 \times 10^{2}$ & $3.55 \times 10^{-6}$ \\
\hline \multirow{7}{*}{ Water $^{\mathrm{b}}(\mathrm{Bq} / \mathrm{L})$} & ${ }^{60} \mathrm{Co}$ & $4.66 \times 10^{-1}$ & $1.00 \times 10^{2}$ & $4.66 \times 10^{-3}$ \\
\hline & ${ }^{137} \mathrm{Cs}$ & $3.23 \times 10^{-1}$ & $2.00 \times 10^{0}$ & $1.62 \times 10^{-1}$ \\
\hline & ${ }^{234} \mathrm{U}$ & $2.18 \times 10^{-1}$ & $7.00 \times 10^{0}$ & $3.11 \times 10^{-2}$ \\
\hline & ${ }^{235} \mathrm{U}$ & $6.51 \times 10^{-3}$ & $8.00 \times 10^{0}$ & $8.14 \times 10^{-3}$ \\
\hline & ${ }^{238} U$ & $1.08 \times 10^{-1}$ & $8.00 \times 10^{0}$ & $1.35 \times 10^{-2}$ \\
\hline & ${ }^{241} \mathrm{Am}$ & $6.51 \times 10^{-4}$ & $2.00 \times 10^{1}$ & $3.26 \times 10^{-5}$ \\
\hline & & & Sum of Fractions & $2.21 \times 10^{-1}$ \\
\hline \multicolumn{5}{|c|}{ Terrestrial System Evaluation } \\
\hline \multirow[t]{6}{*}{ Soil $(\mathrm{Bq} / \mathrm{g})$} & ${ }^{60} \mathrm{Co}$ & $3.66 \times 10^{-4}$ & $3.00 \times 10^{1}$ & $1.22 \times 10^{-5}$ \\
\hline & ${ }^{137} \mathrm{Cs}$ & $1.65 \times 10^{-2}$ & $8.00 \times 10^{-1}$ & $2.06 \times 10^{-2}$ \\
\hline & ${ }^{234} \mathrm{U}$ & $2.09 \times 10^{-2}$ & $2.00 \times 10^{2}$ & $1.05 \times 10^{-4}$ \\
\hline & ${ }^{235} \mathrm{U}$ & $2.32 \times 10^{-3}$ & $1.00 \times 10^{2}$ & $2.32 \times 10^{-5}$ \\
\hline & ${ }^{238} U$ & $2.27 \times 10^{-2}$ & $6.00 \times 10^{1}$ & $3.78 \times 10^{-4}$ \\
\hline & ${ }^{241} \mathrm{Am}$ & $4.18 \times 10^{-4}$ & $1.00 \times 10^{2}$ & $4.18 \times 10^{-6}$ \\
\hline \multirow[t]{7}{*}{ Water $(\mathrm{Bq} / \mathrm{L})$} & ${ }^{60} \mathrm{Co}$ & $4.66 \times 10^{-1}$ & $4.00 \times 10^{4}$ & $1.17 \times 10^{-5}$ \\
\hline & ${ }^{137} \mathrm{Cs}$ & $3.23 \times 10^{-1}$ & $2.00 \times 10^{4}$ & $1.62 \times 10^{-5}$ \\
\hline & ${ }^{234} \mathrm{U}$ & $2.18 \times 10^{-1}$ & $1.00 \times 10^{4}$ & $2.18 \times 10^{-5}$ \\
\hline & ${ }^{235} \mathrm{U}$ & $6.51 \times 10^{-3}$ & $2.00 \times 10^{4}$ & $3.26 \times 10^{-7}$ \\
\hline & ${ }^{238} U$ & $1.08 \times 10^{-1}$ & $2.00 \times 10^{4}$ & $5.40 \times 10^{-6}$ \\
\hline & ${ }^{241} \mathrm{Am}$ & $6.51 \times 10^{-4}$ & $7.00 \times 10^{3}$ & $9.30 \times 10^{-8}$ \\
\hline & & & Sum of Fractions & $2.12 \times 10^{-2}$ \\
\hline
\end{tabular}

a The radionuclide concentration in the medium that would produce a radiation dose in the organism equal to the dose limit under the conservative assumptions in the model.

b Sediment and water samples were assumed to be co-located. 
This page intentionally left blank 


\section{CHAPTER 8 - QUALITY ASSURANCE}

The fundamental objective of a QA program, as applied to environmental work, is to ensure high-quality measurements are produced and reported from the analytical laboratory. The defensibility of data generated by laboratories must be based on sound scientific principles, method evaluations, and data verification and validation. WIPP Laboratories and contract laboratories, Wastren, in Grand Junction, Colorado; Air Toxics, Ltd., in Folsom, California; and Trace Analysis, in Lubbock, Texas, were the laboratories that performed the radiological and nonradiological analyses for WIPP environmental samples. (Wastren was purchased by SM Stoller Corporation in 2002. They will be referred to as "SM Stoller Corp." However, tables provided by the contract laboratory still denote "Wastren" in the title.)

All laboratories were required contractually to have documented QA programs, including standard procedures to perform the work, and to participate in some intercomparison programs with the National Institute of Standards and Technology Radiochemistry Intercomparison Program (NRIP), the Environmental Monitoring Laboratory of the DOE Environmental Measurements Laboratory (EML) Quality Assessment Program (QAP), the Environmental Resource Associates ${ }^{\circledR}$ (ERA) interlaboratory assessment, and/or any other reputable intercomparison program.

The laboratories used one or more of these accepted protocols in their QA program.

- $\quad$ American Society of Mechanical Engineers NQA-1-1989, Quality Assurance Program Requirements for Nuclear Facilities

- $\quad$ Title 10 CFR Part 50, Appendix B, "Quality Assurance Criteria for Nuclear Power Plants and Fuel Reprocessing Plants"

- $\quad$ EPA/600 14-83-004, QAMS-005/80, Interim Guidelines and Specification for Preparing Quality Assurance Project Plans

- $\quad$ NRC Regulatory Guide 4.15, Rev. 1, Quality Assurance for Radiological Monitoring Program-Effluent Streams and the Environment

- HPS N13.30 ANSI [American National Standards Institute], Performance Criteria for Radiobioassay

- $\quad$ Proposed ANSI/ASQC [American Society for Quality Control]-E4, Quality Assurance Program Requirements for Environmental Programs

The WIPP Environmental Monitoring Section performed assessments and audits to ensure the quality of the systems, processes, and deliverables were maintained or improved. Along with these regulatory requirements, the Environmental Monitoring Section also implements DOE Order 414.1A, Quality Assurance. The parameters for performance evaluations are completeness, precision, accuracy, comparability, and representativeness. 


\subsection{Completeness}

The completeness parameter was calculated as the ratio of the number of valid samples collected to the total number of samples collected and analyzed. The gross alpha/beta analyses were 96 percent complete for 2002. Samples for air particulates were 95 percent complete. Samples and measurements for all other media (groundwater, surface water, soil, sediment, and animal and plant tissues) were 100 percent complete. The data quality objective established for the environmental program is 98 percent complete.

\subsection{Precision}

The precision of the measurements was validated through analyses of duplicate samples. A low-volume air sampler was rotated in each quarter from location to location, and sampled along with routine samples. The results of these duplicate comparisons are shown in Tables 8.1, 8.2, 8.3, and 8.4 for the four quarters of 2002. The duplicate samples for other matrices were collected at the same time, same place, and under similar conditions as routine samples. These samples were analyzed in the same analytical batch and/or sample delivery group using similar methods for radiochemical separation and counting as the original samples. Tables $4.10,4.14,4.18$, and 4.20 show duplicate results for water, soil, sediment, and vegetation samples, respectively.

Precision is partially influenced by statistical counting uncertainty, so variances were expected between samples with very low activities (environmental levels). As a part of data validation all radiochemical duplicate samples are evaluated for the RER and on analytical chemistry the relative percent difference (RPD).

$$
R E R=\frac{\mid(\text { Mean Activity })_{o r i}-(\text { Mean Activity })_{d u p} \mid}{\sqrt{(2 \times S D)_{o r i}^{2}+(2 \times S D)_{d u p}^{2}}}
$$

Where:

$(\text { Mean Activity })_{\text {ori }} \quad=\quad$ Mean Activity of Original Sample

$(\text { Mean Activity })_{\text {dup }}=$ Mean Activity of Duplicate Sample

SD $\quad=\quad$ Standard Deviation of Original and Duplicate Samples

Relative error ratio results equal to or less than one are acceptable and considered to demonstrate reproducibility. A gross alpha result for the week of July 24, 2002, RER is greater than one, 1.34 (Table 8.3). A gross beta result for the week of January 30, 2002, RER is also greater than one, 1.07 (Table 8.1). The batches containing these two samples were recounted but still did not pass the RER criteria, which indicates a nonhomogeneous sample. 


$$
R P D=\left[\frac{(S-D)}{(S+D) / 2}\right] \times 100
$$

Where:

$\mathrm{S}=$ Sample concentration

$\mathrm{D}=$ Duplicate sample concentration

An acceptable range for RPD is $<25$ percent for the analytical methods. The duplicate results, RER, and RPD for all required analysis passed the required criteria with the exception of one gross alpha sample and one gross beta sample. WIPP's requirement is to reanalyze the batch of samples associated with the duplicate that failed to meet criteria.

\subsection{Accuracy}

The accuracy of the analyses were assured/controlled by using NIST-traceability for instrument calibration. Internal QC is performed by using NIST-traceable spiked laboratory control samples. Intercomparisons were performed with the DOE EML QAP, NRIP, AbsoluteGrade PT Program, and ERA to ensure the reliability of radiochemical separation methods and counting instruments. Accuracy, expressed as percent bias, was calculated by:

Where:

$$
\% \text { Bias }=\frac{\left(A_{m}-A_{k}\right)}{A_{k}} \times 100
$$

$\begin{array}{lll}\% \text { Bias } & = & \text { Percent Bias } \\ A_{m} & = & \text { Measured Sample Activity } \\ A_{k} & = & \text { Known Sample Activity }\end{array}$

The DOE EML QAP and NRIP prepare QC samples containing various alpha-, beta-, and gamma-emitting nuclides in water, soil, air filter, vegetation, synthetic urine, and tissue media and distributes them to numerous laboratories. ERA and AbsoluteGrade PT Program prepare QC samples with organic and inorganic components. The programs are an interlaboratory comparison in that results from the participants are compared with the experimentally determined results of EML and NRIP. Also, the administering programs assess the results as acceptable or not within a range of bias from the known result. 


\section{Waste Isolation Pilot Plant 2002 Site Environmental Report DOE/WIPP 03-2225}

\subsection{Comparability}

SM Stoller Corp. participated in the QAP and WIPP Laboratories participated in the QAP and NRIP programs. The results for SM Stoller Corp. are provided in Tables 8.5, 8.6, 8.7, and 8.8 for QAP, air, soil, vegetation, and water, respectively. Table 8.9 displays the results for ERA water. Table 8.10 contains the NRIP results for WIPP Laboratories and Tables 8.11, 8.12, 8.13, and 8.14 contain the results for the QAP air, soil, vegetation, and water, respectively. WIPP Laboratories percent bias was acceptable for all radionuclides and all media with two exceptions: ${ }^{239} \mathrm{Pu}$ in soil and in vegetation during the December intercomparison (QAP 57). It was determined that the soil and vegetation samples had been loaded into mislabeled petri dishes. The soil samples were labeled with vegetation information, and the vegetation samples were labeled with soil information. When the samples were recounted with the correct sample information, all results met acceptance criteria. The results for ${ }^{239} \mathrm{Pu}$ in soil and vegetation were acceptable during the June round of testing (QAP 56).

SM Stoller Corp.'s percent bias in evaluating soil was acceptable for all radionuclides and all media except for ${ }^{40} \mathrm{~K}$ in soil and ${ }^{134} \mathrm{Cs}$ in water during the June intercomparison (QAP 56); and ${ }^{234} \mathrm{Th}$ in soil and ${ }^{60} \mathrm{Co}$ in water during the December intercomparison (QAP 57). WIPP does not require the analysis of ${ }^{234} \mathrm{Th}$ and ${ }^{134} \mathrm{Cs}$ in any media. No errors were detected in the analysis of ${ }^{40} \mathrm{~K}$ or ${ }^{60} \mathrm{Co}$. Potassium- 40 measurements on samples with very low activities by gamma spectroscopy where the system background for $40 \mathrm{~K}$ is very high, will result in high uncertainties. The activities of nuclides in the EML samples are always very low, usually near the detection limit where the analytical uncertainties are high. However, EML does not account for the uncertainty reported by laboratories when evaluating results.

DOE EML QAP participant's analytical performance is evaluated based on the historical analytical capabilities for individual analyte/matrix pairs. The criteria for acceptable performance have been chosen to be between the $15^{\text {th }}$ and $85^{\text {th }}$ percentile of the cumulative normalized distribution, which can be viewed as the 70 percent of all historic measurements. The acceptable with warning criteria are between the $5^{\text {th }}$ and $15^{\text {th }}$ percentile and between the $85^{\text {th }}$ and $95^{\text {th }}$ percentile. In other words, the middle 90 percent of all reported values are acceptable, while the outer $5^{\text {th }}$ through $15^{\text {th }}$ (10 percent) and $85^{\text {th }}$ through $95^{\text {th }}$ (10 percent) percentiles are in the warning area. The not acceptable criteria are established at less than the $5^{\text {th }}$ percentile and greater than the $95^{\text {th }}$ percentile, that is, the outer 10 percent of historical data.

Air Toxics, Ltd., participated in the ERA, for 49 VOCs in nonpotable water. Results were 100 percent satisfactory (Table 8.15 ).

Trace Analysis, Inc., participated in several AbsoluteGrade PT Program interlaboratory assessments. For the PT Program runs from March to November 2002 for response performance standards (Tables 8.16, 8.17, and 8.18), 13 of 1508.6 percent) parameters were not acceptable. Subsequently, blind samples were reanalyzed for all analytes missed during later evaluations. When reevaluated, most were acceptable. Examples of some unacceptable analytical results include the following. 
Alkalinity results for the PT study, round 10 (PT study 10), was unacceptable due to contaminated glassware. Corrective action was to rinse glassware with distilled water prior to running alkalinity analysis. Rerun had an acceptable recovery of 98 percent.

Chemical oxygen demand (COD) result on PT study 10 was unacceptable due to dilution error. Corrective action was to take more care when doing dilutions for all analyses when performing wet chemistry.

Phosphate result for PT study 10 was unacceptable due to dilution error. Corrective action was to take more care when doing dilutions for all wet chemistry analyses.

Unacceptable result for PCBs in water for PT study 10 due to lack of injector maintenance. Corrective action was to improve injector maintenance and clipping of column maintenance cycle increased.

Turbidity result was not acceptable for PT study 10 due to improper shaking of sample before analysis. Corrective action was to instruct analysts in proper sample preparation.

Conductivity analysis was not acceptable for PT study 10 due to contaminated glassware. Corrective action was to rinse glassware with distilled water prior to running conductivity.

Bromide analysis for PT study 10 was unacceptable due to IC difficulties. Corrective action was to replace column, guard column, and filters, and prepare a new standards curve.

Unacceptable results for metals beryllium, strontium, and thallium for the WP portion of the PT study 10 due to noisy background from high wattage settings for the RF generator. Corrective action was to reduce wattage output and calibrating instrument at new level.

Unacceptable results for the metals thallium, molybdenum, and zinc for the WS portion of PT study 10 due to noisy background from high wattage setting of the RF generator. Corrective action was to reduce wattage output and recalibrate instrument at new level.

\subsection{Representativeness}

The primary objective of environmental monitoring has been to protect the health and safety of the population surrounding the WIPP facility. The quality objective of representativeness was based on potential radiation exposure of the population through inhalation and ingestion. Samples of ambient air, surface water, sediment, groundwater, and biota were collected from areas representative of potential pathways for intake.

The samples were collected using generally accepted methodologies for environmental sampling and approved procedures, ensuring they were representative of the media 
sampled. These samples were analyzed for natural radioactivity, fallout radioactivity from nuclear weapons tests, and other anthropogenic radionuclides. The reported concentrations at various locations were representative of the baseline information for radionuclides of interest at the WIPP facility. 
Waste Isolation Pilot Plant 2002 Site Environmental Report DOE/WIPP 03-2225

Table 8.1 - Comparison of Duplicate Air Monitoring Results

(First Quarter of 2002) from WIPP Laboratories Data from Carlsbad (CBD) Sampling Location

\begin{tabular}{|c|c|c|c|c|c|c|c|c|c|c|}
\hline \multirow[b]{2}{*}{ Week Beginning } & \multicolumn{5}{|c|}{ Gross Alpha $\left(\mathrm{Bq} / \mathrm{m}^{3}\right)$} & \multicolumn{5}{|c|}{ Gross Beta $\left(\mathrm{Bq} / \mathrm{m}^{3}\right)$} \\
\hline & Sample & $2 \times$ TPU $^{\mathrm{a}}$ & Duplicate & $2 \times$ TPU & RER $^{b}$ & Sample & $2 \times$ TPU & Duplicate & $2 \times$ TPU & RER \\
\hline $1 / 2$ & $1.72 \times 10^{-4}$ & $4.47 \times 10^{-5}$ & $N^{c}$ & NR & $N / A^{d}$ & $1.28 \times 10^{-3}$ & $1.60 \times 10^{-4}$ & NR & NR & N/A \\
\hline $1 / 9$ & $1.16 \times 10^{-4}$ & $3.69 \times 10^{-5}$ & $1.36 \times 10^{-4}$ & $4.03 \times 10^{-5}$ & 0.37 & $8.81 \times 10^{-4}$ & $1.22 \times 10^{-4}$ & $9.99 \times 10^{-4}$ & $1.34 \times 10^{-4}$ & 0.65 \\
\hline $1 / 16$ & $1.33 \times 10^{-4}$ & $3.88 \times 10^{-5}$ & $1.20 \times 10^{-4}$ & $3.67 \times 10^{-5}$ & 0.24 & $1.14 \times 10^{-3}$ & $1.46 \times 10^{-4}$ & $1.20 \times 10^{-3}$ & $1.52 \times 10^{-4}$ & 0.28 \\
\hline $1 / 23$ & $1.04 \times 10^{-4}$ & $3.40 \times 10^{-5}$ & $1.04 \times 10^{-4}$ & $3.38 \times 10^{-5}$ & 0 & $1.05 \times 10^{-3}$ & $1.38 \times 10^{-4}$ & $8.94 \times 10^{-4}$ & $1.21 \times 10^{-4}$ & 0.85 \\
\hline $1 / 30$ & $1.16 \times 10^{-4}$ & $3.59 \times 10^{-5}$ & $8.33 \times 10^{-5}$ & $3.10 \times 10^{-5}$ & 0.69 & $1.33 \times 10^{-3}$ & $1.63 \times 10^{-4}$ & $1.10 \times 10^{-3}$ & $1.41 \times 10^{-4}$ & 1.07 \\
\hline $2 / 6$ & $7.41 \times 10^{-5}$ & $2.90 \times 10^{-5}$ & $9.25 \times 10^{-5}$ & $3.40 \times 10^{-5}$ & 0.41 & $8.82 \times 10^{-4}$ & $1.22 \times 10^{-4}$ & $1.01 \times 10^{-3}$ & $1.38 \times 10^{-4}$ & 0.69 \\
\hline $2 / 13$ & $6.18 \times 10^{-5}$ & $2.24 \times 10^{-5}$ & $5.84 \times 10^{-5}$ & $2.18 \times 10^{-5}$ & 0.11 & $8.65 \times 10^{-4}$ & $1.11 \times 10^{-4}$ & $9.42 \times 10^{-4}$ & $1.19 \times 10^{-4}$ & 0.47 \\
\hline $2 / 20$ & $7.14 \times 10^{-5}$ & $2.96 \times 10^{-5}$ & $5.63 \times 10^{-5}$ & $2.54 \times 10^{-5}$ & 0.39 & $8.10 \times 10^{-4}$ & $1.18 \times 10^{-4}$ & $8.87 \times 10^{-4}$ & $1.24 \times 10^{-4}$ & 0.45 \\
\hline $2 / 27$ & $9.97 \times 10^{-5}$ & $3.41 \times 10^{-5}$ & $7.08 \times 10^{-5}$ & $2.77 \times 10^{-5}$ & 0.66 & $1.20 \times 10^{-3}$ & $1.53 \times 10^{-4}$ & $1.23 \times 10^{-3}$ & $1.54 \times 10^{-4}$ & 0.14 \\
\hline $3 / 6$ & $6.04 \times 10^{-5}$ & $2.72 \times 10^{-5}$ & NR & NR & $\mathrm{N} / \mathrm{A}$ & $9.73 \times 10^{-4}$ & $1.32 \times 10^{-4}$ & NR & NR & $\mathrm{N} / \mathrm{A}$ \\
\hline $3 / 13$ & NR & NR & NR & NR & $\mathrm{N} / \mathrm{A}$ & NR & NR & NR & NR & $\mathrm{N} / \mathrm{A}$ \\
\hline $3 / 20$ & $6.91 \times 10^{-5}$ & $2.80 \times 10^{-5}$ & $7.58 \times 10^{-5}$ & $2.96 \times 10^{-5}$ & 0.16 & $8.36 \times 10^{-4}$ & $1.17 \times 10^{-4}$ & $9.41 \times 10^{-4}$ & $1.28 \times 10^{-4}$ & 0.61 \\
\hline $3 / 27$ & $4.51 \times 10^{-5}$ & $2.19 \times 10^{-5}$ & $7.84 \times 10^{-5}$ & $2.96 \times 10^{-5}$ & 0.9 & $8.66 \times 10^{-4}$ & $1.17 \times 10^{-4}$ & $9.32 \times 10^{-4}$ & $1.26 \times 10^{-4}$ & 0.38 \\
\hline
\end{tabular}

a Total propagated uncertainty

${ }^{\mathrm{b}}$ Relative error ratio

${ }^{\mathrm{c}}$ Not reported

${ }^{\mathrm{d}}$ Not applicable since sample or duplicate value is not reported 
Waste Isolation Pilot Plant 2002 Site Environmental Report DOE/WIPP 03-2225

Table 8.2 - Comparison of Duplicate Air Monitoring Results

(Second Quarter of 2002) from WIPP Laboratories Data from Southeast Control (SEC) Sampling Location

\begin{tabular}{|c|c|c|c|c|c|c|c|c|c|c|}
\hline \multirow[b]{2}{*}{ Week Beginning } & \multicolumn{5}{|c|}{ Gross Alpha $\left(\mathrm{Bq} / \mathrm{m}^{3}\right)$} & \multicolumn{5}{|c|}{ Gross Beta $\left(\mathrm{Bq} / \mathrm{m}^{3}\right)$} \\
\hline & Sample & $2 \times \mathrm{TPU}^{\mathrm{a}}$ & Duplicate & $2 \times$ TPU & RER $^{b}$ & Sample & $2 \times \mathrm{TPU}$ & Duplicate & $2 \times$ TPU & RER \\
\hline $4 / 3$ & $9.21 \times 10^{-5}$ & $3.36 \times 10^{-5}$ & $7.44 \times 10^{-5}$ & $3.06 \times 10^{-5}$ & 0.39 & $9.84 \times 10^{-4}$ & $1.32 \times 10^{-4}$ & $9.50 \times 10^{-4}$ & $1.29 \times 10^{-4}$ & 0.18 \\
\hline $4 / 10$ & $6.96 \times 10^{-5}$ & $2.86 \times 10^{-5}$ & $6.91 \times 10^{-5}$ & $2.90 \times 10^{-5}$ & 0.01 & $1.09 \times 10^{-3}$ & $1.41 \times 10^{-4}$ & $1.13 \times 10^{-3}$ & $1.46 \times 10^{-4}$ & 0.2 \\
\hline $4 / 17$ & $4.05 \times 10^{-5}$ & $2.16 \times 10^{-5}$ & $4.57 \times 10^{-5}$ & $2.28 \times 10^{-5}$ & 0.17 & $8.69 \times 10^{-4}$ & $1.19 \times 10^{-4}$ & $8.27 \times 10^{-4}$ & $1.15 \times 10^{-4}$ & 0.25 \\
\hline $4 / 24$ & $7.40 \times 10^{-5}$ & $2.94 \times 10^{-5}$ & $7.58 \times 10^{-5}$ & $2.96 \times 10^{-5}$ & 0.04 & $9.01 \times 10^{-4}$ & $1.23 \times 10^{-4}$ & $9.11 \times 10^{-4}$ & $1.24 \times 10^{-4}$ & 0.06 \\
\hline $5 / 1$ & $4.02 \times 10^{-5}$ & $2.02 \times 10^{-5}$ & $7.10 \times 10^{-5}$ & $2.76 \times 10^{-5}$ & 0.9 & $8.46 \times 10^{-4}$ & $1.16 \times 10^{-4}$ & $8.87 \times 10^{-4}$ & $1.21 \times 10^{-4}$ & 0.24 \\
\hline $5 / 8$ & $9.00 \times 10^{-5}$ & $3.19 \times 10^{-5}$ & $7.98 \times 10^{-5}$ & $3.05 \times 10^{-5}$ & 0.23 & $9.45 \times 10^{-4}$ & $1.25 \times 10^{-4}$ & $8.55 \times 10^{-4}$ & $1.17 \times 10^{-4}$ & 0.53 \\
\hline $5 / 15$ & $7.49 \times 10^{-5}$ & $3.08 \times 10^{-5}$ & $7.49 \times 10^{-5}$ & $2.92 \times 10^{-5}$ & 0 & $9.48 \times 10^{-4}$ & $1.29 \times 10^{-4}$ & $8.97 \times 10^{-4}$ & $1.21 \times 10^{-4}$ & 0.29 \\
\hline $5 / 22$ & $8.11 \times 10^{-5}$ & $3.15 \times 10^{-5}$ & $5.37 \times 10^{-5}$ & $2.58 \times 10^{-5}$ & 0.67 & $7.83 \times 10^{-4}$ & $1.12 \times 10^{-4}$ & $8.10 \times 10^{-4}$ & $1.15 \times 10^{-4}$ & 0.17 \\
\hline $5 / 29$ & $4.97 \times 10^{-5}$ & $2.39 \times 10^{-5}$ & $4.17 \times 10^{-5}$ & $2.27 \times 10^{-5}$ & 0.24 & $8.02 \times 10^{-4}$ & $1.11 \times 10^{-4}$ & $8.13 \times 10^{-4}$ & $1.14 \times 10^{-4}$ & 0.07 \\
\hline $6 / 5$ & $4.61 \times 10^{-5}$ & $2.24 \times 10^{-5}$ & $6.16 \times 10^{-5}$ & $2.54 \times 10^{-5}$ & 0.46 & $7.66 \times 10^{-4}$ & $1.10 \times 10^{-4}$ & $7.23 \times 10^{-4}$ & $1.04 \times 10^{-4}$ & 0.28 \\
\hline $6 / 12$ & $5.10 \times 10^{-5}$ & $2.40 \times 10^{-5}$ & $6.98 \times 10^{-5}$ & $2.87 \times 10^{-5}$ & 0.5 & $7.94 \times 10^{-4}$ & $1.11 \times 10^{-4}$ & $7.75 \times 10^{-4}$ & $1.10 \times 10^{-4}$ & 0.12 \\
\hline $6 / 19$ & $6.43 \times 10^{-5}$ & $2.82 \times 10^{-5}$ & $5.46 \times 10^{-5}$ & $2.51 \times 10^{-5}$ & 0.26 & $1.07 \times 10^{-3}$ & $1.41 \times 10^{-4}$ & $1.03 \times 10^{-3}$ & $1.36 \times 10^{-4}$ & 0.2 \\
\hline $6 / 26$ & $3.47 \times 10^{-5}$ & $2.06 \times 10^{-5}$ & $5.24 \times 10^{-5}$ & $2.54 \times 10^{-5}$ & 0.54 & $6.94 \times 10^{-4}$ & $1.02 \times 10^{-4}$ & $7.25 \times 10^{-4}$ & $1.06 \times 10^{-4}$ & 0.21 \\
\hline
\end{tabular}

a Total propagated uncertainty

${ }^{\mathrm{b}}$ Relative error ratio 
Waste Isolation Pilot Plant 2002 Site Environmental Report DOE/WIPP 03-2225

Table 8.3 - Comparison of Duplicate Air Monitoring Results

(Third Quarter of 2002) from WIPP Laboratories Data from WIPP Far Field (WFF) Sampling Location

\begin{tabular}{|c|c|c|c|c|c|c|c|c|c|c|}
\hline \multirow[b]{2}{*}{ Week Beginning } & \multicolumn{5}{|c|}{ Gross Alpha $\left(\mathrm{Bq} / \mathrm{m}^{3}\right)$} & \multicolumn{5}{|c|}{ Gross Beta $\left(\mathrm{Bq} / \mathrm{m}^{3}\right)$} \\
\hline & Sample & $2 \times$ TPU $^{a}$ & Duplicate & $2 \times$ TPU & $\mathbf{R E R}^{\mathbf{b}}$ & Sample & $2 \times$ TPU & Duplicate & $2 \times$ TPU & RER \\
\hline $7 / 3$ & $5.87 \times 10^{-5}$ & $2.70 \times 10^{-5}$ & $5.63 \times 10^{-5}$ & $2.66 \times 10^{-5}$ & 0.06 & $1.03 \times 10^{-3}$ & $1.37 \times 10^{-4}$ & $9.13 \times 10^{-4}$ & $1.26 \times 10^{-4}$ & 0.63 \\
\hline $7 / 10$ & $7.76 \times 10^{-5}$ & $3.02 \times 10^{-5}$ & $5.59 \times 10^{-5}$ & $2.63 \times 10^{-5}$ & 0.54 & $8.28 \times 10^{-4}$ & $1.15 \times 10^{-4}$ & $7.42 \times 10^{-4}$ & $1.08 \times 10^{-4}$ & 0.55 \\
\hline $7 / 17$ & $2.36 \times 10^{-5}$ & $1.82 \times 10^{-5}$ & $4.02 \times 10^{-5}$ & $2.12 \times 10^{-5}$ & 0.59 & $6.29 \times 10^{-4}$ & $9.28 \times 10^{-5}$ & $6.23 \times 10^{-4}$ & $9.19 \times 10^{-5}$ & 0.05 \\
\hline $7 / 24$ & $1.01 \times 10^{-4}$ & $3.53 \times 10^{-5}$ & $4.49 \times 10^{-5}$ & $2.24 \times 10^{-5}$ & 1.34 & $7.91 \times 10^{-4}$ & $1.13 \times 10^{-4}$ & $7.88 \times 10^{-4}$ & $1.11 \times 10^{-4}$ & 0.02 \\
\hline $7 / 31$ & $4.52 \times 10^{-5}$ & $2.25 \times 10^{-5}$ & $5.86 \times 10^{-5}$ & $2.57 \times 10^{-5}$ & 0.39 & $8.95 \times 10^{-4}$ & $1.21 \times 10^{-4}$ & $9.74 \times 10^{-4}$ & $1.29 \times 10^{-4}$ & 0.45 \\
\hline $8 / 7$ & $1.45 \times 10^{-4}$ & $4.22 \times 10^{-5}$ & $1.39 \times 10^{-4}$ & $4.13 \times 10^{-5}$ & 0.1 & $9.92 \times 10^{-4}$ & $1.32 \times 10^{-4}$ & $1.02 \times 10^{-3}$ & $1.35 \times 10^{-4}$ & 0.15 \\
\hline $8 / 14$ & $1.02 \times 10^{-4}$ & $3.51 \times 10^{-5}$ & $1.02 \times 10^{-4}$ & $3.53 \times 10^{-5}$ & 0 & $9.53 \times 10^{-4}$ & $1.29 \times 10^{-4}$ & $8.32 \times 10^{-4}$ & $1.16 \times 10^{-4}$ & 0.7 \\
\hline $8 / 21$ & $8.79 \times 10^{-5}$ & $3.21 \times 10^{-5}$ & $8.16 \times 10^{-5}$ & $3.12 \times 10^{-5}$ & 0.14 & $9.28 \times 10^{-4}$ & $1.25 \times 10^{-4}$ & $9.27 \times 10^{-4}$ & $1.26 \times 10^{-4}$ & 0.01 \\
\hline $8 / 28$ & $1.03 \times 10^{-4}$ & $3.56 \times 10^{-5}$ & $9.88 \times 10^{-5}$ & $3.46 \times 10^{-5}$ & 0.08 & $1.21 \times 10^{-3}$ & $1.55 \times 10^{-4}$ & $1.21 \times 10^{-3}$ & $1.54 \times 10^{-4}$ & 0 \\
\hline $9 / 4$ & $5.56 \times 10^{-5}$ & $2.49 \times 10^{-5}$ & $7.56 \times 10^{-5}$ & $2.89 \times 10^{-5}$ & 0.52 & $7.79 \times 10^{-4}$ & $1.09 \times 10^{-4}$ & $6.81 \times 10^{-4}$ & $9.84 \times 10^{-5}$ & 0.67 \\
\hline $9 / 11$ & $1.17 \times 10^{-4}$ & $3.80 \times 10^{-5}$ & $1.03 \times 10^{-4}$ & $3.51 \times 10^{-5}$ & 0.27 & $1.22 \times 10^{-3}$ & $1.57 \times 10^{-4}$ & $1.30 \times 10^{-3}$ & $1.63 \times 10^{-4}$ & 0.35 \\
\hline $9 / 18$ & $1.36 \times 10^{-4}$ & $3.94 \times 10^{-5}$ & $1.19 \times 10^{-4}$ & $3.72 \times 10^{-5}$ & 0.31 & $1.20 \times 10^{-3}$ & $1.52 \times 10^{-4}$ & $1.05 \times 10^{-3}$ & $1.38 \times 10^{-4}$ & 0.73 \\
\hline $9 / 25$ & $1.19 \times 10^{-4}$ & $3.74 \times 10^{-5}$ & $1.42 \times 10^{-4}$ & $4.13 \times 10^{-5}$ & 0.41 & $1.15 \times 10^{-3}$ & $1.48 \times 10^{-4}$ & $1.06 \times 10^{-3}$ & $1.39 \times 10^{-4}$ & 0.44 \\
\hline
\end{tabular}

a Total propagated uncertainty

${ }^{b}$ Relative error ratio 
Waste Isolation Pilot Plant 2002 Site Environmental Report DOE/WIPP 03-2225

Table 8.4 - Comparison of Duplicate Air Monitoring Results (Fourth Quarter of 2002) from WIPP Laboratories Data from WIPP East (WEE) Sampling Location

\begin{tabular}{|c|c|c|c|c|c|c|c|c|c|c|}
\hline \multirow[b]{2}{*}{ Week Beginning } & \multicolumn{5}{|c|}{ Gross Alpha $\left(\mathrm{Bq} / \mathrm{m}^{3}\right)$} & \multicolumn{5}{|c|}{ Gross Beta $\left(\mathrm{Bq} / \mathrm{m}^{3}\right)$} \\
\hline & Sample & $2 \times$ TPU $^{a}$ & Duplicate & $2 \times$ TPU & $\mathbf{R E R}^{\mathbf{b}}$ & Sample & $2 \times$ TPU & Duplicate & $2 \times$ TPU & RER \\
\hline $10 / 2$ & $9.24 \times 10^{-5}$ & $3.28 \times 10^{-5}$ & $9.54 \times 10^{-5}$ & $3.35 \times 10^{-5}$ & 0.06 & $7.31 \times 10^{-4}$ & $1.05 \times 10^{-4}$ & $8.19 \times 10^{-4}$ & $1.14 \times 10^{-4}$ & 0.57 \\
\hline $10 / 9$ & $6.67 \times 10^{-5}$ & $2.76 \times 10^{-5}$ & $6.80 \times 10^{-5}$ & $2.81 \times 10^{-5}$ & 0.03 & $1.11 \times 10^{-3}$ & $1.44 \times 10^{-4}$ & $1.24 \times 10^{-3}$ & $1.57 \times 10^{-4}$ & 0.61 \\
\hline $10 / 16$ & $4.38 \times 10^{-5}$ & $2.26 \times 10^{-5}$ & $5.37 \times 10^{-5}$ & $2.48 \times 10^{-5}$ & 0.3 & $1.13 \times 10^{-3}$ & $1.46 \times 10^{-4}$ & $1.09 \times 10^{-3}$ & $1.41 \times 10^{-4}$ & 0.2 \\
\hline $10 / 23$ & $3.11 \times 10^{-5}$ & $1.79 \times 10^{-5}$ & $4.86 \times 10^{-5}$ & $2.24 \times 10^{-5}$ & 0.61 & $5.48 \times 10^{-4}$ & $8.55 \times 10^{-5}$ & $4.88 \times 10^{-4}$ & $7.87 \times 10^{-5}$ & 0.52 \\
\hline $10 / 30$ & $6.25 \times 10^{-5}$ & $2.78 \times 10^{-5}$ & $4.72 \times 10^{-5}$ & $2.47 \times 10^{-5}$ & 0.41 & $8.68 \times 10^{-4}$ & $1.20 \times 10^{-4}$ & $8.42 \times 10^{-4}$ & $1.17 \times 10^{-4}$ & 0.16 \\
\hline $11 / 6$ & $5.18 \times 10^{-5}$ & $2.80 \times 10^{-5}$ & $7.26 \times 10^{-5}$ & $2.98 \times 10^{-5}$ & 0.51 & $1.02 \times 10^{-3}$ & $1.40 \times 10^{-4}$ & $1.02 \times 10^{-3}$ & $1.35 \times 10^{-4}$ & 0 \\
\hline $11 / 13$ & $5.54 \times 10^{-5}$ & $2.47 \times 10^{-5}$ & $6.27 \times 10^{-5}$ & $2.62 \times 10^{-5}$ & 0.2 & $1.02 \times 10^{-3}$ & $1.35 \times 10^{-4}$ & $1.13 \times 10^{-3}$ & $1.46 \times 10^{-4}$ & 0.55 \\
\hline $11 / 20$ & $1.10 \times 10^{-4}$ & $3.61 \times 10^{-5}$ & $1.22 \times 10^{-4}$ & $3.88 \times 10^{-5}$ & 0.23 & $1.38 \times 10^{-3}$ & $1.73 \times 10^{-4}$ & $1.31 \times 10^{-3}$ & $1.66 \times 10^{-4}$ & 0.29 \\
\hline $11 / 27$ & $3.82 \times 10^{-5}$ & $2.03 \times 10^{-5}$ & $5.69 \times 10^{-5}$ & $2.49 \times 10^{-5}$ & 0.58 & $1.58 \times 10^{-3}$ & $1.91 \times 10^{-4}$ & $1.45 \times 10^{-3}$ & $1.78 \times 10^{-4}$ & 0.5 \\
\hline $12 / 4$ & $2.77 \times 10^{-5}$ & $1.72 \times 10^{-5}$ & $2.75 \times 10^{-5}$ & $1.71 \times 10^{-5}$ & 0.01 & $1.34 \times 10^{-3}$ & $1.68 \times 10^{-4}$ & $1.40 \times 10^{-3}$ & $1.73 \times 10^{-4}$ & 0.25 \\
\hline $12 / 11$ & $1.10 \times 10^{-4}$ & $3.63 \times 10^{-5}$ & $N R^{c}$ & $N R$ & $N / A^{d}$ & $1.38 \times 10^{-3}$ & $1.71 \times 10^{-4}$ & NR & NR & N/A \\
\hline $12 / 18$ & $6.76 \times 10^{-5}$ & $2.68 \times 10^{-5}$ & $5.50 \times 10^{-5}$ & $2.73 \times 10^{-5}$ & 0.33 & $9.07 \times 10^{-4}$ & $1.20 \times 10^{-4}$ & $9.84 \times 10^{-4}$ & $1.35 \times 10^{-4}$ & 0.43 \\
\hline $12 / 25$ & $7.12 \times 10^{-5}$ & $3.44 \times 10^{-5}$ & $7.40 \times 10^{-5}$ & $3.57 \times 10^{-5}$ & 0.06 & $1.32 \times 10^{-3}$ & $1.77 \times 10^{-4}$ & $1.53 \times 10^{-3}$ & $2.00 \times 10^{-4}$ & 0.79 \\
\hline
\end{tabular}

a Total propagated uncertainty

${ }^{b}$ Relative error ratio

${ }^{\mathrm{c}}$ Not reported

${ }^{\mathrm{d}}$ Not applicable since sample or duplicate value is not reported. 


\section{Waste Isolation Pilot Plant 2002 Site Environmental Report DOE/WIPP 03-2225}

Table 8.5 - Environmental Measurements Laboratory Assessments for Wastren, 2002 MATRIX: Air Filter (Bq/Filter)

\begin{tabular}{|c|c|c|c|c|c|c|c|c|c|c|}
\hline \multirow[b]{3}{*}{$\mathbf{R N}^{\mathrm{c}}$} & \multicolumn{5}{|c|}{ QAP 56 June 2002} & \multicolumn{4}{|c|}{ QAP 57 December 2002} & \multirow{3}{*}{$\begin{array}{c}\% \\
\text { Bias }\end{array}$} \\
\hline & \multicolumn{2}{|c|}{ Reported } & \multicolumn{2}{|c|}{$E M L^{b}$} & \multirow{2}{*}{$\begin{array}{c}\% \\
\text { Bias }\end{array}$} & \multicolumn{2}{|c|}{ Reported } & \multicolumn{2}{|c|}{ EML } & \\
\hline & Value & Error & Value & Error & & Value & Error & Value & Error & \\
\hline${ }^{241} \mathrm{Am}$ & 0.087 & 0.01 & 0.09 & 0.01 & 1.136 & 0.189 & 0.01 & 0.191 & 0 & 1.047 \\
\hline${ }^{60} \mathrm{Co}$ & 36 & 2 & 30.52 & 0.652 & 17.96 & 26 & 2 & 23 & 0.06 & 13.04 \\
\hline${ }^{137} \mathrm{Cs}$ & 31 & 2 & 28.23 & 0.701 & 9.81 & 36 & 4 & 32.5 & 0.777 & 10.77 \\
\hline Gross $\alpha$ & 0.542 & 0.056 & 0.534 & 0.053 & 1.498 & 0.322 & 0.036 & 0.287 & 0.03 & 12.2 \\
\hline Gross $\beta$ & 1.29 & 0.13 & 1.3 & 0.13 & 0.77 & 0.822 & 0.098 & 0.871 & 0.09 & 5.626 \\
\hline${ }^{54} \mathrm{Mn}$ & 43 & 8 & 38.53 & 0.867 & 11.6 & 57 & 10 & 52.2 & 1.17 & 9.195 \\
\hline${ }^{238} \mathrm{Pu}$ & 0.057 & 0.01 & 0.06 & 0 & 0 & 0.106 & 0.01 & 0.119 & 0 & 10.92 \\
\hline${ }^{239} \mathrm{Pu}$ & 0.191 & 0.014 & 0.187 & 0 & 2.139 & 0.205 & 0.014 & 0.206 & 0 & 0.485 \\
\hline${ }^{90} \mathrm{Sr}$ & 4.26 & 0.25 & 4.832 & 0.184 & 11.84 & 5.68 & 0.35 & 5.561 & 0.119 & 2.14 \\
\hline U & $N A^{d}$ & NA & NA & NA & NA & 17 & NA & 18.59 & 0.34 & 8.553 \\
\hline${ }^{234} U$ & 0.285 & 0.026 & 0.297 & 0 & 4.04 & 0.216 & 0.019 & 0.228 & 0 & 5.263 \\
\hline${ }^{238} \mathrm{U}$ & 0.281 & 0.026 & 0.298 & 0 & 5.705 & 0.217 & 0.019 & 0.23 & 0 & 5.652 \\
\hline TOT U $(\mu \mathrm{g})$ & 22.7 & $\mathrm{~N} / \mathrm{A}^{\mathrm{e}}$ & 24.11 & 0.103 & 5.829 & NA & $\mathrm{N} / \mathrm{A}$ & NA & NA & NA \\
\hline
\end{tabular}

Table 8.6 - Environmental Measurements Laboratory Assessments for Wastren, 2002 MATRIX: Soil (Bq/kg)

\begin{tabular}{|c|c|c|c|c|c|c|c|c|c|c|}
\hline \multirow[b]{3}{*}{$\mathbf{R N}^{\mathbf{c}}$} & \multicolumn{5}{|c|}{ QAP $^{\mathrm{a}} 56$ June 2002} & \multicolumn{4}{|c|}{ QAP 57 December 2002} & \multirow{3}{*}{$\begin{array}{c}\% \\
\text { Bias }\end{array}$} \\
\hline & \multicolumn{2}{|c|}{ Reported } & \multicolumn{2}{|c|}{$E M L^{b}$} & \multirow{2}{*}{$\begin{array}{c}\% \\
\text { Bias }\end{array}$} & \multicolumn{2}{|c|}{ Reported } & \multicolumn{2}{|c|}{ EML } & \\
\hline & Value & Error & Value & Error & & Value & Error & Value & Error & \\
\hline${ }^{228} \mathrm{Ac}$ & 46 & 10 & 51.167 & 1.941 & 10.098 & NA & NA & NA & NA & NA \\
\hline${ }^{241} \mathrm{Am}$ & 11.6 & 0.64 & 10.927 & 0.373 & 6.159 & 6.89 & 0.34 & 6.767 & 0.301 & 1.818 \\
\hline${ }^{212} \mathrm{Bi}$ & 58 & 22 & 53.43 & 5.215 & 8.553 & 55 & 18 & 45.93 & 4.51 & 19.747 \\
\hline${ }^{214} \mathrm{Bi}$ & 55 & 8 & 53.933 & 2.249 & 1.978 & 33 & 6 & 33.63 & 1.56 & 1.873 \\
\hline${ }^{137} \mathrm{Cs}$ & 1240 & 172 & 1326.67 & 66.51 & 6.533 & 820 & 124 & 829.33 & 41.58 & 1.125 \\
\hline${ }^{40} \mathrm{~K}$ & 482 & 70 & 621.67 & 33.86 & 22.467 & 593 & 66 & 637.67 & 34.26 & 7.005 \\
\hline${ }^{212} \mathrm{~Pb}$ & 62 & 18 & 51.1 & 2.753 & 21.331 & 41 & 8 & 43.43 & 2.71 & 5.595 \\
\hline${ }^{214} \mathrm{~Pb}$ & NA & NA & NA & NA & NA & 39 & 6 & 35.2 & 1.51 & 10.795 \\
\hline${ }^{239} \mathrm{Pu}$ & 20.53 & 1.48 & 19.098 & 0.706 & 7.498 & 13.15 & 0.9 & 12.903 & 0.465 & 1.914 \\
\hline${ }^{90} \mathrm{Sr}$ & 50 & 4.2 & 53.756 & 1.446 & 6.987 & 41.8 & 3.8 & 41.16 & 0.253 & 1.555 \\
\hline${ }^{234} \mathrm{Th}$ & NA & NA & NA & NA & NA & 131 & 24 & 48.4 & 4.83 & 170.661 \\
\hline U & NA & NA & NA & NA & NA & 3.8 & NA & 3.61 & 0.32 & 5.263 \\
\hline${ }^{234} \mathrm{U}$ & 90.7 & 8.2 & 93.885 & 7.767 & 3.392 & 42.37 & 3.7 & 42.32 & 3.1 & 0.118 \\
\hline${ }^{238} \mathrm{U}$ & 91.3 & 8.2 & 96.778 & 8.41 & 5.66 & 45.35 & 3.92 & 44.89 & 3.2 & 1.025 \\
\hline TOTU $(\mu \mathrm{g})$ & 7.8 & $\mathrm{~N} / \mathrm{A}$ & 7.829 & 0.755 & 0.37 & NA & $\mathrm{N} / \mathrm{A}$ & NA & NA & NA \\
\hline
\end{tabular}




\section{Waste Isolation Pilot Plant 2002 Site Environmental Report}

DOE/WIPP 03-2225

Table 8.7 - Environmental Measurements Laboratory Assessments for Wastren, 2002 MATRIX: Vegetation (Bq/kg)

\begin{tabular}{|c|c|c|c|c|c|c|c|c|c|c|}
\hline \multirow[b]{3}{*}{$\mathbf{R N}^{\mathrm{c}}$} & \multicolumn{5}{|c|}{ QAP $^{\text {a }} 56$ June 2002} & \multicolumn{4}{|c|}{ QAP 57 December 2002} & \multirow{3}{*}{$\begin{array}{c}\% \\
\text { Bias }\end{array}$} \\
\hline & \multicolumn{2}{|c|}{ Reported } & \multicolumn{2}{|c|}{$\mathrm{EML}^{\mathrm{b}}$} & \multirow{2}{*}{$\begin{array}{c}\% \\
\text { Bias }\end{array}$} & \multicolumn{2}{|c|}{ Reported } & \multicolumn{2}{|l|}{ EML } & \\
\hline & Value & Error & Value & Error & & Value & Error & Value & Error & \\
\hline${ }^{241} \mathrm{Am}$ & 2.3 & 0.14 & 2.228 & 0.216 & 3.232 & 2.26 & 0.14 & 2.253 & 0.1 & 0.311 \\
\hline${ }^{244} \mathrm{Cm}$ & 1.24 & 0.092 & 1.32 & 0.164 & 6.061 & 1.067 & 0.085 & 1.247 & 0.065 & 14.44 \\
\hline${ }^{60} \mathrm{Co}$ & 13 & 2 & 11.23 & 0.677 & 15.761 & 9 & 2 & 9.66 & 0.63 & 6.832 \\
\hline${ }^{137} \mathrm{Cs}$ & 319 & 44 & 313.667 & 15.91 & 1.7 & 317 & 48 & 300.67 & 15.25 & 5.431 \\
\hline${ }^{40} \mathrm{~K}$ & 800 & 116 & 864.33 & 47.22 & 7.443 & 1453 & 160 & 1480 & 77.8 & 1.824 \\
\hline${ }^{239} \mathrm{Pu}$ & 3.52 & 0.27 & 3.543 & 0.377 & 0.649 & 3.53 & 0.27 & 3.427 & 0.149 & 3.006 \\
\hline${ }^{90} \mathrm{Sr}$ & 580 & 30 & 586.28 & 11.14 & 1.071 & 465 & 29 & 476.26 & 6.673 & 2.364 \\
\hline
\end{tabular}

${ }^{a}$ Quality Assurance Program

${ }^{\mathrm{b}}$ Environmental Measurements Laboratory

${ }^{\mathrm{c}}$ Radionuclide

Table 8.8 - Environmental Measurements Laboratory Assessments for Wastren, 2002 MATRIX: Water $(\mathrm{Bq} / \mathrm{L})$

\begin{tabular}{|c|c|c|c|c|c|c|c|c|c|c|}
\hline \multirow[b]{3}{*}{$\mathbf{R N}^{\mathrm{c}}$} & \multicolumn{5}{|c|}{ QAP $^{a} 56$ June 2002} & \multicolumn{4}{|c|}{ QAP 57 December 2002} & \multirow{3}{*}{$\begin{array}{c}\% \\
\text { Bias } \\
\end{array}$} \\
\hline & \multicolumn{2}{|c|}{ Reported } & \multicolumn{2}{|c|}{$\mathrm{EML}^{\mathrm{b}}$} & \multirow{2}{*}{$\begin{array}{c}\% \\
\text { Bias }\end{array}$} & \multicolumn{2}{|c|}{ Reported } & \multicolumn{2}{|c|}{ EML } & \\
\hline & Value & Error & Value & Error & & Value & Error & Value & Error & \\
\hline${ }^{241} \mathrm{Am}$ & 2.3 & 0.14 & 2.228 & 0.216 & 0.07 & 2.76 & 0.11 & 3.043 & 0.082 & 9.3 \\
\hline${ }^{60} \mathrm{Co}$ & 322 & 28 & 347.33 & 12.4 & 7.293 & 342 & 28 & 268.67 & 9.71 & 27.29 \\
\hline${ }^{134} \mathrm{Cs}$ & 2 & 1 & 3.357 & 0.2 & 40.42 & 55 & 4 & 60.2 & 1.86 & 8.638 \\
\hline${ }^{137} \mathrm{Cs}$ & 45 & 10 & 56.067 & 2.929 & 19.74 & 96 & 12 & 81.43 & 4.28 & 17.89 \\
\hline Gross $\alpha$ & 361 & 40 & 375 & 37.5 & 3.733 & 257 & 28 & 210 & 21 & 22.38 \\
\hline Gross $\beta$ & 930 & 55 & 1030 & 103 & 9.709 & 740 & 37 & 900 & 90 & 17.78 \\
\hline${ }^{3} \mathrm{H}$ & 300 & 11 & 283.7 & 3.38 & 5.746 & 249 & 9 & 227.3 & 5.615 & 9.547 \\
\hline${ }^{238} \mathrm{Pu}$ & 0.518 & 0.039 & 0.49 & 0.032 & 5.714 & 4.18 & 0.28 & 4.331 & 0.117 & 3.486 \\
\hline${ }^{239} \mathrm{Pu}$ & 4.39 & 0.3 & 4.219 & 0.172 & 4.053 & 2.1 & 0.14 & 2.07 & 0.074 & 1.449 \\
\hline${ }^{90} \mathrm{Sr}$ & 6.92 & 0.48 & 7.579 & 0.176 & 8.695 & 8.74 & 0.59 & 8.69 & 0.42 & 0.575 \\
\hline U & NA & NA & NA & NA & NA & 0.241 & NA & 0.273 & 0.012 & 11.72 \\
\hline${ }^{234} U$ & 1.26 & 0.12 & 1.402 & 0.056 & 10.13 & 3.13 & 0.26 & 3.323 & 0.114 & 5.808 \\
\hline${ }^{238} \mathrm{U}$ & 1.28 & 0.12 & 1.381 & 0.079 & 7.314 & 3.08 & 0.25 & 3.37 & 0.14 & 8.605 \\
\hline $\operatorname{TOTU}(\mu \mathrm{g})$ & 0.104 & $N / A^{d}$ & 0.112 & 0.007 & 7.143 & NA & NA & NA & NA & NA \\
\hline
\end{tabular}

${ }^{a}$ Quality Assurance Program

${ }^{b}$ Environmental Measurements Laboratory

${ }^{\mathrm{c}}$ Radionuclide

d Not applicable 


\section{Waste Isolation Pilot Plant 2002 Site Environmental Report DOE/WIPP 03-2225}

Table 8.9 - Environmental Resource Associates $₫$ for Wastren, 2002 MATRIX: Water ( $\mathrm{pCi} / \mathrm{L})$

\begin{tabular}{|c|c|c|c|c|c|c|c|c|c|c|}
\hline \multirow[b]{2}{*}{$\mathbf{R N}^{\mathrm{b}}$} & \multicolumn{2}{|c|}{ Reported } & \multicolumn{2}{|c|}{$E A^{a}$} & \multirow{2}{*}{$\begin{array}{c}\% \\
\text { Bias }\end{array}$} & \multicolumn{2}{|c|}{ Reported } & \multicolumn{2}{|c|}{ ERA } & \multirow{2}{*}{$\begin{array}{c}\% \\
\text { Bias }\end{array}$} \\
\hline & Value & Error & Value & Error & & Value & Error & Value & Error & \\
\hline U(NAT) & $N A^{c}$ & NA & NA & NA & NA & $N / A^{d}$ & $\mathrm{~N} / \mathrm{A}$ & N/A & N/A & $N / A$ \\
\hline${ }^{226} \mathrm{Ra}$ & NA & NA & NA & NA & NA & N/A & N/A & N/A & N/A & $\mathrm{N} / \mathrm{A}$ \\
\hline${ }^{228} \mathrm{Ra}$ & NA & NA & NA & NA & NA & N/A & N/A & N/A & N/A & $\mathrm{N} / \mathrm{A}$ \\
\hline Gross $\alpha$ & N/A & $\mathrm{N} / \mathrm{A}$ & N/A & N/A & $\mathrm{N} / \mathrm{A}$ & NA & NA & NA & NA & NA \\
\hline Gross $\beta$ & $\mathrm{N} / \mathrm{A}$ & $\mathrm{N} / \mathrm{A}$ & $\mathrm{N} / \mathrm{A}$ & $\mathrm{N} / \mathrm{A}$ & $\mathrm{N} / \mathrm{A}$ & NA & NA & NA & NA & NA \\
\hline
\end{tabular}

Table 8.10 - NRIP for WIPP Laboratories, 2002

\begin{tabular}{|c|c|c|c|c|c|c|c|c|c|c|}
\hline \multirow[b]{3}{*}{$\mathbf{R N}^{\mathrm{b}}$} & \multicolumn{5}{|c|}{ Synthetic Urine (Bq/g) } & \multicolumn{4}{|c|}{ Soil (Bq/g) } & \multirow[b]{3}{*}{$\begin{array}{c}\% \\
\text { Bias }\end{array}$} \\
\hline & \multicolumn{2}{|c|}{ Reported } & \multicolumn{2}{|c|}{ NIST $^{a}$} & \multirow[b]{2}{*}{$\begin{array}{c}\% \\
\text { Bias }\end{array}$} & \multicolumn{2}{|c|}{ Reported } & \multicolumn{2}{|c|}{ NIST } & \\
\hline & Value & $\begin{array}{l}\% 2 \sigma \\
\text { Error }\end{array}$ & Value & $\begin{array}{l}\% 2 \sigma \\
\text { Error }\end{array}$ & & Value & $\begin{array}{l}\% 2 \sigma \\
\text { Error }\end{array}$ & Value & $\begin{array}{l}\% 2 \sigma \\
\text { Error }\end{array}$ & \\
\hline${ }^{241} \mathrm{Am}$ & 0.8607 & 50.35 & 0.84 & 0.63 & 2.4 & 0.3993 & 45.5 & 0.426 & 0.67 & -6.3 \\
\hline${ }^{238} \mathrm{Pu}$ & 0.8077 & 43.88 & 0.853 & 1.1 & -5.3 & 0.4231 & 45 & 0.44 & 1.14 & -3.8 \\
\hline${ }^{239} \mathrm{Pu}$ & 0.8365 & 43.3 & 0.84 & 0.76 & -0.4 & 0.4709 & 44.4 & 0.436 & 0.79 & 8 \\
\hline${ }^{90} \mathrm{Sr}$ & 0.841 & 36.07 & 0.858 & 0.75 & -2.1 & 0.4028 & 35.4 & 0.435 & 0.77 & -7.5 \\
\hline \multirow[t]{3}{*}{${ }^{238} \mathrm{U}$} & 0.8224 & 38.16 & 0.828 & 0.6 & -0.7 & 0.4649 & 26.4 & 0.42 & 0.63 & 10.7 \\
\hline & \multicolumn{5}{|c|}{ Synthetic Feces (Bq/g) } & \multicolumn{4}{|c|}{ Water $(\mathrm{Bq} / \mathrm{g})$} & \\
\hline & \multicolumn{2}{|c|}{ Reported } & \multicolumn{2}{|c|}{ NIST $^{a}$} & & \multicolumn{2}{|c|}{ Reported } & \multicolumn{2}{|c|}{ NIST } & \\
\hline $\mathbf{R N}^{\mathbf{b}}$ & Value & $\begin{array}{l}\% 2 \sigma \\
\text { Error }\end{array}$ & Value & $\begin{array}{l}\% 2 \sigma \\
\text { Error }\end{array}$ & $\begin{array}{c}\% \\
\text { Bias }\end{array}$ & Value & $\begin{array}{l}\% 2 \sigma \\
\text { Error }\end{array}$ & Value & $\begin{array}{l}\% 2 \sigma \\
\text { Error }\end{array}$ & $\begin{array}{c}\% \\
\text { Bias }\end{array}$ \\
\hline${ }^{241} \mathrm{Am}$ & 1.956 & 17.17 & 1.84 & 0.64 & 6.3 & 7.055 & 40.36 & 7.99 & 0.64 & -12 \\
\hline${ }^{238} \mathrm{Pu}$ & 1.511 & 18.95 & 1.637 & 1.12 & -7.7 & 7.883 & 37.74 & 7.86 & 0.7 & 0.3 \\
\hline${ }^{90} \mathrm{Sr}$ & 6.337 & 20.22 & 7.288 & 0.74 & -13 & 19.096 & 15.08 & 15.8 & 0.74 & 21 \\
\hline \multirow[t]{4}{*}{${ }^{238} \mathrm{U}$} & 6.523 & 29.39 & 7.193 & 0.6 & -9.3 & 7.884 & 33.2 & 8.06 & 0.6 & -2.2 \\
\hline & \multicolumn{5}{|c|}{ Air Filters (Bq/g) } & & & & & \\
\hline & \multicolumn{2}{|c|}{ Reported } & \multicolumn{2}{|c|}{ NIST $^{a}$} & & & & & & \\
\hline & Value & $\begin{array}{l}\% 2 \sigma \\
\text { Error }\end{array}$ & Value & $\begin{array}{l}\% 2 \sigma \\
\text { Error }\end{array}$ & $\begin{array}{c}\% \\
\text { Bias }\end{array}$ & & & & & \\
\hline${ }^{241} \mathrm{Am}$ & 2.541 & 16.71 & 2.437 & 0.67 & 4.3 & & & & & \\
\hline${ }^{238} \mathrm{Pu}$ & 2.221 & 17.04 & 2.168 & 1.14 & 2.4 & & & & & \\
\hline${ }^{90} \mathrm{Sr}$ & 9.523 & 12.2 & 9.653 & 0.77 & -1.3 & & & & & \\
\hline${ }^{238} \mathrm{U}$ & 9.432 & 14.47 & 9.527 & 0.63 & -1 & & & & & \\
\hline
\end{tabular}

a National Institute of Standards and Technology

${ }^{b}$ Radionuclide 
Table 8.11 - Environmental Measurements Laboratory Assessments for WIPP Laboratories, 2002 MATRIX: Air Filter (Bq/Filter)

\begin{tabular}{|c|c|c|c|c|c|c|c|c|c|c|}
\hline \multirow[b]{3}{*}{$\mathbf{R N}^{\mathrm{c}}$} & \multicolumn{5}{|c|}{ QAP $^{a} 56$ June 2002} & \multicolumn{4}{|c|}{ QAP 57 December 2002} & \multirow{3}{*}{$\begin{array}{c}\% \\
\text { Bias }\end{array}$} \\
\hline & \multicolumn{2}{|c|}{ Reported } & \multicolumn{2}{|c|}{$\mathrm{EML}^{\mathrm{b}}$} & \multirow{2}{*}{$\begin{array}{c}\% \\
\text { Bias }\end{array}$} & \multicolumn{2}{|c|}{ Reported } & \multicolumn{2}{|c|}{ EML } & \\
\hline & Value & Error & Value & Error & & Value & Error & Value & Error & \\
\hline${ }^{241} \mathrm{Am}$ & 0.0954 & 0.18 & 0.0883 & 0.005 & 8.04 & 0.172 & 0.024 & 0.191 & 0.004 & -9.95 \\
\hline${ }^{60} \mathrm{Co}$ & 30.8 & 4.14 & 30.52 & 0.652 & 0.92 & 23.2 & 3.18 & 23 & 0.059 & 0.87 \\
\hline${ }^{137} \mathrm{Cs}$ & 28.9 & 3.93 & 28.23 & 0.701 & 2.37 & 32.7 & 4.41 & 32.5 & 0.777 & 0.62 \\
\hline Gross $\alpha$ & 0.548 & 0.063 & 0.534 & 0.053 & 2.62 & 0.27 & 0.034 & 0.287 & 0.029 & -5.92 \\
\hline Gross $\beta$ & 1.18 & 0.123 & 1.3 & 0.13 & -9.23 & 0.751 & 0.081 & 0.871 & 0.087 & -13.8 \\
\hline${ }^{54} \mathrm{Mn}$ & 39 & 5.31 & 38.53 & 0.867 & 1.22 & 54 & 7.23 & 52.2 & 1.17 & 3.45 \\
\hline${ }^{238} \mathrm{Pu}$ & 0.0573 & 0.01 & 0.0574 & 0.001 & -0.21 & 0.113 & 0.016 & 0.119 & 0.003 & -5.04 \\
\hline${ }^{239} \mathrm{Pu}$ & 0.185 & 0.031 & 0.1874 & 0.003 & -1.28 & 0.21 & 0.028 & 0.206 & 0.002 & 1.94 \\
\hline${ }^{90} \mathrm{Sr}$ & 4.2 & 0.22 & 4.8317 & 0.184 & -13.1 & 4.68 & 0.249 & 5.561 & 0.119 & -15.8 \\
\hline $\mathrm{BqU}$ & 0.574 & 0.065 & 0.6076 & 0.005 & -5.53 & 0.458 & 0.043 & 0.467 & 0.008 & -1.93 \\
\hline
\end{tabular}

Table 8.12 - Environmental Measurements Laboratory Assessments for WIPP Laboratories, 2002 MATRIX: Soil (Bq/kg)

\begin{tabular}{|c|c|c|c|c|c|c|c|c|c|c|}
\hline \multirow[b]{3}{*}{$\mathbf{R N}^{\mathrm{c}}$} & \multicolumn{5}{|c|}{ QAP $^{a} 56$ June 2002} & \multicolumn{4}{|c|}{ QAP 57 December 2002} & \multirow{3}{*}{$\begin{array}{c}\% \\
\text { Bias }\end{array}$} \\
\hline & \multicolumn{2}{|c|}{ Reported } & \multicolumn{2}{|c|}{$\mathrm{EML}^{\mathrm{b}}$} & \multirow{2}{*}{$\begin{array}{c}\% \\
\text { Bias }\end{array}$} & \multicolumn{2}{|c|}{ Reported } & \multicolumn{2}{|c|}{ EML } & \\
\hline & Value & Error & Value & Error & & Value & Error & Value & Error & \\
\hline${ }^{228} \mathrm{Ac}$ & 43.8 & 6.82 & 51.1667 & 1.941 & -14.4 & 40.4 & 6.65 & 42.3 & 1.56 & -4.49 \\
\hline${ }^{241} \mathrm{Am}$ & 12 & 2.23 & 10.9267 & 0.373 & 9.82 & 6.49 & 1.15 & 6.767 & 0.301 & -4.09 \\
\hline${ }^{212} \mathrm{Bi}$ & 53.4 & 12.5 & 53.43 & 5.215 & -0.056 & 40.2 & 10.7 & 45.93 & 4.51 & -12.48 \\
\hline${ }^{214} \mathrm{Bi}$ & $\mathrm{NR}^{\mathrm{e}}$ & $\mathrm{NR}$ & NR & $N R$ & NR & 30.8 & 4.68 & 33.63 & 1.56 & -8.42 \\
\hline $\mathrm{Bq} \mathrm{U}$ & 173 & 17.2 & 194.769 & 15.642 & -11.18 & 70.27 & 6.434 & 87.21 & 7.3 & -19.42 \\
\hline${ }^{137} \mathrm{Cs}$ & 1150 & 145 & 1326.67 & 66.51 & -13.32 & 759 & 96 & 829.33 & 41.58 & -8.48 \\
\hline${ }^{40} \mathrm{~K}$ & 628 & 83.6 & 621.67 & 33.86 & 1.02 & 704 & 94.7 & 637.67 & 34.26 & 10.4 \\
\hline${ }^{212} \mathrm{~Pb}$ & 56 & 8 & 51.1 & 2.753 & 9.59 & 50.3 & 7.24 & 43.43 & 2.71 & 15.82 \\
\hline${ }^{214} \mathrm{~Pb}$ & 53.9 & 7.83 & 54.3667 & 2.249 & -0.858 & 37.6 & 5.97 & 35.2 & 1.51 & 6.82 \\
\hline${ }^{239} \mathrm{Pu}$ & 20.8 & 3.23 & 19.098 & 0.706 & 8.91 & 5.17 & 1.07 & 12.903 & 0.465 & $-40.1 d$ \\
\hline${ }^{90} \mathrm{Sr}$ & 43.8 & 7.97 & 53.7558 & 1.446 & -18.52 & 39 & 6.07 & 41.16 & 0.253 & -5.25 \\
\hline
\end{tabular}

${ }^{a}$ Quality Assurance Program

${ }^{\mathrm{b}}$ Environmental Measurements Laboratory

${ }^{\mathrm{c}}$ Radionuclide

${ }^{\mathrm{d}}$ Not acceptable

e Not requested 


\section{Waste Isolation Pilot Plant 2002 Site Environmental Report DOE/WIPP 03-2225}

Table 8.13 - Environmental Measurements Laboratory Assessments for WIPP Laboratories, 2002 MATRIX: Vegetation (Bq/kg)

\begin{tabular}{|c|c|c|c|c|c|c|c|c|c|c|}
\hline \multirow[b]{3}{*}{$\mathrm{RN}^{\mathrm{c}}$} & \multicolumn{5}{|c|}{ QAP $^{a} 56$ June 2002} & \multicolumn{4}{|c|}{ QAP 57 December 2002} & \multirow{3}{*}{$\begin{array}{c}\% \\
\text { Bias }\end{array}$} \\
\hline & \multicolumn{2}{|c|}{ Reported } & \multicolumn{2}{|c|}{$E M^{b}$} & \multirow{2}{*}{$\begin{array}{c}\% \\
\text { Bias }\end{array}$} & \multicolumn{2}{|c|}{ Reported } & \multicolumn{2}{|c|}{ EML } & \\
\hline & Value & Error & Value & Error & & Value & Error & Value & Error & \\
\hline${ }^{241} \mathrm{Am}$ & 2.19 & 0.48 & 2.2283 & 0.216 & -1.72 & 2.31 & 0.5 & 2.253 & 0.1 & 2.53 \\
\hline${ }^{244} \mathrm{Cm}$ & 1.27 & 0.33 & 1.32 & 0.164 & -3.79 & NR & NR & NR & NR & $\mathrm{NR}^{\mathrm{d}}$ \\
\hline${ }^{60} \mathrm{Co}$ & 10.1 & 1.64 & 11.23 & 0.677 & -10.06 & 9.61 & 1.58 & 9.66 & 0.63 & -0.52 \\
\hline${ }^{137} \mathrm{Cs}$ & 258 & 32.7 & 313.667 & 15.91 & -17.75 & 260 & 33 & 300.67 & 15.25 & -13.53 \\
\hline${ }^{40} \mathrm{~K}$ & 868 & 115 & 864.33 & 47.22 & 0.42 & 1600 & 213 & 1480 & 77.8 & 8.11 \\
\hline${ }^{239} \mathrm{Pu}$ & 3.53 & 0.701 & 3.5433 & 0.377 & -0.375 & 6.49 & 1.16 & 3.427 & 0.149 & 89.4 \\
\hline${ }^{90} \mathrm{Sr}$ & 503 & 75.1 & 586.28 & 11.14 & -14.2 & 365 & 36.5 & 476.26 & 6.673 & -23.36 \\
\hline
\end{tabular}

${ }^{a}$ Quality Assurance Program

${ }^{\mathrm{b}}$ Environmental Measurements Laboratory

${ }^{c}$ Radionuclide

${ }^{\mathrm{d}}$ Not requested

e Not acceptable

Table 8.14 - Environmental Measurements Laboratory Assessments for WIPP Laboratories, 2002 MATRIX: Water (Bq/L)

\begin{tabular}{|c|c|c|c|c|c|c|c|c|c|c|}
\hline \multirow[b]{3}{*}{$\mathbf{R N}^{\mathrm{c}}$} & \multicolumn{5}{|c|}{ QAP $^{a} 56$ June 2002} & \multicolumn{4}{|c|}{ QAP 57 December 2002} & \multirow{3}{*}{$\begin{array}{c}\% \\
\text { Bias }\end{array}$} \\
\hline & \multicolumn{2}{|c|}{ Reported } & \multicolumn{2}{|c|}{$\mathrm{EML}^{\mathrm{b}}$} & \multirow{2}{*}{$\begin{array}{c}\% \\
\text { Bias }\end{array}$} & \multicolumn{2}{|c|}{ Reported } & \multicolumn{2}{|c|}{ EML } & \\
\hline & Value & Error & Value & Error & & Value & Error & Value & Error & \\
\hline${ }^{241} \mathrm{Am}$ & 1.43 & 0.21 & 1.4737 & 0.021 & -2.97 & 2.45 & 0.336 & 3.043 & 0.082 & -19.49 \\
\hline $\mathrm{Bq} \mathrm{U}$ & 2.56 & 0.256 & 2.8355 & 0.121 & -9.72 & 6.27 & 0.314 & 6.836 & 0.266 & -8.28 \\
\hline${ }^{60} \mathrm{Co}$ & 348 & 46.4 & 347.33 & 12.4 & 0.19 & 281 & 36.7 & 268.67 & 9.71 & 4.59 \\
\hline${ }^{137} \mathrm{Cs}$ & 55.5 & 7.66 & 56.067 & 2.929 & -1.01 & 85 & 11.5 & 81.43 & 4.28 & 4.38 \\
\hline${ }^{134} \mathrm{Cs}$ & 3.07 & 0.835 & 3.3572 & 0.2 & -8.55 & 60.8 & 8.23 & 60.2 & 1.86 & 0.99 \\
\hline${ }^{238} \mathrm{Pu}$ & 0.483 & 0.078 & 0.4904 & 0.032 & -1.51 & 4.29 & 0.618 & 4.331 & 0.117 & -0.95 \\
\hline${ }^{239} \mathrm{Pu}$ & 4.38 & 0.581 & 4.219 & 0.172 & 3.82 & 2.06 & 0.304 & 2.07 & 0.074 & -0.48 \\
\hline${ }^{90} \mathrm{Sr}$ & 7.17 & 0.456 & 7.5786 & 0.176 & 5.39 & 7.32 & 0.44 & 8.69 & 0.42 & -15.76 \\
\hline
\end{tabular}

${ }^{a}$ Quality Assurance Program

${ }^{\mathrm{b}}$ Environmental Measurements Laboratory

${ }^{\mathrm{c}}$ Radionuclide

Table 8.15 - Environmental Resource Associates ${ }^{\circledR}$ Assessment of Air Toxics, Ltd., WP-93, December 9, 2002, for Volatile Organic Compounds

\begin{tabular}{lccccc}
\hline \multicolumn{1}{c}{ Analyte } & Units & $\begin{array}{c}\text { Reported } \\
\text { Value }\end{array}$ & $\begin{array}{c}\text { Assigned } \\
\text { Value }\end{array}$ & $\begin{array}{c}\text { Acceptance } \\
\text { Limits }\end{array}$ & $\begin{array}{c}\text { Performance } \\
\text { Evaluation }\end{array}$ \\
\hline Acetone & $\mu \mathrm{g} / \mathrm{L}$ & $<10.00$ & 0 & $\mathrm{NR}^{\mathrm{a}}$ & Acceptable \\
Acetonitrile & $\mu \mathrm{g} / \mathrm{L}$ & $<10.00$ & 0 & $\mathrm{NR}$ & Acceptable \\
Acrylonitrile & $\mu \mathrm{g} / \mathrm{L}$ & $<2.00$ & 0 & $\mathrm{NR}$ & Acceptable \\
Acrolein & $\mu \mathrm{g} / \mathrm{L}$ & $<10.00$ & 0 & $\mathrm{NR}$ & Acceptable \\
Benzene & $\mu \mathrm{g} / \mathrm{L}$ & 66.2 & 65.6 & $47.4-84.2$ & Acceptable \\
Bromodichloromethane & $\mu \mathrm{g} / \mathrm{L}$ & 14.3 & 12.6 & $8.68-16.6$ & Acceptable \\
Bromoform & $\mu \mathrm{g} / \mathrm{L}$ & 58.5 & 52 & $33.9-71.2$ & Acceptable \\
Bromomethane & $\mu \mathrm{g} / \mathrm{L}$ & $<2.00$ & 0 & $\mathrm{NR}$ & Acceptable \\
2-Butanone (MEK) & $\mu \mathrm{g} / \mathrm{L}$ & 17 & 26.4 & $7.4-39.9$ & Acceptable \\
Carbon disulfide & $\mu \mathrm{g} / \mathrm{L}$ & $<2.00$ & 0 & $\mathrm{NR}$ & Acceptable \\
Carbon tetrachloride & $\mu \mathrm{g} / \mathrm{L}$ & 87.8 & 69.7 & $143.0-98.3$ & Acceptable
\end{tabular}




\section{Waste Isolation Pilot Plant 2002 Site Environmental Report DOE/WIPP 03-2225}

Table 8.15 - Environmental Resource Associates ${ }^{\circledR}$ Assessment of Air Toxics, Ltd., WP-93, December 9, 2002, for Volatile Organic Compounds

\begin{tabular}{|c|c|c|c|c|c|}
\hline Analyte & Units & $\begin{array}{l}\text { Reported } \\
\text { Value }\end{array}$ & $\begin{array}{c}\text { Assigned } \\
\text { Value }\end{array}$ & $\begin{array}{l}\text { Acceptance } \\
\text { Limits }\end{array}$ & $\begin{array}{c}\text { Performance } \\
\text { Evaluation }\end{array}$ \\
\hline Chlorobenzene & $\mu g / L$ & 76.2 & 74.7 & $52.3-95.5$ & Acceptable \\
\hline Chlorodibromomethane & $\mu g / L$ & $<2.00$ & 0 & NR & Acceptable \\
\hline Chloroethane & $\mu \mathrm{g} / \mathrm{L}$ & 24 & 20 & $12.0-37.8$ & Acceptable \\
\hline 2-Chloroethylvinylether & $\mu \mathrm{g} / \mathrm{L}$ & $<10.0$ & 0 & NR & Acceptable \\
\hline Chloroform & $\mu g / L$ & 14.5 & 13.7 & $9.8-17.9$ & Acceptable \\
\hline Chloromethane & $\mu g / L$ & $<2.00$ & 0 & NR & Acceptable \\
\hline DBCP & $\mu \mathrm{g} / \mathrm{L}$ & $<10.0$ & 0 & NR & Acceptable \\
\hline 1,2-Dibromoethane (EDB) & $\mu g / L$ & $<2.00$ & 0 & NR & Acceptable \\
\hline Dibromomethane & $\mu \mathrm{g} / \mathrm{L}$ & $<2.00$ & 0 & NR & Acceptable \\
\hline 1,2-Dichlorobenzene & $\mu \mathrm{g} / \mathrm{L}$ & 52.6 & 50 & $35.3-63.2$ & Acceptable \\
\hline 1,3-Dichlorobenzene & $\mu \mathrm{g} / \mathrm{L}$ & $<2.00$ & 0 & NR & Acceptable \\
\hline 1,4-Dichlorobenzene & $\mu \mathrm{g} / \mathrm{L}$ & 30.6 & 28.8 & $19.6-37.5$ & Acceptable \\
\hline Dichlorodifluoromethane & $\mu \mathrm{g} / \mathrm{L}$ & $<2.00$ & 0 & NR & Acceptable \\
\hline 1,1-Dichloroethane & $\mu g / L$ & $<2.00$ & 0 & NR & Acceptable \\
\hline 1,2-Dichloroethane & $\mu g / L$ & 19.6 & 17.4 & $12.2-23.7$ & Acceptable \\
\hline 1,1-Dichloroethylene & $\mu g / L$ & 44.3 & 42.5 & $22.5-66.1$ & Acceptable \\
\hline cis-1,2-Dichloroethylene & $\mu \mathrm{g} / \mathrm{L}$ & 15.8 & 14.7 & $7.3-19.7$ & Acceptable \\
\hline trans-1,2-Dichloroethylene & $\mu g / L$ & 52.1 & 49.1 & $30.0-68.2$ & Acceptable \\
\hline 1,2-Dichloropropane & $\mu \mathrm{g} / \mathrm{L}$ & 115 & 111 & $74.6-141.0$ & Acceptable \\
\hline cis-1,3-Dichloropropylene & $\mu \mathrm{g} / \mathrm{L}$ & $<2.00$ & 0 & NR & Acceptable \\
\hline trans-1,3-Dichloropropylene & $\mu g / L$ & $<2.00$ & 0 & NR & Acceptable \\
\hline Ethylbenzene & $\mu g / L$ & 47.2 & 45.7 & $30.5-59.7$ & Acceptable \\
\hline 2-Hexanone & $\mu \mathrm{g} / \mathrm{L}$ & $<10.0$ & 0 & NR & Acceptable \\
\hline Methylene chloride & $\mu \mathrm{g} / \mathrm{L}$ & 65.7 & 61.5 & $38.8-84.5$ & Acceptable \\
\hline 4-Methyl-2-pentanone (MIBK) & $\mu g / L$ & 154 & 140 & $57.3-214.0$ & Acceptable \\
\hline Styrene & $\mu \mathrm{g} / \mathrm{L}$ & $<2.00$ & 0 & NR & Acceptable \\
\hline 1,1,1,2-Tetrachloroethane & $\mu g / L$ & 90.3 & 86.3 & $50.8-122.0$ & Acceptable \\
\hline 1,1,2,2-Tetrachloroethane & $\mu g / L$ & 199 & 190 & $112.0-265.0$ & Acceptable \\
\hline Tetrachloroethylene & $\mu \mathrm{g} / \mathrm{L}$ & $<2.00$ & 0 & NR & Acceptable \\
\hline Toluene & $\mu g / L$ & 15 & 14 & $9.7-18.0$ & Acceptable \\
\hline 1,1,1-Trichloroethane & $\mu \mathrm{g} / \mathrm{L}$ & 30 & 32.1 & $20.9-42.3$ & Acceptable \\
\hline 1,1,2-Trichloroethane & $\mu g / L$ & $<2.00$ & 0 & NR & Acceptable \\
\hline Trichloroethylene & $\mu g / L$ & 37.8 & 36.5 & $23.7-47.3$ & Acceptable \\
\hline Trichlorofluoromethane & $\mu g / L$ & $<2.00$ & 0 & NR & Acceptable \\
\hline 1,2,3-Trichloropropane & $\mu g / L$ & $<2.00$ & 0 & NR & Acceptable \\
\hline Vinyl acetate & $\mu \mathrm{g} / \mathrm{L}$ & $<10.0$ & 0 & NR & Acceptable \\
\hline Vinyl chloride & $\mu g / L$ & 19.4 & 18 & $4.1-30.1$ & Acceptable \\
\hline Xylenes, total & $\mu \mathrm{g} / \mathrm{L}$ & 169 & 182 & $93.0-217.0$ & Acceptable \\
\hline
\end{tabular}

${ }^{a}$ Not reported 
Table 8.16 - AbsoluteGrade PT Program Assessment of Trace Analysis, Inc. March - November, 2002

\begin{tabular}{|c|c|c|c|c|c|}
\hline Parameter & Units & $\begin{array}{l}\text { Reported } \\
\text { Value }\end{array}$ & $\begin{array}{l}\text { Assigned } \\
\text { Value }\end{array}$ & $\begin{array}{l}\text { Acceptance } \\
\text { Limits }\end{array}$ & $\begin{array}{c}\text { Performance } \\
\text { Evaluation }\end{array}$ \\
\hline $\mathrm{pH}$ & S.U. & 5.74 & 5.8 & $5.67-5.93$ & Acceptable \\
\hline Cyanide & $\mathrm{mg} / \mathrm{L}$ & 0.404 & 0.426 & $0.319-0.532$ & Acceptable \\
\hline Phenolics, total & $\mathrm{mg} / \mathrm{L}$ & 1.7 & 1.31 & $0.723-1.90$ & Acceptable \\
\hline Grease \& Oil (Gravimeteric) & $\mathrm{mg} / \mathrm{L}$ & 23 & 24.9 & $15.2-30.0$ & Acceptable \\
\hline Total Residual Chlorine & $\mathrm{mg} / \mathrm{L}$ & 0.98 & 0.847 & $0.627-1.07$ & Acceptable \\
\hline Mercury & $\mu g / L$ & 3.41 & 2.89 & $2.07-3.72$ & Acceptable \\
\hline Hexavalent Chromium & $\mu g / L$ & 574 & 573 & $467-659$ & Acceptable \\
\hline \multicolumn{6}{|l|}{$\underline{\text { Minerals }}$} \\
\hline Total solids at $105^{\circ} \mathrm{C}$ & $\mathrm{mg} / \mathrm{L}$ & 278 & 316 & $252-380$ & Acceptable \\
\hline Total Dissolved Solids & $\mathrm{mg} / \mathrm{L}$ & 144 & 136 & $102-170$ & Acceptable \\
\hline Conductivity at $25^{\circ} \mathrm{C}$ & $\mu$ mhos & 145 & 136 & $128-144$ & Not Acceptable \\
\hline Alkalinity as $\mathrm{CaCO} 3$ & $\mathrm{mg} / \mathrm{L}$ & 24 & 24.8 & $20.7-29.8$ & Acceptable \\
\hline Chloride & $\mathrm{mg} / \mathrm{L}$ & 39.8 & 44.4 & $39.3-49.0$ & Check for Error \\
\hline Fluoride & $\mathrm{mg} / \mathrm{L}$ & 2.72 & 2.89 & $2.52-3.22$ & Acceptable \\
\hline Potassium & $\mathrm{mg} / \mathrm{L}$ & 16.2 & 15.7 & $13.4-18.0$ & Acceptable \\
\hline Sodium & $\mathrm{mg} / \mathrm{L}$ & 15.5 & 14.9 & $13.2-17.2$ & Acceptable \\
\hline Sulfate & $\mathrm{mg} / \mathrm{L}$ & 17.4 & 19.2 & $3.17-34.8$ & Acceptable \\
\hline \multicolumn{6}{|l|}{$\underline{\text { Hardness }}$} \\
\hline Total suspended solids & $\mathrm{mg} / \mathrm{L}$ & 62.6 & 66.3 & $50.8-71.4$ & Acceptable \\
\hline Calcium & $\mathrm{mg} / \mathrm{L}$ & 12.6 & 11.7 & $10.1-13.5$ & Acceptable \\
\hline Magnesium & $\mathrm{mg} / \mathrm{L}$ & 8.6 & 8.18 & $7.1-9.2$ & Acceptable \\
\hline Calcium hardness as $\mathrm{CaCO}_{3}$ & $\mathrm{mg} / \mathrm{L}$ & $N R^{a}$ & 67.9 & NR & NR \\
\hline Total hardness as $\mathrm{CaCO}_{3}$ & $\mathrm{mg} / \mathrm{L}$ & 669 & 62.8 & $56.0-71.2$ & Acceptable \\
\hline \multicolumn{6}{|l|}{ Demand } \\
\hline BOD & $\mathrm{mg} / \mathrm{L}$ & 166 & 147 & $74.3-219$ & Acceptable \\
\hline CBOD & $\mathrm{mg} / \mathrm{L}$ & 112 & 126 & $56.5-196$ & Acceptable \\
\hline COD & $\mathrm{mg} / \mathrm{L}$ & 159 & 239 & $187-270$ & Not Acceptable \\
\hline TOC & $\mathrm{mg} / \mathrm{L}$ & 87.5 & 94.7 & $79.2-109.0$ & Acceptable \\
\hline \multicolumn{6}{|l|}{ Nutrients } \\
\hline Ammonia as $\mathrm{N}$ & $\mathrm{mg} / \mathrm{L}$ & 4.7 & 5.37 & $4.1-6.6$ & Acceptable \\
\hline Nitrate as $\mathrm{N}$ & $\mathrm{mg} / \mathrm{L}$ & 3.99 & 4.27 & $3.35-5.11$ & Acceptable \\
\hline Ortho-phosphate as $\mathrm{P}$ & $\mathrm{mg} / \mathrm{L}$ & 3.23 & 1.38 & $1.17-1.61$ & Not Acceptable \\
\hline Total phosphorus as $\mathrm{P}$ & $\mathrm{mg} / \mathrm{L}$ & 1.26 & 1.42 & $1.07-1.70$ & Acceptable \\
\hline Total kjeldahl nitrogen as $\mathrm{N}$ & $\mathrm{mg} / \mathrm{L}$ & 12 & 12.1 & $8.7-15.1$ & Acceptable \\
\hline \multicolumn{6}{|l|}{ Trace Metals } \\
\hline Aluminum & $\mu \mathrm{g} / \mathrm{L}$ & 301 & 330 & $270-391$ & Acceptable \\
\hline Antimony & $\mu g / L$ & 31 & 35.9 & $25.1-46.7$ & Acceptable \\
\hline Arsenic & $\mu g / L$ & 129 & 139 & $122-155$ & Acceptable \\
\hline Barium & $\mu g / L$ & 1730 & 1759 & $1760-2340$ & Acceptable \\
\hline Beryllium & $\mu g / L$ & 4.4 & 4.99 & $4.24-5.74$ & Acceptable \\
\hline Boron & $\mu \mathrm{g} / \mathrm{L}$ & 999 & 1029 & $956-1137$ & Acceptable \\
\hline Cadmium & $\mu g / L$ & 43.5 & 47.9 & $38.3-57.5$ & Acceptable \\
\hline Chromium & $\mu g / L$ & 100 & 103 & $87.4-119.0$ & Acceptable \\
\hline Cobalt & $\mu \mathrm{g} / \mathrm{L}$ & 530 & 519 & NR & NR \\
\hline Copper & $\mu g / L$ & 830 & 870 & $783-957$ & Acceptable \\
\hline
\end{tabular}


Table 8.16 - AbsoluteGrade PT Program Assessment of Trace Analysis, Inc. March - November, 2002

\begin{tabular}{|c|c|c|c|c|c|}
\hline Parameter & Units & $\begin{array}{l}\text { Reported } \\
\text { Value }\end{array}$ & $\begin{array}{l}\text { Assigned } \\
\text { Value }\end{array}$ & $\begin{array}{l}\text { Acceptance } \\
\text { Limits }\end{array}$ & $\begin{array}{c}\text { Performance } \\
\text { Evaluation }\end{array}$ \\
\hline Iron & $\mu \mathrm{g} / \mathrm{L}$ & 774 & 829 & $732-938$ & Acceptable \\
\hline Lead & $\mu g / L$ & 71.1 & 76.9 & $53.8-99.9$ & Acceptable \\
\hline Manganese & $\mu g / L$ & 525 & 560 & $521-588$ & Acceptable \\
\hline Molybdenum & $\mu g / L$ & 21.4 & 29.9 & $24.8-35.0$ & Not Acceptable \\
\hline Nickel & $\mu g / L$ & 249 & 260 & $221-299$ & Acceptable \\
\hline Selenium & $\mu \mathrm{g} / \mathrm{L}$ & 67.5 & 71.9 & $57.5-86.3$ & Acceptable \\
\hline Silver & $\mu g / L$ & 357 & 360 & $309-412$ & Acceptable \\
\hline Strontium & $\mu g / L$ & 1930 & 200 & $170-229$ & Not Acceptable \\
\hline Thallium & $\mu \mathrm{g} / \mathrm{L}$ & $<0.05$ & 6.46 & $4.52-8.39$ & Not Acceptable \\
\hline Vanadium & $\mu g / L$ & 1860 & 1850 & NR & NR \\
\hline Zinc & $\mu \mathrm{g} / \mathrm{L}$ & 867 & 880 & $808-946$ & Acceptable \\
\hline \multicolumn{6}{|l|}{ PCBs in $\mathrm{H}_{2} \mathrm{O}$ (Standard \#1) } \\
\hline Aroclor 1016 & $\mu g / L$ & 0 & 0 & 0 & Acceptable \\
\hline Aroclor 1221 & $\mu g / L$ & NR & 0 & NR & Acceptable \\
\hline Aroclor 1232 & $\mu g / L$ & 0 & 0 & 0 & Acceptable \\
\hline Aroclor 1248 & $\mu g / L$ & 0 & 0 & 0 & Acceptable \\
\hline Aroclor 1254 & $\mu g / L$ & 2.07 & 2.83 & $1.4-4.3$ & Acceptable \\
\hline Aroclor 1260 & $\mu g / L$ & 0 & 0 & 0 & Acceptable \\
\hline \multicolumn{6}{|l|}{ 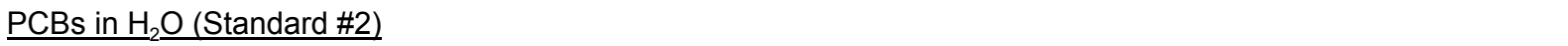 } \\
\hline Aroclor 1016 & $\mu \mathrm{g} / \mathrm{L}$ & 6.33 & 9.28 & $2.9-15.7$ & Acceptable \\
\hline Aroclor 1221 & $\mu g / L$ & NR & 0 & NR & Acceptable \\
\hline Aroclor 1232 & $\mu g / L$ & 0 & 0 & 0 & Acceptable \\
\hline Aroclor 1248 & $\mu g / L$ & 0 & 0 & 0 & Acceptable \\
\hline Aroclor 1254 & $\mu g / L$ & 0 & 0 & 0 & Acceptable \\
\hline Aroclor 1260 & $\mu \mathrm{g} / \mathrm{L}$ & 0 & 0 & 0 & Acceptable \\
\hline \multicolumn{6}{|l|}{ PCBs in Oil (Standard \#1) } \\
\hline Aroclor 1016/1242 & $\mathrm{mg} / \mathrm{kg}$ & 0 & 0 & 0 & Acceptable \\
\hline Aroclor 1254 & $\mathrm{mg} / \mathrm{kg}$ & 13.1 & 34.7 & $7.15-62.2$ & Check for Error \\
\hline Aroclor 1260 & $\mathrm{mg} / \mathrm{kg}$ & 0 & 0 & 0 & Acceptable \\
\hline \multicolumn{6}{|l|}{ PCBs in Oil (Standard \#2) } \\
\hline Aroclor 1016/1242 & $\mathrm{mg} / \mathrm{kg}$ & 0 & 0 & 0 & Acceptable \\
\hline Aroclor 1254 & $\mathrm{mg} / \mathrm{kg}$ & 0 & 0 & 0 & Acceptable \\
\hline Aroclor 1260 & $\mathrm{mg} / \mathrm{kg}$ & 6.36 & 16.2 & $3.8-28.7$ & Check for Error \\
\hline \multicolumn{6}{|l|}{$\underline{\text { Volatiles }}$} \\
\hline Acetone & $\mu g / L$ & NR & 0 & NR & NR \\
\hline Acetonitrile & $\mu g / L$ & NR & 0 & NR & NR \\
\hline Acrylonitrile & $\mu g / L$ & NR & 0 & NR & NR \\
\hline Acrolein & $\mu \mathrm{g} / \mathrm{L}$ & NR & 0 & NR & NR \\
\hline Benzene & $\mu g / L$ & 66.4 & 60 & $43.4-77.1$ & Acceptable \\
\hline Bromodichloromethane & $\mu g / L$ & 30.8 & 27.6 & $19.4-36.1$ & Acceptable \\
\hline Bromoform & $\mu \mathrm{g} / \mathrm{L}$ & 66.5 & 68 & $45.4-92.3$ & Acceptable \\
\hline Bromomethane & $\mu g / L$ & NR & 0 & NR & NR \\
\hline 2-Butanone (MEK) & $\mu g / L$ & NR & 0 & NR & NR \\
\hline Carbon disulfide & $\mu g / L$ & NR & 0 & NR & NR \\
\hline Carbon tetrachloride & $\mu g / L$ & 65.1 & 68 & $41.9-95.9$ & Acceptable \\
\hline
\end{tabular}


Table 8.16 - AbsoluteGrade PT Program Assessment of Trace Analysis, Inc. March - November, 2002

\begin{tabular}{|c|c|c|c|c|c|}
\hline Parameter & Units & $\begin{array}{l}\text { Reported } \\
\text { Value }\end{array}$ & $\begin{array}{l}\text { Assigned } \\
\text { Value }\end{array}$ & $\begin{array}{l}\text { Acceptance } \\
\text { Limits }\end{array}$ & $\begin{array}{l}\text { Performance } \\
\text { Evaluation }\end{array}$ \\
\hline Chlorobenzene & $\mu \mathrm{g} / \mathrm{L}$ & 47.3 & 44 & $31.2-56.0$ & Acceptable \\
\hline Chlorodibromomethane & $\mu g / L$ & 22.1 & 0 & NR & NR \\
\hline Chloroethane & $\mu g / L$ & NR & 0 & NR & NR \\
\hline 2-Chloroethylvinylether & $\mu g / L$ & $N R$ & 0 & $N R$ & $N R$ \\
\hline Chloroform & $\mu g / L$ & 44.7 & 40 & $27.9-51.4$ & Acceptable \\
\hline Chloromethane & $\mu g / L$ & NR & 0 & NR & NR \\
\hline $\mathrm{DBCP}$ & $\mu g / L$ & NR & 0 & NR & NR \\
\hline 1,2-Dibromoethane (EDB) & $\mu g / L$ & NR & 0 & NR & NR \\
\hline Dibromomethane & $\mu g / L$ & NR & 0 & NR & NR \\
\hline 1,2-Dichlorobenzene & $\mu g / L$ & 10.7 & 9.6 & $6.4-12.8$ & Acceptable \\
\hline 1,3-Dichlorobenzene & $\mu \mathrm{g} / \mathrm{L}$ & 63.9 & 56 & $39.7-69.7$ & Acceptable \\
\hline 1,4-Dichlorobenzene & $\mu \mathrm{g} / \mathrm{L}$ & 55.1 & 48 & $33.0-61.9$ & Acceptable \\
\hline Dichlorodifluoromethane & $\mu \mathrm{g} / \mathrm{L}$ & NR & 0 & NR & NR \\
\hline 1,1-Dichloroethane & $\mu \mathrm{g} / \mathrm{L}$ & NR & 0 & NR & NR \\
\hline 1,2-Dichloroethane & $\mu \mathrm{g} / \mathrm{L}$ & 20.6 & 19.2 & $13.4-26.1$ & Acceptable \\
\hline 1,1-Dichloroethylene & $\mu g / L$ & 100 & 86.9 & NR & NR \\
\hline cis-1,2-Dichloroethylene & $\mu g / L$ & 2.01 & 0 & NR & NR \\
\hline trans-1,2-Dichloroethylene & $\mu \mathrm{g} / \mathrm{L}$ & 110 & 94.1 & NR & NR \\
\hline 1,2-Dichloropropane & $\mu g / L$ & 54.2 & 49.7 & NR & NR \\
\hline cis-1,3-Dichloropropylene & $\mu \mathrm{g} / \mathrm{L}$ & 2.82 & 0.911 & NR & NR \\
\hline trans-1,3-Dichloropropylene & $\mu \mathrm{g} / \mathrm{L}$ & 32.3 & 41.4 & NR & NR \\
\hline Ethylbenzene & $\mu g / L$ & 13.8 & 12.4 & $8.5-16.0$ & Acceptable \\
\hline 2-Hexanone & $\mu g / L$ & $N R$ & 0 & NR & NR \\
\hline Methylene chloride & $\mu g / L$ & 28 & 24.8 & $15.7-34.7$ & Acceptable \\
\hline 4-Methyl-2-pentanone (MIBK) & $\mu g / L$ & NR & 0 & NR & NR \\
\hline Styrene & $\mu g / L$ & NR & 0 & NR & NR \\
\hline 1,1,1,2-Tetrachloroethane & $\mu g / L$ & $N R$ & 0 & NR & NR \\
\hline 1,1,2,2-Tetrachloroethane & $\mu g / L$ & 67.5 & 62.4 & NR & NR \\
\hline Tetrachloroethylene & $\mu g / L$ & 19.6 & 29.6 & $19.6-38.2$ & Acceptable \\
\hline Toluene & $\mu g / L$ & 29.5 & 26 & $18.5-32.8$ & Acceptable \\
\hline 1,1,1-Trichloroethane & $\mu g / L$ & 16.3 & 15.2 & $10.1-20.0$ & Acceptable \\
\hline 1,1,2-Trichloroethane & $\mu g / L$ & 63.9 & 58.2 & NR & NR \\
\hline Trichloroethylene & $\mu g / L$ & 16.4 & 16.4 & $10.8-21.4$ & Acceptable \\
\hline Trichlorofluoromethane & $\mu g / L$ & 69.8 & 65.3 & NR & NR \\
\hline 1,2,3-Trichloropropane & $\mu g / L$ & NR & 0 & NR & NR \\
\hline Vinyl acetate & $\mu g / L$ & NR & 0 & NR & NR \\
\hline Vinyl chloride & $\mu g / L$ & $N R$ & 0 & $N R$ & $N R$ \\
\hline Xylenes, total & $\mu g / L$ & 145.8 & 128 & $89.6-166.4$ & Acceptable \\
\hline \multicolumn{6}{|l|}{$\underline{\text { Acids }}$} \\
\hline Benzoic acid & $\mu g / L$ & NR & 0 & NR & NR \\
\hline 4-Chloro-3-methylphenol & $\mu g / L$ & 128 & 114 & NR & NR \\
\hline 2-Chlorophenol. & $\mu g / L$ & 56 & 65.4 & NR & NR \\
\hline 2,4-Dichlorophenol & $\mu g / L$ & 108 & 188 & $67.5-225$ & Acceptable \\
\hline 2,6-Dichlorophenol & $\mu g / L$ & $N R$ & 0 & NR & NR \\
\hline 2,4-Dimethylphenol & $\mu g / L$ & 23.4 & 41.5 & $26.4-56.0$ & Acceptable \\
\hline
\end{tabular}


Table 8.16 - AbsoluteGrade PT Program Assessment of Trace Analysis, Inc. March - November, 2002

\begin{tabular}{|c|c|c|c|c|c|}
\hline Parameter & Units & $\begin{array}{l}\text { Reported } \\
\text { Value }\end{array}$ & $\begin{array}{l}\text { Assigned } \\
\text { Value }\end{array}$ & $\begin{array}{l}\text { Acceptance } \\
\text { Limits }\end{array}$ & $\begin{array}{c}\text { Performance } \\
\text { Evaluation }\end{array}$ \\
\hline 4,6-Dinitro-2-methylphenol & $\mu \mathrm{g} / \mathrm{L}$ & 165 & 194 & $16.9-288$ & Acceptable \\
\hline 2,4-Dinitrophenol & $\mu \mathrm{g} / \mathrm{L}$ & 16.7 & 43.3 & $0.0-71.4$ & Acceptable \\
\hline 2-Methlyphenol & $\mu g / L$ & NR & 0 & NR & NR \\
\hline 3-Methylphenol & $\mu \mathrm{g} / \mathrm{L}$ & NR & 0 & NR & NR \\
\hline 4-Methylphenol & $\mu g / L$ & NR & 0 & NR & NR \\
\hline 2-Nitrophenol & $\mu \mathrm{g} / \mathrm{L}$ & 114 & 197 & $57.4-260$ & Acceptable \\
\hline 3-Nitrophenol & $\mu \mathrm{g} / \mathrm{L}$ & $N R$ & 0 & NR & NR \\
\hline 4-Nitrophenol & $\mu g / L$ & 34.6 & 117 & $0.00-159$ & Acceptable \\
\hline Pentachlorophenol & $\mu \mathrm{g} / \mathrm{L}$ & 148 & 198 & $55.9-275$ & Acceptable \\
\hline Phenol & $\mu \mathrm{g} / \mathrm{L}$ & 37.6 & 184 & $0.00-246$ & Acceptable \\
\hline 2,4,5-Trichlorophenol & $\mu \mathrm{g} / \mathrm{L}$ & $<5.0$ & 0 & 0 & Acceptable \\
\hline 2,4,6-Trichlorophenol & $\mu \mathrm{g} / \mathrm{L}$ & 38.7 & 55.8 & $19.3-73.3$ & Acceptable \\
\hline \multicolumn{6}{|l|}{ Base Neturals } \\
\hline Acenaphthene & $\mu \mathrm{g} / \mathrm{L}$ & 80.2 & 115 & $42.7-147$ & Acceptable \\
\hline Acenaphthylene & $\mu \mathrm{g} / \mathrm{L}$ & 131 & 192 & $77.1-231$ & Acceptable \\
\hline Aniline & $\mu \mathrm{g} / \mathrm{L}$ & NR & 0 & NR & NR \\
\hline Anthracene & $\mu \mathrm{g} / \mathrm{L}$ & 134 & 171 & $56.5-221$ & Acceptable \\
\hline Benzidine & $\mu g / L$ & NR & 0 & NR & NR \\
\hline Benzo(a)anthracene & $\mu \mathrm{g} / \mathrm{L}$ & 83.4 & 113 & $56.8-140$ & Acceptable \\
\hline Benzo(b)fluoranthene & $\mu \mathrm{g} / \mathrm{L}$ & 116 & 187 & $35.5-271$ & Acceptable \\
\hline Benzo(k)fluoranthene & $\mu \mathrm{g} / \mathrm{L}$ & 70.9 & 102 & $25.6-147$ & Acceptable \\
\hline Benzo(g,h,i)perylene & $\mu \mathrm{g} / \mathrm{L}$ & 120 & 186 & $55.9-277$ & Acceptable \\
\hline Benzo(a)pyrene & $\mu \mathrm{g} / \mathrm{L}$ & 113 & 153 & $88.6-218$ & Acceptable \\
\hline Benzyl alcohol & $\mu \mathrm{g} / \mathrm{L}$ & $N R$ & 0 & NR & NR \\
\hline 4-Bromophenyl-phenylether & $\mu \mathrm{g} / \mathrm{L}$ & 124 & 111 & NR & NR \\
\hline Butylbenzylphthalate & $\mu g / L$ & 144 & 134 & NR & NR \\
\hline Carbazole & $\mu \mathrm{g} / \mathrm{L}$ & NR & 0 & NR & NR \\
\hline 4-Chloroaniline & $\mu \mathrm{g} / \mathrm{L}$ & $<5.00$ & 0 & 0 & Acceptable \\
\hline bis(2-Chloroethoxy)methane & $\mu \mathrm{g} / \mathrm{L}$ & 76.1 & 130 & $51.3-154$ & Acceptable \\
\hline bis(2-Chloroethyl)ether & $\mu \mathrm{g} / \mathrm{L}$ & 48.5 & 80.3 & $22.4-99.5$ & Acceptable \\
\hline bis(2-Chloroisopropyl)ether & $\mu g / L$ & 63.1 & 96.5 & $24.0-142$ & Acceptable \\
\hline 1-Chloronaphthalene & $\mu g / L$ & NR & 0 & NR & NR \\
\hline 2-Chloronaphthalene & $\mu \mathrm{g} / \mathrm{L}$ & 38.6 & 45.6 & NR & NR \\
\hline 4-Chlorophenyl-phenylether & $\mu g / L$ & 125 & 170 & $58.5-217$ & Acceptable \\
\hline Chrysene & $\mu \mathrm{g} / \mathrm{L}$ & 117 & 141 & $51.1-186$ & Acceptable \\
\hline Dibenz(a,h)anthracene & $\mu \mathrm{g} / \mathrm{L}$ & 140 & 177 & $124-229$ & Check for Error \\
\hline Dibenzofuran & $\mu \mathrm{g} / \mathrm{L}$ & 44.1 & 55.6 & $37.0-74.2$ & Acceptable \\
\hline Di-n-butylphthalate & $\mu \mathrm{g} / \mathrm{L}$ & 134 & 173 & $16.9-241$ & Acceptable \\
\hline 1,2-Dichlorobenzene & $\mu g / L$ & 46.6 & 67 & $25.8-108$ & Acceptable \\
\hline 1,3-Dichlorobenzene & $\mu \mathrm{g} / \mathrm{L}$ & 51.7 & 67.6 & $31.4-104$ & Acceptable \\
\hline 1,4-Dichlorobenzene & $\mu \mathrm{g} / \mathrm{L}$ & 31 & 40.8 & $21.5-60.1$ & Acceptable \\
\hline 3,3'-Dichlorobenzidine & $\mu g / L$ & NR & 0 & NR & NR \\
\hline Diethylphthalate & $\mu g / L$ & 124 & 164 & $0.00-243$ & Acceptable \\
\hline Dimethlyphthalate & $\mu g / L$ & 47 & 64.4 & $0.00-98.3$ & Acceptable \\
\hline 2,4-Dinitrotoluene & $\mu \mathrm{g} / \mathrm{L}$ & 36.7 & 46.4 & $15.9-61.0$ & Acceptable \\
\hline
\end{tabular}




\section{Waste Isolation Pilot Plant 2002 Site Environmental Report DOE/WIPP 03-2225}

Table 8.16 - AbsoluteGrade PT Program Assessment of Trace Analysis, Inc. March - November, 2002

\begin{tabular}{llcccc}
\hline \multicolumn{1}{c}{ Parameter } & Units & $\begin{array}{c}\text { Reported } \\
\text { Value }\end{array}$ & $\begin{array}{c}\text { Assigned } \\
\text { Value }\end{array}$ & $\begin{array}{c}\text { Acceptance } \\
\text { Limits }\end{array}$ & $\begin{array}{c}\text { Performance } \\
\text { Evaluation }\end{array}$ \\
\hline 2,6-Dinitrotoulene & $\mu \mathrm{g} / \mathrm{L}$ & 29.5 & 37.6 & $14.4-46.9$ & Acceptable \\
Di-n-octylphthalate & $\mu \mathrm{g} / \mathrm{L}$ & 87.8 & 160 & $20.3-231$ & Acceptable \\
bis(2-ethylhexyl)phthalate & $\mu \mathrm{g} / \mathrm{L}$ & 275 & 172 & $21.8-253$ & Not Acceptable \\
Fluoranthene & $\mu \mathrm{g} / \mathrm{L}$ & 35.5 & 41.1 & $19.7-52.7$ & Acceptable \\
Fluorene & $\mu \mathrm{g} / \mathrm{L}$ & 26.6 & 35.8 & $15.2-46.8$ & Acceptable \\
Hexachlorobenzene & $\mu \mathrm{g} / \mathrm{L}$ & 91.4 & 115 & $50.3-149$ & Acceptable \\
Hexachlorobutadiene & $\mu \mathrm{g} / \mathrm{L}$ & 68.2 & 124 & $21.5-149$ & Acceptable \\
Hexachlorocyclopentadiene & $\mu \mathrm{g} / \mathrm{L}$ & 65.8 & 142 & $0-180$ & Acceptable \\
Hexachloroethane & $\mu \mathrm{g} / \mathrm{L}$ & 70.2 & 127 & $10.5-162$ & Acceptable \\
Indeno(1,2,3-cd)pyrene & $\mu \mathrm{g} / \mathrm{L}$ & 114 & 159 & $82.0-235$ & Acceptable \\
Isophorone & $\mu \mathrm{g} / \mathrm{L}$ & 42.9 & 62 & $23.1-81.7$ & Acceptable \\
1-Methylnaphthalene & $\mu \mathrm{g} / \mathrm{L}$ & $\mathrm{NR}$ & 0 & $\mathrm{NR}$ & NR \\
2-Methylnaphthalene & $\mu \mathrm{g} / \mathrm{L}$ & $\mathrm{NR}$ & 0 & $\mathrm{NR}$ & NR \\
Naphthalene & $\mu \mathrm{g} / \mathrm{L}$ & 95.1 & 171 & $40.1-222$ & Acceptable \\
2-Nitroaniline & $\mu \mathrm{g} / \mathrm{L}$ & 31.3 & 38.1 & $28-48.1$ & Check for Error \\
3-Nitroaniline & $\mu \mathrm{g} / \mathrm{L}$ & 47.1 & 48.7 & $14.9-82.5$ & Acceptable \\
4-Nitroaniline & $\mu \mathrm{g} / \mathrm{L}$ & 51.7 & 70.8 & $30.1-112$ & Acceptable \\
Nitrobenzene & $\mu \mathrm{g} / \mathrm{L}$ & 62.4 & 117 & $37.6-153$ & Acceptable \\
N-Nitrosodiethylamine & $\mu \mathrm{g} / \mathrm{L}$ & $\mathrm{NR}$ & 0 & $\mathrm{NR}$ & NR \\
N-Nitrosodimethylamine & $\mu \mathrm{g} / \mathrm{L}$ & 55.3 & 189 & $0.0-220$ & Acceptable \\
N-Nitrosodiphenylamine & $\mu \mathrm{g} / \mathrm{L}$ & $\mathrm{NR}$ & 0 & $\mathrm{NR}$ & NR \\
N-Nitroso-di-n-propylamine & $\mu \mathrm{g} / \mathrm{L}$ & 70.6 & 101 & $31-132$ & Acceptable \\
Phenanthrene & $\mu \mathrm{g} / \mathrm{L}$ & 42.1 & 51 & $24.9-64.4$ & Acceptable \\
Pyrene & $\mu \mathrm{g} / \mathrm{L}$ & 101 & 161 & $53.6-215$ & Acceptable \\
Pyridine & $\mu \mathrm{g} / \mathrm{L}$ & $\mathrm{NR}$ & 0 & $\mathrm{NR}$ & NR \\
1,2,4-Trichlorobenzene & $\mu \mathrm{g} / \mathrm{L}$ & 74 & 134 & $39.2-159$ & Acceptable \\
\hline Notreported & & & & &
\end{tabular}

${ }^{\text {a }}$ Not reported

${ }^{\mathrm{b}}$ Check for Error indicates result is above the warning limit, but within the acceptance limit.

Table 8.17 - AbsoluteGrade PT Program Assessment of Trace Analysis, Inc., Petroleum March - November, 2002

\begin{tabular}{|c|c|c|c|c|c|}
\hline Parameter & Units & $\begin{array}{c}\text { Reported } \\
\text { Value }\end{array}$ & $\begin{array}{c}\text { Assigned } \\
\text { Value }\end{array}$ & $\begin{array}{l}\text { Acceptance } \\
\text { Limits }\end{array}$ & $\begin{array}{c}\text { Performance } \\
\text { Evaluation }\end{array}$ \\
\hline \multicolumn{6}{|l|}{ Gasoline in Water } \\
\hline Unleaded Gasoline & $\mu \mathrm{g} / \mathrm{L}$ & 14800 & 4504 & $2702-6305$ & Not Acceptable \\
\hline Benzene & $\mu g / L$ & 53.4 & 48 & $33.6-62.4$ & Acceptable \\
\hline Ethylbenzene & $\mu g / L$ & 29.5 & 26.8 & $18.8-34.8$ & Acceptable \\
\hline Toluene & $\mu g / L$ & 22.6 & 20 & $14.0-26.0$ & Acceptable \\
\hline Xylenes, M/P & $\mu g / L$ & 113 & 100 & $70-130$ & Acceptable \\
\hline \multicolumn{6}{|l|}{ Diesel in Water } \\
\hline No. 2 Diesel & $\mu g / L$ & 4200 & 3410 & NR & NR \\
\hline \multicolumn{6}{|l|}{ TPH in Water } \\
\hline TPH (gravimetric) & $\mathrm{mg} / \mathrm{bttl}$ & $N R^{a}$ & 120 & NR & NR \\
\hline $\mathrm{TPH}(\mathrm{IR})$ & $\mathrm{mg} / \mathrm{bttl}$ & 184 & 144 & NR & NR \\
\hline BTEX in Water & & & & & \\
\hline
\end{tabular}


Table 8.17 - AbsoluteGrade PT Program Assessment of Trace Analysis, Inc., Petroleum March - November, 2002

\begin{tabular}{lccccc}
\hline Parameter & Units & $\begin{array}{c}\text { Reported } \\
\text { Value }\end{array}$ & $\begin{array}{c}\text { Assigned } \\
\text { Value }\end{array}$ & $\begin{array}{c}\text { Acceptance } \\
\text { Limits }\end{array}$ & $\begin{array}{c}\text { Performance } \\
\text { Evaluation }\end{array}$ \\
\hline Benzene & $\mathrm{mg} / \mathrm{L}$ & 59.2 & 58.6 & $\mathrm{NR}$ & $\mathrm{NR}$ \\
Ethylbenzene & $\mathrm{mg} / \mathrm{L}$ & 9.8 & 10 & $\mathrm{NR}$ & $\mathrm{NR}$ \\
Toluene & $\mathrm{mg} / \mathrm{L}$ & 74.9 & 73.9 & $\mathrm{NR}$ & $\mathrm{NR}$ \\
Xylenes, total & $\mathrm{mg} / \mathrm{L}$ & 197 & 225 & $\mathrm{NR}$ & $\mathrm{NR}$ \\
\hline
\end{tabular}

${ }^{a}$ Not reported

Table 8.18 - AbsoluteGrade PT Program Assessment of Trace Analysis, Inc., Pesticides March - November, 2002

\begin{tabular}{lccccc}
\hline \multicolumn{1}{c}{ Parameter } & Units & $\begin{array}{c}\text { Reported } \\
\text { Value }\end{array}$ & $\begin{array}{c}\text { Assigned } \\
\text { Value }\end{array}$ & $\begin{array}{c}\text { Acceptance } \\
\text { Limits }\end{array}$ & $\begin{array}{c}\text { Performance } \\
\text { Evaluation }\end{array}$ \\
\hline Aldrin & $\mu \mathrm{g} / \mathrm{L}$ & 3.1 & 0.93 & $0.294-1.57$ & Not Acceptable \\
alpha-BHC & $\mu \mathrm{g} / \mathrm{L}$ & 2.5 & 5.24 & $\mathrm{NR}$ & $\mathrm{NR}$ \\
beta-BHC & $\mu \mathrm{g} / \mathrm{L}$ & 2.5 & 3.01 & $\mathrm{NR}$ & $\mathrm{NR}$ \\
delta-BHC & $\mu \mathrm{g} / \mathrm{L}$ & $\mathrm{NR}$ & $\mathrm{NR}$ & $\mathrm{NR}$ & $\mathrm{NR}$ \\
gamma-BHC (Lindane) & $\mu \mathrm{g} / \mathrm{L}$ & 2.8 & 6.32 & $\mathrm{NR}$ & $\mathrm{NR}$ \\
alpha-Chlordane & $\mu \mathrm{g} / \mathrm{L}$ & $\mathrm{NR}$ & $\mathrm{NR}$ & $\mathrm{NR}$ & $\mathrm{NR}$ \\
gamma-Chlordane & $\mu \mathrm{g} / \mathrm{L}$ & 1.9 & 2.7 & $\mathrm{NR}$ & $\mathrm{NR}$ \\
Chlordane, technical & $\mu \mathrm{g} / \mathrm{L}$ & 8.2 & 9.01 & $3.93-12.8$ & Acceptable \\
$4,4^{\prime}-\mathrm{DDD}$ & $\mu \mathrm{g} / \mathrm{L}$ & 5.86 & 4.51 & $2.35-6.66$ & Acceptable \\
4,4'-DDE & $\mu \mathrm{g} / \mathrm{L}$ & 5.32 & 2.08 & $1.07-3.09$ & Not Acceptable \\
4,4'-DDT & $\mu \mathrm{g} / \mathrm{L}$ & 6.47 & 6.38 & $3.23-9.52$ & Acceptable \\
Dieldrin & $\mu \mathrm{g} / \mathrm{L}$ & 5.76 & 3.67 & $2.00-5.34$ & Not Acceptable \\
Endrin & $\mu \mathrm{g} / \mathrm{L}$ & $\mathrm{NR}$ & 1.09 & $\mathrm{NR}$ & $\mathrm{NR}$ \\
Endrin aldehyde & $\mu \mathrm{g} / \mathrm{L}$ & $\mathrm{NR}$ & $\mathrm{NR}$ & $\mathrm{NR}$ & $\mathrm{NR}$ \\
Endrin ketone & $\mu \mathrm{g} / \mathrm{L}$ & $\mathrm{NR}$ & $\mathrm{NR}$ & $\mathrm{NR}$ & $\mathrm{NR}$ \\
Endosulfan I & $\mu \mathrm{g} / \mathrm{L}$ & 1.5 & 2.19 & $\mathrm{NR}$ & $\mathrm{NR}$ \\
Endosulfan II & $\mu \mathrm{g} / \mathrm{L}$ & 2.4 & 3.83 & $\mathrm{NR}$ & $\mathrm{NR}$ \\
Endosulfan sulfate & $\mu \mathrm{g} / \mathrm{L}$ & 6 & 7.77 & $\mathrm{NR}$ & $\mathrm{NR}$ \\
Heptachlor & $\mu \mathrm{g} / \mathrm{L}$ & 3.56 & 1.16 & $0.375-1.96$ & Not Acceptable \\
Heptachlor epoxide & $\mu \mathrm{g} / \mathrm{L}$ & 2.99 & 1.08 & $0.61-1.55$ & Not Acceptable \\
Methoxychlor & $\mu \mathrm{g} / \mathrm{L}$ & 5 & 6.39 & $\mathrm{NR}$ & $\mathrm{NR}$ \\
Toxaphene & $\mu \mathrm{g} / \mathrm{L}$ & $\mathrm{NR}$ & $\mathrm{NR}$ & $\mathrm{NR}$ & $\mathrm{NR}$ \\
\hline Not & & & & &
\end{tabular}

a Not reported 


\section{REFERENCES}

10 CFR Part 50, Appendix B. "Quality Assurance Criteria for Nuclear Power Plants and Fuel Reprocessing Plants." Code of Federal Regulations. Office of the Federal Register, National Archives and Records Administration, Washington, D.C.

10 CFR Part 61. "Licensing Requirements for Land Disposal of Radioactive Waste." Code of Federal Regulations. Office of the Federal Register, National Archives and Records Administration, Washington, D.C.

10 CFR Part 71. "Packaging and Transportation of Radioactive Material." Code of Federal Regulations. Office of the Federal Register, National Archives and Records Administration, Washington, D.C.

10 CFR Part 834. "Radiation Protection of the Public and the Environment"; Proposed Rule. Code of Federal Regulations. Office of the Federal Register, National Archives and Records Administration, Washington, D.C.

10 CFR Part 835. "Occupational Radiation Protection." Code of Federal Regulations. Office of the Federal Register, National Archives and Records Administration, Washington, D.C.

10 CFR Part 1021. "National Environmental Policy Act Implementing Procedures." Code of Federal Regulations. Office of the Federal Register, National Archives and Records Administration, Washington, D.C.

10 CFR §1021.331. "National Environmental Policy Act Implementing Procedures, Mitigation Action Plans." Code of Federal Regulations. Office of the Federal Register, National Archives and Records Administration, Washington, D.C.

40 CFR Part 61. "National Emission Standards for Hazardous Air Pollutants." Code of Federal Regulations. Office of the Federal Register, National Archives and Records Administration, Washington, D.C.

40 CFR §61.92. "National Emission Standards for Hazardous Air Pollutants, Standard." Code of Federal Regulations. Office of the Federal Register, National Archives and Records Administration, Washington, D.C.

40 CFR Part 122. "EPA Administered Permit Programs: the National Pollutant Discharge Elimination System." Code of Federal Regulations. Office of the Federal Register, National Archives and Records Administration, Washington, D.C. 


\section{Waste Isolation Pilot Plant 2002 Site Environmental Report DOE/WIPP 03-2225}

40 CFR Part 191. "Environmental Radiation Protection Standards for Management and Disposal of Spent Nuclear Fuel, High-Level and Transuranic Radioactive Wastes." Code of Federal Regulations. Office of the Federal Register, National Archives and Records Administration, Washington, D.C.

40 CFR Part 247. "Comprehensive Procurement Guideline for Products Containing Recovered Materials." Code of Federal Regulations. Office of the Federal Register, National Archives and Records Administration, Washington, D.C.

40 CFR Part 262. "Standards Applicable to Generators of Hazardous Waste." Code of Federal Regulations. Office of the Federal Register, National Archives and Records Administration, Washington, D.C.

40 CFR Part 264. "Standards for Owners and Operators of Hazardous Waste Treatment, Storage, and Disposal Facilities." Code of Federal Regulations. Office of the Federal Register, National Archives and Records Administration, Washington, D.C.

40 CFR Part 270, "EPA Administered Permit Programs: the Hazardous Waste Permit Program." Code of Federal Regulations. Office of the Federal Register, National Archives and Records Administration, Washington, D.C.

40 CFR Part 280, "Technical Standards and Corrective Action Requirements for Owners and Operators of Underground Storage Tanks (UST)." Code of Federal Regulations. Office of the Federal Register, National Archives and Records Administration, Washington, D.C.

40 CFR Part 281, "Approval of State Underground Storage Tank Programs." Code of Federal Regulations. Office of the Federal Register, National Archives and Records Administration, Washington, D.C.

40 CFR Part 300, "National Oil and Hazardous Substances Pollution Contingency Plan." Code of Federal Regulations. Office of the Federal Register, National Archives and Records Administration, Washington, D.C.

40 CFR Part 302. "Designation, Reportable Quantities, and Notification." Code of Federal Regulations. Office of the Federal Register, National Archives and Records Administration, Washington, D.C.

40 CFR Part 503. "Standards for the Use or Disposal of Sewage Sludge." Code of Federal Regulations. Office of the Federal Register, National Archives and Records Administration, Washington, D.C.

40 CFR Parts 1500-1517. "Council on Environmental Quality." Code of Federal Regulations. Office of the Federal Register, National Archives and Records Administration, Washington, D.C. 
49 CFR. Transportation. Code of Federal Regulations. Office of the Federal Register, National Archives and Records Administration, Washington, D.C.

49 CFR Parts 106-178. "Research and Special Programs Administration, Department of Transportation." Code of Federal Regulations. Office of the Federal Register, National Archives and Records Administration, Washington, D.C.

20.2.72 NMAC. "Construction Permits." Title 20, New Mexico Administrative Code. (Air Quality Control Regulation 702). Santa Fe, NM.

20.4.1 NMAC. "Hazardous Waste Management." Title 20, New Mexico Administrative Code. Santa Fe, NM.

20.6.2 NMAC. "Ground and Surface Water Protection." Title 20, New Mexico Administrative Code. Santa Fe, NM.

7 U.S.C. §136-136y. Federal Insecticide, Fungicide, and Rodenticide Act, as amended. United States Code. U.S. Government Printing Office, Washington, D.C.

15 U.S.C. §2301 et seq. Toxic Substances Control Act. U.S. Government Printing Office, Washington, D.C.

16 U.S.C. \$1531-1544. Endangered Species Act of 1973. United States Code.

U.S. Government Printing Office, Washington, D.C.

16 U.S.C. $\$ 470$ et seq. National Historic Preservation Act. United States Code. U.S. Government Printing Office, Washington, D.C.

33 U.S.C. §1251-1376. Federal Water Pollution Control Act of 1948 (Clean Water Act), Section 402. United States Code. U.S. Government Printing Office, Washington, D.C.

42 U.S.C. §2278a. Atomic Energy Act of 1954. United States Code. U.S. Government Printing Office, Washington, D.C.

42 U.S.C. §300f et seq. Safe Drinking Water Act. United States Code.

U.S. Government Printing Office, Washington, D.C.

42 U.S.C. $\$ 6901$ et seq. Resource Conservation and Recovery Act. United States Code. U.S. Government Printing Office, Washington, D.C.

42 U.S.C. §§4321-4345. National Environmental Policy Act. United States Code. U.S. Government Printing Office, Washington, D.C.

42 U.S.C. §7112. Department of Energy Organization Act. United States Code. U.S. Government Printing Office, Washington, D.C. 
42 U.S.C. $§ 7401$ et seq. Clean Air Act. United States Code. U.S. Government Printing Office, Washington, D.C.

42 U.S.C. $\$ 9601$ et seq. Comprehensive Environmental Response, Compensation, and Liability Act (including the Superfund Amendments and Reauthorization Act of 1986). United States Code. U.S. Government Printing Office, Washington, D.C.

43 U.S.C. $\$ 1751$ et seq. Federal Land Policy and Management Act, 1976. United States Code. U.S. Government Printing Office, Washington, D.C.

49 U.S.C. $\S 5101$ et seq.; 49 CFR Parts 105-179. Hazardous Materials Transportation Act. United States Code. U.S. Government Printing Office, Washington, D.C.

ANSI/ASQC - E4. Proposed. Quality Assurance Program Requirements for Environmental Programs. American National Standards Institute/American Society for Quality Control, Washington, D.C.

DOE/CAO 96-2184. 1996. 40 CFR Part 191 Compliance Certification Application for the Waste Isolation Pilot Plant. U.S. Department of Energy, Carlsbad Field Office. Carlsbad, NM.

DOE/CBFO 98-2276, Integrated Safety Management System Description. U.S. Department of Energy, Carlsbad Field Office. Carlsbad, NM.

DOE/EA-1340. Environmental Assessment for Conducting Astrophysics and Other Basic Science Experiments at the WIPP Site. U.S. Department of Energy, Washington, D.C.

DOE/EA-1404. Final. Environmental Assessment for Actinide Chemistry and Repository Science Laboratory. U.S. Department of Energy, Washington, D.C.

DOE/EH-0173T. 1991. Environmental Regulatory Guide for Radiological Effluent Monitoring and Environmental Surveillance, Department of Environment, Safety, and Health, U.S. Department of Energy, Washington, D.C.

DOE/EIS-0026. 1980. Final Environmental Impact Statement (FEIS), Waste Isolation Pilot Plant, Volumes 1 and 2. U.S. Department of Energy, Washington, D.C.

DOE/EIS-0026-FS. 1990. Final Supplemental Environmental Impact Statement (SEIS-I), Volumes 1-3. U.S. Department of Energy, Washington, D.C.

DOE/EIS-0026-S-2. 1997. Waste Isolation Pilot Plant Disposal Phase Final Supplemental Environmental Impact Statement (SEIS-II), Volumes 1-3. U.S. Department of Energy, Washington, D.C.

DOE Order 151.1A. 1996. Comprehensive Emergency Management System. U.S. Department of Energy, Washington, D.C. 
DOE Order 225.1A. 1997. Accident Investigation. U.S. Department of Energy, Washington, D.C.

DOE Order 231.1. 1996. Environmental, Safety, and Health Reporting. U.S. Department of Energy, Washington, D.C.

DOE Order 414.1A. 1998. Quality Assurance. U.S. Department of Energy, Washington, D.C.

DOE Order 430.1A. 1995. Life-Cycle Assessment Management. U.S. Department of Energy, Washington, D.C.

DOE Order 435.1. 1999. Radioactive Waste Management. U.S. Department of Energy, Washington, D.C.

DOE Order 451.1B. 1995. National Environmental Compliance Policy Act Compliance Program. U.S. Department of Energy, Washington, D.C.

DOE Order 460.1B. 1996. Packaging and Transportation Safety. U.S. Department of Energy, Washington, D.C.

DOE Order 460.2. 1995. Departmental Materials Transportation and Packaging Management. U.S. Department of Energy, Washington, D.C.

DOE Order 5400.1. 1990. General Environmental Protection Programs. U.S. Department of Energy, Washington, D.C.

DOE Order 5400.5. 1988. Radiation Protection of the Public and the Environment. U.S. Department of Energy, Washington, D.C.

DOE Order 5480.23. 1994. Nuclear Safety Analysis Reports. U.S. Department of Energy, Washington, D.C.

DOE-STD-1153-2002. 2002. A Graded Approach for Evaluating Radiation Doses to Aquatic and Terrestrial Biota. National Technical Information Service, Washington, D.C.

DOE/WIPP 92-037. 1992. Statistical Summary of the Radiological Baseline for the Waste Isolation Pilot Plant. Waste Isolation Pilot Plant, Carlsbad, NM.

DOE/WIPP 93-004. Waste Isolation Pilot Plant Land Management Plan. Waste Isolation Pilot Plant, Carlsbad, NM.

DOE/WIPP 95-2065. Waste Isolated Pilot Plant Contact Handled (CH) Safety Analysis Report. Waste Isolation Pilot Plant, Carlsbad, NM. 
DOE/WIPP 98-2285. 1998. Waste Isolation Pilot Plant RCRA Background Groundwater Quality Baseline Report. Waste Isolation Pilot Plant, Carlsbad, NM.

DOE/WIPP 02-2171. 2002. Waste Isolation Pilot Plant Biennial Environmental Compliance Report. Waste Isolation Pilot Plant, Carlsbad, NM.

DOE/WIPP 99-2194. 1999. Waste Isolation Pilot Plant Environmental Monitoring Plan. Waste Isolation Pilot Plant, Carlsbad, NM.

DOE/WIPP 02-2225. 2002. Waste Isolation Pilot Plant 2001 Annual Site Environmental Report. Waste Isolation Pilot Plant, Carlsbad, NM.

DP-831. 1997. WIPP Discharge Plan. New Mexico Environment Department, Santa Fe, NM.

EPA 402-R-97-01, Guidance for the Implementation of EPA's Standards for Management and Storage of Transuranic Waste at WIPP. U.S. Environmental Protection Agency, Washington, D.C.

Executive Order 13101. 1998. Greening the Government Through Waste Prevention, Recycling, and Federal Acquisition. Office of the President, Washington, D.C.

Executive Order 13148. 1998. Greening the Government Through Leadership in Environmental Management. Office of the President, Washington, D.C.

Hawks Aloft, Inc. 2002. WIPP Raptor Program 2002 Annual Report. Waste Isolation Pilot Plant, Carlsbad, NM.

HPS N13.30. 1996. Performance Criteria for Radiobioassay. Health Physics Society, Washington, D.C.

ISO 14001. Environmental Management System Standards. International Organizations for Standardization. Geneva, Switzerland.

IT Corporation. 2000. Waste Isolation Pilot Plant RCRA Background Groundwater Quality Baseline Update Report. Albuquerque, NM.

NCRP. 1987a. Report No. 94, Exposure of the Population in the United States and Canada from Natural Background Radiation. National Council on Radiation Protection and Measurements. Bethesda, MD.

NCRP. 1987b. Use of Bioassay Procedures for Assessment of Internal Radionuclide Deposition. National Council on Radiation Protection and Measurements. Bethesda, MD.

NCRP. 1991. Report No. 109, Effects of lonizing Radiation on Aquatic Organisms. National Council on Radiation Protection and Measurements. Bethesda, MD. 
NEPA ID \# WIP:00:002. 2002. 2002 Annual Mitigation Report for the Waste Isolation Pilot Plant. Waste Isolation Pilot Plant, Carlsbad, NM.

NM4890139088-TSDF. 1999. Waste Isolation Pilot Plant Hazardous Waste Facility Permit. New Mexico Environment Department, Santa Fe, NM.

NMR05A823. 2001. New Mexico NPDES Multi-Sector General Permit. New Mexico Environment Department, Santa Fe, NM.

NMSA 1978 §74-2. New Mexico Air Quality Control Act. New Mexico Statutes Annotated 1978. State of New Mexico, Santa Fe, NM.

NMSA 1978, §74-4-1. New Mexico Hazardous Waste Act. New Mexico Statutes Annotated 1978. State of New Mexico, Santa Fe, NM.

NQA-1-1994. 1994. Quality Assurance Program Requirements for Nuclear Facilities. American National Standards Institute, Washington, D.C.

NRC-Docket-71-9218. TRUPACT-II Safety Analysis Report for Packaging. Nuclear Regulator Commission, Washington, D.C.

PPOA 99-02. 1999. Pollution Prevention Opportunity Assessment, CRC Lectra Motive Replacement. Waste Isolation Pilot Plant, Carlsbad, NM.

Public Law 96-164. National Security and Military Applications of Nuclear Energy Authorization Act of 1980.

Public Law 102-579. Waste Isolation Pilot Plant Land Withdrawal Act. October 1992, as amended October 1996 by Public Law 104-201.

QAMS-005/80. 1980. Interim Guidelines and Specifications for Preparing Quality Assurance Project Plans. U.S. Environmental Protection Agency, Washington, D.C.

Regulatory Guide 4.15, Rev. 1. 1979. Quality Assurance for Radiological Monitoring Programs-Effluent Streams and the Environment. U.S. Nuclear Regulatory Commission, Washington, D.C.

TO-14A. 1999. Compendium of Methods for the Determination of Toxic Organic Compounds in Ambient Air. U.S. Environmental Protection Agency, Washington, D.C.

U.S. Department of Energy. 1994. Waste Acceptance Criteria for Off-Site Generators. Fernald Environmental Management Project. Cincinnati, OH.

U.S. Department of Energy. 1986. Environmental Policy Statement, Secretary Herrington. U.S. Department of Energy, Washington, D.C. 
U.S. Department of Energy. 2003. Memorandum EH-41:Natoli:6-1336. Guidance for the Preparation of DOE Annual Site Environmental Reports (ASERs) for Calendar Year 2002. U.S. Department of Energy, Washington, D.C.

MP 1.2, Work Suspension and Stop-Work Direction. Washington TRU Solutions LLC, Waste Isolation Pilot Plant, Carlsbad, NM.

MP 1.12, Worker Protection Policy. Washington TRU Solutions LLC, Waste Isolation Pilot Plant, Carlsbad, NM.

MP 1.14, Environmental Management. Washington TRU Solutions LLC, Waste Isolation Pilot Plant, Carlsbad, NM.

MP 1.28, Integrated Safety Management. Washington TRU Solutions LLC, Waste Isolation Pilot Plant, Carlsbad, NM.

WP 02-1, WIPP Groundwater Monitoring Program Plan. Washington TRU Solutions LLC. Waste Isolation Pilot Plant, Carlsbad, NM.

WP 02-EC.0, Environmental Management System Description Document. Washington TRU Solutions LLC. Waste Isolation Pilot Plant, Carlsbad, NM.

WP 02-EC.07, Waste Isolation Pilot Plant Affirmative Procurement Plan. Washington TRU Solutions LLC. Waste Isolation Pilot Plant, Carlsbad, NM.

WP 02-EC.08, National Environmental Policy Act Compliance Plan. Washington TRU Solutions LLC. Waste Isolation Pilot Plant, Carlsbad, NM.

WP 02-EC.11, Waste Isolation Pilot Plant Pollution Prevention Program Plan. Washington TRU Solutions LLC. Waste Isolation Pilot Plant, Carlsbad, NM.

WP 08-NT3103, Shipment of Nonradioactive Waste. Washington TRU Solutions LLC. Waste Isolation Pilot Plant, Carlsbad, NM.

WP12-VC.01, Confirmatory Volatile Organic Compound Monitoring Program. Washington TRU Solutions LLC. Waste Isolation Pilot Plant, Carlsbad, NM.

WP 13-QA.03, Quality Assurance Independent Assessment Program. Washington TRU Solutions LLC. Waste Isolation Pilot Plant, Carlsbad, NM.

WP 15-PR, WIPP Records Management Program. Washington TRU Solutions LLC. Waste Isolation Pilot Plant, Carlsbad, NM. 


\section{Appendix A \\ Acronyms, Abbreviations, and Symbols}

$\begin{array}{ll}\text { A } & \\ \text { ACAA } & \begin{array}{l}\text { Accelerated Corrective Action Approach } \\ \text { above mean sea level }\end{array} \\ \text { ANSL } & \text { Analysis of Variance } \\ \text { ANSI } & \text { American National Standards Institute } \\ \text { AOC } & \text { Area of Concern } \\ \text { ASER } & \text { annual site environmental report } \\ \text { ASTM } & \text { American Society for Testing and Materials } \\ \text { B } & \\ \text { BCG } & \text { Biota Concentration Guides } \\ \text { BLM } & \text { U.S. Department of the Interior, Bureau of Land Management } \\ \text { Bq } & \text { becquerel } \\ \text { Bq/L } & \text { becquerels per liter } \\ \text { Bq/m } & \text { becquerels per cubic meter } \\ \text { C } & \\ \text { C of C } & \text { Certificate of Compliance } \\ \text { CAA } & \text { Clean Air Act } \\ \text { CAP88 } & \text { computer code for calculating both dose and risk from radionuclide } \\ \text { CBFO } & \text { emissions } \\ \text { CERCLA } & \text { Carlsbad Field Office } \\ \text { Comprehensive Environmental Response, Compensation and Liability } \\ \text { CFR } & \text { Act } \\ \text { CH } & \text { Code of Federal Regulations } \\ \text { Ci } & \text { contact-handled } \\ \text { Cm } & \text { curie } \\ \text { COD } & \text { centimeter } \\ \text { chemical oxygen demand } \\ \text { D } & \\ \text { DOE } & \text { U.S. Department of Energy } \\ \text { DOT } & \text { U.S. Department of Transportation } \\ \text { DP } & \text { Discharge Permit } \\ \text { E } & \\ \text { EA } & \text { Environmental Assessment } \\ \text { EDE } & \text { effective dose equivalent } \\ \text { EEG } & \text { Environmental Evaluation Group } \\ \text { Eh } & \text { Intensity Factor } \\ \text { EH } & \text { DOE Environment, Safety, and Health } \\ \text { EIS } & \text { Environmental Impact Statement } \\ \text { EML } & \text { Environmental Measurements Laboratory } \\ \text { EMP } & \text { WIPP Environmental Monitoring Plan } \\ & \\ & \end{array}$


EMS

E.O.

EPA

ERA

$\mathbf{F}$

$\mathrm{ft}$

$\mathrm{ft}^{3}$

FEIS

FY

G

g

gpd

Gy

H

HalfPACT

HEPA

HMTA

HWFP

I

IAEA

ISMS

ISO

K

$\mathrm{kg}$

$\mathrm{km}$

$\mathrm{km}^{2}$

L

L

LMP

LUR

LWA

M

$\mathrm{m}$

$\mathrm{m}^{3}$

$\mathrm{mBq}$

MDC

MDL

$\mathrm{MeV}$

$\mathrm{mg}$

$\mathrm{mg} / \mathrm{L}$
Environmental Management System

Executive Order

U.S. Environmental Protection Agency

Environmental Resource Associates

foot

cubic foot

Final Environmental Impact Statement

fiscal year

gram

gallons per day

Gray

Short Transuranic Package Transporter

high-efficiency particulate air (filter)

Hazardous Materials Transportation Act

Hazardous Waste Facility Permit

International Atomic Energy Agency

Integrated Safety Management System

International Organization for Standardization

kilogram

kilometer

square kilometers

liter

Land Management Plan

Land Use Request

Land Withdrawal Act

meter

cubic meters

millibecquerel

Minimum Detectable Concentration

Method Detection Limit

million electron volts

milligram

milligram per liter 


$\begin{array}{ll}\mathrm{mi} & \text { mile } \\ \mathrm{mi}^{2} & \text { square miles } \\ \mathrm{ml} & \text { milliliter } \\ \mathrm{MOU} & \text { Memorandum of Understanding } \\ \mathrm{MP} & \text { Management Policy } \\ \mathrm{mrem} & \text { millirem } \\ \mathrm{MSDS} & \text { material safety data sheet } \\ \mathrm{mSv} & \text { millisievert } \\ \mathrm{mSv} / \mathrm{yr} & \text { millisievert per year }\end{array}$

\section{$\mathbf{N}$}

$\mathrm{N} / \mathrm{A}$

$\mathrm{N} / \mathrm{C}$

NCRP

NEPA

NESHAP

NFA

NHPA

NIST

NMAC

NMED

NMIMT

NMSA

NOI

NPDES

NQA

NR

NRC

NRIP

0

$\mathrm{OZ}$

$\mathbf{P}$

P\&A plugging and abandonment

P2

Pub. L.

PCB

$\mathrm{pCi}$

$\mathrm{pCi} / \mathrm{L}$

PIP

ppbv

PPOA

not applicable

not collected

No Further Action

Notice of Intent

Nuclear Quality Assurance

not reported

Intercomparison Program

ounce

pollution prevention

Public Law

polychlorinated biphenyl

picoCuries

picoCuries per liter

production injection packer

parts per billion by volume
National Council for Radiation Protection and Measurements

National Environmental Policy Act

National Emission Standards for Hazardous Air Pollutants

National Historic Preservation Act

National Institute of Standards and Technology

New Mexico Administrative Code

New Mexico Environment Department

New Mexico Institute of Mining Technology

New Mexico Statutes Annotated

National Pollutant Discharge Elimination System

Nuclear Regulatory Commission

National Institute of Standards and Technology Radiochemistry

Pollution Prevention Opportunity Assessment 


\begin{tabular}{|c|c|}
\hline $\begin{array}{l}\text { Q } \\
\text { QA } \\
\text { QAP } \\
\text { QC }\end{array}$ & $\begin{array}{l}\text { quality assurance } \\
\text { Quality Assurance Program } \\
\text { quality control }\end{array}$ \\
\hline $\begin{array}{l}\text { R } \\
\text { RCRA } \\
\text { rem } \\
\text { RER } \\
\text { RFI } \\
\text { RFI/CMS } \\
\text { RH } \\
\text { RL } \\
\text { ROD } \\
\text { RPD }\end{array}$ & $\begin{array}{l}\text { Resource Conservation and Recovery Act } \\
\text { Roentgen equivalent man } \\
\text { Relative Error Ratio } \\
\text { RCRA Facility Investigation } \\
\text { RCRA Facility Investigation/Corrective Measures Study } \\
\text { remote-handled } \\
\text { Reporting Limit } \\
\text { Record of Decision } \\
\text { relative percent difference }\end{array}$ \\
\hline $\begin{array}{l}\text { S } \\
\text { SARA } \\
\text { SD } \\
\text { SDWA } \\
\text { SEIS-I } \\
\text { SEIS - II } \\
\text { SI } \\
\text { SMA } \\
\text { SS } \\
\text { SU } \\
\text { SWMU }\end{array}$ & $\begin{array}{l}\text { Superfund Amendments and Reauthorization Act } \\
\text { Standard Deviation } \\
\text { Safe Drinking Water Act } \\
\text { First Supplemental Environmental Impact Statement } \\
\text { Second Supplemental Environmental Impact Statement } \\
\text { Soil Intermediate } \\
\text { Special Management Area } \\
\text { Soil Surface } \\
\text { Standard Unit } \\
\text { Solid Waste Management Unit }\end{array}$ \\
\hline $\begin{array}{l}\text { T } \\
\text { TDS } \\
\text { TOC } \\
\text { TPU } \\
\text { TRANSCOM } \\
\text { TRU } \\
\text { TRUPACT - II } \\
\text { TSDF }\end{array}$ & $\begin{array}{l}\text { Total Dissolved Solid } \\
\text { Total Organic Compound } \\
\text { Total Propagated Uncertainty } \\
\text { Transportation Tracking and Communications (system) } \\
\text { transuranic (waste) } \\
\text { Transuranic Package Transporter Model II } \\
\text { treatment, storage, and disposal facility }\end{array}$ \\
\hline $\begin{array}{l}\text { U } \\
\text { U.S. } \\
\text { U.S.C. } \\
\text { UST } \\
\text { UTLV }\end{array}$ & $\begin{array}{l}\text { United States } \\
\text { United States Code } \\
\text { underground storage tank } \\
\text { Upper Tolerance Limit Value }\end{array}$ \\
\hline $\begin{array}{l}\text { V } \\
\text { VOC }\end{array}$ & Volatile Organic Compound \\
\hline
\end{tabular}




\section{W}

WIPP

WLWA

WQSP

WRES

WRRP

WTS

$\sigma$

${ }^{\circ} \mathrm{C}$

${ }^{\circ} \mathrm{F}$

$\mu \mathrm{Ci}$

$\mu \mathrm{g}$

$\mu$ mhos

$\%$

$[\mathrm{RN}]$
Waste Isolation Pilot Plant

WIPP Land Withdrawal Area

WIPP Groundwater Quality Sampling Program

Washington Regulatory and Environmental Services

WIPP Raptor Research Program

Washington TRU Solutions LLC

\section{Symbols}

sigma

Degrees Celsius

Degrees Fahrenheit

microcurie

microgram

micromhos

Percent

Radionuclide concentration 
This page intentionally left blank 


\section{Appendix B \\ Location Codes}

Table B.1 - Codes Used to Identify the Sites from Which Samples Were Collected

\begin{tabular}{llll}
\hline Code & \multicolumn{1}{c}{ Location } & Code & \multicolumn{1}{c}{ Location } \\
\hline BHT & Bottom of the Hill Tank & RCP & Rainwater Catchment Pond \\
BRA & Brantley Lake & RED & Red Tank \\
CBD & Carlsbad & RNS & Rinse Aid Blank \\
COW & Coyote Well (deionized water blank) & SE1 & South East 1 \\
COY & Coyote (surface water duplicate) & SE2 & South East 2 \\
CT1 & Control 1 & SEC & South East Control \\
CT2 & Control 2 & SMR & Smith Ranch \\
FWT & Fresh Water Tank & SOO & Sample Of Opportunity \\
HIL & Hill Tank & SWL & Sewage Lagoons \\
IDN & Indian Tank & TUT & Tut Tank \\
LAG & Laguna Grande del Sol & UPR & Upper Pecos River \\
LST & Lost Tank & WAB & WIPP Air Blank \\
MLR & Mills Ranch & WE1 & WIPP East 1 \\
NOY & Noya Tank & WEE & WIPP East \\
NW1 & NorthWest1 & WIP & WIPP 16 Sections \\
NW2 & NorthWest2 & WFF & WIPP Far Field \\
PCN & Pierce Canyon & WQSP & Water Quality Sample Program \\
PEC & Pecos River & WSS & WIPP South \\
PKT & Poker Trap & & \\
\hline & & & \\
\hline
\end{tabular}


This page intentionally left blank 


\section{Appendix C Equations}

\section{Minimum Detectable Concentration (MDC)}

MDC is equal to the mean of a distribution such that 95 percent of the measurements of the distribution will produce analytical results that have the activity above that of a blank. It is possible to achieve a very low level of detection by analyzing a large sample size and counting for a very long time.

The laboratory used the following equation for calculating the MDCs for each radionuclide in various sample matrices:

$$
M D C=\frac{4.65 S_{b}}{K T}+\frac{3}{K T}
$$

Where:

$$
\begin{array}{lll}
S_{b}= & \begin{array}{l}
\text { Standard deviation of the background count } \\
K
\end{array} \quad \begin{array}{l}
\text { A correction factor that includes items such as unit } \\
\text { conversions, sample volume/weight, decay correction, } \\
\text { detector efficiency, chemical recovery and abundance }
\end{array} \\
T \quad & \begin{array}{l}
\text { correction, etc. } \\
\text { Counting time }
\end{array}
\end{array}
$$

For further evaluation of MDC, refer to HPS N13.30 - 1996, Performance Criteria for Radiobioassay.

\section{Total Propagated Uncertainty (TPU)}

TPU is an estimate of the uncertainty in the measurement due to all sources, including counting error, measurement error, chemical recovery error, detector efficiency, randomness of radioactive decay, and any other sources of uncertainty.

Total propagated uncertainty for each data point must be reported at $2 \sigma$ level. The TPU was calculated by using the following equation:

$$
T P U_{1 \sigma}=\sigma_{A C T}=\frac{\sqrt{\sigma_{N C R}^{2}+(N C R)^{2} *\left(R E_{E F F}^{2}+R E_{A L I}^{2}+R E_{R}^{2}+\Sigma R E_{C F}^{2}\right)}}{2.22 * E F F * A L I * R * A B N_{S} * e^{-\lambda t} * C F}
$$

Where:

$$
\begin{array}{ll}
\mathrm{EFF} & =\text { Detector Efficiency } \\
\mathrm{ALI} & =\text { Sample Aliquot Volume or Mass } \\
\mathrm{R} & =\text { Sample Tracer/Carrier Recovery }
\end{array}
$$




$$
\begin{aligned}
& \mathrm{ABN}_{\mathrm{s}}=\text { Abundance Fraction of the Emissions Used for } \\
& \text { Identification/Quantification } \\
& \sigma^{2}{ }_{\text {NCR }}=\text { Variance of the Net Sample Count Rate } \\
& \text { NCR = Net Sample Count Rate } \\
& \mathrm{RE}_{\mathrm{EFF}}^{2}=\text { Square of the Relative Error of the Efficiency Term } \\
& \mathrm{RE}^{2}{ }_{\mathrm{ALI}}=\text { Square of the Relative Error of the Aliquot } \\
& \mathrm{RE}^{2}{ }_{\mathrm{R}}=\text { Square of the Relative Error of the Sample Recovery } \\
& \mathrm{RE}^{2}{ }_{\mathrm{CF}}=\text { Square of the Relative Error of Other Correction Factors } \\
& \lambda=\text { Analyte Decay Constant }=\ln 2 / \text { (half-life) [Same units as the } \\
& \text { half-life used to compute } \lambda \text { ] } \\
& \mathrm{t}=\text { Time from Sample Collection to Radionuclide Separation or } \\
& \text { Mid-Point of Count Time (Same units as half-life) } \\
& \mathrm{CF}=\text { Other Correction Factors as Appropriate (i.e., ingrowth factor, } \\
& \text { self-absorption factor, etc.). }
\end{aligned}
$$

For further discussion of TPU, refer to HPS N13.30-1996, Performance Criteria for Radiobioassay, and/or Waste Acceptance Criteria for Off-Site Generators, Fernald Environmental Management Project (DOE, 1994).

\section{Relative Error Ratio (RER)}

The Relative Error Ratio is a method, similar to a t-test, with which to compare duplicate results (see Chapters 4 and 8; WP 02-EM3004).

$$
R E R=\frac{\left|x_{A}-x_{B}\right|}{\sqrt{\left(2 \sigma_{A}\right)^{2}+\left(2 \sigma_{R}\right)^{2}}}
$$

Where:

$$
\begin{array}{ll}
X_{A} & =\text { Mean Activity of Population A } \\
X_{B} & =\text { Mean Activity of Population B } \\
\sigma_{A} & =\text { Standard Deviation of Population A } \\
\sigma_{B} & =\text { Standard Deviation of Population B. }
\end{array}
$$

\section{Percent Bias (\% Bias)}

A measure of the accuracy of radiochemical separation methods and counting instruments; that is, a measure of how reliable the results of analyses are when compared to the actual values.

$$
\% B I A S=\left[\frac{A_{m}-A_{k}}{A_{k}}\right] * 100 \%
$$

Where:

$$
\begin{array}{lll}
\% \text { BIAS } & =\text { Percent Bias } \\
A_{m} & =\text { Measured Sample Activity } \\
A_{k} & =\quad \text { Known Sample Activity }
\end{array}
$$




\section{Appendix D \\ Concentrations of Alpha and Beta Activities in Air Particulates}

Table D.1 - Results of Gross Alpha and Gross Beta Analyses in Air Particulates (Bq/m $\left.{ }^{3}\right)$

\begin{tabular}{|c|c|c|c|c|c|}
\hline \multirow[b]{2}{*}{ Week } & \multirow[b]{2}{*}{ Sample ID } & \multicolumn{2}{|c|}{ Gross Alpha } & \multicolumn{2}{|c|}{ Gross Beta } \\
\hline & & Concentration & $2 \times \mathrm{TPU}^{\mathrm{a}}$ & Concentration & $2 \times$ TPU \\
\hline \multicolumn{6}{|c|}{ Carlsbad } \\
\hline 1 & AL-CBD-20020102 1.2 & $1.72 \times 10^{-4}$ & $4.47 \times 10^{-5}$ & $1.28 \times 10^{-3}$ & $1.60 \times 10^{-4}$ \\
\hline 2 & AL-CBD-20020109 1.2 & $1.16 \times 10^{-4}$ & $3.69 \times 10^{-5}$ & $8.81 \times 10^{-4}$ & $1.22 \times 10^{-4}$ \\
\hline 3 & AL-CBD-20020116 1.2 & $1.33 \times 10^{-4}$ & $3.88 \times 10^{-5}$ & $1.14 \times 10^{-3}$ & $1.46 \times 10^{-4}$ \\
\hline 4 & AL-CBD-200201231.2 & $1.04 \times 10^{-4}$ & $3.40 \times 10^{-5}$ & $1.05 \times 10^{-3}$ & $1.38 \times 10^{-4}$ \\
\hline 5 & AL-CBD-200201301.2 & $1.16 \times 10^{-4}$ & $3.59 \times 10^{-5}$ & $1.33 \times 10^{-3}$ & $1.63 \times 10^{-4}$ \\
\hline 6 & AL-CBD-20020206 1.2 & $7.41 \times 10^{-5}$ & $2.90 \times 10^{-5}$ & $8.82 \times 10^{-4}$ & $1.22 \times 10^{-4}$ \\
\hline 7 & AL-CBD-20020213 1.2 & $6.18 \times 10^{-5}$ & $2.24 \times 10^{-5}$ & $8.65 \times 10^{-4}$ & $1.11 \times 10^{-4}$ \\
\hline 8 & AL-CBD-20020220 1.2 & $7.14 \times 10^{-5}$ & $2.96 \times 10^{-5}$ & $8.10 \times 10^{-4}$ & $1.18 \times 10^{-4}$ \\
\hline 9 & AL-CBD-20020227 1.2 & $9.97 \times 10^{-5}$ & $3.41 \times 10^{-5}$ & $1.20 \times 10^{-3}$ & $1.53 \times 10^{-4}$ \\
\hline 10 & AL-CBD-20020306 1.2 & $6.04 \times 10^{-5}$ & $2.72 \times 10^{-5}$ & $9.73 \times 10^{-4}$ & $1.32 \times 10^{-4}$ \\
\hline 11 & AL-CBD-20020313 1.2 & $N / C^{b}$ & $\mathrm{~N} / \mathrm{C}$ & $\mathrm{N} / \mathrm{C}$ & $\mathrm{N} / \mathrm{C}$ \\
\hline 12 & AL-CBD-20020320 1.2 & $6.91 \times 10^{-5}$ & $2.80 \times 10^{-5}$ & $8.36 \times 10^{-4}$ & $1.17 \times 10^{-4}$ \\
\hline 13 & AL-CBD-20020327 1.2 & $4.51 \times 10^{-5}$ & $2.19 \times 10^{-5}$ & $8.66 \times 10^{-4}$ & $1.17 \times 10^{-4}$ \\
\hline 14 & AL-CBD-20020403 1.1 & $6.80 \times 10^{-5}$ & $2.85 \times 10^{-5}$ & $9.54 \times 10^{-4}$ & $1.28 \times 10^{-4}$ \\
\hline 15 & AL-CBD-20020410 1.1 & $6.05 \times 10^{-5}$ & $2.77 \times 10^{-5}$ & $1.01 \times 10^{-3}$ & $1.35 \times 10^{-4}$ \\
\hline 16 & AL-CBD-20020417 1.1 & $4.71 \times 10^{-5}$ & $2.36 \times 10^{-5}$ & $8.37 \times 10^{-4}$ & $1.17 \times 10^{-4}$ \\
\hline 17 & AL-CBD-20020424 1.1 & $8.74 \times 10^{-5}$ & $3.20 \times 10^{-5}$ & $7.91 \times 10^{-4}$ & $1.12 \times 10^{-4}$ \\
\hline 18 & AL-CBD-20020501 1.1 & $6.14 \times 10^{-5}$ & $2.54 \times 10^{-5}$ & $7.03 \times 10^{-4}$ & $1.02 \times 10^{-4}$ \\
\hline 19 & AL-CBD-20020508 1.1 & $5.00 \times 10^{-5}$ & $2.41 \times 10^{-5}$ & $8.10 \times 10^{-4}$ & $1.12 \times 10^{-4}$ \\
\hline 20 & AL-CBD-20020515 1.1 & $3.62 \times 10^{-5}$ & $2.22 \times 10^{-5}$ & $7.68 \times 10^{-4}$ & $1.11 \times 10^{-4}$ \\
\hline 21 & AL-CBD-20020522 1.1 & $5.49 \times 10^{-5}$ & $2.64 \times 10^{-5}$ & $8.01 \times 10^{-4}$ & $1.14 \times 10^{-4}$ \\
\hline 22 & AL-CBD-20020529 1.1 & $3.88 \times 10^{-5}$ & $2.19 \times 10^{-5}$ & $8.32 \times 10^{-4}$ & $1.16 \times 10^{-4}$ \\
\hline 23 & AL-CBD-20020605 1.1 & $4.59 \times 10^{-5}$ & $2.17 \times 10^{-5}$ & $6.53 \times 10^{-4}$ & $9.61 \times 10^{-5}$ \\
\hline 24 & AL-CBD-20020612 1.1 & $\mathrm{~N} / \mathrm{C}$ & $\mathrm{N} / \mathrm{C}$ & $\mathrm{N} / \mathrm{C}$ & $\mathrm{N} / \mathrm{C}$ \\
\hline 25 & AL-CBD-20020619 1.1 & $6.80 \times 10^{-5}$ & $2.80 \times 10^{-5}$ & $9.52 \times 10^{-4}$ & $1.28 \times 10^{-4}$ \\
\hline 26 & AL-CBD-20020626 1.1 & $4.74 \times 10^{-5}$ & $2.44 \times 10^{-5}$ & $6.68 \times 10^{-4}$ & $1.00 \times 10^{-4}$ \\
\hline 27 & AL-CBD-20020703 1.1 & $7.29 \times 10^{-5}$ & $2.95 \times 10^{-5}$ & $8.48 \times 10^{-4}$ & $1.18 \times 10^{-4}$ \\
\hline 28 & AL-CBD-20020710 1.1 & $4.76 \times 10^{-5}$ & $2.37 \times 10^{-5}$ & $8.29 \times 10^{-4}$ & $1.15 \times 10^{-4}$ \\
\hline 29 & AL-CBD-20020717 1.1 & $2.76 \times 10^{-5}$ & $1.88 \times 10^{-5}$ & $6.94 \times 10^{-4}$ & $1.01 \times 10^{-4}$ \\
\hline 30 & AL-CBD-20020724 1.1 & $3.28 \times 10^{-5}$ & $1.96 \times 10^{-5}$ & $7.15 \times 10^{-4}$ & $1.04 \times 10^{-4}$ \\
\hline 31 & AL-CBD-20020731 1.1 & $7.20 \times 10^{-5}$ & $2.86 \times 10^{-5}$ & $9.96 \times 10^{-4}$ & $1.32 \times 10^{-4}$ \\
\hline 32 & AL-CBD-20020807 1.1 & $1.19 \times 10^{-4}$ & $3.78 \times 10^{-5}$ & $1.02 \times 10^{-3}$ & $1.35 \times 10^{-4}$ \\
\hline 33 & AL-CBD-20020814 1.1 & $8.95 \times 10^{-5}$ & $3.27 \times 10^{-5}$ & $8.98 \times 10^{-4}$ & $1.23 \times 10^{-4}$ \\
\hline 34 & AL-CBD-20020821 1.1 & $8.84 \times 10^{-5}$ & $3.23 \times 10^{-5}$ & $9.84 \times 10^{-4}$ & $1.31 \times 10^{-4}$ \\
\hline 35 & AL-CBD-20020828 1.1 & $7.70 \times 10^{-5}$ & $3.00 \times 10^{-5}$ & $1.19 \times 10^{-3}$ & $1.52 \times 10^{-4}$ \\
\hline 36 & AL-CBD-20020904 1.1 & $8.05 \times 10^{-5}$ & $3.03 \times 10^{-5}$ & $7.94 \times 10^{-4}$ & $1.11 \times 10^{-4}$ \\
\hline 37 & AL-CBD-20020911 1.1 & $9.58 \times 10^{-5}$ & $3.36 \times 10^{-5}$ & $1.22 \times 10^{-3}$ & $1.55 \times 10^{-4}$ \\
\hline 38 & AL-CBD-20020918 1.1 & $1.15 \times 10^{-4}$ & $3.62 \times 10^{-5}$ & $1.11 \times 10^{-3}$ & $1.43 \times 10^{-4}$ \\
\hline 39 & AL-CBD-20020925 1.1 & $1.15 \times 10^{-4}$ & $3.64 \times 10^{-5}$ & $1.19 \times 10^{-3}$ & $1.52 \times 10^{-4}$ \\
\hline 40 & AL-CBD-20021002 1.1 & $9.07 \times 10^{-5}$ & $3.27 \times 10^{-5}$ & $8.92 \times 10^{-4}$ & $1.22 \times 10^{-4}$ \\
\hline 41 & AL-CBD-20021009 1.1 & $1.02 \times 10^{-4}$ & $3.40 \times 10^{-5}$ & $1.38 \times 10^{-3}$ & $1.71 \times 10^{-4}$ \\
\hline 42 & AL-CBD-20021016 1.1 & $7.95 \times 10^{-5}$ & $3.01 \times 10^{-5}$ & $1.15 \times 10^{-3}$ & $1.47 \times 10^{-4}$ \\
\hline 43 & AL-CBD-20021023 1.1 & $4.36 \times 10^{-5}$ & $2.12 \times 10^{-5}$ & $5.62 \times 10^{-4}$ & $8.66 \times 10^{-5}$ \\
\hline 44 & AL-CBD-20021030 1.1 & $5.94 \times 10^{-5}$ & $2.71 \times 10^{-5}$ & $9.52 \times 10^{-4}$ & $1.28 \times 10^{-4}$ \\
\hline 45 & AL-CBD-20021106 1.1 & $5.84 \times 10^{-5}$ & $2.67 \times 10^{-5}$ & $1.10 \times 10^{-3}$ & $1.42 \times 10^{-4}$ \\
\hline
\end{tabular}


Table D.1 - Results of Gross Alpha and Gross Beta Analyses in Air Particulates $\left(\mathrm{Bq} / \mathrm{m}^{3}\right)$

\begin{tabular}{|c|c|c|c|c|c|}
\hline \multirow[b]{2}{*}{ Week } & \multirow[b]{2}{*}{ Sample ID } & \multicolumn{2}{|c|}{ Gross Alpha } & \multicolumn{2}{|c|}{ Gross Beta } \\
\hline & & Concentration & $2 \times$ TPU $^{\mathrm{a}}$ & Concentration & $2 \times$ TPU \\
\hline 46 & AL-CBD-20021113 1.1 & $9.36 \times 10^{-5}$ & $3.22 \times 10^{-5}$ & $1.08 \times 10^{-3}$ & $1.40 \times 10^{-4}$ \\
\hline 47 & AL-CBD-200211201.1 & $8.73 \times 10^{-5}$ & $3.06 \times 10^{-5}$ & $1.52 \times 10^{-3}$ & $1.84 \times 10^{-4}$ \\
\hline 48 & AL-CBD-20021127 1.1 & $9.43 \times 10^{-5}$ & $3.26 \times 10^{-5}$ & $1.77 \times 10^{-3}$ & $2.10 \times 10^{-4}$ \\
\hline 49 & AL-CBD-20021204 1.1 & $4.36 \times 10^{-5}$ & $2.17 \times 10^{-5}$ & $1.50 \times 10^{-3}$ & $1.84 \times 10^{-4}$ \\
\hline 50 & AL-CBD-20021211 1.1 & $1.17 \times 10^{-4}$ & $3.78 \times 10^{-5}$ & $1.37 \times 10^{-3}$ & $1.71 \times 10^{-4}$ \\
\hline 51 & AL-CBD-20021218 1.1 & $3.88 \times 10^{-5}$ & $2.05 \times 10^{-5}$ & $9.59 \times 10^{-4}$ & $1.25 \times 10^{-4}$ \\
\hline 52 & AL-CBD-20021225 1.1 & $3.85 \times 10^{-5}$ & $2.78 \times 10^{-5}$ & $1.50 \times 10^{-3}$ & $1.99 \times 10^{-4}$ \\
\hline
\end{tabular}

Mills Ranch

\begin{tabular}{|c|c|c|c|c|c|}
\hline 1 & AL-MLR-20020102 1.1 & $2.31 \times 10^{-4}$ & $5.35 \times 10^{-5}$ & $1.40 \times 10^{-3}$ & $1.73 \times 10^{-4}$ \\
\hline 2 & AL-MLR-20020109 1.1 & $1.23 \times 10^{-4}$ & $3.73 \times 10^{-5}$ & $8.77 \times 10^{-4}$ & $1.20 \times 10^{-4}$ \\
\hline 3 & AL-MLR-20020116 1.1 & $1.54 \times 10^{-5}$ & $4.18 \times 10^{-5}$ & $1.30 \times 10^{-3}$ & $1.62 \times 10^{-4}$ \\
\hline 4 & AL-MLR-20020123 1.1 & $1.02 \times 10^{-4}$ & $3.28 \times 10^{-5}$ & $9.31 \times 10^{-4}$ & $1.24 \times 10^{-4}$ \\
\hline 5 & AL-MLR-20020130 1.1 & $9.63 \times 10^{-5}$ & $3.26 \times 10^{-5}$ & $1.24 \times 10^{-3}$ & $1.55 \times 10^{-4}$ \\
\hline 6 & AL-MLR-20020206 1.1 & $5.90 \times 10^{-5}$ & $2.44 \times 10^{-5}$ & $8.61 \times 10^{-4}$ & $1.17 \times 10^{-4}$ \\
\hline 7 & AL-MLR-20020213 1.1 & $6.10 \times 10^{-5}$ & $2.48 \times 10^{-5}$ & $9.18 \times 10^{-4}$ & $1.23 \times 10^{-4}$ \\
\hline 8 & AL-MLR-20020220 1.1 & $5.14 \times 10^{-5}$ & $2.44 \times 10^{-5}$ & $7.66 \times 10^{-4}$ & $1.12 \times 10^{-4}$ \\
\hline 9 & AL-MLR-20020227 1.1 & $8.79 \times 10^{-5}$ & $3.18 \times 10^{-5}$ & $1.24 \times 10^{-3}$ & $1.57 \times 10^{-4}$ \\
\hline 10 & AL-MLR-20020306 1.1 & $7.51 \times 10^{-5}$ & $2.89 \times 10^{-5}$ & $9.89 \times 10^{-4}$ & $1.31 \times 10^{-4}$ \\
\hline 11 & AL-MLR-20020313 1.1 & $3.47 \times 10^{-5}$ & $1.92 \times 10^{-5}$ & $8.26 \times 10^{-4}$ & $1.13 \times 10^{-4}$ \\
\hline 12 & AL-MLR-20020320 1.1 & $9.54 \times 10^{-5}$ & $3.26 \times 10^{-5}$ & $1.10 \times 10^{-3}$ & $1.43 \times 10^{-4}$ \\
\hline 13 & AL-MLR-20020327 1.1 & $6.14 \times 10^{-5}$ & $2.58 \times 10^{-5}$ & $8.70 \times 10^{-4}$ & $1.18 \times 10^{-4}$ \\
\hline 14 & AL-MLR-20020403 1.1 & $6.59 \times 10^{-5}$ & $2.88 \times 10^{-5}$ & $9.81 \times 10^{-4}$ & $1.32 \times 10^{-4}$ \\
\hline 15 & AL-MLR-20020410 1.1 & $4.91 \times 10^{-5}$ & $2.37 \times 10^{-5}$ & $1.05 \times 10^{-3}$ & $1.36 \times 10^{-4}$ \\
\hline 16 & AL-MLR-20020417 1.1 & $4.24 \times 10^{-5}$ & $2.26 \times 10^{-5}$ & $8.73 \times 10^{-4}$ & $1.21 \times 10^{-4}$ \\
\hline 17 & AL-MLR-20020424 1.1 & $6.65 \times 10^{-5}$ & $2.86 \times 10^{-5}$ & $8.46 \times 10^{-4}$ & $1.19 \times 10^{-4}$ \\
\hline 18 & AL-MLR-20020501 1.1 & $7.05 \times 10^{-5}$ & $2.75 \times 10^{-5}$ & $7.77 \times 10^{-4}$ & $1.10 \times 10^{-4}$ \\
\hline 19 & AL-MLR-20020508 1.1 & $5.54 \times 10^{-5}$ & $2.60 \times 10^{-5}$ & $7.89 \times 10^{-4}$ & $1.11 \times 10^{-4}$ \\
\hline 20 & AL-MLR-20020515 1.1 & $6.22 \times 10^{-5}$ & $2.78 \times 10^{-5}$ & $8.84 \times 10^{-4}$ & $1.22 \times 10^{-4}$ \\
\hline 21 & AL-MLR-20020522 1.1 & $3.32 \times 10^{-5}$ & $2.03 \times 10^{-5}$ & $6.89 \times 10^{-4}$ & $1.01 \times 10^{-4}$ \\
\hline 22 & AL-MLR-20020529 1.1 & $\mathrm{~N} / \mathrm{C}$ & $\mathrm{N} / \mathrm{C}$ & $\mathrm{N} / \mathrm{C}$ & $\mathrm{N} / \mathrm{C}$ \\
\hline 23 & AL-MLR-20020605 1.1 & $5.16 \times 10^{-5}$ & $2.32 \times 10^{-5}$ & $5.97 \times 10^{-4}$ & $9.06 \times 10^{-5}$ \\
\hline 24 & AL-MLR-20020612 1.1 & $6.21 \times 10^{-5}$ & $2.78 \times 10^{-5}$ & $8.02 \times 10^{-4}$ & $1.15 \times 10^{-4}$ \\
\hline 25 & AL-MLR-20020619 1.1 & $5.69 \times 10^{-5}$ & $2.61 \times 10^{-5}$ & $9.16 \times 10^{-4}$ & $1.25 \times 10^{-4}$ \\
\hline 26 & AL-MLR-20020626 1.1 & $5.70 \times 10^{-5}$ & $2.69 \times 10^{-5}$ & $5.20 \times 10^{-4}$ & $8.53 \times 10^{-5}$ \\
\hline 27 & AL-MLR-20020703 1.1 & $5.09 \times 10^{-5}$ & $2.54 \times 10^{-5}$ & $9.19 \times 10^{-4}$ & $1.27 \times 10^{-4}$ \\
\hline 28 & AL-MLR-20020710 1.1 & $4.35 \times 10^{-5}$ & $2.38 \times 10^{-5}$ & $5.91 \times 10^{-4}$ & $9.27 \times 10^{-5}$ \\
\hline 29 & AL-MLR-20020717 1.1 & $2.72 \times 10^{-5}$ & $1.95 \times 10^{-5}$ & $5.96 \times 10^{-4}$ & $9.33 \times 10^{-5}$ \\
\hline 30 & AL-MLR-20020724 1.1 & $\mathrm{~N} / \mathrm{C}$ & $\mathrm{N} / \mathrm{C}$ & $\mathrm{N} / \mathrm{C}$ & $\mathrm{N} / \mathrm{C}$ \\
\hline 31 & AL-MLR-20020731 1.1 & $6.93 \times 10^{-5}$ & $3.04 \times 10^{-5}$ & $9.03 \times 10^{-4}$ & $1.28 \times 10^{-4}$ \\
\hline 32 & AL-MLR-20020807 1.1 & $1.58 \times 10^{-4}$ & $4.43 \times 10^{-5}$ & $9.66 \times 10^{-4}$ & $1.30 \times 10^{-4}$ \\
\hline 33 & AL-MLR-20020814 1.1 & $1.16 \times 10^{-4}$ & $3.73 \times 10^{-5}$ & $9.48 \times 10^{-4}$ & $1.27 \times 10^{-4}$ \\
\hline 34 & AL-MLR-20020821 1.1 & $8.84 \times 10^{-5}$ & $3.23 \times 10^{-5}$ & $9.67 \times 10^{-4}$ & $1.29 \times 10^{-4}$ \\
\hline 35 & AL-MLR-20020828 1.1 & $9.85 \times 10^{-5}$ & $3.45 \times 10^{-5}$ & $1.22 \times 10^{-3}$ & $1.56 \times 10^{-4}$ \\
\hline 36 & AL-MLR-20020904 1.1 & $7.96 \times 10^{-5}$ & $3.00 \times 10^{-5}$ & $7.30 \times 10^{-4}$ & $1.04 \times 10^{-4}$ \\
\hline 37 & AL-MLR-20020911 1.1 & $1.06 \times 10^{-4}$ & $3.59 \times 10^{-5}$ & $1.29 \times 10^{-3}$ & $1.63 \times 10^{-4}$ \\
\hline 38 & AL-MLR-20020918 1.1 & $9.67 \times 10^{-5}$ & $3.31 \times 10^{-5}$ & $1.20 \times 10^{-3}$ & $1.52 \times 10^{-4}$ \\
\hline 39 & AL-MLR-20020925 1.1 & $1.11 \times 10^{-4}$ & $3.57 \times 10^{-5}$ & $1.21 \times 10^{-3}$ & $1.54 \times 10^{-4}$ \\
\hline 40 & AL-MLR-20021002 1.1 & $8.48 \times 10^{-5}$ & $3.15 \times 10^{-5}$ & $8.73 \times 10^{-4}$ & $1.20 \times 10^{-4}$ \\
\hline
\end{tabular}


Table D.1 - Results of Gross Alpha and Gross Beta Analyses in Air Particulates $\left(\mathrm{Bq} / \mathrm{m}^{3}\right)$

\begin{tabular}{|c|c|c|c|c|c|}
\hline \multirow[b]{2}{*}{ Week } & \multirow[b]{2}{*}{ Sample ID } & \multicolumn{2}{|c|}{ Gross Alpha } & \multicolumn{2}{|c|}{ Gross Beta } \\
\hline & & Concentration & $2 \times$ TPU $^{\mathrm{a}}$ & Concentration & $2 \times$ TPU \\
\hline 41 & AL-MLR-20021009 1.1 & $6.70 \times 10^{-5}$ & $2.77 \times 10^{-5}$ & $1.13 \times 10^{-3}$ & $1.45 \times 10^{-4}$ \\
\hline 42 & AL-MLR-20021016 1.1 & $4.40 \times 10^{-5}$ & $2.27 \times 10^{-5}$ & $1.14 \times 10^{-3}$ & $1.47 \times 10^{-4}$ \\
\hline 43 & AL-MLR-20021023 1.1 & $2.88 \times 10^{-5}$ & $1.73 \times 10^{-5}$ & $5.07 \times 10^{-4}$ & $8.14 \times 10^{-5}$ \\
\hline 44 & AL-MLR-20021030 1.1 & $7.19 \times 10^{-5}$ & $2.94 \times 10^{-5}$ & $9.16 \times 10^{-4}$ & $1.24 \times 10^{-4}$ \\
\hline 45 & AL-MLR-20021106 1.1 & $7.37 \times 10^{-5}$ & $2.97 \times 10^{-5}$ & $1.07 \times 10^{-3}$ & $1.39 \times 10^{-4}$ \\
\hline 46 & AL-MLR-20021113 1.1 & $1.04 \times 10^{-4}$ & $3.42 \times 10^{-5}$ & $1.04 \times 10^{-3}$ & $1.37 \times 10^{-4}$ \\
\hline 47 & AL-MLR-20021120 1.1 & $7.61 \times 10^{-5}$ & $2.91 \times 10^{-5}$ & $1.40 \times 10^{-3}$ & $1.74 \times 10^{-4}$ \\
\hline 48 & AL-MLR-20021127 1.1 & $8.58 \times 10^{-5}$ & $3.05 \times 10^{-5}$ & $1.59 \times 10^{-3}$ & $1.92 \times 10^{-4}$ \\
\hline 49 & AL-MLR-20021204 1.1 & $3.51 \times 10^{-5}$ & $1.92 \times 10^{-5}$ & $1.31 \times 10^{-3}$ & $1.64 \times 10^{-4}$ \\
\hline 50 & AL-MLR-20021211 1.1 & $1.19 \times 10^{-4}$ & $3.64 \times 10^{-5}$ & $1.35 \times 10^{-3}$ & $1.66 \times 10^{-4}$ \\
\hline 51 & AL-MLR-20021218 1.1 & $4.04 \times 10^{-5}$ & $2.13 \times 10^{-5}$ & $8.42 \times 10^{-4}$ & $1.14 \times 10^{-4}$ \\
\hline 52 & AL-MLR-20021225 1.1 & $7.01 \times 10^{-5}$ & $3.48 \times 10^{-5}$ & $1.41 \times 10^{-3}$ & $1.87 \times 10^{-4}$ \\
\hline
\end{tabular}

Southeast Control

\begin{tabular}{|c|c|c|c|c|c|}
\hline 1 & AL-SEC-20020102 1.1 & $1.84 \times 10^{-4}$ & $4.73 \times 10^{-5}$ & $1.59 \times 10^{-3}$ & $1.93 \times 10^{-4}$ \\
\hline 2 & AL-SEC-20020109 1.1 & $1.62 \times 10^{-4}$ & $4.31 \times 10^{-5}$ & $8.45 \times 10^{-4}$ & $1.16 \times 10^{-4}$ \\
\hline 3 & AL-SEC-20020116 1.1 & $1.47 \times 10^{-4}$ & $4.06 \times 10^{-5}$ & $1.36 \times 10^{-3}$ & $1.68 \times 10^{-4}$ \\
\hline 4 & AL-SEC-20020123 1.1 & $1.32 \times 10^{-4}$ & $3.87 \times 10^{-5}$ & $1.05 \times 10^{-3}$ & $1.37 \times 10^{-4}$ \\
\hline 5 & AL-SEC-200201301.1 & $9.77 \times 10^{-5}$ & $3.27 \times 10^{-5}$ & $1.27 \times 10^{-3}$ & $1.57 \times 10^{-4}$ \\
\hline 6 & AL-SEC-20020206 1.1 & $9.52 \times 10^{-5}$ & $3.35 \times 10^{-5}$ & $8.07 \times 10^{-4}$ & $1.15 \times 10^{-4}$ \\
\hline 7 & AL-SEC-20020213 1.1 & $5.95 \times 10^{-5}$ & $2.52 \times 10^{-5}$ & $1.01 \times 10^{-3}$ & $1.34 \times 10^{-4}$ \\
\hline 8 & AL-SEC-20020220 1.1 & $2.58 \times 10^{-5}$ & $1.73 \times 10^{-5}$ & $8.45 \times 10^{-4}$ & $1.21 \times 10^{-4}$ \\
\hline 9 & AL-SEC-20020227 1.1 & $1.44 \times 10^{-4}$ & $3.98 \times 10^{-5}$ & $1.25 \times 10^{-3}$ & $1.56 \times 10^{-4}$ \\
\hline 10 & AL-SEC-20020306 1.1 & $4.94 \times 10^{-5}$ & $2.34 \times 10^{-5}$ & $9.24 \times 10^{-4}$ & $1.24 \times 10^{-4}$ \\
\hline 11 & AL-SEC-20020313 1.1 & $4.34 \times 10^{-5}$ & $2.11 \times 10^{-5}$ & $8.36 \times 10^{-4}$ & $1.13 \times 10^{-4}$ \\
\hline 12 & AL-SEC-20020320 1.1 & $9.99 \times 10^{-5}$ & $3.41 \times 10^{-5}$ & $1.08 \times 10^{-3}$ & $1.42 \times 10^{-4}$ \\
\hline 13 & AL-SEC-20020327 1.1 & $6.47 \times 10^{-5}$ & $2.67 \times 10^{-5}$ & $9.34 \times 10^{-4}$ & $1.25 \times 10^{-4}$ \\
\hline 14 & AL-SEC-20020403 1.2 & $9.21 \times 10^{-5}$ & $3.36 \times 10^{-5}$ & $9.84 \times 10^{-4}$ & $1.32 \times 10^{-4}$ \\
\hline 15 & AL-SEC-20020410 1.2 & $6.96 \times 10^{-5}$ & $2.86 \times 10^{-5}$ & $1.09 \times 10^{-3}$ & $1.41 \times 10^{-4}$ \\
\hline 16 & AL-SEC-20020417 1.2 & $4.05 \times 10^{-5}$ & $2.16 \times 10^{-5}$ & $8.69 \times 10^{-4}$ & $1.19 \times 10^{-4}$ \\
\hline 17 & AL-SEC-20020424 1.2 & $7.40 \times 10^{-5}$ & $2.94 \times 10^{-5}$ & $9.01 \times 10^{-4}$ & $1.23 \times 10^{-4}$ \\
\hline 18 & AL-SEC-20020501 1.2 & $4.02 \times 10^{-5}$ & $2.02 \times 10^{-5}$ & $8.46 \times 10^{-4}$ & $1.16 \times 10^{-4}$ \\
\hline 19 & AL-SEC-20020508 1.2 & $9.00 \times 10^{-5}$ & $3.19 \times 10^{-5}$ & $9.45 \times 10^{-4}$ & $1.25 \times 10^{-4}$ \\
\hline 20 & AL-SEC-20020515 1.2 & $7.49 \times 10^{-5}$ & $3.08 \times 10^{-5}$ & $9.48 \times 10^{-4}$ & $1.29 \times 10^{-4}$ \\
\hline 21 & AL-SEC-20020522 1.2 & $8.11 \times 10^{-5}$ & $3.15 \times 10^{-5}$ & $7.83 \times 10^{-4}$ & $1.12 \times 10^{-4}$ \\
\hline 22 & AL-SEC-20020529 1.2 & $4.97 \times 10^{-5}$ & $2.39 \times 10^{-5}$ & $8.02 \times 10^{-4}$ & $1.11 \times 10^{-4}$ \\
\hline 23 & AL-SEC-20020605 1.2 & $4.61 \times 10^{-5}$ & $2.24 \times 10^{-5}$ & $7.66 \times 10^{-4}$ & $1.10 \times 10^{-4}$ \\
\hline 24 & AL-SEC-20020612 1.2 & $5.10 \times 10^{-5}$ & $2.40 \times 10^{-5}$ & $7.94 \times 10^{-4}$ & $1.11 \times 10^{-4}$ \\
\hline 25 & AL-SEC-20020619 1.2 & $6.43 \times 10^{-5}$ & $2.82 \times 10^{-5}$ & $1.07 \times 10^{-3}$ & $1.41 \times 10^{-4}$ \\
\hline 26 & AL-SEC-20020626 1.2 & $3.47 \times 10^{-5}$ & $2.06 \times 10^{-5}$ & $6.94 \times 10^{-4}$ & $1.02 \times 10^{-4}$ \\
\hline 27 & AL-SEC-20020703 1.1 & $5.62 \times 10^{-5}$ & $2.52 \times 10^{-5}$ & $8.24 \times 10^{-4}$ & $1.14 \times 10^{-4}$ \\
\hline 28 & AL-SEC-20020710 1.1 & $4.05 \times 10^{-5}$ & $2.21 \times 10^{-5}$ & $7.71 \times 10^{-4}$ & $1.09 \times 10^{-4}$ \\
\hline 29 & AL-SEC-20020717 1.1 & $2.28 \times 10^{-5}$ & $1.76 \times 10^{-5}$ & $7.19 \times 10^{-4}$ & $1.04 \times 10^{-4}$ \\
\hline 30 & AL-SEC-20020724 1.1 & $6.43 \times 10^{-5}$ & $2.70 \times 10^{-5}$ & $7.73 \times 10^{-4}$ & $1.09 \times 10^{-4}$ \\
\hline 31 & AL-SEC-20020731 1.1 & $8.36 \times 10^{-5}$ & $3.06 \times 10^{-5}$ & $9.70 \times 10^{-4}$ & $1.29 \times 10^{-4}$ \\
\hline 32 & AL-SEC-20020807 1.1 & $1.33 \times 10^{-4}$ & $4.07 \times 10^{-5}$ & $9.76 \times 10^{-4}$ & $1.31 \times 10^{-4}$ \\
\hline 33 & AL-SEC-20020814 1.1 & $8.99 \times 10^{-5}$ & $3.24 \times 10^{-5}$ & $8.56 \times 10^{-4}$ & $1.18 \times 10^{-4}$ \\
\hline 34 & AL-SEC-20020821 1.1 & $9.45 \times 10^{-5}$ & $3.40 \times 10^{-5}$ & $8.85 \times 10^{-4}$ & $1.22 \times 10^{-4}$ \\
\hline 35 & AL-SEC-20020828 1.1 & $7.87 \times 10^{-5}$ & $3.07 \times 10^{-5}$ & $1.26 \times 10^{-3}$ & $1.60 \times 10^{-4}$ \\
\hline
\end{tabular}


Table D.1 - Results of Gross Alpha and Gross Beta Analyses in Air Particulates $\left(\mathrm{Bq} / \mathrm{m}^{3}\right)$

\begin{tabular}{|c|c|c|c|c|c|}
\hline \multirow[b]{2}{*}{ Week } & \multirow[b]{2}{*}{ Sample ID } & \multicolumn{2}{|c|}{ Gross Alpha } & \multicolumn{2}{|c|}{ Gross Beta } \\
\hline & & Concentration & $2 \times$ TPU $^{a}$ & Concentration & $2 \times$ TPU \\
\hline 36 & AL-SEC-20020904 1.1 & $4.93 \times 10^{-5}$ & $2.39 \times 10^{-5}$ & $7.45 \times 10^{-4}$ & $1.06 \times 10^{-4}$ \\
\hline 37 & AL-SEC-20020911 1.1 & $9.27 \times 10^{-5}$ & $3.30 \times 10^{-5}$ & $1.19 \times 10^{-3}$ & $1.52 \times 10^{-4}$ \\
\hline 38 & AL-SEC-20020918 1.1 & $1.19 \times 10^{-4}$ & $3.69 \times 10^{-5}$ & $1.17 \times 10^{-3}$ & $1.49 \times 10^{-4}$ \\
\hline 39 & AL-SEC-20020925 1.1 & $1.26 \times 10^{-4}$ & $3.86 \times 10^{-5}$ & $1.15 \times 10^{-3}$ & $1.48 \times 10^{-4}$ \\
\hline 40 & AL-SEC-20021002 1.1 & $9.23 \times 10^{-5}$ & $3.28 \times 10^{-5}$ & $8.30 \times 10^{-4}$ & $1.15 \times 10^{-4}$ \\
\hline 41 & AL-SEC-20021009 1.1 & $5.13 \times 10^{-5}$ & $2.43 \times 10^{-5}$ & $1.23 \times 10^{-3}$ & $1.55 \times 10^{-4}$ \\
\hline 42 & AL-SEC-20021016 1.1 & $6.65 \times 10^{-5}$ & $2.75 \times 10^{-5}$ & $1.19 \times 10^{-3}$ & $1.51 \times 10^{-4}$ \\
\hline 43 & AL-SEC-20021023 1.1 & $3.95 \times 10^{-5}$ & $2.04 \times 10^{-5}$ & $4.94 \times 10^{-4}$ & $8.01 \times 10^{-5}$ \\
\hline 44 & AL-SEC-20021030 1.1 & $5.46 \times 10^{-5}$ & $2.55 \times 10^{-5}$ & $8.41 \times 10^{-4}$ & $1.15 \times 10^{-4}$ \\
\hline 45 & AL-SEC-20021106 1.1 & $6.45 \times 10^{-5}$ & $2.81 \times 10^{-5}$ & $1.05 \times 10^{-3}$ & $1.38 \times 10^{-4}$ \\
\hline 46 & AL-SEC-20021113 1.1 & $1.24 \times 10^{-4}$ & $4.87 \times 10^{-5}$ & $1.19 \times 10^{-3}$ & $1.75 \times 10^{-4}$ \\
\hline 47 & AL-SEC-20021120 1.1 & $8.48 \times 10^{-5}$ & $3.05 \times 10^{-5}$ & $1.31 \times 10^{-3}$ & $1.64 \times 10^{-4}$ \\
\hline 48 & AL-SEC-20021127 1.1 & $7.65 \times 10^{-5}$ & $2.88 \times 10^{-5}$ & $1.55 \times 10^{-3}$ & $1.88 \times 10^{-4}$ \\
\hline 49 & AL-SEC-20021204 1.1 & $3.04 \times 10^{-5}$ & $1.81 \times 10^{-5}$ & $1.36 \times 10^{-3}$ & $1.70 \times 10^{-4}$ \\
\hline 50 & AL-SEC-20021211 1.1 & $1.27 \times 10^{-4}$ & $3.93 \times 10^{-5}$ & $1.22 \times 10^{-3}$ & $1.55 \times 10^{-4}$ \\
\hline 51 & AL-SEC-20021218 1.1 & $2.79 \times 10^{-5}$ & $1.80 \times 10^{-5}$ & $8.75 \times 10^{-4}$ & $1.17 \times 10^{-4}$ \\
\hline 52 & AL-SEC-20021225 1.1 & $8.87 \times 10^{-5}$ & $3.88 \times 10^{-5}$ & $1.57 \times 10^{-3}$ & $2.04 \times 10^{-4}$ \\
\hline
\end{tabular}

Smith Ranch

\begin{tabular}{|c|c|c|c|c|c|}
\hline 1 & AL-SMR-20020102 1.1 & $1.65 \times 10^{-4}$ & $4.47 \times 10^{-5}$ & $1.46 \times 10^{-3}$ & $1.80 \times 10^{-4}$ \\
\hline 2 & AL-SMR-20020109 1.1 & $\mathrm{~N} / \mathrm{C}$ & $\mathrm{N} / \mathrm{C}$ & $\mathrm{N} / \mathrm{C}$ & $\mathrm{N} / \mathrm{C}$ \\
\hline 3 & AL-SMR-20020116 1.1 & $1.81 \times 10^{-4}$ & $4.81 \times 10^{-5}$ & $1.29 \times 10^{-3}$ & $1.65 \times 10^{-4}$ \\
\hline 4 & AL-SMR-20020123 1.1 & $8.16 \times 10^{-5}$ & $2.92 \times 10^{-5}$ & $8.97 \times 10^{-4}$ & $1.20 \times 10^{-4}$ \\
\hline 5 & AL-SMR-200201301.1 & $9.75 \times 10^{-5}$ & $3.34 \times 10^{-5}$ & $1.14 \times 10^{-3}$ & $1.46 \times 10^{-4}$ \\
\hline 6 & AL-SMR-20020206 1.1 & $8.17 \times 10^{-5}$ & $3.05 \times 10^{-5}$ & $8.34 \times 10^{-4}$ & $1.17 \times 10^{-4}$ \\
\hline 7 & AL-SMR-20020213 1.1 & $4.55 \times 10^{-5}$ & $1.97 \times 10^{-5}$ & $8.24 \times 10^{-4}$ & $1.09 \times 10^{-4}$ \\
\hline 8 & AL-SMR-20020220 1.1 & $7.38 \times 10^{-5}$ & $3.00 \times 10^{-5}$ & $7.54 \times 10^{-4}$ & $1.11 \times 10^{-4}$ \\
\hline 9 & AL-SMR-20020227 1.1 & $1.01 \times 10^{-4}$ & $3.36 \times 10^{-5}$ & $1.31 \times 10^{-3}$ & $1.63 \times 10^{-4}$ \\
\hline 10 & AL-SMR-20020306 1.1 & $6.40 \times 10^{-5}$ & $2.69 \times 10^{-5}$ & $9.64 \times 10^{-4}$ & $1.29 \times 10^{-4}$ \\
\hline 11 & AL-SMR-20020313 1.1 & $6.06 \times 10^{-5}$ & $2.56 \times 10^{-5}$ & $7.40 \times 10^{-4}$ & $1.04 \times 10^{-4}$ \\
\hline 12 & AL-SMR-20020320 1.1 & $7.92 \times 10^{-5}$ & $2.95 \times 10^{-5}$ & $1.13 \times 10^{-3}$ & $1.46 \times 10^{-4}$ \\
\hline 13 & AL-SMR-20020327 1.1 & $7.39 \times 10^{-5}$ & $2.83 \times 10^{-5}$ & $7.59 \times 10^{-4}$ & $1.07 \times 10^{-4}$ \\
\hline 14 & AL-SMR-20020403 1.1 & $5.44 \times 10^{-5}$ & $2.62 \times 10^{-5}$ & $9.41 \times 10^{-4}$ & $1.28 \times 10^{-4}$ \\
\hline 15 & AL-SMR-20020410 1.1 & $8.09 \times 10^{-5}$ & $3.05 \times 10^{-5}$ & $9.56 \times 10^{-4}$ & $1.27 \times 10^{-4}$ \\
\hline 16 & AL-SMR-20020417 1.1 & $2.65 \times 10^{-5}$ & $1.84 \times 10^{-5}$ & $7.90 \times 10^{-4}$ & $1.12 \times 10^{-4}$ \\
\hline 17 & AL-SMR-20020424 1.1 & $5.11 \times 10^{-5}$ & $2.41 \times 10^{-5}$ & $8.67 \times 10^{-4}$ & $1.19 \times 10^{-4}$ \\
\hline 18 & AL-SMR-20020501 1.1 & $8.29 \times 10^{-5}$ & $3.04 \times 10^{-5}$ & $8.27 \times 10^{-4}$ & $1.16 \times 10^{-4}$ \\
\hline 19 & AL-SMR-20020508 1.1 & $8.92 \times 10^{-5}$ & $3.21 \times 10^{-5}$ & $8.66 \times 10^{-4}$ & $1.18 \times 10^{-4}$ \\
\hline 20 & AL-SMR-20020515 1.1 & $4.88 \times 10^{-5}$ & $2.49 \times 10^{-5}$ & $8.42 \times 10^{-4}$ & $1.17 \times 10^{-4}$ \\
\hline 21 & AL-SMR-20020522 1.1 & $3.97 \times 10^{-5}$ & $2.24 \times 10^{-5}$ & $7.04 \times 10^{-4}$ & $1.03 \times 10^{-4}$ \\
\hline 22 & AL-SMR-20020529 1.1 & $3.27 \times 10^{-5}$ & $2.10 \times 10^{-5}$ & $7.18 \times 10^{-4}$ & $1.06 \times 10^{-4}$ \\
\hline 23 & AL-SMR-20020605 1.1 & $4.11 \times 10^{-5}$ & $2.06 \times 10^{-5}$ & $7.09 \times 10^{-4}$ & $1.02 \times 10^{-4}$ \\
\hline 24 & AL-SMR-20020612 1.1 & $7.98 \times 10^{-5}$ & $3.11 \times 10^{-5}$ & $8.00 \times 10^{-4}$ & $1.14 \times 10^{-4}$ \\
\hline 25 & AL-SMR-20020619 1.1 & $7.76 \times 10^{-5}$ & $2.93 \times 10^{-5}$ & $9.60 \times 10^{-4}$ & $1.27 \times 10^{-4}$ \\
\hline 26 & AL-SMR-20020626 1.1 & $5.49 \times 10^{-5}$ & $2.52 \times 10^{-5}$ & $7.18 \times 10^{-4}$ & $1.03 \times 10^{-4}$ \\
\hline 27 & AL-SMR-20020703 1.1 & $6.36 \times 10^{-5}$ & $2.93 \times 10^{-5}$ & $8.72 \times 10^{-4}$ & $1.24 \times 10^{-4}$ \\
\hline 28 & AL-SMR-20020710 1.1 & $4.73 \times 10^{-5}$ & $2.42 \times 10^{-5}$ & $6.71 \times 10^{-4}$ & $1.00 \times 10^{-4}$ \\
\hline 29 & AL-SMR-20020717 1.1 & $1.76 \times 10^{-5}$ & $1.59 \times 10^{-5}$ & $6.38 \times 10^{-4}$ & $9.56 \times 10^{-5}$ \\
\hline 30 & AL-SMR-20020724 1.1 & $5.21 \times 10^{-5}$ & $2.46 \times 10^{-5}$ & $6.71 \times 10^{-4}$ & $9.96 \times 10^{-5}$ \\
\hline
\end{tabular}


Table D.1 - Results of Gross Alpha and Gross Beta Analyses in Air Particulates $\left(\mathrm{Bq} / \mathrm{m}^{3}\right)$

\begin{tabular}{|c|c|c|c|c|c|}
\hline \multirow[b]{2}{*}{ Week } & \multirow[b]{2}{*}{ Sample ID } & \multicolumn{2}{|c|}{ Gross Alpha } & \multicolumn{2}{|c|}{ Gross Beta } \\
\hline & & Concentration & $2 \times$ TPU $^{a}$ & Concentration & $2 \times \mathrm{TPU}$ \\
\hline 31 & AL-SMR-20020731 1.1 & $6.05 \times 10^{-5}$ & $2.60 \times 10^{-5}$ & $8.83 \times 10^{-4}$ & $1.20 \times 10^{-4}$ \\
\hline 32 & AL-SMR-20020807 1.1 & $1.07 \times 10^{-4}$ & $3.61 \times 10^{-5}$ & $1.03 \times 10^{-3}$ & $1.36 \times 10^{-4}$ \\
\hline 33 & AL-SMR-20020814 1.1 & $9.27 \times 10^{-5}$ & $3.34 \times 10^{-5}$ & $8.87 \times 10^{-4}$ & $1.22 \times 10^{-4}$ \\
\hline 34 & AL-SMR-20020821 1.1 & $8.61 \times 10^{-5}$ & $3.24 \times 10^{-5}$ & $8.60 \times 10^{-4}$ & $1.19 \times 10^{-4}$ \\
\hline 35 & AL-SMR-20020828 1.1 & $7.86 \times 10^{-5}$ & $3.06 \times 10^{-5}$ & $1.18 \times 10^{-3}$ & $1.51 \times 10^{-4}$ \\
\hline 36 & AL-SMR-20020904 1.1 & $\mathrm{~N} / \mathrm{C}$ & $\mathrm{N} / \mathrm{C}$ & $\mathrm{N} / \mathrm{C}$ & $\mathrm{N} / \mathrm{C}$ \\
\hline 37 & AL-SMR-20020911 1.1 & $\mathrm{~N} / \mathrm{C}$ & $\mathrm{N} / \mathrm{C}$ & $\mathrm{N} / \mathrm{C}$ & $\mathrm{N} / \mathrm{C}$ \\
\hline 38 & AL-SMR-20020918 1.1 & $1.12 \times 10^{-4}$ & $3.56 \times 10^{-5}$ & $1.04 \times 10^{-3}$ & $1.35 \times 10^{-4}$ \\
\hline 39 & AL-SMR-20020925 1.1 & $1.17 \times 10^{-4}$ & $3.70 \times 10^{-5}$ & $1.18 \times 10^{-3}$ & $1.51 \times 10^{-4}$ \\
\hline 40 & AL-SMR-20021002 1.1 & $6.45 \times 10^{-5}$ & $2.77 \times 10^{-5}$ & $8.26 \times 10^{-4}$ & $1.15 \times 10^{-4}$ \\
\hline 41 & AL-SMR-20021009 1.1 & $7.46 \times 10^{-5}$ & $2.92 \times 10^{-5}$ & $1.31 \times 10^{-3}$ & $1.64 \times 10^{-4}$ \\
\hline 42 & AL-SMR-20021016 1.1 & $2.05 \times 10^{-5}$ & $1.63 \times 10^{-5}$ & $1.14 \times 10^{-3}$ & $1.47 \times 10^{-4}$ \\
\hline 43 & AL-SMR-20021023 1.1 & $2.04 \times 10^{-5}$ & $1.44 \times 10^{-5}$ & $4.82 \times 10^{-4}$ & $7.81 \times 10^{-5}$ \\
\hline 44 & AL-SMR-200210301.1 & $6.95 \times 10^{-5}$ & $2.90 \times 10^{-5}$ & $9.01 \times 10^{-4}$ & $1.23 \times 10^{-4}$ \\
\hline 45 & AL-SMR-20021106 1.1 & $8.63 \times 10^{-5}$ & $3.20 \times 10^{-5}$ & $1.04 \times 10^{-3}$ & $1.36 \times 10^{-4}$ \\
\hline 46 & AL-SMR-200211131.1 & $8.16 \times 10^{-5}$ & $3.01 \times 10^{-5}$ & $1.12 \times 10^{-3}$ & $1.45 \times 10^{-4}$ \\
\hline 47 & AL-SMR-200211201.1 & $6.35 \times 10^{-5}$ & $2.60 \times 10^{-5}$ & $1.16 \times 10^{-3}$ & $1.49 \times 10^{-4}$ \\
\hline 48 & AL-SMR-20021127 1.1 & $7.17 \times 10^{-5}$ & $2.79 \times 10^{-5}$ & $1.44 \times 10^{-3}$ & $1.77 \times 10^{-4}$ \\
\hline 49 & AL-SMR-20021204 1.1 & $3.06 \times 10^{-5}$ & $1.82 \times 10^{-5}$ & $1.40 \times 10^{-3}$ & $1.73 \times 10^{-4}$ \\
\hline 50 & AL-SMR-20021211 1.1 & $1.31 \times 10^{-4}$ & $3.98 \times 10^{-5}$ & $1.29 \times 10^{-3}$ & $1.62 \times 10^{-4}$ \\
\hline 51 & AL-SMR-20021218 1.1 & $5.34 \times 10^{-5}$ & $2.39 \times 10^{-5}$ & $8.80 \times 10^{-4}$ & $1.17 \times 10^{-4}$ \\
\hline 52 & AL-SMR-20021225 1.1 & $5.90 \times 10^{-5}$ & $3.22 \times 10^{-5}$ & $1.32 \times 10^{-3}$ & $1.78 \times 10^{-4}$ \\
\hline
\end{tabular}

WIPP Air Blank

\begin{tabular}{|c|c|c|c|c|c|}
\hline 1 & AL-WAB-20020102 1.1 & $2.96 \times 10^{-3}$ & $5.09 \times 10^{-3}$ & $3.68 \times 10^{-2}$ & $1.68 \times 10^{-2}$ \\
\hline 2 & AL-WAB-20020109 1.1 & $4.46 \times 10^{-3}$ & $5.89 \times 10^{-3}$ & $4.24 \times 10^{-2}$ & $1.76 \times 10^{-2}$ \\
\hline 3 & AL-WAB-20020116 1.1 & $7.44 \times 10^{-3}$ & $7.23 \times 10^{-3}$ & $6.24 \times 10^{-2}$ & $2.04 \times 10^{-2}$ \\
\hline 4 & AL-WAB-200201231.1 & $8.94 \times 10^{-5}$ & $7.82 \times 10^{-3}$ & $6.56 \times 10^{-2}$ & $2.09 \times 10^{-2}$ \\
\hline 5 & AL-WAB-200201301.1 & $-5.53 \times 10^{-5}$ & $5.14 \times 10^{-3}$ & $5.12 \times 10^{-2}$ & $1.86 \times 10^{-2}$ \\
\hline 6 & AL-WAB-20020206 1.1 & $5.92 \times 10^{-3}$ & $5.85 \times 10^{-3}$ & $4.54 \times 10^{-2}$ & $1.79 \times 10^{-2}$ \\
\hline 7 & AL-WAB-200202131.1 & $4.41 \times 10^{-3}$ & $5.04 \times 10^{-3}$ & $6.67 \times 10^{-2}$ & $2.09 \times 10^{-2}$ \\
\hline 8 & AL-WAB-200202201.1 & $8.89 \times 10^{-3}$ & $7.19 \times 10^{-3}$ & $5.63 \times 10^{-2}$ & $1.94 \times 10^{-2}$ \\
\hline 9 & AL-WAB-20020227 1.1 & $4.43 \times 10^{-3}$ & $6.52 \times 10^{-3}$ & $4.23 \times 10^{-2}$ & $1.76 \times 10^{-2}$ \\
\hline 10 & AL-WAB-20020306 1.1 & $8.89 \times 10^{-3}$ & $8.28 \times 10^{-3}$ & $3.64 \times 10^{-2}$ & $1.68 \times 10^{-2}$ \\
\hline 11 & AL-WAB-20020313 1.1 & $9.19 \times 10^{-3}$ & $8.01 \times 10^{-3}$ & $5.01 \times 10^{-2}$ & $1.80 \times 10^{-2}$ \\
\hline 12 & AL-WAB-20020320 1.1 & $1.06 \times 10^{-2}$ & $7.95 \times 10^{-3}$ & $6.16 \times 10^{-2}$ & $1.99 \times 10^{-2}$ \\
\hline 13 & AL-WAB-20020327 1.1 & $5.95 \times 10^{-3}$ & $7.17 \times 10^{-3}$ & $3.01 \times 10^{-2}$ & $1.63 \times 10^{-2}$ \\
\hline 14 & AL-WAB-20020403 1.1 & $6.09 \times 10^{-3}$ & $7.93 \times 10^{-3}$ & $3.55 \times 10^{-2}$ & $1.75 \times 10^{-2}$ \\
\hline 15 & AL-WAB-20020410 1.1 & $6.08 \times 10^{-3}$ & $7.93 \times 10^{-3}$ & $4.56 \times 10^{-2}$ & $1.89 \times 10^{-2}$ \\
\hline 16 & AL-WAB-20020417 1.1 & $7.50 \times 10^{-3}$ & $7.83 \times 10^{-3}$ & $4.66 \times 10^{-2}$ & $1.89 \times 10^{-2}$ \\
\hline 17 & AL-WAB-20020424 1.1 & $-1.53 \times 10^{-3}$ & $5.13 \times 10^{-3}$ & $3.82 \times 10^{-2}$ & $1.77 \times 10^{-2}$ \\
\hline 18 & AL-WAB-20020501 1.1 & $6.04 \times 10^{-3}$ & $5.95 \times 10^{-3}$ & $3.43 \times 10^{-2}$ & $1.69 \times 10^{-2}$ \\
\hline 19 & AL-WAB-20020508 1.1 & $-1.54 \times 10^{-3}$ & $5.97 \times 10^{-3}$ & $6.85 \times 10^{-2}$ & $2.13 \times 10^{-2}$ \\
\hline 20 & AL-WAB-20020515 1.1 & $1.50 \times 10^{-3}$ & $5.95 \times 10^{-3}$ & $4.81 \times 10^{-2}$ & $1.85 \times 10^{-2}$ \\
\hline 21 & AL-WAB-20020522 1.1 & $-7.53 \times 10^{-6}$ & $5.12 \times 10^{-3}$ & $4.38 \times 10^{-2}$ & $1.89 \times 10^{-2}$ \\
\hline 22 & AL-WAB-20020529 1.1 & $1.50 \times 10^{-3}$ & $5.91 \times 10^{-3}$ & $6.17 \times 10^{-2}$ & $2.13 \times 10^{-2}$ \\
\hline 23 & AL-WAB-20020605 1.1 & $1.34 \times 10^{-2}$ & $8.86 \times 10^{-3}$ & $4.54 \times 10^{-2}$ & $1.79 \times 10^{-2}$ \\
\hline 24 & AL-WAB-20020612 1.1 & $-1.04 \times 10^{-5}$ & $4.16 \times 10^{-3}$ & $4.57 \times 10^{-2}$ & $1.78 \times 10^{-2}$ \\
\hline 25 & AL-WAB-20020619 1.1 & $2.93 \times 10^{-3}$ & $5.88 \times 10^{-3}$ & $6.22 \times 10^{-2}$ & $2.01 \times 10^{-2}$ \\
\hline
\end{tabular}


Table D.1 - Results of Gross Alpha and Gross Beta Analyses in Air Particulates $\left(\mathrm{Bq} / \mathrm{m}^{3}\right)$

\begin{tabular}{|c|c|c|c|c|c|}
\hline \multirow[b]{2}{*}{ Week } & \multirow[b]{2}{*}{ Sample ID } & \multicolumn{2}{|c|}{ Gross Alpha } & \multicolumn{2}{|c|}{ Gross Beta } \\
\hline & & Concentration & $2 \times$ TPU $^{\mathrm{a}}$ & Concentration & $2 \times$ TPU \\
\hline 26 & AL-WAB-20020626 1.1 & $-1.55 \times 10^{-3}$ & $5.23 \times 10^{-3}$ & $4.46 \times 10^{-2}$ & $1.89 \times 10^{-2}$ \\
\hline 27 & AL-WAB-20020703 1.1 & $-1.55 \times 10^{-3}$ & $5.23 \times 10^{-3}$ & $4.68 \times 10^{-2}$ & $1.92 \times 10^{-2}$ \\
\hline 28 & AL-WAB-20020710 1.1 & $-1.50 \times 10^{-3}$ & $5.83 \times 10^{-3}$ & $3.08 \times 10^{-2}$ & $1.76 \times 10^{-2}$ \\
\hline 29 & AL-WAB-20020717 1.1 & $-2.98 \times 10^{-3}$ & $6.52 \times 10^{-3}$ & $2.00 \times 10^{-2}$ & $1.61 \times 10^{-2}$ \\
\hline 30 & AL-WAB-20020724 1.1 & $4.50 \times 10^{-3}$ & $5.90 \times 10^{-3}$ & $5.69 \times 10^{-2}$ & $1.92 \times 10^{-2}$ \\
\hline 31 & AL-WAB-20020731 1.1 & $-1.53 \times 10^{-3}$ & $5.15 \times 10^{-3}$ & $4.13 \times 10^{-2}$ & $1.84 \times 10^{-2}$ \\
\hline 32 & AL-WAB-20020807 1.1 & $3.10 \times 10^{-3}$ & $6.08 \times 10^{-3}$ & $4.20 \times 10^{-2}$ & $1.84 \times 10^{-2}$ \\
\hline 33 & AL-WAB-20020814 1.1 & $3.09 \times 10^{-3}$ & $6.08 \times 10^{-3}$ & $4.75 \times 10^{-2}$ & $1.92 \times 10^{-2}$ \\
\hline 34 & AL-WAB-20020821 1.1 & $1.08 \times 10^{-2}$ & $9.18 \times 10^{-3}$ & $3.70 \times 10^{-2}$ & $1.77 \times 10^{-2}$ \\
\hline 35 & AL-WAB-20020828 1.1 & $7.75 \times 10^{-3}$ & $8.07 \times 10^{-3}$ & $3.39 \times 10^{-2}$ & $1.73 \times 10^{-2}$ \\
\hline 36 & AL-WAB-20020904 1.1 & $2.98 \times 10^{-3}$ & $5.86 \times 10^{-3}$ & $3.27 \times 10^{-2}$ & $1.61 \times 10^{-2}$ \\
\hline 37 & AL-WAB-20020911 1.1 & $-3.00 \times 10^{-3}$ & $5.87 \times 10^{-3}$ & $3.86 \times 10^{-2}$ & $1.70 \times 10^{-2}$ \\
\hline 38 & AL-WAB-20020918 1.1 & $4.43 \times 10^{-3}$ & $6.52 \times 10^{-3}$ & $4.04 \times 10^{-2}$ & $1.73 \times 10^{-2}$ \\
\hline 39 & AL-WAB-20020925 1.1 & $1.44 \times 10^{-3}$ & $5.03 \times 10^{-3}$ & $6.59 \times 10^{-2}$ & $2.08 \times 10^{-2}$ \\
\hline 40 & AL-WAB-20021002 1.1 & $-4.55 \times 10^{-3}$ & $7.27 \times 10^{-3}$ & $3.06 \times 10^{-2}$ & $1.72 \times 10^{-2}$ \\
\hline 41 & AL-WAB-20021009 1.1 & $5.90 \times 10^{-3}$ & $7.14 \times 10^{-3}$ & $6.67 \times 10^{-2}$ & $2.09 \times 10^{-2}$ \\
\hline 42 & AL-WAB-20021016 1.1 & $4.42 \times 10^{-3}$ & $6.51 \times 10^{-3}$ & $5.80 \times 10^{-2}$ & $1.97 \times 10^{-2}$ \\
\hline 43 & AL-WAB-20021023 1.1 & $4.51 \times 10^{-3}$ & $5.13 \times 10^{-3}$ & $3.95 \times 10^{-2}$ & $1.73 \times 10^{-2}$ \\
\hline 44 & AL-WAB-200210301.1 & $8.84 \times 10^{-3}$ & $9.19 \times 10^{-3}$ & $3.24 \times 10^{-2}$ & $1.71 \times 10^{-2}$ \\
\hline 45 & AL-WAB-20021106 1.1 & $1.03 \times 10^{-2}$ & $9.64 \times 10^{-3}$ & $4.33 \times 10^{-2}$ & $1.86 \times 10^{-2}$ \\
\hline 46 & AL-WAB-20021113 1.1 & $4.45 \times 10^{-3}$ & $5.09 \times 10^{-3}$ & $4.03 \times 10^{-2}$ & $1.69 \times 10^{-2}$ \\
\hline 47 & AL-WAB-20021120 1.1 & $5.95 \times 10^{-3}$ & $5.89 \times 10^{-3}$ & $4.56 \times 10^{-2}$ & $1.77 \times 10^{-2}$ \\
\hline 48 & AL-WAB-20021127 1.1 & $8.99 \times 10^{-3}$ & $7.26 \times 10^{-3}$ & $2.46 \times 10^{-2}$ & $1.45 \times 10^{-2}$ \\
\hline 49 & AL-WAB-20021204 1.1 & $5.92 \times 10^{-3}$ & $5.88 \times 10^{-3}$ & $6.21 \times 10^{-2}$ & $2.00 \times 10^{-2}$ \\
\hline 50 & AL-WAB-20021211 1.1 & $-1.54 \times 10^{-3}$ & $5.96 \times 10^{-3}$ & $4.57 \times 10^{-2}$ & $1.91 \times 10^{-2}$ \\
\hline 51 & AL-WAB-20021218 1.1 & $-1.36 \times 10^{-5}$ & $5.16 \times 10^{-3}$ & $2.89 \times 10^{-2}$ & $1.67 \times 10^{-2}$ \\
\hline 52 & AL-WAB-20021225 1.1 & $-1.54 \times 10^{-3}$ & $5.97 \times 10^{-3}$ & $5.69 \times 10^{-2}$ & $2.05 \times 10^{-2}$ \\
\hline \multicolumn{6}{|c|}{ WIPP East } \\
\hline 1 & AL-WEE-20020102 1.1 & $2.35 \times 10^{-4}$ & $5.35 \times 10^{-4}$ & $1.58 \times 10^{-3}$ & $1.90 \times 10^{-4}$ \\
\hline 2 & AL-WEE-20020109 1.1 & $1.25 \times 10^{-4}$ & $3.88 \times 10^{-5}$ & $1.01 \times 10^{-3}$ & $1.36 \times 10^{-4}$ \\
\hline 3 & AL-WEE-20020116 1.1 & $1.47 \times 10^{-4}$ & $4.05 \times 10^{-5}$ & $1.32 \times 10^{-3}$ & $1.64 \times 10^{-4}$ \\
\hline 4 & AL-WEE-20020123 1.1 & $8.97 \times 10^{-5}$ & $3.08 \times 10^{-5}$ & $9.20 \times 10^{-4}$ & $1.23 \times 10^{-4}$ \\
\hline 5 & AL-WEE-200201301.1 & $7.80 \times 10^{-5}$ & $2.91 \times 10^{-5}$ & $1.81 \times 10^{-3}$ & $1.48 \times 10^{-4}$ \\
\hline 6 & AL-WEE-20020206 1.1 & $4.87 \times 10^{-5}$ & $2.26 \times 10^{-5}$ & $8.34 \times 10^{-4}$ & $1.16 \times 10^{-4}$ \\
\hline 7 & AL-WEE-20020213 1.1 & $7.53 \times 10^{-5}$ & $2.90 \times 10^{-5}$ & $9.63 \times 10^{-4}$ & $1.30 \times 10^{-4}$ \\
\hline 8 & AL-WEE-20020220 1.1 & $5.77 \times 10^{-5}$ & $2.44 \times 10^{-5}$ & $7.53 \times 10^{-4}$ & $1.06 \times 10^{-4}$ \\
\hline 9 & AL-WEE-20020227 1.1 & $9.17 \times 10^{-5}$ & $3.18 \times 10^{-5}$ & $1.29 \times 10^{-3}$ & $1.61 \times 10^{-4}$ \\
\hline 10 & AL-WEE-20020306 1.1 & $6.44 \times 10^{-5}$ & $2.77 \times 10^{-5}$ & $9.02 \times 10^{-4}$ & $1.24 \times 10^{-4}$ \\
\hline 11 & AL-WEE-20020313 1.1 & $4.38 \times 10^{-5}$ & $2.20 \times 10^{-5}$ & $8.49 \times 10^{-4}$ & $1.16 \times 10^{-4}$ \\
\hline 12 & AL-WEE-20020320 1.1 & $8.65 \times 10^{-5}$ & $3.00 \times 10^{-5}$ & $1.18 \times 10^{-3}$ & $1.49 \times 10^{-4}$ \\
\hline 13 & AL-WEE-20020327 1.1 & $4.92 \times 10^{-5}$ & $2.32 \times 10^{-5}$ & $8.10 \times 10^{-4}$ & $1.12 \times 10^{-4}$ \\
\hline 14 & AL-WEE-20020403 1.1 & $5.54 \times 10^{-5}$ & $2.60 \times 10^{-5}$ & $9.17 \times 10^{-4}$ & $1.25 \times 10^{-4}$ \\
\hline 15 & AL-WEE-20020410 1.1 & $\mathrm{~N} / \mathrm{C}$ & $\mathrm{N} / \mathrm{C}$ & $\mathrm{N} / \mathrm{C}$ & $\mathrm{N} / \mathrm{C}$ \\
\hline 16 & AL-WEE-20020417 1.1 & $4.36 \times 10^{-5}$ & $2.32 \times 10^{-5}$ & $6.19 \times 10^{-4}$ & $9.52 \times 10^{-5}$ \\
\hline 17 & AL-WEE-20020424 1.1 & $1.07 \times 10^{-4}$ & $3.56 \times 10^{-5}$ & $8.31 \times 10^{-4}$ & $1.16 \times 10^{-4}$ \\
\hline 18 & AL-WEE-20020501 1.1 & $6.26 \times 10^{-5}$ & $2.64 \times 10^{-5}$ & $8.60 \times 10^{-4}$ & $1.20 \times 10^{-4}$ \\
\hline 19 & AL-WEE-20020508 1.1 & $6.30 \times 10^{-5}$ & $2.82 \times 10^{-5}$ & $9.45 \times 10^{-4}$ & $1.28 \times 10^{-4}$ \\
\hline 20 & AL-WEE-20020515 1.1 & $5.83 \times 10^{-5}$ & $2.67 \times 10^{-5}$ & $8.60 \times 10^{-4}$ & $1.19 \times 10^{-4}$ \\
\hline
\end{tabular}


Table D.1 - Results of Gross Alpha and Gross Beta Analyses in Air Particulates $\left(\mathrm{Bq} / \mathrm{m}^{3}\right)$

\begin{tabular}{|c|c|c|c|c|c|}
\hline \multirow[b]{2}{*}{ Week } & \multirow[b]{2}{*}{ Sample ID } & \multicolumn{2}{|c|}{ Gross Alpha } & \multicolumn{2}{|c|}{ Gross Beta } \\
\hline & & Concentration & $2 \times$ TPU $^{a}$ & Concentration & $2 \times$ TPU \\
\hline 21 & AL-WEE-20020522 1.1 & $4.31 \times 10^{-5}$ & $2.43 \times 10^{-5}$ & $8.20 \times 10^{-4}$ & $1.18 \times 10^{-4}$ \\
\hline 22 & AL-WEE-20020529 1.1 & $4.82 \times 10^{-5}$ & $2.46 \times 10^{-5}$ & $8.16 \times 10^{-4}$ & $1.15 \times 10^{-4}$ \\
\hline 23 & AL-WEE-20020605 1.1 & $5.96 \times 10^{-5}$ & $2.51 \times 10^{-5}$ & $6.19 \times 10^{-4}$ & $9.30 \times 10^{-5}$ \\
\hline 24 & AL-WEE-20020612 1.1 & $6.99 \times 10^{-5}$ & $2.88 \times 10^{-5}$ & $7.45 \times 10^{-4}$ & $1.07 \times 10^{-4}$ \\
\hline 25 & AL-WEE-20020619 1.1 & $7.58 \times 10^{-5}$ & $2.86 \times 10^{-5}$ & $8.79 \times 10^{-4}$ & $1.18 \times 10^{-4}$ \\
\hline 26 & AL-WEE-20020626 1.1 & $6.66 \times 10^{-5}$ & $2.85 \times 10^{-5}$ & $6.56 \times 10^{-4}$ & $9.87 \times 10^{-5}$ \\
\hline 27 & AL-WEE-20020703 1.1 & $1.02 \times 10^{-4}$ & $3.48 \times 10^{-5}$ & $8.71 \times 10^{-4}$ & $1.20 \times 10^{-4}$ \\
\hline 28 & AL-WEE-20020710 1.1 & $2.36 \times 10^{-5}$ & $1.82 \times 10^{-5}$ & $7.07 \times 10^{-4}$ & $1.04 \times 10^{-4}$ \\
\hline 29 & AL-WEE-20020717 1.1 & $3.43 \times 10^{-5}$ & $2.02 \times 10^{-5}$ & $6.12 \times 10^{-4}$ & $9.19 \times 10^{-5}$ \\
\hline 30 & AL-WEE-20020724 1.1 & $5.60 \times 10^{-5}$ & $2.58 \times 10^{-5}$ & $7.07 \times 10^{-4}$ & $1.04 \times 10^{-4}$ \\
\hline 31 & AL-WEE-20020731 1.1 & $6.04 \times 10^{-5}$ & $2.65 \times 10^{-5}$ & $9.25 \times 10^{-4}$ & $1.25 \times 10^{-4}$ \\
\hline 32 & AL-WEE-20020807 1.1 & $1.65 \times 10^{-4}$ & $4.52 \times 10^{-5}$ & $1.04 \times 10^{-3}$ & $1.36 \times 10^{-4}$ \\
\hline 33 & AL-WEE-20020814 1.1 & $8.78 \times 10^{-5}$ & $3.26 \times 10^{-5}$ & $8.11 \times 10^{-4}$ & $1.14 \times 10^{-4}$ \\
\hline 34 & AL-WEE-20020821 1.1 & $1.10 \times 10^{-4}$ & $3.66 \times 10^{-5}$ & $9.89 \times 10^{-4}$ & $1.32 \times 10^{-4}$ \\
\hline 35 & AL-WEE-20020828 1.1 & $1.13 \times 10^{-4}$ & $3.67 \times 10^{-5}$ & $1.15 \times 10^{-3}$ & $1.48 \times 10^{-4}$ \\
\hline 36 & AL-WEE-20020904 1.1 & $8.41 \times 10^{-5}$ & $3.07 \times 10^{-5}$ & $7.54 \times 10^{-4}$ & $1.06 \times 10^{-4}$ \\
\hline 37 & AL-WEE-20020911 1.1 & $1.02 \times 10^{-4}$ & $3.53 \times 10^{-5}$ & $1.30 \times 10^{-3}$ & $1.65 \times 10^{-4}$ \\
\hline 38 & AL-WEE-20020918 1.1 & $1.02 \times 10^{-4}$ & $3.40 \times 10^{-5}$ & $1.06 \times 10^{-3}$ & $1.38 \times 10^{-4}$ \\
\hline 39 & AL-WEE-20020925 1.1 & $7.91 \times 10^{-5}$ & $3.04 \times 10^{-5}$ & $1.18 \times 10^{-3}$ & $1.51 \times 10^{-4}$ \\
\hline 40 & AL-WEE-20021002 1.2 & $9.24 \times 10^{-5}$ & $3.28 \times 10^{-5}$ & $7.31 \times 10^{-4}$ & $1.05 \times 10^{-4}$ \\
\hline 41 & AL-WEE-20021009 1.2 & $6.67 \times 10^{-5}$ & $2.76 \times 10^{-5}$ & $1.11 \times 10^{-3}$ & $1.44 \times 10^{-4}$ \\
\hline 42 & AL-WEE-20021016 1.2 & $4.38 \times 10^{-5}$ & $2.26 \times 10^{-5}$ & $1.13 \times 10^{-3}$ & $1.46 \times 10^{-4}$ \\
\hline 43 & AL-WEE-20021023 1.2 & $3.11 \times 10^{-5}$ & $1.79 \times 10^{-5}$ & $5.48 \times 10^{-4}$ & $8.55 \times 10^{-5}$ \\
\hline 44 & AL-WEE-20021030 1.2 & $6.25 \times 10^{-5}$ & $2.78 \times 10^{-5}$ & $8.68 \times 10^{-4}$ & $1.20 \times 10^{-4}$ \\
\hline 45 & AL-WEE-20021106 1.2 & $5.18 \times 10^{-5}$ & $2.80 \times 10^{-5}$ & $1.02 \times 10^{-3}$ & $1.40 \times 10^{-4}$ \\
\hline 46 & AL-WEE-20021113 1.2 & $5.54 \times 10^{-5}$ & $2.47 \times 10^{-5}$ & $1.02 \times 10^{-3}$ & $1.35 \times 10^{-4}$ \\
\hline 47 & AL-WEE-20021120 1.2 & $1.10 \times 10^{-4}$ & $3.61 \times 10^{-5}$ & $1.38 \times 10^{-3}$ & $1.73 \times 10^{-4}$ \\
\hline 48 & AL-WEE-20021127 1.2 & $3.82 \times 10^{-5}$ & $2.03 \times 10^{-5}$ & $1.58 \times 10^{-3}$ & $1.91 \times 10^{-4}$ \\
\hline 49 & AL-WEE-20021204 1.2 & $2.77 \times 10^{-5}$ & $1.72 \times 10^{-5}$ & $1.34 \times 10^{-3}$ & $1.68 \times 10^{-4}$ \\
\hline 50 & AL-WEE-20021211 1.2 & $1.10 \times 10^{-4}$ & $3.63 \times 10^{-5}$ & $1.38 \times 10^{-3}$ & $1.71 \times 10^{-4}$ \\
\hline 51 & AL-WEE-20021218 1.2 & $6.76 \times 10^{-5}$ & $2.68 \times 10^{-5}$ & $9.07 \times 10^{-4}$ & $1.20 \times 10^{-4}$ \\
\hline 52 & AL-WEE-20021225 1.2 & $7.12 \times 10^{-5}$ & $3.44 \times 10^{-5}$ & $1.32 \times 10^{-3}$ & $1.77 \times 10^{-4}$ \\
\hline \multicolumn{6}{|c|}{ WIPP Far Field } \\
\hline 1 & AL-WFF-20020102 1.1 & $2.05 \times 10^{-4}$ & $5.02 \times 10^{-5}$ & $1.41 \times 10^{-3}$ & $1.75 \times 10^{-4}$ \\
\hline 2 & AL-WFF-20020109 1.1 & $1.11 \times 10^{-4}$ & $3.48 \times 10^{-5}$ & $9.71 \times 10^{-4}$ & $1.28 \times 10^{-4}$ \\
\hline 3 & AL-WFF-20020116 1.1 & $1.43 \times 10^{-4}$ & $3.91 \times 10^{-5}$ & $1.31 \times 10^{-3}$ & $1.61 \times 10^{-4}$ \\
\hline 4 & AL-WFF-20020123 1.1 & $\mathrm{~N} / \mathrm{C}$ & $\mathrm{N} / \mathrm{C}$ & $\mathrm{N} / \mathrm{C}$ & $\mathrm{N} / \mathrm{C}$ \\
\hline 5 & AL-WFF-200201301.1 & $8.71 \times 10^{-5}$ & $3.11 \times 10^{-5}$ & $1.14 \times 10^{-3}$ & $1.45 \times 10^{-4}$ \\
\hline 6 & AL-WFF-20020206 1.1 & $8.81 \times 10^{-5}$ & $3.10 \times 10^{-5}$ & $8.20 \times 10^{-4}$ & $1.14 \times 10^{-4}$ \\
\hline 7 & AL-WFF-20020213 1.1 & $6.45 \times 10^{-5}$ & $2.58 \times 10^{-5}$ & $9.18 \times 10^{-4}$ & $1.23 \times 10^{-4}$ \\
\hline 8 & AL-WFF-20020220 1.1 & $3.86 \times 10^{-5}$ & $2.00 \times 10^{-5}$ & $7.75 \times 10^{-4}$ & $1.10 \times 10^{-4}$ \\
\hline 9 & AL-WFF-20020227 1.1 & $9.39 \times 10^{-5}$ & $3.17 \times 10^{-5}$ & $1.29 \times 10^{-3}$ & $1.60 \times 10^{-4}$ \\
\hline 10 & AL-WFF-20020306 1.1 & $8.21 \times 10^{-5}$ & $3.10 \times 10^{-5}$ & $1.03 \times 10^{-3}$ & $1.37 \times 10^{-4}$ \\
\hline 11 & AL-WFF-20020313 1.1 & $5.11 \times 10^{-5}$ & $2.30 \times 10^{-5}$ & $8.34 \times 10^{-4}$ & $1.13 \times 10^{-4}$ \\
\hline 12 & AL-WFF-20020320 1.1 & $6.66 \times 10^{-5}$ & $2.65 \times 10^{-5}$ & $9.29 \times 10^{-4}$ & $1.24 \times 10^{-4}$ \\
\hline 13 & AL-WFF-20020327 1.1 & $6.84 \times 10^{-5}$ & $2.76 \times 10^{-5}$ & $9.34 \times 10^{-4}$ & $1.26 \times 10^{-4}$ \\
\hline 14 & AL-WFF-20020403 1.1 & $6.96 \times 10^{-5}$ & $2.86 \times 10^{-5}$ & $9.69 \times 10^{-4}$ & $1.29 \times 10^{-4}$ \\
\hline 15 & AL-WFF-20020410 1.1 & $6.66 \times 10^{-5}$ & $2.91 \times 10^{-5}$ & $1.14 \times 10^{-3}$ & $1.49 \times 10^{-4}$ \\
\hline
\end{tabular}


Table D.1 - Results of Gross Alpha and Gross Beta Analyses in Air Particulates $\left(\mathrm{Bq} / \mathrm{m}^{3}\right)$

\begin{tabular}{|c|c|c|c|c|c|}
\hline \multirow[b]{2}{*}{ Week } & \multirow[b]{2}{*}{ Sample ID } & \multicolumn{2}{|c|}{ Gross Alpha } & \multicolumn{2}{|c|}{ Gross Beta } \\
\hline & & Concentration & $2 \times$ TPU $^{\mathrm{a}}$ & Concentration & $2 \times$ TPU \\
\hline 16 & AL-WFF-20020417 1.1 & $5.88 \times 10^{-5}$ & $2.59 \times 10^{-5}$ & $8.98 \times 10^{-4}$ & $1.22 \times 10^{-4}$ \\
\hline 17 & AL-WFF-20020424 1.1 & $5.16 \times 10^{-5}$ & $2.51 \times 10^{-5}$ & $1.00 \times 10^{-3}$ & $1.35 \times 10^{-4}$ \\
\hline 18 & AL-WFF-20020501 1.1 & $7.37 \times 10^{-5}$ & $2.83 \times 10^{-5}$ & $8.65 \times 10^{-4}$ & $1.19 \times 10^{-4}$ \\
\hline 19 & AL-WFF-20020508 1.1 & $1.19 \times 10^{-4}$ & $3.88 \times 10^{-5}$ & $8.74 \times 10^{-4}$ & $1.21 \times 10^{-4}$ \\
\hline 20 & AL-WFF-20020515 1.1 & $5.26 \times 10^{-5}$ & $2.54 \times 10^{-5}$ & $9.29 \times 10^{-4}$ & $1.25 \times 10^{-4}$ \\
\hline 21 & AL-WFF-20020522 1.1 & $\mathrm{~N} / \mathrm{C}$ & $\mathrm{N} / \mathrm{C}$ & $\mathrm{N} / \mathrm{C}$ & $\mathrm{N} / \mathrm{C}$ \\
\hline 22 & AL-WFF-20020529 1.1 & $3.33 \times 10^{-5}$ & $2.04 \times 10^{-5}$ & $7.94 \times 10^{-4}$ & $1.12 \times 10^{-4}$ \\
\hline 23 & AL-WFF-20020605 1.1 & $5.49 \times 10^{-5}$ & $2.47 \times 10^{-5}$ & $6.60 \times 10^{-4}$ & $9.89 \times 10^{-5}$ \\
\hline 24 & AL-WFF-20020612 1.1 & $8.52 \times 10^{-5}$ & $3.21 \times 10^{-5}$ & $7.78 \times 10^{-4}$ & $1.11 \times 10^{-4}$ \\
\hline 25 & AL-WFF-20020619 1.1 & $6.71 \times 10^{-5}$ & $2.66 \times 10^{-5}$ & $9.31 \times 10^{-4}$ & $1.23 \times 10^{-4}$ \\
\hline 26 & AL-WFF-20020626 1.1 & $9.18 \times 10^{-5}$ & $3.31 \times 10^{-5}$ & $7.54 \times 10^{-4}$ & $1.08 \times 10^{-4}$ \\
\hline 27 & AL-WFF-20020703 1.2 & $5.87 \times 10^{-5}$ & $2.70 \times 10^{-5}$ & $1.03 \times 10^{-3}$ & $1.37 \times 10^{-4}$ \\
\hline 28 & AL-WFF-20020710 1.2 & $7.76 \times 10^{-5}$ & $3.02 \times 10^{-5}$ & $8.28 \times 10^{-4}$ & $1.15 \times 10^{-4}$ \\
\hline 29 & AL-WFF-20020717 1.2 & $4.05 \times 10^{-5}$ & $2.14 \times 10^{-5}$ & $6.29 \times 10^{-4}$ & $9.28 \times 10^{-5}$ \\
\hline 30 & AL-WFF-20020724 1.2 & $1.01 \times 10^{-4}$ & $3.53 \times 10^{-5}$ & $7.91 \times 10^{-4}$ & $1.13 \times 10^{-4}$ \\
\hline 31 & AL-WFF-20020731 1.2 & $4.52 \times 10^{-5}$ & $2.25 \times 10^{-5}$ & $8.95 \times 10^{-4}$ & $1.21 \times 10^{-4}$ \\
\hline 32 & AL-WFF-20020807 1.2 & $1.45 \times 10^{-4}$ & $4.22 \times 10^{-5}$ & $9.92 \times 10^{-4}$ & $1.32 \times 10^{-4}$ \\
\hline 33 & AL-WFF-20020814 1.2 & $1.02 \times 10^{-4}$ & $3.51 \times 10^{-5}$ & $9.53 \times 10^{-4}$ & $1.29 \times 10^{-4}$ \\
\hline 34 & AL-WFF-20020821 1.2 & $8.79 \times 10^{-5}$ & $3.21 \times 10^{-5}$ & $9.28 \times 10^{-4}$ & $1.25 \times 10^{-4}$ \\
\hline 35 & AL-WFF-20020828 1.2 & $1.03 \times 10^{-4}$ & $3.56 \times 10^{-5}$ & $1.21 \times 10^{-3}$ & $1.55 \times 10^{-4}$ \\
\hline 36 & AL-WFF-20020904 1.2 & $5.56 \times 10^{-5}$ & $2.49 \times 10^{-5}$ & $7.79 \times 10^{-4}$ & $1.09 \times 10^{-4}$ \\
\hline 37 & AL-WFF-20020911 1.2 & $1.17 \times 10^{-4}$ & $3.80 \times 10^{-5}$ & $1.22 \times 10^{-3}$ & $1.57 \times 10^{-4}$ \\
\hline 38 & AL-WFF-20020918 1.2 & $1.36 \times 10^{-4}$ & $3.94 \times 10^{-5}$ & $1.20 \times 10^{-3}$ & $1.52 \times 10^{-4}$ \\
\hline 39 & AL-WFF-20020925 1.2 & $1.19 \times 10^{-4}$ & $3.74 \times 10^{-5}$ & $1.15 \times 10^{-3}$ & $1.48 \times 10^{-4}$ \\
\hline 40 & AL-WFF-20021002 1.1 & $7.43 \times 10^{-5}$ & $2.90 \times 10^{-5}$ & $8.60 \times 10^{-4}$ & $1.17 \times 10^{-4}$ \\
\hline 41 & AL-WFF-20021009 1.1 & $4.70 \times 10^{-5}$ & $2.36 \times 10^{-5}$ & $1.25 \times 10^{-3}$ & $1.58 \times 10^{-4}$ \\
\hline 42 & AL-WFF-20021016 1.1 & $5.08 \times 10^{-5}$ & $2.41 \times 10^{-5}$ & $1.15 \times 10^{-3}$ & $1.47 \times 10^{-4}$ \\
\hline 43 & AL-WFF-20021023 1.1 & $4.28 \times 10^{-5}$ & $2.08 \times 10^{-5}$ & $5.15 \times 10^{-4}$ & $8.11 \times 10^{-5}$ \\
\hline 44 & AL-WFF-20021030 1.1 & $4.66 \times 10^{-5}$ & $2.44 \times 10^{-5}$ & $8.15 \times 10^{-4}$ & $1.14 \times 10^{-4}$ \\
\hline 45 & AL-WFF-20021106 1.1 & $1.02 \times 10^{-4}$ & $3.47 \times 10^{-5}$ & $1.09 \times 10^{-3}$ & $1.41 \times 10^{-4}$ \\
\hline 46 & AL-WFF-20021113 1.1 & $9.56 \times 10^{-5}$ & $3.25 \times 10^{-5}$ & $1.07 \times 10^{-3}$ & $1.39 \times 10^{-4}$ \\
\hline 47 & AL-WFF-200211201.1 & $1.03 \times 10^{-4}$ & $3.34 \times 10^{-5}$ & $1.24 \times 10^{-3}$ & $1.55 \times 10^{-4}$ \\
\hline 48 & AL-WFF-20021127 1.1 & $5.93 \times 10^{-5}$ & $2.54 \times 10^{-5}$ & $1.55 \times 10^{-3}$ & $1.88 \times 10^{-4}$ \\
\hline 49 & AL-WFF-20021204 1.1 & $4.79 \times 10^{-5}$ & $2.25 \times 10^{-5}$ & $1.19 \times 10^{-3}$ & $1.51 \times 10^{-4}$ \\
\hline 50 & AL-WFF-20021211 1.1 & $1.64 \times 10^{-4}$ & $4.53 \times 10^{-5}$ & $1.46 \times 10^{-3}$ & $1.80 \times 10^{-4}$ \\
\hline 51 & AL-WFF-20021218 1.1 & $4.84 \times 10^{-5}$ & $2.28 \times 10^{-5}$ & $8.59 \times 10^{-4}$ & $1.15 \times 10^{-4}$ \\
\hline 52 & AL-WFF-20021225 1.1 & $8.77 \times 10^{-5}$ & $3.84 \times 10^{-5}$ & $1.35 \times 10^{-3}$ & $1.81 \times 10^{-4}$ \\
\hline \multicolumn{6}{|c|}{ WIPP South } \\
\hline 1 & AL-WSS-20020102 1.1 & $1.77 \times 10^{-4}$ & $4.60 \times 10^{-5}$ & $1.42 \times 10^{-3}$ & $1.76 \times 10^{-4}$ \\
\hline 2 & AL-WSS-20020109 1.1 & $1.20 \times 10^{-4}$ & $3.64 \times 10^{-5}$ & $1 . .01 \times 10^{-3}$ & $1.32 \times 10^{-4}$ \\
\hline 3 & AL-WSS-20020116 1.1 & $1.39 \times 10^{-4}$ & $3.95 \times 10^{-5}$ & $1.21 \times 10^{-3}$ & $1.53 \times 10^{-4}$ \\
\hline 4 & AL-WSS-200201231.1 & $7.83 \times 10^{-5}$ & $2.88 \times 10^{-5}$ & $9.65 \times 10^{-4}$ & $1.28 \times 10^{-4}$ \\
\hline 5 & AL-WSS-200201301.1 & $\mathrm{N} / \mathrm{C}$ & $\mathrm{N} / \mathrm{C}$ & $\mathrm{N} / \mathrm{C}$ & $\mathrm{N} / \mathrm{C}$ \\
\hline 6 & AL-WSS-20020206 1.1 & $8.90 \times 10^{-5}$ & $3.09 \times 10^{-5}$ & $8.04 \times 10^{-4}$ & $1.12 \times 10^{-4}$ \\
\hline 7 & AL-WSS-200202131.1 & $5.01 \times 10^{-5}$ & $2.33 \times 10^{-5}$ & $9.63 \times 10^{-4}$ & $1.30 \times 10^{-4}$ \\
\hline 8 & AL-WSS-200202201.1 & $3.51 \times 10^{-5}$ & $1.89 \times 10^{-5}$ & $7.18 \times 10^{-4}$ & $1.03 \times 10^{-4}$ \\
\hline 9 & AL-WSS-20020227 1.1 & $9.63 \times 10^{-5}$ & $3.26 \times 10^{-5}$ & $1.32 \times 10^{-3}$ & $1.64 \times 10^{-4}$ \\
\hline 10 & AL-WSS-20020306 1.1 & $5.48 \times 10^{-5}$ & $2.53 \times 10^{-5}$ & $1.05 \times 10^{-3}$ & $1.39 \times 10^{-4}$ \\
\hline
\end{tabular}


Table D.1 - Results of Gross Alpha and Gross Beta Analyses in Air Particulates $\left(\mathrm{Bq} / \mathrm{m}^{3}\right)$

\begin{tabular}{|c|c|c|c|c|c|}
\hline \multirow[b]{2}{*}{ Week } & \multirow[b]{2}{*}{ Sample ID } & \multicolumn{2}{|c|}{ Gross Alpha } & \multicolumn{2}{|c|}{ Gross Beta } \\
\hline & & Concentration & $2 \times$ TPU $^{\mathrm{a}}$ & Concentration & $2 \times$ TPU \\
\hline 11 & AL-WSS-20020313 1.1 & $5.83 \times 10^{-5}$ & $2.51 \times 10^{-5}$ & $7.34 \times 10^{-4}$ & $1.04 \times 10^{-4}$ \\
\hline 12 & AL-WSS-20020320 1.1 & $8.87 \times 10^{-5}$ & $3.16 \times 10^{-5}$ & $1.08 \times 10^{-3}$ & $1.41 \times 10^{-4}$ \\
\hline 13 & AL-WSS-20020327 1.1 & $3.63 \times 10^{-5}$ & $2.00 \times 10^{-5}$ & $8.33 \times 10^{-4}$ & $1.14 \times 10^{-4}$ \\
\hline 14 & AL-WSS-20020403 1.1 & $8.33 \times 10^{-5}$ & $3.24 \times 10^{-5}$ & $8.82 \times 10^{-4}$ & $1.23 \times 10^{-4}$ \\
\hline 15 & AL-WSS-200204101.1 & $7.61 \times 10^{-5}$ & $2.96 \times 10^{-5}$ & $1.09 \times 10^{-3}$ & $1.41 \times 10^{-4}$ \\
\hline 16 & AL-WSS-20020417 1.1 & $5.29 \times 10^{-5}$ & $2.44 \times 10^{-5}$ & $6.95 \times 10^{-4}$ & $1.01 \times 10^{-4}$ \\
\hline 17 & AL-WSS-20020424 1.1 & $5.70 \times 10^{-5}$ & $2.56 \times 10^{-5}$ & $8.08 \times 10^{-4}$ & $1.13 \times 10^{-4}$ \\
\hline 18 & AL-WSS-20020501 1.1 & $7.28 \times 10^{-5}$ & $2.84 \times 10^{-5}$ & $6.33 \times 10^{-4}$ & $9.58 \times 10^{-5}$ \\
\hline 19 & AL-WSS-20020508 1.1 & $7.86 \times 10^{-5}$ & $3.23 \times 10^{-5}$ & $8.41 \times 10^{-4}$ & $1.20 \times 10^{-4}$ \\
\hline 20 & AL-WSS-20020515 1.1 & $4.13 \times 10^{-5}$ & $2.18 \times 10^{-5}$ & $8.33 \times 10^{-4}$ & $1.13 \times 10^{-4}$ \\
\hline 21 & AL-WSS-20020522 1.1 & $6.16 \times 10^{-5}$ & $2.69 \times 10^{-5}$ & $7.72 \times 10^{-4}$ & $1.09 \times 10^{-4}$ \\
\hline 22 & AL-WSS-20020529 1.1 & $3.59 \times 10^{-5}$ & $2.20 \times 10^{-5}$ & $7.05 \times 10^{-4}$ & $1.05 \times 10^{-4}$ \\
\hline 23 & AL-WSS-20020605 1.1 & $6.54 \times 10^{-5}$ & $2.65 \times 10^{-5}$ & $7.59 \times 10^{-4}$ & $1.08 \times 10^{-4}$ \\
\hline 24 & AL-WSS-20020612 1.1 & $9.58 \times 10^{-5}$ & $3.40 \times 10^{-5}$ & $7.54 \times 10^{-4}$ & $1.09 \times 10^{-4}$ \\
\hline 25 & AL-WSS-20020619 1.1 & $5.55 \times 10^{-5}$ & $2.43 \times 10^{-5}$ & $9.07 \times 10^{-4}$ & $1.21 \times 10^{-4}$ \\
\hline 26 & AL-WSS-20020626 1.1 & $6.18 \times 10^{-5}$ & $2.65 \times 10^{-5}$ & $7.12 \times 10^{-4}$ & $1.02 \times 10^{-4}$ \\
\hline 27 & AL-WSS-20020703 1.1 & $6.98 \times 10^{-5}$ & $2.93 \times 10^{-5}$ & $8.98 \times 10^{-4}$ & $1.24 \times 10^{-4}$ \\
\hline 28 & AL-WSS-20020710 1.1 & $6.03 \times 10^{-5}$ & $2.70 \times 10^{-5}$ & $7.48 \times 10^{-4}$ & $1.08 \times 10^{-4}$ \\
\hline 29 & AL-WSS-20020717 1.1 & $4.13 \times 10^{-5}$ & $2.18 \times 10^{-5}$ & $5.55 \times 10^{-4}$ & $8.57 \times 10^{-5}$ \\
\hline 30 & AL-WSS-20020724 1.1 & $3.83 \times 10^{-5}$ & $2.12 \times 10^{-5}$ & $6.40 \times 10^{-4}$ & $9.63 \times 10^{-5}$ \\
\hline 31 & AL-WSS-20020731 1.1 & $8.33 \times 10^{-5}$ & $3.00 \times 10^{-5}$ & $9.34 \times 10^{-4}$ & $1.24 \times 10^{-4}$ \\
\hline 32 & AL-WSS-20020807 1.1 & $1.38 \times 10^{-4}$ & $4.13 \times 10^{-5}$ & $9.77 \times 10^{-4}$ & $1.31 \times 10^{-4}$ \\
\hline 33 & AL-WSS-20020814 1.1 & $1.05 \times 10^{-4}$ & $3.53 \times 10^{-5}$ & $8.45 \times 10^{-4}$ & $1.17 \times 10^{-4}$ \\
\hline 34 & AL-WSS-20020821 1.1 & $7.55 \times 10^{-5}$ & $3.05 \times 10^{-5}$ & $8.59 \times 10^{-4}$ & $1.20 \times 10^{-4}$ \\
\hline 35 & AL-WSS-20020828 1.1 & $1.55 \times 10^{-4}$ & $4.33 \times 10^{-5}$ & $1.29 \times 10^{-3}$ & $1.62 \times 10^{-4}$ \\
\hline 36 & AL-WSS-20020904 1.1 & $4.65 \times 10^{-5}$ & $2.25 \times 10^{-5}$ & $7.63 \times 10^{-4}$ & $1.06 \times 10^{-4}$ \\
\hline 37 & AL-WSS-20020911 1.1 & $9.72 \times 10^{-5}$ & $3.36 \times 10^{-5}$ & $1.32 \times 10^{-3}$ & $1.65 \times 10^{-4}$ \\
\hline 38 & AL-WSS-20020918 1.1 & $\mathrm{~N} / \mathrm{C}$ & $\mathrm{N} / \mathrm{C}$ & $\mathrm{N} / \mathrm{C}$ & $\mathrm{N} / \mathrm{C}$ \\
\hline 39 & AL-WSS-20020925 1.1 & $1.04 \times 10^{-4}$ & $3.85 \times 10^{-5}$ & $9.35 \times 10^{-4}$ & $1.33 \times 10^{-4}$ \\
\hline 40 & AL-WSS-20021002 1.1 & $9.40 \times 10^{-5}$ & $3.29 \times 10^{-5}$ & $7.84 \times 10^{-4}$ & $1.10 \times 10^{-4}$ \\
\hline 41 & AL-WSS-20021009 1.1 & $5.10 \times 10^{-5}$ & $2.36 \times 10^{-5}$ & $1.30 \times 10^{-3}$ & $1.61 \times 10^{-4}$ \\
\hline 42 & AL-WSS-20021016 1.1 & $6.73 \times 10^{-5}$ & $2.73 \times 10^{-5}$ & $1.36 \times 10^{-3}$ & $1.67 \times 10^{-4}$ \\
\hline 43 & AL-WSS-20021023 1.1 & $4.17 \times 10^{-5}$ & $2.09 \times 10^{-5}$ & $6.04 \times 10^{-4}$ & $9.15 \times 10^{-5}$ \\
\hline 44 & AL-WSS-20021030 1.1 & $4.15 \times 10^{-5}$ & $2.32 \times 10^{-5}$ & $8.71 \times 10^{-4}$ & $1.20 \times 10^{-4}$ \\
\hline 45 & AL-WSS-20021106 1.1 & $5.33 \times 10^{-5}$ & $2.56 \times 10^{-5}$ & $9.64 \times 10^{-4}$ & $1.29 \times 10^{-4}$ \\
\hline 46 & AL-WSS-200211131.1 & $1.08 \times 10^{-4}$ & $3.47 \times 10^{-5}$ & $1.04 \times 10^{-3}$ & $1.36 \times 10^{-4}$ \\
\hline 47 & AL-WSS-200211201.1 & $1.24 \times 10^{-4}$ & $3.73 \times 10^{-5}$ & $1.16 \times 10^{-3}$ & $1.49 \times 10^{-4}$ \\
\hline 48 & AL-WSS-20021127 1.1 & $8.75 \times 10^{-5}$ & $3.06 \times 10^{-5}$ & $1.55 \times 10^{-3}$ & $1.86 \times 10^{-4}$ \\
\hline 49 & AL-WSS-20021204 1.1 & $1.47 \times 10^{-5}$ & $1.27 \times 10^{-5}$ & $1.35 \times 10^{-3}$ & $1.70 \times 10^{-4}$ \\
\hline 50 & AL-WSS-20021211 1.1 & $1.56 \times 10^{-4}$ & $5.03 \times 10^{-5}$ & $1.61 \times 10^{-3}$ & $2.06 \times 10^{-4}$ \\
\hline 51 & AL-WSS-20021218 1.1 & $4.31 \times 10^{-5}$ & $2.20 \times 10^{-5}$ & $7.17 \times 10^{-4}$ & $1.01 \times 10^{-4}$ \\
\hline 52 & AL-WSS-20021225 1.1 & $5.81 \times 10^{-5}$ & $3.18 \times 10^{-5}$ & $1.42 \times 10^{-3}$ & $1.88 \times 10^{-4}$ \\
\hline \multicolumn{6}{|c|}{ Duplicate Samples } \\
\hline \multicolumn{6}{|c|}{ Carlsbad (CBD) } \\
\hline 1 & AL-CBD-20020102 1.2 & $\mathrm{~N} / \mathrm{C}^{\mathrm{b}}$ & $\mathrm{N} / \mathrm{C}$ & $\mathrm{N} / \mathrm{C}$ & $\mathrm{N} / \mathrm{C}$ \\
\hline 2 & AL-CBD-20020109 1.2 & $1.36 \times 10^{-4}$ & $4.03 \times 10^{-5}$ & $9.99 \times 10^{-4}$ & $1.34 \times 10^{-4}$ \\
\hline 3 & AL-CBD-20020116 1.2 & $1.20 \times 10^{-4}$ & $3.67 \times 10^{-5}$ & $1.20 \times 10^{-3}$ & $1.52 \times 10^{-4}$ \\
\hline 4 & AL-CBD-200201231.2 & $1.04 \times 10^{-4}$ & $3.38 \times 10^{-5}$ & $8.94 \times 10^{-4}$ & $1.21 \times 10^{-4}$ \\
\hline
\end{tabular}


Table D.1 - Results of Gross Alpha and Gross Beta Analyses in Air Particulates $\left(\mathrm{Bq} / \mathrm{m}^{3}\right)$

\begin{tabular}{|c|c|c|c|c|c|}
\hline \multirow[b]{2}{*}{ Week } & \multirow[b]{2}{*}{ Sample ID } & \multicolumn{2}{|c|}{ Gross Alpha } & \multicolumn{2}{|c|}{ Gross Beta } \\
\hline & & Concentration & $2 \times$ TPU $^{a}$ & Concentration & $2 \times$ TPU \\
\hline 5 & AL-CBD-200201301.2 & $8.33 \times 10^{-5}$ & $3.10 \times 10^{-5}$ & $1.10 \times 10^{-3}$ & $1.41 \times 10^{-4}$ \\
\hline 6 & AL-CBD-20020206 1.2 & $9.25 \times 10^{-5}$ & $3.40 \times 10^{-5}$ & $1.01 \times 10^{-3}$ & $1.38 \times 10^{-4}$ \\
\hline 7 & AL-CBD-20020213 1.2 & $5.84 \times 10^{-5}$ & $2.18 \times 10^{-5}$ & $9.42 \times 10^{-4}$ & $1.19 \times 10^{-4}$ \\
\hline 8 & AL-CBD-20020220 1.2 & $5.63 \times 10^{-5}$ & $2.54 \times 10^{-5}$ & $8.87 \times 10^{-4}$ & $1.24 \times 10^{-4}$ \\
\hline 9 & AL-CBD-20020227 1.2 & $7.08 \times 10^{-5}$ & $2.77 \times 10^{-5}$ & $1.23 \times 10^{-3}$ & $1.54 \times 10^{-4}$ \\
\hline 10 & AL-CBD-20020306 1.2 & $\mathrm{~N} / \mathrm{C}$ & $\mathrm{N} / \mathrm{C}$ & $\mathrm{N} / \mathrm{C}$ & $\mathrm{N} / \mathrm{C}$ \\
\hline 11 & AL-CBD-20020313 1.2 & $\mathrm{~N} / \mathrm{C}$ & $\mathrm{N} / \mathrm{C}$ & $\mathrm{N} / \mathrm{C}$ & $\mathrm{N} / \mathrm{C}$ \\
\hline 12 & AL-CBD-20020320 1.2 & $7.58 \times 10^{-5}$ & $2.96 \times 10^{-5}$ & $9.41 \times 10^{-4}$ & $1.28 \times 10^{-4}$ \\
\hline 13 & AL-CBD-20020327 1.2 & $7.84 \times 10^{-5}$ & $2.96 \times 10^{-5}$ & $9.32 \times 10^{-4}$ & $1.26 \times 10^{-4}$ \\
\hline \multicolumn{6}{|c|}{ South East Control (SEC) } \\
\hline 14 & AL-SEC-20020403 1.2 & $7.44 \times 10^{-5}$ & $3.06 \times 10^{-5}$ & $9.50 \times 10^{-4}$ & $1.29 \times 10^{-4}$ \\
\hline 15 & AL-SEC-20020410 1.2 & $6.91 \times 10^{-5}$ & $2.90 \times 10^{-5}$ & $1.13 \times 10^{-3}$ & $1.46 \times 10^{-4}$ \\
\hline 16 & AL-SEC-20020417 1.2 & $4.57 \times 10^{-5}$ & $2.28 \times 10^{-5}$ & $8.27 \times 10^{-4}$ & $1.15 \times 10^{-4}$ \\
\hline 17 & AL-SEC-20020424 1.2 & $7.58 \times 10^{-5}$ & $2.96 \times 10^{-5}$ & $9.11 \times 10^{-4}$ & $1.24 \times 10^{-4}$ \\
\hline 18 & AL-SEC-20020501 1.2 & $7.10 \times 10^{-5}$ & $2.76 \times 10^{-5}$ & $8.87 \times 10^{-4}$ & $1.21 \times 10^{-4}$ \\
\hline 19 & AL-SEC-20020508 1.2 & $7.98 \times 10^{-5}$ & $3.05 \times 10^{-5}$ & $8.55 \times 10^{-4}$ & $1.17 \times 10^{-4}$ \\
\hline 20 & AL-SEC-20020515 1.2 & $7.49 \times 10^{-5}$ & $2.92 \times 10^{-5}$ & $8.97 \times 10^{-4}$ & $1.21 \times 10^{-4}$ \\
\hline 21 & AL-SEC-20020522 1.2 & $5.37 \times 10^{-5}$ & $2.58 \times 10^{-5}$ & $8.10 \times 10^{-4}$ & $1.15 \times 10^{-4}$ \\
\hline 22 & AL-SEC-20020529 1.2 & $4.17 \times 10^{-5}$ & $2.27 \times 10^{-5}$ & $8.13 \times 10^{-4}$ & $1.14 \times 10^{-4}$ \\
\hline 23 & AL-SEC-20020605 1.2 & $6.16 \times 10^{-5}$ & $2.54 \times 10^{-5}$ & $7.23 \times 10^{-4}$ & $1.04 \times 10^{-4}$ \\
\hline 24 & AL-SEC-20020612 1.2 & $6.98 \times 10^{-5}$ & $2.87 \times 10^{-5}$ & $7.75 \times 10^{-4}$ & $1.10 \times 10^{-4}$ \\
\hline 25 & AL-SEC-20020619 1.2 & $5.46 \times 10^{-5}$ & $2.51 \times 10^{-5}$ & $1.03 \times 10^{-3}$ & $1.36 \times 10^{-4}$ \\
\hline 26 & AL-SEC-20020626 1.2 & $5.24 \times 10^{-5}$ & $2.54 \times 10^{-5}$ & $7.25 \times 10^{-4}$ & $1.06 \times 10^{-4}$ \\
\hline \multicolumn{6}{|c|}{ WIPP Far Field (WFF) } \\
\hline 27 & AL-WFF-20020703 1.2 & $5.63 \times 10^{-5}$ & $2.66 \times 10^{-5}$ & $9.13 \times 10^{-4}$ & $1.26 \times 10^{-4}$ \\
\hline 28 & AL-WFF-20020710 1.2 & $5.59 \times 10^{-5}$ & $2.63 \times 10^{-5}$ & $7.42 \times 10^{-4}$ & $1.08 \times 10^{-4}$ \\
\hline 29 & AL-WFF-20020717 1.2 & $4.02 \times 10^{-5}$ & $2.12 \times 10^{-5}$ & $6.23 \times 10^{-4}$ & $9.19 \times 10^{-5}$ \\
\hline 30 & AL-WFF-20020724 1.2 & $4.49 \times 10^{-5}$ & $2.24 \times 10^{-5}$ & $7.88 \times 10^{-4}$ & $1.11 \times 10^{-4}$ \\
\hline 31 & AL-WFF-20020731 1.2 & $5.86 \times 10^{-5}$ & $2.57 \times 10^{-5}$ & $9.74 \times 10^{-4}$ & $1.29 \times 10^{-4}$ \\
\hline 32 & AL-WFF-20020807 1.2 & $1.39 \times 10^{-4}$ & $4.13 \times 10^{-5}$ & $1.02 \times 10^{-3}$ & $1.35 \times 10^{-4}$ \\
\hline 33 & AL-WFF-20020814 1.2 & $1.02 \times 10^{-4}$ & $3.53 \times 10^{-5}$ & $8.32 \times 10^{-4}$ & $1.16 \times 10^{-4}$ \\
\hline 34 & AL-WFF-20020821 1.2 & $8.16 \times 10^{-5}$ & $3.12 \times 10^{-5}$ & $9.27 \times 10^{-4}$ & $1.26 \times 10^{-4}$ \\
\hline 35 & AL-WFF-20020828 1.2 & $9.88 \times 10^{-5}$ & $3.46 \times 10^{-5}$ & $1.21 \times 10^{-3}$ & $1.54 \times 10^{-4}$ \\
\hline 36 & AL-WFF-20020904 1.2 & $7.56 \times 10^{-5}$ & $2.89 \times 10^{-5}$ & $6.81 \times 10^{-4}$ & $9.84 \times 10^{-5}$ \\
\hline 37 & AL-WFF-20020911 1.2 & $1.03 \times 10^{-4}$ & $3.51 \times 10^{-5}$ & $1.30 \times 10^{-3}$ & $1.63 \times 10^{-4}$ \\
\hline 38 & AL-WFF-20020918 1.2 & $1.19 \times 10^{-4}$ & $3.72 \times 10^{-5}$ & $1.05 \times 10^{-3}$ & $1.38 \times 10^{-4}$ \\
\hline 39 & AL-WFF-20020925 1.2 & $1.42 \times 10^{-4}$ & $4.13 \times 10^{-5}$ & $1.06 \times 10^{-3}$ & $1.39 \times 10^{-4}$ \\
\hline \multicolumn{6}{|c|}{ WIPP East (WEE) } \\
\hline 40 & AL-WEE-20021002 1.2 & $9.54 \times 10^{-5}$ & $3.35 \times 10^{-5}$ & $8.19 \times 10^{-4}$ & $1.14 \times 10^{-4}$ \\
\hline 41 & AL-WEE-20021009 1.2 & $6.80 \times 10^{-5}$ & $2.81 \times 10^{-5}$ & $1.24 \times 10^{-3}$ & $1.57 \times 10^{-4}$ \\
\hline 42 & AL-WEE-20021016 1.2 & $5.37 \times 10^{-5}$ & $2.48 \times 10^{-5}$ & $1.09 \times 10^{-3}$ & $1.41 \times 10^{-4}$ \\
\hline 43 & AL-WEE-20021023 1.2 & $4.86 \times 10^{-5}$ & $2.24 \times 10^{-5}$ & $4.88 \times 10^{-4}$ & $7.87 \times 10^{-5}$ \\
\hline 44 & AL-WEE-20021030 1.2 & $4.72 \times 10^{-5}$ & $2.47 \times 10^{-5}$ & $8.42 \times 10^{-4}$ & $1.17 \times 10^{-4}$ \\
\hline 45 & AL-WEE-20021106 1.2 & $7.26 \times 10^{-5}$ & $2.98 \times 10^{-5}$ & $1.02 \times 10^{-3}$ & $1.35 \times 10^{-4}$ \\
\hline 46 & AL-WEE-20021113 1.2 & $6.27 \times 10^{-5}$ & $2.62 \times 10^{-5}$ & $1.13 \times 10^{-3}$ & $1.46 \times 10^{-4}$ \\
\hline 47 & AL-WEE-20021120 1.2 & $1.22 \times 10^{-4}$ & $3.88 \times 10^{-5}$ & $1.31 \times 10^{-3}$ & $1.66 \times 10^{-4}$ \\
\hline 48 & AL-WEE-20021127 1.2 & $5.69 \times 10^{-5}$ & $2.49 \times 10^{-5}$ & $1.45 \times 10^{-3}$ & $1.78 \times 10^{-4}$ \\
\hline 49 & AL-WEE-20021204 1.2 & $2.75 \times 10^{-5}$ & $1.71 \times 10^{-5}$ & $1.40 \times 10^{-3}$ & $1.73 \times 10^{-4}$ \\
\hline 50 & AL-WEE-20021211 1.2 & $\mathrm{~N} / \mathrm{C}$ & $\mathrm{N} / \mathrm{C}$ & $\mathrm{N} / \mathrm{C}$ & $\mathrm{N} / \mathrm{C}$ \\
\hline
\end{tabular}


Waste Isolation Pilot Plant 2002 Site Environmental Report

DOE/WIPP 03-2225

Table D.1 - Results of Gross Alpha and Gross Beta Analyses in Air Particulates $\left(\mathrm{Bq} / \mathrm{m}^{3}\right)$

\begin{tabular}{|c|c|c|c|c|c|}
\hline \multirow[b]{2}{*}{ Week } & \multirow[b]{2}{*}{ Sample ID } & \multicolumn{2}{|c|}{ Gross Alpha } & \multicolumn{2}{|c|}{ Gross Beta } \\
\hline & & Concentration & $2 \times$ TPU $^{a}$ & Concentration & $2 \times$ TPU \\
\hline 51 & AL-WEE-20021218 1.2 & $5.50 \times 10^{-5}$ & $2.73 \times 10^{-5}$ & $9.84 \times 10^{-4}$ & $1.35 \times 10^{-4}$ \\
\hline 52 & AL-WEE-20021225 1.2 & $7.40 \times 10^{-5}$ & $3.57 \times 10^{-5}$ & $1.53 \times 10^{-3}$ & $2.00 \times 10^{-4}$ \\
\hline
\end{tabular}

a Total propagated uncertainty

${ }^{\text {b }}$ Not collected 
This page intentionally left blank 
Waste Isolation Pilot Plant 2002 Site Environmental Report

DOE/WIPP 03-2225

\section{Appendix E \\ Air Sampling Data: Mass and Volume of Composite Air Samples}

Table E.1 - Mass (mg) of Air Particulates and Volume $\left(\mathrm{m}^{3}\right)$ of Air Sampled (First Quarter of 2002).

\begin{tabular}{|c|c|c|c|c|c|c|c|c|}
\hline \multirow[t]{2}{*}{ Week } & Mass & Volume & Mass & Volume & Mass & Volume & Mass & Volume \\
\hline & \multicolumn{2}{|c|}{ WIPP Far Field (WFF) } & \multicolumn{2}{|c|}{ WIPP East (WEE) } & \multicolumn{2}{|c|}{ WIPP South (WSS) } & \multicolumn{2}{|c|}{ Mills Ranch (MLR) } \\
\hline 1 & 3 & 568.519 & 4.1 & 590.644 & 3.8 & 572.767 & 5.8 & 576.024 \\
\hline 2 & 7 & 603.322 & 7.5 & 547.459 & 9.2 & 597.372 & 12.9 & 583.415 \\
\hline 3 & 12.2 & 633.029 & 14.2 & 606.421 & 12.2 & 598.719 & 14.5 & 598.371 \\
\hline 4 & $\mathrm{~N} / \mathrm{C}^{\mathrm{a}}$ & $\mathrm{N} / \mathrm{C}$ & 9.7 & 612.241 & 12.3 & 605.157 & 11.9 & 615.188 \\
\hline 5 & 6.4 & 612.817 & 6 & 625.708 & $\mathrm{~N} / \mathrm{C}$ & $\mathrm{N} / \mathrm{C}$ & 7.2 & 616.316 \\
\hline 6 & 9.3 & 570.115 & 9.3 & 573.27 & 11.5 & 581.349 & 9.5 & 598.923 \\
\hline 7 & 12 & 593.002 & 12.6 & 547.703 & 12.2 & 555.598 & 11.3 & 603.019 \\
\hline 8 & 9.8 & 569.845 & 11.1 & 587.327 & 12.6 & 584.49 & 12.2 & 515.237 \\
\hline 9 & 14.5 & 612.279 & 16.7 & 594.759 & 19.6 & 596.908 & 18.1 & 569.889 \\
\hline 10 & 19.1 & 557.116 & 20.7 & 549.244 & 23.5 & 563.137 & 21.8 & 588.79 \\
\hline 11 & 20.6 & 625.286 & 25.8 & 589.74 & 29.9 & 601.191 & 20 & 611.915 \\
\hline 12 & 18.7 & 591.582 & 24.4 & 612.948 & 20.6 & 564.146 & 22.6 & 572.352 \\
\hline 13 & 11.5 & 585.136 & 17.2 & 601.903 & 18.5 & 610.461 & 17.6 & 602.62 \\
\hline Total & 144.1 & 7122 & 179.3 & 7639.4 & 185.9 & 7031.3 & 185.4 & 7652.1 \\
\hline
\end{tabular}

${ }^{\text {a }}$ Not collected 
Waste Isolation Pilot Plant 2002 Site Environmental Report DOE/WIPP 03-2225

\begin{tabular}{|c|c|c|c|c|c|c|c|c|}
\hline \multirow[t]{2}{*}{ Week } & Mass & Volume & Mass & Volume & Mass & Volume & Mass & Volume \\
\hline & \multicolumn{2}{|c|}{ Smith Ranch (SMR) } & \multicolumn{2}{|c|}{ Carlsbad (CBD) \#1 } & \multicolumn{2}{|c|}{ Carlsbad (CBD) \#2 } & \multicolumn{2}{|c|}{ Southeast Control (SEC) } \\
\hline 1 & 5.3 & 558.954 & 11 & 589.811 & $\mathrm{~N} / \mathrm{C}$ & $\mathrm{N} / \mathrm{C}$ & 3.3 & 566.165 \\
\hline 2 & $\mathrm{~N} / \mathrm{C}^{\mathrm{a}}$ & $\mathrm{N} / \mathrm{C}$ & 15.1 & 554.491 & 15.9 & 557.034 & 9 & 591.932 \\
\hline 3 & 21 & 535.029 & 23 & 591.582 & 24.4 & 591.937 & 13.3 & 598.683 \\
\hline 4 & 22.2 & 618.399 & 21.1 & 586.44 & 24 & 589.315 & 10.2 & 586.94 \\
\hline 5 & 7 & 593.953 & 7.2 & 615.575 & 7.5 & 587.338 & 5.1 & 622.242 \\
\hline 6 & 18.7 & 542.355 & 17.3 & 537.38 & 17.2 & 494.691 & 7.9 & 528.202 \\
\hline 7 & 23 & 708.966 & 27.4 & 761.747 & 27.8 & 754.492 & 14.5 & 567.34 \\
\hline 8 & 24.9 & 500.446 & 15 & 495.921 & 17.1 & 522.565 & 15.6 & 506.073 \\
\hline 9 & 33.4 & 585.484 & 28.4 & 562.128 & 30.6 & 601.903 & 17.3 & 615.432 \\
\hline 10 & 46.4 & 575.543 & 29.1 & 535.654 & $\mathrm{~N} / \mathrm{C}$ & $\mathrm{N} / \mathrm{C}$ & 28.3 & 595.133 \\
\hline 11 & 29.5 & 603.916 & $\mathrm{~N} / \mathrm{C}$ & $\mathrm{N} / \mathrm{C}$ & $\mathrm{N} / \mathrm{C}$ & $\mathrm{N} / \mathrm{C}$ & 25.7 & 630.567 \\
\hline 12 & 26.8 & 573.827 & 18.1 & 548.261 & 22.8 & 540.061 & 22.5 & 546.725 \\
\hline 13 & 18.8 & 602.542 & 25.3 & 623.353 & 26.3 & 586.18 & 17.6 & 595.133 \\
\hline Total & 277 & 6999.4 & 238 & 7002.3 & 213.6 & 5825.5 & 190.3 & 7550.6 \\
\hline
\end{tabular}

a Not collected 
Waste Isolation Pilot Plant 2002 Site Environmental Report DOE/WIPP 03-2225

\begin{tabular}{|c|c|c|c|c|c|c|c|c|}
\hline & & .2 - Mass & ir Part & and Vol & Air S & Second Qu & 2002) & \\
\hline Week & Mass & Volume & Mass & Volume & Mass & Volume & Mass & Volume \\
\hline & WII & ld (WFF) & & t (WEE) & & h (WSS) & & $\mathrm{h}$ (MLR) \\
\hline 14 & 7.9 & 588.751 & 8.5 & 574.598 & 7.8 & 546.949 & 8.7 & 551.954 \\
\hline 15 & 10.1 & 546.149 & $\mathrm{~N} / \mathrm{C}$ & $\mathrm{N} / \mathrm{C}$ & 12.2 & 597.973 & 13.1 & 616.176 \\
\hline 16 & 14.8 & 582.698 & 10 & 547.605 & 14.8 & 592.292 & 18.1 & 560.803 \\
\hline 17 & 23.6 & 547.163 & 26 & 561.562 & 25.4 & 575.961 & 24.8 & 539.009 \\
\hline 18 & 17.8 & 572.454 & 17.6 & 553.279 & 15.5 & 559.623 & 18 & 577.013 \\
\hline 19 & 16.8 & 546.398 & 19.7 & 551.591 & 16.6 & 519.539 & 19.6 & 573.141 \\
\hline 20 & 16.4 & 573.564 & 18.3 & 569.999 & 21.3 & 620.849 & 15 & 559.129 \\
\hline 21 & $\mathrm{~N} / \mathrm{C}^{\mathrm{a}}$ & $\mathrm{N} / \mathrm{C}$ & 14.8 & 522.448 & 16.2 & 586.13 & 20.1 & 587.633 \\
\hline 22 & 13.5 & 586.624 & 13.8 & 560.782 & 14.7 & 544.115 & $\mathrm{~N} / \mathrm{C}$ & $\mathrm{N} / \mathrm{C}$ \\
\hline 23 & 8 & 542.035 & 8.1 & 573.922 & 12.8 & 568.519 & 9.6 & 576.693 \\
\hline 24 & 17.1 & 544.526 & 17.2 & 555.93 & 18.6 & 546.725 & 17 & 529.408 \\
\hline 25 & 14.4 & 623.412 & 13.4 & 611.242 & 18.4 & 619.387 & 15 & 551.618 \\
\hline 26 & 9 & 567.633 & 8.9 & 552.545 & 11.8 & 594.514 & 8.4 & 537.479 \\
\hline Total & 169.4 & 6821.4 & 176.3 & 6735.5 & 206.1 & 7472.6 & 187.4 & 6208.1 \\
\hline & & h (SMR) & & (CBD) & South & trol (SEC) \#1 & South & trol (SEC) \#2 \\
\hline 14 & 13.7 & 556.946 & 19.4 & 580.259 & 8.8 & 560.782 & 8.2 & 550.629 \\
\hline 15 & 20.6 & 600.834 & 21 & 551.212 & 11.6 & 587.99 & 10.2 & 570.524 \\
\hline 16 & 23.1 & 556.783 & 27.5 & 568.485 & 14.8 & 586.24 & 13.8 & 586.24 \\
\hline 17 & 33.2 & 583.221 & 35.7 & 565.313 & 23.9 & 565.492 & 24.1 & 571.204 \\
\hline 18 & 26.1 & 563.473 & 31 & 588.734 & 20 & 597.618 & 18.9 & 577.259 \\
\hline 19 & 24.3 & 594.067 & 37.1 & 604.035 & 20.2 & 605.075 & 17 & 588.031 \\
\hline 20 & 22.2 & 557.034 & 28.9 & 541.084 & 20 & 544.925 & 17.5 & 605.473 \\
\hline 21 & 24.2 & 567.333 & 28.6 & 547.277 & 16 & 556.783 & 15.2 & 559.958 \\
\hline 22 & 19.9 & 551.76 & 38.4 & 579.855 & 17.3 & 604.713 & 14.7 & 576.323 \\
\hline 23 & 12.4 & 578.289 & 18.5 & 583.668 & 8.2 & 548.096 & 8.7 & 579.661 \\
\hline 24 & 24.2 & 543.877 & $\mathrm{~N} / \mathrm{C}$ & N/C & 19.4 & 585.832 & 17.1 & 557.255 \\
\hline 25 & 22.9 & 597.326 & 24.4 & 571.081 & 13.7 & 534.655 & 14 & 573.64 \\
\hline 26 & 18.8 & 585.136 & 17.1 & 548.588 & 10.4 & 571.883 & 9 & 555.4 \\
\hline Total & 285.6 & 7436.1 & 327.6 & 6829.6 & 204.3 & 7450.1 & 188.4 & 7451.6 \\
\hline
\end{tabular}


Waste Isolation Pilot Plant 2002 Site Environmental Report DOE/WIPP 03-2225

\begin{tabular}{|c|c|c|c|c|c|c|c|c|}
\hline Week & Mass & Volume & Mass & Volume & Mass & Volume & Mass & Volume \\
\hline & \multicolumn{2}{|c|}{ WIPP Far Field (WFF) \#1 } & \multicolumn{2}{|c|}{ WIPP Far Field (WFF) \#2 } & \multicolumn{2}{|c|}{ WIPP East (WEE) } & \multicolumn{2}{|c|}{ WIPP South (WSS) } \\
\hline 27 & 11.9 & 546.725 & 11.3 & 543.228 & 12 & 571.328 & 14.4 & 548.261 \\
\hline 28 & 7.6 & 570.376 & 7.5 & 553.179 & 7.2 & 556.375 & 8.1 & 562.111 \\
\hline 29 & 8.1 & 617.002 & 8.2 & 622.823 & 7.2 & 599.988 & 9.1 & 605.785 \\
\hline 30 & 8.4 & 522.371 & 8.5 & 567.306 & 9.5 & 535.278 & 9.8 & 547.193 \\
\hline 31 & 11.4 & 599.039 & 11 & 590.44 & 11.2 & 573.294 & 14.7 & 615.05 \\
\hline 32 & 11 & 567.466 & 11.1 & 567.466 & 11.8 & 572.797 & 12.6 & 561.924 \\
\hline 33 & 13.4 & 563.64 & 14.4 & 561.112 & 14.1 & 564.309 & 18.1 & 575.767 \\
\hline 34 & 9.5 & 581.398 & 9.9 & 569.437 & 9.9 & 562.938 & 10.4 & 553.786 \\
\hline 35 & 13.1 & 555.913 & 13.6 & 564.251 & 13.5 & 576.916 & 16.6 & 580.462 \\
\hline 36 & 9 & 589.213 & 8.7 & 592.159 & 9.2 & 585.929 & 11.3 & 608.781 \\
\hline 37 & 6.3 & 536.599 & 6.3 & 550.428 & 7.4 & 540.622 & 8.5 & 567.024 \\
\hline 38 & 11.9 & 587.64 & 11.6 & 570.424 & 13 & 579.427 & $\mathrm{~N} / \mathrm{C}$ & $\mathrm{N} / \mathrm{C}$ \\
\hline 39 & 8.5 & 560.446 & 8.4 & 560.446 & 10.2 & 558.115 & 9 & 456.691 \\
\hline \multirow[t]{2}{*}{ Total } & 130.1 & 7397.8 & 130.5 & 7412.7 & 136.2 & 7377.3 & 142.6 & 6782.8 \\
\hline & \multicolumn{2}{|c|}{ Mills Ranch (MLR) } & \multicolumn{2}{|c|}{ Smith Ranch (SMR) } & \multicolumn{2}{|c|}{ Carlsbad (CBD) } & \multicolumn{2}{|c|}{ Southeast Control (SEC } \\
\hline 27 & 10 & 540.061 & 13.2 & 505.031 & 17.7 & 567.33 & 10.9 & 599.353 \\
\hline 28 & 6.5 & 541.393 & 12 & 559.78 & 16.2 & 586.529 & 6.4 & 579.957 \\
\hline 29 & 7.8 & 539.658 & 14.1 & 578.357 & 16.5 & 583.459 & 8.6 & 574.537 \\
\hline 30 & $\mathrm{~N} / \mathrm{C}$ & $\mathrm{N} / \mathrm{C}$ & 16.5 & 547.173 & 18.1 & 547.494 & 10 & 560.249 \\
\hline 31 & 9.4 & 500.05 & 15.4 & 596.823 & 19.3 & 585.29 & 11.6 & 595.133 \\
\hline 32 & 14.5 & 567.571 & 18.7 & 564.408 & 20 & 573.484 & 11 & 558.285 \\
\hline 33 & 14.6 & 573.922 & 25.6 & 568.183 & 33.2 & 570.864 & 14.7 & 585.747 \\
\hline 34 & 10.1 & 577.66 & 16.1 & 557.586 & 22.9 & 577.776 & 9.5 & 557.116 \\
\hline 35 & 11.4 & 565.631 & 29.2 & 570.986 & 26 & 582.531 & 14.3 & 570.15 \\
\hline 36 & 9.2 & 580.519 & $\mathrm{~N} / \mathrm{C}$ & $\mathrm{N} / \mathrm{C}$ & 19 & 574.17 & 8.7 & 574.17 \\
\hline 37 & 10.1 & 546.127 & $\mathrm{~N} / \mathrm{C}$ & $\mathrm{N} / \mathrm{C}$ & 13.2 & 560.293 & 4.5 & 562.361 \\
\hline 38 & 14.3 & 579.427 & 24.3 & 582.628 & 19.8 & 579.661 & 15.2 & 581.034 \\
\hline 39 & 10.1 & 572.767 & 15.4 & 566.501 & 23.2 & 575.543 & 8.5 & 562.262 \\
\hline Total & 128 & 6684.8 & 200.5 & 6197.5 & 265.1 & 7464.4 & 133.9 & 7460.4 \\
\hline
\end{tabular}


Waste Isolation Pilot Plant 2002 Site Environmental Report DOE/WIPP 03-2225

\begin{tabular}{|c|c|c|c|c|c|c|c|c|}
\hline \multirow[b]{2}{*}{ Week } & Mass & Volume & Mass & Volume & Mass & Volume & Mass & Volume \\
\hline & \multicolumn{2}{|c|}{ WIPP Far Field (WFF) } & \multicolumn{2}{|c|}{ WIPP East (WEE) \#1 } & \multicolumn{2}{|c|}{ WIPP East (WEE) \#2 } & \multicolumn{2}{|c|}{ WIPP South (WSS) } \\
\hline 40 & 9.2 & 604.64 & 9.3 & 584.577 & 9.9 & 581.639 & 10.1 & 590.644 \\
\hline 41 & 6.5 & 559.773 & 7.4 & 573.141 & 6.5 & 561.791 & 8.1 & 602.62 \\
\hline 42 & 10.7 & 576.382 & 7.8 & 567.571 & 8.4 & 573.219 & 8.9 & 588.386 \\
\hline 43 & 2.9 & 596.526 & 2.2 & 579.24 & 2.4 & 587.676 & 3.9 & 576.08 \\
\hline 44 & 5.2 & 564.819 & 4.6 & 562.636 & 5.1 & 556.924 & 5.1 & 562.97 \\
\hline 45 & 8.6 & 576.109 & 7.8 & 479.526 & 9.7 & 564.644 & 8.8 & 576.109 \\
\hline 46 & 6.7 & 571.883 & 6.1 & 554.273 & 6.2 & 560.293 & 6.8 & 574.598 \\
\hline 47 & 10 & 587.64 & 9.7 & 536.315 & 9.3 & 520.128 & 11 & 575.426 \\
\hline 48 & 8.9 & 560.293 & 9.8 & 554.214 & 8.1 & 559.413 & 14.8 & 585.484 \\
\hline 49 & 4.8 & 574.095 & 5.1 & 556.045 & 4.7 & 556.375 & 5 & 536.3 \\
\hline 50 & 14.5 & 562.6 & 17.1 & 574.857 & $\mathrm{~N} / \mathrm{C}$ & $\mathrm{N} / \mathrm{C}$ & 4 & 424.937 \\
\hline 51 & 7.5 & 652.946 & 8.4 & 646.787 & 7.8 & 520.2 & 9.8 & 628.888 \\
\hline 52 & 3.1 & 412.524 & 4.7 & 422.735 & 4 & 406.397 & 3.7 & 413.21 \\
\hline \multirow[t]{2}{*}{ Total } & 98.6 & 7400.2 & 100 & 7191.9 & 82.1 & 6548.7 & 100 & 7235.7 \\
\hline & \multicolumn{2}{|c|}{ Mills Ranch (MLR) } & \multicolumn{2}{|c|}{ Smith Ranch (SMR) } & \multicolumn{2}{|c|}{ Carlsbad (CBD) } & \multicolumn{2}{|c|}{ Southeast Control (SEC) } \\
\hline 40 & 14.7 & 583.321 & 18.6 & 579.427 & 17.1 & 578.392 & 8.3 & 584.707 \\
\hline 41 & 5.1 & 570.376 & 9.1 & 570.874 & 10.7 & 578.392 & 6.8 & 570.201 \\
\hline 42 & 10.8 & 565.247 & 10.5 & 561.083 & 18.9 & 574.254 & 6.7 & 574.656 \\
\hline 43 & 3.3 & 572.111 & 3.7 & 585.98 & 4.9 & 585.635 & 2 & 570.714 \\
\hline 44 & 3.7 & 571.204 & 4.1 & 569.362 & 7.8 & 566.165 & 4.9 & 590.09 \\
\hline 45 & 9.4 & 576.109 & 18.1 & 577.602 & 16.3 & 575.084 & 8 & 566.995 \\
\hline 46 & 11.4 & 567.525 & 9.2 & 559.623 & 16 & 568.485 & 5 & 322.548 \\
\hline 47 & 13.6 & 557.326 & 17.1 & 575.767 & 22.4 & 586.787 & 11.6 & 571.19 \\
\hline 48 & 18.6 & 579.318 & 20.9 & 569.505 & 15.4 & 557.95 & 8.4 & 571.501 \\
\hline 49 & 5.7 & 567.333 & 5.9 & 550.639 & 11 & 556.045 & 5.3 & 554.148 \\
\hline 50 & 16.3 & 622.405 & 27 & 574.857 & 24.9 & 566.319 & 15.9 & 569.889 \\
\hline 51 & 7.1 & 632.587 & 10.7 & 648.478 & 15.3 & 658.254 & 6.6 & 644.526 \\
\hline 52 & 3.9 & 407.334 & 6.3 & 407.334 & 9 & 387.251 & 3.6 & 407.334 \\
\hline Total & 123.6 & 7372.2 & 161.2 & 7330.5 & 189.7 & 7339 & 93.1 & 7098.5 \\
\hline
\end{tabular}

${ }^{a}$ Not collected 
This page intentionally left blank 


\section{Appendix F \\ Time Trend Plots for Detectable Constituents in Groundwater}

The figures in this appendix show the concentrations of various groundwater constituents relative to a baseline concentration, and are in a form required by the NMED and the HWFP. Baseline concentrations were measured from 1995 through 2000. These plots indicate the sample and duplicate concentration values with respect to sample round. Sampling round 14 occurred in March through May 2002 and sampling round 15 occurred from September through November 2002. See Chapter 6 for specific concentration information on the groundwater wells.

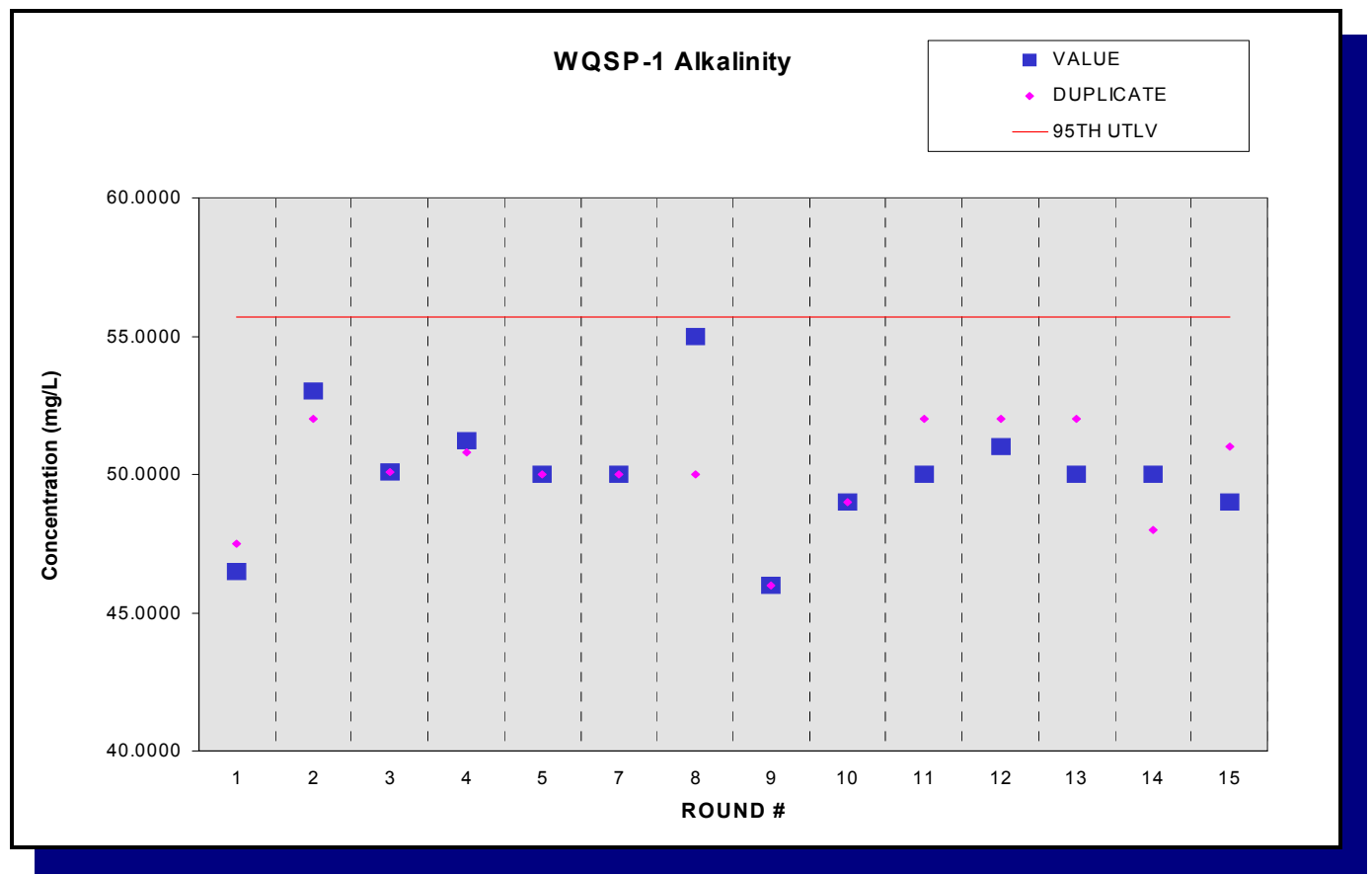

Figure F.1 - Time Trend Plot for Alkalinity at WQSP-1 


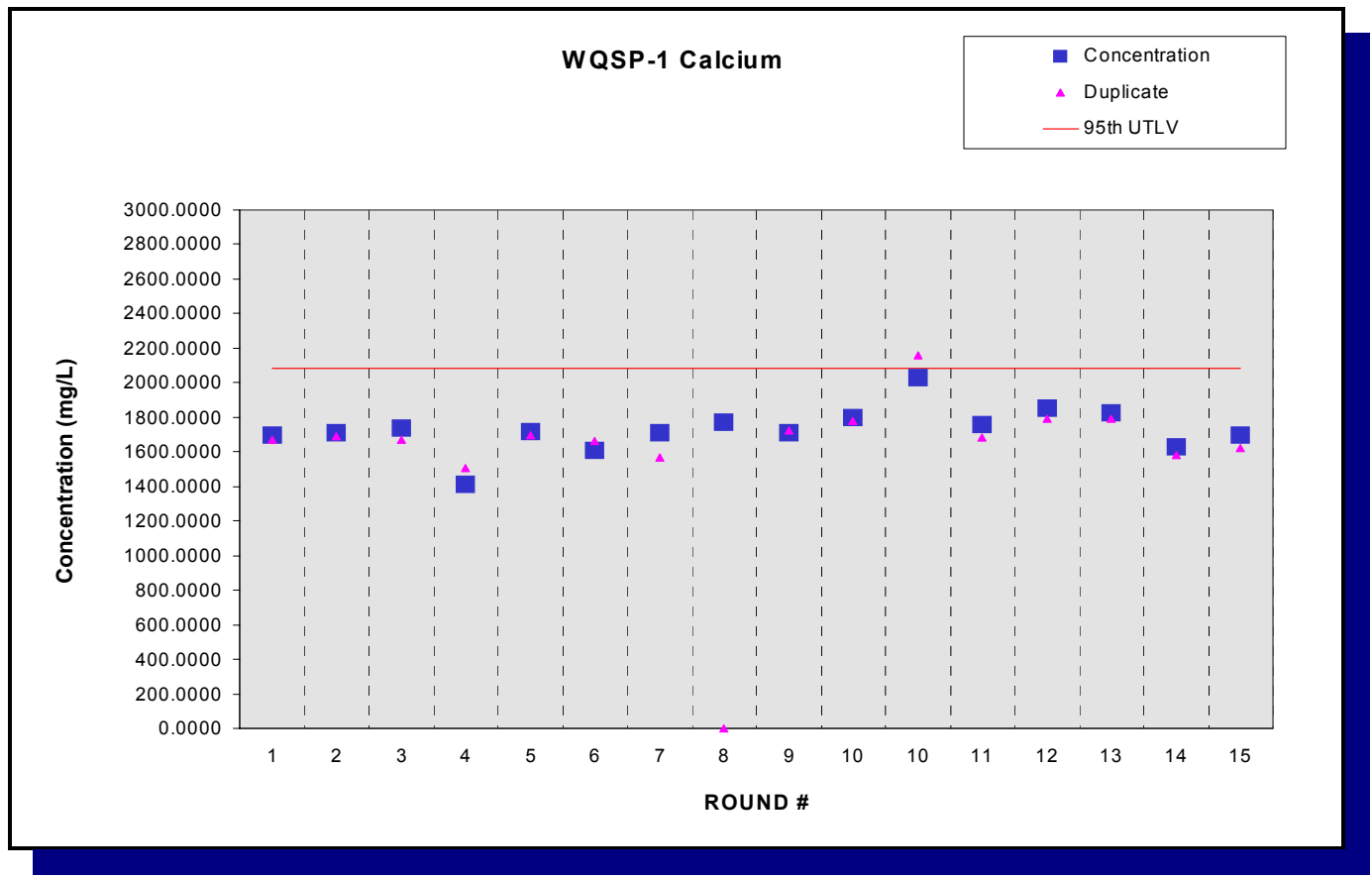

Figure F.2 - Time Trend Plot for Calcium at WQSP-1

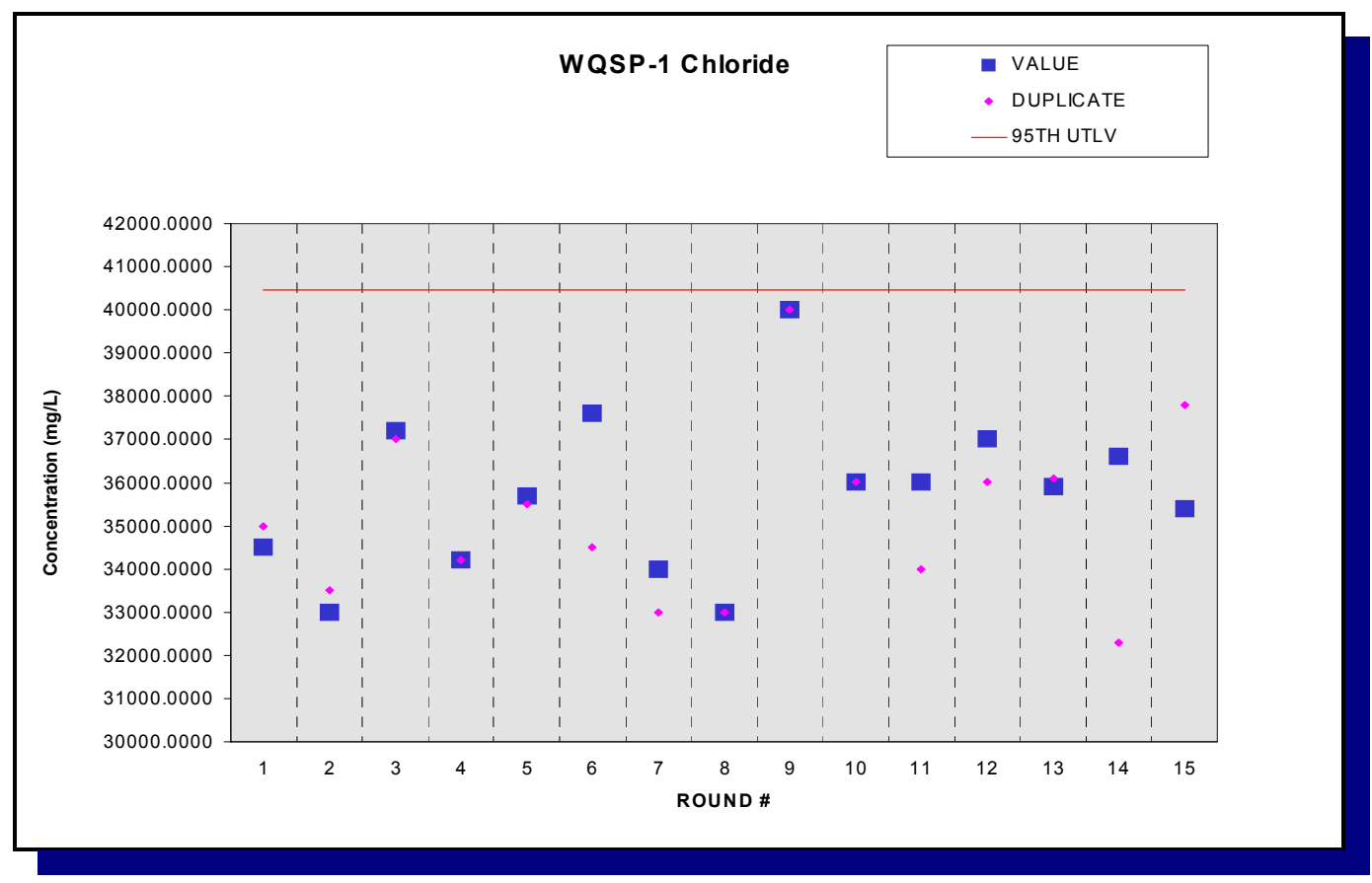

Figure F.3 - Time Trend Plot for Chloride at WQSP-1 


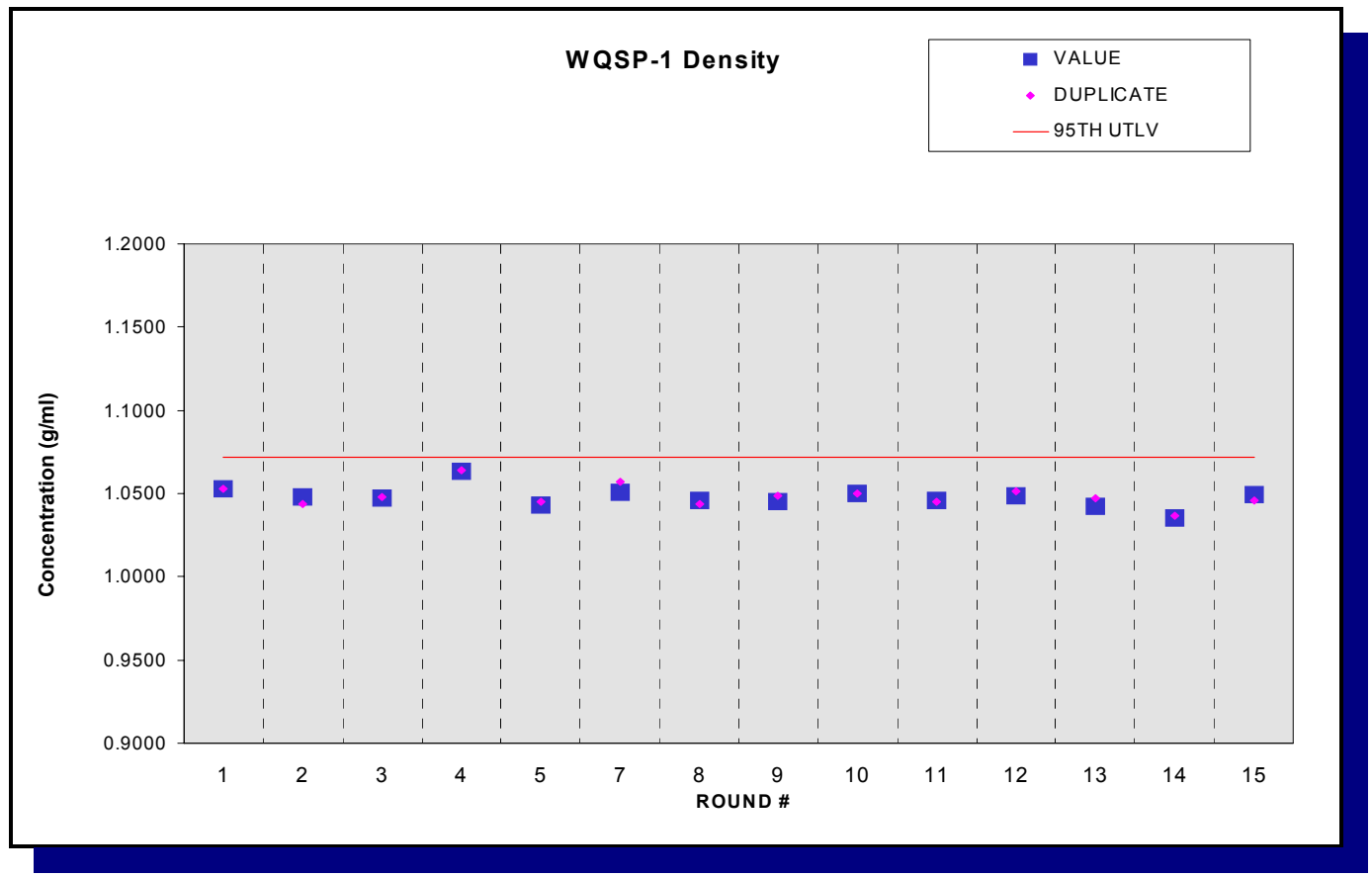

Figure F.4 - Time Trend Plot for Density at WQSP-1

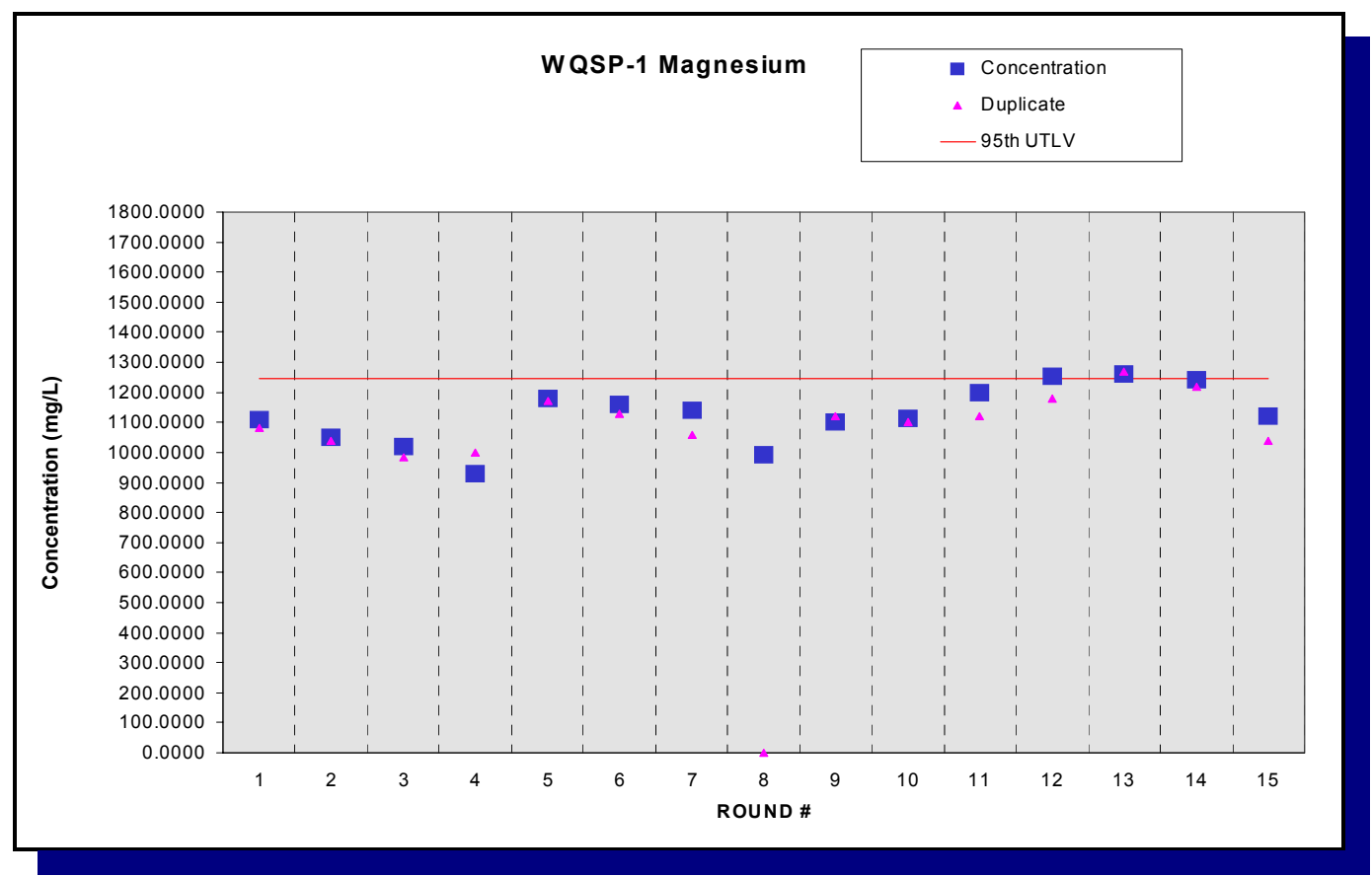

Figure F.5 - Time Trend Plot for Magnesium at WQSP-1 


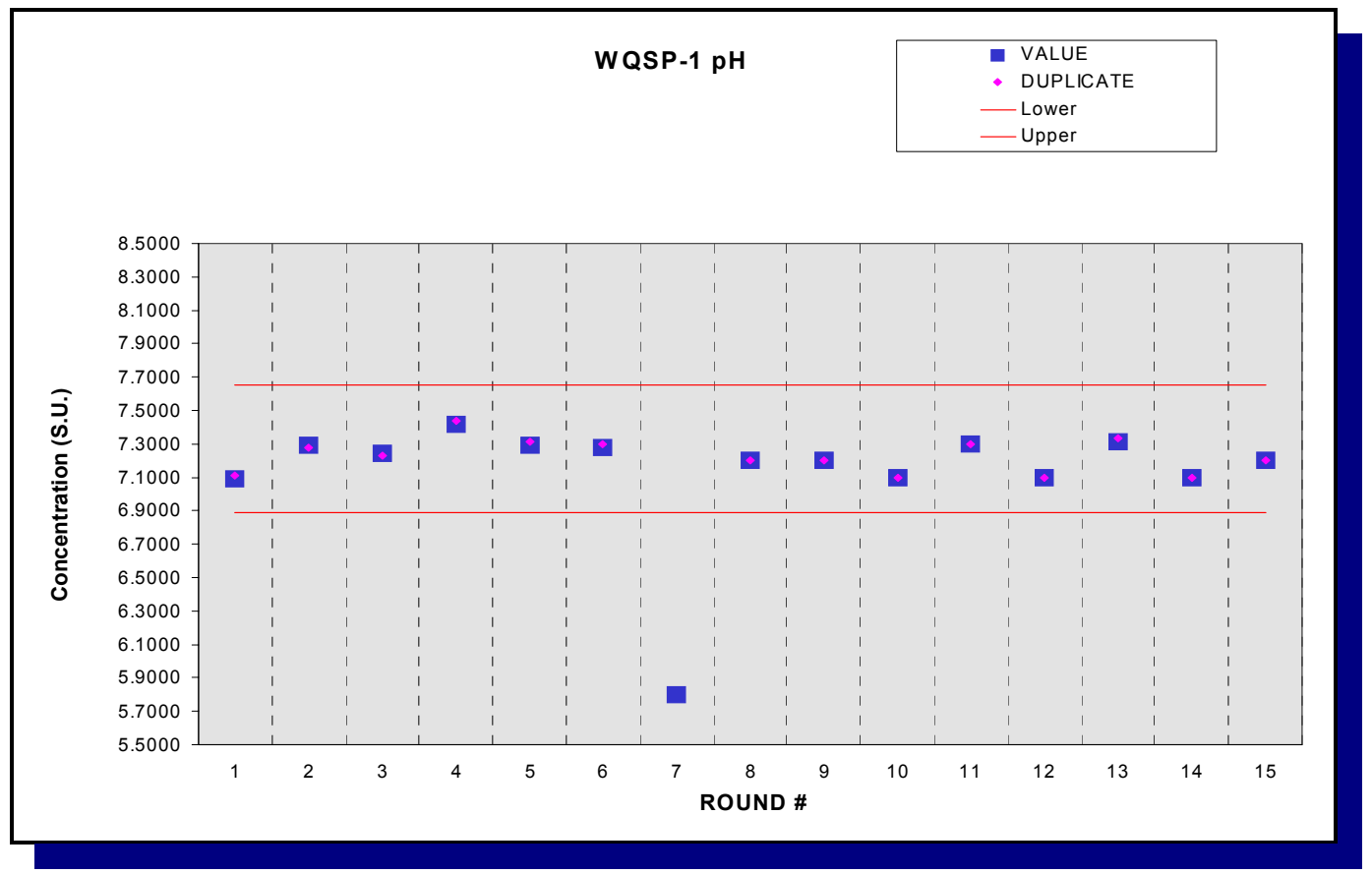

Figure F.6 - Time Trend Plot for pH at WQSP-1

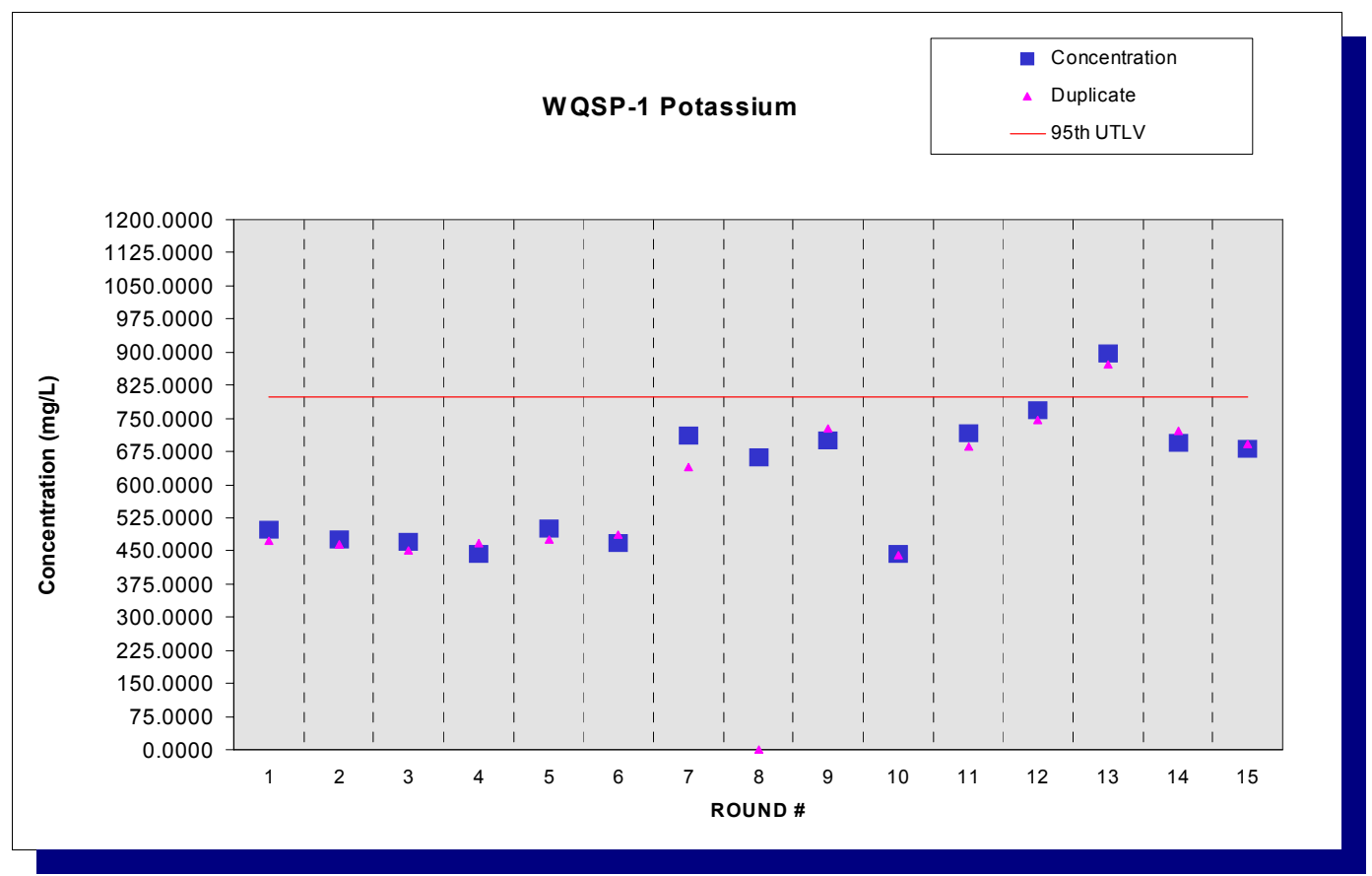

Figure F.7 - Time Trend Plot for Potassium at WQSP-1 


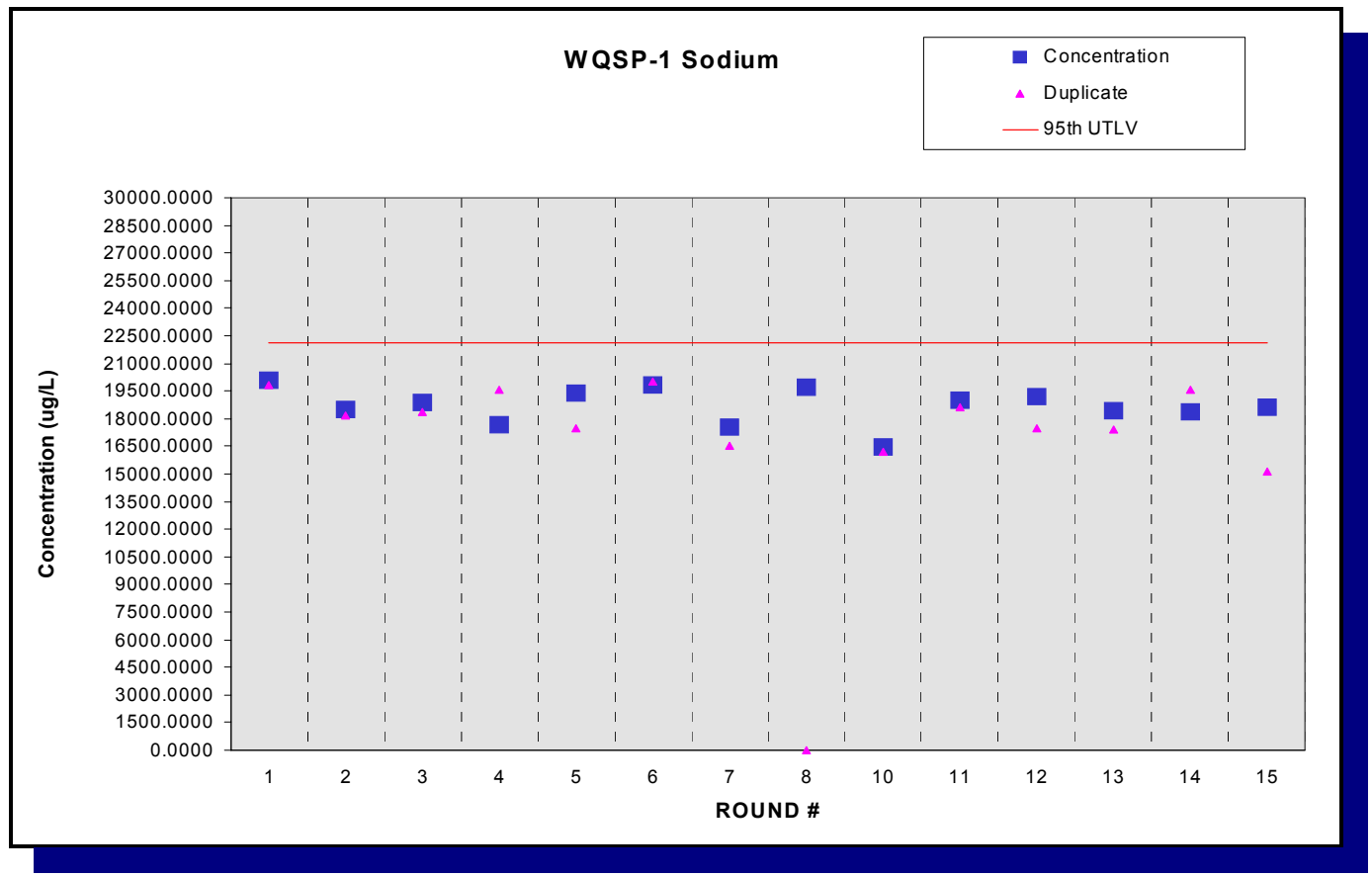

Figure F.8 - Time Trend Plot for Sodium at WQSP-1

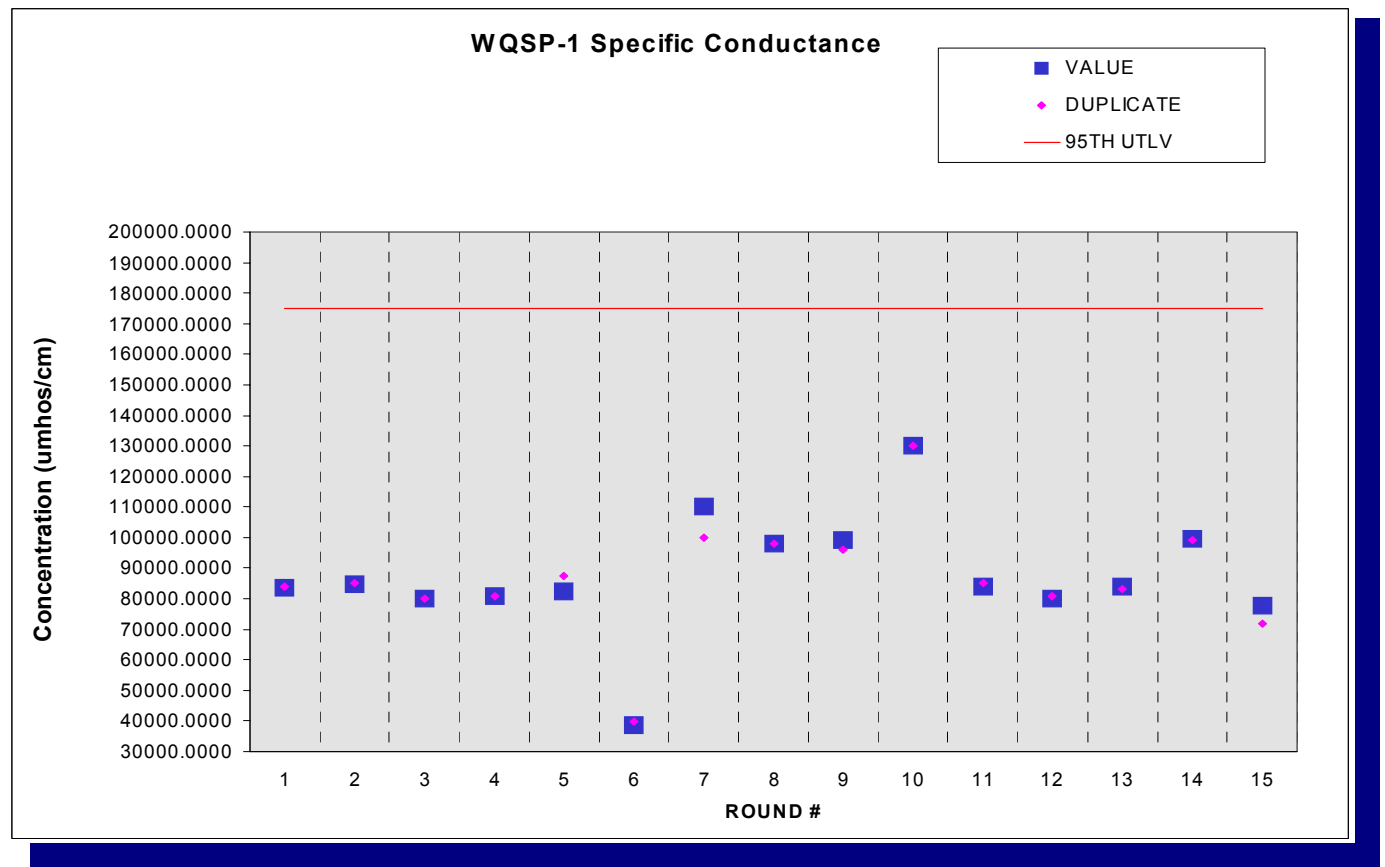

Figure F.9 - Time Trend Plot for Specific Conductance at WQSP-1 


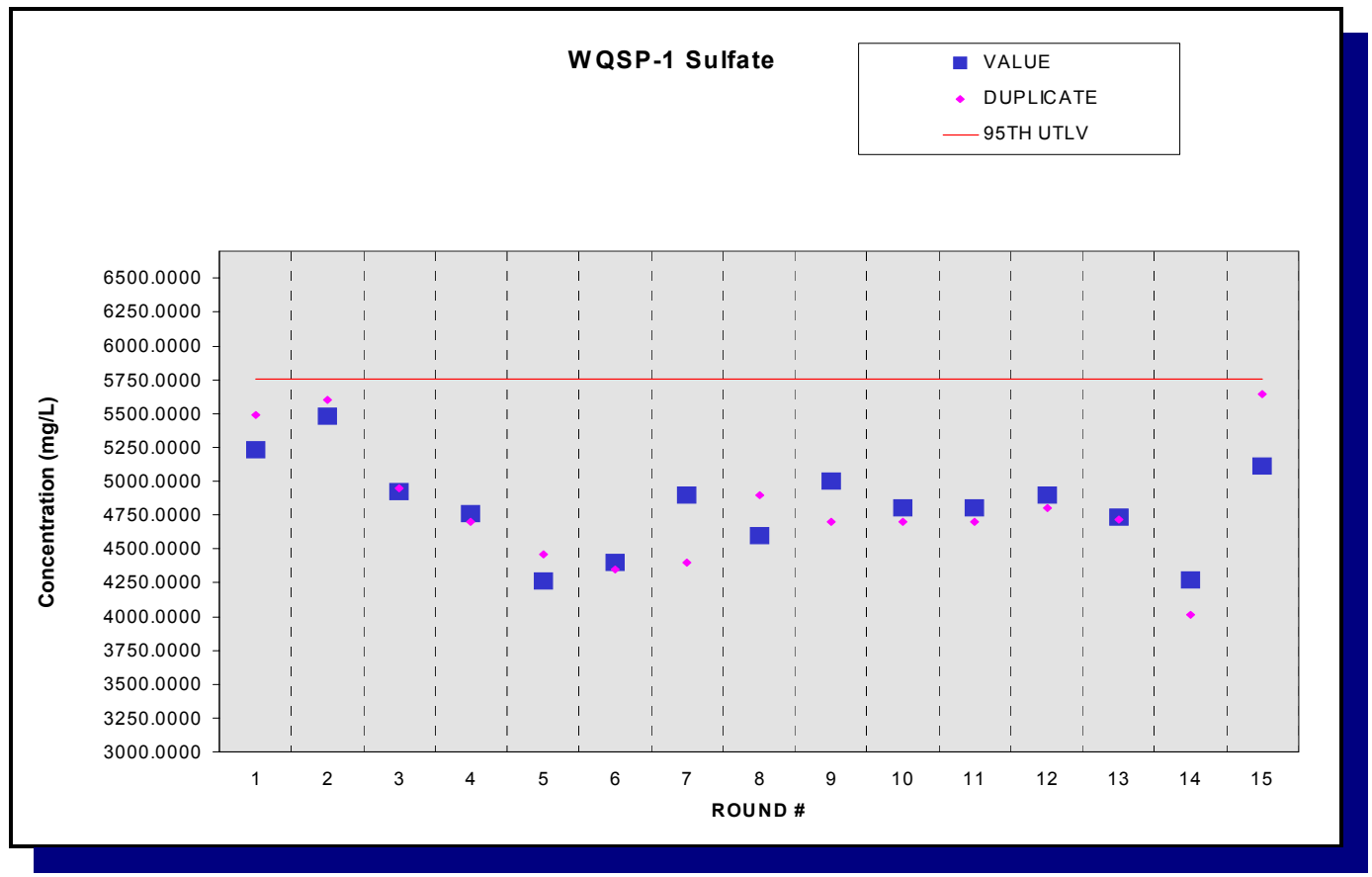

Figure F.10 - Time Trend Plot for Sulfate at WQSP-1

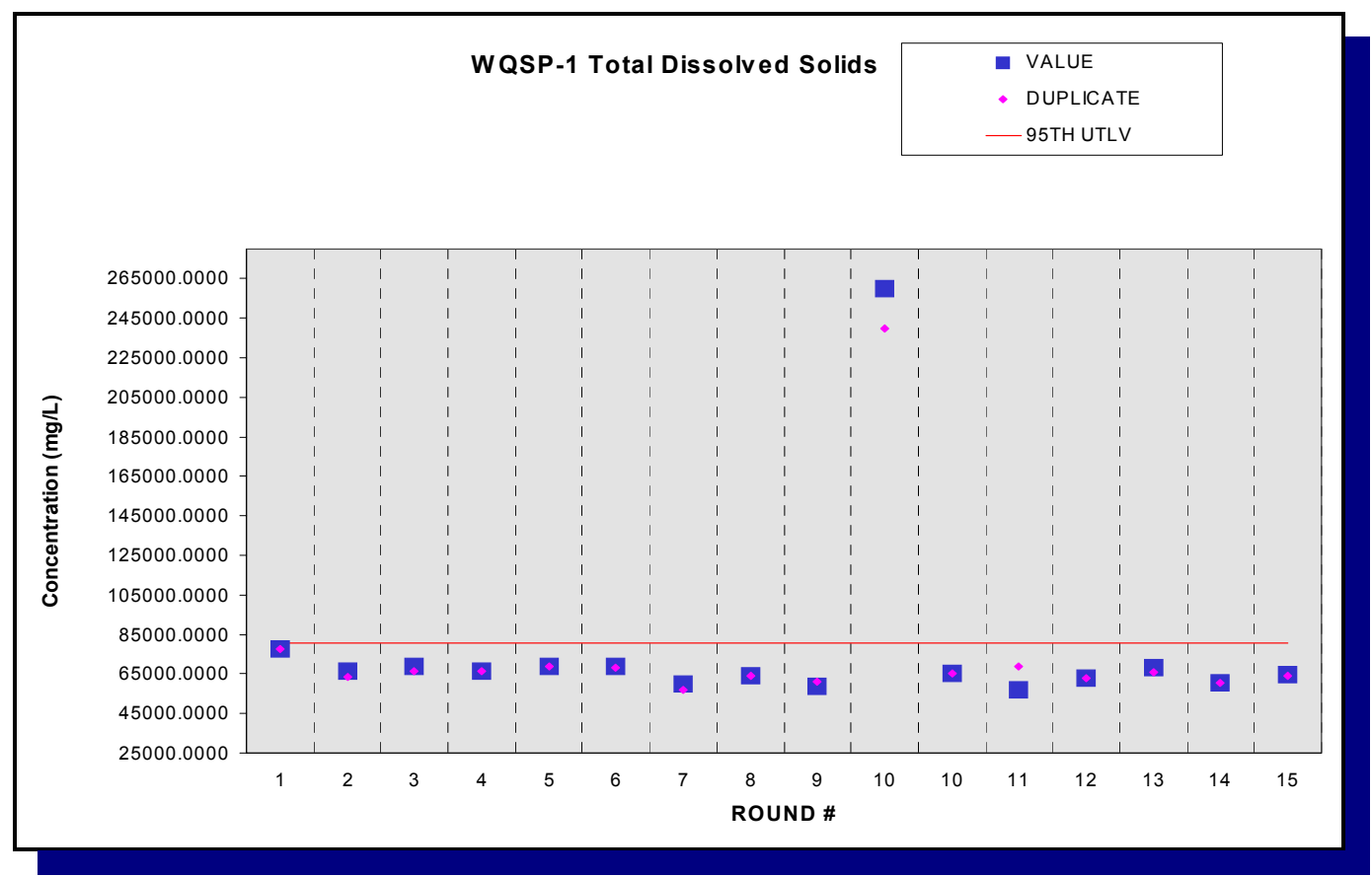

Figure F.11 - Time Trend Plot for Total Dissolved Solids at WQSP-1 


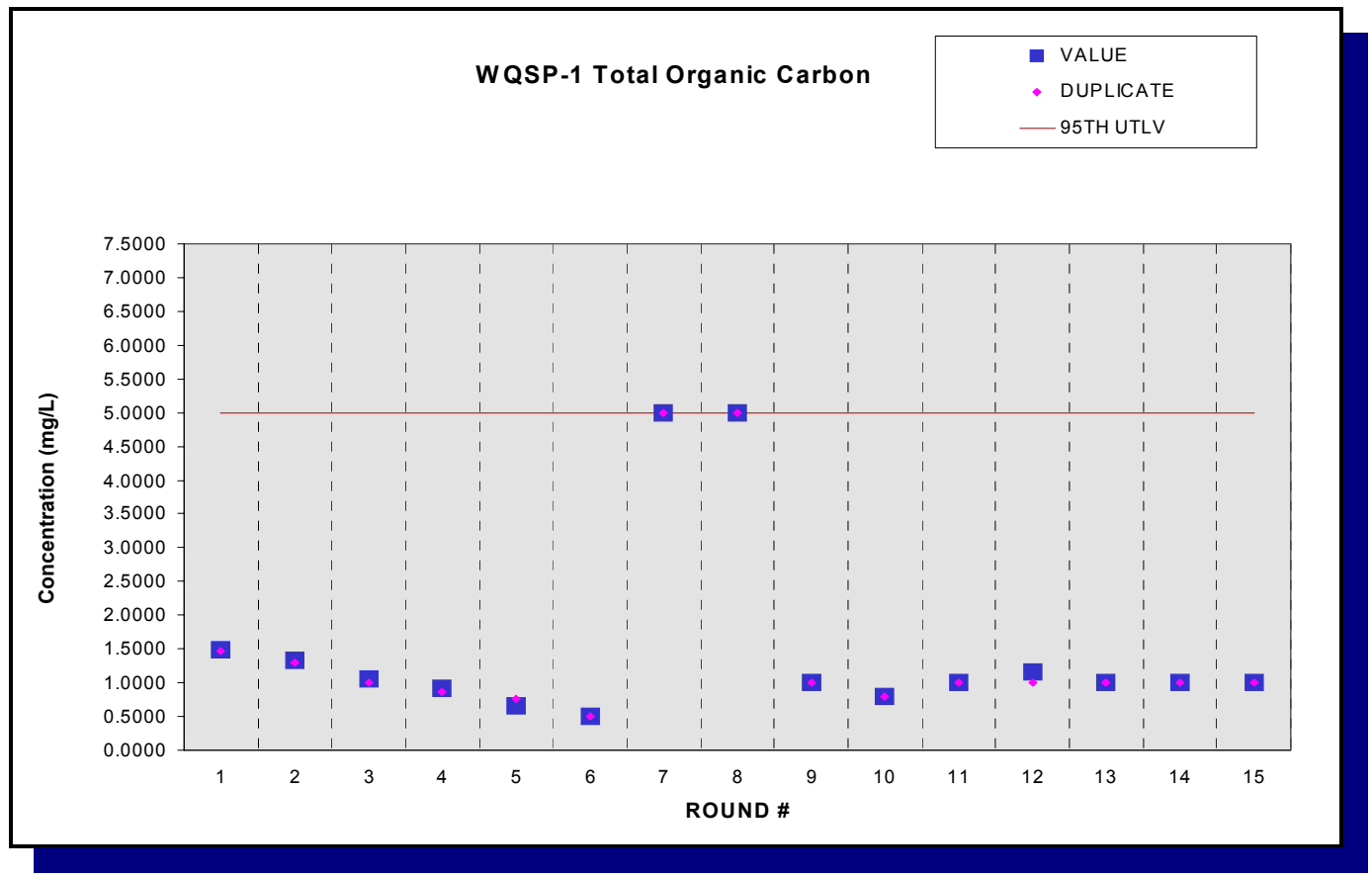

Figure F.12 - Time Trend Plot for Total Organic Carbon at WQSP-1

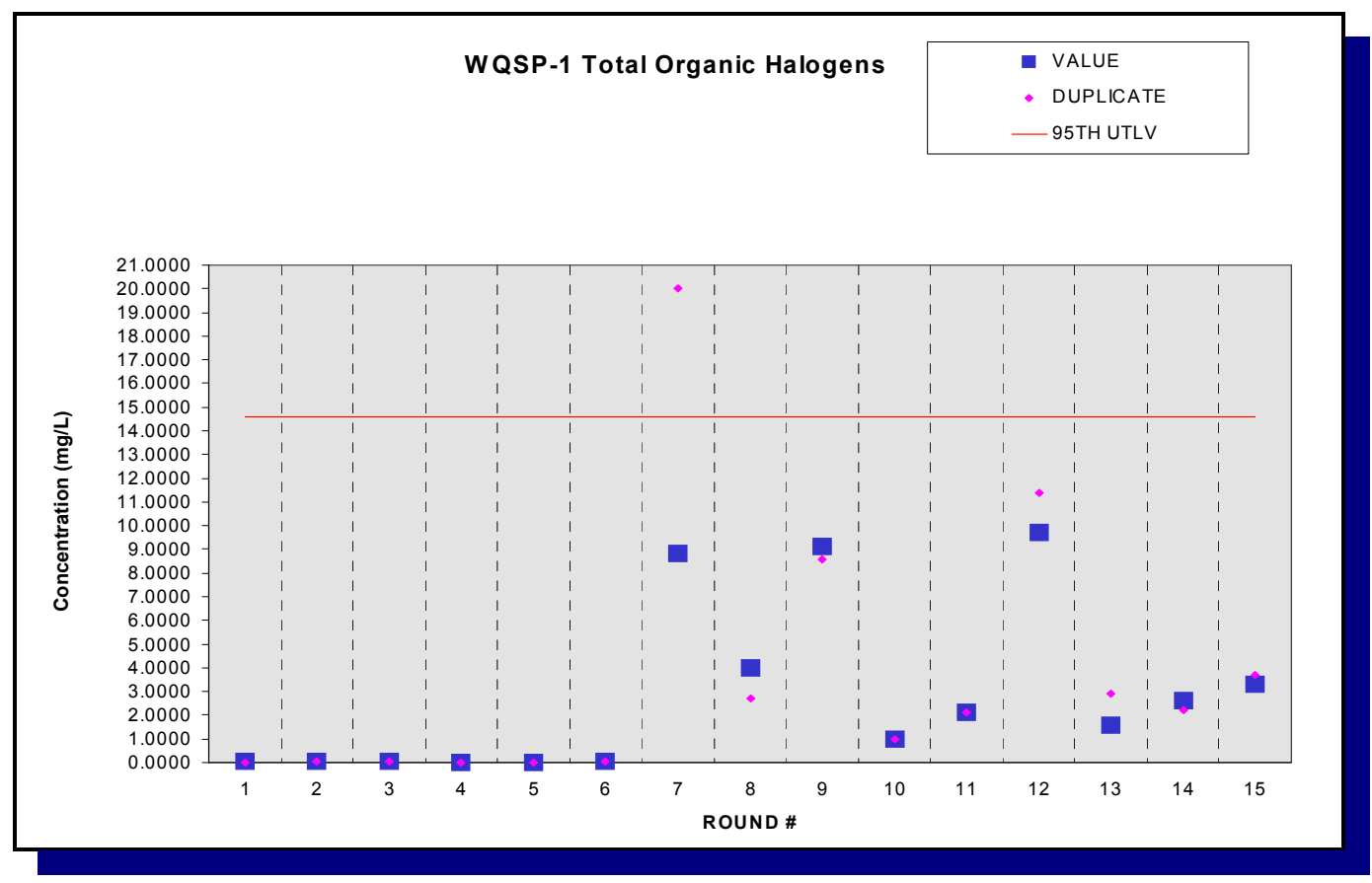

Figure F.13 - Time Trend Plot for Total Organic Halogens at WQSP-1 


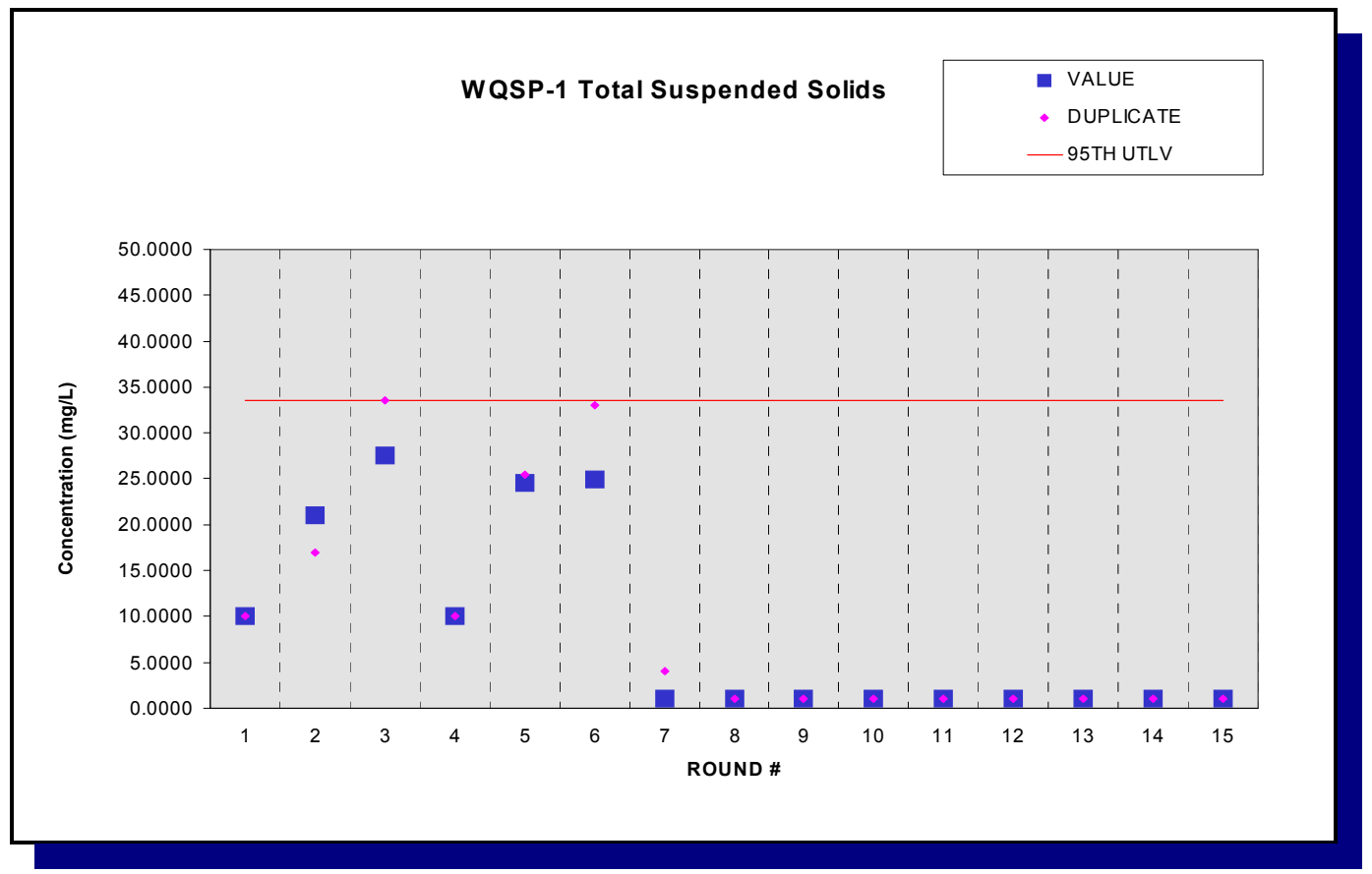

Figure F.14 - Time Trend Plot for Total Suspended Solids at WQSP-1

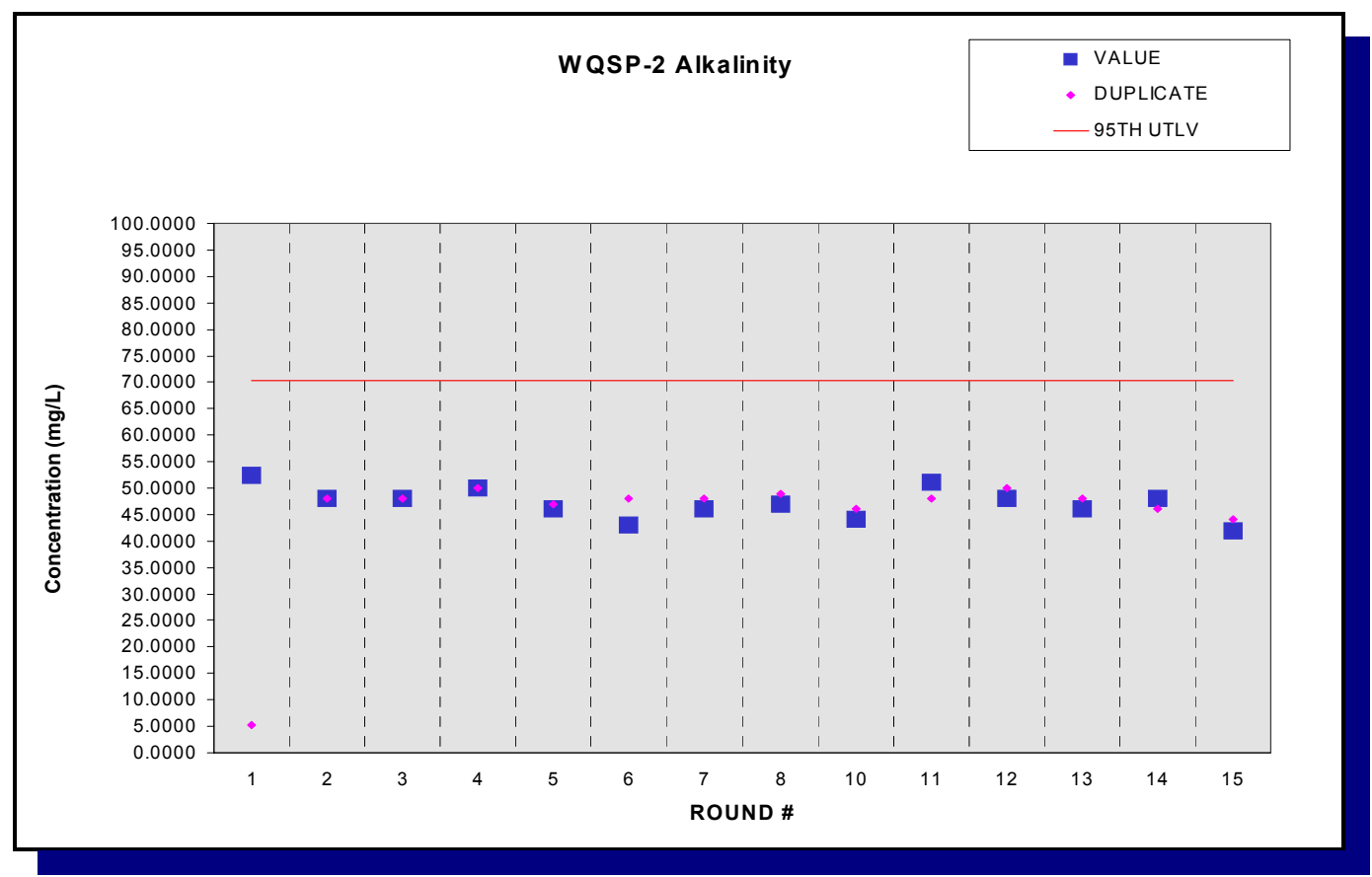

Figure F.15 - Time Trend Plot for Alkalinity at WQSP-2 


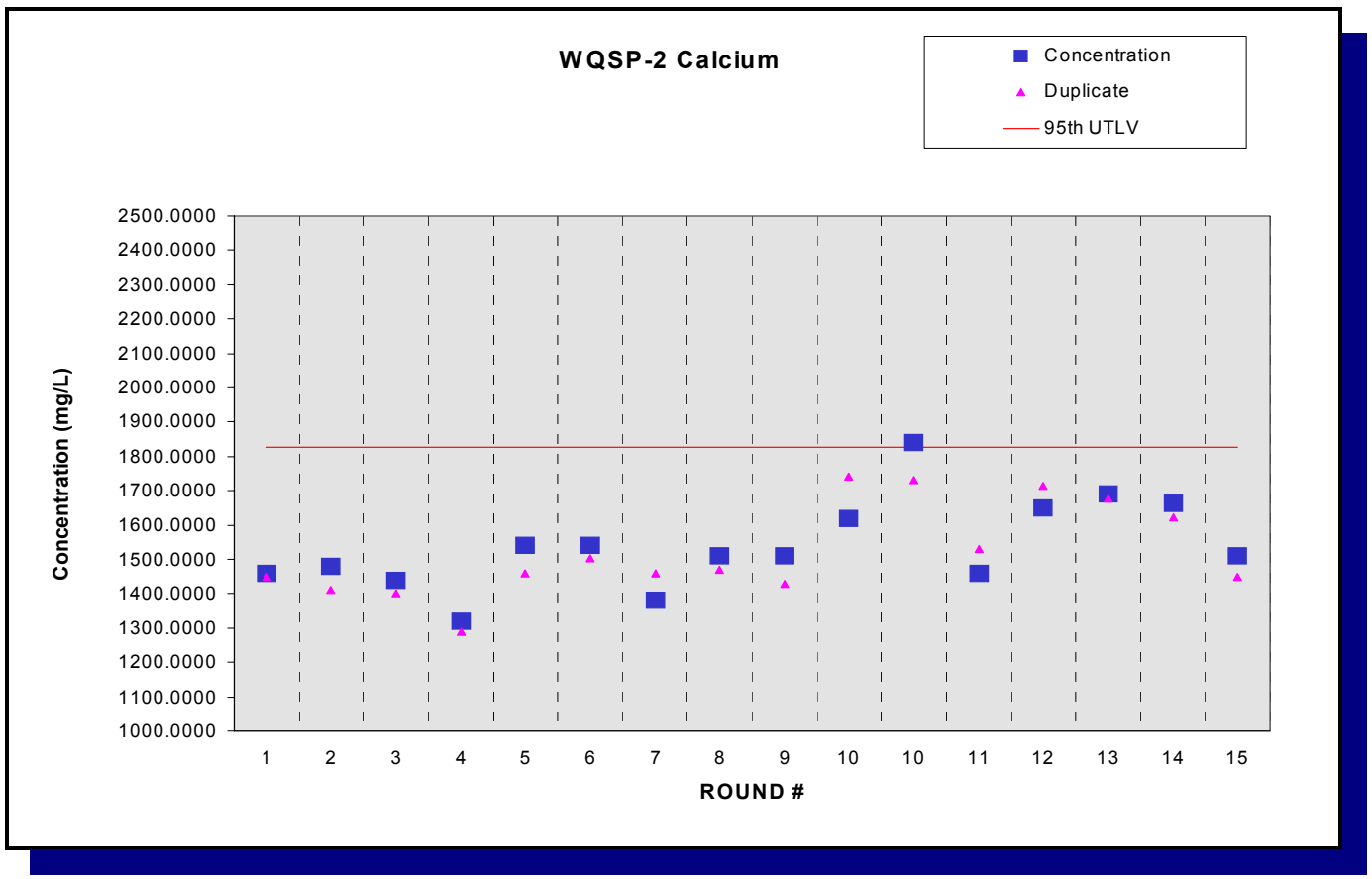

Figure F.16 - Time Trend Plot for Calcium at WQSP-2

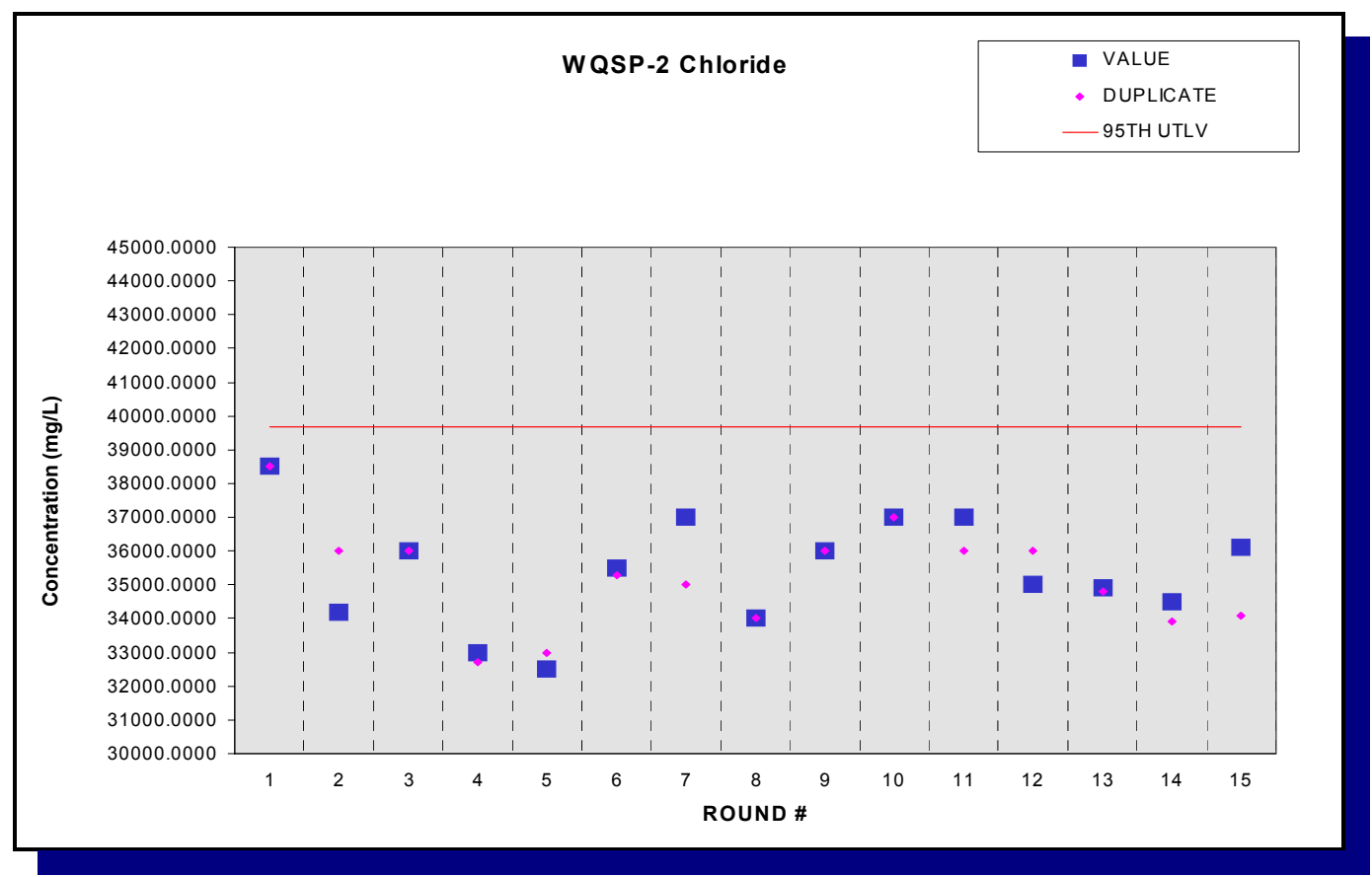

Figure F.17 - Time Trend Plot for Chloride at WQSP-2 


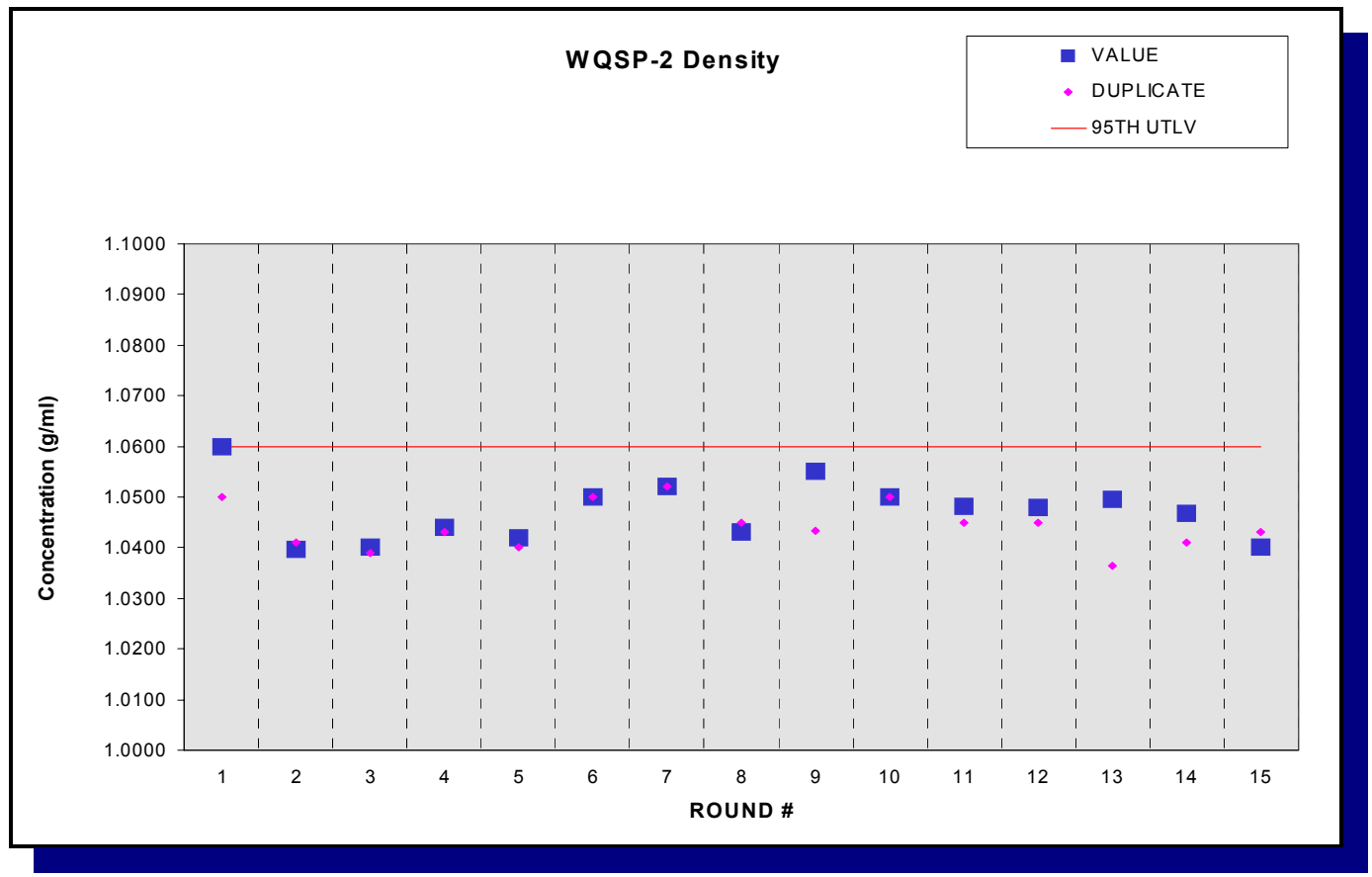

Figure F.18 - Time Trend Plot for Density at WQSP-2

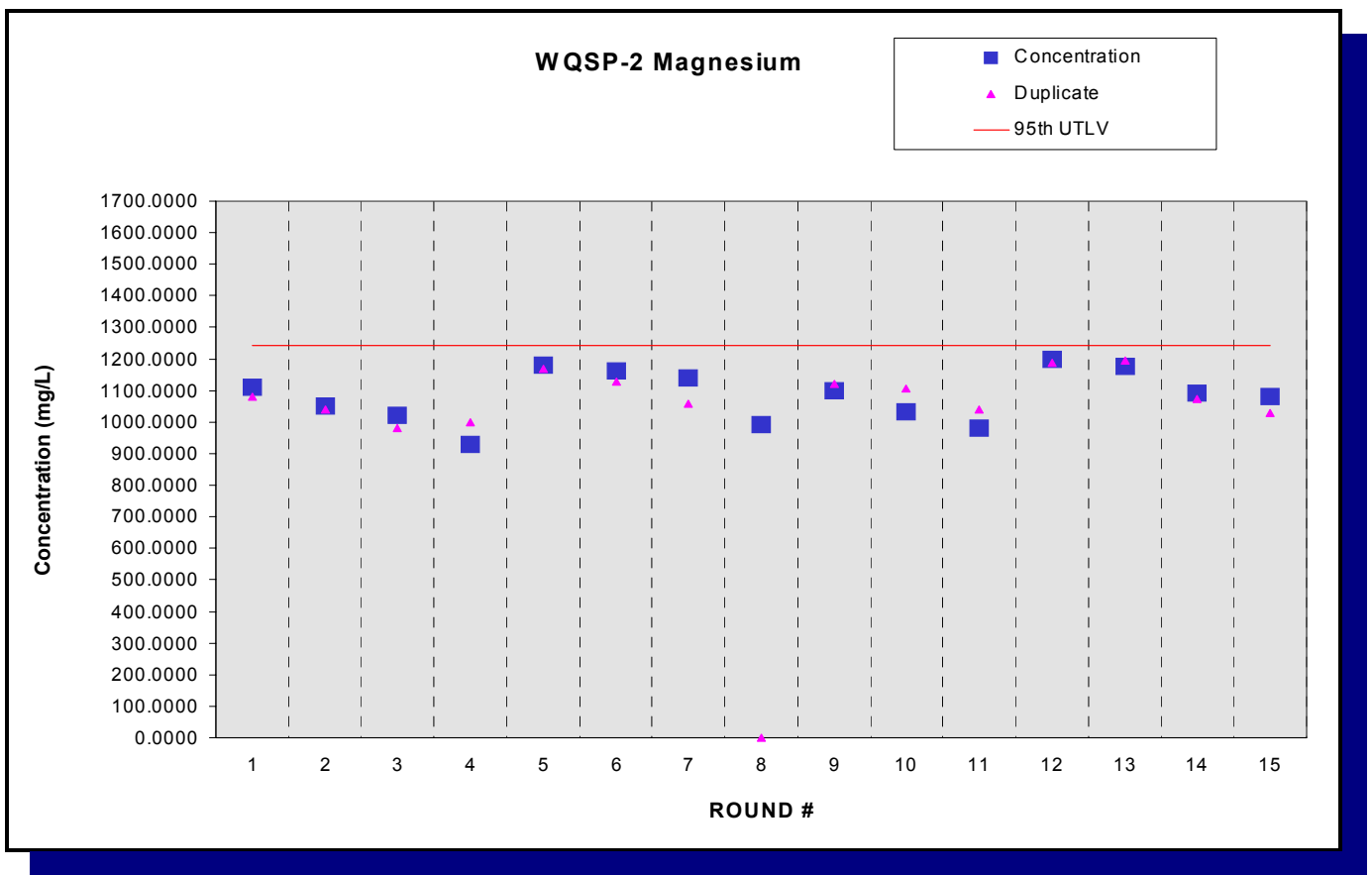

Figure F.19 - Time Trend Plot for Magnesium at WQSP-2 


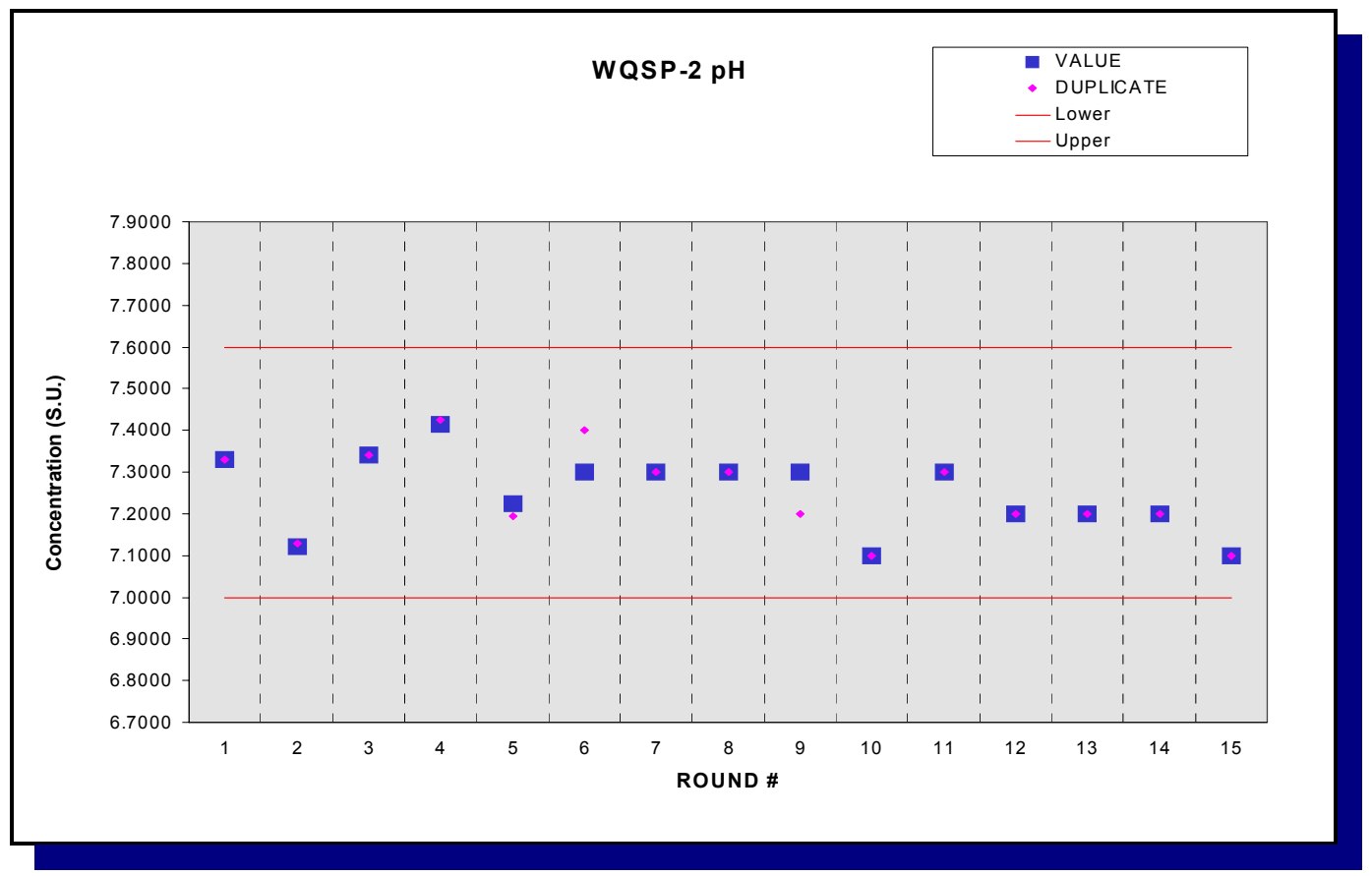

Figure F.20 - Time Trend Plot for pH at WQSP-2

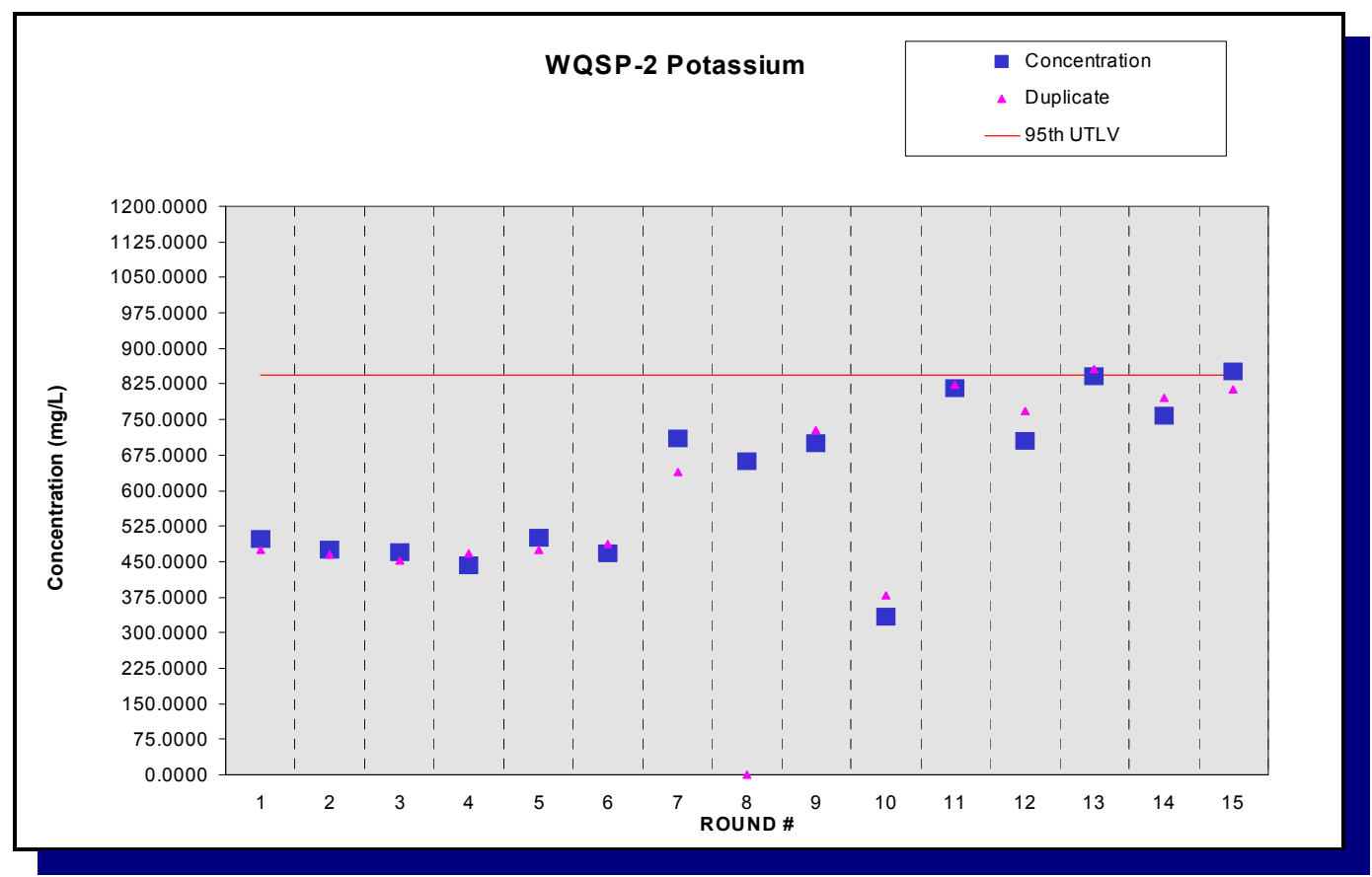

Figure F.21 - Time Trend Plot for Potassium at WQSP-2 


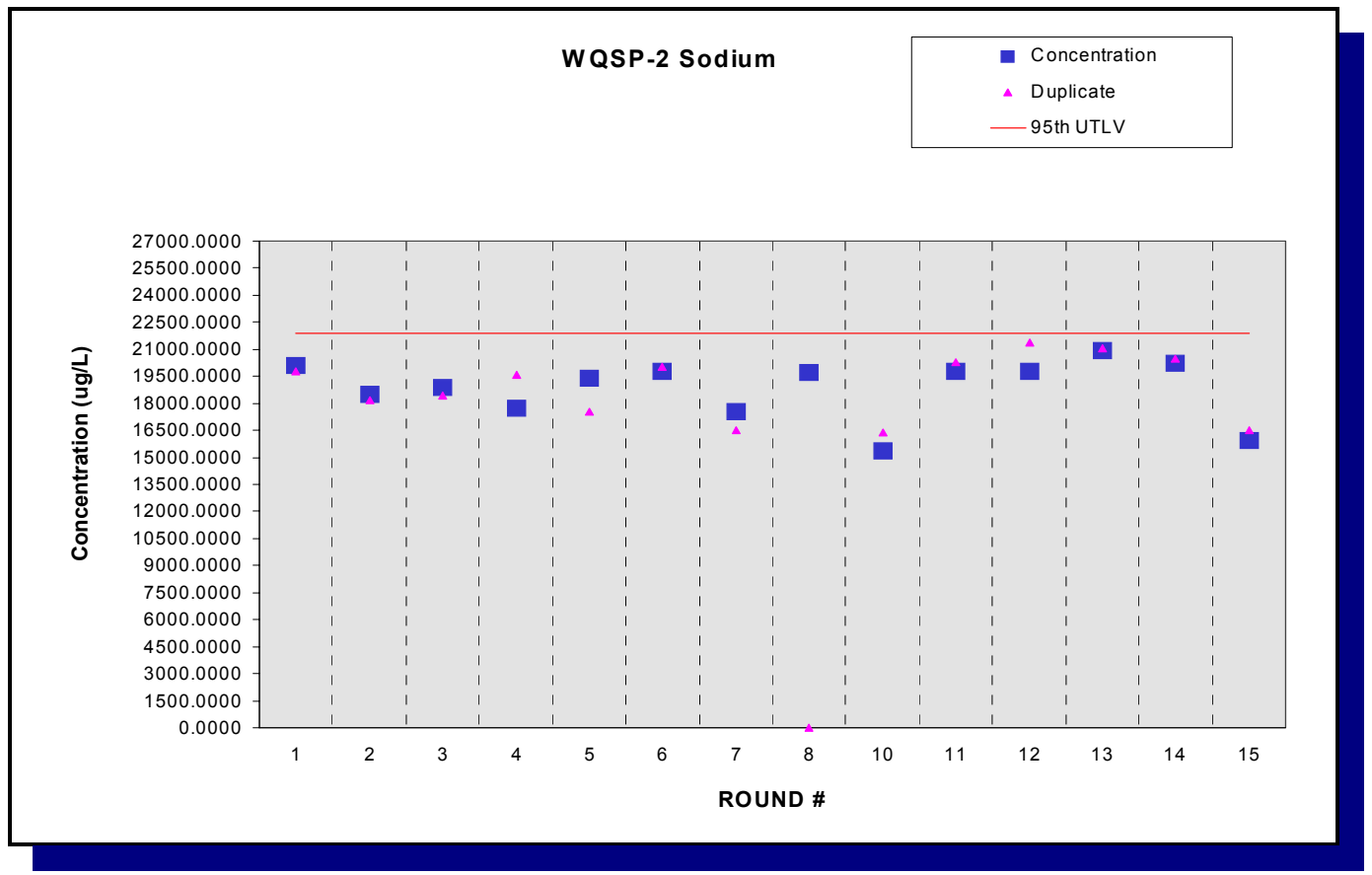

Figure F.22 - Time Trend Plot for Sodium at WQSP-2

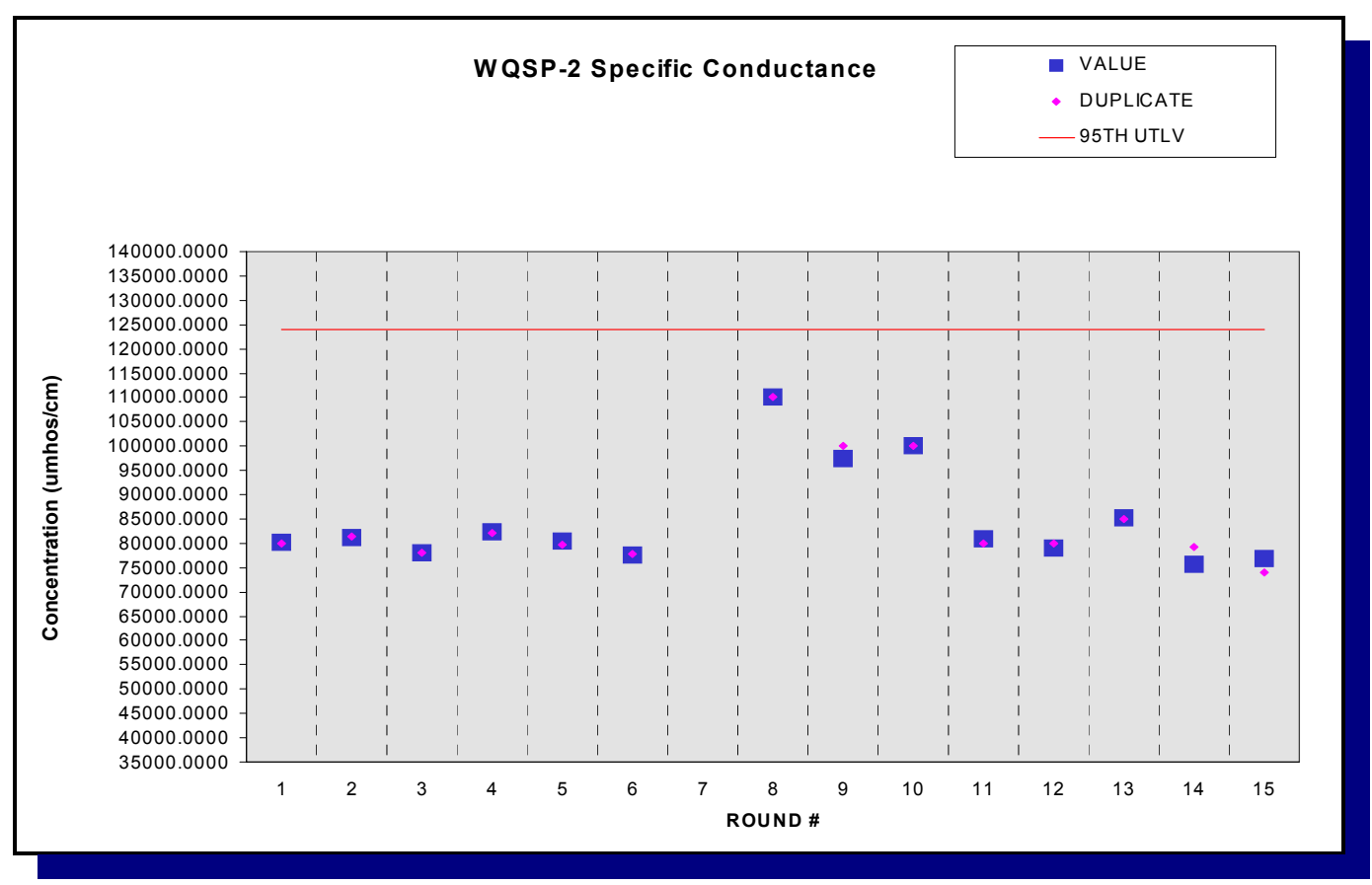

Figure F.23 - Time Trend Plot for Specific Conductance at WQSP-2 


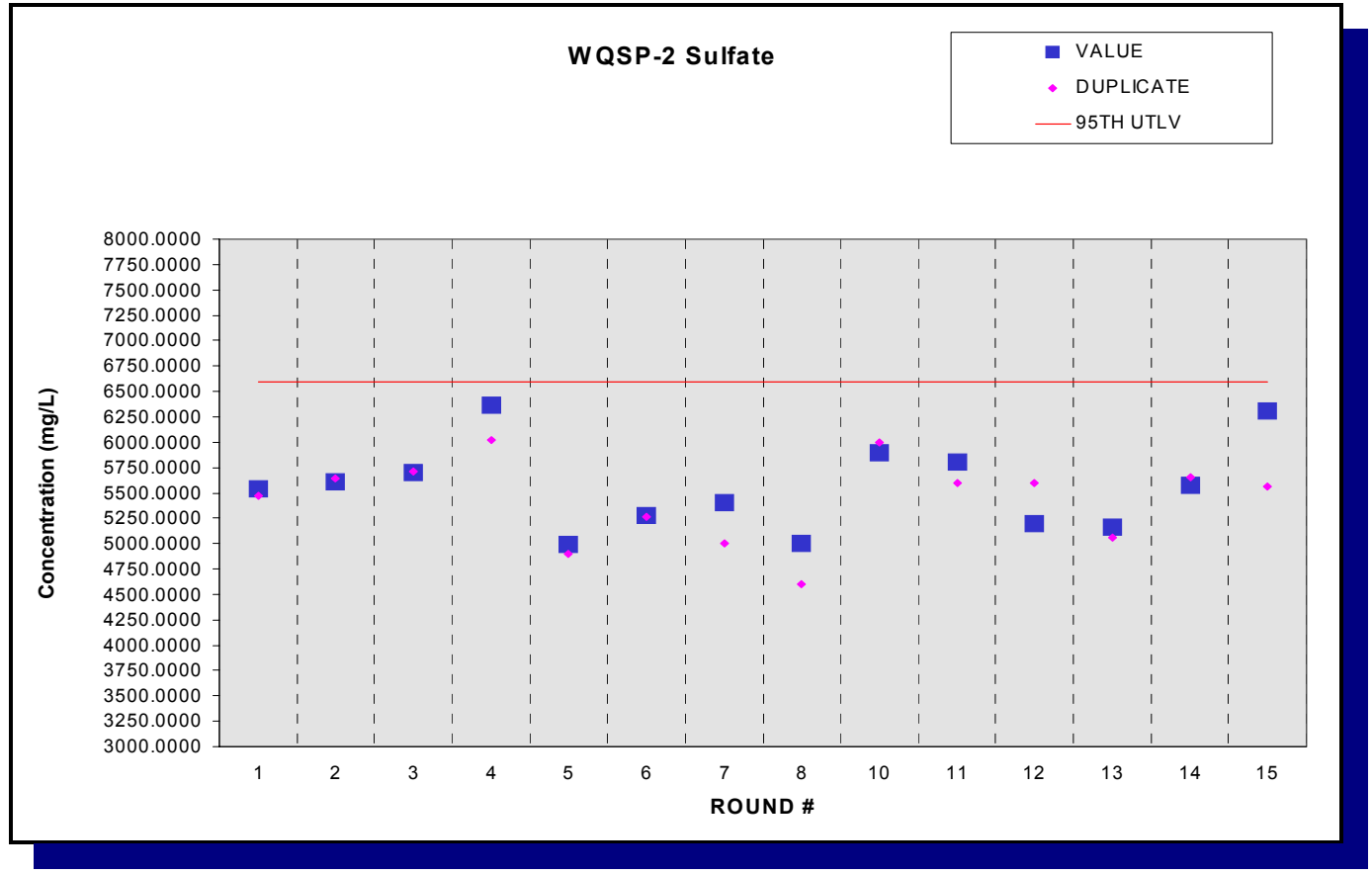

Figure F.24 - Time Trend Plot for Sulfate at WQSP-2

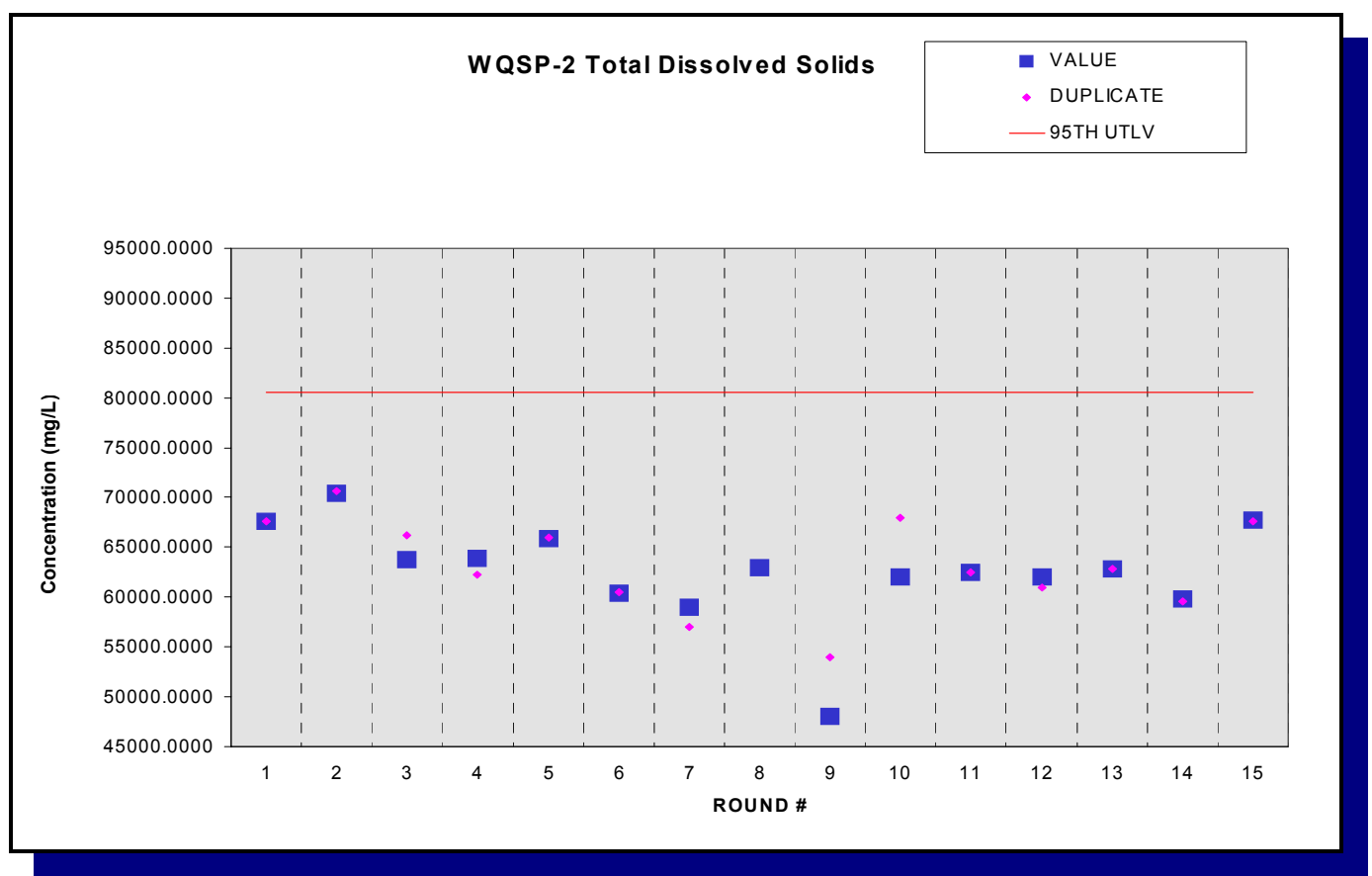

Figure F.25 - Time Trend Plot for Total Dissolved Solids at WQSP-2 


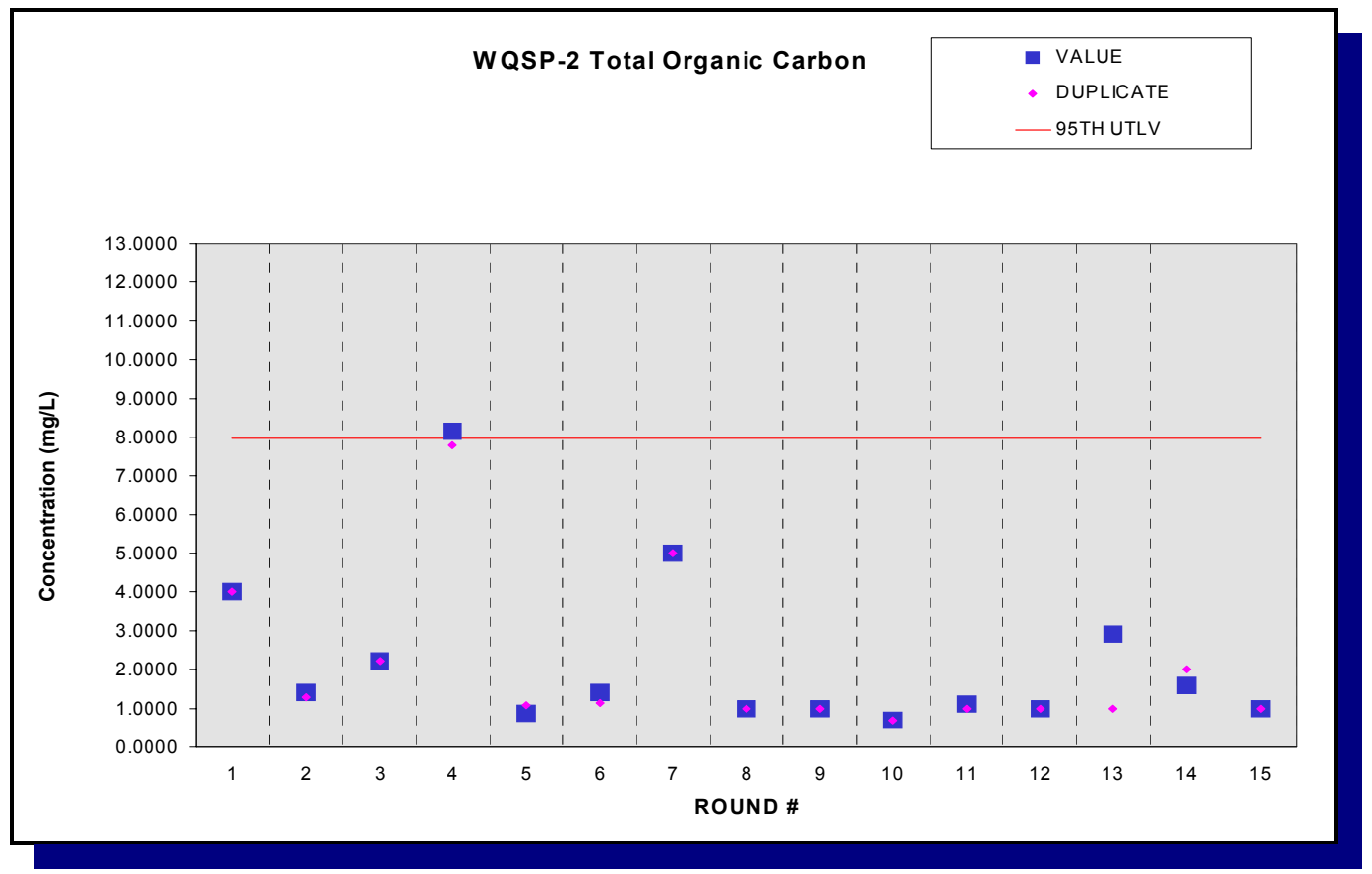

Figure F.26 - Time Trend Plot for Total Organic Carbon at WQSP-2

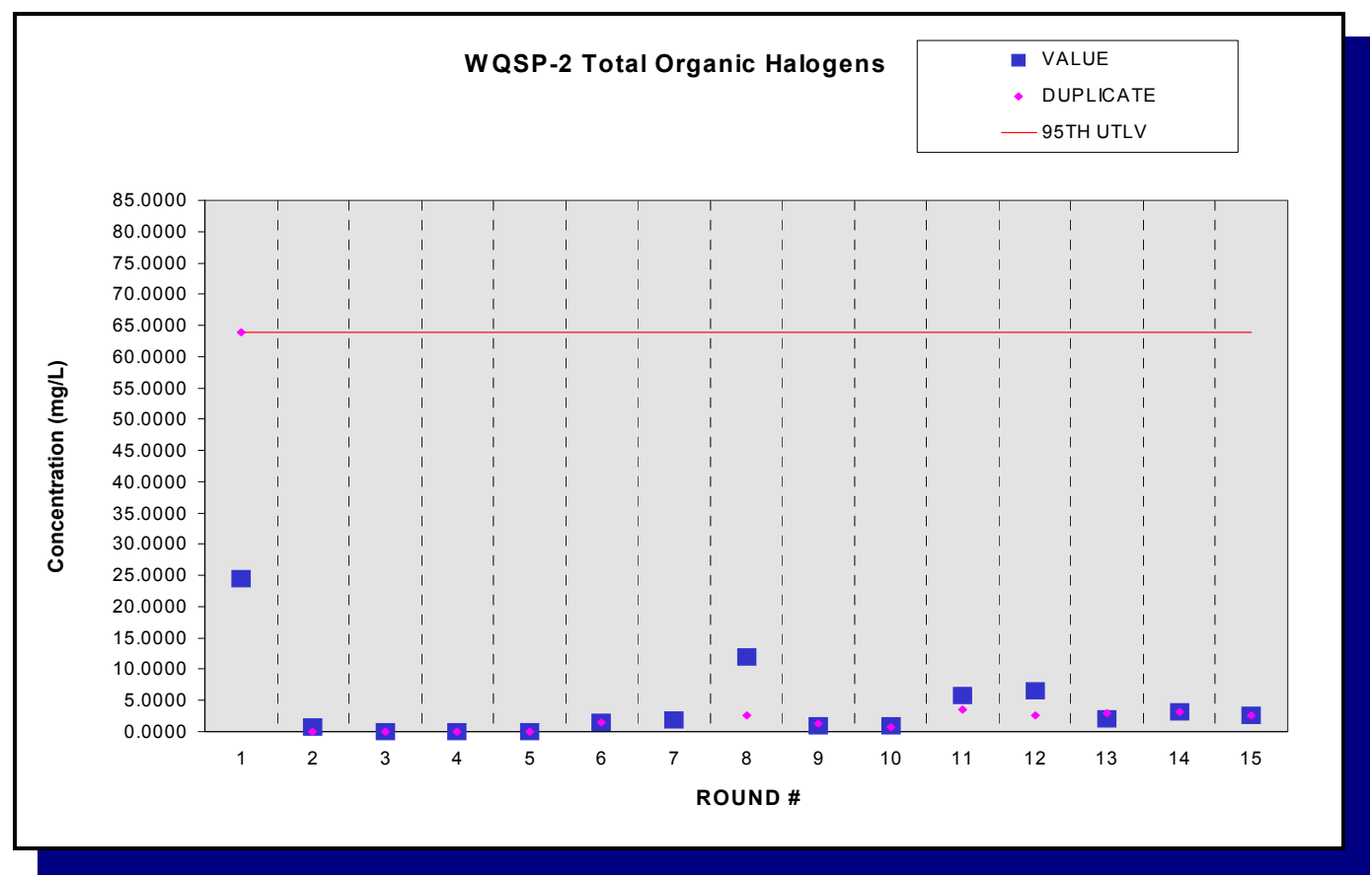

Figure F.27 - Time Trend Plot for Total Organic Halogens at WQSP-2 


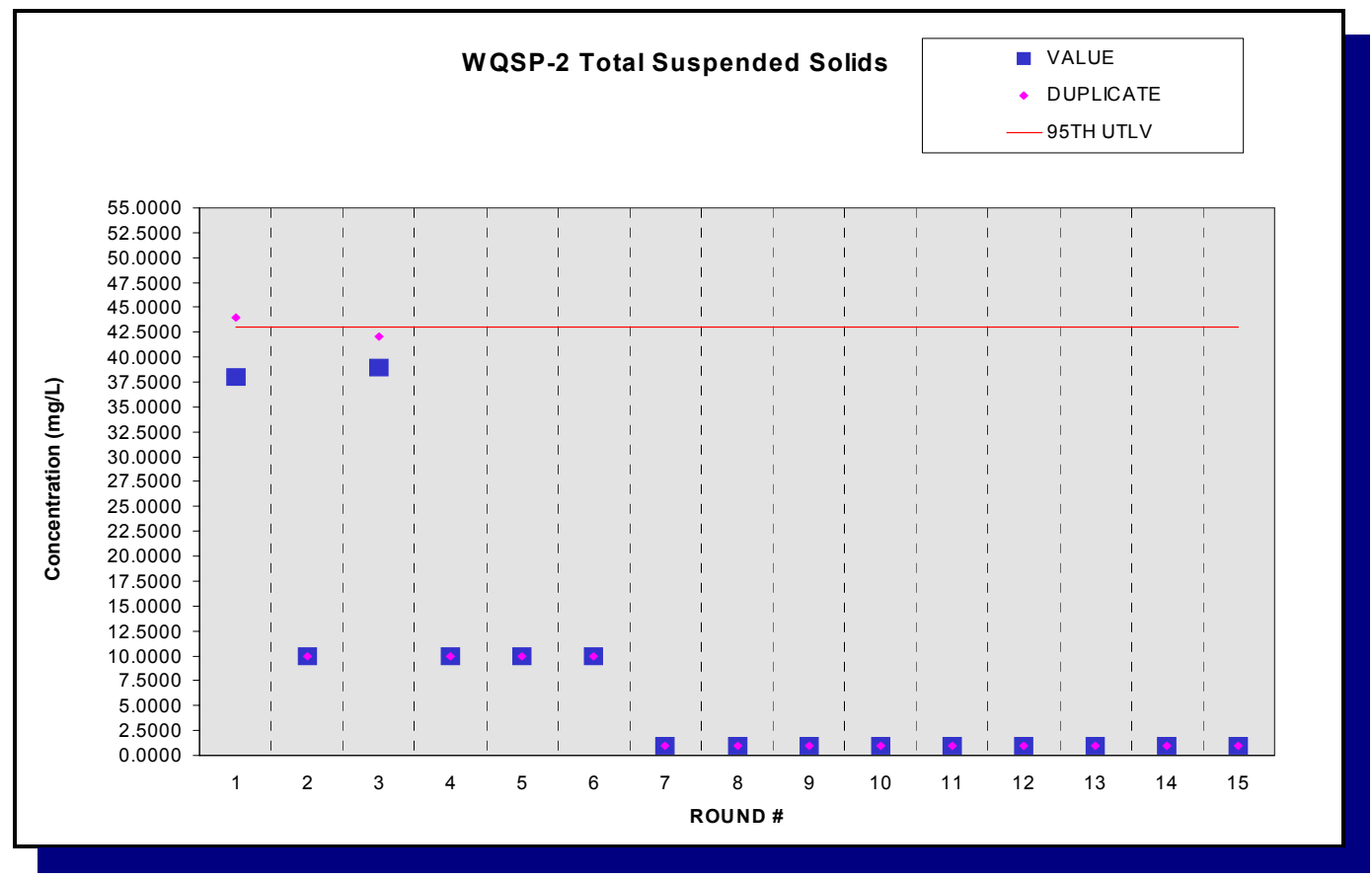

Figure F.28 - Time Trend Plot for Total Suspended Solids at WQSP-2

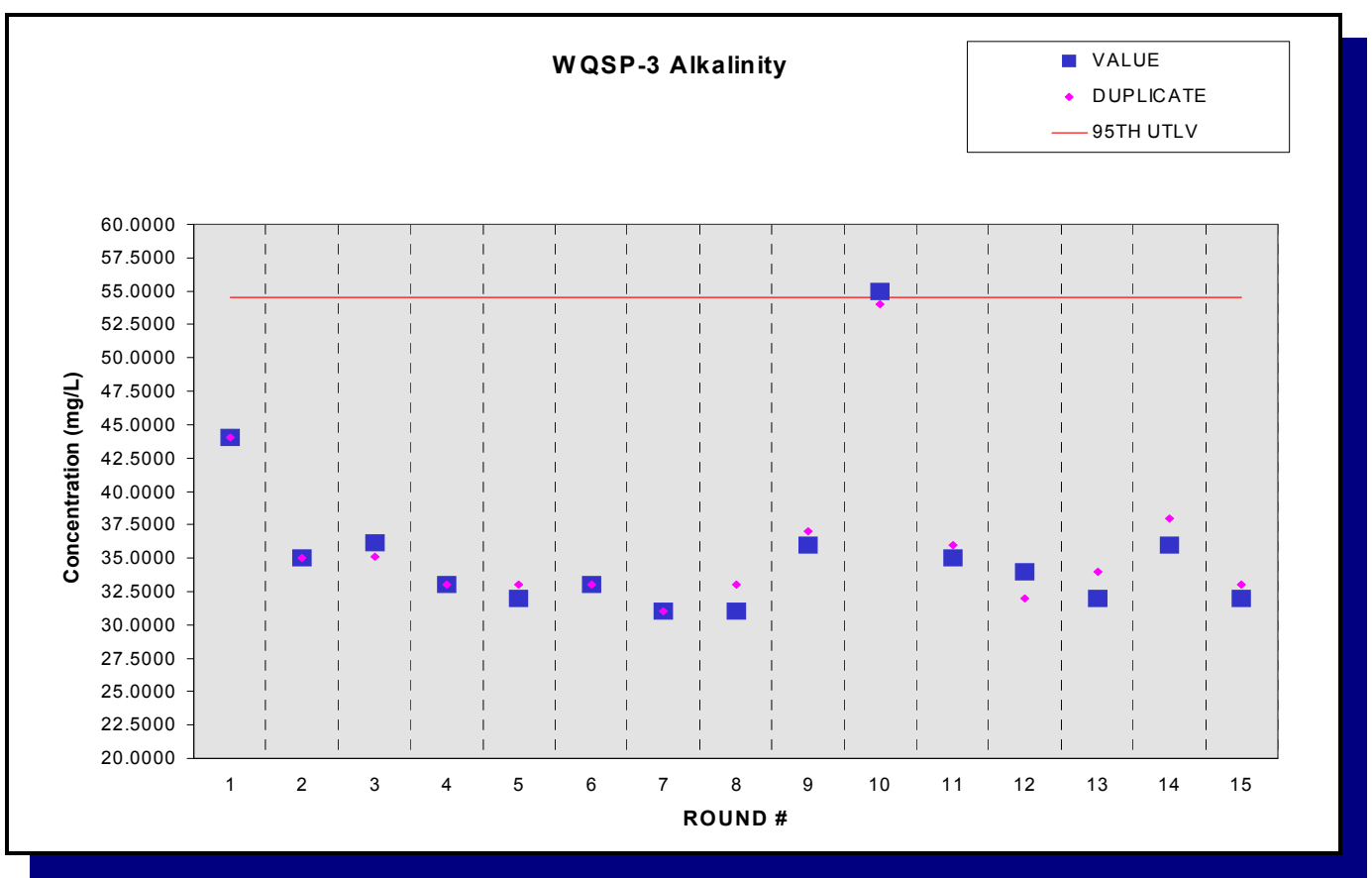

Figure F.29 - Time Trend Plot for Alkalinity at WQSP-3 


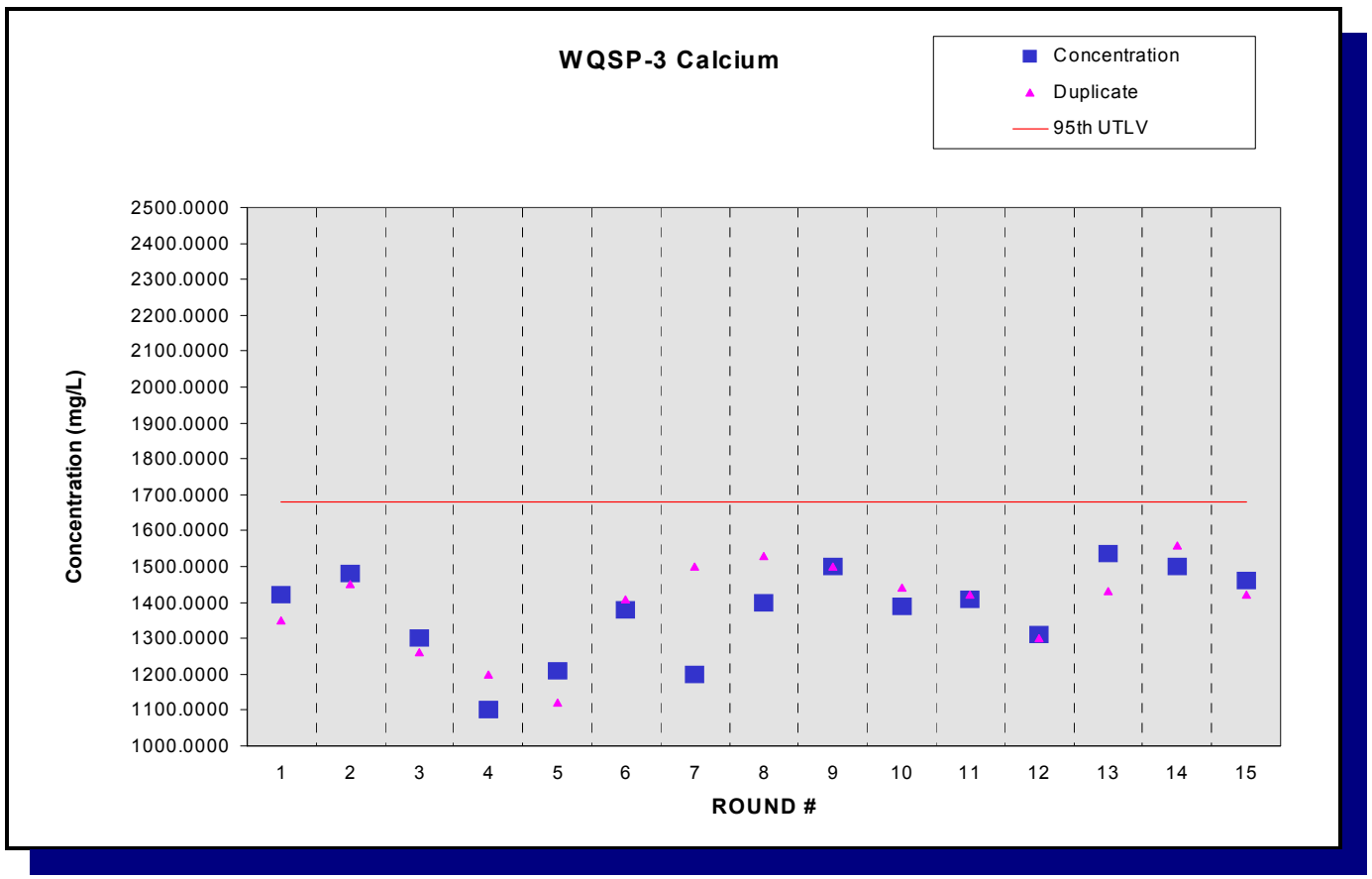

Figure F.30 - Time Trend Plot for Calcium at WQSP-3

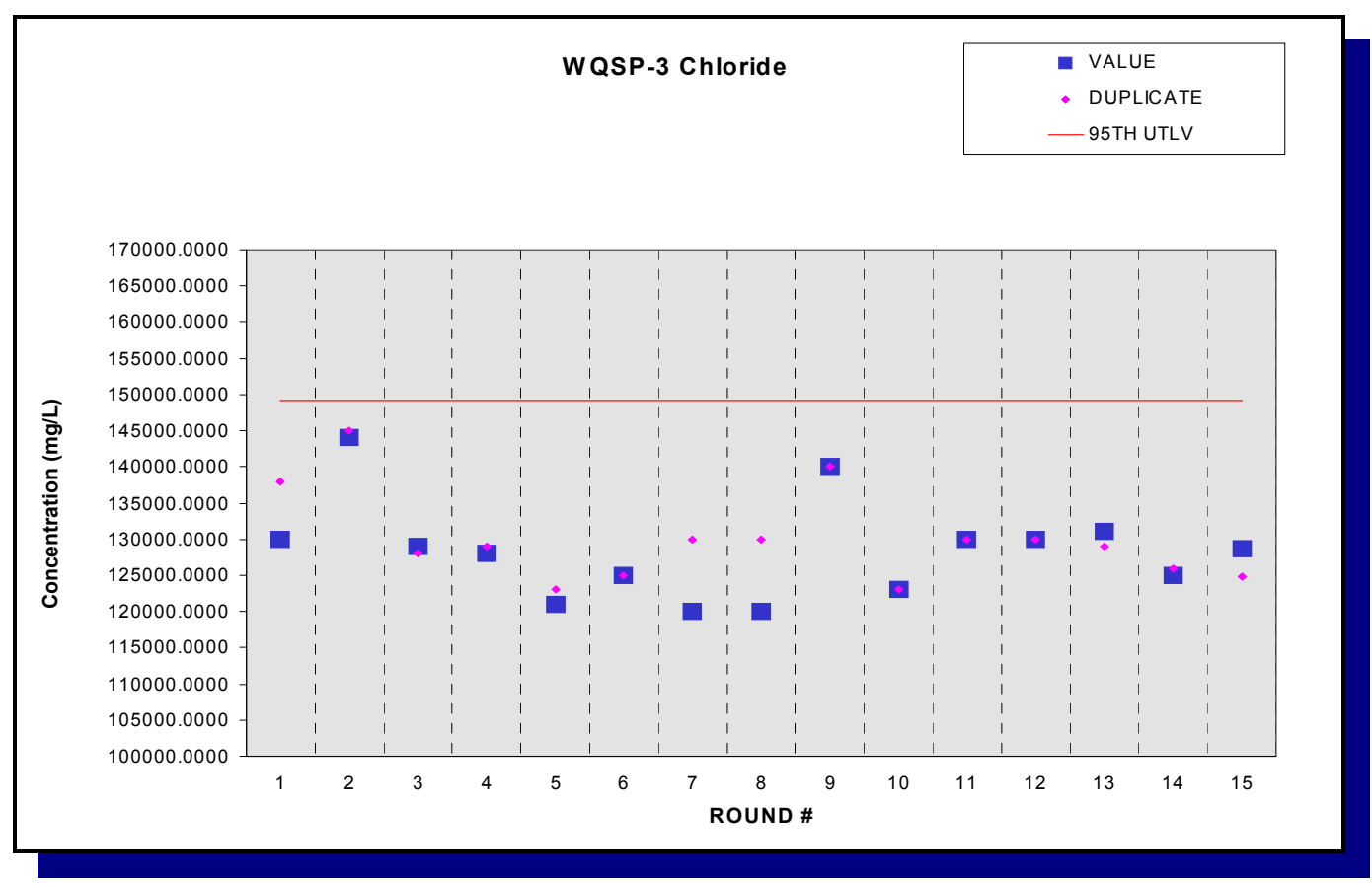

Figure F.31 - Time Trend Plot for Chloride at WQSP-3 


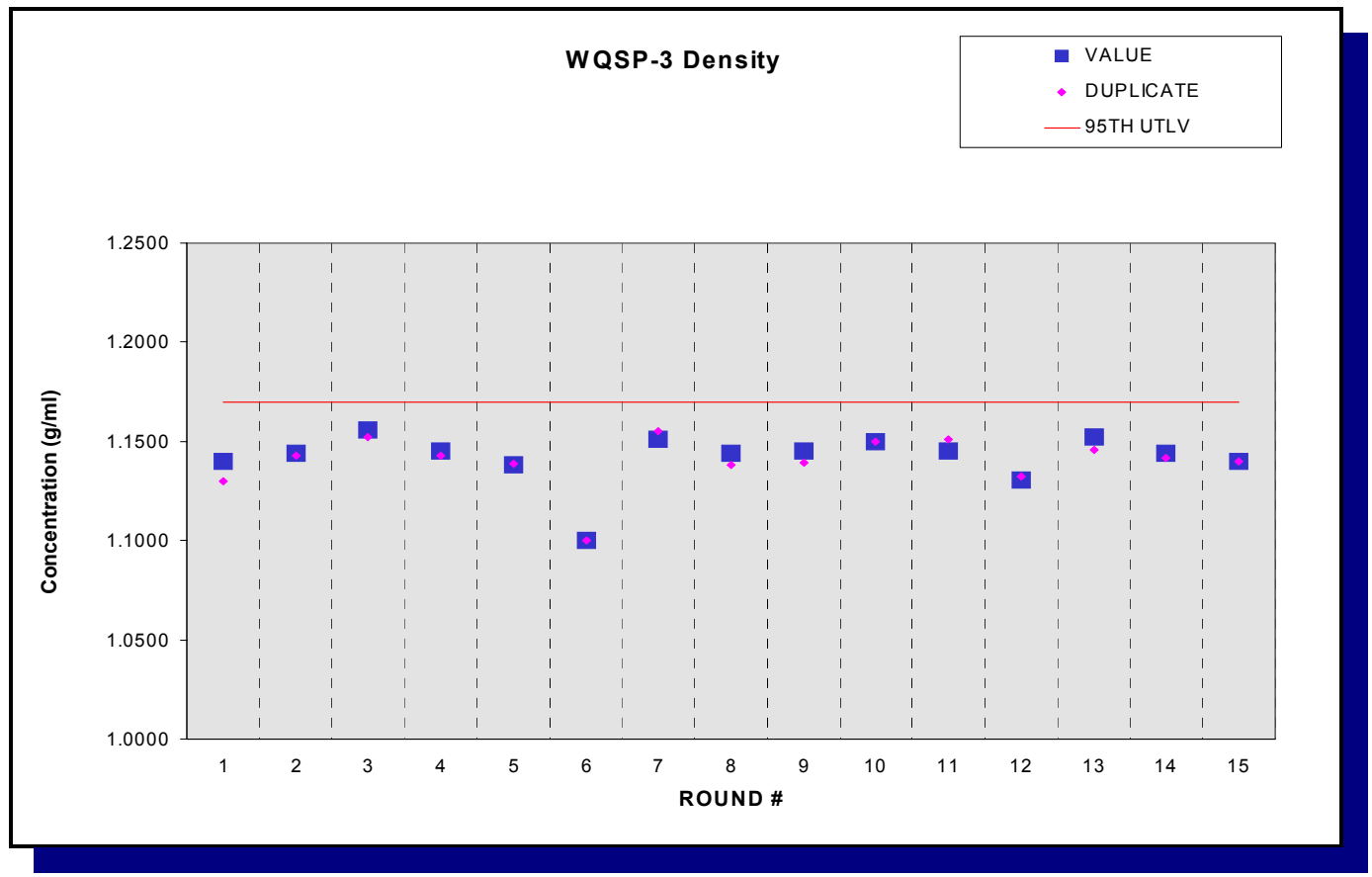

Figure F.32 - Time Trend Plot for Density at WQSP-3

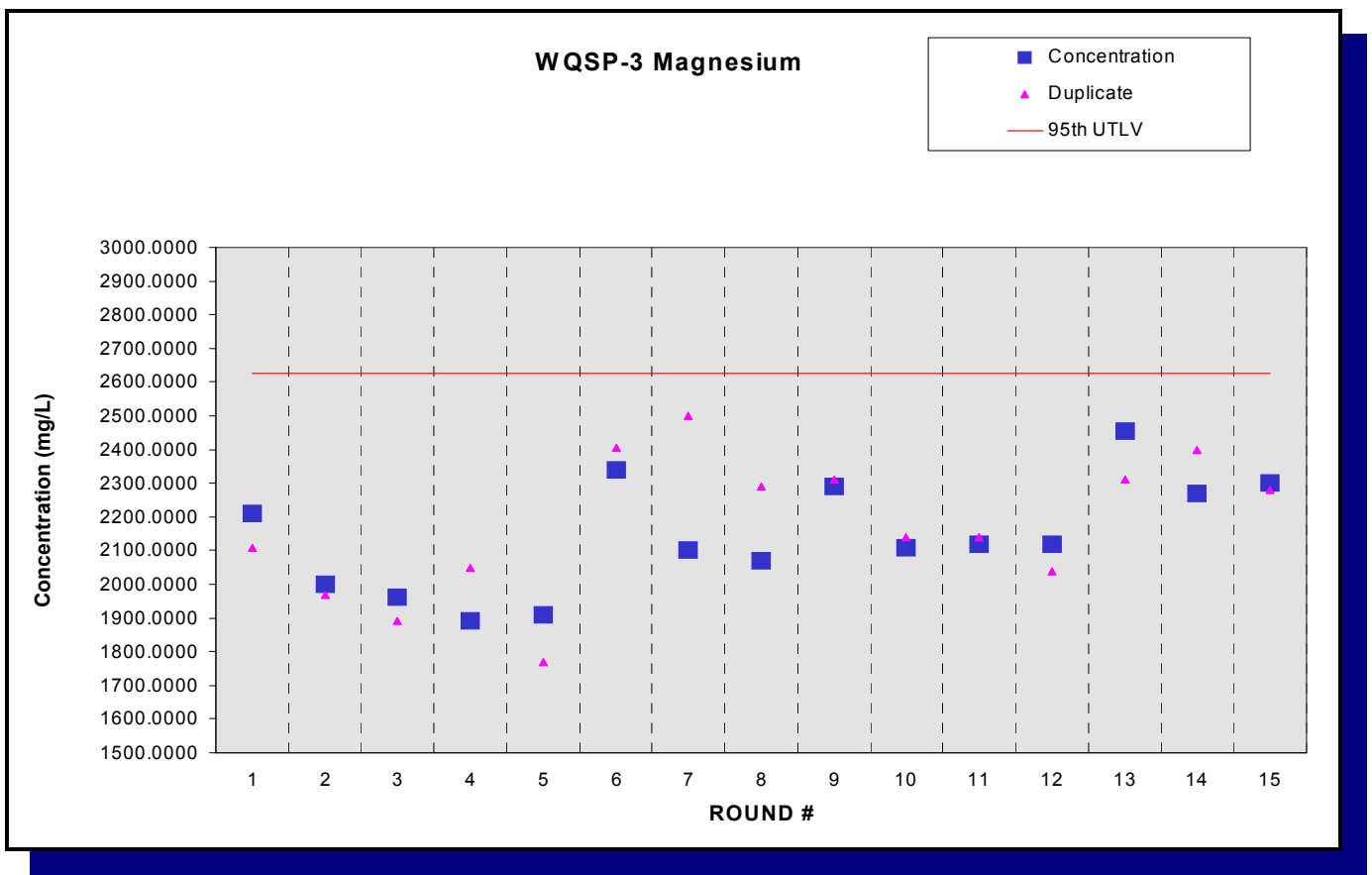

Figure F.33 - Time Trend Plot for Magnesium at WQSP-3 


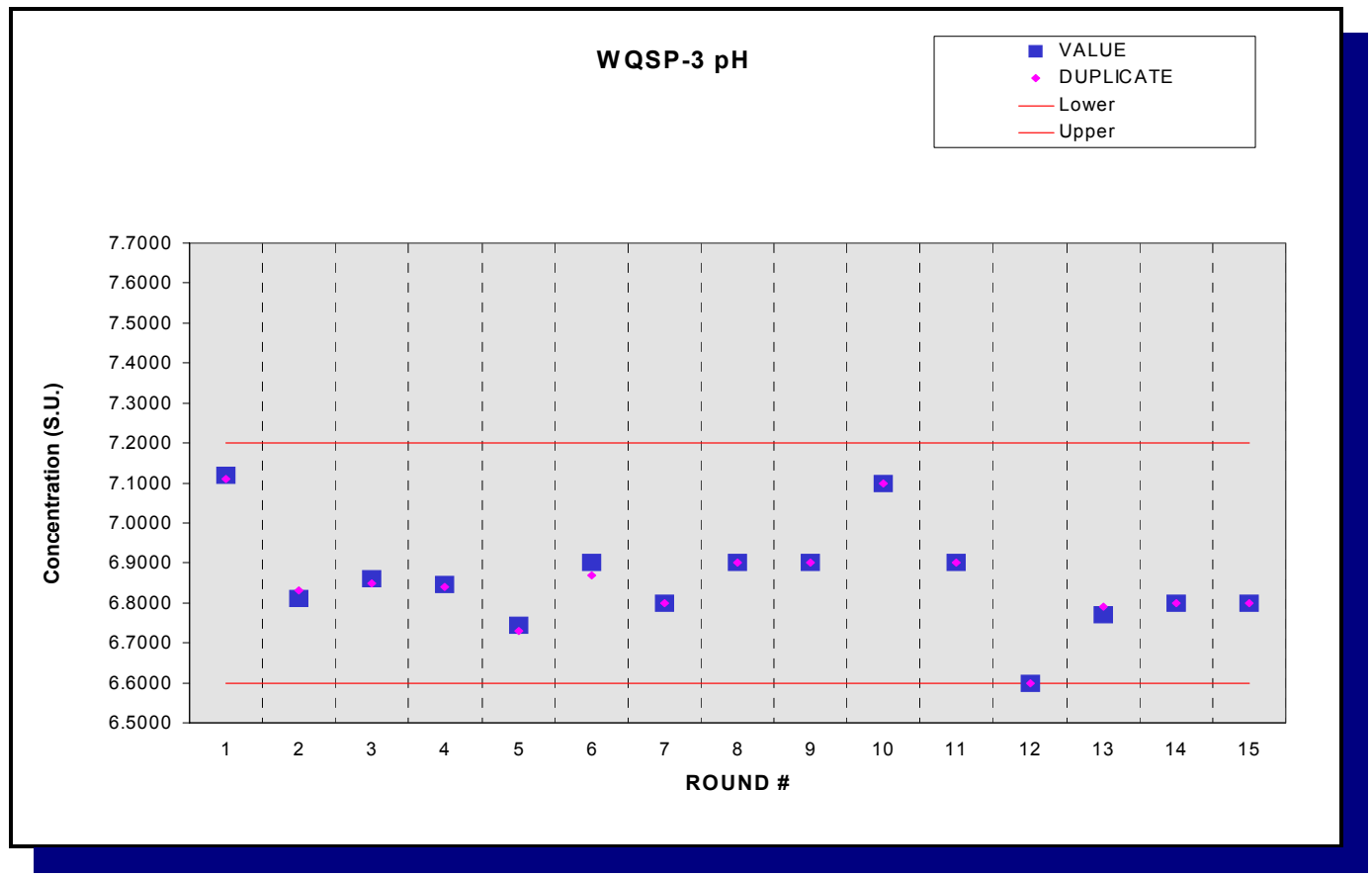

Figure F.34 - Time Trend Plot for $\mathrm{pH}$ at WQSP-3

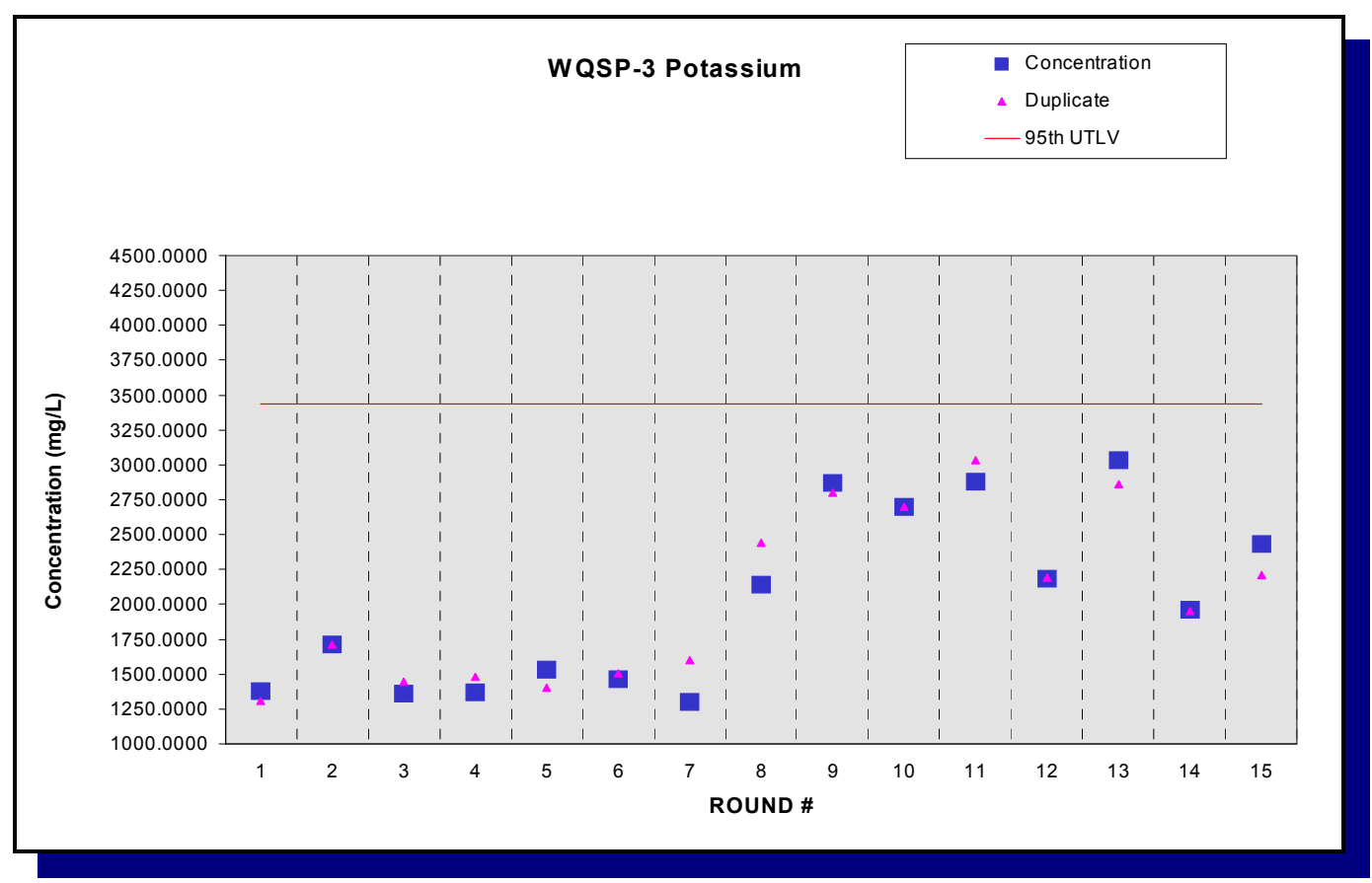

Figure F.35 - Time Trend Plot for Potassium at WQSP-3 


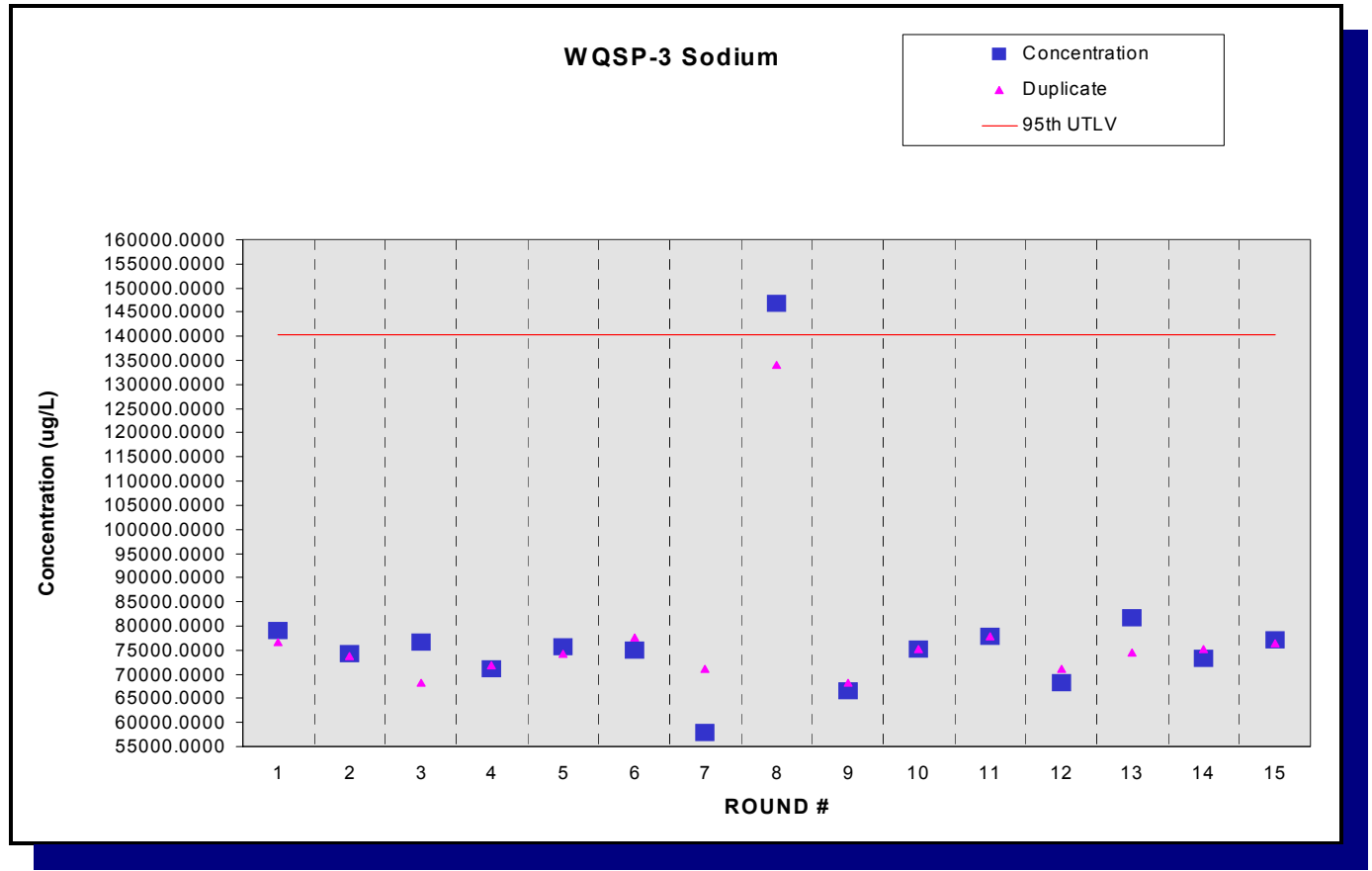

Figure F.36 - Time Trend Plot for Sodium at WQSP-3

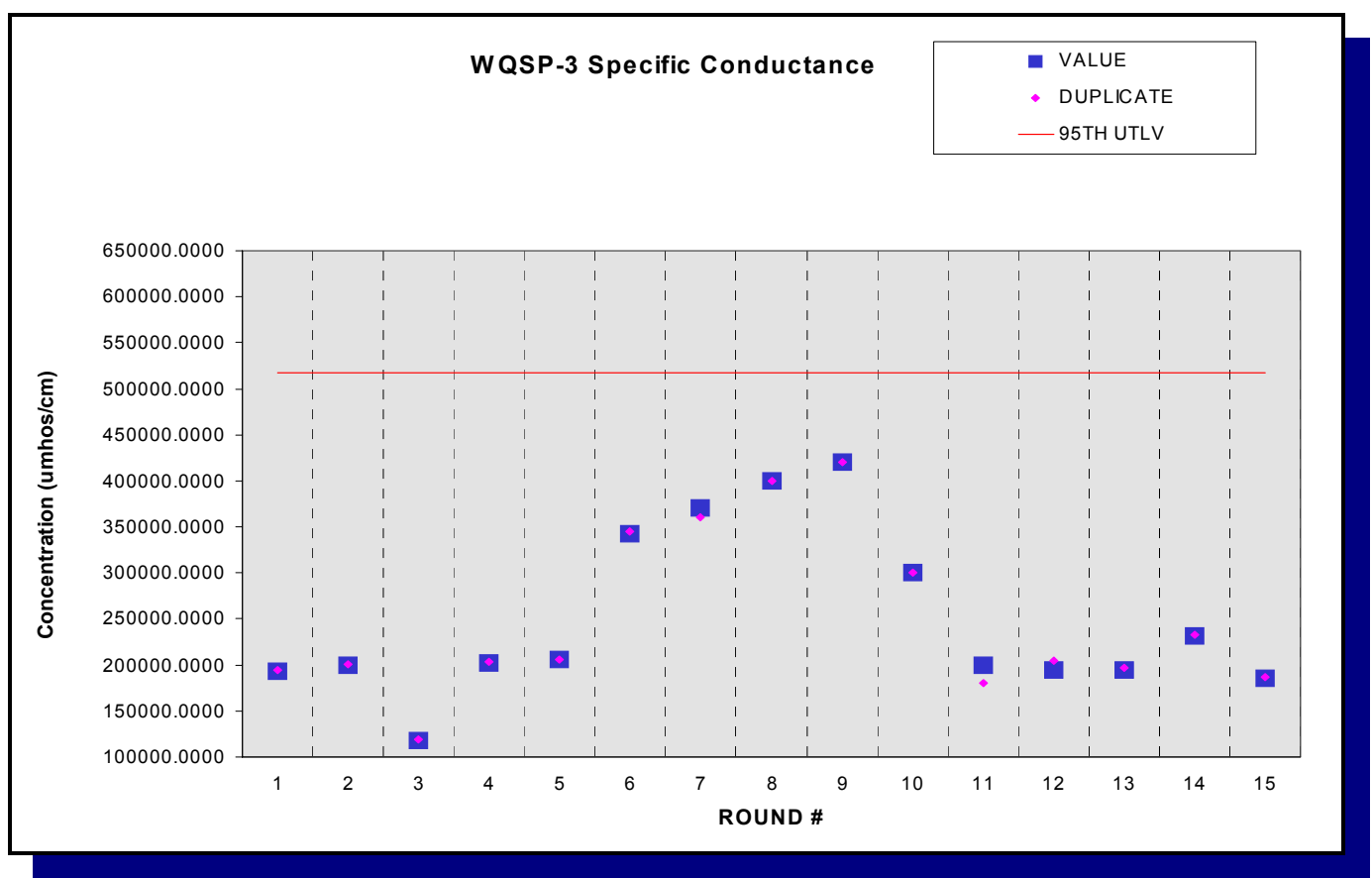

Figure F.37 - Time Trend Plot for Specific Conductance at WQSP-3 


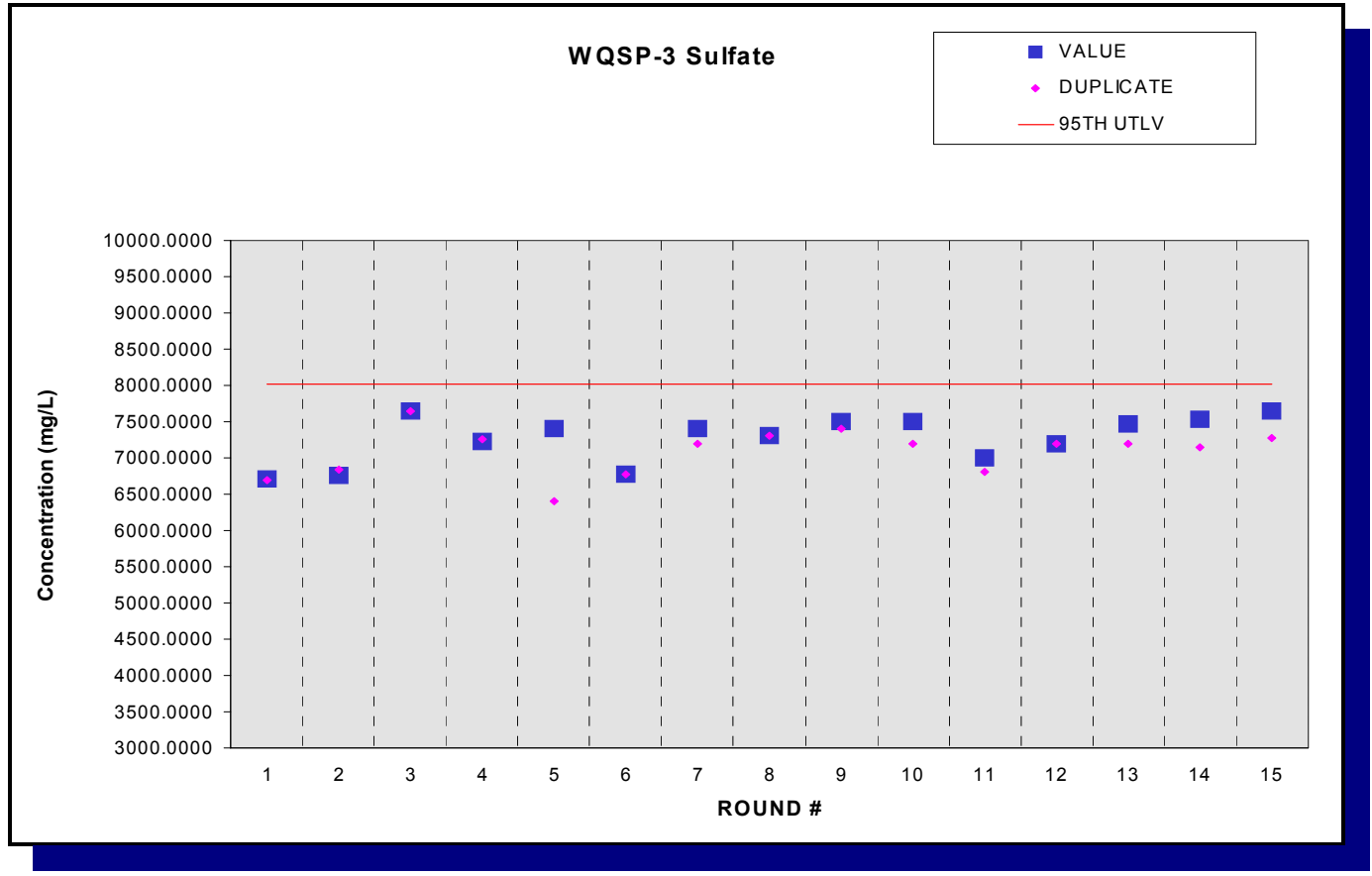

Figure F.38 - Time Trend Plot for Sulfate at WQSP-3

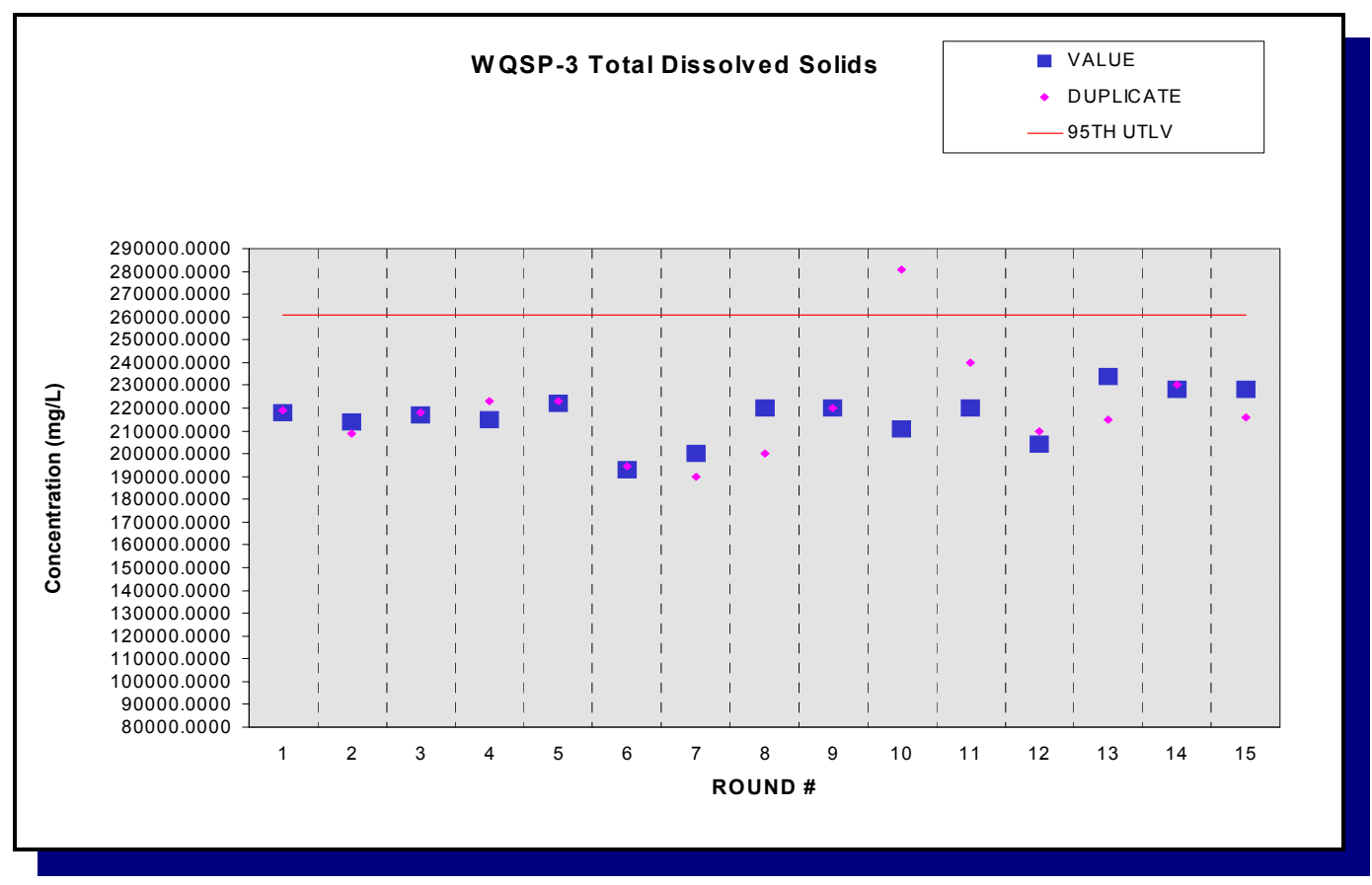

Figure F.39 - Time Trend Plot for Total Dissolved Solids at WQSP-3 


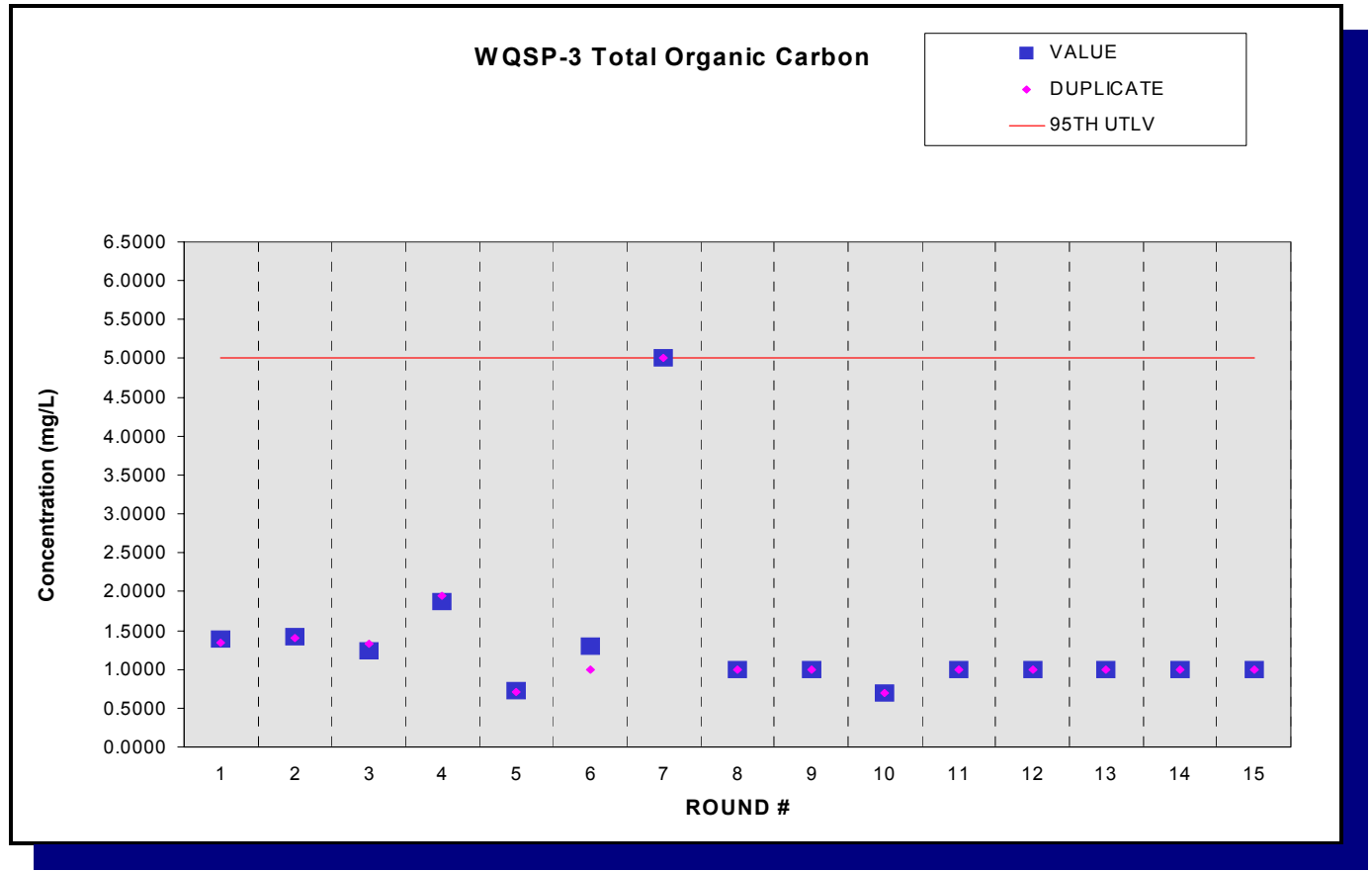

Figure F.40 - Time Trend Plot for Total Organic Carbon at WQSP-3

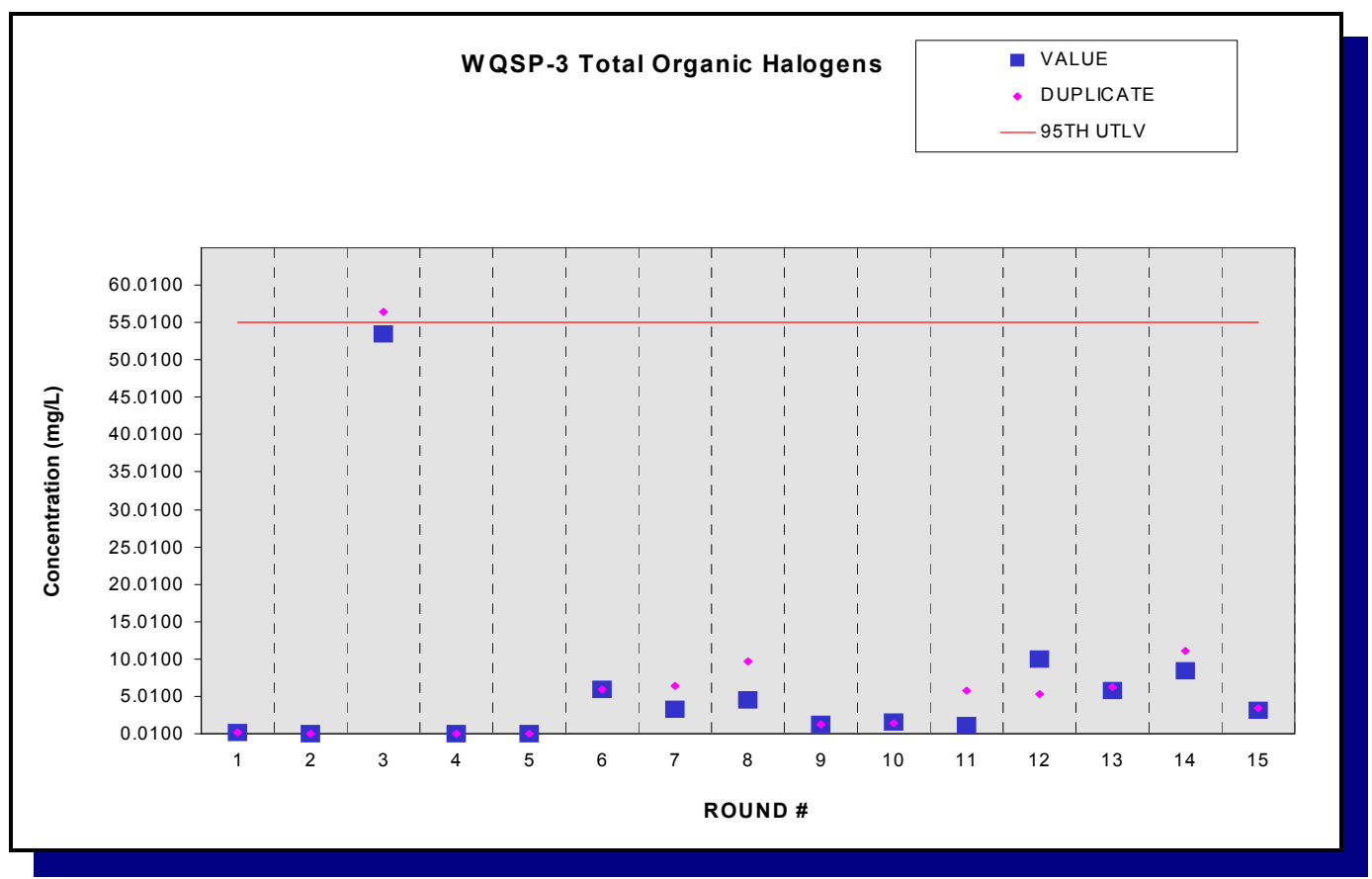

Figure F.41 - Time Trend Plot for Total Organic Halogens at WQSP-3 


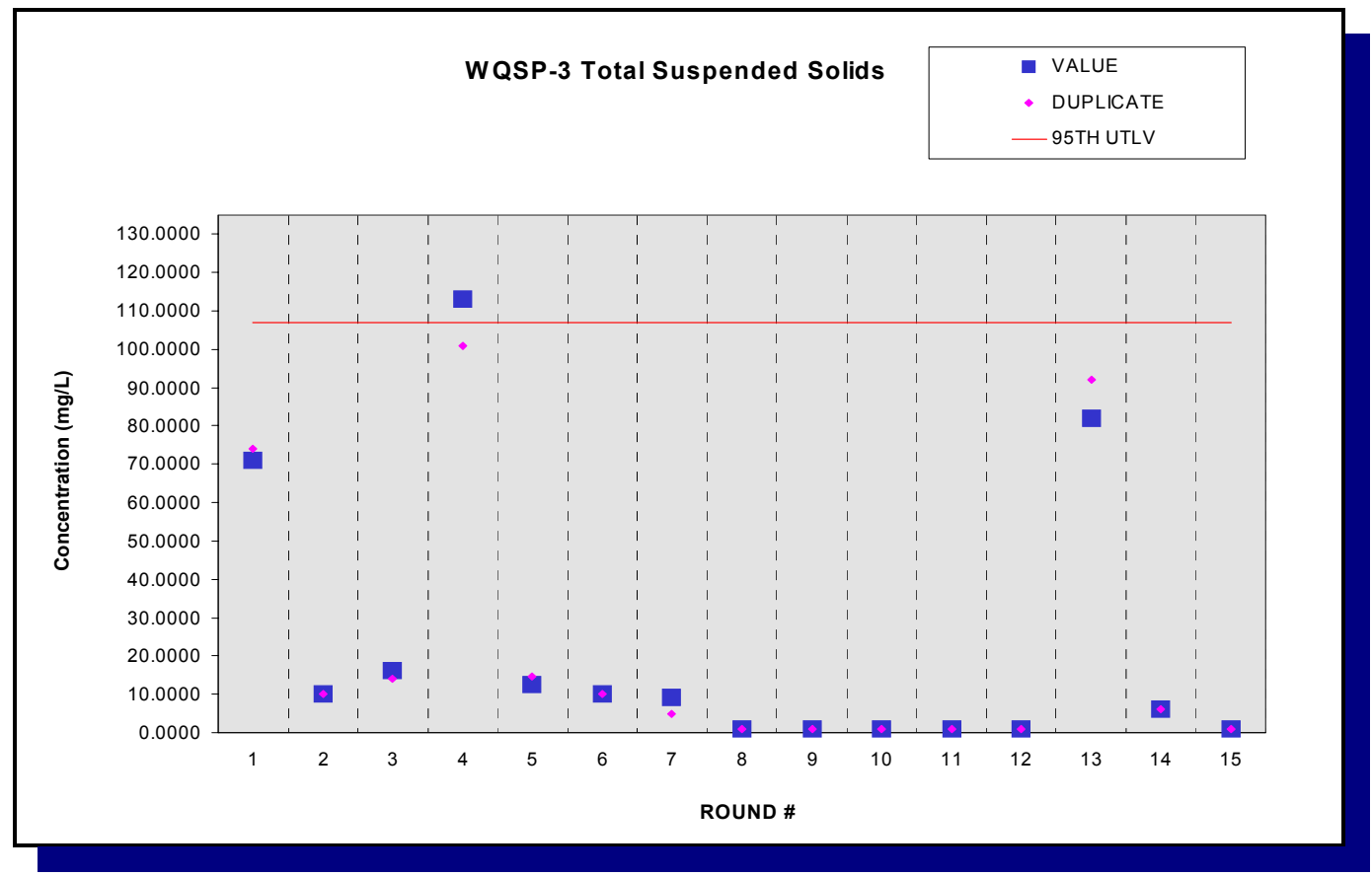

Figure F.42 - Time Trend Plot for Total Suspended Solids at WQSP-3

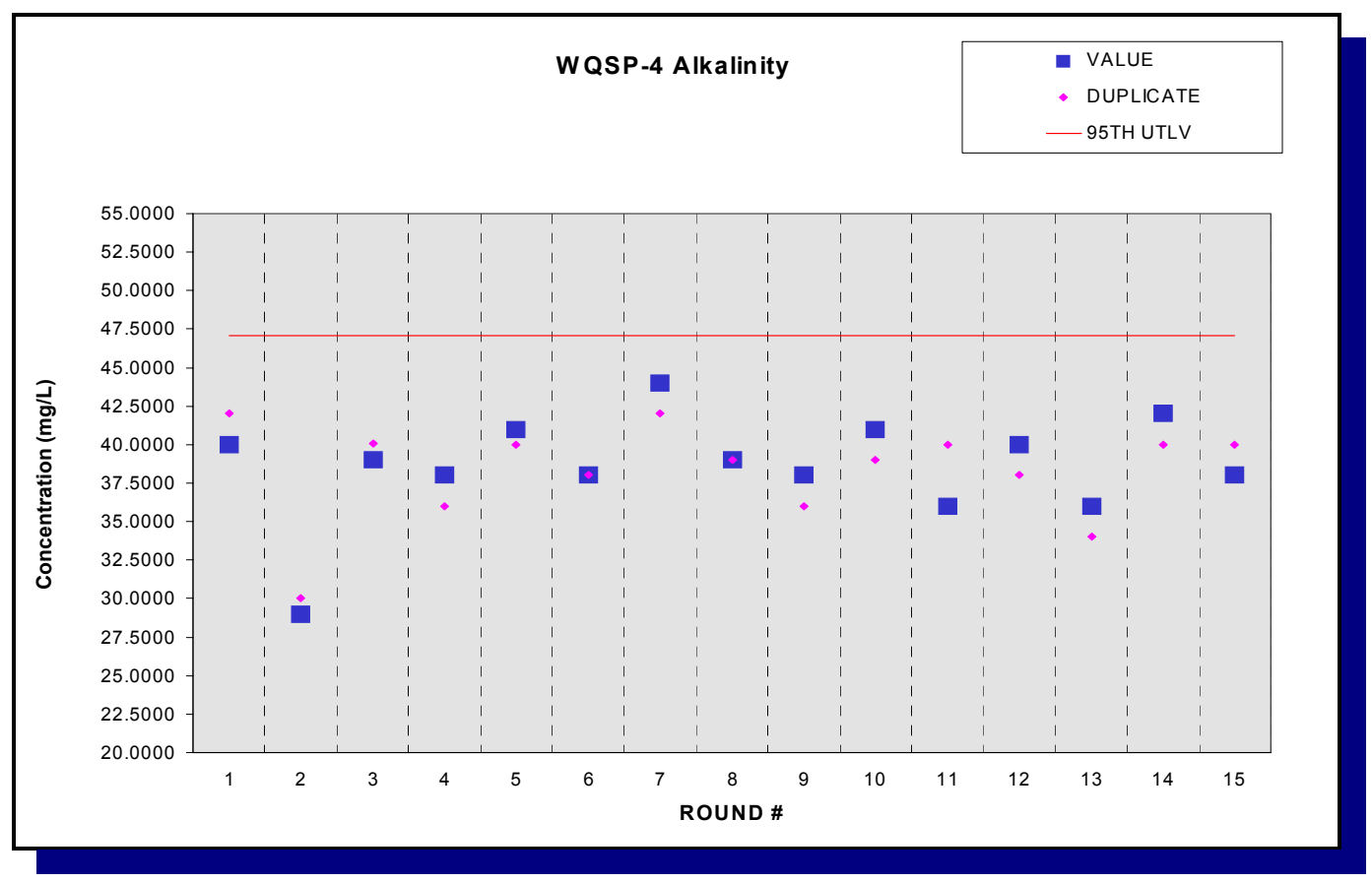

Figure F.43 - Time Trend Plot for Alkalinity at WQSP-4 


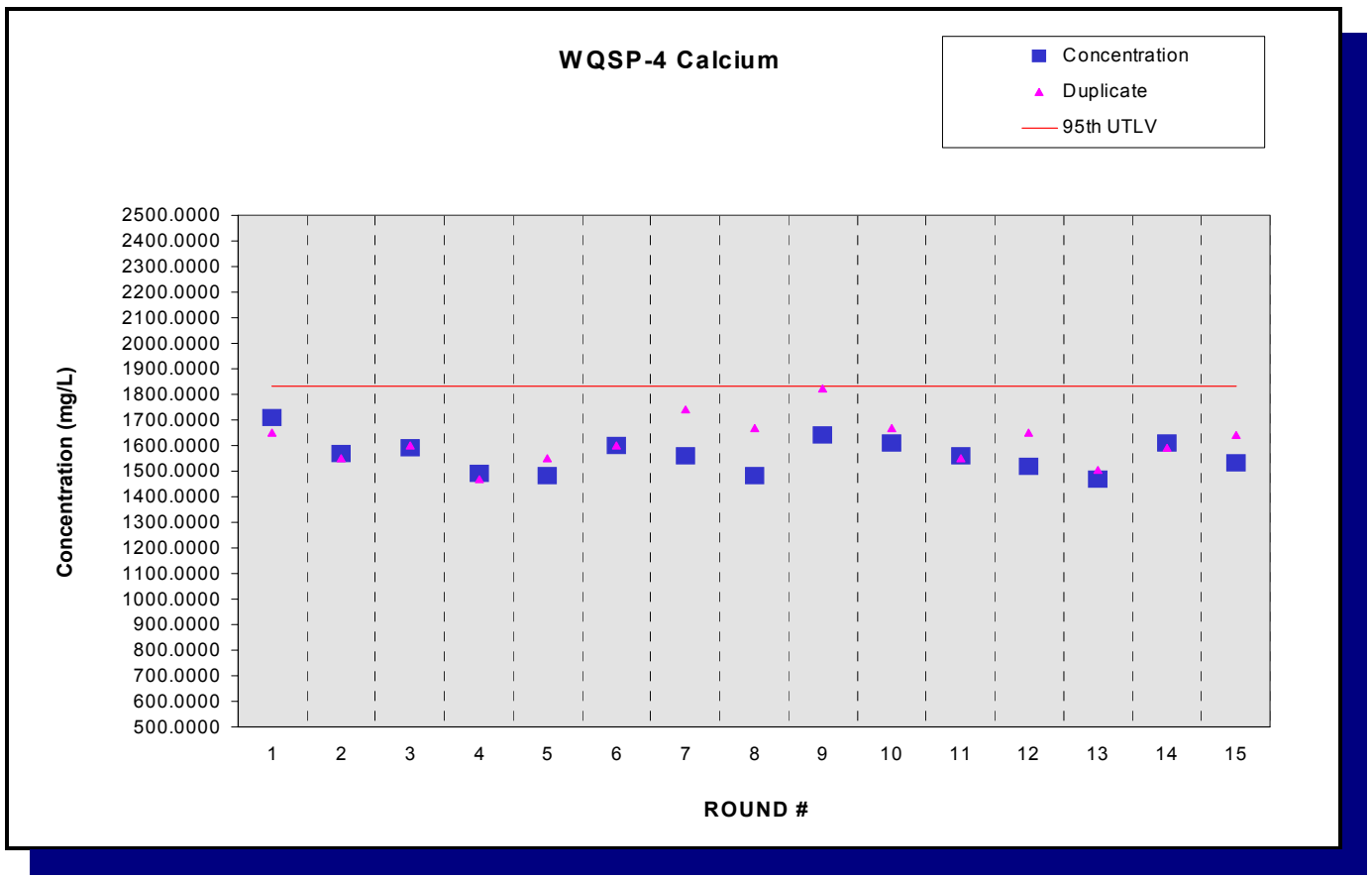

Figure F.44 - Time Trend Plot for Calcium at WQSP-4

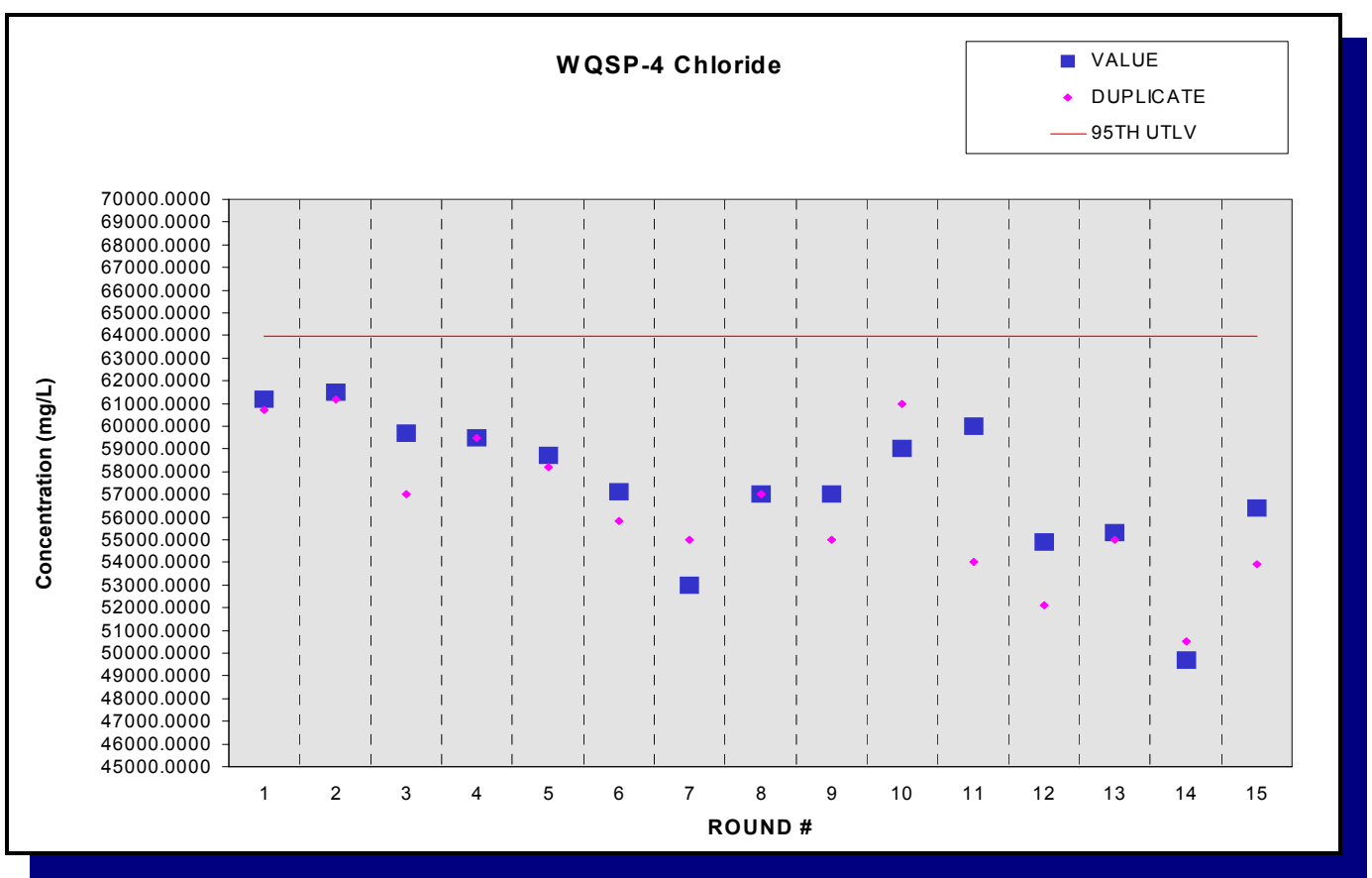

Figure F.45 - Time Trend Plot for Chloride at WQSP-4 


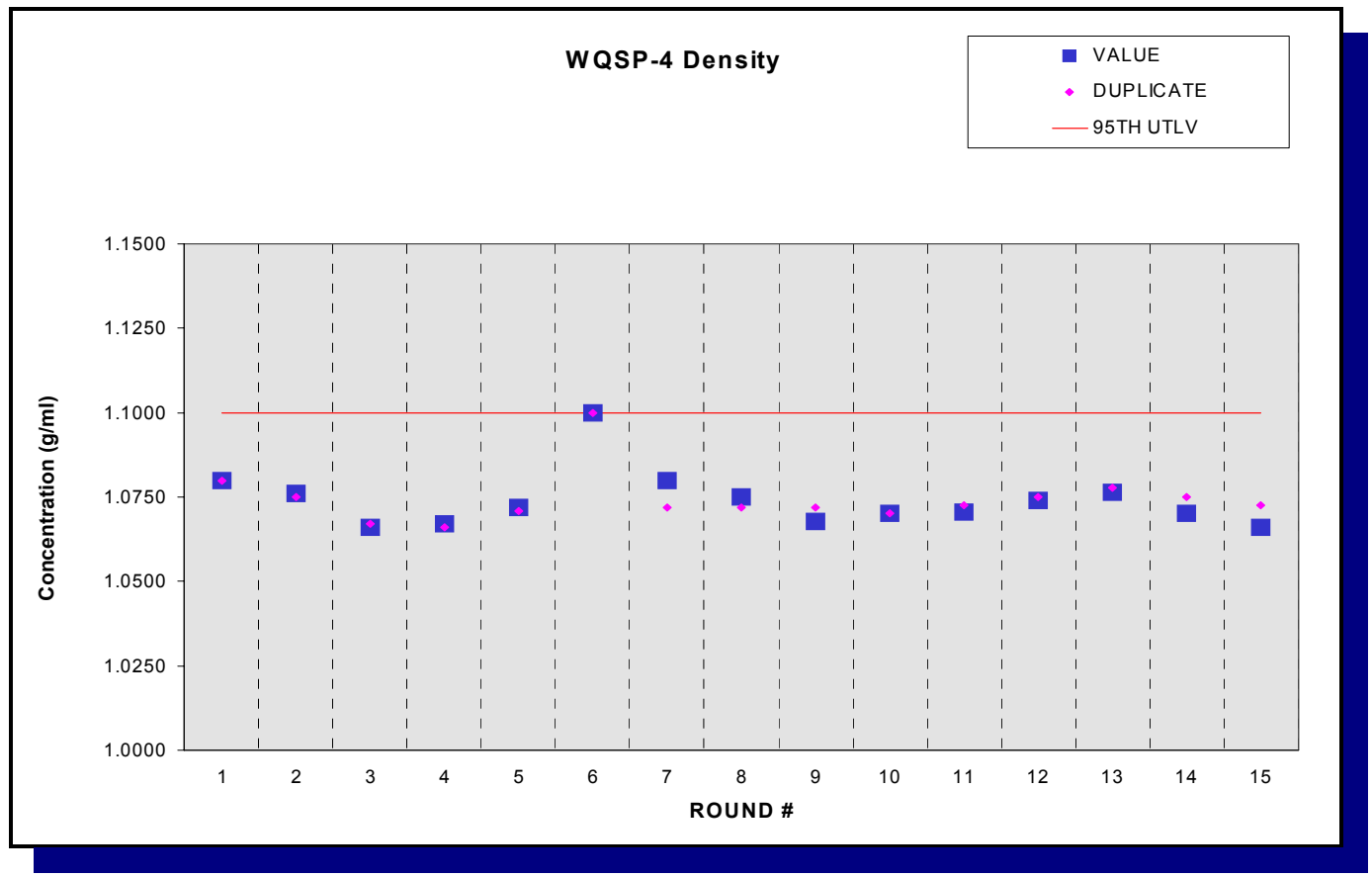

Figure F.46 - Time Trend Plot for Density at WQSP-4

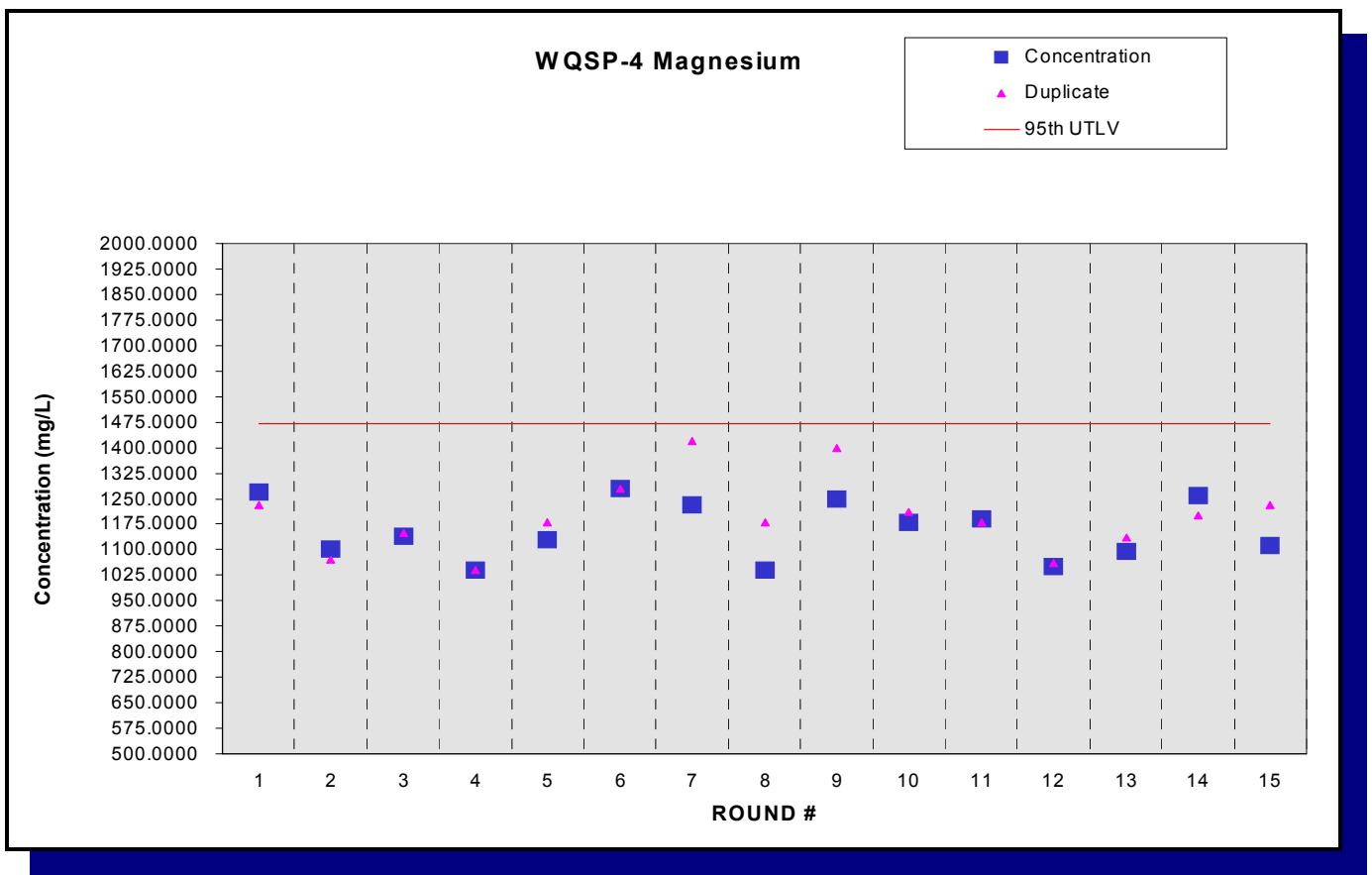

Figure F.47 - Time Trend Plot for Magnesium at WQSP-4 


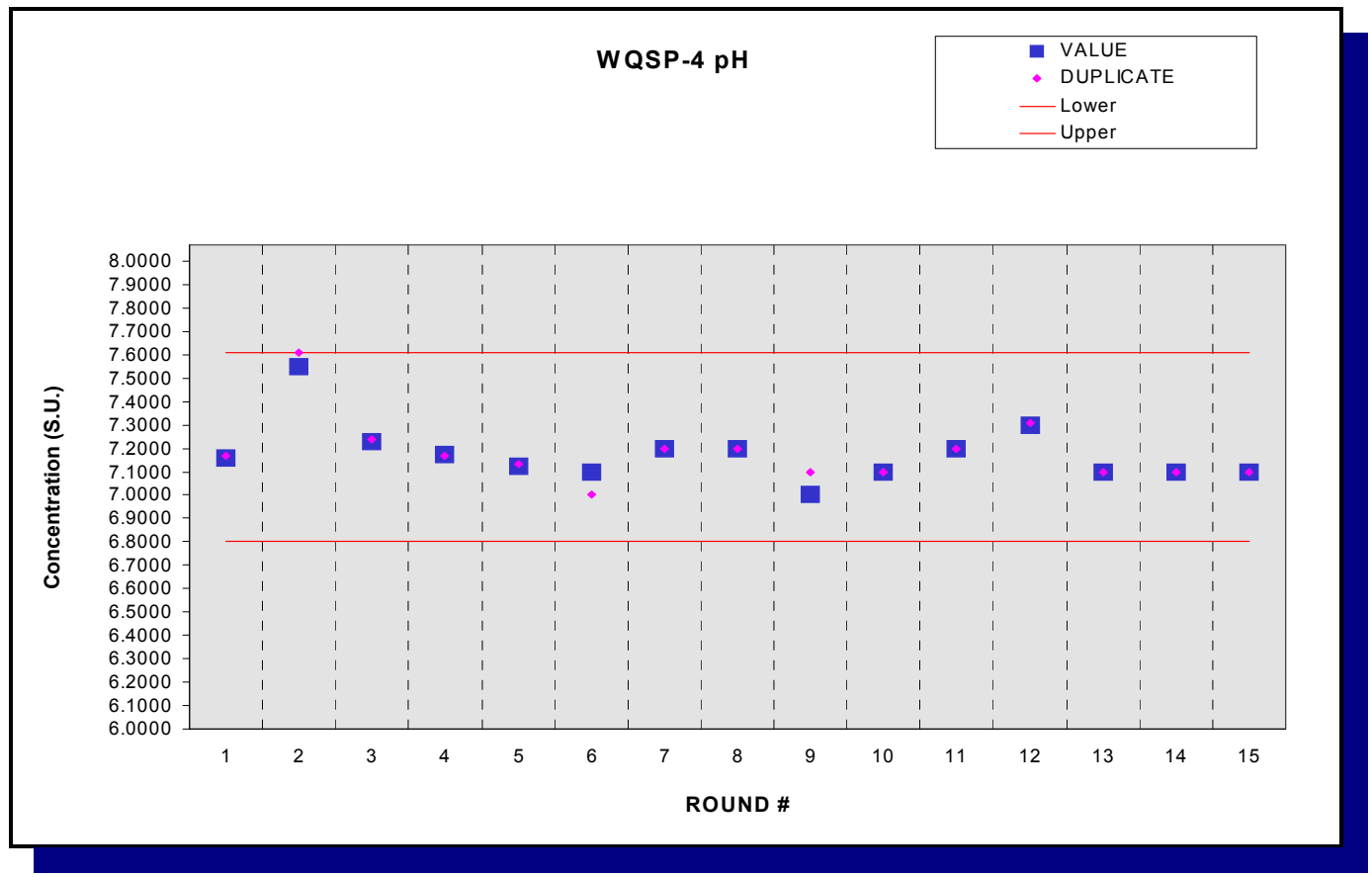

Figure F.48 - Time Trend Plot for $\mathrm{pH}$ at WQSP-4

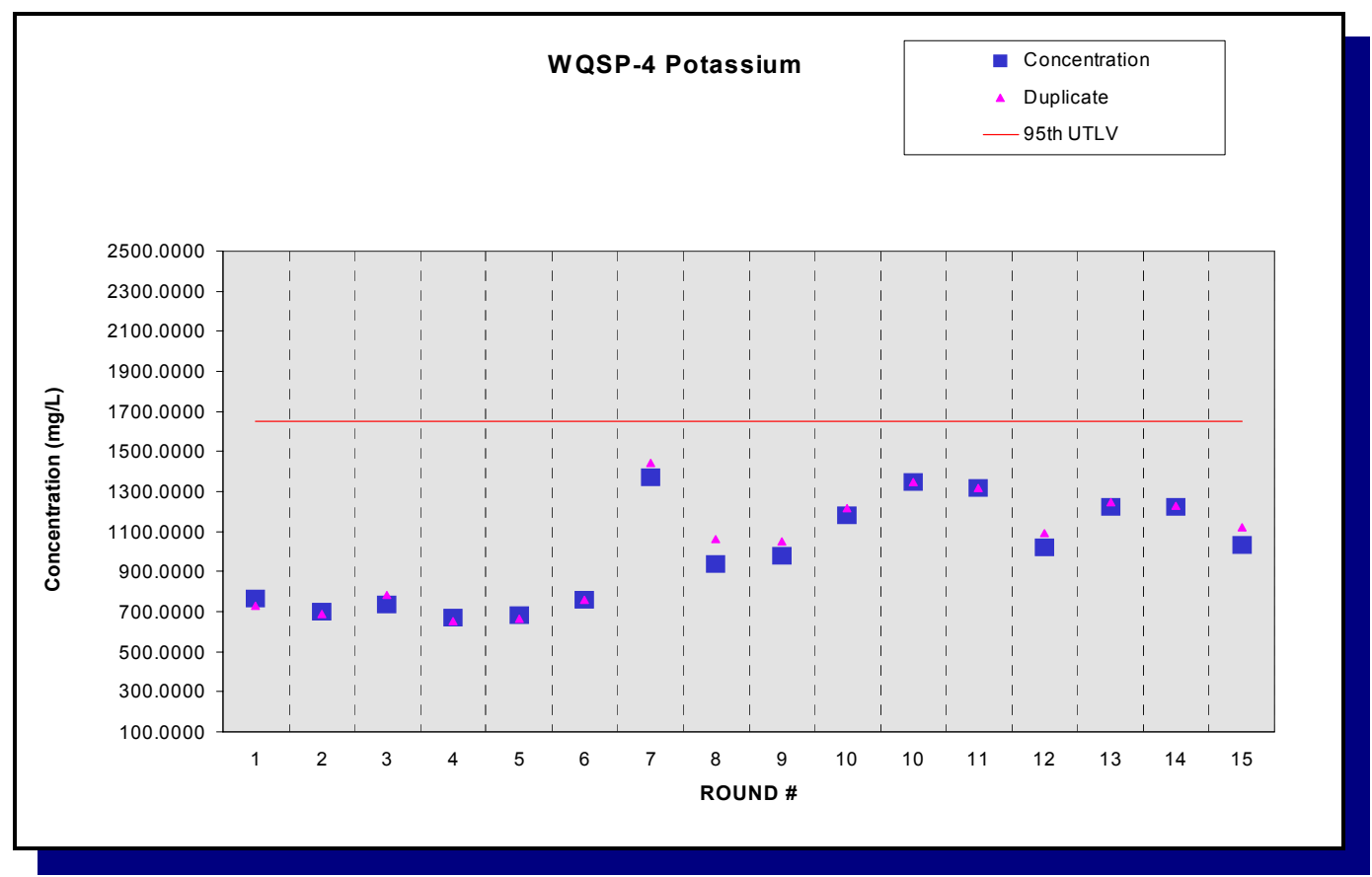

Figure F.49 - Time Trend Plot for Potassium at WQSP-4 


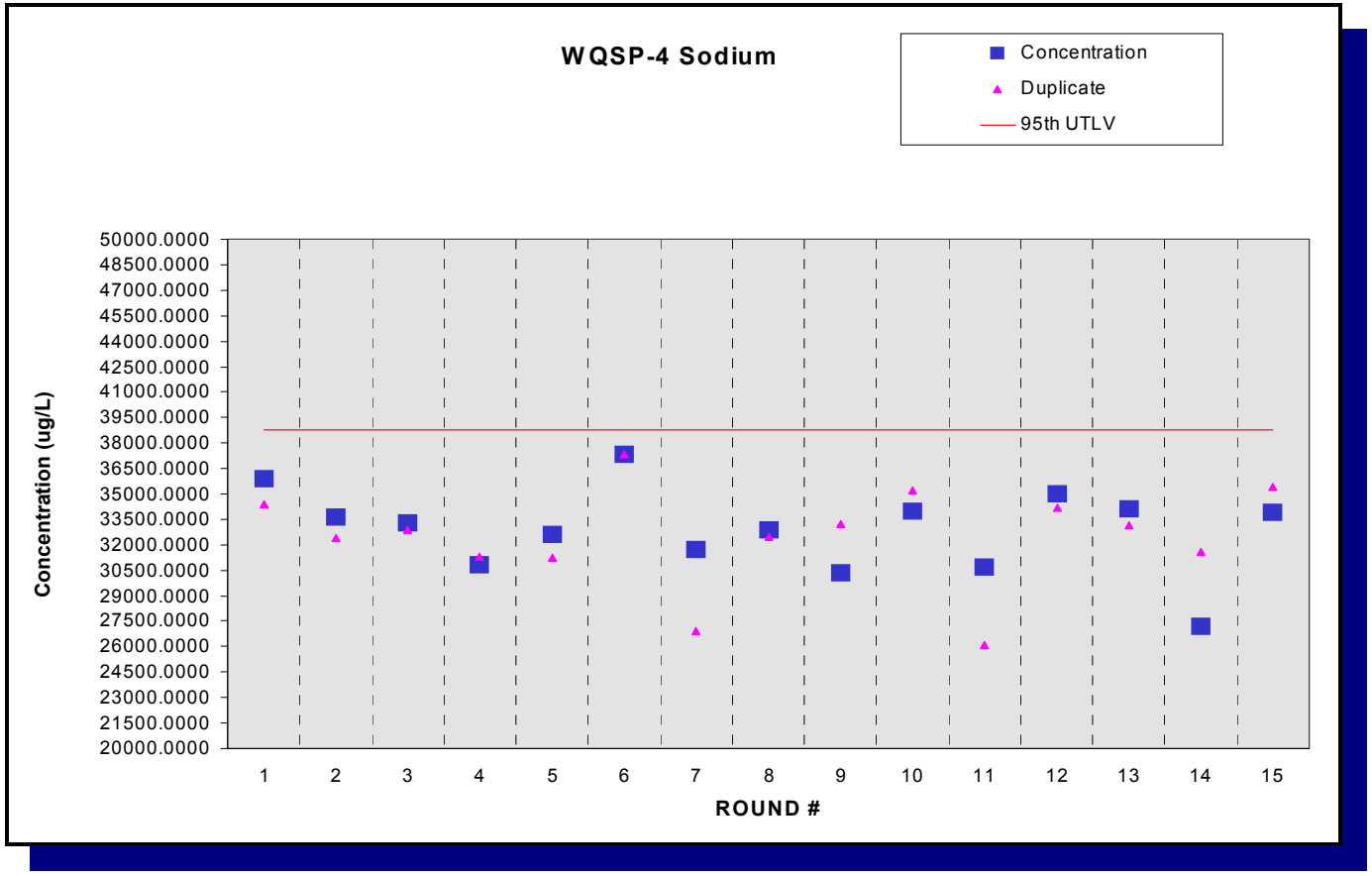

Figure F.50 - Time Trend Plot for Sodium at WQSP-4

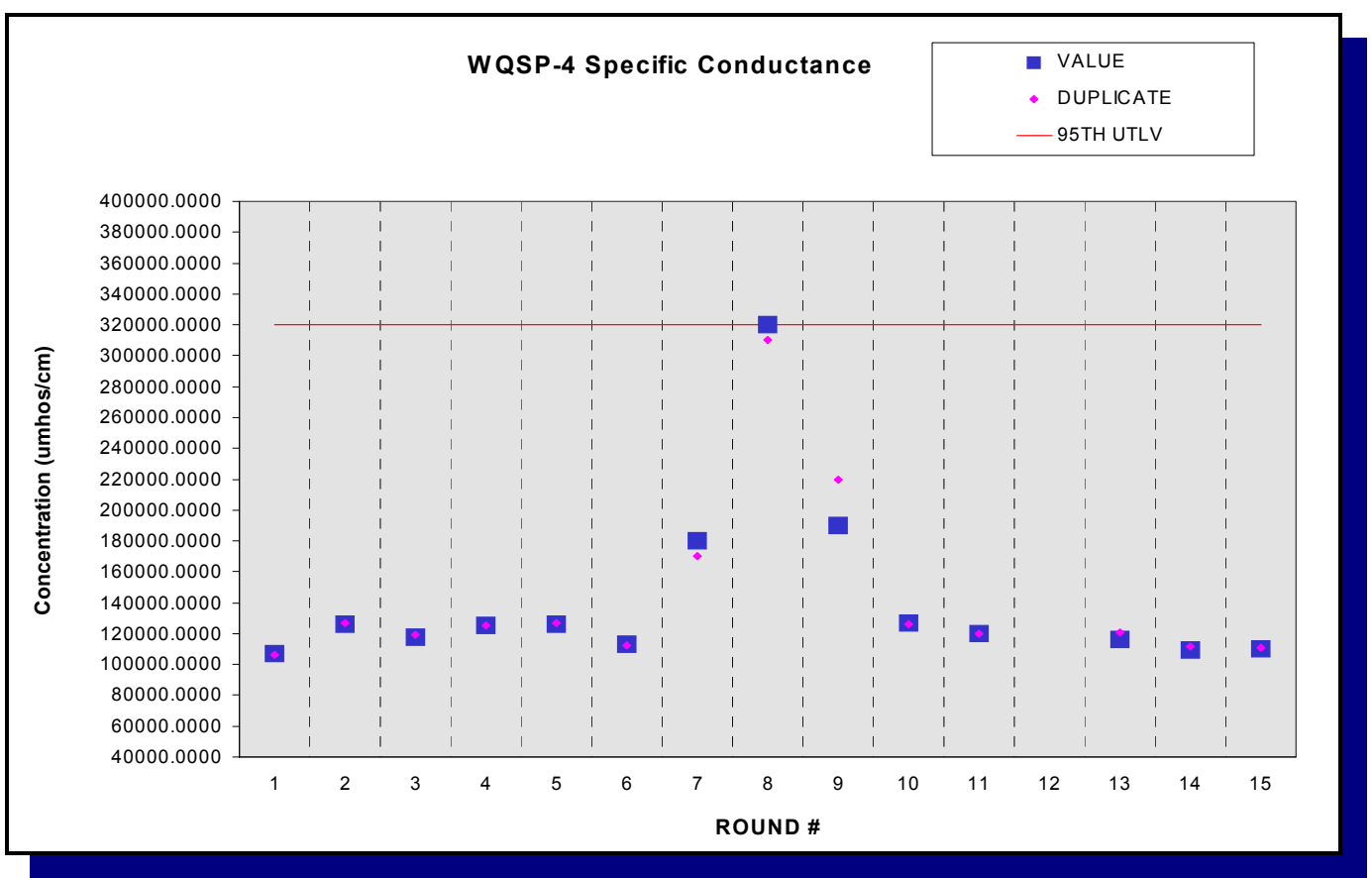

Figure F.51 - Time Trend Plot for Specific Conductance at WQSP-4 


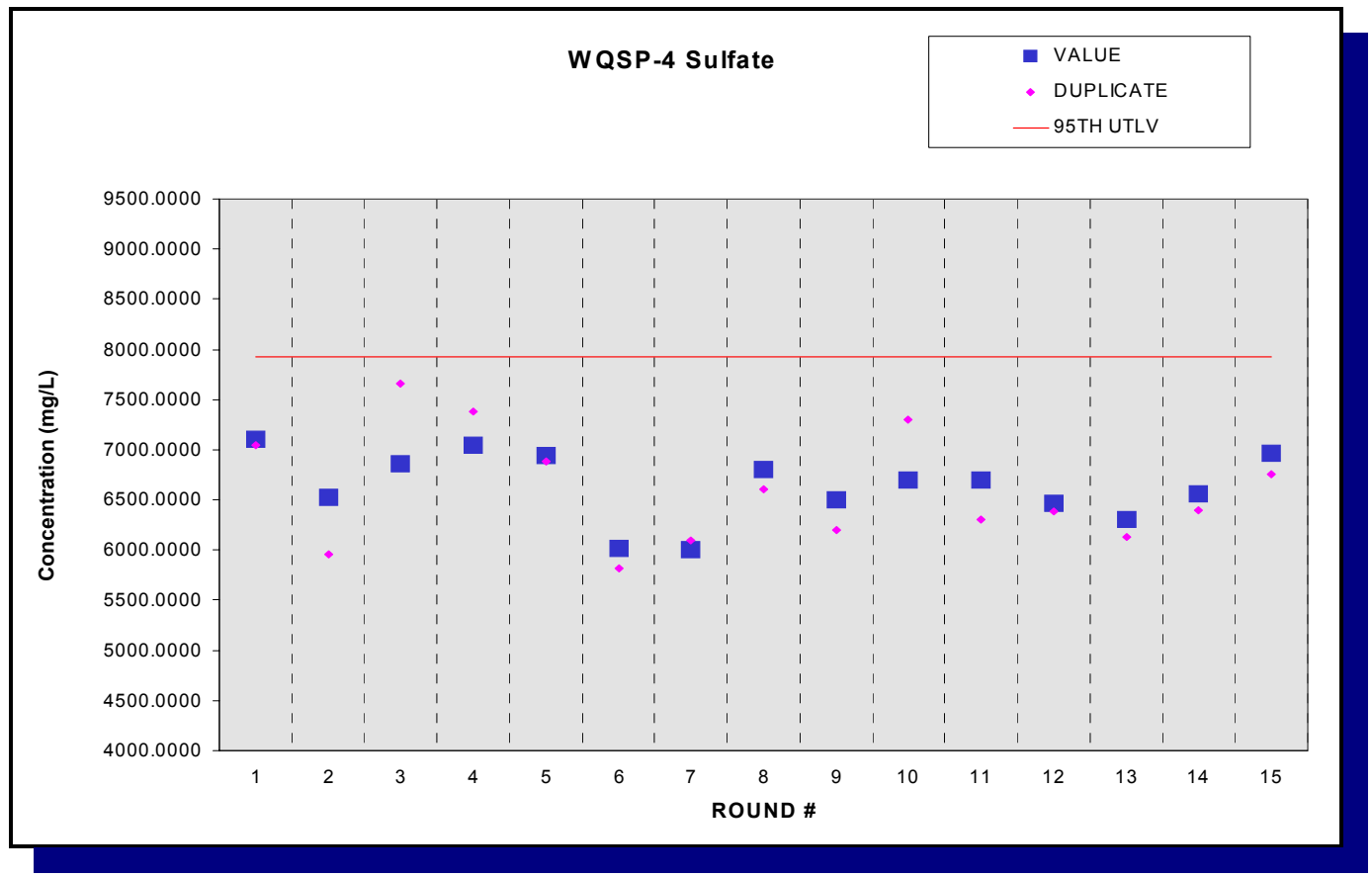

Figure F.52 - Time Trend Plot for Sulfate at WQSP-4

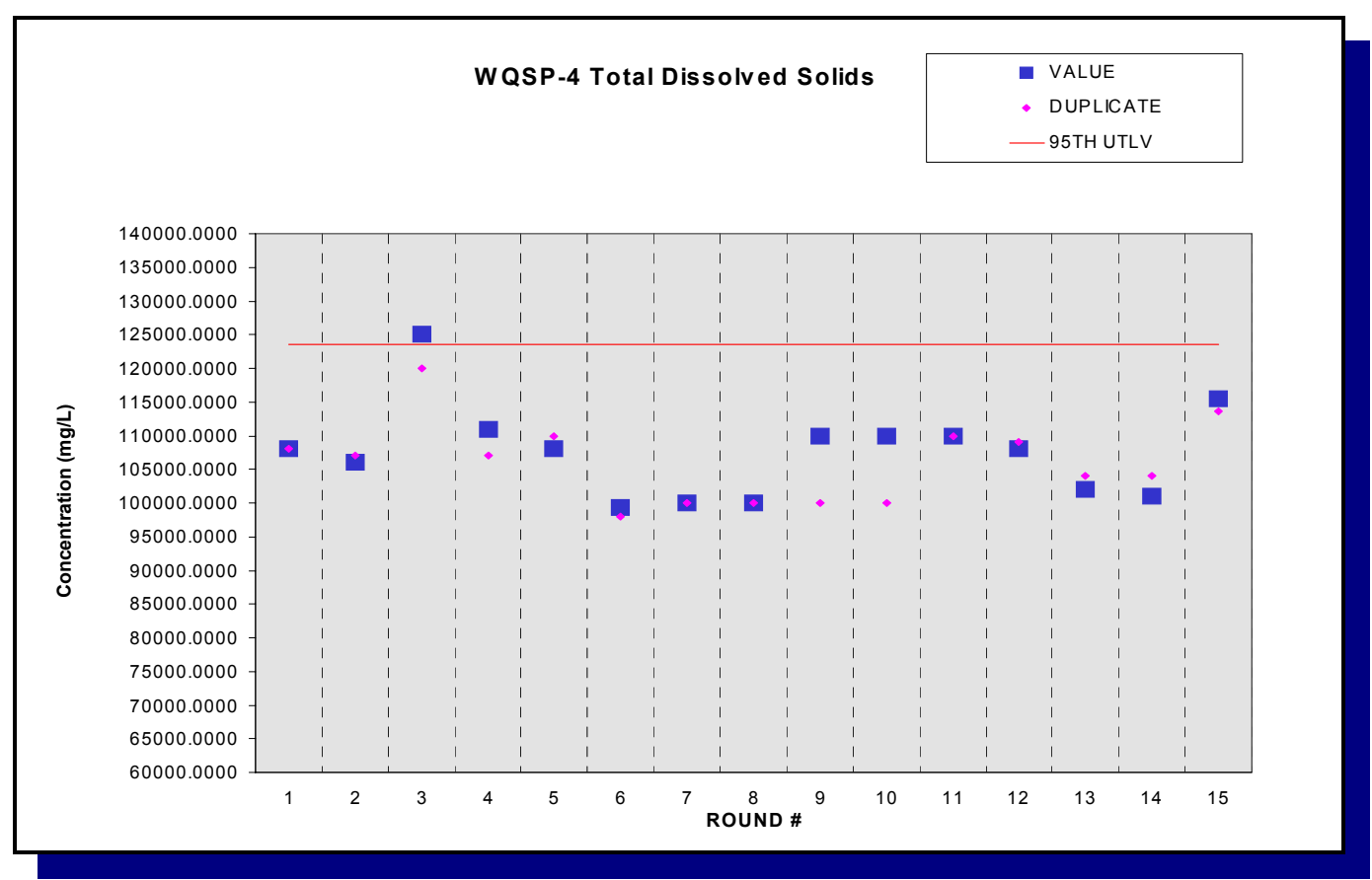

Figure F.53 - Time Trend Plot for Total Dissolved Solids at WQSP-4 


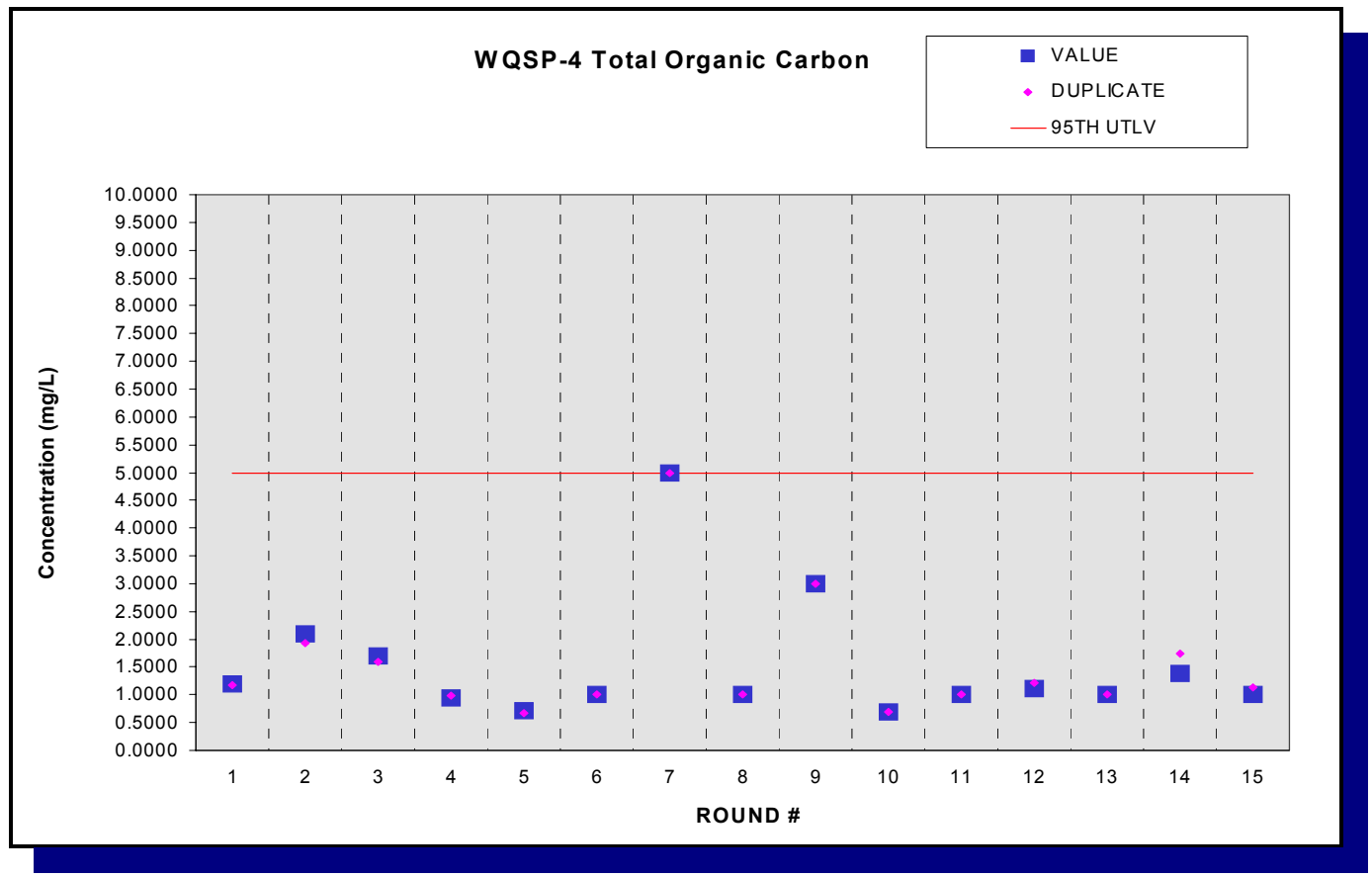

Figure F.54 - Time Trend Plot for Total Organic Carbon at WQSP-4

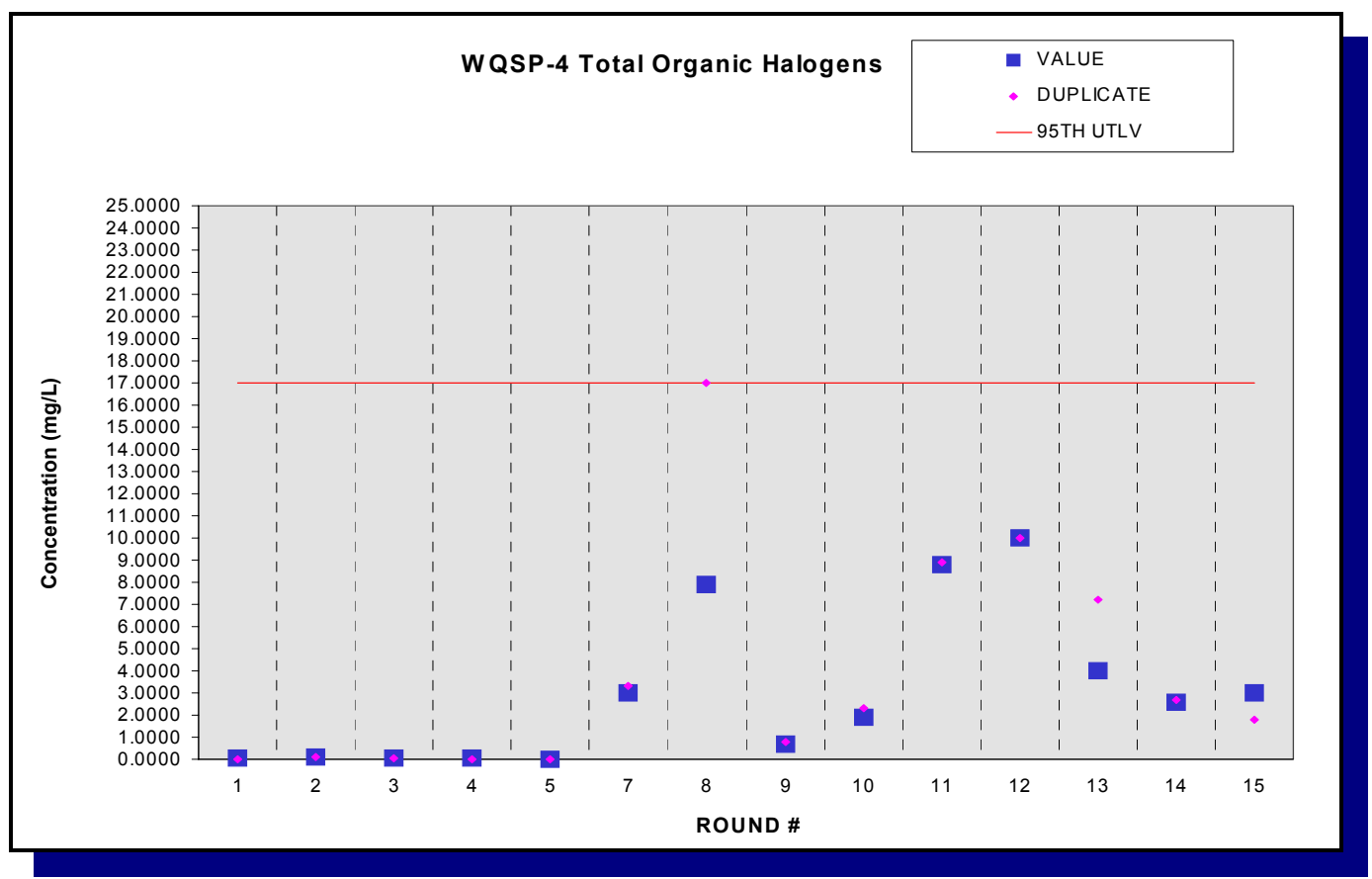

Figure F.55 - Time Trend Plot for Total Organic Halogens at WQSP-4 


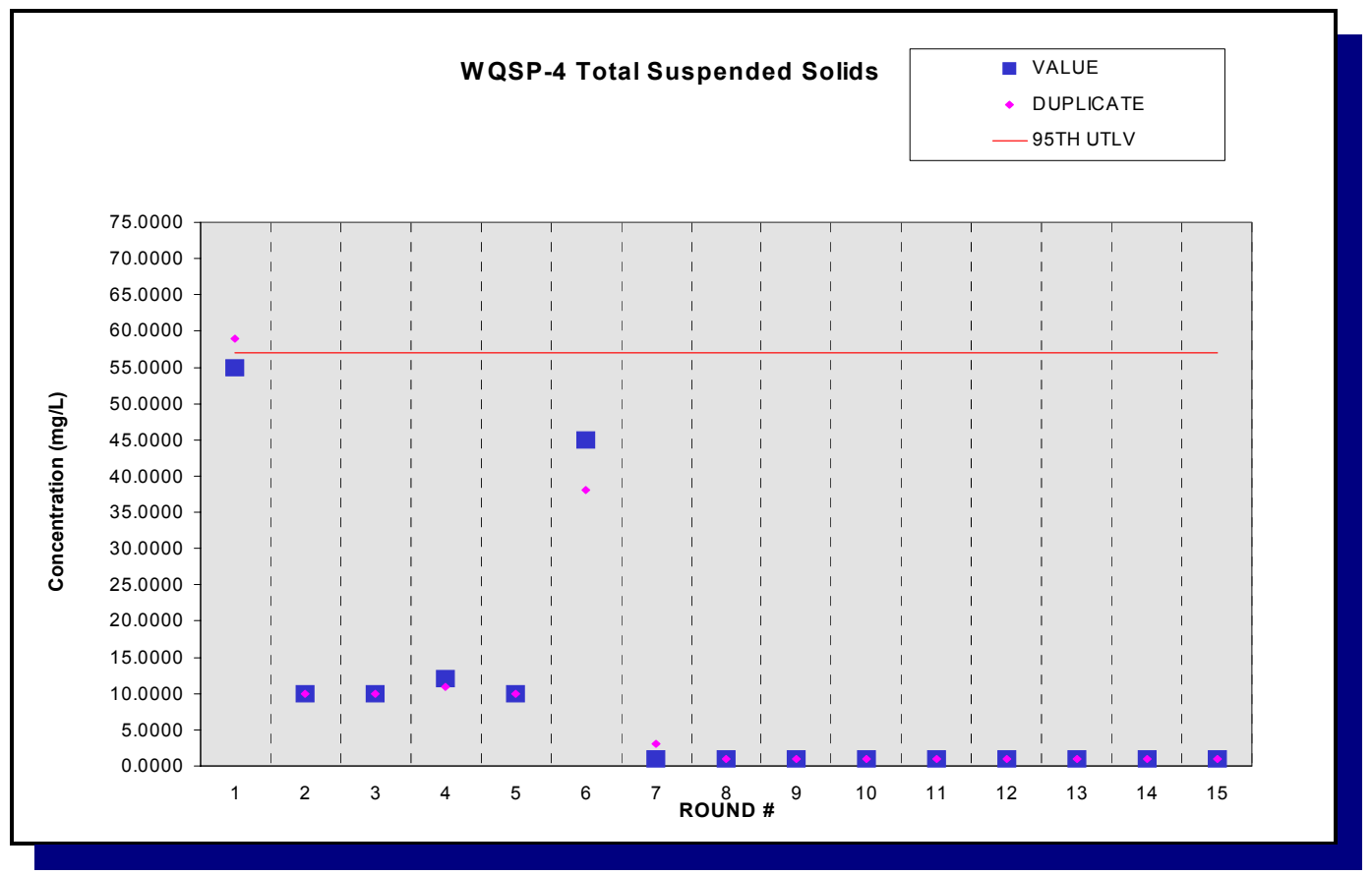

Figure F.56 - Time Trend Plot for Total Suspended Solids at WQSP-4

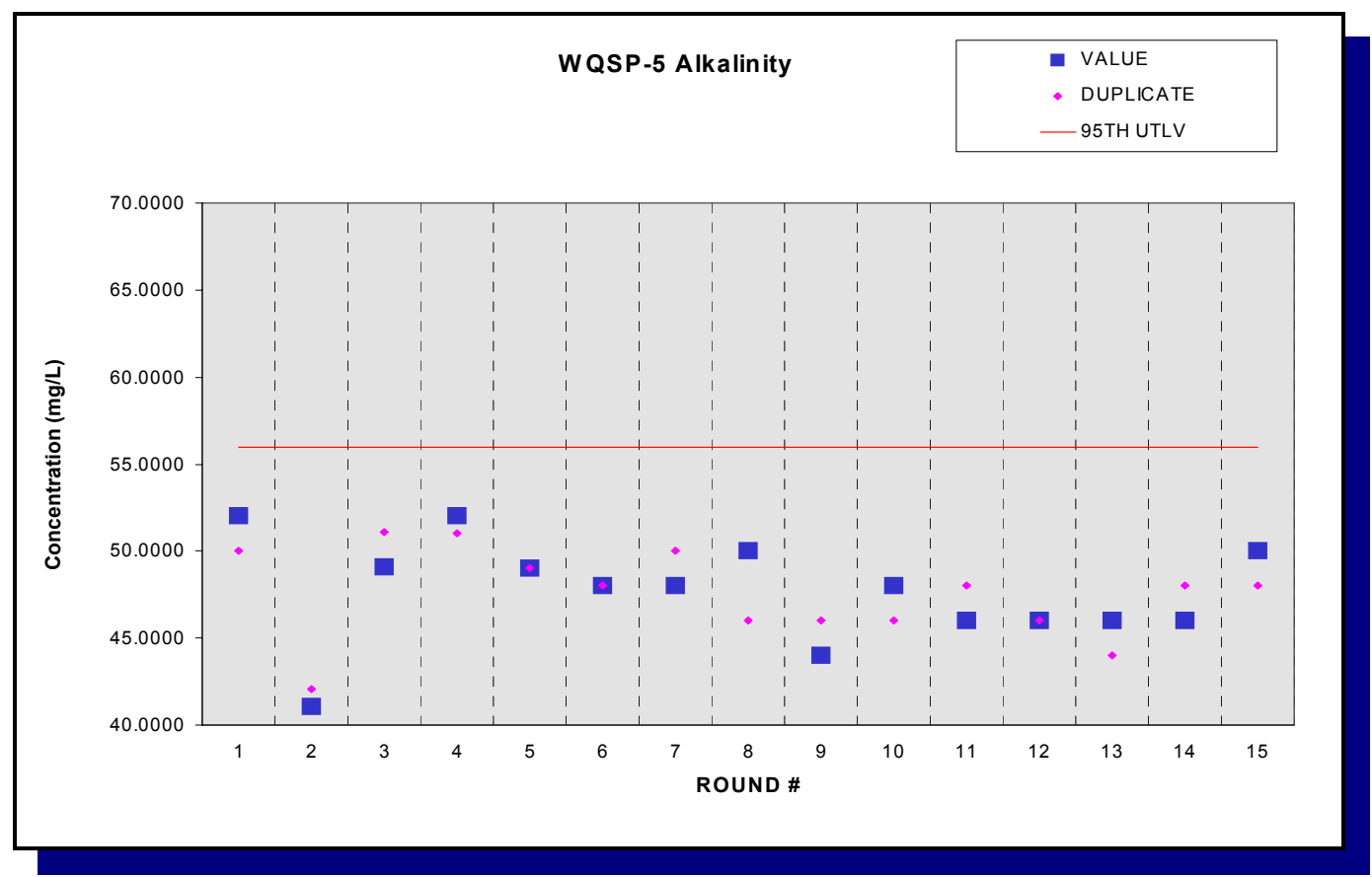

Figure F.57 - Time Trend Plot for Alkalinity at WQSP-5 


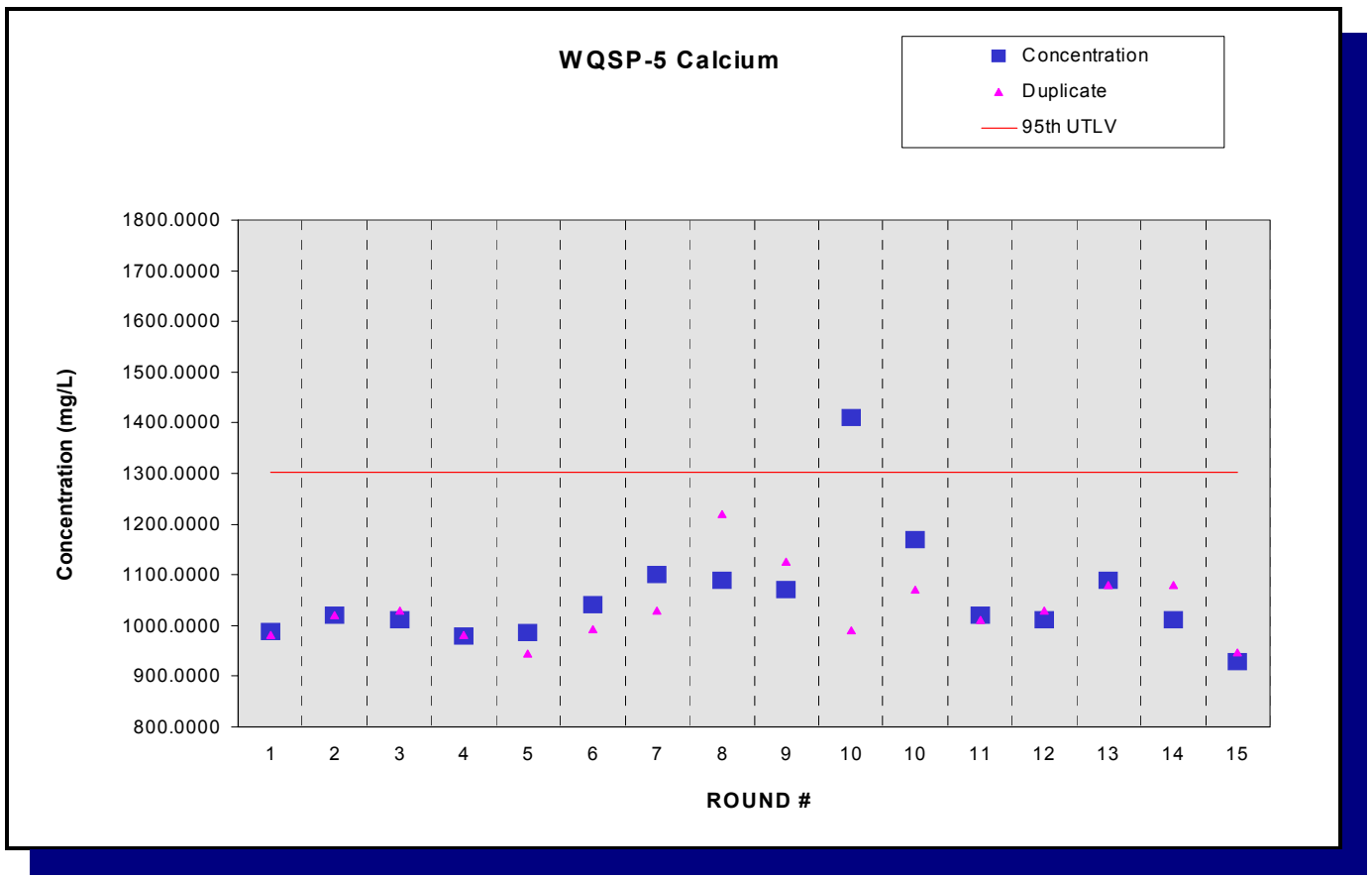

Figure F.58 - Time Trend Plot for Calcium at WQSP-5

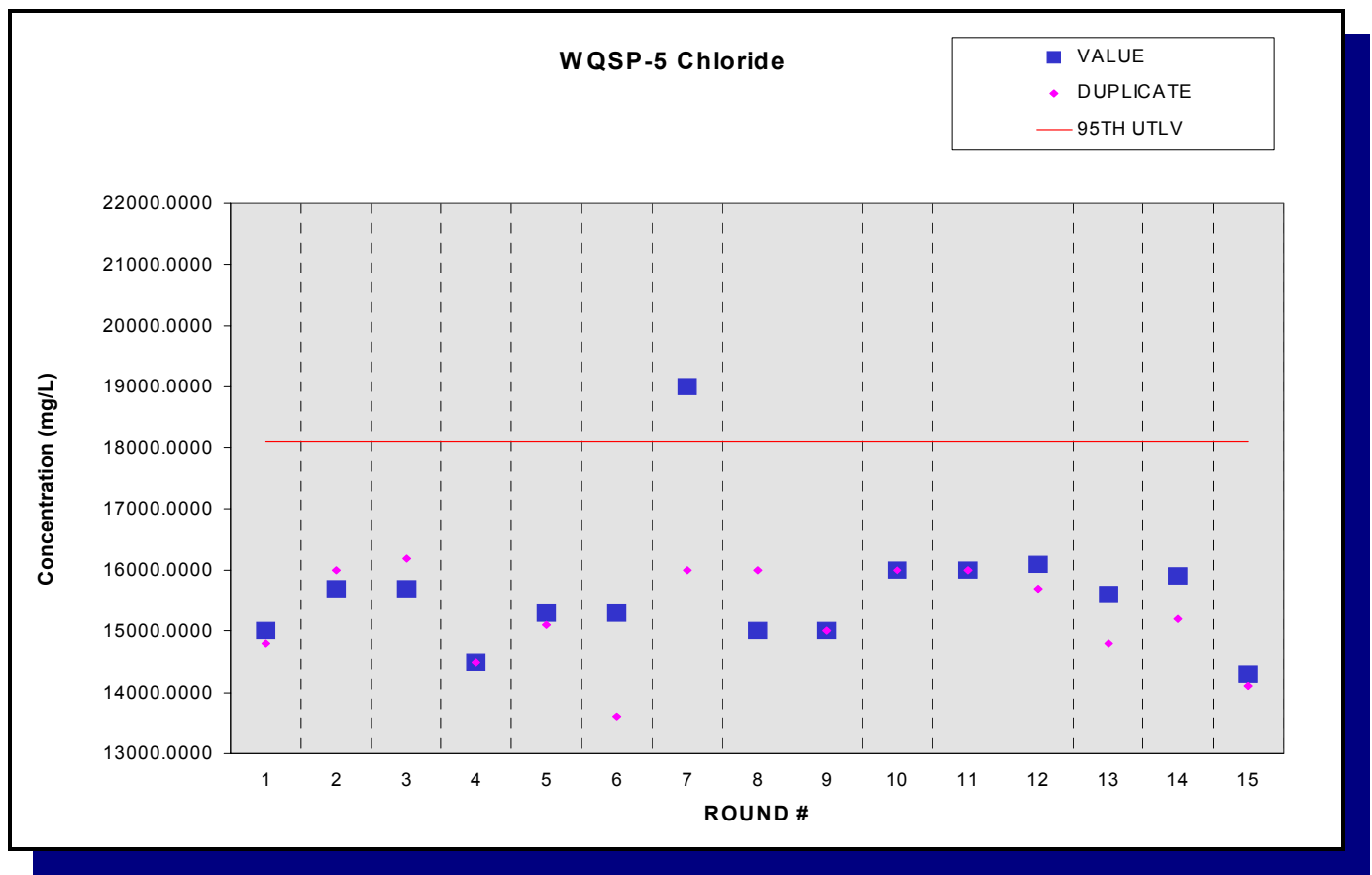

Figure F.59 - Time Trend Plot for Chloride at WQSP-5 


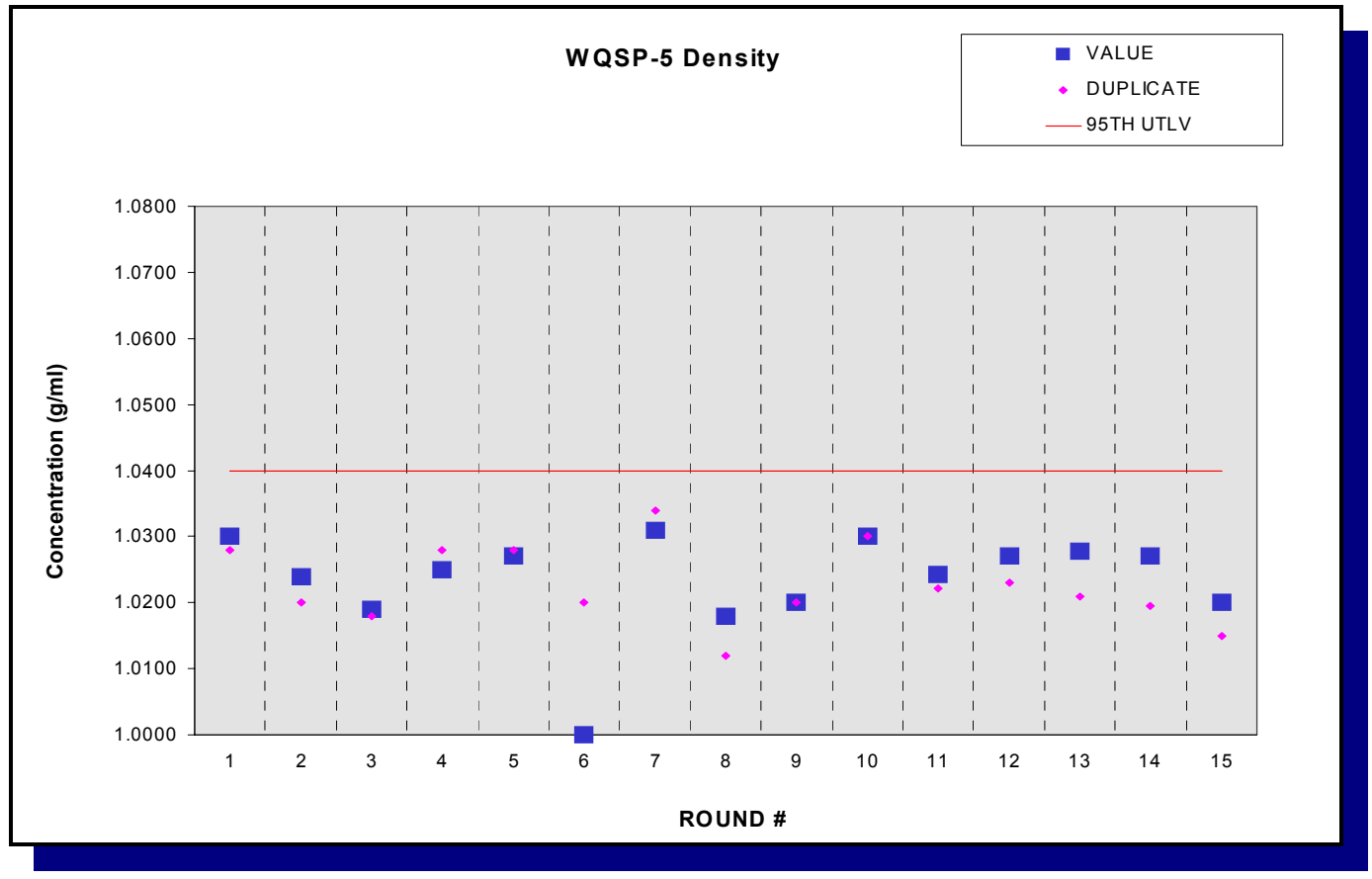

Figure F.60 - Time Trend Plot for Density at WQSP-5

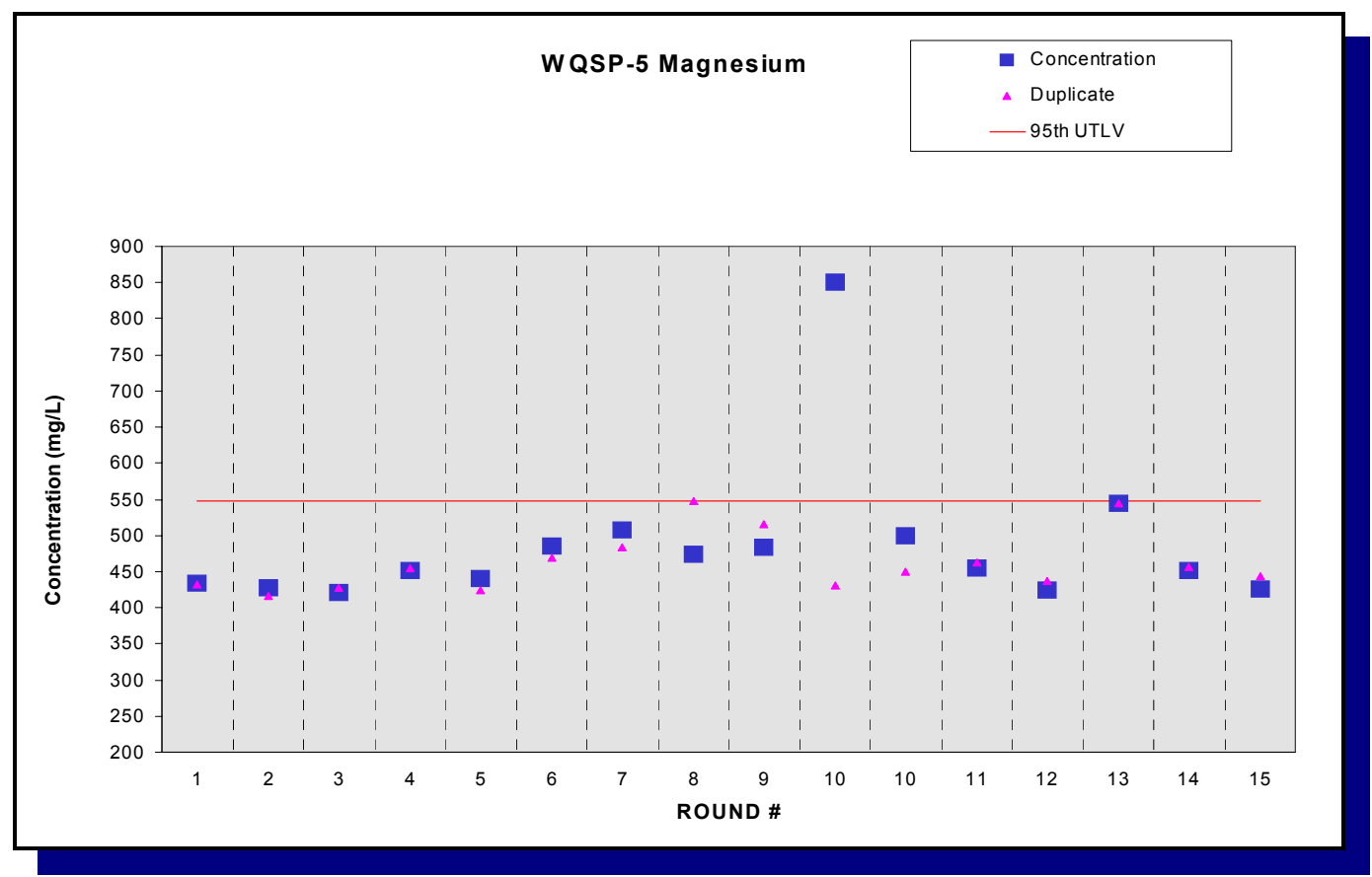

Figure F.61 - Time Trend Plot for Magnesium at WQSP-5 


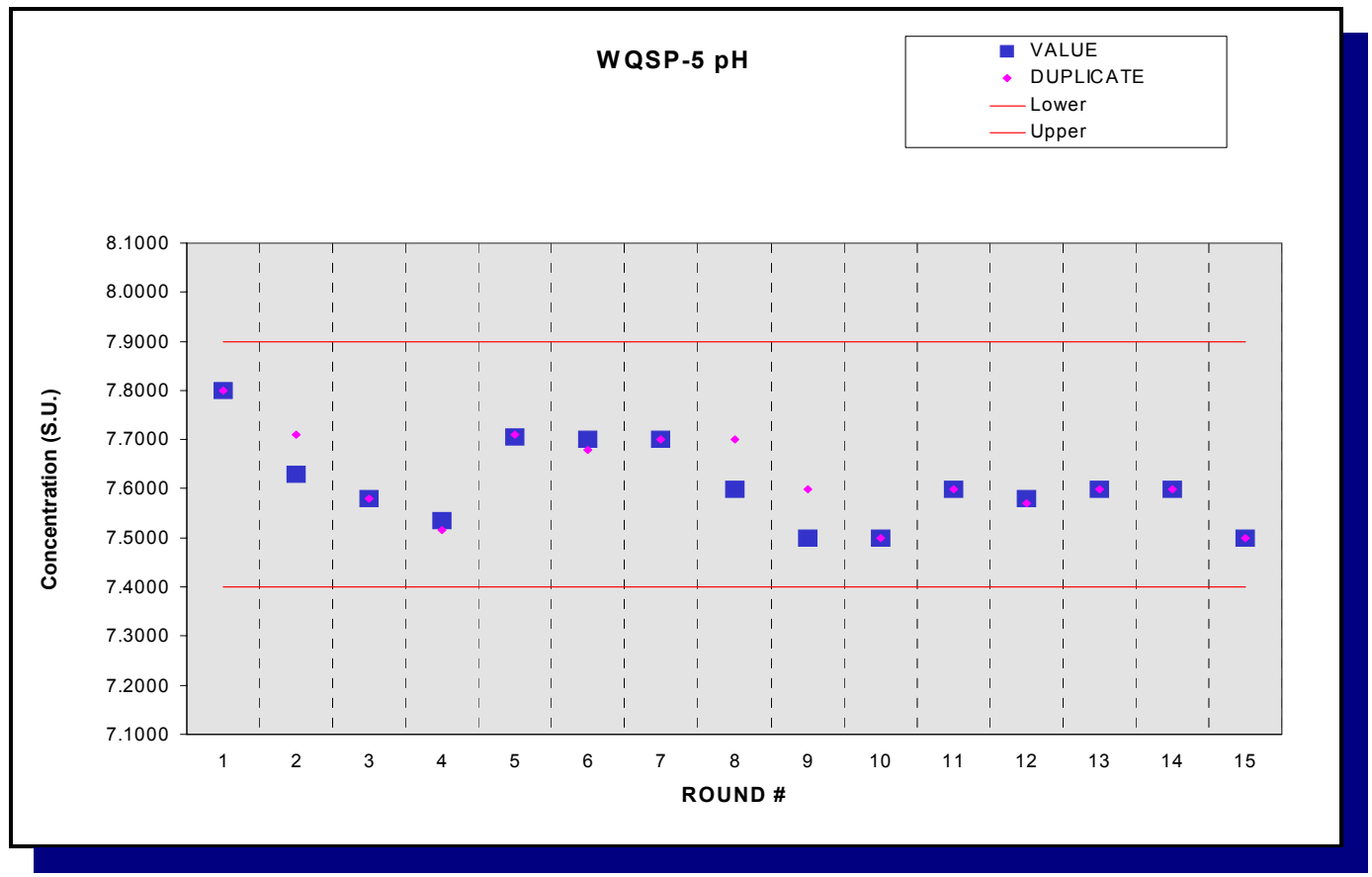

Figure F.62 - Time Trend Plot for pH at WQSP-5

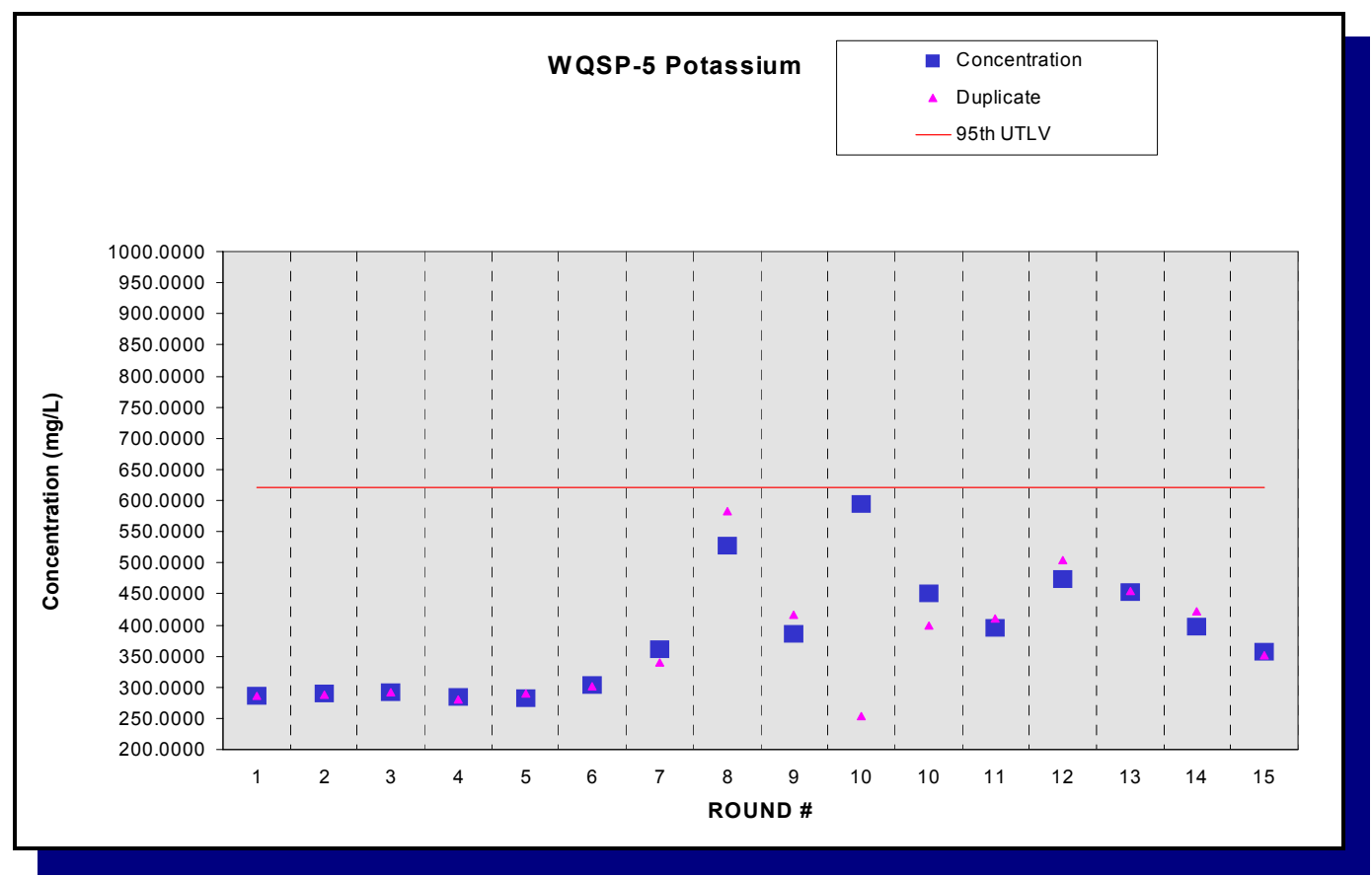

Figure F.63 - Time Trend Plot for Potassium at WQSP-5 


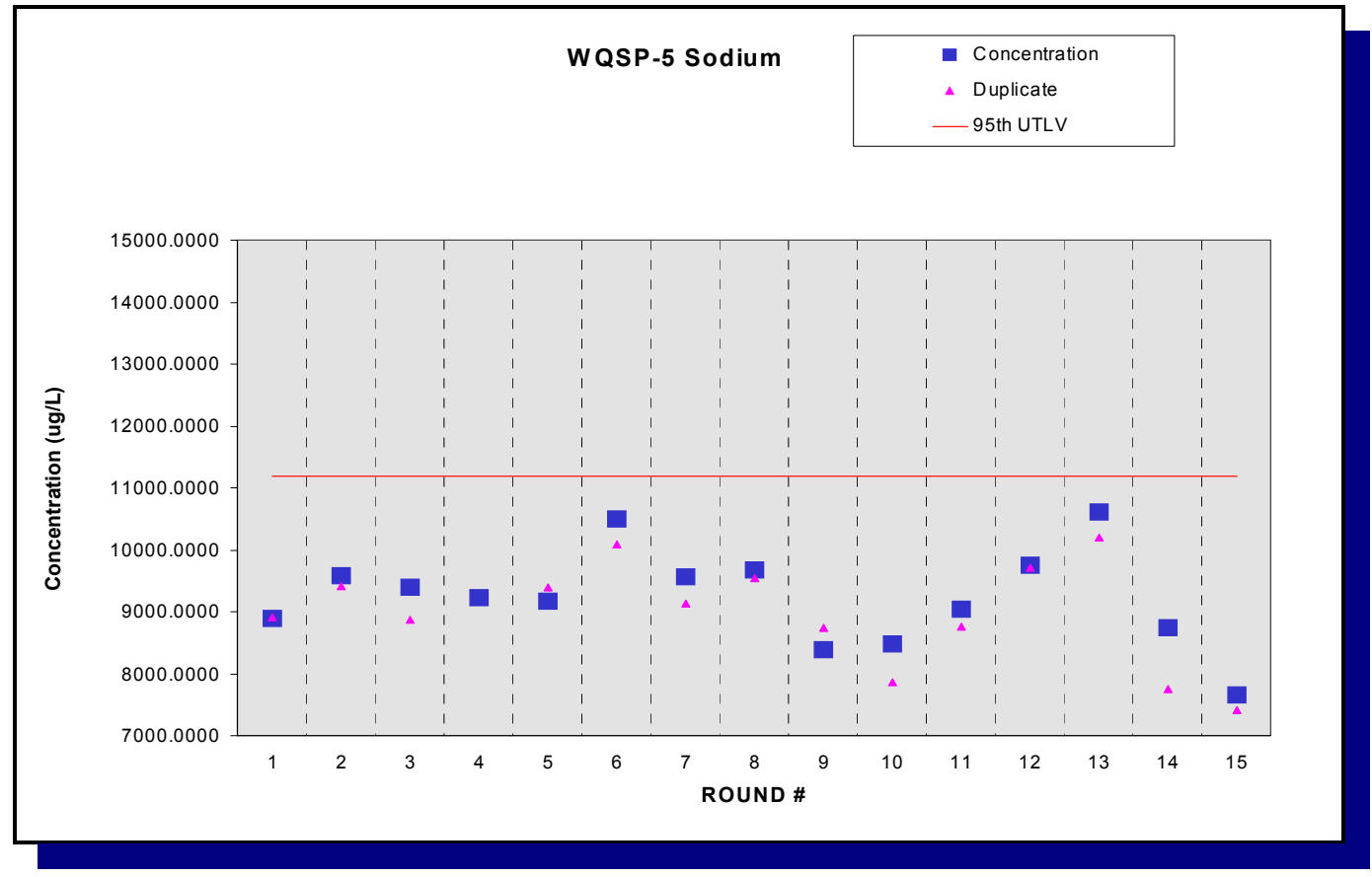

Figure F.64 - Time Trend Plot for Sodium at WQSP-5

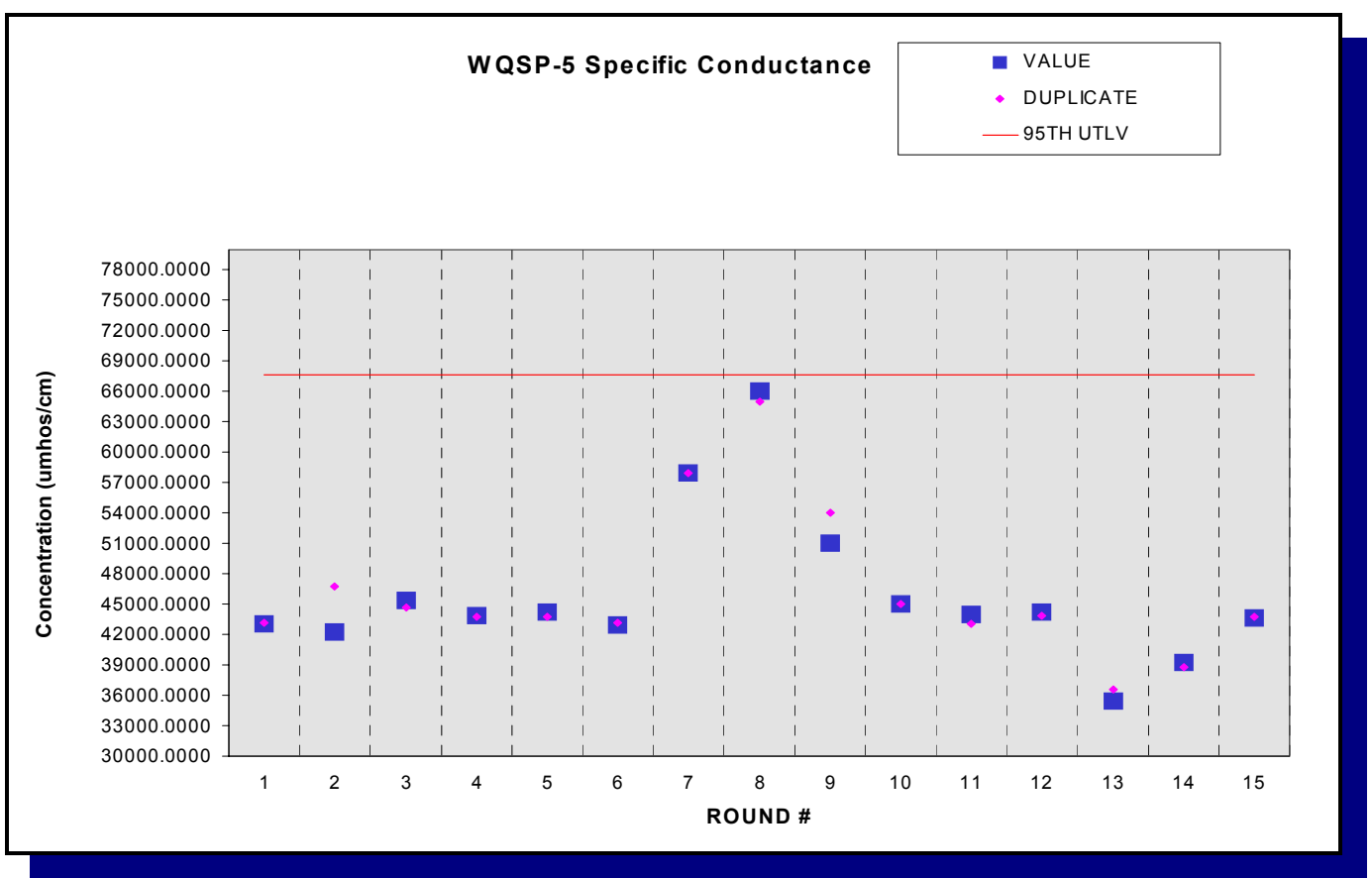

Figure F.65 - Time Trend Plot for Specific Conductance at WQSP-5 


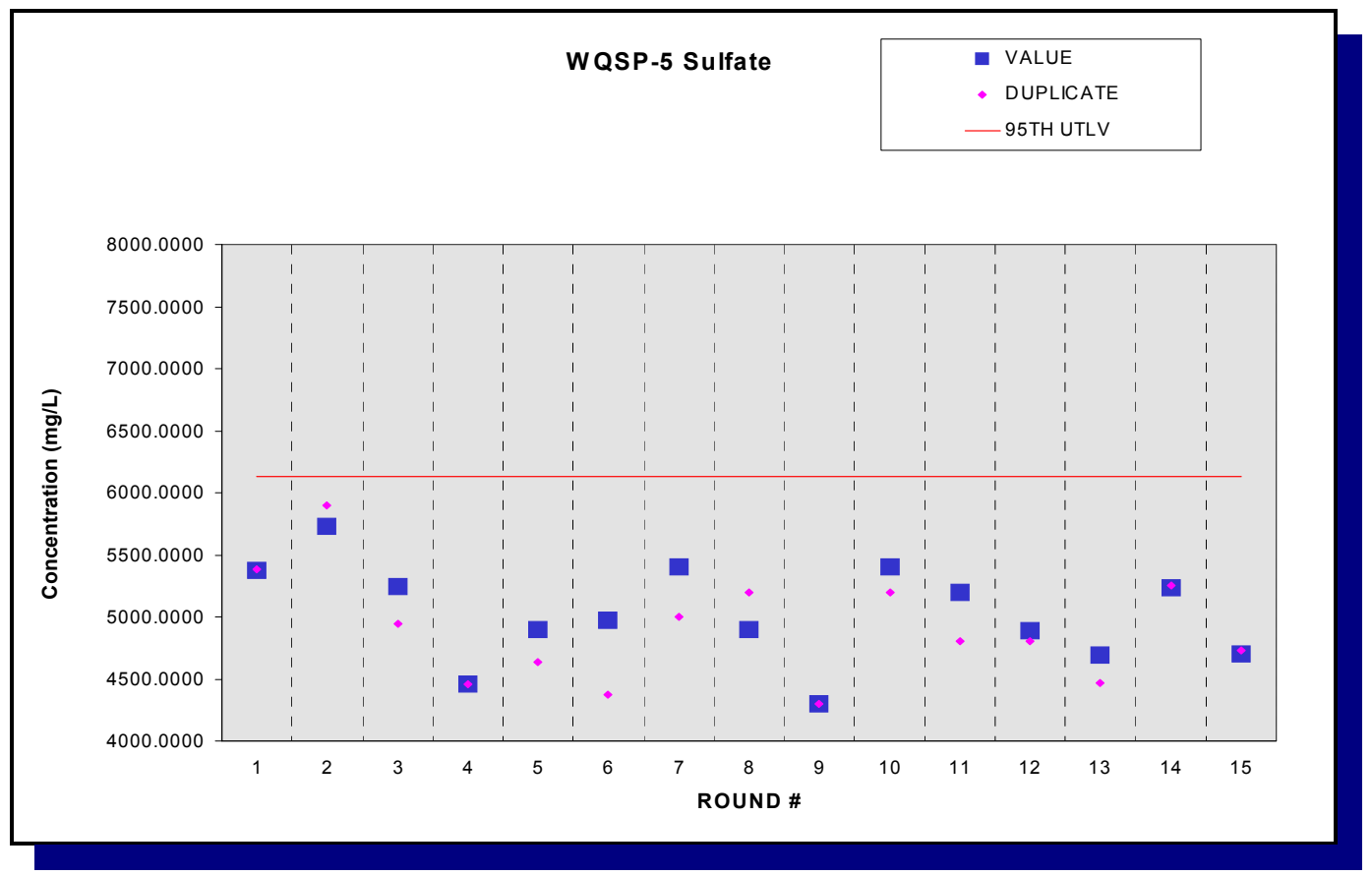

Figure F.66 - Time Trend Plot for Sulfate at WQSP-5

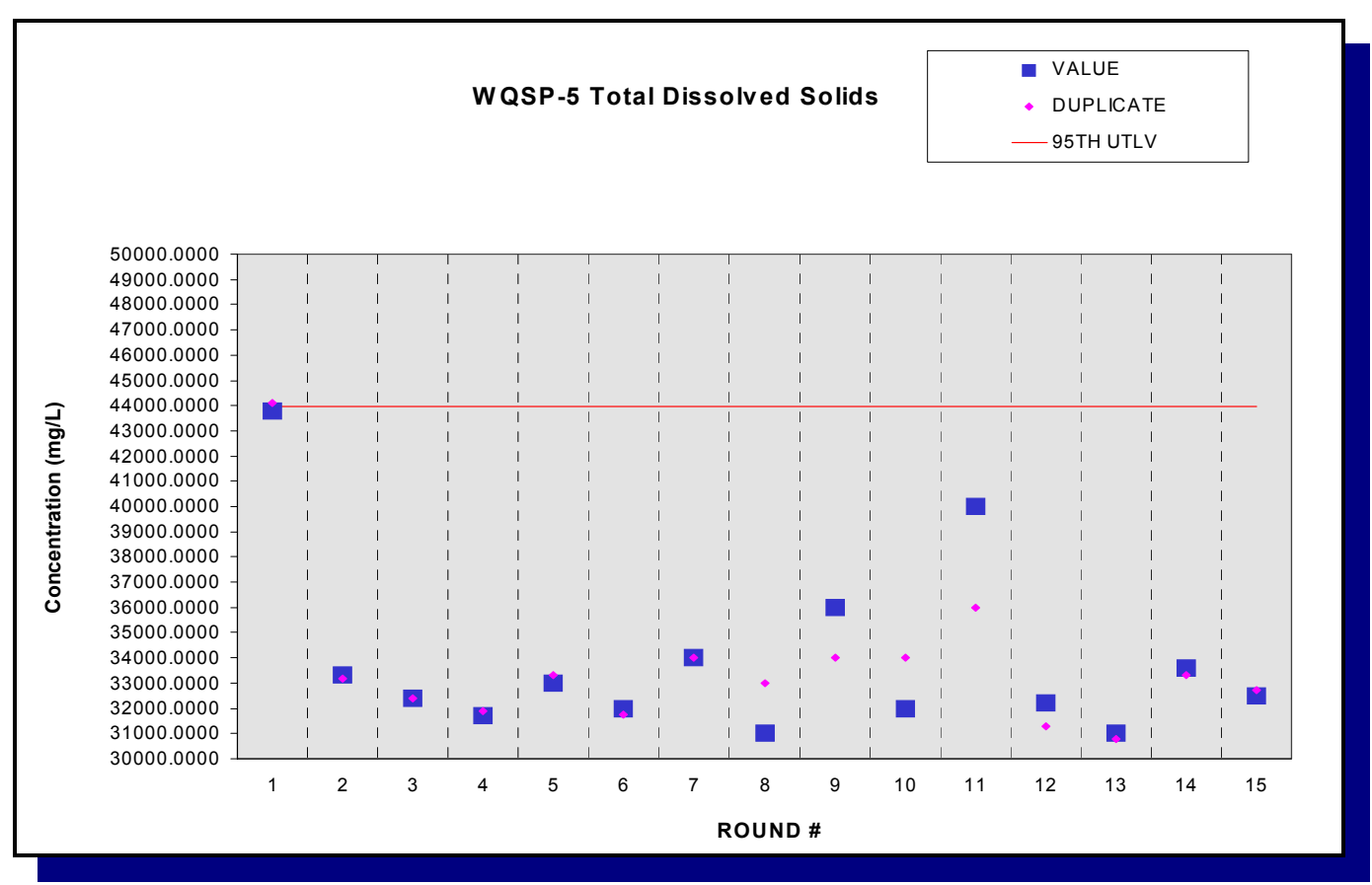

Figure F.67 - Time Trend Plot for Total Dissolved Solids at WQSP-5 


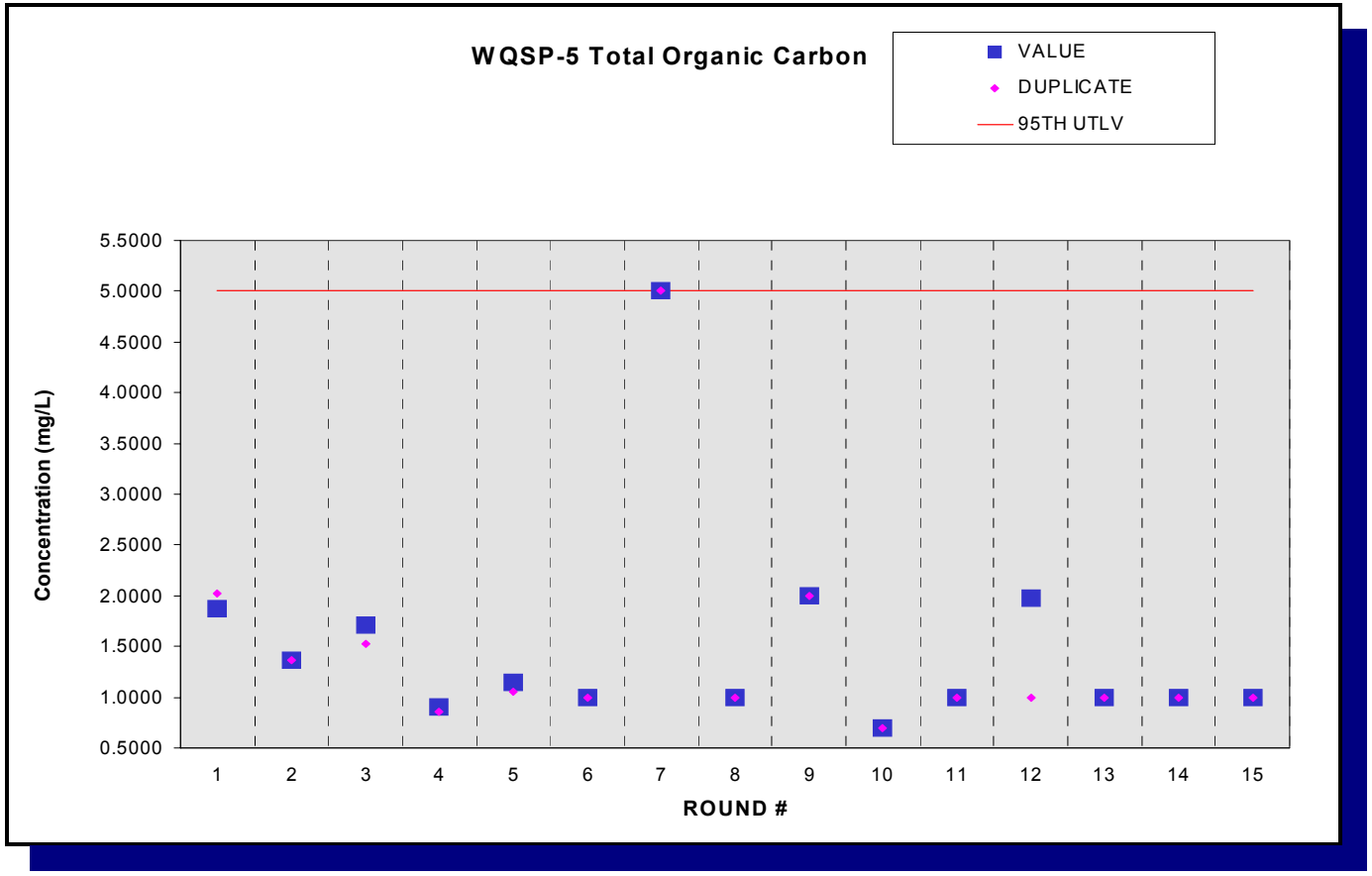

Figure F.68 - Time Trend Plot for Total Organic Carbon at WQSP-5

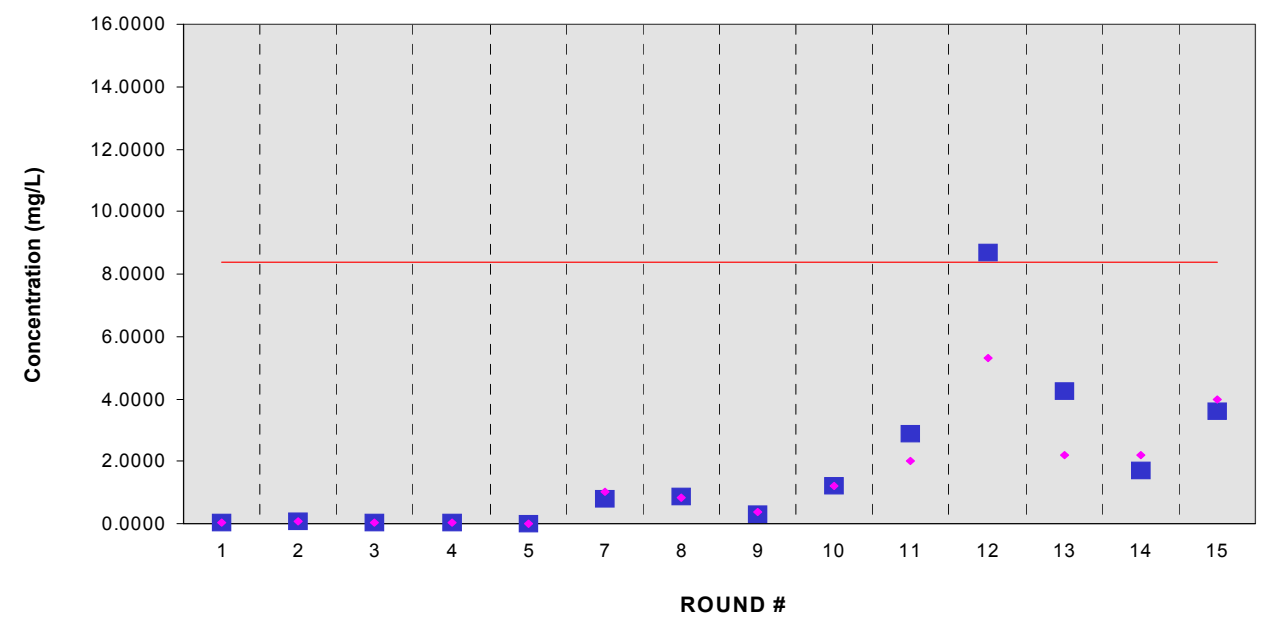

Figure F.69 - Time Trend Plot for Total Organic Halogens at WQSP-5 


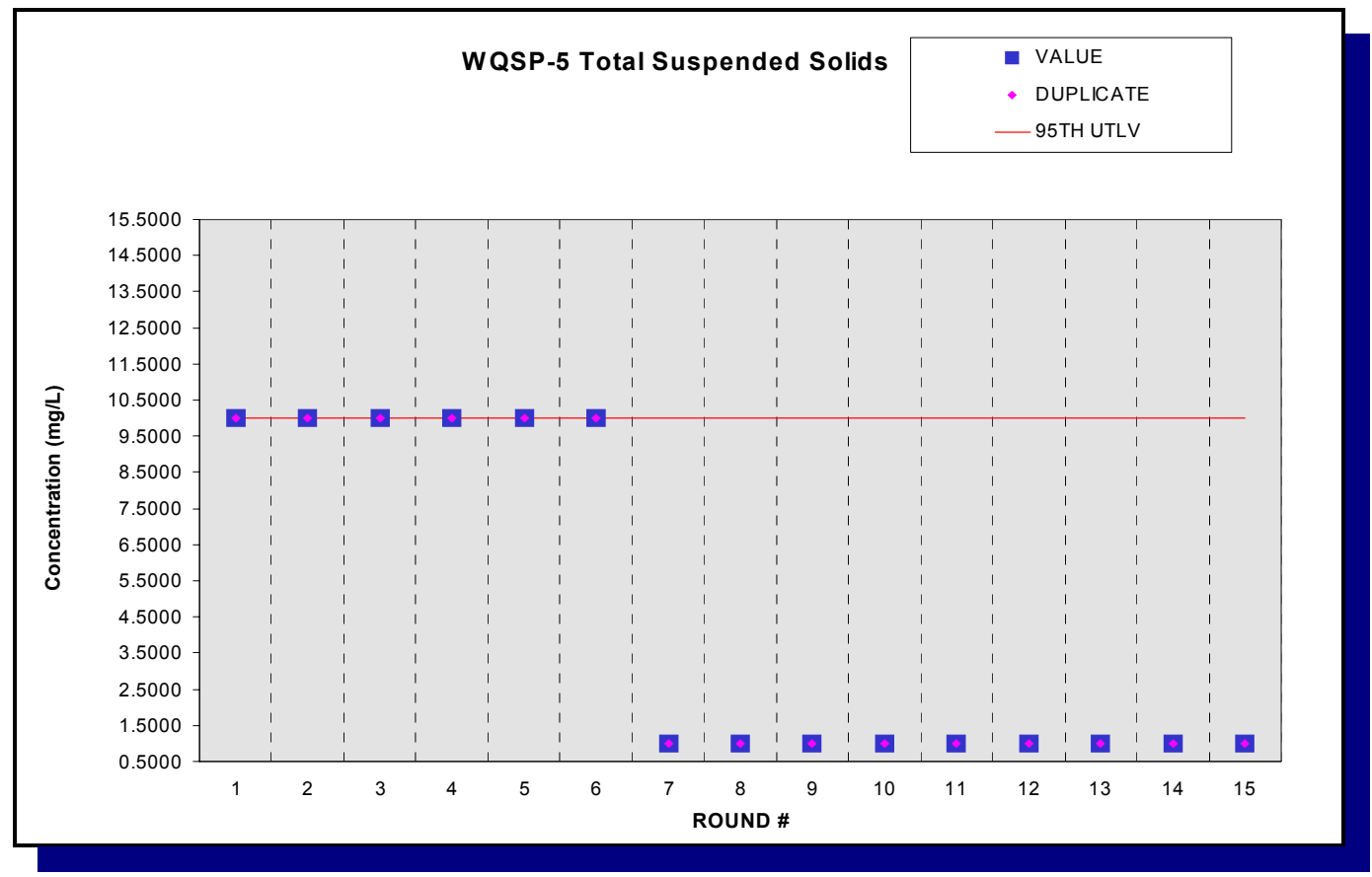

Figure F.70 - Time Trend Plot for Total Suspended Solids at WQSP-5

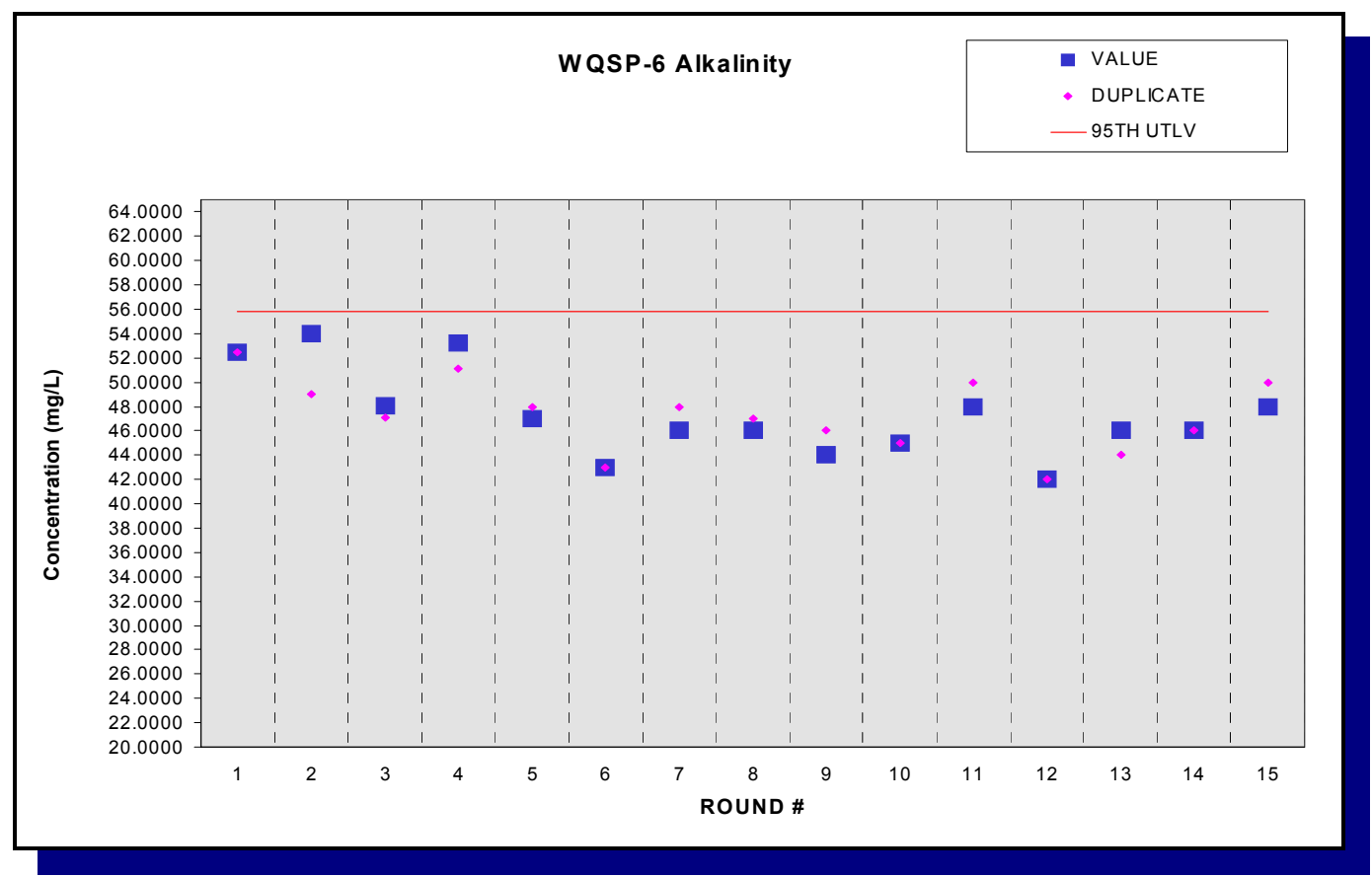

Figure F.71 - Time Trend Plot for Alkalinity at WQSP-6 


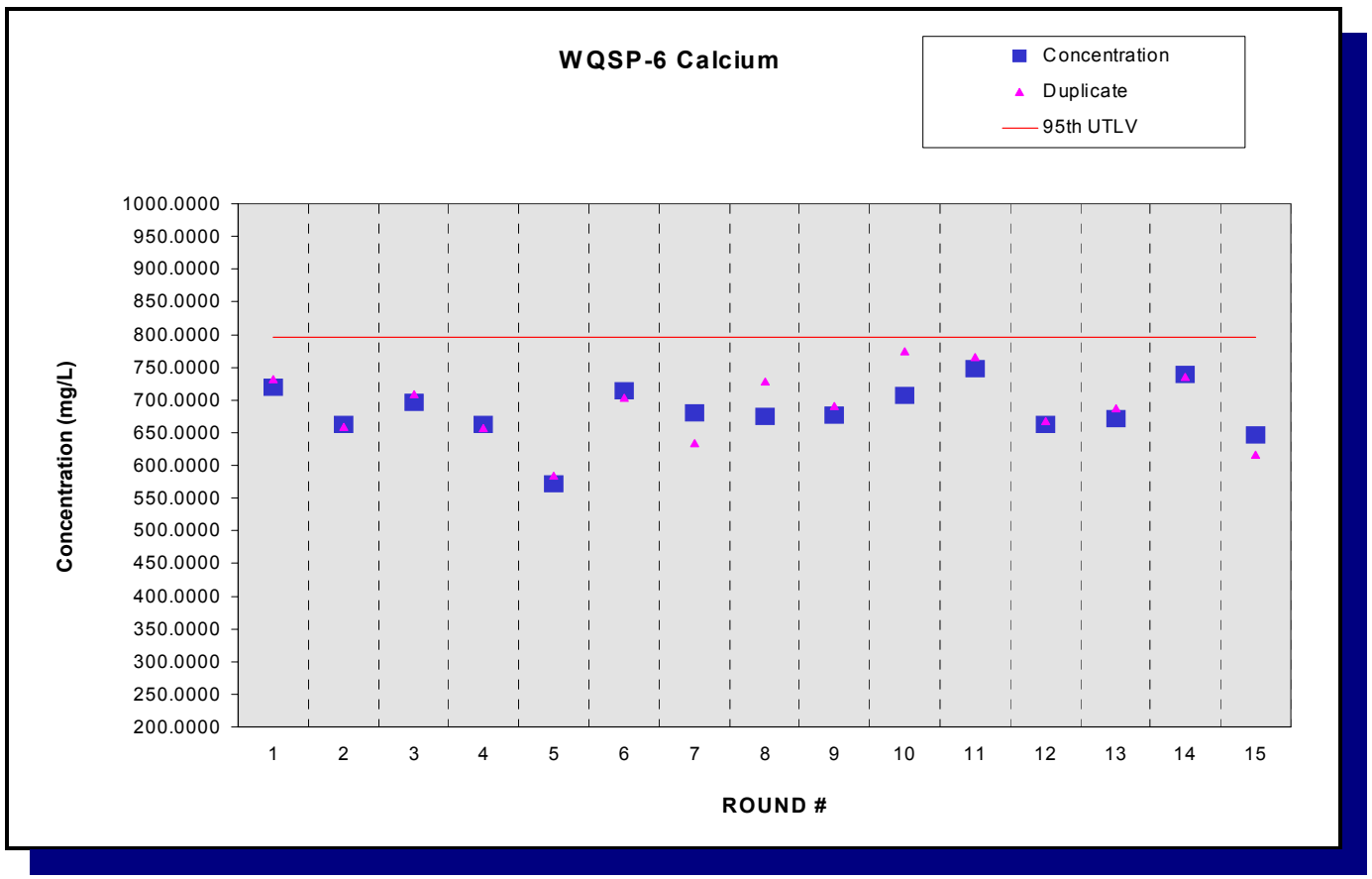

Figure F.72 - Time Trend Plot for Calcium at WQSP-6

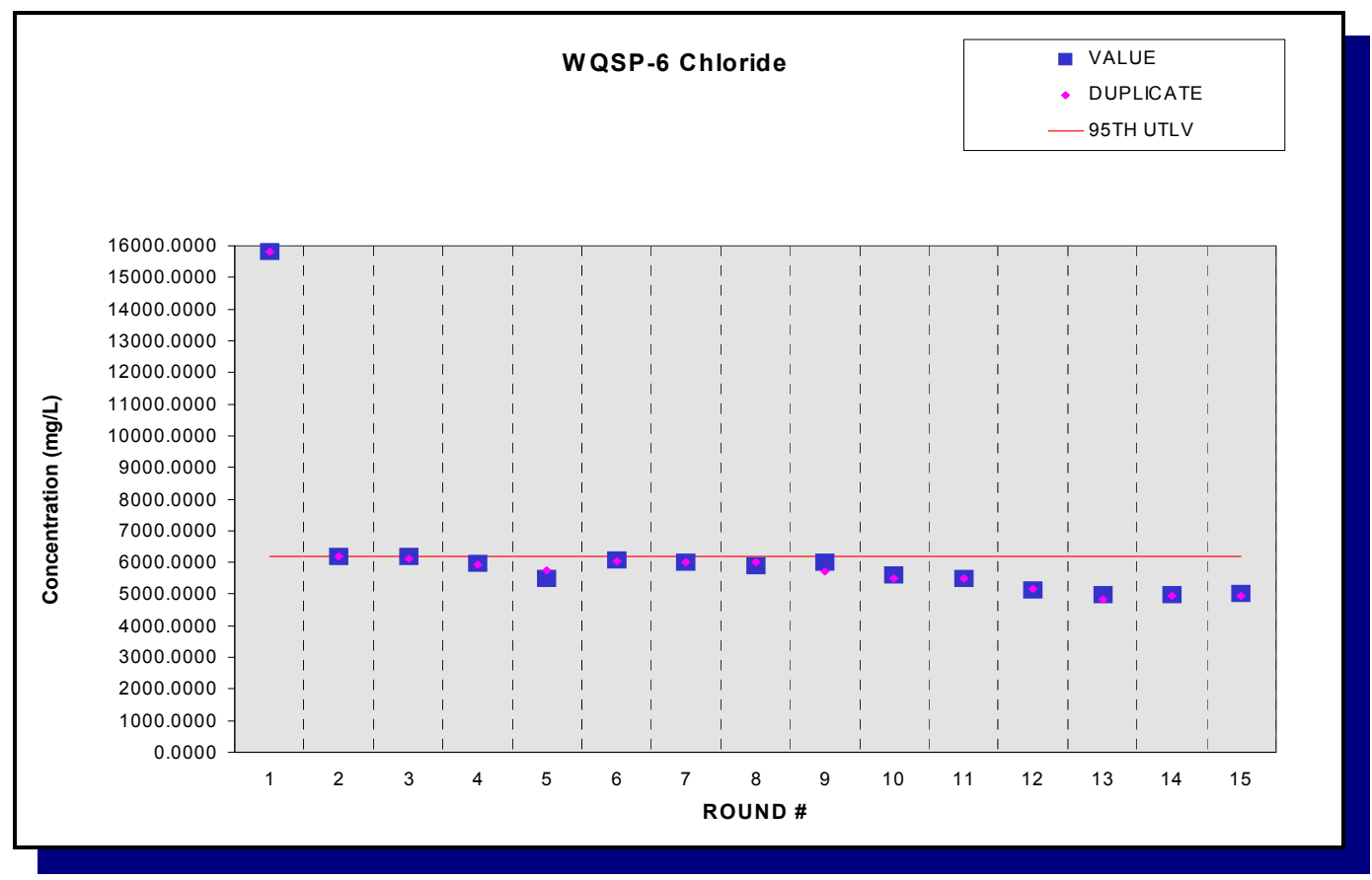

Figure F.73 - Time Trend Plot for Chloride at WQSP-6 


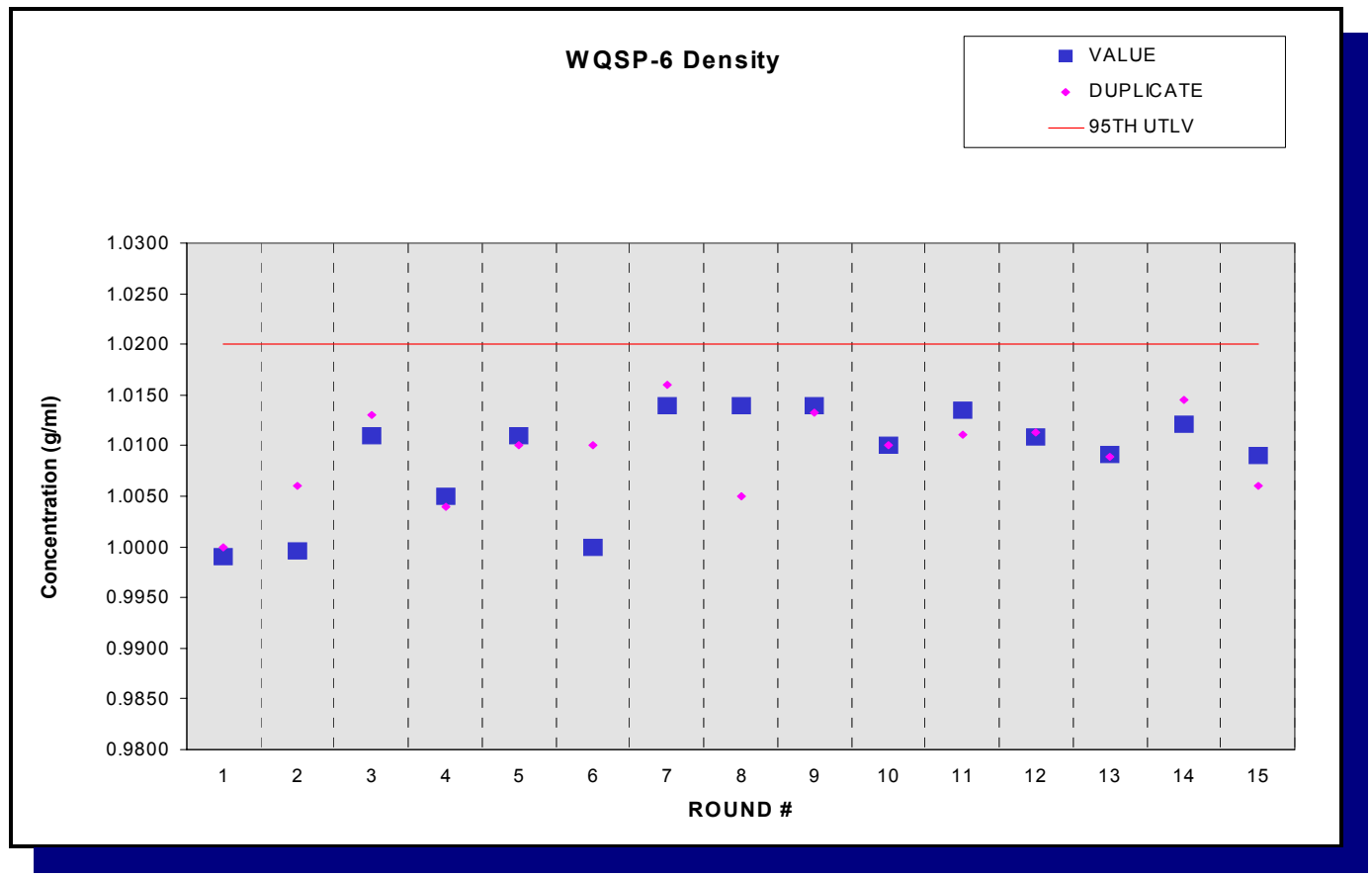

Figure F.74 - Time Trend Plot for Density at WQSP-6

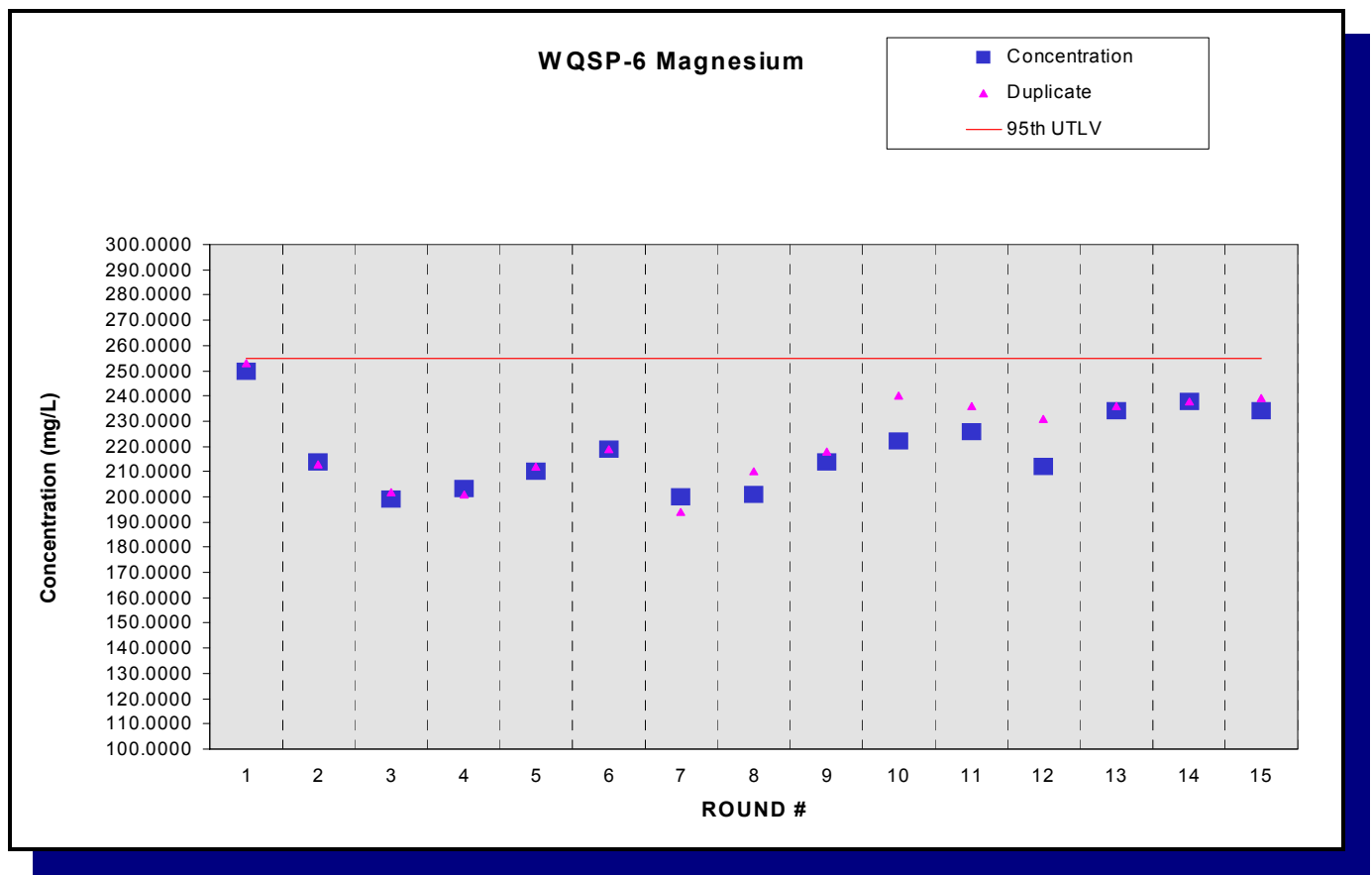

Figure F.75 - Time Trend Plot for Magnesium at WQSP-6 


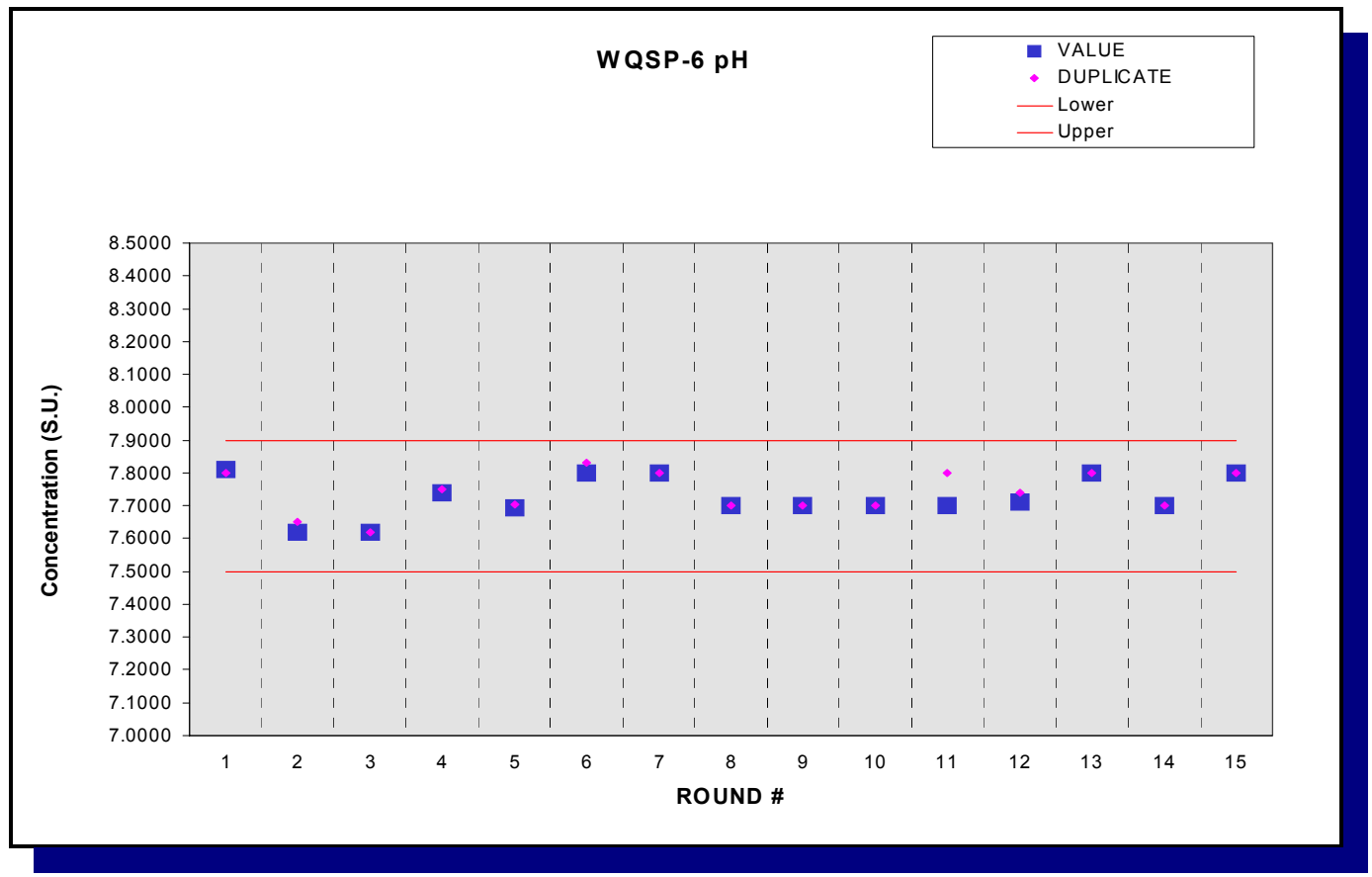

Figure F.76 - Time Trend Plot for pH at WQSP-6

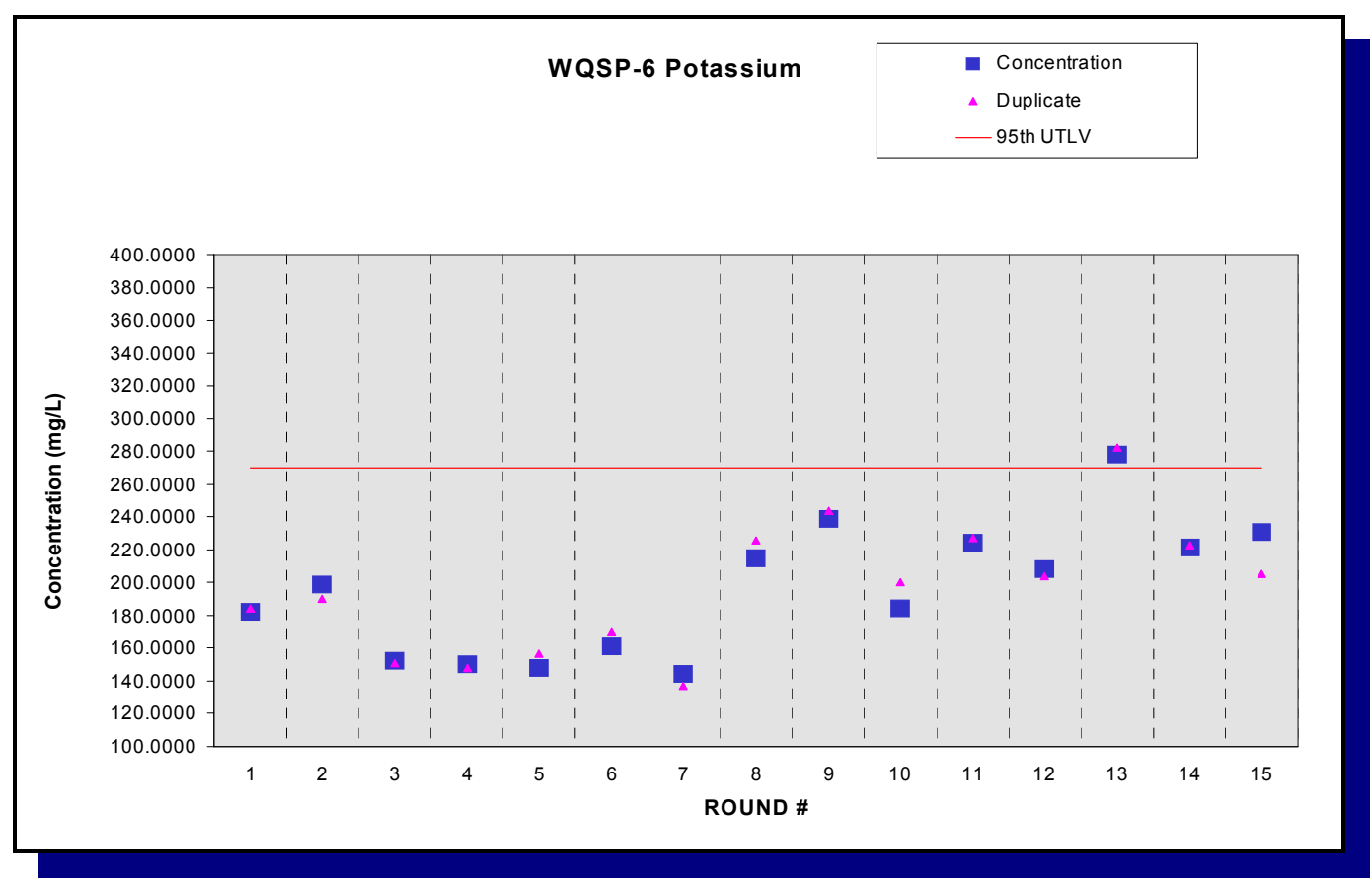

Figure F.77 - Time Trend Plot for Potassium at WQSP-6 


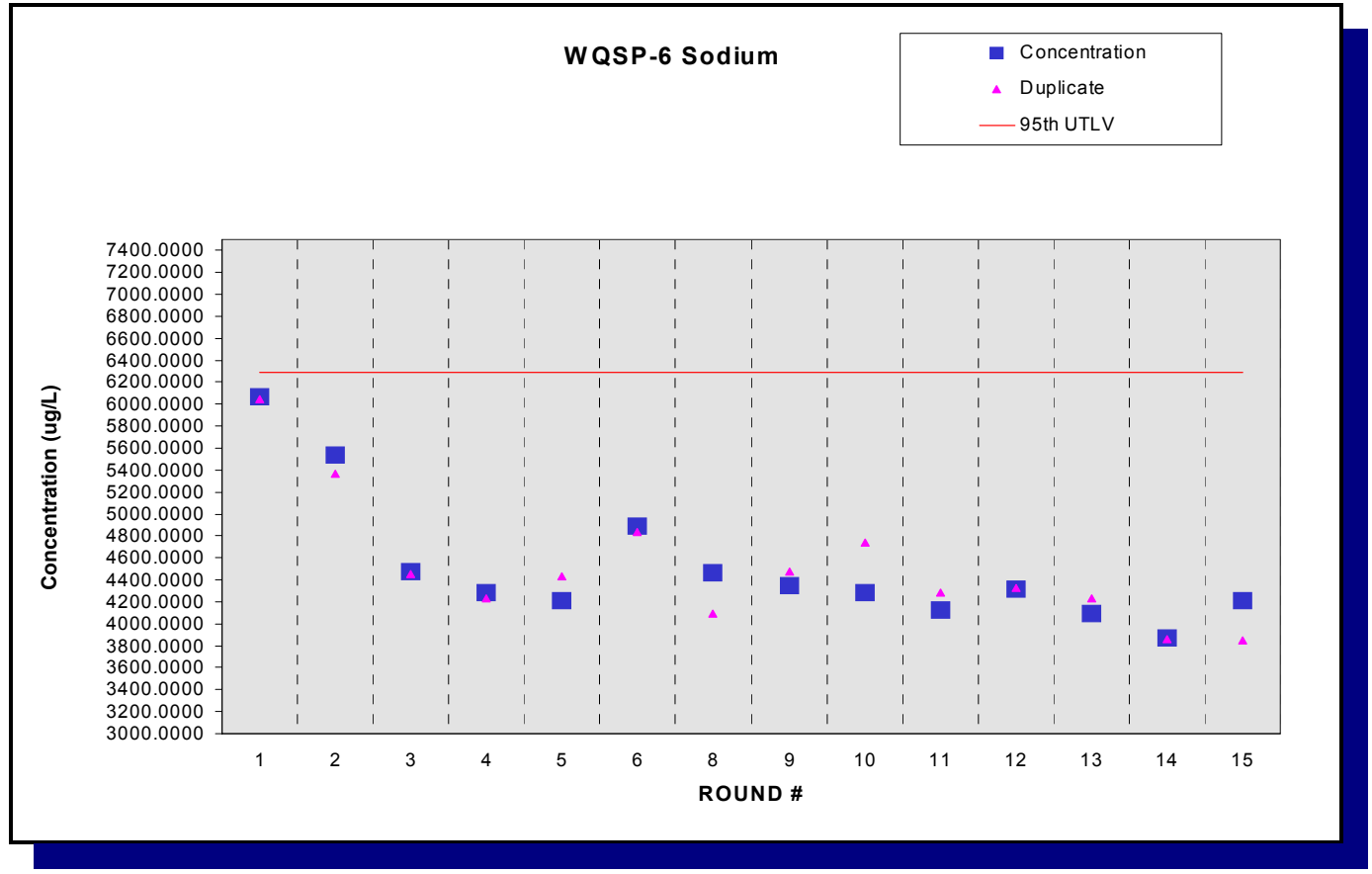

Figure F.78 - Time Trend Plot for Sodium at WQSP-6

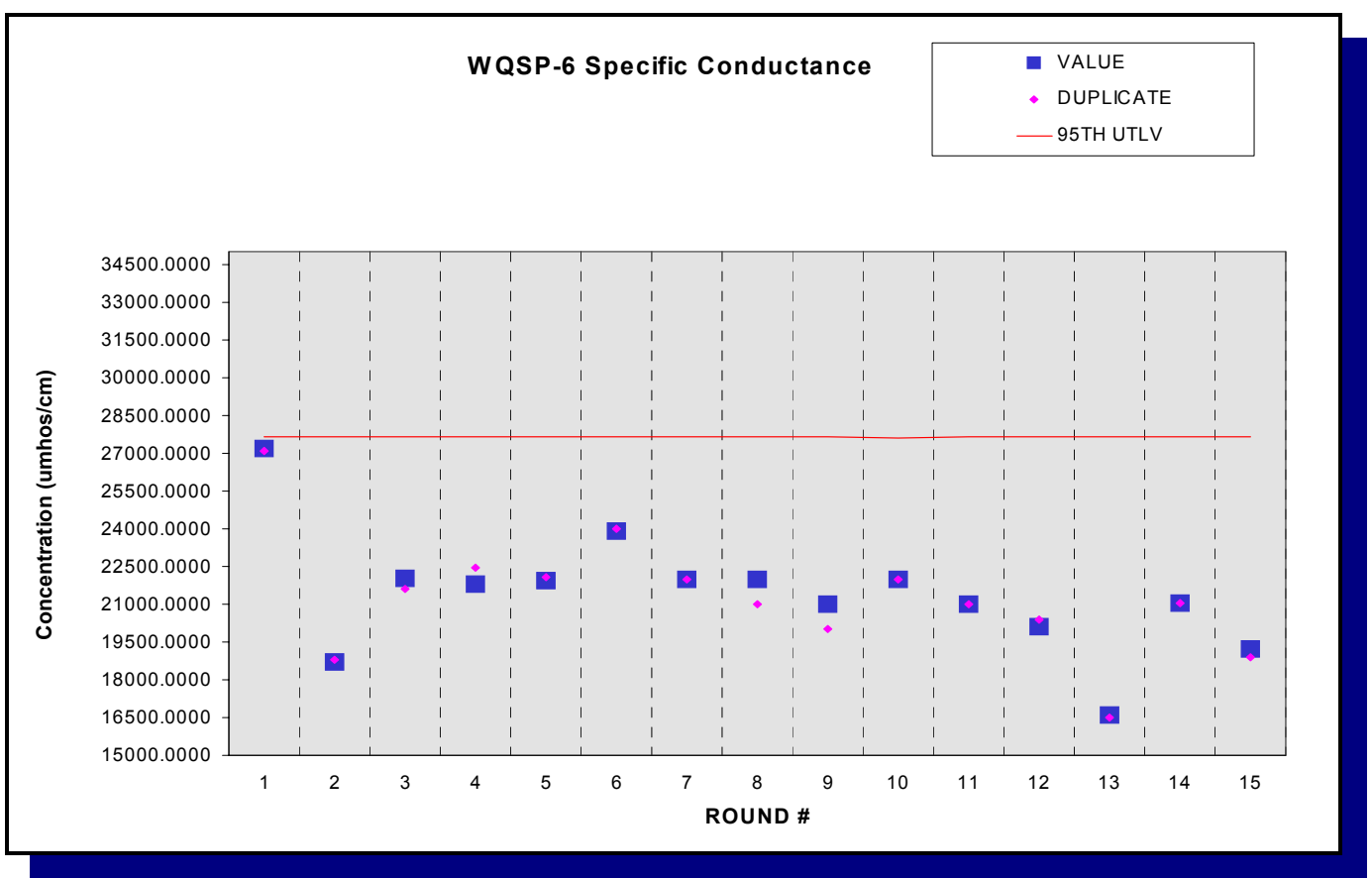

Figure F.79 - Time Trend Plot for Specific Conductance at WQSP-6 


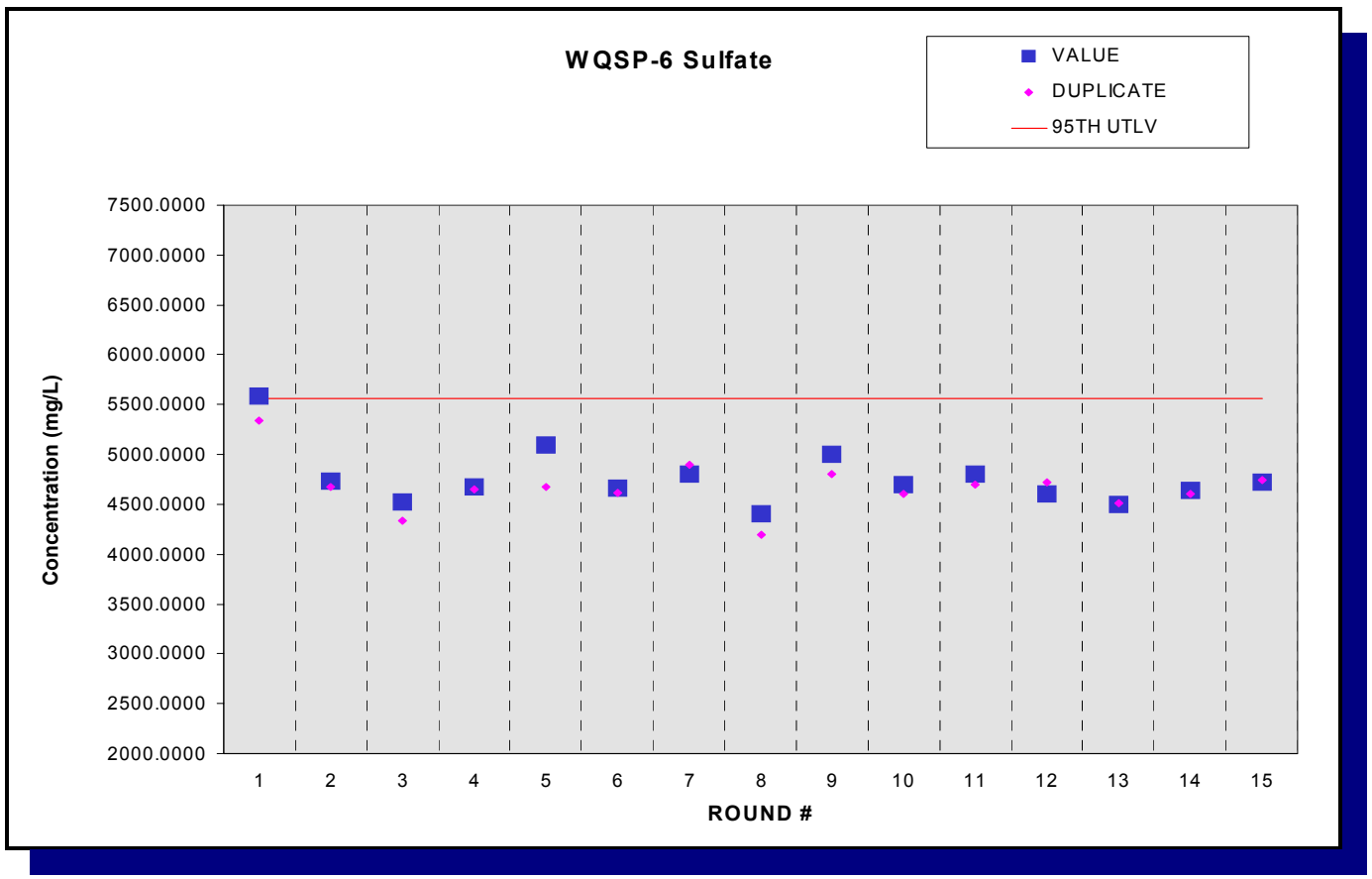

Figure F.80 - Time Trend Plot for Sulfate at WQSP-6

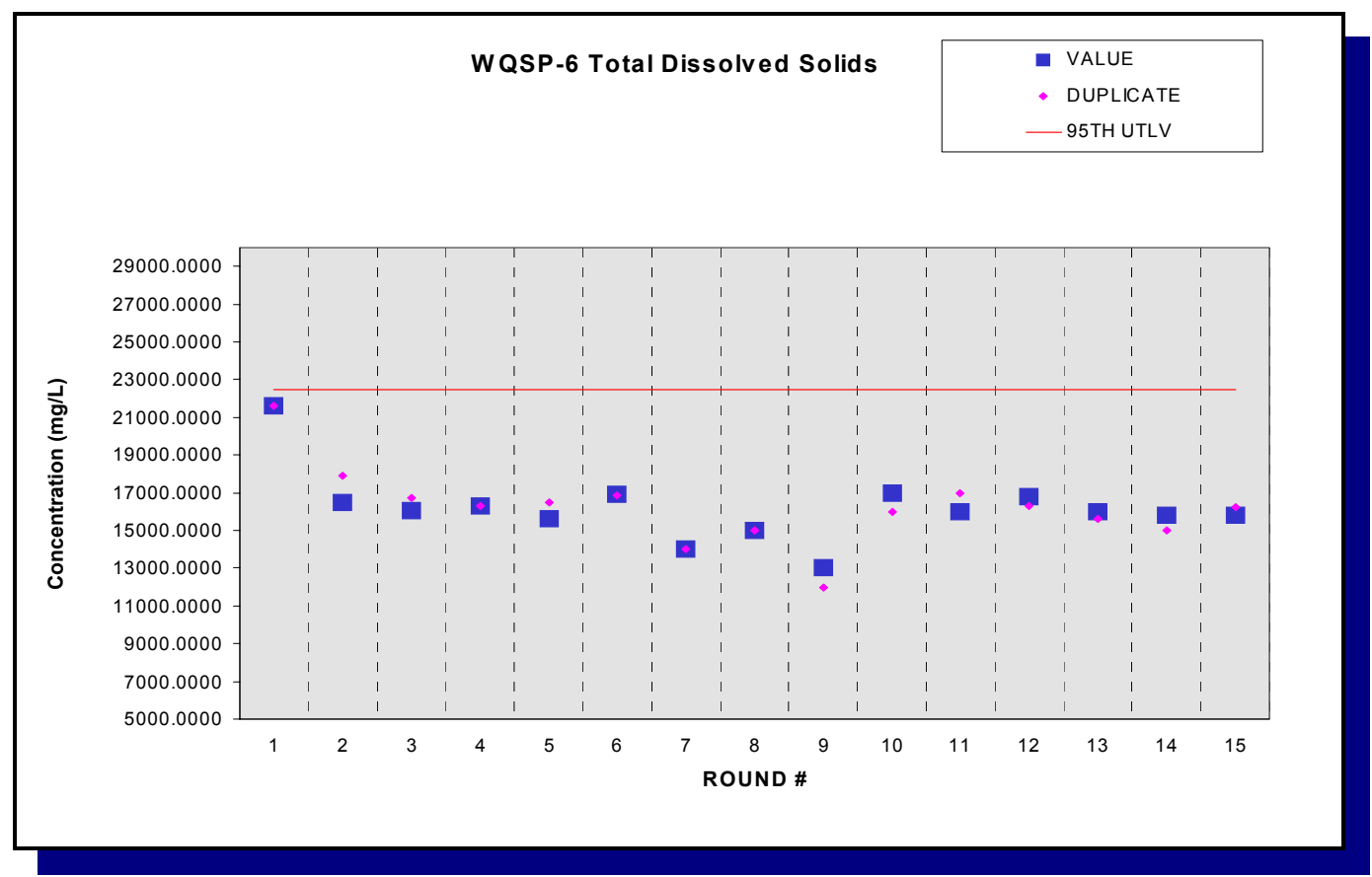

Figure F.81 - Time Trend Plot for Total Dissolved Solids at WQSP-6 


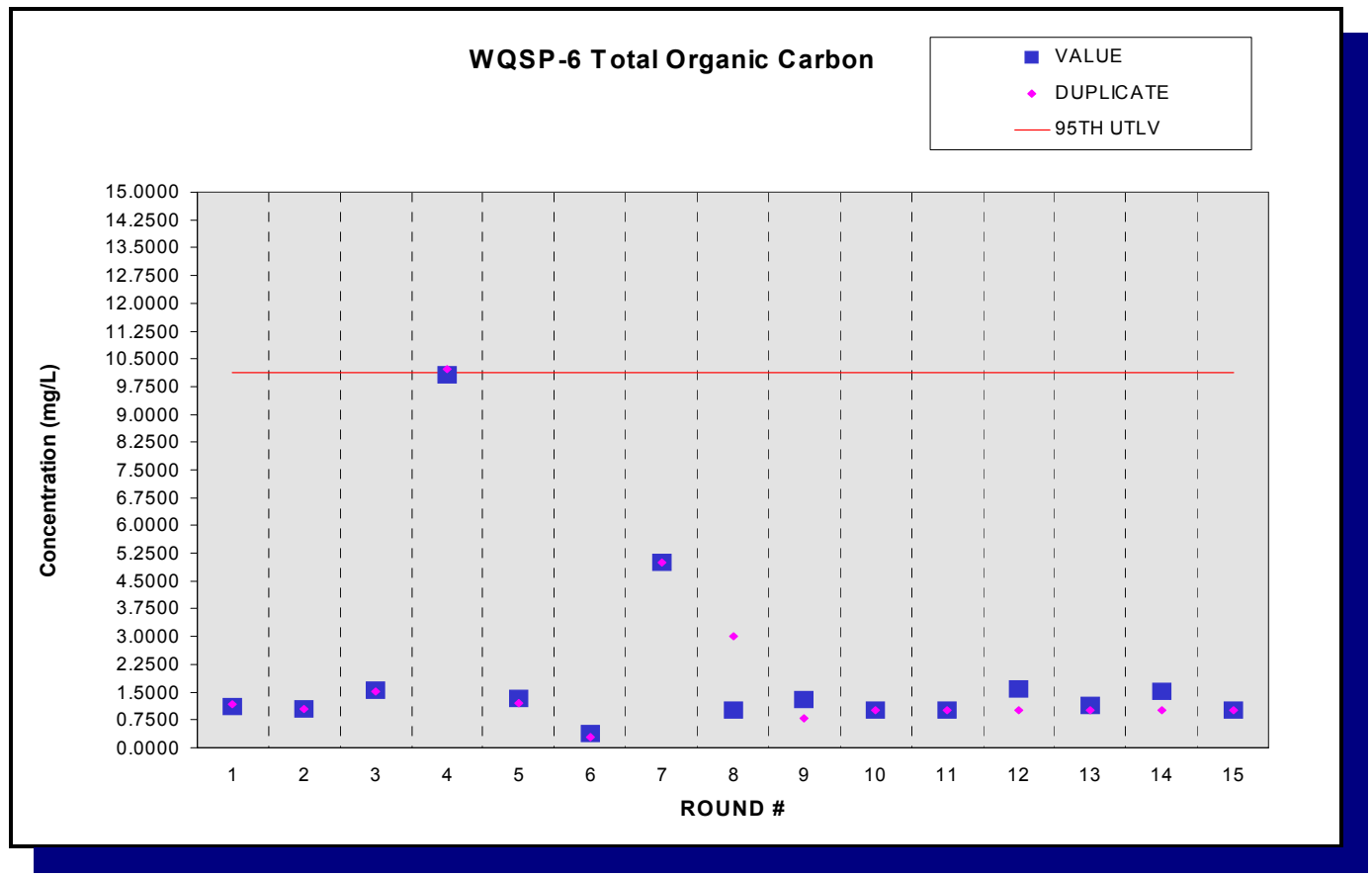

Figure F.82 - Time Trend Plot for Total Organic Carbon at WQSP-6

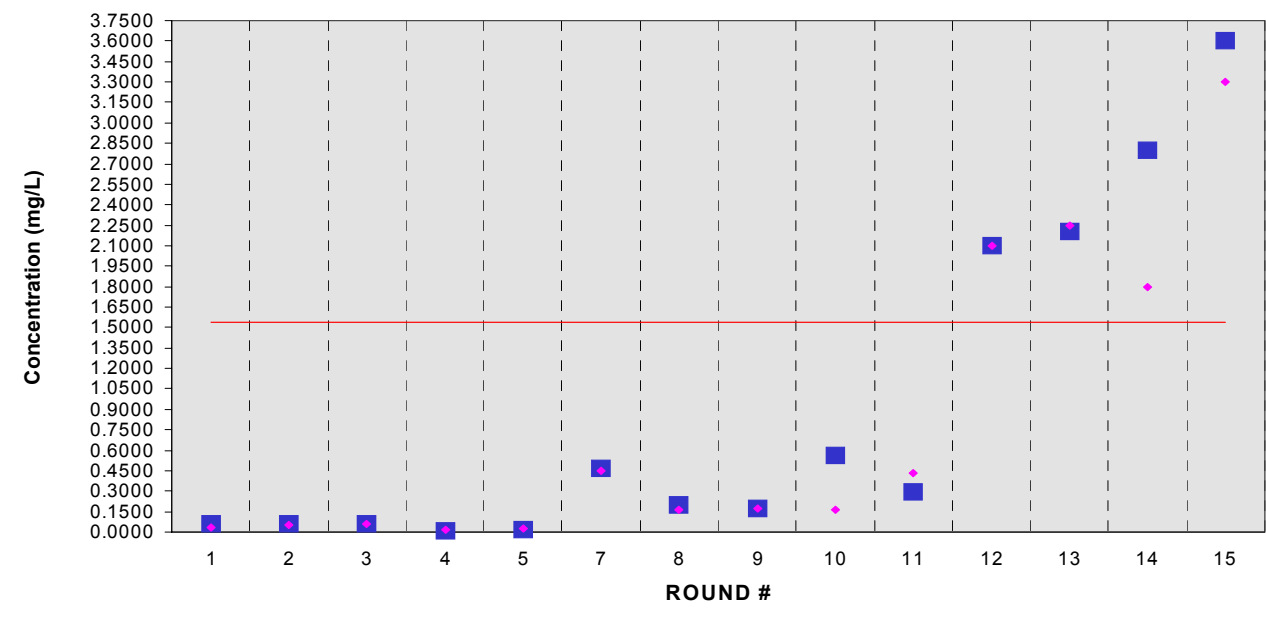

Figure F.83 - Time Trend Plot for Total Organic Halogens at WQSP-6 


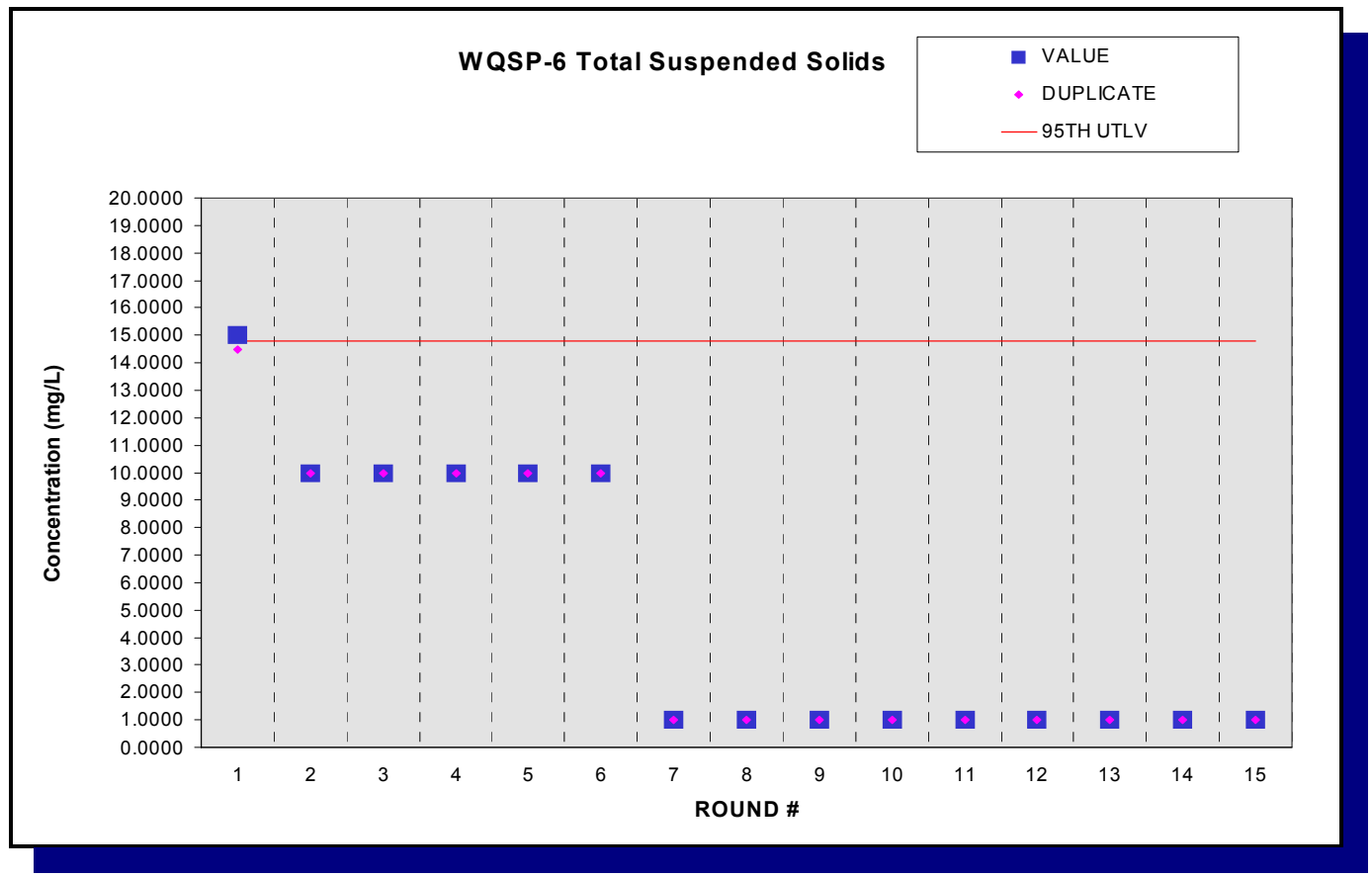

Figure F.84 - Time Trend Plot for Total Suspended Solids at WQSP-6

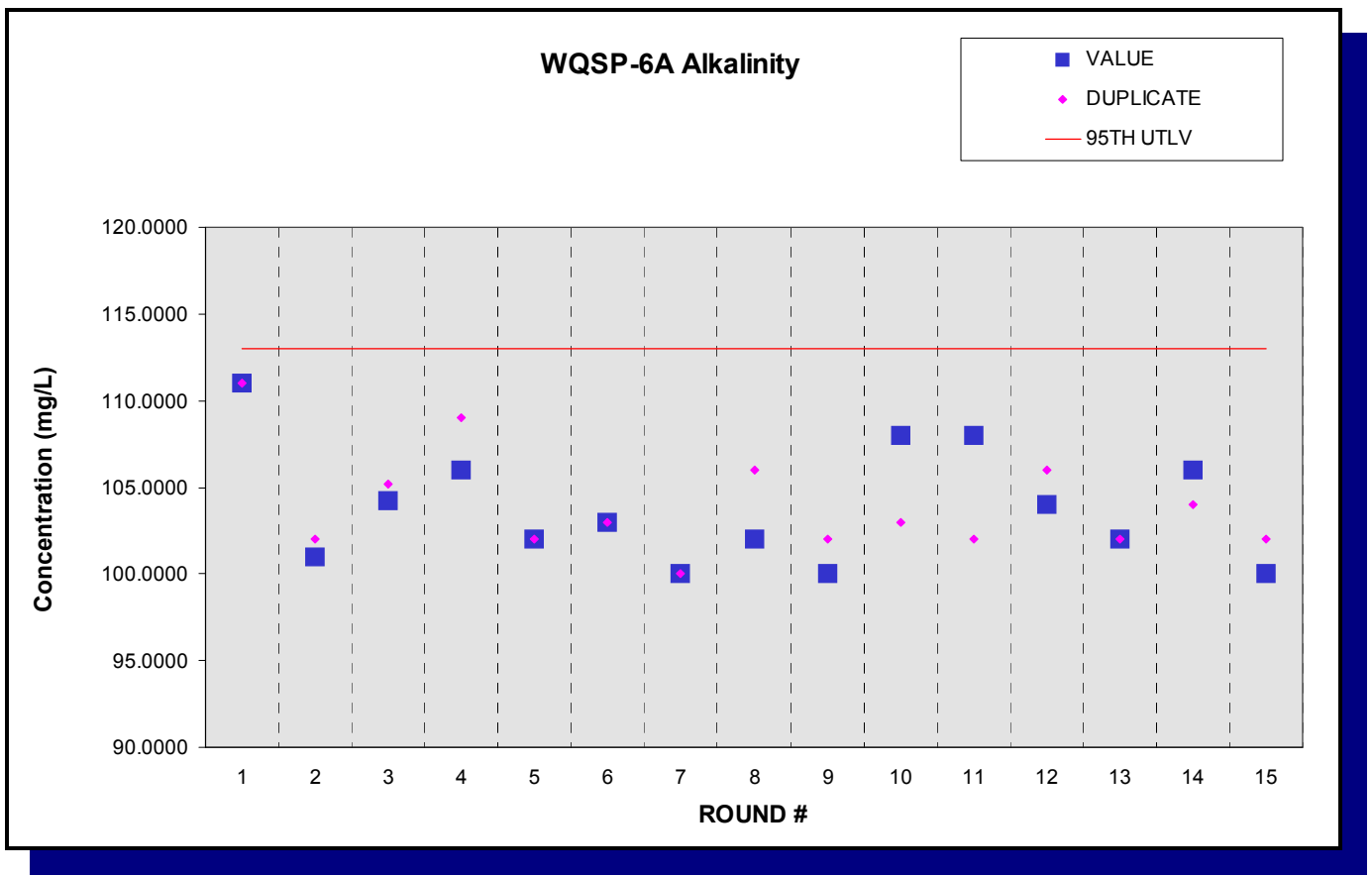

Figure F.85 - Time Trend Plot for Alkalinity at WQSP-6A 


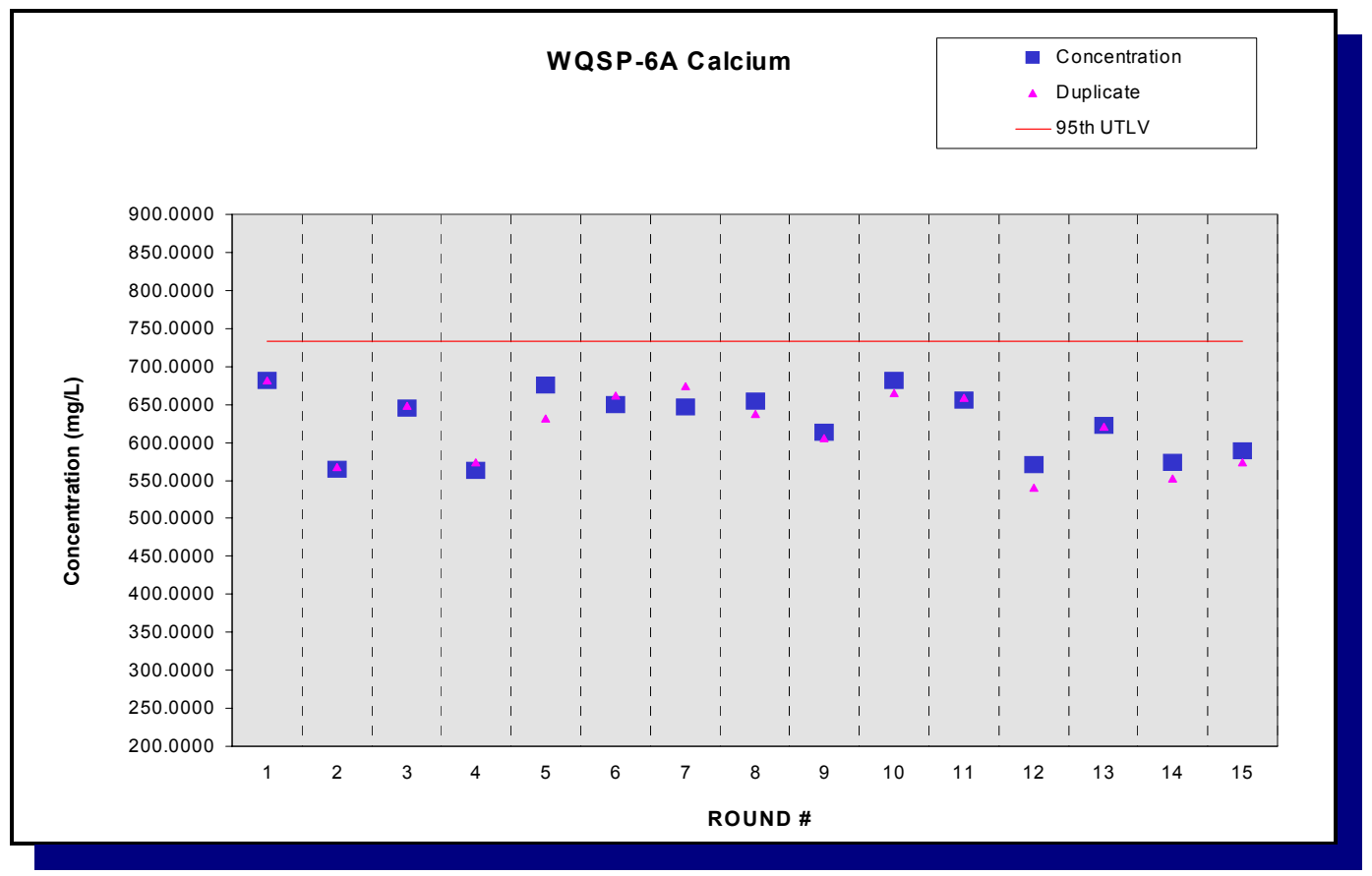

Figure F.86 - Time Trend Plot for Calcium at WQSP-6A

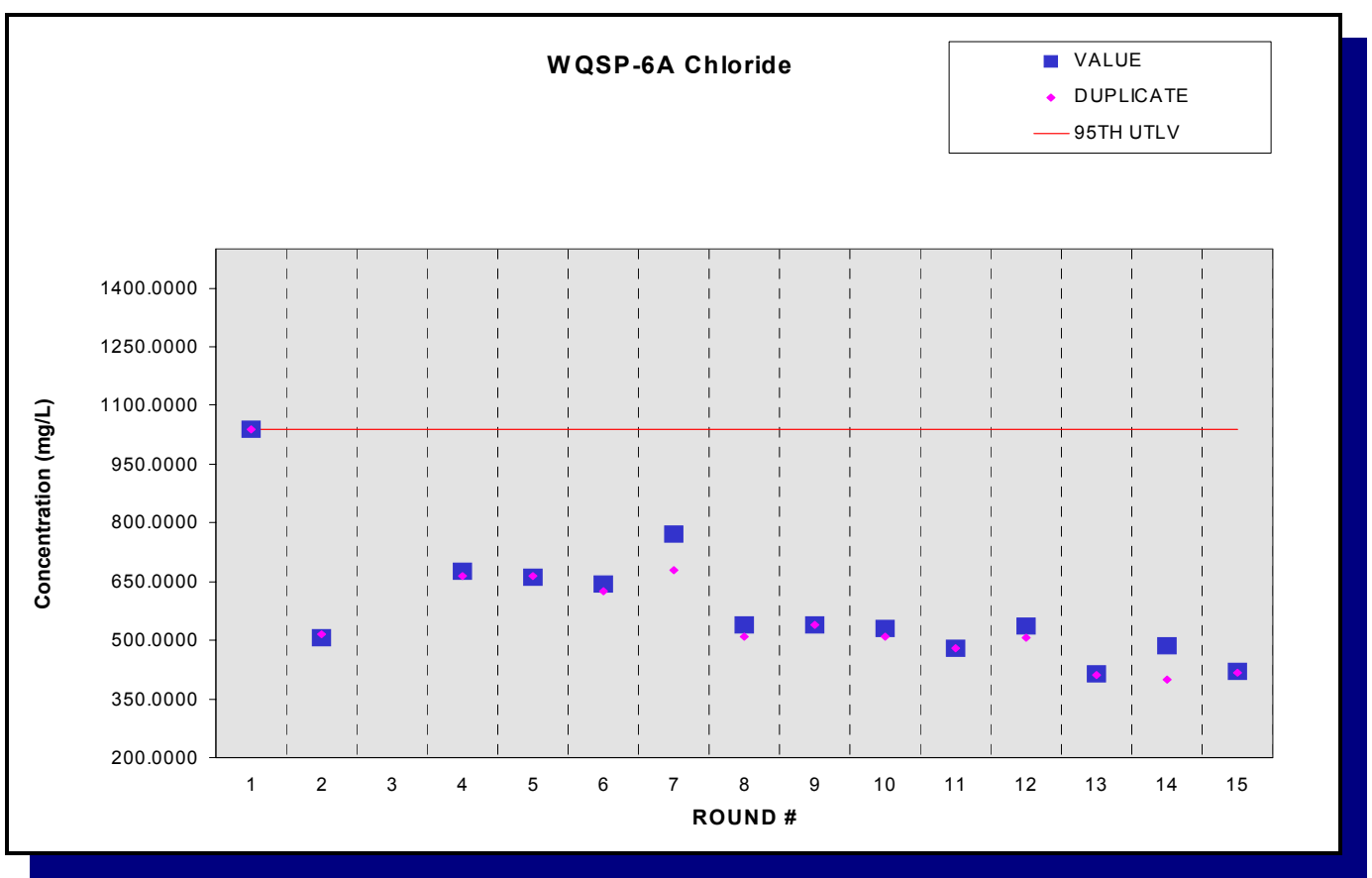

Figure F.87 - Time Trend Plot for Chloride at WQSP-6A 


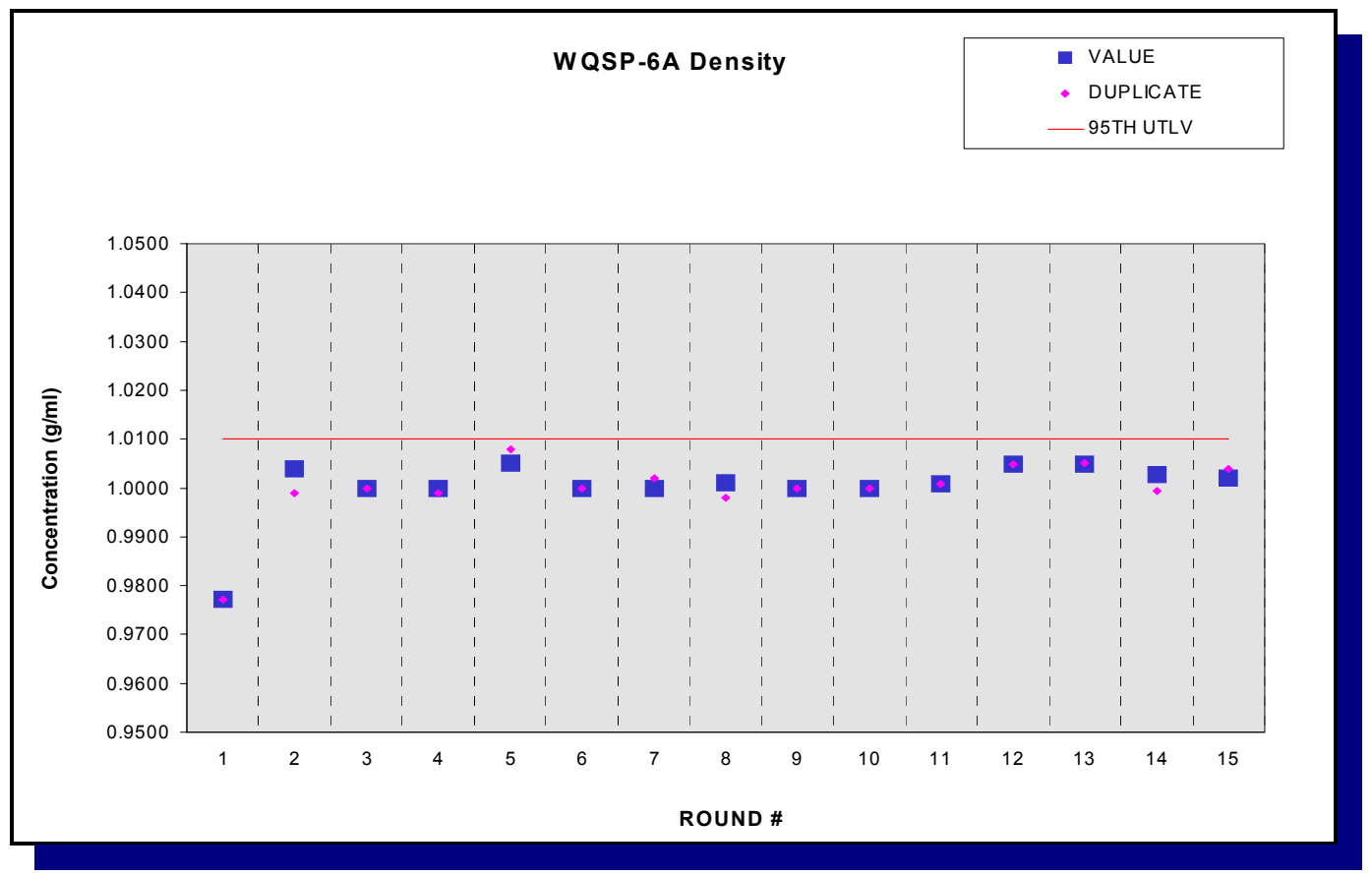

Figure F.88 - Time Trend Plot for Density at WQSP-6A

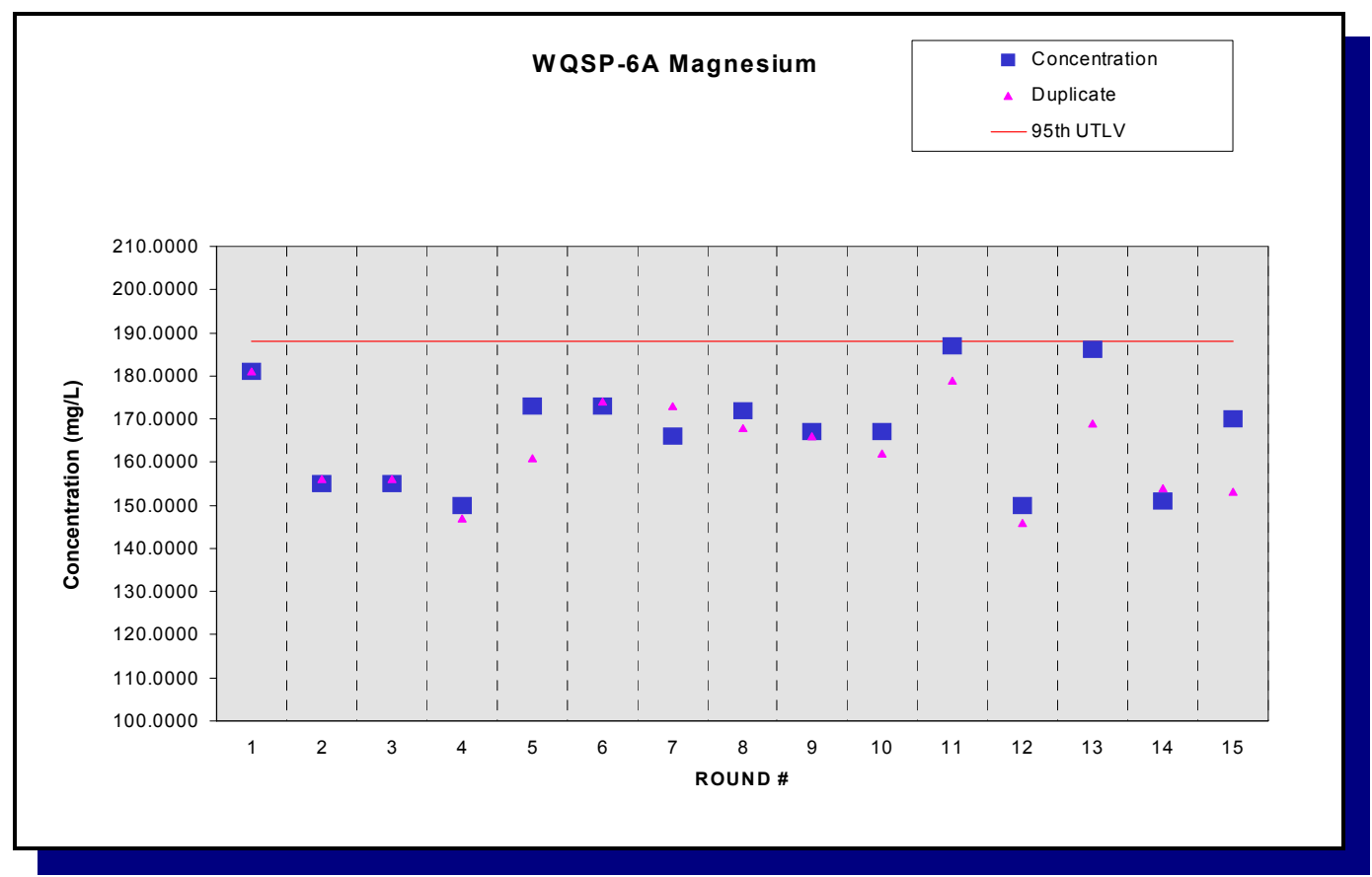

Figure F.89 - Time Trend Plot for Magnesium at WQSP-6A 


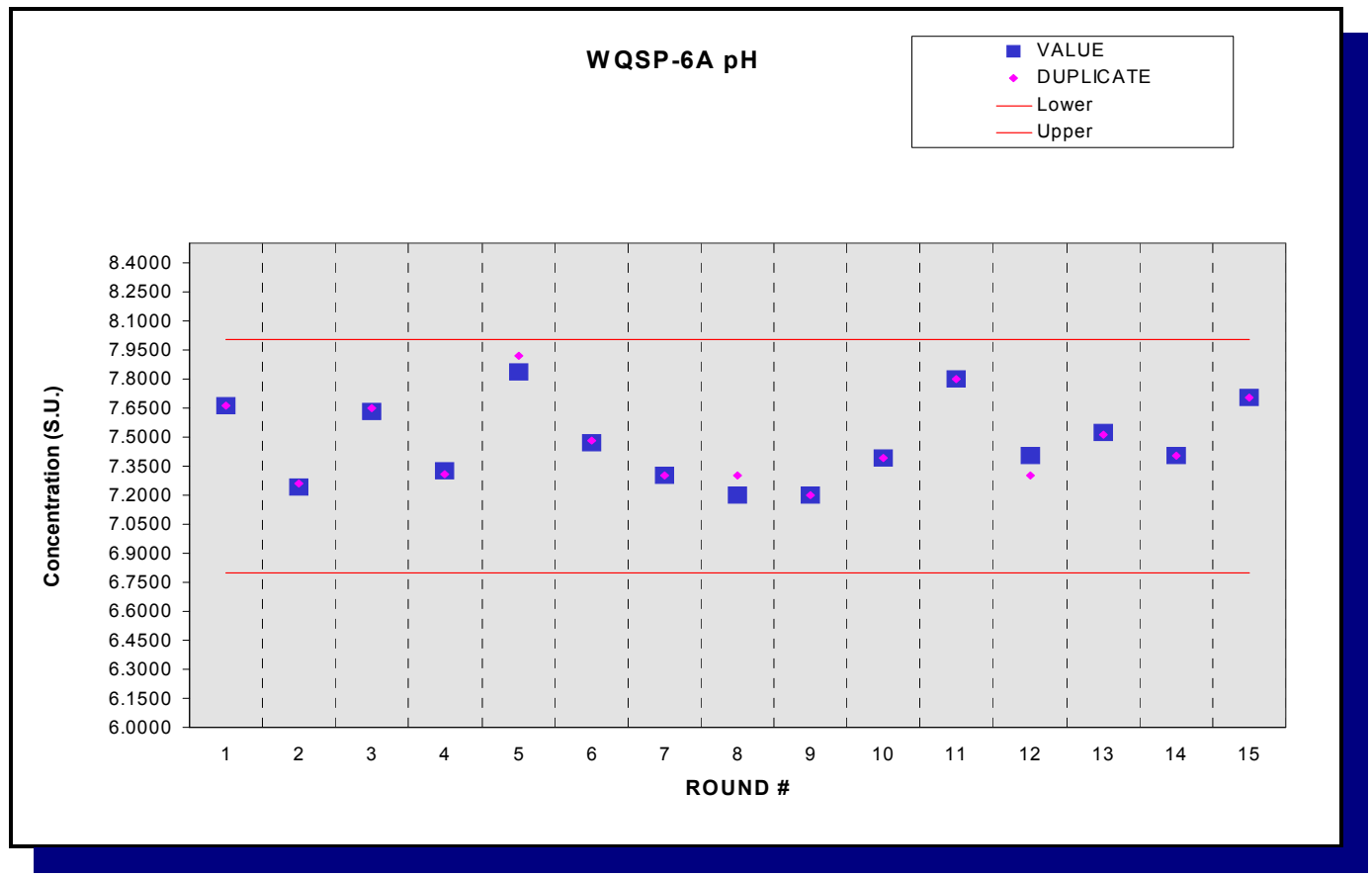

Figure F.90 - Time Trend Plot for pH at WQSP-6A

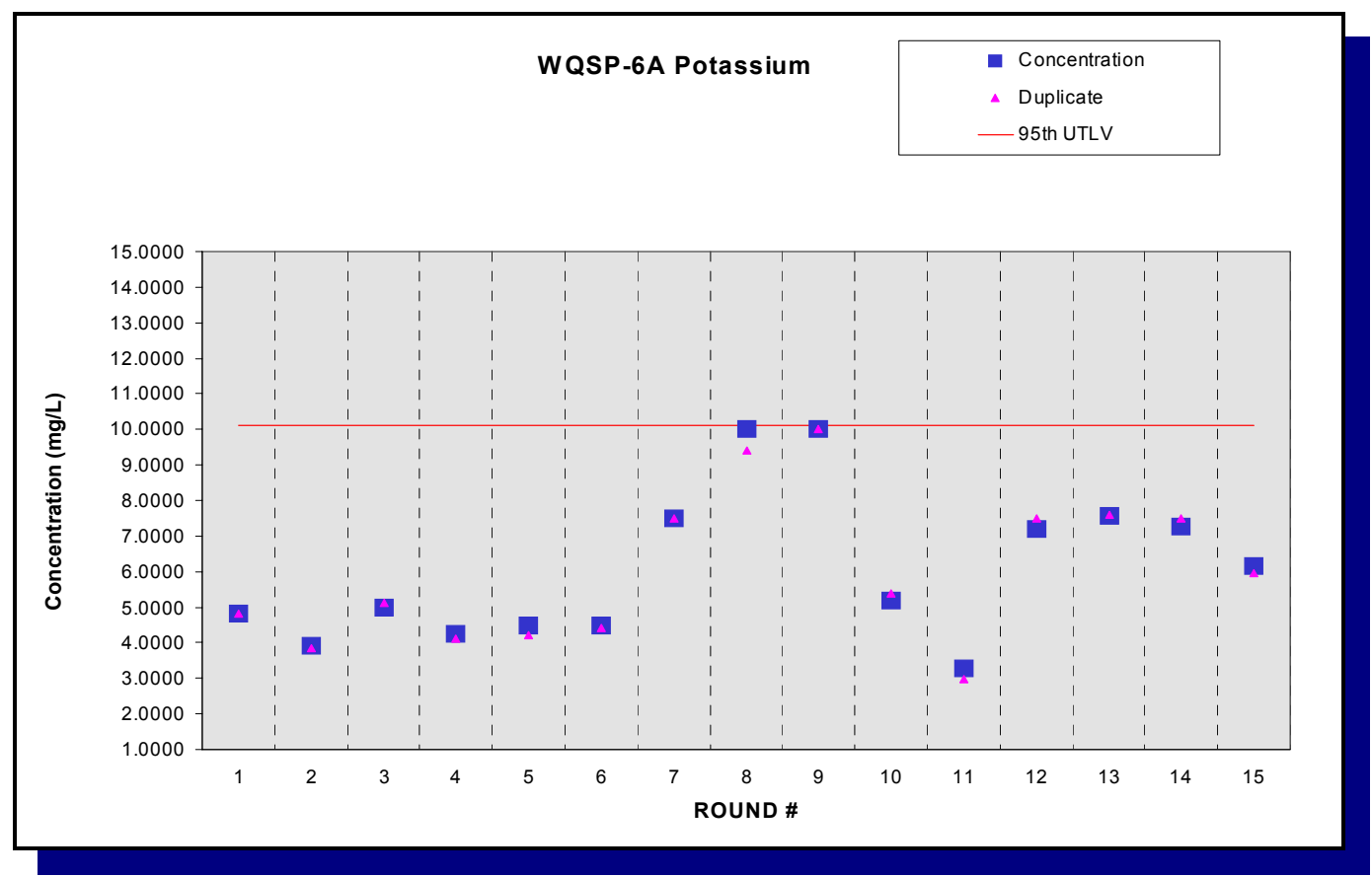

Figure F.91 - Time Trend Plot for Potassium at WQSP-6A 


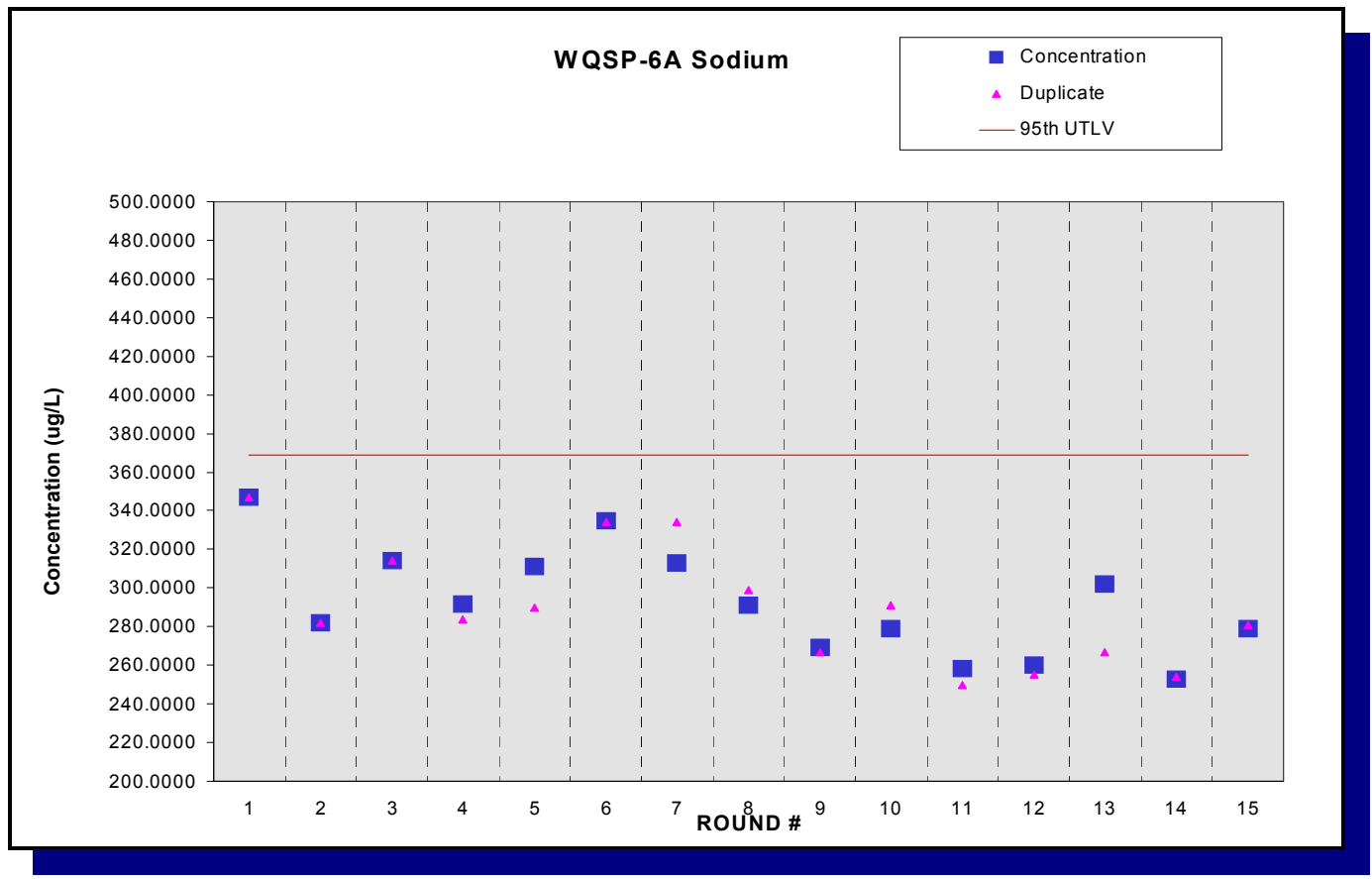

Figure F.92 - Time Trend Plot for Sodium at WQSP-6A

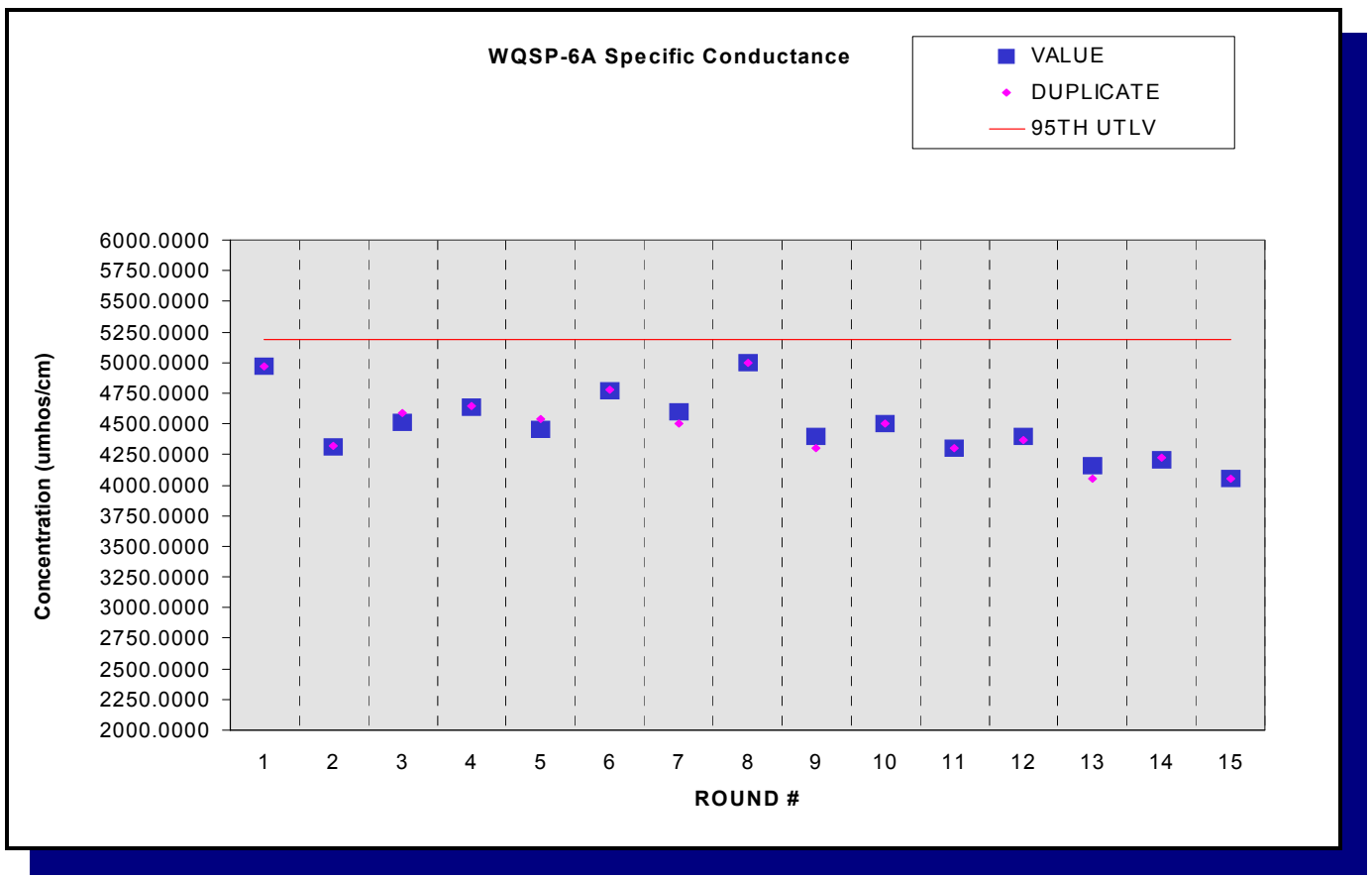

Figure F.93 - Time Trend Plot for Specific Conductance at WQSP-6A 


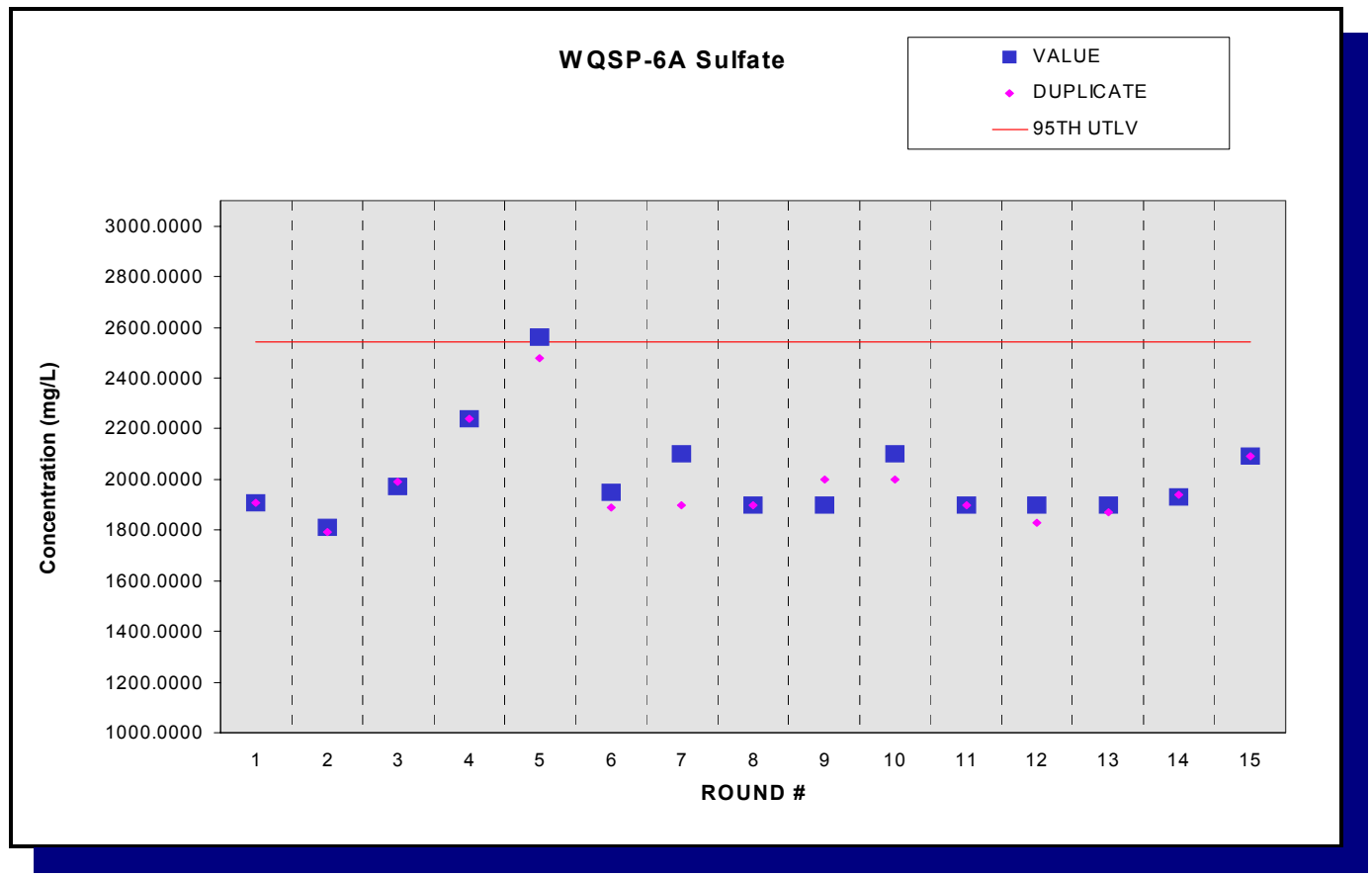

Figure F.94 - Time Trend Plot for Sulfate at WQSP-6A

WQSP-6A Total Dissolved Solids

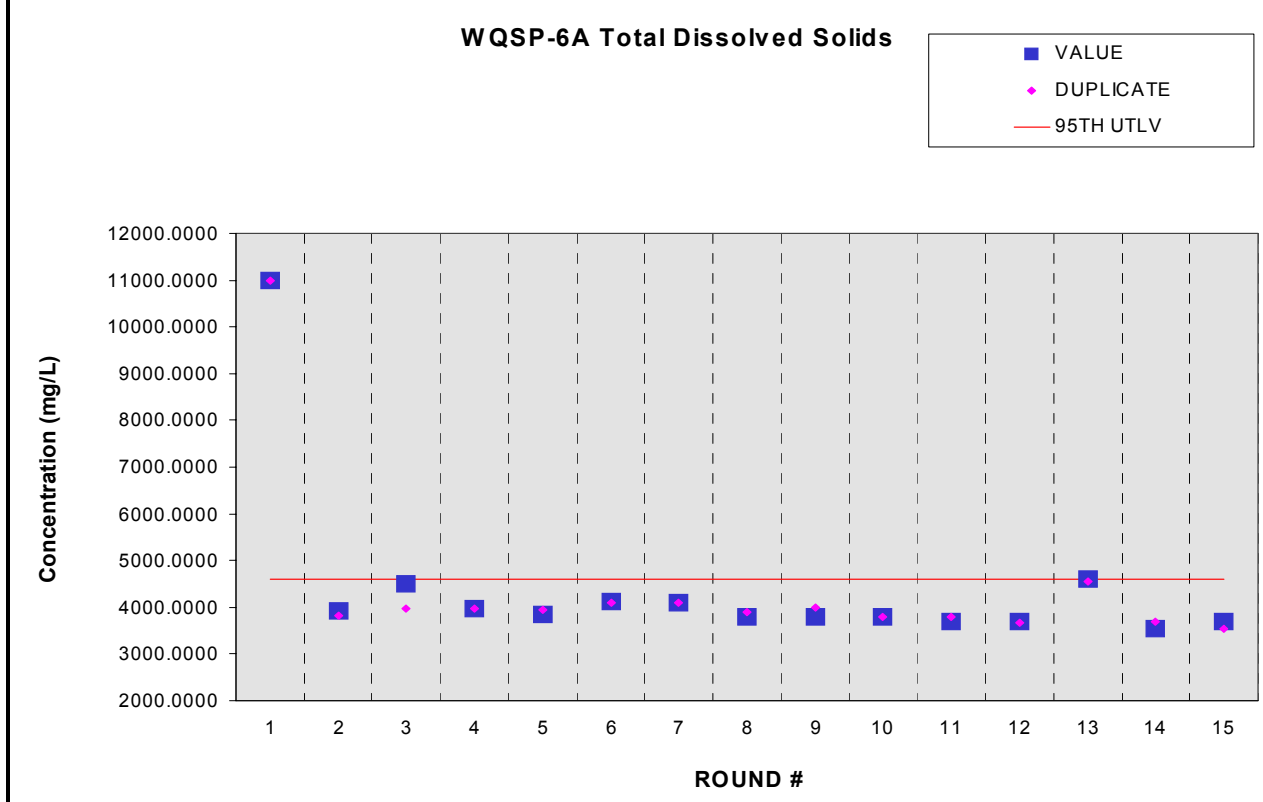

Figure F.95 - Time Trend Plot for Total Dissolved Solids at WQSP-6A 


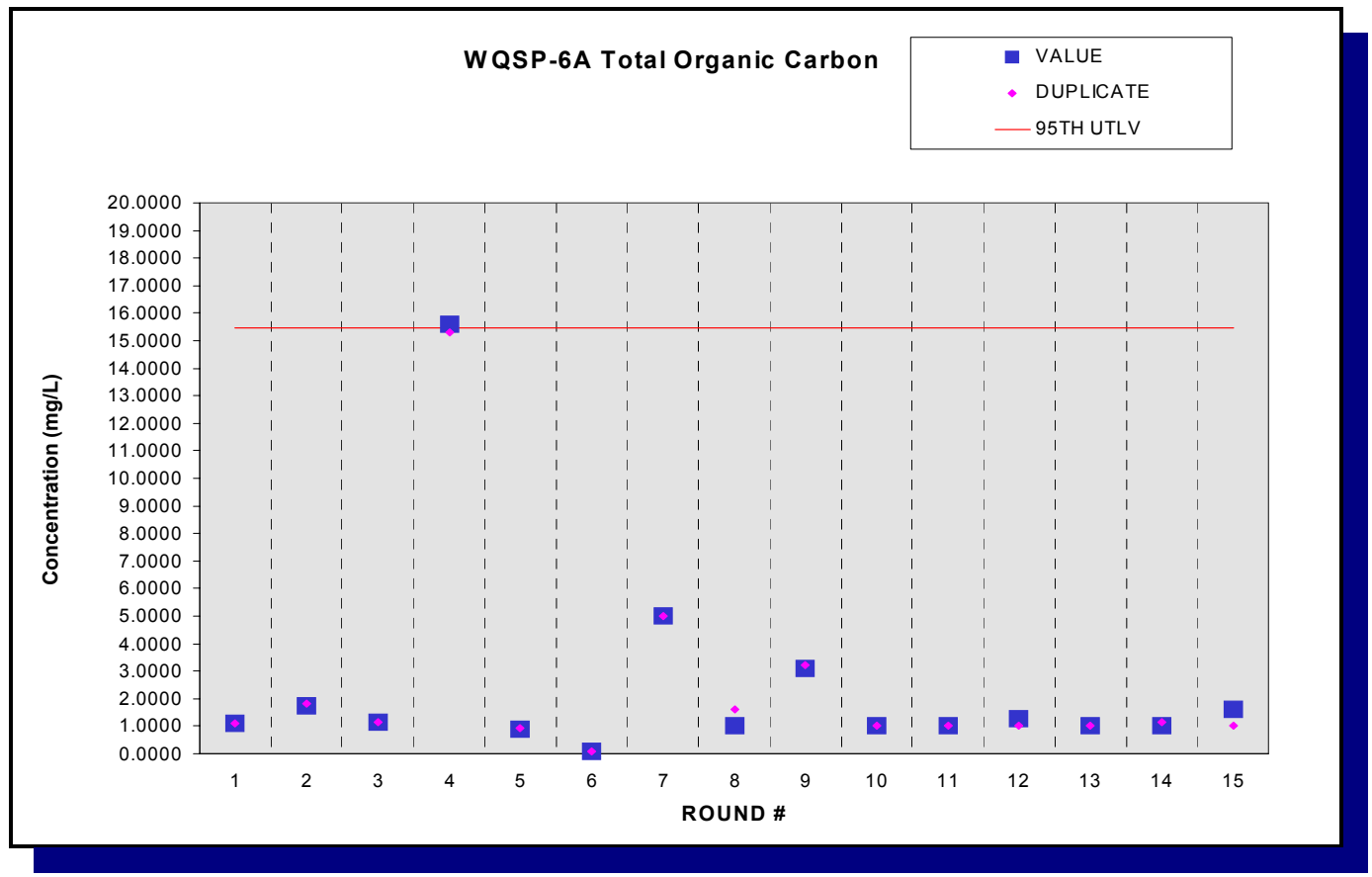

Figure F.96 - Time Trend Plot for Total Organic Carbon at WQSP-6A

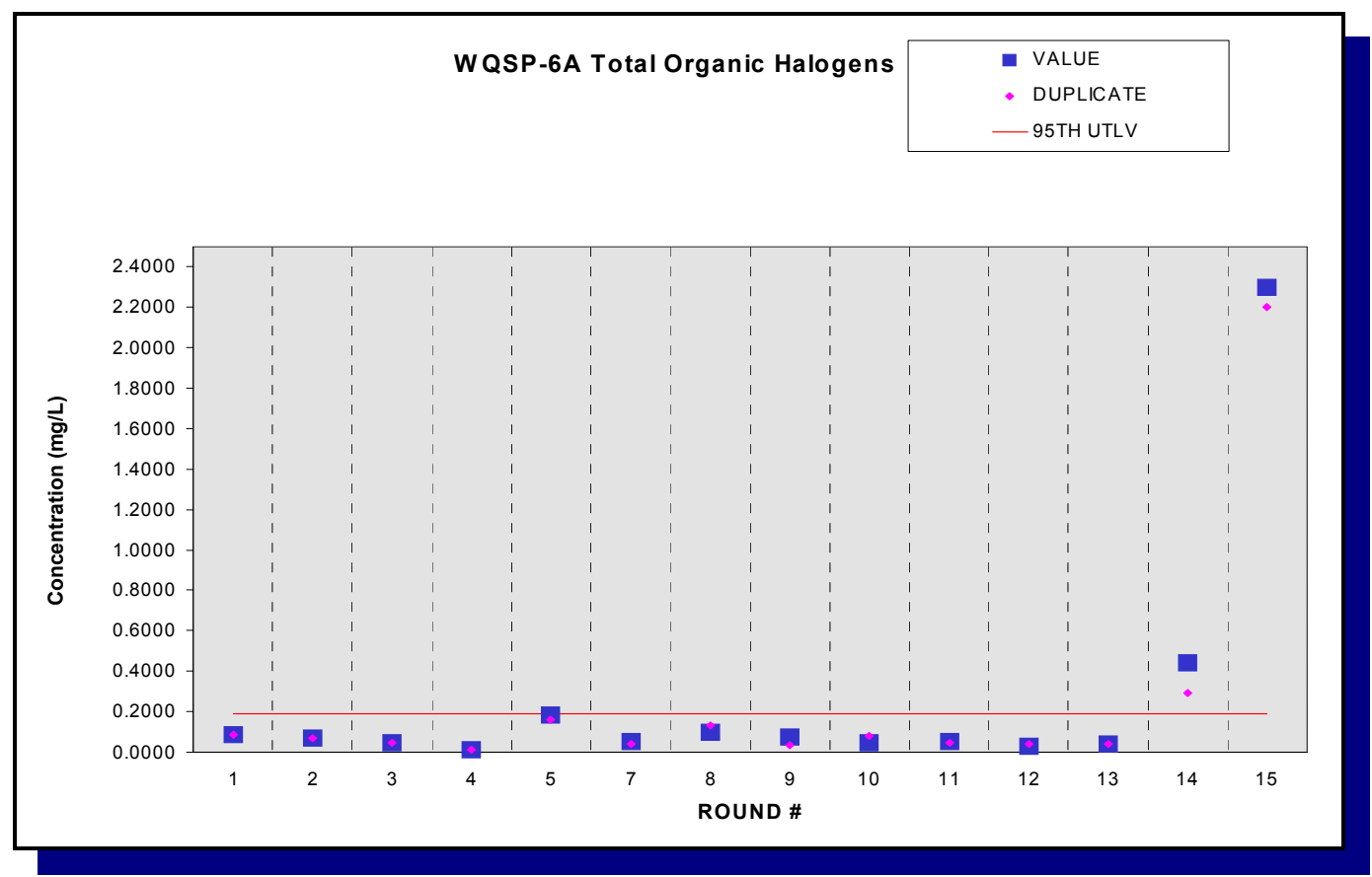

Figure F.97 - Time Trend Plot for Total Organic Halogens at WQSP-6A 
Waste Isolation Pilot Plant 2002 Site Environmental Report

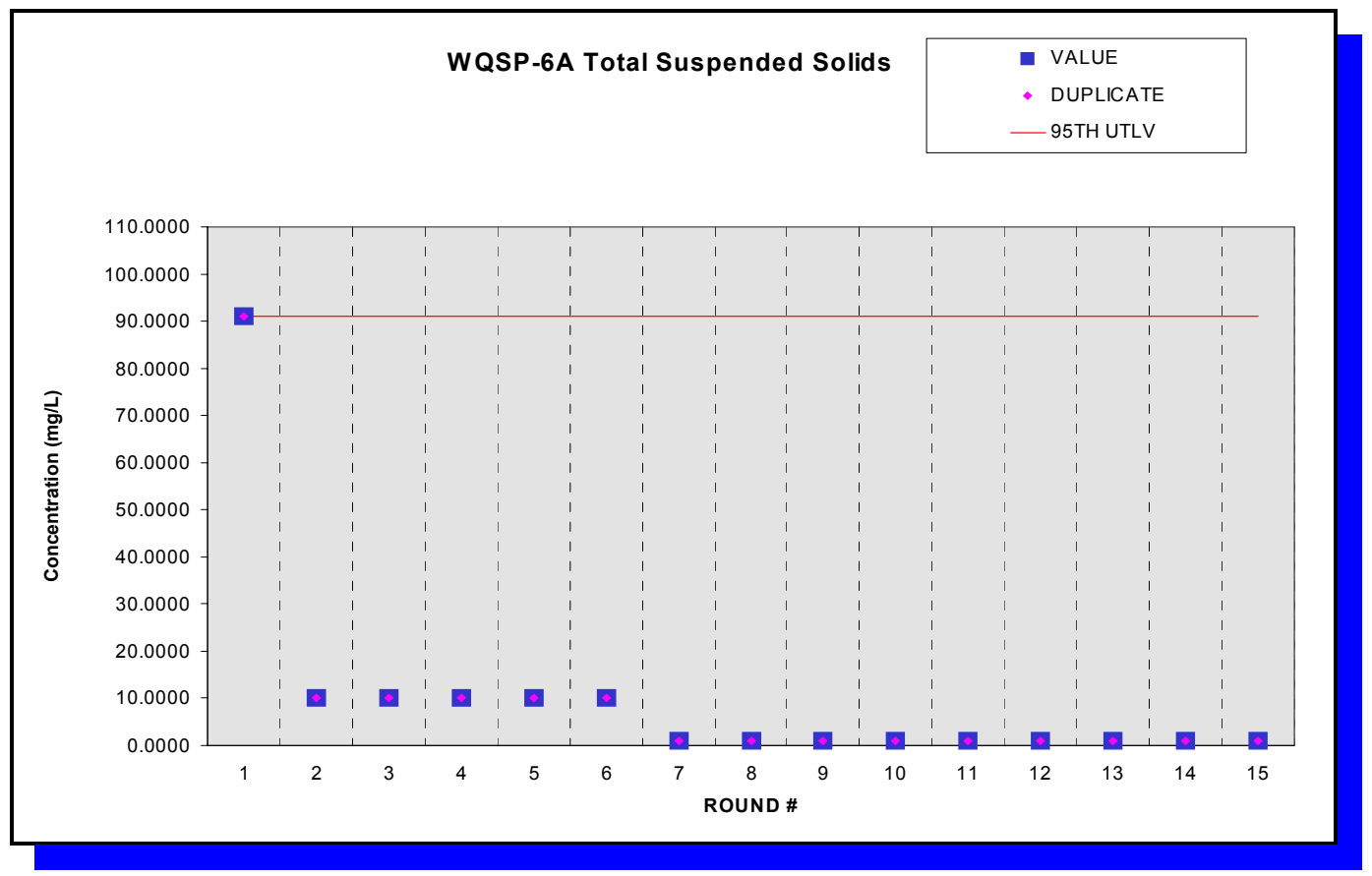

Figure F.98 - Time Trend Plot for Total Suspended Solids at WQSP-6A 


\section{Appendix G \\ Air Sampling Data: Concentrations of Radionuclides}

Table G.1 - Radionuclide Concentrations $\left(\mathrm{Bq} / \mathrm{m}^{3}\right)$ in Quarterly Composite Air Filters Collected from Locations Surrounding the WIPP Site. See Appendix $B$ for the sampling locations.

\begin{tabular}{|c|c|c|c|c|c|c|c|c|c|c|}
\hline Location & Quarter & {$[\mathrm{RN}]^{\mathrm{a}}$} & $2 x T^{\prime b}$ & $M^{\prime} C^{c}$ & [RN] & 2xTPU & MDC & [RN] & 2xTPU & MDC \\
\hline & & & ${ }^{241} \mathrm{Am}$ & & & ${ }^{238} \mathrm{Pu}$ & & & ${ }^{239+240} \mathrm{Pu}$ & \\
\hline CBD & 1 & $2.92 \times 10^{-8}$ & $5.88 \times 10^{-8}$ & $1.08 \times 10^{-7}$ & $3.39 \times 10^{-8}$ & $4.81 \times 10^{-8}$ & $4.59 \times 10^{-8}$ & $1.69 \times 10^{-8}$ & $3.39 \times 10^{-8}$ & $4.59 \times 10^{-8}$ \\
\hline CBD & 2 & $0.00 \times 10^{0}$ & $0.00 \times 10^{0}$ & $1.38 \times 10^{-7}$ & $0.00 \times 10^{0}$ & $0.00 \times 10^{0}$ & $4.88 \times 10^{-8}$ & $7.22 \times 10^{-8}$ & $7.33 \times 10^{-8}$ & $4.88 \times 10^{-8}$ \\
\hline CBD & 3 & $4.12 \times 10^{-8}$ & $8.26 \times 10^{-8}$ & $1.52 \times 10^{-7}$ & $2.13 \times 10^{-6}$ & $2.49 \times 10^{-6}$ & $1.91 \times 10^{-6}$ & $1.41 \times 10^{-6}$ & $2.01 \times 10^{-6}$ & $1.91 \times 10^{-6}$ \\
\hline CBD & 4 & $3.92 \times 10^{-8}$ & $5.59 \times 10^{-8}$ & $5.31 \times 10^{-8}$ & $-2.40 \times 10^{-8}$ & $8.31 \times 10^{-8}$ & $2.22 \times 10^{-7}$ & $2.39 \times 10^{-8}$ & $4.80 \times 10^{-8}$ & $6.47 \times 10^{-8}$ \\
\hline MLR & 1 & $2.81 \times 10^{-8}$ & $5.62 \times 10^{-8}$ & $1.03 \times 10^{-7}$ & $3.46 \times 10^{-8}$ & $4.92 \times 10^{-8}$ & $4.66 \times 10^{-8}$ & $5.18 \times 10^{-8}$ & $6.03 \times 10^{-8}$ & $4.66 \times 10^{-8}$ \\
\hline MLR & 2 & $6.33 \times 10^{-8}$ & $9.47 \times 10^{-8}$ & $1.55 \times 10^{-7}$ & $1.65 \times 10^{-8}$ & $3.31 \times 10^{-8}$ & $4.44 \times 10^{-8}$ & $6.59 \times 10^{-8}$ & $8.10 \times 10^{-8}$ & $1.21 \times 10^{-7}$ \\
\hline MLR & 3 & $8.12 \times 10^{-8}$ & $8.69 \times 10^{-8}$ & $1.20 \times 10^{-7}$ & $2.69 \times 10^{-6}$ & $5.42 \times 10^{-6}$ & $9.88 \times 10^{-6}$ & $0.00 \times 10^{0}$ & $0.00 \times 10^{0}$ & $3.63 \times 10^{-6}$ \\
\hline MLR & 4 & $3.09 \times 10^{-8}$ & $6.21 \times 10^{-8}$ & $1.14 \times 10^{-7}$ & $0.00 \times 10^{0}$ & $0.00 \times 10^{0}$ & $2.09 \times 10^{-7}$ & $0.00 \times 10^{0}$ & $0.00 \times 10^{0}$ & $6.09 \times 10^{-8}$ \\
\hline SEC & 1 & $4.29 \times 10^{-8}$ & $5.00 \times 10^{-8}$ & $3.85 \times 10^{-8}$ & $5.62 \times 10^{-8}$ & $6.55 \times 10^{-8}$ & $5.07 \times 10^{-8}$ & $3.74 \times 10^{-8}$ & $5.33 \times 10^{-8}$ & $5.07 \times 10^{-8}$ \\
\hline SEC & 2 & $7.07 \times 10^{-8}$ & $7.14 \times 10^{-8}$ & $4.77 \times 10^{-8}$ & $5.62 \times 10^{-8}$ & $6.59 \times 10^{-8}$ & $5.07 \times 10^{-8}$ & $0.00 \times 10^{0}$ & $0.00 \times 10^{0}$ & $5.07 \times 10^{-8}$ \\
\hline SEC & 3 & $7.69 \times 10^{-8}$ & $8.22 \times 10^{-8}$ & $1.13 \times 10^{-7}$ & $-6.80 \times 10^{-7}$ & $1.37 \times 10^{-6}$ & $4.99 \times 10^{-6}$ & $-6.77 \times 10^{-7}$ & $1.36 \times 10^{-6}$ & $4.99 \times 10^{-6}$ \\
\hline SEC & 4 & $1.82 \times 10^{-8}$ & $6.30 \times 10^{-8}$ & $1.34 \times 10^{-7}$ & $0.00 \times 10^{0}$ & $0.00 \times 10^{0}$ & $4.03 \times 10^{-7}$ & $3.83 \times 10^{-7}$ & $3.74 \times 10^{-7}$ & $5.08 \times 10^{-7}$ \\
\hline SMR & 1 & $5.11 \times 10^{-8}$ & $7.62 \times 10^{-8}$ & $1.25 \times 10^{-7}$ & $-2.45 \times 10^{-8}$ & $4.92 \times 10^{-8}$ & $1.80 \times 10^{-7}$ & $0.00 \times 10^{0}$ & $0.00 \times 10^{0}$ & $6.62 \times 10^{-8}$ \\
\hline SMR & 2 & $0.00 \times 10^{0}$ & $0.00 \times 10^{0}$ & $1.41 \times 10^{-7}$ & $3.37 \times 10^{-8}$ & $6.77 \times 10^{-8}$ & $1.24 \times 10^{-7}$ & $0.00 \times 10^{0}$ & $0.00 \times 10^{0}$ & $4.55 \times 10^{-8}$ \\
\hline SMR & 3 & $7.01 \times 10^{-8}$ & $8.18 \times 10^{-8}$ & $6.33 \times 10^{-8}$ & $1.72 \times 10^{-6}$ & $3.45 \times 10^{-6}$ & $6.29 \times 10^{-6}$ & $1.71 \times 10^{-6}$ & $2.44 \times 10^{-6}$ & $2.31 \times 10^{-6}$ \\
\hline SMR & 4 & $4.94 \times 10^{-8}$ & $5.76 \times 10^{-8}$ & $4.46 \times 10^{-8}$ & $0.00 \times 10^{0}$ & $0.00 \times 10^{0}$ & $1.81 \times 10^{-7}$ & $0.00 \times 10^{0}$ & $0.00 \times 10^{0}$ & $5.27 \times 10^{-8}$ \\
\hline WEE & 1 & $5.77 \times 10^{-8}$ & $5.85 \times 10^{-8}$ & $3.92 \times 10^{-8}$ & $8.25 \times 10^{-8}$ & $9.66 \times 10^{-8}$ & $7.44 \times 10^{-8}$ & $0.00 \times 10^{0}$ & $0.00 \times 10^{0}$ & $7.44 \times 10^{-8}$ \\
\hline WEE & 2 & $7.36 \times 10^{-8}$ & $9.10 \times 10^{-8}$ & $1.35 \times 10^{-7}$ & $0.00 \times 10^{0}$ & $0.00 \times 10^{0}$ & $1.29 \times 10^{-7}$ & $3.49 \times 10^{-8}$ & $4.96 \times 10^{-8}$ & $4.74 \times 10^{-8}$ \\
\hline WEE & 3 & $6.00 \times 10^{-8}$ & $7.00 \times 10^{-8}$ & $5.42 \times 10^{-8}$ & $0.00 \times 10^{0}$ & $0.00 \times 10^{0}$ & $3.48 \times 10^{-6}$ & $2.57 \times 10^{-6}$ & $3.68 \times 10^{-6}$ & $3.48 \times 10^{-6}$ \\
\hline WEE & 4 & $6.11 \times 10^{-8}$ & $7.54 \times 10^{-8}$ & $1.13 \times 10^{-7}$ & $9.19 \times 10^{-8}$ & $1.11 \times 10^{-7}$ & $1.71 \times 10^{-7}$ & $1.83 \times 10^{-8}$ & $3.68 \times 10^{-8}$ & $4.97 \times 10^{-8}$ \\
\hline WFF & 1 & $3.68 \times 10^{-8}$ & $5.25 \times 10^{-8}$ & $5.00 \times 10^{-8}$ & $-2.53 \times 10^{-8}$ & $5.07 \times 10^{-8}$ & $1.86 \times 10^{-7}$ & $0.00 \times 10^{0}$ & $0.00 \times 10^{0}$ & $6.81 \times 10^{-8}$ \\
\hline WFF & 2 & $4.77 \times 10^{-8}$ & $6.81 \times 10^{-8}$ & $6.48 \times 10^{-8}$ & $3.54 \times 10^{-8}$ & $7.10 \times 10^{-8}$ & $1.30 \times 10^{-7}$ & $3.53 \times 10^{-8}$ & $5.03 \times 10^{-8}$ & $4.77 \times 10^{-8}$ \\
\hline WFF & 3 & $9.48 \times 10^{-8}$ & $9.07 \times 10^{-8}$ & $1.16 \times 10^{-7}$ & $1.50 \times 10^{-6}$ & $3.02 \times 10^{-6}$ & $4.04 \times 10^{-6}$ & $5.97 \times 10^{-6}$ & $6.15 \times 10^{-6}$ & $4.04 \times 10^{-6}$ \\
\hline WFF & 4 & $5.59 \times 10^{-8}$ & $6.53 \times 10^{-8}$ & $5.05 \times 10^{-8}$ & $1.38 \times 10^{-7}$ & $1.99 \times 10^{-7}$ & $1.87 \times 10^{-7}$ & $4.14 \times 10^{-7}$ & $4.05 \times 10^{-7}$ & $5.08 \times 10^{-7}$ \\
\hline WSS & 1 & $1.60 \times 10^{-8}$ & $5.51 \times 10^{-8}$ & $1.18 \times 10^{-7}$ & $1.87 \times 10^{-8}$ & $6.48 \times 10^{-8}$ & $1.37 \times 10^{-7}$ & $3.74 \times 10^{-8}$ & $5.29 \times 10^{-8}$ & $5.03 \times 10^{-8}$ \\
\hline WSS & 2 & $3.46 \times 10^{-8}$ & $6.92 \times 10^{-8}$ & $1.27 \times 10^{-7}$ & $1.44 \times 10^{-8}$ & $2.89 \times 10^{-8}$ & $3.89 \times 10^{-8}$ & $2.87 \times 10^{-8}$ & $4.11 \times 10^{-8}$ & $3.89 \times 10^{-8}$ \\
\hline WSS & 3 & $7.37 \times 10^{-8}$ & $7.47 \times 10^{-8}$ & $4.99 \times 10^{-8}$ & $2.17 \times 10^{-6}$ & $3.10 \times 10^{-6}$ & $2.93 \times 10^{-6}$ & $0.00 \times 10^{0}$ & $0.00 \times 10^{0}$ & $7.96 \times 10^{-5}$ \\
\hline WSS & 4 & $0.00 \times 10^{0}$ & $0.00 \times 10^{0}$ & $1.31 \times 10^{-7}$ & $0.00 \times 10^{0}$ & $0.00 \times 10^{0}$ & $1.55 \times 10^{-7}$ & $9.99 \times 10^{-8}$ & $8.31 \times 10^{-8}$ & $4.51 \times 10^{-8}$ \\
\hline WAB & 1 & $-1.14 \times 10^{-4}$ & $2.28 \times 10^{-4}$ & $8.36 \times 10^{-4}$ & $-1.19 \times 10^{-4}$ & $2.39 \times 10^{-4}$ & $8.77 \times 10^{-4}$ & $1.19 \times 10^{-4}$ & $2.38 \times 10^{-4}$ & $3.22 \times 10^{-4}$ \\
\hline WAB & 2 & $2.15 \times 10^{-4}$ & $4.29 \times 10^{-4}$ & $7.92 \times 10^{-4}$ & $-1.07 \times 10^{-4}$ & $2.15 \times 10^{-4}$ & $7.84 \times 10^{-4}$ & $0.00 \times 10^{0}$ & $0.00 \times 10^{0}$ & $2.89 \times 10^{-4}$ \\
\hline
\end{tabular}

G-1 
Waste Isolation Pilot Plant 2002 Site Environmental Report DOE/WIPP 03-2225

Table G.1 - Radionuclide Concentrations $\left(\mathrm{Bq} / \mathrm{m}^{3}\right)$ in Quarterly Composite Air Filters Collected from Locations Surrounding the WIPP Site. See Appendix B for the sampling locations.

\begin{tabular}{|c|c|c|c|c|c|c|c|c|c|c|}
\hline Location & Quarter & {$[\mathrm{RN}]^{\mathrm{a}}$} & $2 x T P U^{b}$ & $\mathrm{MDC}^{\mathrm{c}}$ & [RN] & 2xTPU & MDC & [RN] & 2xTPU & MDC \\
\hline WAB & 3 & $1.28 \times 10^{-4}$ & $4.45 \times 10^{-4}$ & $9.45 \times 10^{-4}$ & $6.04 \times 10^{-3}$ & $1.22 \times 10^{-2}$ & $1.63 \times 10^{-2}$ & $2.41 \times 10^{-2}$ & $2.45 \times 10^{-2}$ & $1.63 \times 10^{-2}$ \\
\hline WAB & 4 & $0.00 \times 10^{0}$ & $0.00 \times 10^{0}$ & $8.43 \times 10^{-4}$ & $-4.55 \times 10^{-4}$ & $9.17 \times 10^{-4}$ & $3.34 \times 10^{-3}$ & $-4.53 \times 10^{-4}$ & $9.14 \times 10^{-4}$ & $3.34 \times 10^{-3}$ \\
\hline Minimum & & $0.00 \times 10^{0}$ & $0.00 \times 10^{0}$ & $3.85 \times 10^{-8}$ & $-6.80 \times 10^{-7}$ & $1.37 \times 10^{-6}$ & $3.89 \times 10^{-8}$ & $-6.77 \times 10^{-7}$ & $1.36 \times 10^{-6}$ & $3.89 \times 10^{-8}$ \\
\hline Maximum & & $9.48 \times 10^{-8}$ & $9.07 \times 10^{-8}$ & $1.55 \times 10^{-7}$ & $2.69 \times 10^{-6}$ & $5.42 \times 10^{-6}$ & $9.88 \times 10^{-6}$ & $5.97 \times 10^{-6}$ & $6.15 \times 10^{-6}$ & $7.96 \times 10^{-5}$ \\
\hline Mean $^{c}$ & & $4.66 \times 10^{-8}$ & $\begin{array}{l}4.98 \times 10^{-8} \\
{ }^{234} \mathrm{U}\end{array}$ & $9.64 \times 10^{-8}$ & $3.60 \times 10^{-7}$ & $\begin{array}{c}1.63 \times 10^{-6} \\
{ }^{235} \mathrm{U}\end{array}$ & $1.30 \times 10^{-6}$ & $4.39 \times 10^{-7}$ & $\begin{array}{c}2.46 \times 10^{-6} \\
{ }^{238} \mathrm{U}\end{array}$ & $3.64 \times 10^{-6}$ \\
\hline CBD & 1 & $4.74 \times 10^{-6}$ & $1.57 \times 10^{-6}$ & $1.51 \times 10^{-7}$ & $2.06 \times 10^{-7}$ & $2.43 \times 10^{-7}$ & $1.86 \times 10^{-7}$ & $3.05 \times 10^{-6}$ & $1.12 \times 10^{-6}$ & $1.50 \times 10^{-7}$ \\
\hline CBD & 2 & $2.77 \times 10^{-6}$ & $6.07 \times 10^{-7}$ & $1.14 \times 10^{-7}$ & $9.51 \times 10^{-8}$ & $1.02 \times 10^{-7}$ & $1.40 \times 10^{-7}$ & $2.73 \times 10^{-6}$ & $5.96 \times 10^{-7}$ & $4.14 \times 10^{-7}$ \\
\hline CBD & 3 & $3.17 \times 10^{-6}$ & $7.01 \times 10^{-7}$ & $4.55 \times 10^{-8}$ & $1.04 \times 10^{-7}$ & $9.41 \times 10^{-8}$ & $5.61 \times 10^{-8}$ & $2.67 \times 10^{-6}$ & $6.14 \times 10^{-7}$ & $4.53 \times 10^{-8}$ \\
\hline CBD & 4 & $2.39 \times 10^{-6}$ & $6.08 \times 10^{-7}$ & $5.50 \times 10^{-8}$ & $2.50 \times 10^{-8}$ & $5.02 \times 10^{-8}$ & $6.78 \times 10^{-8}$ & $2.36 \times 10^{-6}$ & $6.02 \times 10^{-7}$ & $5.47 \times 10^{-8}$ \\
\hline MLR & 1 & $3.63 \times 10^{-6}$ & $7.14 \times 10^{-7}$ & $3.60 \times 10^{-8}$ & $2.29 \times 10^{-7}$ & $1.28 \times 10^{-7}$ & $4.44 \times 10^{-8}$ & $3.81 \times 10^{-6}$ & $7.36 \times 10^{-7}$ & $3.58 \times 10^{-8}$ \\
\hline MLR & 2 & $3.34 \times 10^{-6}$ & $7.03 \times 10^{-7}$ & $4.51 \times 10^{-8}$ & $8.21 \times 10^{-8}$ & $8.29 \times 10^{-8}$ & $5.55 \times 10^{-8}$ & $2.95 \times 10^{-6}$ & $6.40 \times 10^{-7}$ & $4.48 \times 10^{-8}$ \\
\hline MLR & 3 & $2.79 \times 10^{-6}$ & $6.37 \times 10^{-7}$ & $1.30 \times 10^{-7}$ & $2.18 \times 10^{-8}$ & $7.54 \times 10^{-8}$ & $1.60 \times 10^{-7}$ & $2.34 \times 10^{-6}$ & $5.61 \times 10^{-7}$ & $1.63 \times 10^{-7}$ \\
\hline MLR & 4 & $2.23 \times 10^{-6}$ & $5.32 \times 10^{-7}$ & $4.55 \times 10^{-8}$ & $2.07 \times 10^{-8}$ & $4.16 \times 10^{-8}$ & $5.61 \times 10^{-8}$ & $2.17 \times 10^{-6}$ & $5.21 \times 10^{-7}$ & $4.53 \times 10^{-8}$ \\
\hline SEC & 1 & $3.62 \times 10^{-6}$ & $7.14 \times 10^{-7}$ & $3.67 \times 10^{-8}$ & $6.70 \times 10^{-8}$ & $8.25 \times 10^{-8}$ & $1.23 \times 10^{-7}$ & $3.08 \times 10^{-6}$ & $6.29 \times 10^{-7}$ & $9.95 \times 10^{-8}$ \\
\hline SEC & 2 & $3.05 \times 10^{-6}$ & $6.36 \times 10^{-7}$ & $3.89 \times 10^{-8}$ & $2.29 \times 10^{-7}$ & $1.41 \times 10^{-7}$ & $1.30 \times 10^{-7}$ & $2.63 \times 10^{-6}$ & $5.66 \times 10^{-7}$ & $3.85 \times 10^{-8}$ \\
\hline SEC & 3 & $2.79 \times 10^{-6}$ & $6.34 \times 10^{-7}$ & $4.57 \times 10^{-8}$ & $6.25 \times 10^{-8}$ & $7.29 \times 10^{-8}$ & $5.64 \times 10^{-8}$ & $2.15 \times 10^{-6}$ & $5.34 \times 10^{-7}$ & $1.24 \times 10^{-7}$ \\
\hline SEC & 4 & $2.11 \times 10^{-6}$ & $5.07 \times 10^{-7}$ & $4.39 \times 10^{-8}$ & $4.00 \times 10^{-8}$ & $5.69 \times 10^{-8}$ & $5.42 \times 10^{-8}$ & $1.87 \times 10^{-6}$ & $4.65 \times 10^{-7}$ & $4.37 \times 10^{-8}$ \\
\hline SMR & 1 & $3.26 \times 10^{-6}$ & $8.29 \times 10^{-7}$ & $6.85 \times 10^{-8}$ & $1.87 \times 10^{-7}$ & $1.57 \times 10^{-7}$ & $8.44 \times 10^{-8}$ & $3.27 \times 10^{-6}$ & $8.33 \times 10^{-7}$ & $6.81 \times 10^{-8}$ \\
\hline SMR & 2 & $3.16 \times 10^{-6}$ & $6.40 \times 10^{-7}$ & $3.81 \times 10^{-8}$ & $1.22 \times 10^{-7}$ & $9.40 \times 10^{-8}$ & $4.74 \times 10^{-8}$ & $2.78 \times 10^{-6}$ & $5.77 \times 10^{-7}$ & $3.81 \times 10^{-8}$ \\
\hline SMR & 3 & $2.34 \times 10^{-6}$ & $5.65 \times 10^{-7}$ & $5.11 \times 10^{-8}$ & $2.10 \times 10^{-7}$ & $1.44 \times 10^{-7}$ & $6.31 \times 10^{-8}$ & $2.82 \times 10^{-6}$ & $6.47 \times 10^{-7}$ & $5.09 \times 10^{-8}$ \\
\hline SMR & 4 & $2.79 \times 10^{-6}$ & $6.43 \times 10^{-7}$ & $1.28 \times 10^{-7}$ & $1.29 \times 10^{-7}$ & $1.07 \times 10^{-7}$ & $5.82 \times 10^{-8}$ & $2.27 \times 10^{-6}$ & $5.50 \times 10^{-7}$ & $4.70 \times 10^{-8}$ \\
\hline WEE & 1 & $4.29 \times 10^{-6}$ & $8.36 \times 10^{-7}$ & $3.70 \times 10^{-8}$ & $1.86 \times 10^{-7}$ & $1.16 \times 10^{-7}$ & $4.59 \times 10^{-8}$ & $4.22 \times 10^{-6}$ & $8.21 \times 10^{-7}$ & $3.69 \times 10^{-8}$ \\
\hline WEE & 2 & $2.69 \times 10^{-6}$ & $5.96 \times 10^{-7}$ & $1.17 \times 10^{-7}$ & $1.38 \times 10^{-7}$ & $1.06 \times 10^{-7}$ & $5.33 \times 10^{-8}$ & $3.29 \times 10^{-6}$ & $6.92 \times 10^{-7}$ & $4.29 \times 10^{-8}$ \\
\hline WEE & 3 & $2.65 \times 10^{-6}$ & $6.00 \times 10^{-7}$ & $4.55 \times 10^{-8}$ & $8.28 \times 10^{-8}$ & $8.39 \times 10^{-8}$ & $5.61 \times 10^{-8}$ & $2.41 \times 10^{-6}$ & $5.60 \times 10^{-7}$ & $4.53 \times 10^{-8}$ \\
\hline WEE & 4 & $2.12 \times 10^{-6}$ & $5.26 \times 10^{-7}$ & $4.78 \times 10^{-8}$ & $8.70 \times 10^{-8}$ & $8.82 \times 10^{-8}$ & $5.89 \times 10^{-8}$ & $1.90 \times 10^{-6}$ & $4.85 \times 10^{-7}$ & $4.76 \times 10^{-8}$ \\
\hline WFF & 1 & $3.96 \times 10^{-6}$ & $7.66 \times 10^{-7}$ & $3.92 \times 10^{-8}$ & $1.07 \times 10^{-7}$ & $8.88 \times 10^{-8}$ & $4.85 \times 10^{-8}$ & $3.70 \times 10^{-6}$ & $7.25 \times 10^{-7}$ & $3.92 \times 10^{-8}$ \\
\hline WFF & 2 & $2.76 \times 10^{-6}$ & $5.88 \times 10^{-7}$ & $4.03 \times 10^{-8}$ & $5.51 \times 10^{-8}$ & $6.44 \times 10^{-8}$ & $5.00 \times 10^{-8}$ & $2.27 \times 10^{-6}$ & $5.11 \times 10^{-7}$ & $4.03 \times 10^{-8}$ \\
\hline WFF & 3 & $2.22 \times 10^{-6}$ & $5.51 \times 10^{-7}$ & $5.15 \times 10^{-8}$ & $9.38 \times 10^{-8}$ & $9.51 \times 10^{-8}$ & $6.35 \times 10^{-8}$ & $1.93 \times 10^{-6}$ & $4.97 \times 10^{-7}$ & $5.13 \times 10^{-8}$ \\
\hline WFF & 4 & $2.19 \times 10^{-6}$ & $5.31 \times 10^{-7}$ & $1.29 \times 10^{-7}$ & $6.47 \times 10^{-8}$ & $7.55 \times 10^{-8}$ & $5.85 \times 10^{-8}$ & $1.74 \times 10^{-6}$ & $4.52 \times 10^{-7}$ & $1.28 \times 10^{-7}$ \\
\hline WSS & 1 & $4.55 \times 10^{-6}$ & $8.81 \times 10^{-7}$ & $4.00 \times 10^{-8}$ & $1.09 \times 10^{-7}$ & $9.07 \times 10^{-8}$ & $4.92 \times 10^{-8}$ & $3.51 \times 10^{-6}$ & $7.14 \times 10^{-7}$ & $4.00 \times 10^{-8}$ \\
\hline WSS & 2 & $3.49 \times 10^{-6}$ & $7.14 \times 10^{-7}$ & $4.11 \times 10^{-8}$ & $9.36 \times 10^{-8}$ & $8.47 \times 10^{-8}$ & $5.07 \times 10^{-8}$ & $2.88 \times 10^{-6}$ & $6.14 \times 10^{-7}$ & $4.11 \times 10^{-8}$ \\
\hline WSS & 3 & $2.87 \times 10^{-6}$ & $6.77 \times 10^{-7}$ & $5.29 \times 10^{-8}$ & $4.81 \times 10^{-8}$ & $6.85 \times 10^{-8}$ & $6.52 \times 10^{-8}$ & $2.31 \times 10^{-6}$ & $5.77 \times 10^{-7}$ & $5.26 \times 10^{-8}$ \\
\hline WSS & 4 & $2.12 \times 10^{-6}$ & $5.16 \times 10^{-7}$ & $4.59 \times 10^{-8}$ & $1.04 \times 10^{-7}$ & $9.49 \times 10^{-8}$ & $5.66 \times 10^{-8}$ & $2.21 \times 10^{-6}$ & $5.32 \times 10^{-7}$ & $4.57 \times 10^{-8}$ \\
\hline
\end{tabular}


Waste Isolation Pilot Plant 2002 Site Environmental Report DOE/WIPP 03-2225

Table G.1 - Radionuclide Concentrations $\left(\mathrm{Bq} / \mathrm{m}^{3}\right)$ in Quarterly Composite Air Filters Collected from Locations Surrounding the WIPP Site. See Appendix B for the sampling locations.

\begin{tabular}{|c|c|c|c|c|c|c|c|c|c|c|}
\hline Location & Quarter & {$[\mathrm{RN}]^{\mathrm{a}}$} & $2 \times T_{P}{ }^{b}$ & MDC $^{\mathrm{c}}$ & {$[R N]$} & 2xTPU & MDC & {$[R N]$} & 2xTPU & MDC \\
\hline WAB & 1 & $2.19 \times 10^{-2}$ & $4.44 \times 10^{-3}$ & $2.78 \times 10^{-4}$ & $3.77 \times 10^{-4}$ & $5.66 \times 10^{-4}$ & $9.32 \times 10^{-4}$ & $2.15 \times 10^{-2}$ & $4.37 \times 10^{-3}$ & $2.76 \times 10^{-4}$ \\
\hline WAB & 2 & $1.77 \times 10^{-2}$ & $4.37 \times 10^{-3}$ & $3.70 \times 10^{-4}$ & $3.37 \times 10^{-4}$ & $4.81 \times 10^{-4}$ & $4.55 \times 10^{-4}$ & $1.72 \times 10^{-2}$ & $4.26 \times 10^{-3}$ & $3.68 \times 10^{-4}$ \\
\hline WAB & 3 & $2.29 \times 10^{-2}$ & $5.28 \times 10^{-3}$ & $9.98 \times 10^{-4}$ & $6.68 \times 10^{-4}$ & $6.78 \times 10^{-4}$ & $4.53 \times 10^{-4}$ & $1.50 \times 10^{-2}$ & $3.83 \times 10^{-3}$ & $3.65 \times 10^{-4}$ \\
\hline WAB & 4 & $1.07 \times 10^{-2}$ & $2.89 \times 10^{-3}$ & $9.07 \times 10^{-4}$ & $7.59 \times 10^{-4}$ & $6.90 \times 10^{-4}$ & $4.12 \times 10^{-4}$ & $1.43 \times 10^{-2}$ & $3.51 \times 10^{-3}$ & $3.32 \times 10^{-4}$ \\
\hline Minimum & & $2.11 \times 10^{-6}$ & $5.07 \times 10^{-7}$ & $3.60 \times 10^{-8}$ & $2.07 \times 10^{-8}$ & $4.16 \times 10^{-8}$ & $4.44 \times 10^{-8}$ & $1.74 \times 10^{-6}$ & $4.52 \times 10^{-7}$ & $3.58 \times 10^{-8}$ \\
\hline Maximum & & $4.74 \times 10^{-6}$ & $1.57 \times 10^{-6}$ & $1.51 \times 10^{-7}$ & $2.29 \times 10^{-7}$ & $1.41 \times 10^{-7}$ & $1.86 \times 10^{-7}$ & $4.22 \times 10^{-6}$ & $8.21 \times 10^{-7}$ & $4.14 \times 10^{-7}$ \\
\hline Mean & & $3.00 \times 10^{-6}$ & $\begin{array}{l}1.45 \times 10^{-6} \\
{ }^{40} \mathrm{~K}\end{array}$ & $6.29 \times 10^{-8}$ & $1.07 \times 10^{-7}$ & $\begin{array}{c}1.22 \times 10^{-7} \\
{ }^{60} \mathrm{Co}\end{array}$ & $7.28 \times 10^{-8}$ & $2.69 \times 10^{-6}$ & $1.24 \times 10^{-6}$ & $7.41 \times 10^{-8}$ \\
\hline CBD & 1 & $4.07 \times 10^{-4}$ & $3.32 \times 10^{-4}$ & $3.89 \times 10^{-4}$ & $3.07 \times 10^{-5}$ & $3.34 \times 10^{-5}$ & $3.96 \times 10^{-5}$ & & & \\
\hline CBD & 2 & $4.00 \times 10^{-4}$ & $2.39 \times 10^{-4}$ & $3.22 \times 10^{-4}$ & $2.75 \times 10^{-5}$ & $2.38 \times 10^{-5}$ & $3.10 \times 10^{-5}$ & & & \\
\hline CBD & 3 & $2.49 \times 10^{-4}$ & $1.85 \times 10^{-4}$ & $2.36 \times 10^{-4}$ & $-1.28 \times 10^{-5}$ & $2.12 \times 10^{-5}$ & $2.22 \times 10^{-5}$ & & & \\
\hline CBD & 4 & $2.89 \times 10^{-4}$ & $1.89 \times 10^{-4}$ & $2.44 \times 10^{-4}$ & $1.26 \times 10^{-5}$ & $1.96 \times 10^{-5}$ & $2.37 \times 10^{-5}$ & & & \\
\hline MLR & 1 & $2.66 \times 10^{-4}$ & $1.13 \times 10^{-4}$ & $1.48 \times 10^{-4}$ & $4.22 \times 10^{-6}$ & $1.82 \times 10^{-5}$ & $2.12 \times 10^{-5}$ & & & \\
\hline MLR & 2 & $1.12 \times 10^{-4}$ & $2.93 \times 10^{-4}$ & $3.51 \times 10^{-4}$ & $9.58 \times 10^{-6}$ & $2.84 \times 10^{-5}$ & $3.41 \times 10^{-5}$ & & & \\
\hline MLR & 3 & $2.57 \times 10^{-4}$ & $3.79 \times 10^{-4}$ & $4.30 \times 10^{-4}$ & $3.47 \times 10^{-5}$ & $3.87 \times 10^{-5}$ & $4.30 \times 10^{-5}$ & & & \\
\hline MLR & 4 & $3.09 \times 10^{-4}$ & $2.57 \times 10^{-4}$ & $4.03 \times 10^{-4}$ & $2.17 \times 10^{-5}$ & $3.76 \times 10^{-5}$ & $4.10 \times 10^{-5}$ & & & \\
\hline SEC & 1 & $2.12 \times 10^{-4}$ & $3.09 \times 10^{-4}$ & $3.56 \times 10^{-4}$ & $4.40 \times 10^{-6}$ & $3.06 \times 10^{-5}$ & $3.52 \times 10^{-5}$ & & & \\
\hline SEC & 2 & $1.33 \times 10^{-4}$ & $8.51 \times 10^{-4}$ & $1.23 \times 10^{-4}$ & $5.85 \times 10^{-6}$ & $1.88 \times 10^{-5}$ & $2.22 \times 10^{-5}$ & & & \\
\hline SEC & 3 & $2.51 \times 10^{-4}$ & $1.16 \times 10^{-4}$ & $1.49 \times 10^{-4}$ & $-6.77 \times 10^{-6}$ & $2.52 \times 10^{-5}$ & $2.80 \times 10^{-5}$ & & & \\
\hline SEC & 4 & $1.26 \times 10^{-4}$ & $1.54 \times 10^{-4}$ & $2.47 \times 10^{-4}$ & $4.08 \times 10^{-6}$ & $2.43 \times 10^{-5}$ & $2.87 \times 10^{-5}$ & & & \\
\hline SMR & 1 & $1.92 \times 10^{-4}$ & $1.12 \times 10^{-4}$ & $1.55 \times 10^{-4}$ & $1.39 \times 10^{-5}$ & $2.34 \times 10^{-5}$ & $2.94 \times 10^{-5}$ & & & \\
\hline SMR & 2 & $2.54 \times 10^{-4}$ & $1.14 \times 10^{-4}$ & $1.54 \times 10^{-4}$ & $-7.66 \times 10^{-6}$ & $2.08 \times 10^{-5}$ & $2.25 \times 10^{-5}$ & & & \\
\hline SMR & 3 & $2.80 \times 10^{-4}$ & $3.56 \times 10^{-4}$ & $4.05 \times 10^{-4}$ & $3.57 \times 10^{-5}$ & $3.76 \times 10^{-5}$ & $4.30 \times 10^{-5}$ & & & \\
\hline SMR & 4 & $3.77 \times 10^{-4}$ & $1.67 \times 10^{-4}$ & $2.34 \times 10^{-4}$ & $5.13 \times 10^{-5}$ & $3.35 \times 10^{-5}$ & $3.66 \times 10^{-5}$ & & & \\
\hline WEE & 1 & $2.26 \times 10^{-4}$ & $1.00 \times 10^{-4}$ & $1.31 \times 10^{-4}$ & $8.88 \times 10^{-6}$ & $1.83 \times 10^{-5}$ & $2.18 \times 10^{-5}$ & & & \\
\hline WEE & 2 & $2.02 \times 10^{-4}$ & $2.48 \times 10^{-4}$ & $3.12 \times 10^{-4}$ & $1.21 \times 10^{-5}$ & $2.62 \times 10^{-5}$ & $3.17 \times 10^{-5}$ & & & \\
\hline WEE & 3 & $1.60 \times 10^{-4}$ & $9.78 \times 10^{-5}$ & $1.42 \times 10^{-4}$ & $-3.42 \times 10^{-7}$ & $1.96 \times 10^{-5}$ & $2.23 \times 10^{-5}$ & & & \\
\hline WEE & 4 & $4.15 \times 10^{-4}$ & $1.71 \times 10^{-4}$ & $2.36 \times 10^{-4}$ & $2.60 \times 10^{-5}$ & $3.32 \times 10^{-5}$ & $3.76 \times 10^{-5}$ & & & \\
\hline WFF & 1 & $2.05 \times 10^{-4}$ & $1.14 \times 10^{-4}$ & $1.63 \times 10^{-4}$ & $-7.77 \times 10^{-6}$ & $2.21 \times 10^{-5}$ & $2.38 \times 10^{-5}$ & & & \\
\hline WFF & 2 & $1.57 \times 10^{-4}$ & $1.12 \times 10^{-4}$ & $1.69 \times 10^{-4}$ & $-1.99 \times 10^{-6}$ & $2.12 \times 10^{-5}$ & $2.37 \times 10^{-5}$ & & & \\
\hline WFF & 3 & $6.69 \times 10^{-4}$ & $3.31 \times 10^{-4}$ & $3.90 \times 10^{-4}$ & $3.72 \times 10^{-5}$ & $3.50 \times 10^{-5}$ & $3.91 \times 10^{-5}$ & & & \\
\hline WFF & 4 & $3.20 \times 10^{-4}$ & $1.74 \times 10^{-4}$ & $2.33 \times 10^{-4}$ & $-3.41 \times 10^{-6}$ & $2.11 \times 10^{-5}$ & $2.32 \times 10^{-5}$ & & & \\
\hline WSS & 1 & $4.03 \times 10^{-4}$ & $3.25 \times 10^{-4}$ & $3.81 \times 10^{-4}$ & $5.40 \times 10^{-7}$ & $3.19 \times 10^{-5}$ & $3.63 \times 10^{-5}$ & & & \\
\hline WSS & 2 & $2.11 \times 10^{-4}$ & $1.09 \times 10^{-4}$ & $1.52 \times 10^{-4}$ & $7.29 \times 10^{-6}$ & $1.87 \times 10^{-5}$ & $2.22 \times 10^{-5}$ & & & \\
\hline
\end{tabular}


Waste Isolation Pilot Plant 2002 Site Environmental Report DOE/WIPP 03-2225

Table G.1 - Radionuclide Concentrations $\left(\mathrm{Bq} / \mathrm{m}^{3}\right)$ in Quarterly Composite Air Filters Collected from Locations Surrounding the WIPP Site. See Appendix B for the sampling locations.

\begin{tabular}{|c|c|c|c|c|c|c|c|c|c|c|}
\hline Location & Quarter & {$[R N]^{a}$} & $2 \times T^{\prime} U^{b}$ & MDC $^{c}$ & {$[\mathrm{RN}]$} & 2xTPU & MDC & [RN] & $2 \times T P U$ & MDC \\
\hline WSS & 3 & $2.27 \times 10^{-4}$ & $2.57 \times 10^{-4}$ & $3.24 \times 10^{-4}$ & $3.31 \times 10^{-5}$ & $2.41 \times 10^{-5}$ & $3.20 \times 10^{-5}$ & & & \\
\hline WSS & 4 & $1.87 \times 10^{-4}$ & $2.42 \times 10^{-4}$ & $3.01 \times 10^{-4}$ & $3.53 \times 10^{-6}$ & $2.30 \times 10^{-5}$ & $2.71 \times 10^{-5}$ & & & \\
\hline WAB & 1 & $1.20 \times 10^{0}$ & $7.70 \times 10^{-1}$ & $1.13 \times 10^{0}$ & $6.03 \times 10^{-2}$ & $1.45 \times 10^{-1}$ & $1.72 \times 10^{-1}$ & & & \\
\hline WAB & 2 & $1.59 \times 10^{0}$ & $1.23 \times 10^{0}$ & $1.88 \times 10^{0}$ & $3.47 \times 10^{-2}$ & $1.76 \times 10^{-1}$ & $2.09 \times 10^{-1}$ & & & \\
\hline WAB & 3 & $4.39 \times 10^{0}$ & $2.52 \times 10^{0}$ & $2.94 \times 10^{0}$ & $1.04 \times 10^{-1}$ & $2.67 \times 10^{-1}$ & $2.91 \times 10^{-1}$ & & & \\
\hline WAB & 4 & $9.10 \times 10^{-1}$ & $2.50 \times 10^{0}$ & $2.82 \times 10^{0}$ & $3.68 \times 10^{-1}$ & $2.64 \times 10^{-1}$ & $2.98 \times 10^{-1}$ & & & \\
\hline Minimum & & $1.12 \times 10^{-4}$ & $2.93 \times 10^{-4}$ & $1.23 \times 10^{-4}$ & $-1.28 \times 10^{-5}$ & $2.12 \times 10^{-5}$ & $2.12 \times 10^{-5}$ & & & \\
\hline Maximum & & $6.69 \times 10^{-4}$ & $3.31 \times 10^{-4}$ & $4.30 \times 10^{-4}$ & $3.72 \times 10^{-5}$ & $3.50 \times 10^{-5}$ & $4.30 \times 10^{-5}$ & & & \\
\hline Mean & & $2.68 \times 10^{-4}$ & $\begin{array}{l}2.30 \times 10^{-4} \\
{ }^{90} \mathrm{Sr}\end{array}$ & $2.60 \times 10^{-4}$ & $1.06 \times 10^{-5}$ & $\begin{array}{c}2.88 \times 10^{-5} \\
{ }^{137} \mathrm{Cs}\end{array}$ & $3.01 \times 10^{-5}$ & & & \\
\hline CBD & 1 & $-1.59 \times 10^{-6}$ & $3.19 \times 10^{-6}$ & $5.44 \times 10^{-6}$ & $-5.07 \times 10^{-5}$ & $3.57 \times 10^{-5}$ & $3.53 \times 10^{-5}$ & & & \\
\hline CBD & 2 & $1.08 \times 10^{-6}$ & $2.80 \times 10^{-6}$ & $4.85 \times 10^{-6}$ & $5.00 \times 10^{-6}$ & $2.32 \times 10^{-6}$ & $2.64 \times 10^{-6}$ & & & \\
\hline CBD & 3 & $3.55 \times 10^{-6}$ & $2.41 \times 10^{-6}$ & $3.89 \times 10^{-6}$ & $3.50 \times 10^{-6}$ & $1.45 \times 10^{-5}$ & $1.74 \times 10^{-5}$ & & & \\
\hline CBD & 4 & $-5.47 \times 10^{-7}$ & $3.68 \times 10^{-6}$ & $6.35 \times 10^{-6}$ & $1.20 \times 10^{-6}$ & $1.53 \times 10^{-5}$ & $1.80 \times 10^{-5}$ & & & \\
\hline MLR & 1 & $-1.86 \times 10^{-6}$ & $2.88 \times 10^{-6}$ & $4.92 \times 10^{-6}$ & $5.96 \times 10^{-6}$ & $1.41 \times 10^{-5}$ & $1.70 \times 10^{-5}$ & & & \\
\hline MLR & 2 & $8.14 \times 10^{-7}$ & $3.08 \times 10^{-6}$ & $5.37 \times 10^{-6}$ & $2.13 \times 10^{-5}$ & $2.57 \times 10^{-5}$ & $3.03 \times 10^{-5}$ & & & \\
\hline MLR & 3 & $3.39 \times 10^{-6}$ & $2.74 \times 10^{-6}$ & $4.48 \times 10^{-6}$ & $-2.27 \times 10^{-5}$ & $3.90 \times 10^{-5}$ & $3.99 \times 10^{-5}$ & & & \\
\hline MLR & 4 & $5.89 \times 10^{-8}$ & $3.61 \times 10^{-6}$ & $6.17 \times 10^{-6}$ & $-3.72 \times 10^{-5}$ & $3.46 \times 10^{-5}$ & $3.65 \times 10^{-5}$ & & & \\
\hline SEC & 1 & $-2.13 \times 10^{-6}$ & $2.84 \times 10^{-6}$ & $4.88 \times 10^{-6}$ & $-1.53 \times 10^{-5}$ & $3.13 \times 10^{-5}$ & $3.35 \times 10^{-5}$ & & & \\
\hline SEC & 2 & $1.55 \times 10^{-6}$ & $2.42 \times 10^{-6}$ & $4.14 \times 10^{-6}$ & $1.31 \times 10^{-5}$ & $1.44 \times 10^{-5}$ & $1.78 \times 10^{-5}$ & & & \\
\hline SEC & 3 & $1.69 \times 10^{-6}$ & $2.30 \times 10^{-6}$ & $3.85 \times 10^{-6}$ & $1.74 \times 10^{-5}$ & $2.11 \times 10^{-5}$ & $2.49 \times 10^{-5}$ & & & \\
\hline SEC & 4 & $-1.22 \times 10^{-6}$ & $3.46 \times 10^{-6}$ & $6.01 \times 10^{-6}$ & $-1.02 \times 10^{-5}$ & $2.33 \times 10^{-5}$ & $2.51 \times 10^{-5}$ & & & \\
\hline SMR & 1 & $-4.77 \times 10^{-7}$ & $3.23 \times 10^{-6}$ & $5.40 \times 10^{-6}$ & $-1.94 \times 10^{-5}$ & $2.45 \times 10^{-5}$ & $2.53 \times 10^{-5}$ & & & \\
\hline SMR & 2 & $3.74 \times 10^{-6}$ & $2.49 \times 10^{-6}$ & $4.07 \times 10^{-6}$ & $9.62 \times 10^{-6}$ & $1.47 \times 10^{-5}$ & $1.79 \times 10^{-5}$ & & & \\
\hline SMR & 3 & $2.48 \times 10^{-6}$ & $2.27 \times 10^{-6}$ & $2.93 \times 10^{-6}$ & $-5.44 \times 10^{-5}$ & $3.83 \times 10^{-5}$ & $3.87 \times 10^{-5}$ & & & \\
\hline SMR & 4 & $-5.31 \times 10^{-7}$ & $3.60 \times 10^{-6}$ & $6.20 \times 10^{-6}$ & $-1.52 \times 10^{-5}$ & $3.06 \times 10^{-5}$ & $3.37 \times 10^{-5}$ & & & \\
\hline WEE & 1 & $-2.28 \times 10^{-6}$ & $2.79 \times 10^{-6}$ & $4.81 \times 10^{-6}$ & $2.08 \times 10^{-5}$ & $1.38 \times 10^{-5}$ & $1.75 \times 10^{-5}$ & & & \\
\hline WEE & 2 & $1.91 \times 10^{-6}$ & $2.61 \times 10^{-6}$ & $4.44 \times 10^{-6}$ & $1.28 \times 10^{-5}$ & $2.41 \times 10^{-5}$ & $2.80 \times 10^{-5}$ & & & \\
\hline WEE & 3 & $4.02 \times 10^{-6}$ & $2.50 \times 10^{-6}$ & $4.00 \times 10^{-6}$ & $-1.59 \times 10^{-6}$ & $1.55 \times 10^{-5}$ & $1.81 \times 10^{-5}$ & & & \\
\hline WEE & 4 & $7.27 \times 10^{-7}$ & $3.54 \times 10^{-6}$ & $6.00 \times 10^{-6}$ & $-5.19 \times 10^{-5}$ & $3.39 \times 10^{-5}$ & $3.41 \times 10^{-5}$ & & & \\
\hline WFF & 1 & $-1.77 \times 10^{-7}$ & $3.26 \times 10^{-6}$ & $5.44 \times 10^{-6}$ & $-8.77 \times 10^{-7}$ & $1.61 \times 10^{-5}$ & $1.88 \times 10^{-5}$ & & & \\
\hline WFF & 2 & $3.52 \times 10^{-6}$ & $2.69 \times 10^{-6}$ & $4.44 \times 10^{-6}$ & $1.04 \times 10^{-6}$ & $1.58 \times 10^{-5}$ & $1.88 \times 10^{-5}$ & & & \\
\hline WFF & 3 & $2.60 \times 10^{-6}$ & $2.28 \times 10^{-6}$ & $3.94 \times 10^{-6}$ & $-1.83 \times 10^{-5}$ & $3.53 \times 10^{-5}$ & $3.63 \times 10^{-5}$ & & & \\
\hline WFF & 4 & $1.01 \times 10^{-6}$ & $3.71 \times 10^{-6}$ & $6.28 \times 10^{-6}$ & $-4.84 \times 10^{-6}$ & $1.52 \times 10^{-5}$ & $1.73 \times 10^{-5}$ & & & \\
\hline
\end{tabular}




\section{Waste Isolation Pilot Plant 2002 Site Environmental Report}

DOE/WIPP 03-2225

Table G.1 - Radionuclide Concentrations $\left(\mathrm{Bq} / \mathrm{m}^{3}\right)$ in Quarterly Composite Air Filters Collected from Locations Surrounding the WIPP Site. See Appendix B for the sampling locations.

\begin{tabular}{|c|c|c|c|c|c|c|c|c|c|c|}
\hline Location & Quarter & {$[R N]^{\mathrm{a}}$} & $2 \times T_{P U}^{b}$ & MDC $^{\mathrm{c}}$ & {$[\mathrm{RN}]$} & $2 \times$ TPU & MDC & {$[\mathrm{RN}]$} & 2xTPU & MDC \\
\hline WSS & 1 & $-1.21 \times 10^{-6}$ & $3.36 \times 10^{-6}$ & $5.70 \times 10^{-6}$ & $-5.99 \times 10^{-5}$ & $3.74 \times 10^{-5}$ & $3.61 \times 10^{-5}$ & & & \\
\hline WSS & 2 & $1.48 \times 10^{-6}$ & $2.48 \times 10^{-6}$ & $4.26 \times 10^{-6}$ & $-2.75 \times 10^{-7}$ & $1.51 \times 10^{-5}$ & $1.77 \times 10^{-5}$ & & & \\
\hline WSS & 3 & $1.92 \times 10^{-6}$ & $2.69 \times 10^{-6}$ & $4.51 \times 10^{-6}$ & $-1.10 \times 10^{-5}$ & $2.54 \times 10^{-5}$ & $2.73 \times 10^{-5}$ & & & \\
\hline WSS & 4 & $-1.55 \times 10^{-6}$ & $3.54 \times 10^{-6}$ & $6.15 \times 10^{-6}$ & $7.02 \times 10^{-6}$ & $2.18 \times 10^{-5}$ & $2.51 \times 10^{-5}$ & & & \\
\hline WAB & 1 & $9.99 \times 10^{-4}$ & $2.27 \times 10^{-2}$ & $3.92 \times 10^{-2}$ & $-5.85 \times 10^{-3}$ & $1.08 \times 10^{-1}$ & $1.27 \times 10^{-1}$ & & & \\
\hline WAB & 2 & $-2.42 \times 10^{-3}$ & $1.31 \times 10^{-2}$ & $2.25 \times 10^{-2}$ & $1.65 \times 10^{-1}$ & $1.55 \times 10^{-1}$ & $1.85 \times 10^{-1}$ & & & \\
\hline WAB & 3 & $2.31 \times 10^{-2}$ & $2.06 \times 10^{-2}$ & $3.39 \times 10^{-2}$ & $-3.31 \times 10^{-1}$ & $2.79 \times 10^{-1}$ & $2.70 \times 10^{-1}$ & & & \\
\hline WAB & 4 & $1.48 \times 10^{-3}$ & $2.49 \times 10^{-2}$ & $4.24 \times 10^{-2}$ & $-2.77 \times 10^{-2}$ & $2.57 \times 10^{-1}$ & $2.72 \times 10^{-1}$ & & & \\
\hline Minimum & & $-2.28 \times 10^{-6}$ & $2.79 \times 10^{-6}$ & $2.93 \times 10^{-6}$ & $-5.99 \times 10^{-5}$ & $3.74 \times 10^{-5}$ & $1.70 \times 10^{-5}$ & & & \\
\hline Maximum & & $4.02 \times 10^{-6}$ & $2.50 \times 10^{-6}$ & $6.35 \times 10^{-6}$ & $2.13 \times 10^{-5}$ & $2.57 \times 10^{-5}$ & $3.99 \times 10^{-5}$ & & & \\
\hline Mean & & $7.01 \times 10^{-7}$ & $3.76 \times 10^{-6}$ & $4.96 \times 10^{-6}$ & $-9.11 \times 10^{-6}$ & $4.55 \times 10^{-5}$ & $2.62 \times 10^{-5}$ & & & \\
\hline
\end{tabular}

Note: An anomaly in the Canberra software for the alpha spectrometer prevents it from calculating uncertainty when the activity is 0 . 
This page intentionally left blank 